



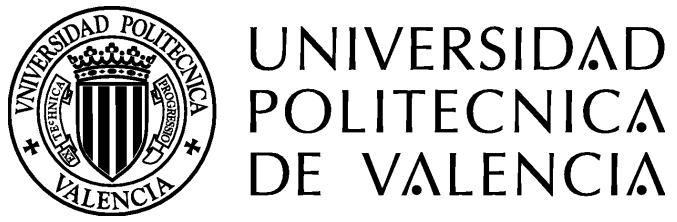

DEPARTAMENTO DE BIOTECNOLOGÍA

\title{
Aislamiento y caracterización de genes MADS-box en Medicago truncatula: duplicaciones génicas y subfuncionalización en el linaje euAGAMOUS
}

\author{
Memoria presentada por \\ JOANNA SERWATOWSKA \\ para optar al grado de \\ DOCTOR por la Universidad Politécnica de Valencia
}

Directores

Dr. LUIS ANTONIO CAÑAS CLEMENTE

Dr. JOSÉ PÍO BELTRÁN PORTER 

D. Luis Cañas Clemente, Doctor en Ciencias Biológicas, Investigador Científico del CSIC y D. José Pío Beltrán Porter, Doctor en Ciencias Químicas, Profesor de Investigación del CSIC, ambos del Instituto de Biología Molecular de Plantas (Universidad Politécnica - Consejo Superior de Investigaciones Científicas) de Valencia,

\section{CERTIFICAN que,}

Doña Joanna Serwatowska, Ingeniera Bioquímica, ha realizado bajo nuestra dirección el trabajo que con el título "Aislamiento y caracterización de genes MADS-box en Medicago truncatula: duplicaciones génicas y subfuncionalización en el linaje eUAGAMOUS", presenta para optar al grado de Doctor por la Universidad Politécnica de Valencia.

Para que así conste a los efectos oportunos, firman el presente certificado en Valencia, a 13 de Febrero de 2012. 



\section{AGRADECIMIENTOS}

Mi más sincero agradecimiento a todas las personas que de una manera $u$ otra, de cerca o de lejos, me han apoyado durante los últimos nueve años.

En primer lugar, quisiera agradecer a mis directores de Tesis, Dr. Luis Antonio Cañas Clemente y Dr. José Pío Beltrán Porter, por la oportunidad que me brindaron de realizar este trabajo y por la confianza depositada en mí.

A José María Bellés, por tutelar este trabajo y apoyarme cuando lo necesité.

A Kirankumar S. Mysore y Jiangqi Wen (Samuel Roberts Foundation, Oklahoma, USA) por facilitarnos las semillas de la línea NF4908 con inserción del retrotransposón Tnt1.

A los Drs. Elisabeth I. Johansen, Ole S. Lund y Gabriela D. Constantin por dejarme ser parte de su laboratorio durante mi estancia en Frederiksberg, Dinamarca. Por formarme y ayudarme en el desarrollo de los experimentos VIGS presentados en esta Tesis.

Quiero hacer constar $\mathrm{mi}$ agradecimiento a todo el personal del IBMCP (Administración y Servicios), cuya labor ha sido imprescindible para llevar a cabo el presente trabajo. En especial a Santiago y a Rafa, por su trato siempre afectuoso y amable.

A Ana y a Majo por estar al pendiente tanto de mis Arabidopsis como de mí.

A Marisol y a MD, por el aporte cultural en los almuerzos.

Gracias a todos mis compañeros de laboratorio, a los de siempre y a los recién llegados, por su cariño y por soportarme cada día en las buenas y en las malas.

A Edelín, Maricruz, Bego, Auri y Tere, sin cuyo trabajo el mío no habría sido posible.

A Concha por sus ideas claras y por hacerme ver que mi trabajo es bueno. Gracias de corazón.

Además, quiero agradecer a muchas personas que han llegado a formar parte de mi vida en estos últimos años y sin cuya amistad y apoyo no me habría sentido "en casa" estando del otro lado del mundo.

Gracias a mis amigos, a los de aquí y a los de allá, por estar. 
A Mónica, por su amistad, su compañía y por ser tan buena. Espero que sigamos viviendo juntas muchos más momentos inolvidables.

A Marina, por ser tan buena amiga y por los estupendos ratos pasados.

A Lina, por la empatía en los malos tiempos que finalmente no fueron tan malos.

A José Manuel y a Susana, por estar ahí.

A Rosalía, Indalecio, Inés, Maricha, Jose, Jose Luis e Inesita por cuidarme y haberme acogido como una más de la familia.

A mis padres por mostrarme el significado de la constancia y el trabajo bien hecho y por darme la oportunidad de llegar hasta aquí.

A Roberto, porque sin ti no habría llegado.

Y a Rysio. En definitiva, esto es para ti.

El presente trabajo ha sido financiado por una beca-contrato Predoctoral para el Desarrollo de Tesis Doctoral en Líneas de Investigación con Interés para el Sector Industrial, así como por la Ayuda Complementaria para la Realización de Estancias Breves en Centros de I+D y Empresas en España y en el Extranjero, concedidas por el CSIC. 
Ukochanym Rodzicom

A Roberto 



\section{ResúMENES}





\section{Aislamiento y caracterización de genes MADS-box en Medicago truncatula: duplicaciones génicas y subfuncionalización en el linaje eUAGAMOUS}

Las angiospermas presentan gran diversidad en el desarrollo y la morfología de sus inflorescencias, flores y frutos, si bien se ha establecido que estos procesos poseen una base genética común. Esta diversidad exige analizar dichos procesos en plantas modelo diferentes a Arabidopsis thaliana o Antirrhinum majus. En el presente trabajo, se ha utilizado la leguminosa Medicago truncatula, la cual tiene las características apropiadas para servir como sistema modelo para las leguminosas.

Se aislaron y caracterizaron genes de la familia MADS-box en $M$. truncatula. Estos genes son factores de transcripción que participan en procesos como el control del tiempo de floración, la determinación de la identidad del meristemo floral o el desarrollo de órganos florales, frutos y semillas. Hemos estudiado 11 genes MADS-box: dos genes de clase B (MtTM6 y MtNMH7), tres genes de clase C (MtSHP, MtAGa y $M t A G b)$, un gen de clase $E(M t S E P)$ y cinco genes que no forman parte del modelo ABC(DE) (MtAGL6, MtAGL6-like, MtSOC1a, MtSOC1b y MtSOC1-like). De entre dichos genes, hemos prestado especial atención a la caracterización funcional de los genes de clase C. Los patrones de expresión de los genes aislados se estudiaron mediante Northern blot e hibridación in situ, observando que todos se expresan en diferentes tejidos florales y/o diferentes estadios de desarrollo floral, aunque varios se expresan también en tejidos vegetativos, tal vez cumpliendo un rango de funciones más amplio que la regulación de los eventos del desarrollo floral. Los resultados obtenidos conforman la base para determinar las funciones de estos genes en el desarrollo de inflorescencias, flores y frutos de $M$. truncatula.

Se ha descrito que varios genes duplicados en Arabidopsis están representados por un único gen en $M$. truncatula y también que esta leguminosa presenta duplicaciones de genes que son únicos en Arabidopsis. Esto último sucede con los genes de clase $C$. En $M$. truncatula hemos aislado tres genes MADS-box pertenecientes a este linaje: MtSHP, MtAGa y MtAGb; el primero es miembro del linaje PLE y los otros dos son miembros del linaje euAG. La duplicación en el linaje euAG parece ser específica de las especies leguminosas. Por ello, investigamos si los genes parálogos MtAGa y MtAGb desempeñan papeles en la especificación de la identidad de los órganos florales y/o en la determinación del meristemo floral, funciones descritas para los genes de clase $C$. Se analizaron plantas transgénicas de $M$. trucatula con construcciones de RNA interferente y un mutante de pérdida de función $C$ etiquetado por el retrotransposón Tnt1. Además, utilizando la tecnología VIGS se obtuvieron plantas de $M$. truncatula y de Pisum sativum (leguminosa filogenéticamente cercana) con pérdida de función de los genes MtAGa/MtAGb y PsAGa/PsAGb, respectivamente. También se realizaron experimentos de ganancia de función mediante la expresión constitutiva en el sistema heterólogo $A$. thaliana.

Los resultados del presente trabajo indican que MtAGa y MtAGb son genes de clase $C$ que además de tener un alto grado de redundancia funcional, se han subfuncionalizado, distribuyendo la función $C$ ancestral entre ambos parálogos, de tal manera que $M t A G a$ tiene un papel prioritario en la determinación del meristemo floral, mientras que MtAGb juega un papel clave en la especificación de la identidad de los órganos reproductores florales. 


\section{Isolation and characterization of MADS-box genes in Medicago truncatula: gene duplications and subfunctionalization in the euAGAMOUS lineage}

Angiosperms show great diversity in the development and morphology of inflorescences, flowers and fruits, although it has been established that these processes have a common genetic basis. This diversity demands an analysis of these processes in model plants different from Arabidopsis thaliana or Antirrhinum majus. In this study, we have used Medicago truncatula, which has the appropriate characteristics to serve as a model system for legumes.

We have isolated and characterized MADS-box family genes in $M$. truncatula. These genes are transcription factors that are involved in processes such as control of flowering time, determination of the identity of the floral meristem or development of floral organs, fruits and seeds. We have studied 11 MADS-box genes: two B-class genes (MtTM6 and MtNMH7), three C-class genes (MtSHP, MtAGa and MtAGb), one E-class gene (MtSEP) and five genes that do not belong to the $A B C(D E)$ model (MtAGL6, MtAGL6-like, MtSOC1a, MtSOC1b and MtSOC1-like). We have paid special attention to the functional characterization of the C-class genes. The expression patterns of the isolated genes were studied by Northern blot and in situ hybridization, finding that all of them are expressed in different floral tissues and/or different floral development stages, although several of them are also expressed in vegetative tissues, perhaps perfoming a broader range of functions than just regulation of flower development events. These results are the basis for determining the functions of these genes in the development of inflorescences, flowers and fruits of $M$. truncatula.

It has been described that many Arabidopsis duplicated genes are represented by a single gene in $M$. truncatula and that this legume presents duplication of genes that are unique in Arabidopsis. The latter happens with C-class genes. We have isolated three MADS-box genes belonging to this class in M. truncatula: MtSHP, MtAGa and MtAGb. The first is member of the PLE lineage and the last two are members of the euAG lineage. Duplication in the euAG lineage appears to be specific of leguminous species. For this reason, we investigated if MtAGa and MtAGb paralog genes play roles in the floral organ identity specification and/or in the floral meristem determination, described functions for C-class genes. $M$. trucatula transgenic plants with RNA interference constructs and a loss of C-function mutant labelled by Tnt1 retrotransposon were analysed. In addition, using VIGS technology, plants of $M$. truncatula and Pisum sativum (phylogenetically close legume) with loss of function of MtAGa/MtAGb and PSAGa/PsAGb genes, respectively, were obtained. Also, we carried out experiments of gain of function through constitutive expression in the heterologous system $A$. thaliana.

The results of this study indicate that MtAGa and MtAGb are C-class genes that have a high degree of functional redundancy, and furthermore, they subfunctionalized distributing the ancestral C-function between both paralogs, in such a way that MtAGa has a priority role in the floral meristem determination, while MtAGb plays a key role in the specification of the identity of floral reproductive organs. 


\section{Aïllament i caracterització de gens MADS-box en Medicago truncatula: duplicacions gèniques i subfuncionalització en el llinatge euAGAMOUS}

Les angiospermes presenten una gran diversitat en el desenvolupament i la morfologia de les inflorescències, flors i fruits, si bé s'ha establit que aquests processos tenen una base genètica comuna. Aquesta diversitat exigeix analitzar aquests processos en plantes model diferents a Arabidopsis thaliana o Antirrhinum majus. En el treball, s'ha utilitzat la lleguminosa Medicago truncatula, la qual té les característiques apropiades per a servir com a sistema model per a les lleguminoses.

Es van aïllar i es van caracteritzar gens de la família MADS-box en $M$. truncatula. Aquests gens són factors de transcripció que participen en processos com ara el control del temps de floració, la determinació de la identitat del meristema floral o el desenvolupament d'òrgans florals, fruits i llavors. Hem estudiat 11 gens MADS-box: dos gens de classe B (MtTM6 i MtNMH7), tres gens de classe $\mathrm{C}$ (MtSHP, MtAGa i MtAGb), un gen de classe $E(M t S E P)$ i cinc gens que no formen part del model ABC (DE) (MtAGL6, MtAGL6-like, MtSOC1a, MtSOC1b i MtSOC1-like). Entre aquests gens, hem prestat una atenció especial a la caracterització funcional dels gens de classe C. Els patrons d'expressió dels gens aïllats es van estudiar mitjançant Northern blot i hibridació in situ, i es va observar que tots s'expressen en diferents teixits florals i/o diferents estadis de desenvolupament floral, encara que n'hi ha diversos que s'expressen també en teixits vegetatius, tal vegada complint un rang de funcions més ampli que la regulació dels esdeveniments del desenvolupament floral. Els resultats obtinguts conformen la base per a determinar les funcions d'aquests gens en el desenvolupament d'inflorescències, flors i fruits de $M$. truncatula.

$S^{\prime}$ ha descrit que diversos gens duplicats en Arabidopsis estan representats per un únic gen en $M$. truncatula i també que aquesta lleguminosa presenta duplicacions de gens que són únics en Arabidopsis. Aquest darrer fet succeeix amb els gens de classe $C$. En $M$. truncatula hem aïllat tres gens MADS-box que pertanyen a aquest llinatge: MtSHP, MtAGa i MtAGb; el primer és membre del llinatge PLE i els altres dos són membres del llinatge euAG. La duplicació en el llinatge euAG sembla que és específica de les espècies lleguminoses. Per això, investiguem si els gens paràlegs MtAGa i MtAGb exerceixen papers en l'especificació de la identitat dels òrgans florals i/o en la determinació del meristema floral, funcions descrites per als gens de classe $C$. Es van analitzar plantes transgèniques de $M$. trucatula amb construccions de RNA interferent $\mathrm{i}$ un mutant de pèrdua de funció $C$ etiquetat pel retrotransposó Tnt1. A més, utilitzant la tecnologia VIGS es van obtenir plantes de $M$. truncatula i de Pisum sativum (lleguminosa filogenèticament propera) amb pèrdua de funció dels gens $M t A G a / M t A G b$ i PsAGa/PsAGb, respectivament. També es van fer experiments de guany de funció mitjançant l'expressió constitutiva en el sistema heteròleg $A$. thaliana.

Els resultats del treball indiquen que $M t A G a$ i $M t A G b$ són gens de classe $C$ que, a més de tenir un grau alt de redundància funcional, s'han subfuncionalitzat, i han distribuït la funció $C$ ancestral entre tots dos paràlegs, de manera que MtAGa té un paper prioritari en la determinació del meristema floral, mentre que MtAGb juga un paper clau en l'especificació de la identitat dels òrgans reproductors florals. 

ÍNDICE

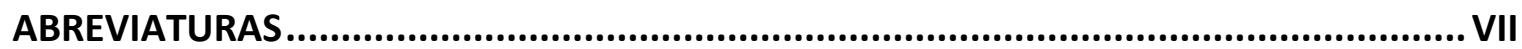

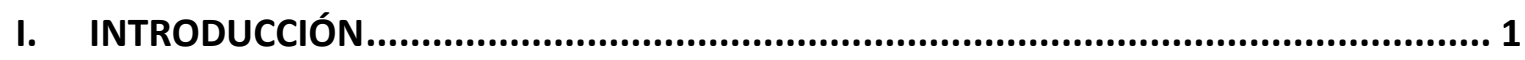

1. Las leguminosas: alta diversidad e importancia agronómica ................................... 4

1.1 Medicago truncatula como especie modelo ................................................. 6

2. El desarrollo floral en las especies modelo tradicionales y en las leguminosas .........8

2.1 Descripción de la inflorescencia y la ontogenia floral .................................. 8

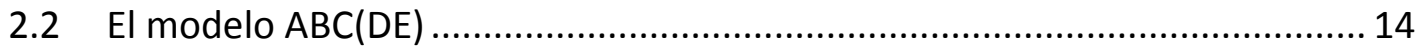

2.2.1 Genes de función A ........................................................................ 16

2.2.2 Genes de función B ..................................................................... 16

2.2.3 Genes de función C ................................................................. 17

2.2.4 Genes de función D .................................................................. 18

2.2.5 Genes de función E...................................................................... 18

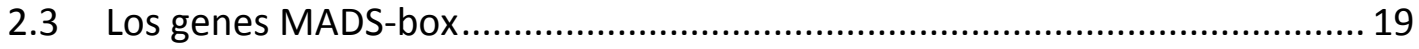

2.3.1 Clasificación y filogenia de los genes MADS-box ............................. 21

3. Los genes MADS-box y su implicación en la biología evolutiva del desarrollo de las plantas

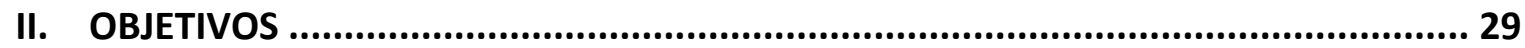

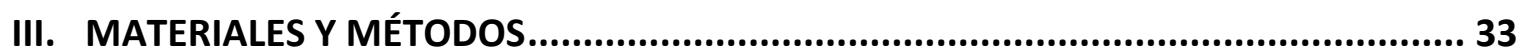

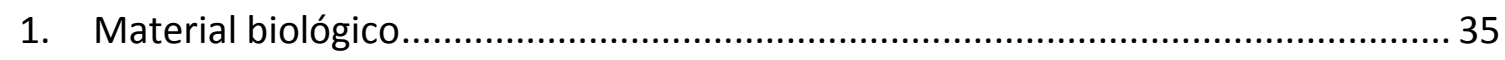

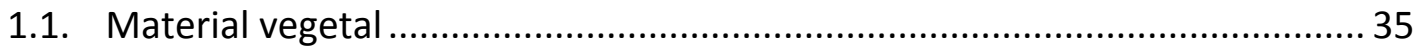

1.1.1. Condiciones de cultivo de las plantas ............................................. 35

1.1.1.1. Cultivo de Medicago truncatula............................................... 35

1.1.1.2. Cultivo de Pisum sativum ...................................................... 36

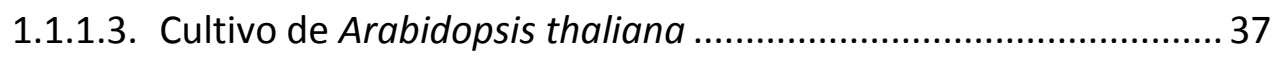

1.1.1.3.1. Cultivo en placas petri .................................................... 37

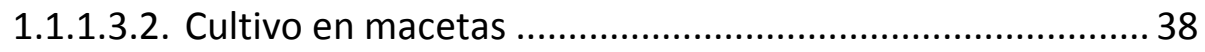

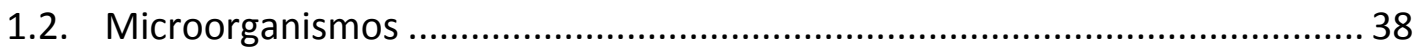




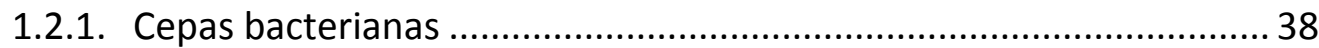

1.2.2. Condiciones de cultivo de microorganismos ..................................... 39

1.2.3. Medios de cultivo de microorganismos .......................................... 39

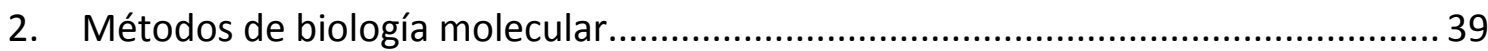

2.1. Aislamiento y purificación de ácidos nucleicos .............................................. 39

2.1.1. Aislamiento de DNA plasmídico de E. coli....................................... 39

2.1.2. Aislamiento de DNA plasmídico de A. tumefaciens ..............................40

2.1.3. Aislamiento y cuantificación de DNA genómico .............................. 40

2.1.4. Aislamiento de RNA total ............................................................. 41

2.2. Amplificación de DNA por reacción en cadena de la polimerasa (PCR) ......... 42

2.3. Técnicas de clonación ................................................................................... 43

2.3.1. Vectores plasmídicos utilizados ...................................................... 43

2.3.2. Digestiones del DNA con enzimas de restricción ............................... 43

2.3.3. Purificación de fragmentos de DNA de geles de agarosa .................. 44

2.3.4. Reacciones de ligación de DNA ...................................................... 44

2.4. Transformación de cepas bacterianas ........................................................... 44

2.4.1. Preparación de células competentes y transformación por

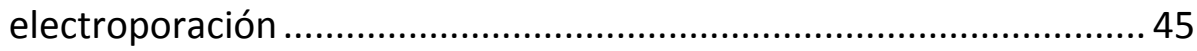

2.4.2. Selección de recombinantes bacterianos ........................................... 45

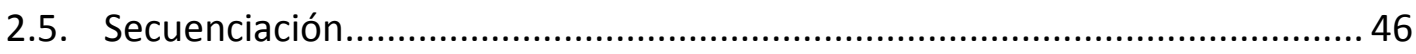

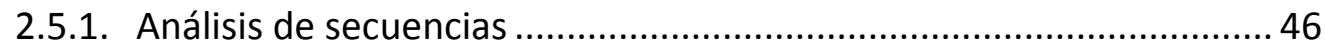

2.6. Escrutinio de genoteca de Medicago truncatula ......................................... 47

2.6.1. Titulación y rastreo de la genoteca .................................................. 47

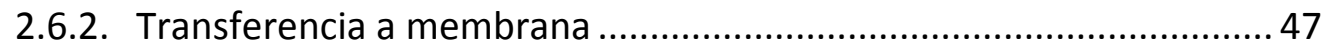

2.6.3. Síntesis de sondas radiactivas ...................................................... 47

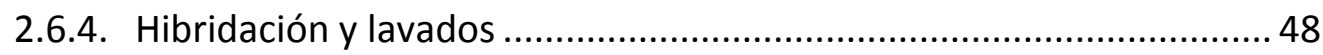

2.6.5. Detección de la señal: autorradiografía ........................................... 48

2.6.6. Identificación y aislamiento de clones positivos.............................. 48

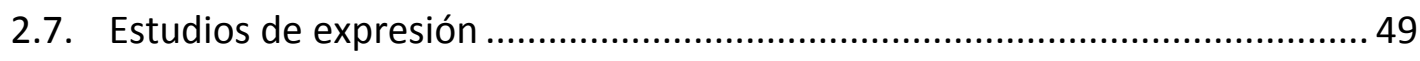

2.7.1. Análisis Northern blot y Southern blot ............................................. 49

2.7.1.1. Electroforesis de RNA y DNA para transferencia a membrana ... 49

2.7.1.2. Transferencia y fijación de RNA y DNA a membrana...................5 50 
2.7.1.3. Marcaje de sondas radiactivas .................................................. 50

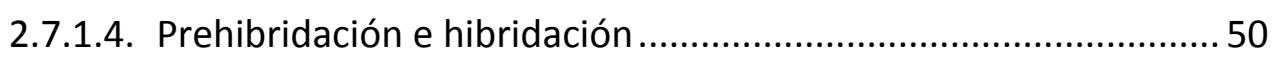

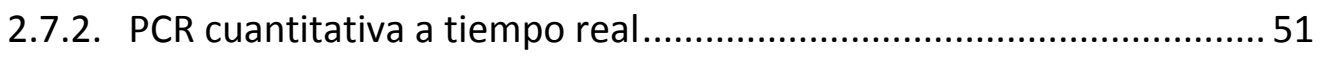

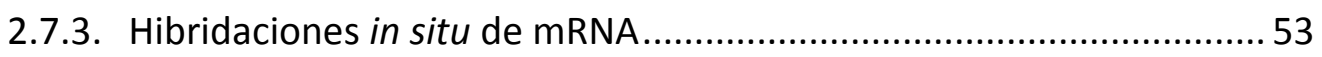

2.7.3.1. Generación de ribosondas marcadas con digoxigenina ...............53

2.7.3.2. Cuantificación de las sondas ................................................... 54

2.7.3.3. Preparación de las muestras .......................................................... 54

2.7.3.4. Prehibridación e hibridación ...................................................... 55

2.7.3.5. Inmunodetección colorimétrica de la señal............................... 56

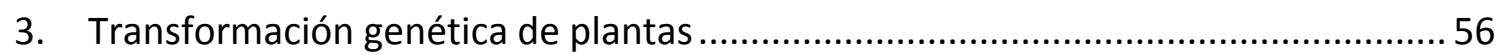

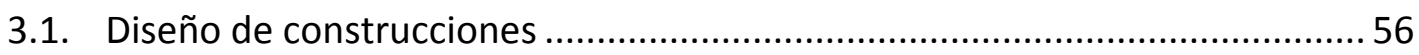

3.1.1. Construcciones generadas para el silenciamiento de los genes AGAMOUS de Medicago truncatula mediante RNA interferente .......56

3.1.2. Construcciones generadas para el silenciamiento de los genes AGAMOUS de Pisum sativum y Medicago truncatula mediante silenciamiento génico inducido por virus (VIGS) .............................. 58

3.1.3. Construcciones generadas para la expresión constitutiva de los genes AGAMOUS de Medicago truncatula en Arabidopsis thaliana.. 60

3.2. Transformación genética de plantas............................................................ 61

3.2.1. Transformación estable de Medicago truncatula.............................. 61

3.2.2. Transformación transitoria de Pisum sativum y Medicago truncatula.....

3.2.3. Transformación estable de Arabidopsis thaliana y análisis de

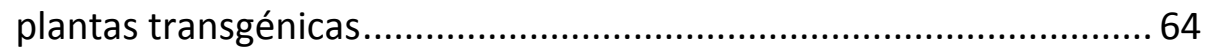

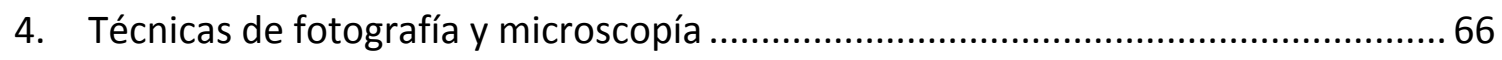

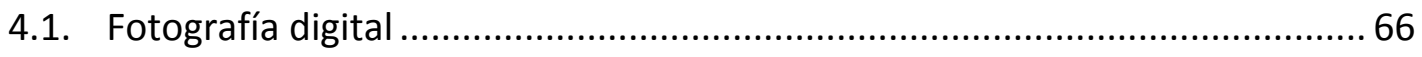

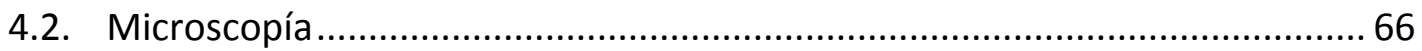

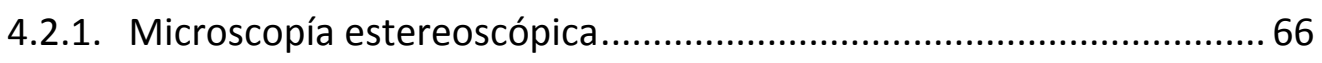

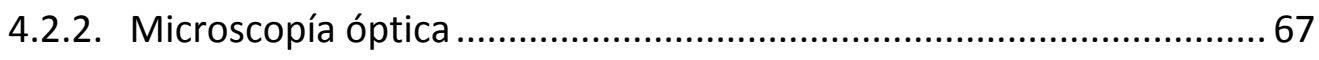

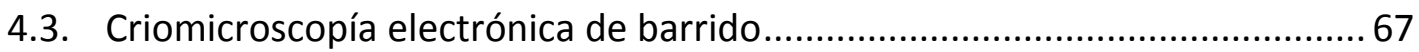




\section{CAPÍTULO I: Aislamiento y caracterización de miembros de la familia MADS-box} en Medicago truncatula.

1. Aislamiento y caracterización de miembros de la familia MADS-box en Medicago truncatula

1.1. Aislamiento de once clones diferentes con homología a genes MADS-box .. 75

1.2. MtSEP: un gen con homología a genes MADS-box del grupo AGL2 .............. 77

1.2.1. Aislamiento y análisis de secuencia de MtSEP ................................ 77

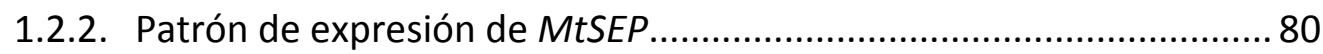

1.3. MtAGL6 y MtAGL6-like: genes con homología a genes MADS-box del grupo $A G L 6$.

1.3.1. Aislamiento y análisis de secuencia de MtAGL6 y MtAGL6-like ......... 83

1.3.2. Patrón de expresión de MtAGL6 y MtAGL6-like .................................. 88

1.3.2.1. Patrón de expresión de MtAGL6 ............................................... 89

1.3.2.2. Patrón de expresión de MtAGL6-like ......................................... 91

1.4. MtSOC1a, MtSOC1b y MtSOC1-like: genes con homología a genes MADSbox del grupo TDR3 (SOC1)

1.4.1. Aislamiento y análisis de secuencia de MtSOC1a, MtSOC1b y MtSOC1-like

1.4.2. Patrón de expresión de MtSOC1a, MtSOC1b y MtSOC1-like. 101

1.4.2.1. Patrón de expresión de MtSOC1a y MtSOC1b. 101

1.4.2.2. Patrón de expresión de MtSOC1-like 103

1.5. MtAGa, MtAGb y MtSHP: genes con homología a genes MADS-box del grupo $A G$

1.5.1. Aislamiento de MtAGa, MtAGb y MtSHP. 105

1.5.2. Análisis de secuencia de MtSHP.

1.5.3. Patrón de expresión de MtSHP

1.6. MtTM6 y MtNMH7: genes con homología a genes MADS-box del grupo $D E F / A P 3$

1.6.1. Aislamiento y análisis de secuencia de MtTM6 y MtNMH7

1.6.2. Patrón de expresión de MtTM6 y MtNMH7 
1.6.2.1. Patrón de expresión de MtTM6 121

1.6.2.2. Patrón de expresión de MtNMH7

DISCUSIÓN 125

1. MtSEP es el ortólogo de los genes SEP1/2 en Medicago truncatula 129

2. MtAGL6 es el ortólogo del gen AGL6 en Medicago truncatula 131

3. MtAGL6-like forma parte de un nuevo grupo génico exclusivo de leguminosas .. 134

4. MtSOC1a y MtSOC1b son ortólogos del gen integrador floral SOC1 135

5. MtSOC1-like es un gen del grupo TDR3/SOC1 que se expresa en tejido floral adulto

6. MtSHP: gen ortólogo de los genes SHP1/SHP2 con expresión en óvulos 138

7. MtTM6 y MtNMH7: genes de clase $\mathrm{B}$ originados por una duplicación génica, pertenecientes al linaje $A P 3 / D E F$.

V. CAPÍTULO II: Caracterización molecular y funcional de los genes MtAGa y MtAGb de Medicago truncatula

1. Caracterización molecular y funcional de los genes MtAGa y MtAGb de Medicago truncatula

1.1. Caracterización molecular de los genes MtAGa y MtAGb de Medicago truncatula

1.1.1. Análisis de las secuencias proteicas de MtAGa y MtAGb

1.1.2. Análisis de las secuencias genómicas de MtAGa y MtAGb

1.1.3. Análisis Southern blot.

1.1.4. Patrón de expresión de MtAGa y MtAGb 164

1.1.4.1. Patrón de expresión de MtAGa 164

1.1.4.2. Patrón de expresión de MtAGb 166

1.2. Caracterización funcional de los genes MtAGa y MtAGb de Medicago truncatula 168

1.2.1. Silenciamiento génico mediante RNA interferente 168

1.2.1.1. Fenotipo de las plantas transgénicas 35S::RNAi-MtAGb 172

1.2.1.2. Niveles de expresión de $M t A G a$ y $M t A G b$ en las plantas transgénicas 35S::RNAi-MtAGb 
1.2.2. Mutante mtagb: etiquetado por inserción del retrotransposón Tnt1

1.2.2.1. Caracterización molecular de la inserción y genotipado

1.2.2.2. Caracterización fenotípica del mutante $m \operatorname{tag} b$ 178

1.2.3. Silenciamiento génico inducido por virus (VIGS) 180

1.2.3.1. VIGS en Pisum sativum 181

1.2.3.2. VIGS en Medicago truncatula 189

1.2.4. Expresión constitutiva en plantas de Arabidopsis thaliana ... 193

1.2.4.1. Expresión constitutiva de MtAGa en plantas de Arabidopsis thaliana

1.2.4.2. Expresión constitutiva de $M t A G b S$ y $M t A G b L$ en plantas de Arabidopsis thaliana

DISCUSIÓN 205

1. MtAGa y MtAGb presentan homología estructural con genes de función C ........207

2. MtAGa y MtAGb funcionan como genes de clase $C$ 210

3. El umbral de expresión de $M t A G a$ y $M t A G b$ requerido para determinar el meristemo o para establecer la identidad de órgano floral es variable

4. MtAGa y MtAGb son genes duplicados parcialmente redundantes que se han subfuncionalizado adquiriendo papeles en diferentes aspectos de la función C.. 216

VI. CONCLUSIONES

VII. BIBLIOGRAFÍA

VIII. ANEXOS

1. Secuencia genómica amplificada que contiene la región codificante del gen MtAGa de Medicago truncatula.

2. Secuencia genómica amplificada que contiene la región codificante del gen MtAGb de Medicago truncatula 


\section{ABREVIATURAS}

${ }^{\circ} \mathrm{C}$

grado Celsius

$\mu \mathrm{Ci}$

microcurio

$\mu \mathrm{E}$

microeinstein

$\mu \mathrm{F}$

microfaradio

$\mu \mathrm{g}$

microgramo

$\mu \mathrm{L}$

microlitro

$\mu \mathrm{M}$

micromolar

Acc

número de acceso ("accession number")

ADH1

promotor alcohol deshidrogenasa 1 de maíz

Amp

ampicilina

ATP

mononucleótido trifosfato de adenosina

Basta

DL-fosfinotricina o PPT (“DL-phosphinothricin”)

BCIP 5-bromo-4-cloro-3-indolil-fosfato

BSA seroalbúmina de bovino

CaMV 355 promotor $35 \mathrm{~S}$ del virus del mosaico de coliflor

cDNA DNA complementario ("complementary DNA")

$\mathrm{cm}$

centímetro

$\mathrm{Ct}$

ciclo umbral ("cycle threshold")

C-terminal carboxilo terminal

CTP mononucleótido trifosfato de citosina

cv. cultivar

dir directo

DL día largo

DNA ácido desoxirribonucleico ("deoxyribonucleic acid")

dpi días post inoculación

DPP días post-polinización

EDTA ácido etilendiaminotetracético

EST marcador de secuencia expresada ("expressed sequence tag")

FAE formaldehído / ácido acético glacial / etanol 


\begin{tabular}{|c|c|}
\hline g & gramo \\
\hline GTP & mononucleótido trifosfato de guanidina \\
\hline $\mathrm{h}$ & hora \\
\hline Kan & kanamicina \\
\hline $\mathrm{kb}$ & kilobase \\
\hline kDa & kilodalton \\
\hline kV & kilovoltio \\
\hline L & litro \\
\hline lacz & $\beta$-galactosidasa \\
\hline LB & borde izquierdo ("left border") \\
\hline leu2 & leucina 2 \\
\hline Ix & lux \\
\hline $\mathrm{m}$ & metro \\
\hline M & molar \\
\hline MES & tampón ácido 2-(N-morfolino) etano sulfónico \\
\hline $\mathrm{mg}$ & miligramo \\
\hline $\mathrm{mL}$ & mililitro \\
\hline $\mathrm{mm}$ & milímetro \\
\hline $\mathrm{mM}$ & milimolar \\
\hline MOPS & tampón ácido 3-(N-morfolino) propano sulfónico \\
\hline MPM & marcador de peso molecular \\
\hline mRNA & RNA mensajero ("messenger RNA") \\
\hline NBT & nitroazul de tetrazolio \\
\hline ng & nanogramo \\
\hline NOS & terminador de la nopalin sintetasa \\
\hline$n p t / l$ & neomicina fosfotransferasa \\
\hline N-terminal & amino terminal \\
\hline OCS & terminador de la octopina sintetasa \\
\hline ORF & marco de lectura abierto ("open reading frame") \\
\hline $\mathrm{p} / \mathrm{v}$ & peso / volumen \\
\hline $\mathrm{pb}$ & pares de bases \\
\hline
\end{tabular}




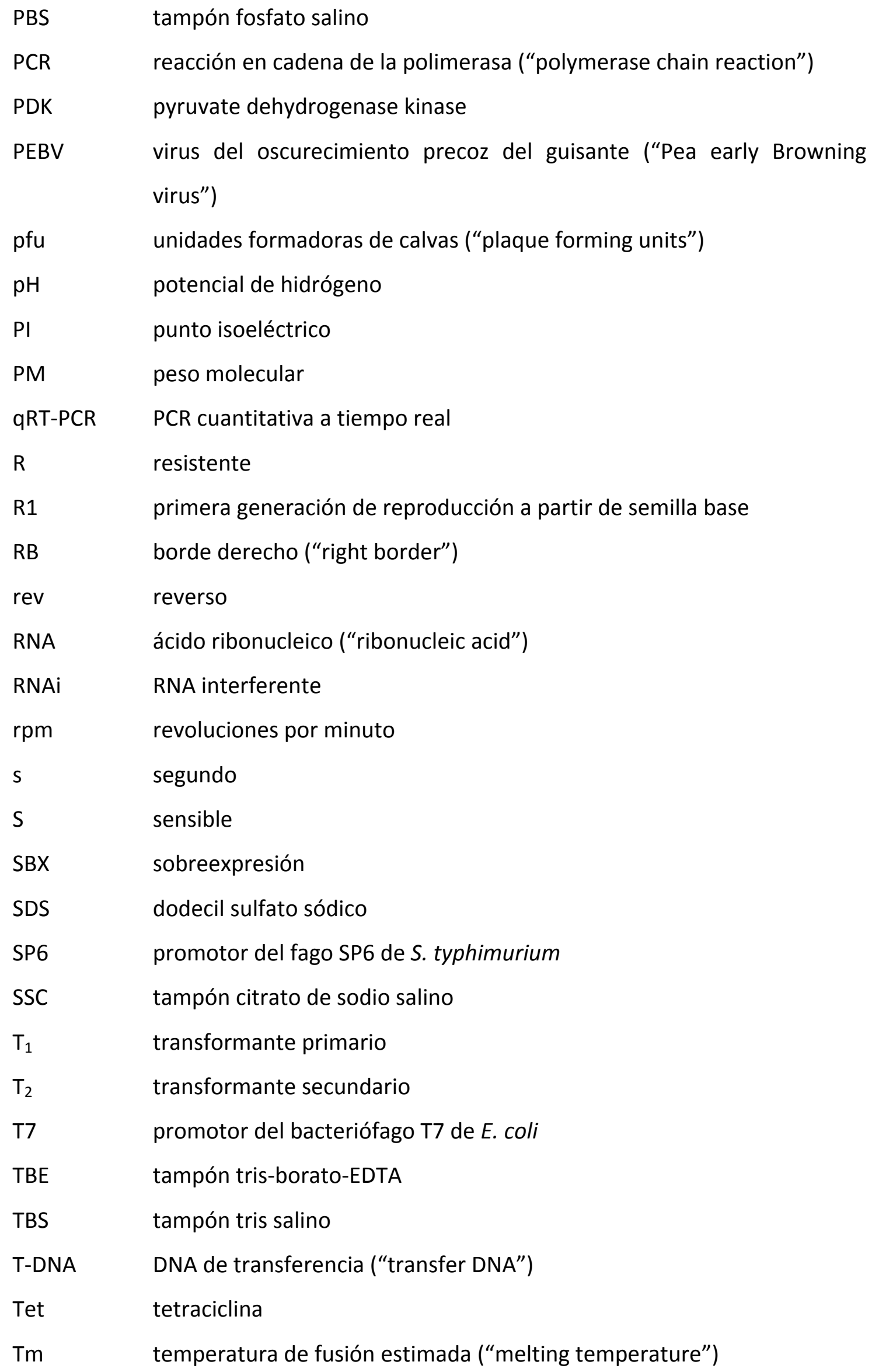




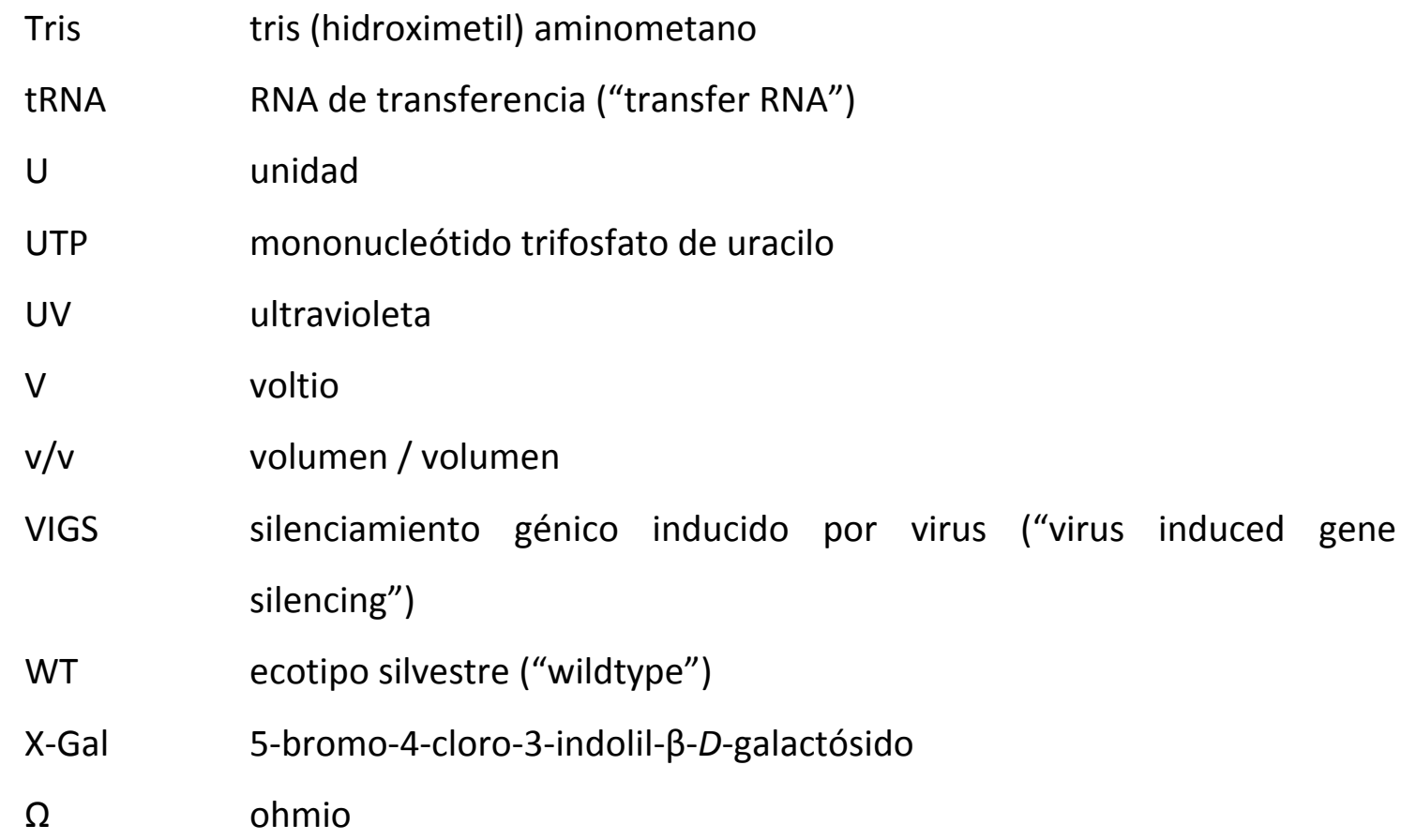


INTRODUCCIÓN 

La transición del desarrollo vegetativo al reproductivo es un cambio crítico en la vida de las plantas y la inducción, expresión y mantenimiento del estado floral están regulados por muchos factores exógenos y endógenos. Diversos estudios han demostrado la importancia de la luz (por ejemplo, en el fotoperiodo o en el efecto de la calidad de la luz) y la temperatura (por ejemplo, en la vernalización) como reguladores ambientales de la floración. Además, son importantes otros factores como el nivel de nutrientes, las hormonas endógenas, el estrés y el estadio de desarrollo de la planta.

El proceso de floración ha sido sometido a análisis genéticos detallados en la planta modelo Arabidopsis thaliana y los resultados obtenidos han sido importantes para el esbozo de las rutas genéticas que controlan las respuestas florales a fotoperiodo, vernalización o estímulos hormonales (Amasino, 2004; Boss et al., 2004; Putterill et al., 2004). Con el aumento de recursos genéticos disponibles en varias plantas modelo, la información obtenida en Arabidopsis thaliana y Antirrhinum majus se ha ido extendiendo a otras especies. La secuenciación de genomas completos ha permitido la comparación de las rutas de floración entre Arabidopsis thaliana y otras especies. También se ha descrito la filogenia de familias génicas relacionadas con la floración y/o el estudio funcional de genes en especies como Oryza sativa (arroz), Hordeum vulgare (cebada), Solanum lycopersicum (tomate), Petunia hybrida (petunia) o Antirrhinum majus, entre otras (Carmel-Goren et al., 2003; Griffiths et al., 2003; Hayama et al., 2003; Vandenbussche et al., 2003b). Sin embargo, se conoce poco a nivel genético sobre los procesos de floración en leguminosas, a pesar de la importancia que tienen en los sistemas de producción de estas plantas.

Las leguminosas, tanto las modelo como las de cultivo, presentan gran diversidad en la arquitectura de sus inflorescencias y periodo de vida, así como en su respuesta frente al fotoperiodo o la temperatura. Sin embargo, estudios genéticos, fisiológicos y moleculares de la floración de Pisum sativum (guisante) han mostrado que las rutas de floración básicas están conservadas. Además, una gran proporción de genes de floración de Arabidopsis thaliana están representados en estas especies, así que es razonable el uso de genes de Arabidopsis para identificar posibles ortólogos en leguminosas (revisado por Hecht et al., 2005). 


\section{LAS LEGUMINOSAS: ALTA DIVERSIDAD E IMPORTANCIA AGRONÓMICA}

Las leguminosas (Leguminosae o Fabaceae), con más de 670 géneros y cerca de 20.000 especies (Polhill et al., 1981, Lewis et al., 2005), son la tercera familia más grande de plantas angiospermas. Estas plantas crecen en condiciones agro-ecológicas muy variables y su morfología varía desde diminutas hierbas hasta árboles forestales gigantescos. Desde la época Neolítica, las leguminosas han sido un componente esencial de los sistemas agronómicos (Zohary y Hopf, 2000) y actualmente son el segundo grupo de plantas en importancia agronómica tras las gramíneas (Doyle, 2001), considerando la producción total y el área de cosecha.

Entre los diferentes cultivos, las leguminosas son las únicas plantas capaces de fijar el nitrógeno atmosférico mediante una relación endosimbiótica con bacterias rizobias o micorrizas (Jensen y Haugaard-Nielsen, 2003; Hirsch, 2004), la cual ocurre en una estructura especializada conocida como nódulo. Esta simbiosis provee a las leguminosas (y a los cultivos que se sembrarán tras ellas) de una fuente gratuita y renovable de nitrógeno, que es el principal nutriente limitante en la producción de cultivos (Seastedt y Knapp, 1993; Vitousek et al., 1997; Smil, 1999).

El papel central de las leguminosas en la agricultura no es sorprendente, ya que además de su contribución a la fertilidad de los suelos, las semillas de estas plantas presentan altos contenidos de proteína (entre $20 \%$ y $50 \%$ ), conformando la mayor fuente de proteína vegetal para la alimentación humana y animal. Las leguminosas de grano por si solas aportan hasta el $33 \%$ de las necesidades proteicas de la dieta humana (Vance et al., 2000; Graham y Vance, 2003).

Las leguminosas de consumo más importantes son la judía común (Phaseolus vulgaris L.), el caupí (Vigna unguiculata L.), el gandul (Cajanus cajan L. Millsp.), el garbanzo (Cicer arietinum L.), el haba (Vicia faba L.), la lenteja (Lens culinaris Medik.), la soja verde (Vigna radiata L. Wilczek), la judía adzuki (Vigna angularis Willd. Ohwi \& Ohashi) y el guisante (Pisum sativum L.). La soja (Glycine max L. Merr.) y el cacahuate (Arachis hipogea L.) son las mayores fuentes de aceite vegetal. Las leguminosas forrajeras incluyen la alfalfa (Medicago sativa L.), trébol (Trifolium pratense L.) y cuernecillo (Lotus corniculatus L.) (revisado en Singh et al., 2007). 
Las leguminosas forrajeras han sido la base de la producción cárnica y láctea desde hace siglos (Russelle, 2001). Sin embargo, además de los usos tradicionales como alimento y forraje, las leguminosas son una excelente fuente de madera y aceites y se han utilizado industrialmente para preparar plásticos biodegradables (Paetau et al., 1994), gomas, tintes, resinas, barnices y productos eco-amigables como el etanol o el diesel de soja (revisado en Singh et al., 2007).

Otra propiedad de las leguminosas que las hace especialmente interesantes es que sintetizan un gran número de productos secundarios con actividad biológica de interés, incluyendo isoflavonas y saponinas triterpénicas (Andersen et al., 1984; Grusak, 2002; Madar y Stark, 2002). Se ha descrito que el consumo regular de leguminosas puede ayudar a prevenir enfermedades cardiovasculares, hepáticas, Parkinson, Alzheimer o Huntington (Singh 2005, Singh et al., 2007).

Los taxónomos han dividido a las leguminosas en tres grandes subfamilias basándose en rasgos morfológicos, particularmente de la estructura floral. Estas subfamilias se conocen como Papilionoideae (476 géneros y cerca de 14.000 especies), Caesalpinioideae (162 géneros y cerca de 3000 especies) y Mimosoideae (77 géneros y aproximadamente 3000 especies) (Doyle y Luckow, 2003).

Las Papilionoideae son la subfamilia numéricamente dominante y representan gran parte de las leguminosas económicamente importantes, especialmente en alimentación humana y animal, y comprenden aproximadamente el $40 \%$ de las variaciones fenotípicas de todas las leguminosas (Gepts et al., 2005). Esta subfamilia se divide en dos clados (Wojciechowski, 2003), conocidos como Hologalegina (leguminosas "de invierno" o "de clima templado") y Millettioide (leguminosas "de verano" o "de clima tropical") (Figura 1). Se ha demostrado que existen altos niveles de sintenia a nivel genómico entre las especies de invierno, como Medicago truncatula, Lotus japonicus y Pisum sativum (Kalo et al., 2004) o entre las especies de verano como Phaseolus vulgaris o Glycine max (Lee et al., 2001).

Los niveles elevados de sintenia entre Medicago truncatula, Lotus japonicus y muchas leguminosas económicamente importantes apoyan la elección de estas dos especies como plantas modelo para el estudio de las leguminosas. Estas plantas modelo se están utilizando para buscar respuesta a cuestiones biológicas exclusivas de las leguminosas (Somers et al., 2003), como la base molecular de la fijación de nitrógeno o las rutas 
metabólicas que llevan a la producción de determinados metabolitos secundarios. Lo más importante en el estudio de estas plantas modelo es la posibilidad de extender los conocimientos obtenidos a cultivos de interés económico y/o agronómico.

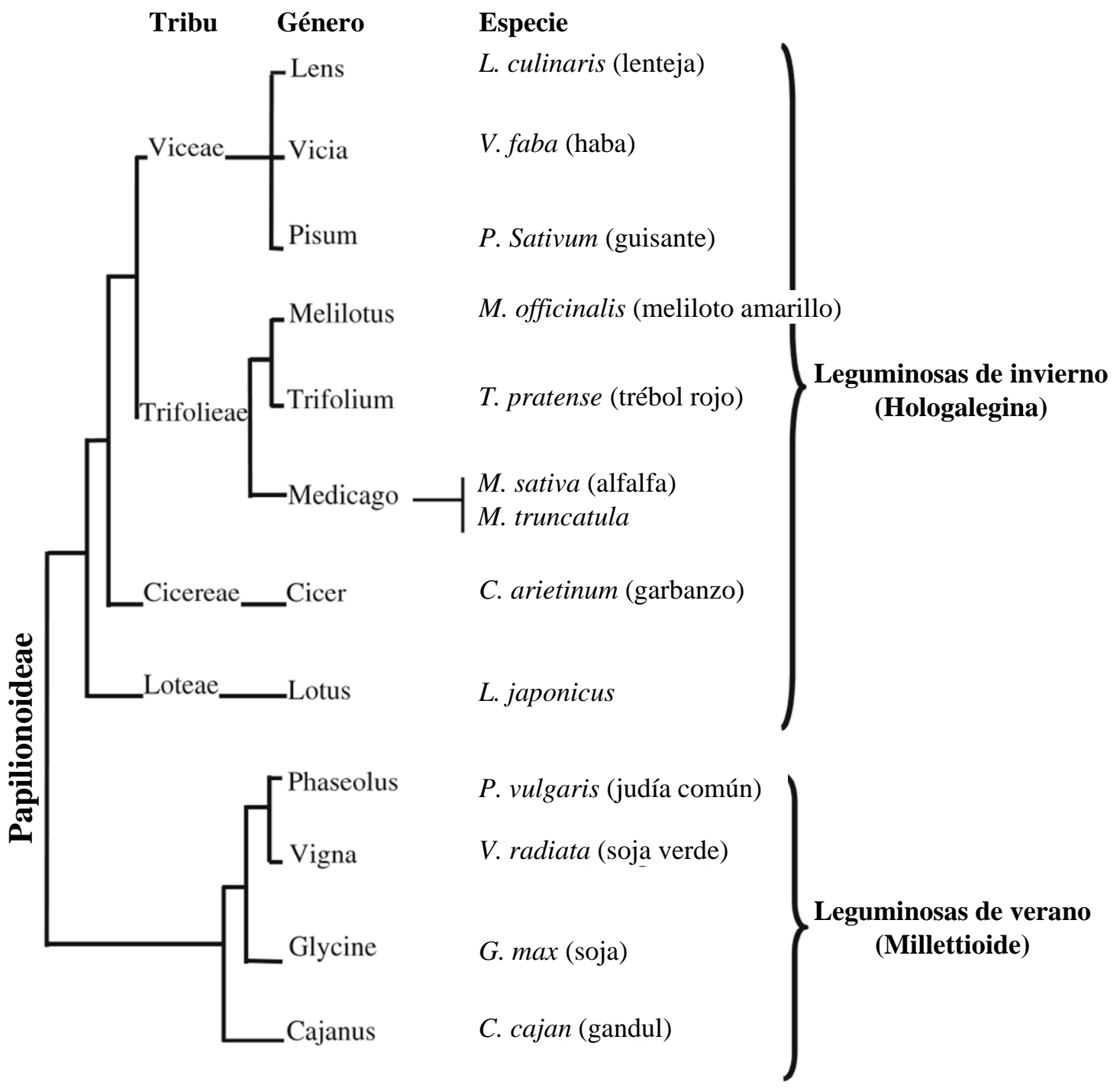

Figura 1. Árbol filogenético de las especies de interés contenidas en la subfamilia Papilionoideae. Se observa la división en los clados Hologalegina y Millettioide. Imagen adaptada de Nayak et al. (2010).

\subsection{Medicago truncatula COMO ESPECIE MODELO}

Medicago truncatula (Figura 2) es una leguminosa forrajera anual que se cultiva comúnmente en Australia, aunque se originó en la cuenca Mediterránea, donde aún puede encontrarse (Crawford et al., 1989). Está estrechamente relacionada con la leguminosa forrajera más importante a nivel mundial, la alfalfa (Medicago sativa) y ha llamado la atención como sistema modelo genómico y molecular para estudios 
biológicos de las leguminosas (Cook, 1999; Oldroyd y Geurts, 2001), debido a sus características peculiares: genoma pequeño ( $\sim 500-550 \mathrm{Mpb})$ y diploide $(2 n=16)$, ciclo de vida corto (2-3 meses), autofecundación, posibilidad de transformación genética y existencia de grandes colecciones de diferentes ecotipos (Young y Udvardi, 2009).
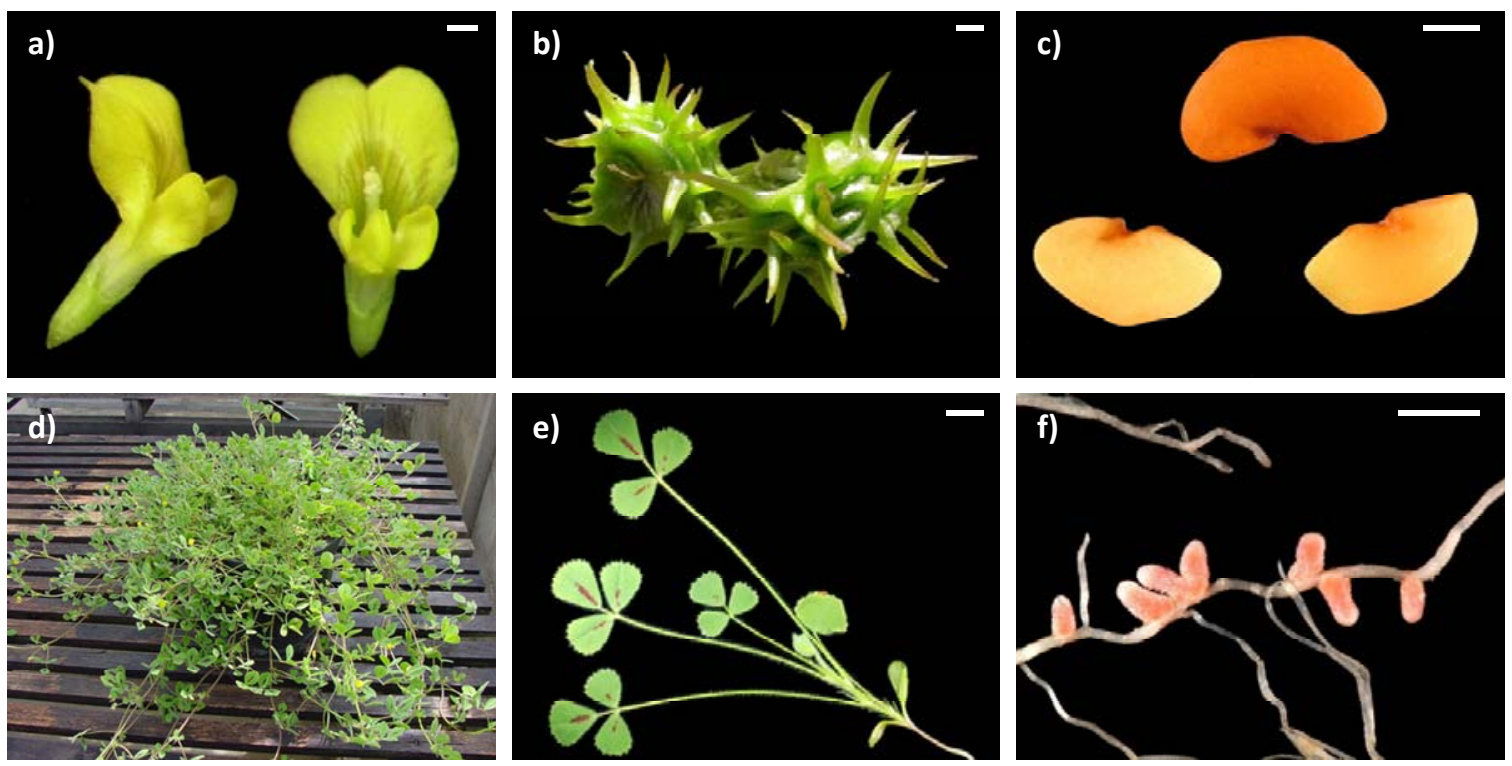

Figura 2. Medicago truncatula. a) Flor. b) Frutos. c) Semillas. d) Planta entera. e) Hojas. f) Nódulos. Las barras indican $1 \mathrm{~mm}$ en a y c; $5 \mathrm{~mm}$ en b y f y $1 \mathrm{~cm}$ en e. Fotografías de Joanna Serwatowska (a); Peter Greenwoods (b); Ninjatacoshell (c, e y f) y http://www1.montpellier.inra.fr (d).

Medicago truncatula es un modelo valioso para el estudio de muchos aspectos de la biología de las leguminosas que son únicos para esta familia de plantas. Cuestiones importantes de simbiosis, patogénesis, biología de las semillas, desarrollo radicular, metabolismo secundario (Oldroyd y Geurts, 2001) y últimamente genómica, transcriptómica, proteómica y metabolómica (Benedito et al., 2008; Repetto et al., 2008; Farag et al., 2008) se están estudiando en esta planta modelo.

Además, el género Medicago está relacionado con un buen número de leguminosas de cultivo importantes como la alfalfa, guisante, haba, garbanzo, lenteja, trébol, lotus, soja y judía común (Doyle et al., 1996). Es notable el alto nivel de macrosintenia entre Medicago truncatula y Pisum sativum, aunque el genoma del segundo sea diez veces mayor que el de la primera (Young et al., 2005).

Medicago truncatula es una planta modelo con un despliegue impresionante de herramientas genéticas. Hay cerca de 270,000 EST (“Expressed sequence tags” o 
marcadores de secuencia expresada) depositados en GenBank (noviembre, 2011) y un GeneChip de Affymetrix ${ }^{\circledR}$ con aproximadamente 51,000 sets de prueba para genes de esta planta. Este chip es la base de un atlas de expresión génica recientemente desarrollado (Benedito et al., 2008).

Para la genética reversa, Medicago truncatula tiene disponibles poblaciones mutantes caracterizadas con inserciones de Tnt1 (Tadege et al., 2008), de bombardeo con neutrones rápido ("Fast neutron bombardment" o FNB) (Starker et al., 2006) y TILLING ("target-induced local lesions in genomes") (Cook, unpublished). También puede realizarse el silenciamiento génico basado en RNA interferente (Limpens et al., 2004) y se están haciendo avances en el silenciamiento génico transitorio mediado por virus ("virus induced gene silencing" o VIGS) (Grønlund et al., 2008). Finalmente, Medicago truncatula es diana de la iniciativa internacional BAC-by-BAC de secuenciación del genoma, cuya finalización es inminente (http://www.medicagohapmap.org).

Con todas estas herramientas disponibles, Medicago truncatula está lista para proveer una gran riqueza en descubrimientos genómicos para la comunidad de investigación aplicada a las leguminosas.

\section{EL DESARROLLO FLORAL EN LAS ESPECIES MODELO TRADICIONALES Y EN LAS LEGUMINOSAS}

\subsection{DESCRIPCIÓN DE LA INFLORESCENCIA Y LA ONTOGENIA FLORAL}

La arquitectura de la inflorescencia en especies modelo como Arabidopsis thaliana o Antirrhinum majus es relativamente simple: tras la transición floral, el meristemo apical del tallo produce un meristemo inflorescente que forma flores solitarias, sustentadas o no por brácteas. Las inflorescencias de Medicago truncatula son muy similares a las de Pisum sativum y otras leguminosas (Tucker, 1989; Ferrándiz et al., 1999). Presentan un mayor grado de complejidad que las inflorescencias de Arabidopsis thaliana y Antirrhinum majus ya que, tras la transición floral, el meristemo apical del tallo se convierte en un meristemo inflorescente primario que diferencia lateralmente meristemos inflorescentes secundarios. Estos últimos dan lugar a un número variable de 
flores antes de terminar en un órgano residual llamado "spike" (Figura 3, Ferrándiz et al., 1999; Benlloch et al., 2003).

a)

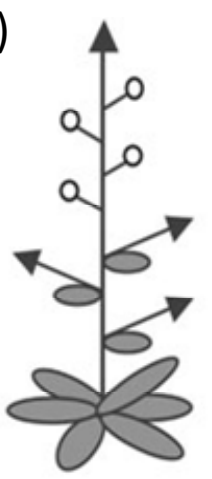

Arabidopsis thaliana

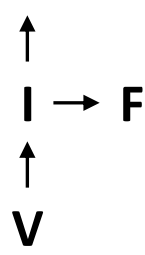

b)

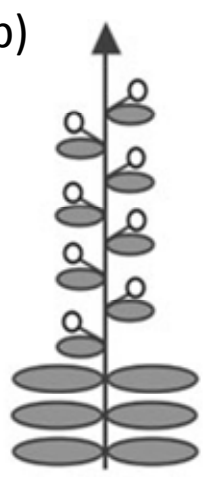

Antirrhinum majus

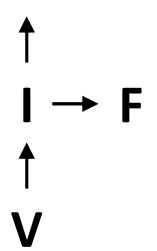

c)

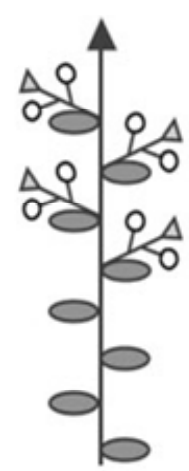

Medicago truncatula

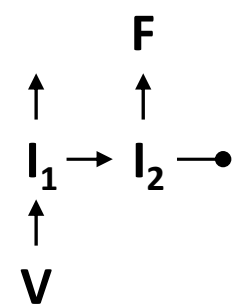

Figura 3. Esquema comparativo de la arquitectura de diferentes inflorescencias. a) Arquitectura de la inflorescencia de Arabidopsis thaliana. b) Arquitectura de la inflorescencia de Antirrhinum majus. c) Arquitectura de la inflorescencia de Medicago truncatula. V, Meristemo vegetativo; I, Meristemo inflorescente; $l_{1}$, Meristemo inflorescente primario; $I_{2}$, Meristemo inflorescente secundario; $F$, Meristemo floral. La terminación $(\longrightarrow$ ) indica el agotamiento del meristemo inflorescente en un órgano residual. Imagen adaptada de Benlloch, R., Tesis Doctoral (2005) y Benlloch et al. (2007).

Idealmente, una flor contiene cuatro tipos de órganos florales organizados en cuatro verticilos (revisado en Soltis et al., 2007). La mayoría de las flores de leguminosas de la subfamilia Papilionoideae presentan este tipo de estructura; poseen un primer verticilo con cinco sépalos, un segundo verticilo con cinco pétalos, un tercer verticilo compuesto por diez estambres y un cuarto verticilo conformado por un carpelo (Tucker, 2003). No obstante, los órganos que conforman estas flores presentan morfologías características que las distinguen de las flores de las otras subfamilias de leguminosas.

La flor de Medicago truncatula, en la cual se ha realizado la mayoría de estudios de esta Tesis Doctoral, presenta una morfología y ontogenia que recuerdan a las de otras leguminosas modelo como Pisum sativum o Lotus japonicus (Tucker, 1989; Ferrandiz et al., 1999; Benlloch et al., 2003). Los cinco sépalos de Medicago truncatula están fusionados por su base formando un tubo con los lóbulos libres. La corola presenta tres tipos de pétalos: un estandarte o "vexillum", que es el más grande y está situado en 
posición adaxial, dos pétalos laterales llamados alas o "alae" y dos pétalos cortos fusionados por el margen formando la quilla en posición abaxial. Los diez primordios de estambres se inician en dos verticilos contiguos de cinco primordios cada uno, los cuales se reorientan en un solo verticilo cuando se alarga el receptáculo (Tucker, 2003). Es en ese momento cuando nueve estambres fusionan sus filamentos formando un tubo estaminal que rodea al carpelo y el décimo (en posición adaxial) permanece libre. El carpelo es subsésil y el estilo está flexionado en el extremo distal, encajado en el interior de la quilla. Una particularidad del género Medicago es que, tras la fertilización, el ovario crece girando helicoidalmente y forma una vaina con espinas que contiene las semillas (Benlloch et al., 2003).

Los estudios de ontogenia de las flores de las especies modelo Medicago truncatula, Pisum sativum y Lotus japonicus han mostrado que existen diferencias morfológicas sustanciales entre las flores de las Papilionoideae y las flores de muchas otras plantas eudicotiledóneas como Arabidopsis thaliana o Antirrhinum majus (Figura 4).

En las flores de Arabidopsis thaliana y Antirrhinum majus los órganos del mismo verticilo se inician simultáneamente y los verticilos se inician secuencialmente, esto es, no solapan en el tiempo de iniciación (Smyth et al., 1990; Sommer et al., 1990). En la mayoría de las Papilionoideae la iniciación de los primordios de los diferentes tipos de órganos florales transcurre de manera unidireccional (desde las posiciones abaxiales hacia las adaxiales), con un alto grado de solapamiento entre diferentes verticilos (Benlloch et al., 2003; Dong et al., 2005). Este solapamiento es extremo en el caso de Medicago truncatula y Pisum sativum (Ferrándiz et al., 1999; Benlloch et al., 2003). También es característica la iniciación temprana del carpelo. En Arabidopsis thaliana o Antirrhinum majus este órgano es el último en aparecer, mientras que en Medicago truncatula y Pisum sativum el primordio de carpelo puede verse en el centro del meristemo floral muy prematuramente (Benlloch et al., 2003).

Otra diferencia es el verticilo heterogéneo que presentan especies como Medicago truncatula, Pisum sativum o Lotus japonicus. Antes de la iniciación de los primordios de pétalos y estambres, se forman unos "primordios comunes" a ambos órganos. Estos primordios comunes darán lugar a los primordios de pétalos y estambres (Ferrándiz et al., 1999; Benlloch et al., 2003; Dong et al., 2005). Este tipo de primordios comunes han sido descritos también en diversas especies leguminosas y no leguminosas (Sattler, 
1967; Sundberg, 1982; Tucker, 1984; 1987; 1989; Ronse et al., 1993; Kamenetsky y Akhmetova, 1994; Delaet et al., 1995; Evans y Dickinson, 1996; Kirchoff, 1997). Sin embargo, en la mayoría de las demás leguminosas Papilionoideae (por ejemplo, Lupinus affinis [Tucker, 1984] o Melitolus alba [Hirsch, 2002]), así como en la mayoría de las eudicotiledóneas, los pétalos y estambres se inician individualmente a partir de verticilos diferentes. Así pues, los primordios comunes son bastante raros entre las leguminosas y probablemente representan una especialización evolutiva (Tucker, 2003).

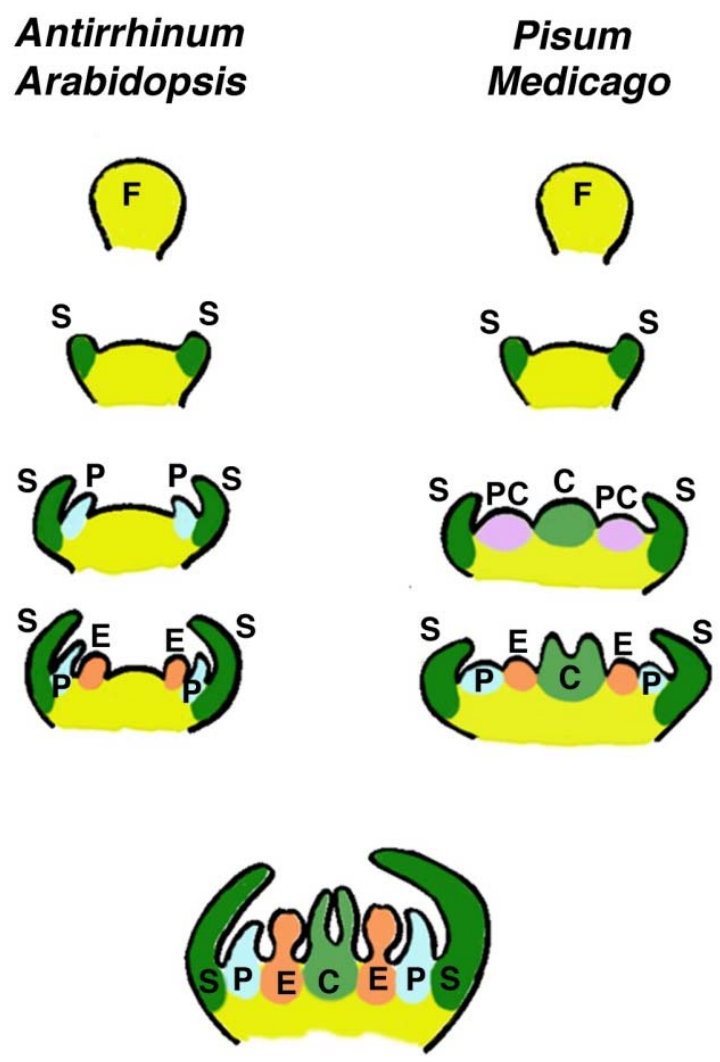

Figura 4. Esquema de las diferencias en la ontogenia floral de Pisum sativum y Medicago truncatula con otras especies modelo. Los rasgos característicos en estas especies leguminosas son: la iniciación abaxial-adaxial de los primordios y el solapamiento entre distintos órganos; la iniciación temprana del carpelo y la aparición de los primordios comunes que diferenciarán estambres y pétalos. $F$, Meristemo floral; S, Sépalo; P, Pétalo; PC, Primordio común; E, Estambre; C, Carpelo. Figura extraída de Benlloch, R., Tesis Doctoral (2005).

En cuanto a la caracterización de la ontogenia floral en leguminosas, se han publicado numerosos trabajos en diversas especies (Tucker, 2003). Tanto en Medicago truncatula como en Pisum sativum la ontogenia floral transcurre de acuerdo con los siguientes estadios (Figura 5, Ferrándiz et al., 1999; Benlloch et al., 2003):

- ESTADIO 1: El meristemo inflorescente primario diferencia lateralmente un meristemo inflorescente secundario y un primordio de hoja.

- ESTADIO 2: El meristemo inflorescente secundario diferencia lateralmente uno, dos o tres meristemos florales. 

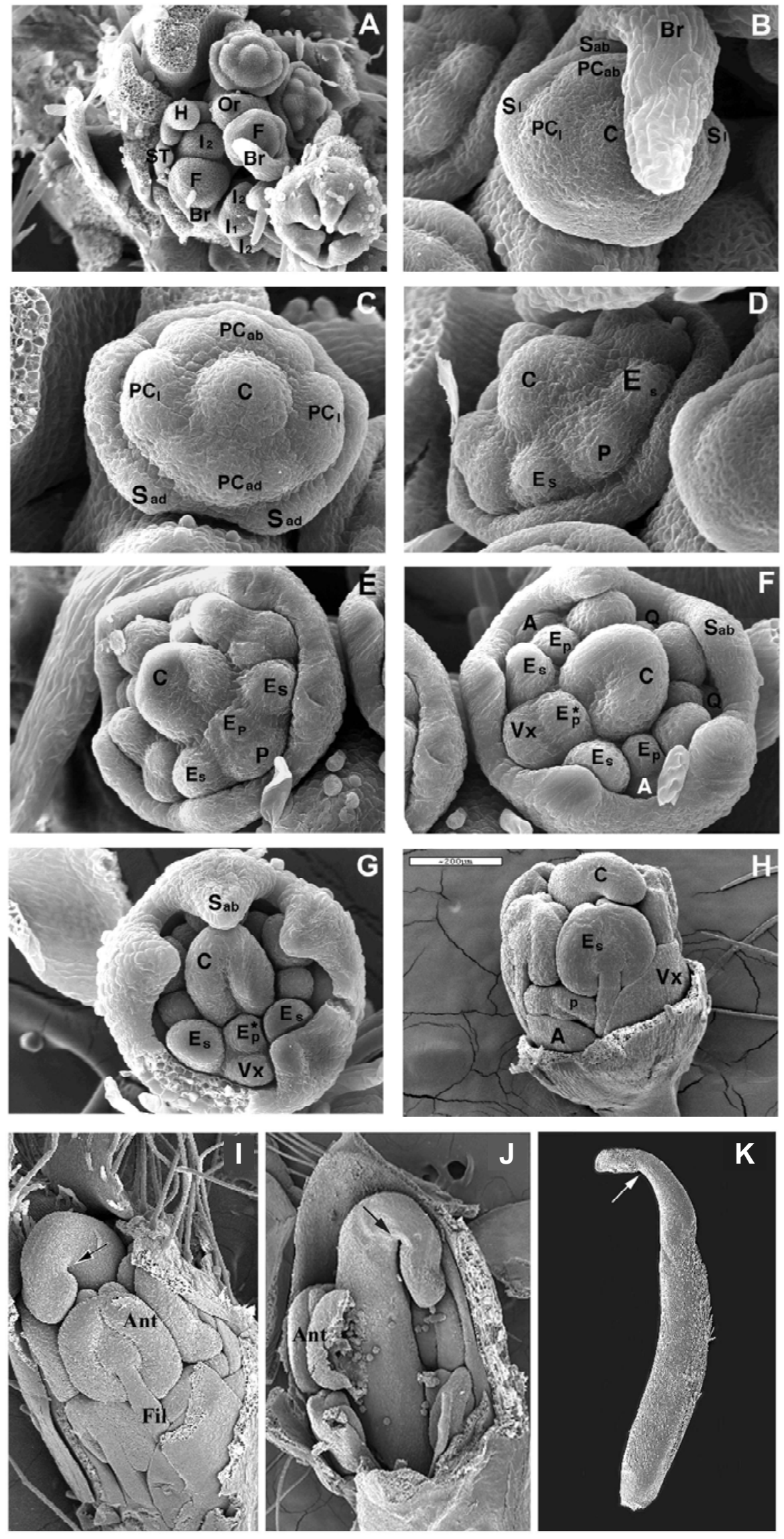

Figura 5.Ontogenia de la flor silvestre de Medicago truncatula. 
- ESTADIO 3: El meristemo floral produce un meristemo de sépalo en posición abaxial y a continuación dos primordios de sépalos laterales.

- ESTADIO 4: Se forman los cuatro primordios comunes. Aparece el último primordio de sépalo en la zona adaxial, seguido del primordio común abaxial y el primordio del carpelo en la zona central del meristemo. A continuación aparecen los primordios comunes laterales y finalmente el primordio común adaxial.

- ESTADIO 5: Los primordios comunes diferencian tempranamente a los pétalos y los estambres antesépalos. Este proceso ocurre de manera secuencial desde la zona abaxial hacia la zona adaxial del meristemo. En este estadio tardío se diferencian los estambres antepétalos, comenzando por los abaxiales y el último estambre en diferenciarse es el estambre adaxial que permanece libre.

- ESTADIO 6: Los sépalos crecen cubriendo el resto de los primordios de órganos florales. Los estambres comienzan a diferenciar los filamentos y las anteras.

- $\quad$ ESTADIO 7: Los pétalos adquieren su forma característica. Los dos pétalos que forman la quilla se fusionan. El estilo y el estigma están doblados sobre el ovario. Los estambres se han diferenciado.

- ESTADIO 8: Se forma el tubo estaminal. El carpelo se desdobla y crece.

Figura 5. Ontogenia de la flor silvestre de Medicago truncatula. A) Ápice floral silvestre. Estadios 1 y 2: el meristemo inflorescente primario ha diferenciado dos meristemos inflorescentes secundarios; $\mathrm{El}$ meristemo inflorescente secundario se encuentra sustentado por una hoja. B) Estadio 3: el meristemo floral ha desarrollado una bráctea y diferencia los primeros primordios de órganos florales. C) Estadio 4: se forman los cuatro primordios comunes y se inician los primordios de sépalos adaxiales. D) Estadio 5 temprano: los primordios comunes empiezan a diferenciar los órganos de segundo y tercer verticilo. Se diferencian los primordios de pétalos y estambres antesépalos. E) y F) Estadio 5 tardío: los primordios comunes diferencian estambres antepétalos. El último estambre en diferenciarse es el estambre vexilar que permanece libre. G) estadio 6: los sépalos crecen y cubren a los demás órganos florales. H) Estadio 7: Empiezan a diferenciarse las formas de los pétalos. Los estambres han diferenciado anteras y filamentos. I) y J) Estadio 8: crecen los filamentos de los estambres. El carpelo permanece flexionado (flecha) y encajado dentro de la quilla. K) Tras la polinización y durante la antesis el carpelo se desdobla quedando completamente estirado. $I_{1}$, Meristemo inflorescente primario; $I_{2}$, Meristemo inflorescente secundario; $H$, Hoja; F, Meristemo floral; Br, Bráctea; $\mathrm{S}_{\mathrm{ab}}$, Or, Spike; Sépalo abaxial; $\mathrm{S}_{\mathrm{l}}$, Sépalo lateral; $\mathrm{PC}_{\mathrm{ab}}$, Primordio común abaxial; $P C_{1}$, Primordio común lateral; $C$, Carpelo; $\mathrm{S}_{\mathrm{ad}}$, Sépalo adaxial; $\mathrm{PC}_{\mathrm{ad}}$, Primordio común adaxial; $P$, Pétalo; $E_{s}$, Estambre antesépalo; $E_{p}$, estambre antepétalo; $E_{p}{ }^{*}$, estambre antepétalo libre; $V x$, Vexillum; A, Ala; Q, Quilla, Ant, Antera; Fil, Filamento. La barra representa $150 \mu \mathrm{m}$ en A; $50 \mu \mathrm{m}$ en B, C, D, E y F; $60 \mu \mathrm{m}$ en G; $250 \mu \mathrm{m}$ en I y J; 1,5 mm en K. Imagen adaptada de Benlloch, R., Tesis Doctoral (2005). 
Como ha podido observarse, la evidencia sugiere que los mecanismos moleculares que subyacen al proceso de la ontogenia floral en las leguminosas Papilionoideae varían hasta cierto punto de los mecanismos que rigen la ontogenia floral en otras eudicotiledóneas.

\subsection{EL MODELO ABC (DE)}

Las flores son uno de los productos más exitosos en la evolución de las plantas desde su aparición en el periodo cretáceo temprano. Por otra parte, los mecanismos moleculares que controlan la especificación de los órganos florales suelen estar bastante conservados entre las especies (Soltis et al., 2002).

A inicios de la década de los '90, partiendo de análisis genéticos y moleculares realizados en varios mutantes homeóticos de las especies modelo Arabidopsis thaliana y Antirrhinum majus (Schwarz-Sommer et al., 1990; Coen y Meyerowitz, 1991; Weigel y Meyerowitz, 1994), se propuso un modelo simple y elegante que explica cómo unos cuantos genes actúan juntos para especificar la identidad de los cuatro tipos de órganos florales que forman una flor eudicotiledónea típica (Coen y Meyerowitz, 1991). Este modelo, conocido como el modelo $A B C$, propone que existen tres funciones, $A, B$ y $C$ (cada una definida por una clase de mutante homeótico de Arabidopsis thaliana o Antirrhinum majus), que especifican el tipo de órgano que se forma en cada uno de los cuatro verticilos de la flor. Las funciones A, B y C ocupan cada una dos verticilos adyacentes, los cuales solapan entre sí de tal manera que cada verticilo está definido por la expresión de una única combinación de funciones (Figura 6).

La expresión de la función C en el cuarto verticilo da lugar a la formación de carpelos, en el tercer verticilo se expresan las funciones B y C especificando la formación de estambres, los pétalos se forman en el segundo verticilo debido a la expresión conjunta de las funciones A y B y, finalmente, la expresión de la función A en el primer verticilo resulta en la formación de sépalos. La represión mutua entre las funciones $A$ y $C$ completa el modelo (revisado por Causier et al., 2010). 
a)

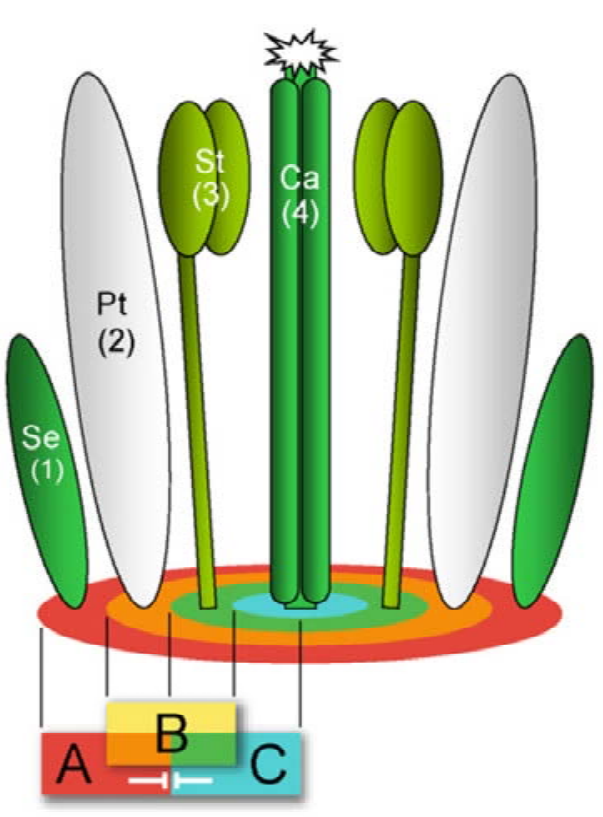

b)

Silvestre
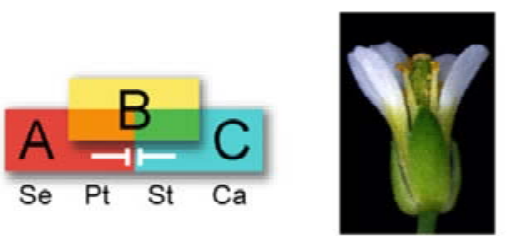

c)
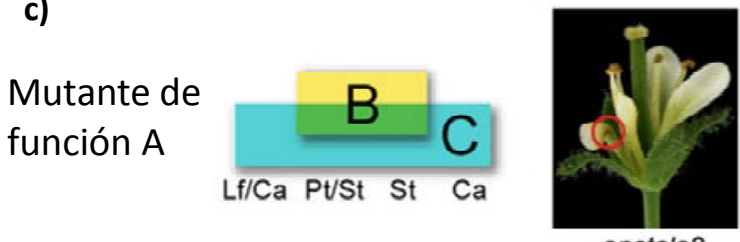

apetala2

d)

Mutante de función $B$
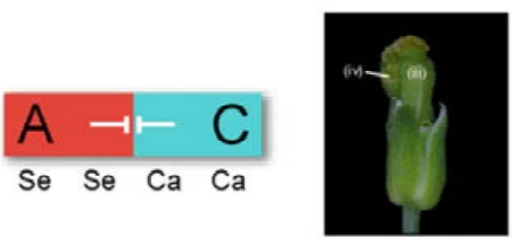

pistillata

e)

Mutante de función $\mathrm{C}$

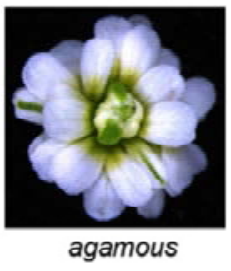

Figura 6. Modelo $A B C$ clásico. a) Diagrama de flor modelo con sépalos (Se) en el primer verticilo, pétalos $(\mathrm{Pt})$ en el segundo, estambres (St) en el tercero y carpelos ( $\mathrm{Ca}$ ) en el cuarto. Bajo la flor se encuentra el modelo $A B C$. En el primer verticilo se expresan los genes de función A (rojo). En el segundo verticilo se coexpresan los genes de función A y B (naranja). En el tercer verticilo los genes de función B (amarillo) y C (azul) actúan juntos (verde), mientras que en el cuarto verticilo solo actúa la función $C$. El modelo $A B C$ propone la represión mutua entre las funciones $A$ y $C$, como se indica mediante líneas truncadas. b - e) Mutantes de Arabidopsis thaliana a partir de los cuales se propuso el modelo ABC. b) Flor silvestre. c) Mutante de función A apetala2 en el cual los sépalos están convertidos en estructuras carpeloides o foliares (dependiendo del alelo) y los pétalos en estructuras tipo estambre (el círculo marca una antera en el segundo verticilo). d) Mutante de clase b pistillata. Los dos primeros verticilos presentan identidad de sépalo y el tercer verticilo está convertido en carpelo. Se observa como los carpelos del tercer verticilo (iii) atrapan a los carpelos del cuarto verticilo (IV). e) Mutante de clase C agamous. Se presenta conversión de órganos reproductivos (estambres y carpelos) en órganos de periantio (sépalos y pétalos) y pérdida de determinación floral, generando un fenotipo "una flor dentro de otra". Imagen adaptada de Causier et al. (2010).

Posteriormente, en 1995, se añadió al modelo la función D para especificar la identidad de los óvulos, los cuales subsecuentemente se consideraron como órganos separados (Colombo et al., 1995). En 2000, los genes de clase E se integraron al modelo como cofactores que son coresponsables de la identidad de los tres verticilos internos (Pelaz et al., 2000; Theissen y Saedler, 2001; Robles y Pelaz, 2005). El modelo resultante se conoce como modelo "ABCDE" (Figura 7). 


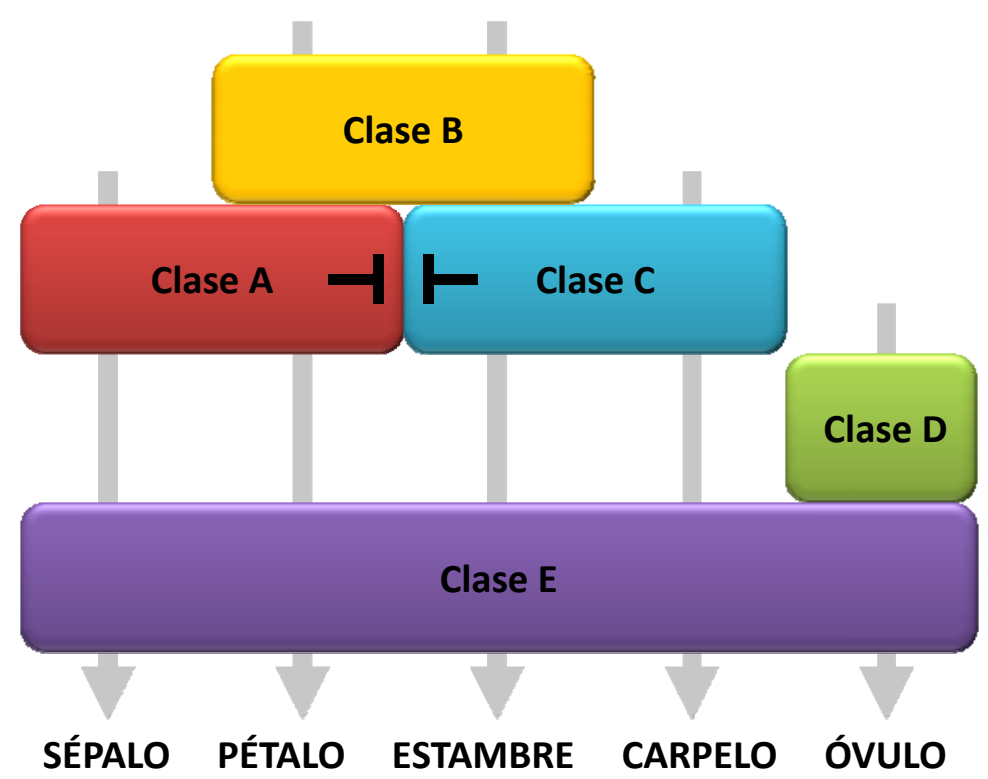

Figura 7. Modelo ABCDE. Las distintas clases de genes especifican de manera combinatoria los diferentes órganos florales. Además, las clases A y C se regulan antagónicamente. Imagen adaptada de LeebensMack et al. (2005).

\subsubsection{Genes de función A}

En Arabidopsis thaliana, la función A se ha atribuido a dos genes: APETALA1 (AP1) y APETALA2 (AP2) (Mandel et al., 1992b; Jofuku et al., 1994). En los mutantes de estos genes, los sépalos están transformados en órganos tipo hoja o bráctea (o desarrollan características carpeloides) y los pétalos están ausentes o transformados en estructuras tipo estambre.

En leguminosas se han aislado homólogos funcionales de AP1 en Medicago truncatula (MtAP1; Benlloch, R., Tesis Doctoral, 2005) y Pisum sativum (PEAM4; Ferrándiz, C., Tesis Doctoral, 1996; Navarro, C., Tesis Doctoral, 2001; Berbel, A., Tesis Doctoral, 2002; Berbel et al., 2001) cuya expresión en sépalos y pétalos concuerda con su función en la especificación de la identidad de estos órganos. Además, estos genes están implicados en el proceso de iniciación floral en estas leguminosas. Lotus japonicus presenta dos homólogos de AP1, LjAP1a y LjAP1b, ambos con un patrón de expresión similar al de los genes arriba mencionados (Dong et al., 2005).

\subsubsection{Genes de función B}

Tanto Arabidopsis thaliana como Antirrhinum majus contienen dos genes de función B: APETALA3 (AP3) y PISTILLATA (PI); DEFICIENS (DEF) y GLOBOSA (GLO), respectivamente, los cuales se requieren para especificar la identidad de pétalos y 
estambres en los verticilos segundo y tercero. Todos sus mutantes simples presentan las mismas transformaciones homeóticas de pétalos en sépalos y de estambres en carpelos (Tröbner et al., 1992; Goto y Meyerowitz, 1994).

En Medicago truncatula se han descrito dos genes parálogos homólogos a PI, MtPI y MtNGL9 (Benlloch, R., Tesis Doctoral, 2005). MtPI podría haber mantenido un papel predominante en el desarrollo de los pétalos y estambres, mientras que MtNGL9 podría estar involucrado en el desarrollo de los nódulos de raíz, al igual que su ortólogo en Medicago sativa, MsNGL9 (Zucchero et al., 2001). En Pisum sativum se aisló el gen PsPI que contribuye a la especificación de la identidad de pétalos y estambres (Berbel, A., Tesis Doctoral, 2002; Berbel, et al., 2005). En Lotus japonicus se han descrito dos ortólogos de PI (LjPla y LjPIb) y uno de AP3 (LjAP3), todos específicos de pétalos y estambres (Dong et al., 2005) y en Glycine max se han aislado secuencias homólogas a PI y a AP3 (Hecht et al., 2005).

\subsubsection{Genes de función C}

En Arabidopsis thaliana, el gen de función C AGAMOUS $(A G)$ está involucrado en la especificación del desarrollo de los órganos reproductores femeninos y masculinos y en la regulación de la determinación del meristemo floral (Yanofsky et al., 1990; Lenhard et al., 2001). El mutante de este gen presenta cambio de identidad de estambres a pétalos y de carpelos a sépalos (Bowman et al., 1989). Dos genes adicionales, SHATTERPROOF1 y 2 (SHP1 y SHP2), comparten funciones redundantes en la especificación de la zona de dehiscencia y funcionan con $A G$ en el desarrollo del carpelo (Liljegren et al., 2000; Pinyopich et al., 2003).

En Pisum sativum se ha descrito un gen ortólogo a AG, PsMADS7, cuyo patrón de expresión y fenotipo de expresión constitutiva en Arabidopsis thaliana apuntan a un gen de función C (Navarro, C., Tesis Doctoral, 2001). Se ha aislado una secuencia homóloga a este gen en Medicago truncatula (Hecht et al., 2005). En Lotus japonicus, en cambio, se han descrito dos genes homólogos a $A G, L j A G a$ y $L j A G b$, que presentan patrones de expresión similares durante la ontogenia floral: inicialmente se expresan en el centro del meristemo floral y posteriormente su expresión se restringe a los primordios de estambres (Dong et al., 2005). Se ha aislado un ortólogo de SHP1/2 en Pisum sativum, PSMADS8, que presenta expresión en tercer y cuarto verticilo y cuyo fenotipo de 
expresión constitutiva en Arabidopsis thaliana apoya la hipótesis de que es un gen de función C (Navarro, C., Tesis Doctoral, 2001). También existen secuencias homólogas a SHP1/2 en Medicago truncatula, Lotus japonicus y Glycine max (Hecht et al., 2005; Cheung et al., unpublished).

\subsubsection{Genes de función D}

Hay un gen de función D en Arabidopsis thaliana, SEEDSTICK (STK). Este gen está involucrado en el desarrollo del óvulo y se requiere para la dispersión de las semillas cuando el fruto madura. En la promoción de la identidad del óvulo, STK actúa redundantemente con SHP1, SHP2 y AG (Pinyopich et al., 2003). Ya que los genes de función D pertenecen a la misma subfamilia que los genes de función $C$ y varios genes de función C comparten funciones con los de clase D en el desarrollo del óvulo, los genes de función D podrían considerarse como genes de función C más especializados (Rijpkema et al., 2010).

Únicamente se ha descrito la existencia de secuencias homólogas a STK en Medicago truncatula y Glycine max (Hecht et al., 2005).

\subsubsection{Genes de función $\mathrm{E}$}

Las proteínas codificadas por los genes de función E actúan como mediadores en la formación de complejos proteicos entre las proteínas B, C y D (Melzer et al., 2009; Immink et al., 2009). La función E en Arabidopsis thaliana está codificada por la subfamilia de genes SEPALLATA (SEP), la cual consta de cuatro genes: SEPALLATA1, 2, 3 y 4 (SEP1, SEP2, SEP3 y SEP4; Pelaz et al., 2000). Los cuatro genes muestran un alto grado de redundancia funcional, aunque han demostrado alguna diversificación en sus funciones (Favaro et al., 2003).

Se ha descrito PSMADS6, el ortólogo de SEP1/2 en Pisum sativum, gen de identidad de órgano floral de tipo SEP que además parece estar implicado en el proceso de iniciación floral de esta planta (Berbel, A., Tesis Doctoral, 2002). Se han aislado secuencias homólogas en Medicago truncatula y Glycine max (Hecht et al., 2005). También en Pisum sativum se aisló un ortólogo de SEP3, PSMTF1, importante en el establecimiento de la identidad de pétalos, estambres y carpelos y para la determinación del meristemo floral (Buchner y Boutin, 1998). Se han aislado secuencias 
homólogas en Medicago truncatula, Lotus japonicus y Glycine max. A día de hoy, solo en Lotus japonicus se ha encontrado una secuencia homóloga a SEP4 (Hecht et al., 2005).

Las enormes similitudes en la regulación de las funciones B y C entre Arabidopsis thaliana y Antirrhinum majus llevaron a asumir la aplicabilidad universal del modelo $A B C$ (revisado por Rijpkema et al., 2010). Sin embargo, aunque se espera que el modelo sea parcialmente válido en leguminosas, se requiere la caracterización funcional de ortólogos $A B C$ para determinar cómo este modelo puede usarse para explicar el diseño único de las flores de estas plantas (Dong et al., 2005).

\subsection{LOS GENES MADS-box}

Entre los primeros genes $A B C$ clonados están el gen de clase $B D E F$ de Antirrhinum majus (Sommer et al., 1990) y el gen de clase C AG de Arabidopsis thaliana (Yanofsky et al., 1990). Los productos de estos genes presentan alta homología con los dominios de unión a DNA de los factores de transcripción identificados en Saccharomyces cerevisiae (MINICHROMOSOME MAINTENANCE 1, MCM1; Sprague, 1990) y Homo sapiens (SERUM RESPONSE FACTOR, SRF; Norman et al., 1988). Así, estas cuatro proteínas se convirtieron en miembros fundadores de una gran familia de factores de transcripción conocida como "MADS-box" (MCM1, AG, DEF, SRF; Schwarz-Sommer et al., 1990). A excepción de algunos genes de clase A, como APETALA2 (AP2) de Arabidopsis thaliana, todos los genes de identidad de órgano floral que han sido caracterizados molecularmente pertenecen a la familia de genes MADS-box (revisado por Becker y Theissen, 2003)

Los miembros de la familia génica MADS-box codifican factores de transcripción que juegan papeles fundamentales en el control del desarrollo y la transducción de señales en los eucariotes (revisado por Becker y Theissen, 2003). La familia génica MADS-box puede dividirse en dos linajes principales, llamados tipo I y tipo II, ambos presentes en plantas, animales y hongos. Todos los miembros de la familia poseen una secuencia de aproximadamente 180 pb, llamada caja MADS (Alvarez-Buylla et al., 2000a), la cual codifica el dominio que es responsable de la localización nuclear, unión a DNA, unión de "factores accesorios" y dimerización de estos factores de transcripción (Theissen et al., 2000; Ng y Yanofsky, 2001; Immink et al., 2002). Excepto por la caja MADS, los genes de tipo I no comparten similitud de secuencia con los genes de tipo II (de Bodt et al., 2003). 
A este último linaje es al que pertenecen todos los genes MADS-box caracterizados que contribuyen al desarrollo de las plantas (revisado por Becker y Theissen, 2003).

En las plantas, los genes MADS-box de tipo II se conocen como genes "MIKC" (Münster et al., 1997), ya que sus proteínas presentan una organización estructural conservada (Figura 8) que incluye los dominios MADS (M), Intervening (o región intermedia, I), Keratin-like (K) y C-terminal (C) (Ma et al., 1991; Theissen et al., 1996; Hasebe y Banks, 1997; Münster et al., 1997). El dominio MADS es el mayor determinante en la unión a DNA, mientras que la región I es un factor molecular para la formación selectiva de dímeros de unión a DNA (Riechmann y Meyerowitz, 1997), el dominio K permite la formación de hélices anfipáticas involucradas en la dimerización de las proteínas (Ma et al., 1991; Shore y Sharrocks, 1995) y el dominio C-terminal, la región más variable en secuencia y longitud, está involucrado en la activación transcripcional o en la formación de complejos multiméricos (Cho et al., 1999; Egea-Cortines et al., 1999).

\begin{tabular}{|l|l|l|l|l|}
\hline $\mathrm{N}$ & MADS & $\mathrm{I}$ & $\mathrm{K}$ & $\mathrm{C}$ \\
\hline
\end{tabular}

Figura 8. Estructura de las proteínas MADS-box de tipo MIKC. Se muestran las distintas regiones de la proteína. El dominio MADS (el más conservado) junto con la región intermedia I media la unión a DNA. EI dominio $\mathrm{K}$ media interacciones proteína-proteína. El dominio terminal C (el más divergente) contiene en algunos casos un dominio de activación de la transcripción.

En el caso de los genomas de monocotiledóneas se han aislado 61 genes MADS-box en Zea mays (Soderlund et al., 2009) y 75 en Oryza sativa (Arora et al., 2007), mientras que el número total de genes MADS-box en eudicotiledóneas va desde 105 en Populus trichocarpa (Leseberg et al., 2003) y 107 en Arabidopsis thaliana (Pařenicová et al., 2003), hasta 212 en Glycine max (Schmutz et al., 2010). Hasta el momento se han identificado 22 genes MADS-box de tipo MIKC en Medicago truncatula (Hecht et al., 2005). El número de factores de transcripción de dominio MADS puede ser mucho más alto debido, por ejemplo, al splicing alternativo (Lightfoot et al., 2008). Sin embargo, solo hay evidencia limitada de que este fenómeno sea de importancia funcional para los genes MADS-box en las plantas. 
La mayoría de los genes implicados en el modelo $A B C$ tienen historias evolutivas complejas, las cuales pueden correlacionarse con diferencias en el desarrollo floral. Estos genes presentan duplicaciones frecuentes y pérdidas que afectan desde el taxón entero de angiospermas hasta un pequeño número de especies (Litt y Kramer, 2010). Tras la duplicación, las copias génicas pueden tomar diferentes caminos: mantener la función en una copia y perder la función en la otra; neofuncionalización (una o ambas copias adoptan una función nueva) o subfuncionalización (partición de la función original entre las dos copias) (Prince y Pickett, 2002). Varios candidatos a estudios de neofuncionalización o subfuncionalización se encuentran entre los genes MADS-box. También se han descrito grupos de genes redundantes (Alvarez-Buylla et al., 2000a), los cuales pueden estar en vías de neofuncionalización o subfuncionalización.

Entre las duplicaciones más notables de los genes MADS-box está la que coincide con el origen de las eudicotiledóneas superiores (Kramer et al., 1998, 2004; Litt e Irish, 2003; Zahn et al., 2005a). El surgimiento de esta clase está acompañado por duplicaciones en casi todos los linajes $A B C D E$ de genes: $A P 1, A P 3, A G$ y SEP. La duplicación de los genes homeóticos florales, seguida por la modificación de sus patrones de expresión, puede haber jugado un papel crucial en la diversificación de la función de estos genes y, más ampliamente, en la evolución de las flores (Ferrario et al., 2004).

\subsubsection{Clasificación y filogenia de los genes MADS-box}

Tras la propuesta del modelo $A B C$ se identificaron más genes MADS-box y comenzaron a estructurarse las relaciones filogenéticas entre ellos. Estos genes pueden subdividirse en diferentes "clados" o "subfamilias génicas", cada uno conteniendo ortólogos de diferentes especies de plantas y nombrado según el primer miembro identificado en dicho clado (Theissen et al., 1996; de Bodt, 2003). Se han definido filogenéticamente 14 clados denominados: AG, AGL2 (SEP), AGL6, AGL12, AGL15, AGL17 (ANR1), DEF (AP3), FLC, GGM13 (TT16), GLO, TM8, SQUA (AP1), STMADS11 (SVP) y TDR3 (SOC1). Todos los genes MIKC caracterizados hasta ahora son miembros de alguno de estos clados (Becker y Theissen, 2003).

Los genes de clase A, B, C, D y E conocidos hasta ahora se localizan en clados separados: SQUA (clase A), DEF y GLO (clase B), AG (clases C y D) y AGL2 (clase E) (Doyle, 1994; Purugganan et al., 1995; Theissen y Saedler, 1995; Angenent y Colombo, 1996; 
Theissen et al., 1996, 2000; Münster et al., 1997). Aquí se incluyen también los genes homeóticos florales de leguminosas aislados hasta la fecha (Hecht et al., 2005). Los miembros del mismo clado tienden a tener patrones de expresión similares (Theissen et al., 1996), aunque esta correlación es más estricta en los genes involucrados en la formación de flores que en los genes que se expresan en otros tejidos (Becker y Theissen, 2003).

Además de proveer funciones homeóticas florales, los genes MADS-box tienen muchos otros papeles en las redes génicas que dirigen el desarrollo reproductivo en las eudicotiledóneas (revisado por Becker y Theissen, 2003). Existen también genes MADSbox que se transcriben fuera de las flores y los frutos, así como gran número de mutantes y plantas transgénicas que sugieren que varios miembros de esta familia juegan papeles reguladores también durante el desarrollo vegetativo, como en el desarrollo de embriones, raíces u hojas (por ejemplo, Ma et al., 1991; Rounsley et al., 1995; Huang et al., 1995; Alvarez-Buylla et al., 2000a; Theissen et al., 2000). Todos estos genes se localizan en los demás clados que componen la filogenia de los genes MADSbox. En lo que respecta a las leguminosas, no se han aislado secuencias pertenecientes a los clados AGL12, AGL15, TM8, GGM13 ni FLC en Medicago truncatula, Glycine max ni Lotus japonicus (Hecht et al., 2005). Los primeros cuatro clados no están bien estudiados, pero el clado FLC en Arabidopsis thaliana contiene varios genes con un papel en la regulación del tiempo de floración (Boss et al., 2004). FLC es el gen mejor caracterizado de este clado y es el represor central de la floración y un mediador importante de la respuesta a vernalización (Boss et al., 2004).

La función de los genes del clado AGL6 en Arabidopsis thaliana (AGL6 y AGL13) no se ha demostrado, pero tanto estos como otros genes relacionados en otras especies se expresan en órganos florales y óvulos (Rounsley et al., 1995; Immink et al., 2003) y pueden influir en la floración al ser expresados ectópicamente (Carlsbecker et al., 2004).

Se han aislado dos genes pertenecientes a este clado en Pisum sativum: PsMADS5 y PSMADS3). PSMADS5 es un gen MADS-box de expresión específicamente floral y temprana durante el desarrollo de la flor, mientras que PsMADS3 es un gen con expresión en tejidos florales y además en tejidos vegetativos, excepto en raíz, por lo que se ha relacionado con procesos diferentes al desarrollo floral (Ferrandiz, C., Tesis 
Doctoral, 1996). Solo se han identificado ESTs en Medicago truncatula y Glycine max (Hecht et al., 2005).

EI gen SUPPRESSOR OF OVEREXPRESSION OF CONSTANS 1 (SOC1) se identificó como gen relacionado con la floración en Sinapis alba (Menzel et al., 1996) y se mostró que es una diana directa de regulación por CONSTANS (CO, Samach et al., 2000), además de tener un papel importante en la integración de señales de fotoperiodo, giberelinas y vernalización (Moon et al., 2003). En Arabidopsis thaliana hay cinco miembros más en el clado SOC1, cuyas funciones aún se desconocen. Sin embargo, AGL14, uno de ellos, se expresa en raíces (Rounsley et al., 1995), sugiriendo que no todos los miembros de este clado tienen un papel en la floración.

Se han identificado tres ESTs de Medicago truncatula pertenecientes a este clado, de los cuales uno es un claro homólogo de SOC1. También existe un homólogo en Glycine max y hay dos secuencias relacionadas a SOC1 en Pisum sativum (SOC1a y SOC1b) (Hecht et al., 2005).

En Arabidopsis thaliana hay dos genes pertenecientes al clado SVP: SVP y AGL24. SVP actúa como un represor de la floración dependiente de dosis (Hartmann et al., 2000), mientras que $A G L 24$ es un regulador negativo de la identidad del meristemo floral (Yu et al., 2004). En Medicago truncatula existen dos secuencias relacionadas a SVP, una de ellas también presente en Lotus japonicus, Glycine max y Pisum sativum (Hecht et al., 2005).

El clado ANR1 de Arabidopsis thaliana comprende cuatro miembros que se expresan principalmente en raíces (Burgeff et al., 2002). El gen ANR1 controla el desarrollo radicular lateral en respuesta a la aplicación de $\mathrm{NO}_{3}^{-}$(Zhang y Forde, 1998). Se han aislado cuatro secuencias de Medicago truncatula y una de Glycine max pertenecientes a este clado (Hecht et al., 2005).

Es probable que los estudios adicionales de los genes MADS-box identificados en el presente trabajo proporcionen una nueva perspectiva acerca de los aspectos característicos de la fisiología de la floración y la arquitectura de la inflorescencia de Medicago truncatula y ayuden a descubrir las bases moleculares para la variación genética natural que controla la floración en las leguminosas. 


\section{LOS GENES MADS-box Y SU IMPLICACIÓN EN LA BIOLOGÍA EVOLUTIVA DEL DESARROLLO DE LAS PLANTAS}

La biología evolutiva del desarrollo ("evo-devo") intenta explicar la diversidad de fisonomías en las plantas y en los animales. En este ámbito, los cambios en los patrones de expresión o en las funciones de genes homeóticos son especialmente importantes para la generación de novedades morfológicas. En el caso de la enorme diversidad de plantas existentes, la evolución de la familia génica MADS-box parece haber jugado un papel clave, principalmente mediante duplicaciones génicas. De hecho, todas las duplicaciones en esta familia han sido esenciales para formar la red reguladora que está involucrada en el desarrollo floral de hoy en día (Rijpkema et al., 2007).

Cuando ocurre la duplicación génica, las copias resultantes se conocen como parálogos, mientras que los miembros del mismo linaje génico separados por la especiación se conocen como ortólogos (Kramer, 2007). Los genes duplicados pueden originarse a partir de duplicaciones a gran o pequeña escala. En muchos organismos eucariotes, por ejemplo, Arabidopsis thaliana o Populus trichocarpa, han ocurrido varias duplicaciones del genoma completo (Maere et al., 2005; Cui et al., 2006). A menor escala, un evento de duplicación génica simple produce dos genes parálogos con funciones altamente redundantes que habitualmente no suelen mantenerse a lo largo del tiempo (Force et al., 1999). Tras la duplicación, una de las copias es neutralizada debido a la acumulación de mutaciones deletéreas. Este fenómeno, conocido como nofuncionalización o pseudogenización, es considerado como el resultado más probable de un evento de duplicación (Lynch y Conery, 2000) y se ha descrito en análisis genómicos de Arabidopsis thaliana, Oryza sativa y Populus trichocarpa, entre otros (Pařenicová et al., 2003; Nam et al., 2004; Leseberg et al., 2006).

Sin embargo, la redundancia génica (existencia de genes parálogos que realizan la misma función) es común en la familia de genes MADS-box (ejemplos: Liljegren et al., 2000; Pelaz et al., 2000; Pinyopich et al., 2003; Vandenbussche et al., 2004). Parece ser que estas copias génicas redundantes pueden mantenerse por algún tiempo ya que protegen contra las mutaciones deletéreas y contribuyen a la robustez genética de un organismo (Moore et al., 2005). Además, se cree que la redundancia es una ventaja para 
los genes que codifican grandes cantidades de productos benéficos (Kondrashov et al., 2002).

Aunque se encuentran muchos casos de redundancia parcial o total en la familia MADS-box, también hay varios ejemplos de diversificación funcional entre los genes duplicados (de Martino et al., 2006; Duarte et al., 2006; Rijpkema et al., 2006; AlvarezBuylla et al., 2006). El mecanismo más común de diversificación es la subfuncionalización, en la cual los múltiples papeles funcionales del gen ancestral se dividen entre los parálogos resultantes de tal manera que ambas copias deben mantenerse para conservar el repertorio original de funciones. Se han descrito casos de subfuncionalización en genes MADS-box de clase B, C y E (ejemplos: Yanofsky et al., 1990; Tröbner et al., 1992; Bradley et al., 1993; Goto y Meyerowitz, 1994; Davies et al., 1999; Liljegren et al., 2000; Vandenbussche et al., 2003b; Ditta et al., 2004; Rijpkema et al., 2006;). Un claro ejemplo son OsMADS3 y OsMADS58 (ortólogos de AG en Oryza sativa). Estos dos parálogos han dividido entre ellos las funciones de clase $\mathrm{C}$, pero juntos completan el papel ancestral definido para el gen AG de Arabidopsis thaliana: regulación de la identidad de estambres y carpelos y regulación de la determinación del meristemo floral (Yamaguchi et al., 2006).

La subfuncionalización es un proceso aleatorio que sucede de manera independiente en diferentes especies. Los ortólogos no necesariamente tienen la misma función, mientras que los homólogos que tienen la misma función no son necesariamente ortólogos. Esto ha ocurrido con los homólogos funcionalmente equivalentes PLE de Antirrhinum majus y $A G$ de Arabidopsis thaliana, los cuales en realidad son parálogos (Kramer et al., 2004; Causier et al., 2005). La explicación está en que tras la duplicación génica de un ancestro común, los diferentes miembros del par génico duplicado han retenido las funciones homeóticas primarias en diferentes linajes (PLE en Antirrhinum majus y $A G$ en Arabidopsis thaliana), mientras que sus respectivos ortólogos (SHP en Arabidopsis thaliana y FAR en Antirrhinum majus) han experimentado un proceso de subfuncionalización independiente y divergente a la vez (Kramer et al., 2004; Causier et al., 2005).

La naturaleza aleatoria de la subfuncionalización también se refleja en el número variable de miembros de una subfamilia génica (incluso entre especies estrechamente relacionadas) y en las diferencias en el grado de redundancia y subfuncionalización entre 
estos genes. Si se considera en conjunto todo el repertorio de funciones de un grupo de genes subfuncionalizados, se observa que las funciones están bien conservadas entre las especies. En estos casos, la diferencia de función génica entre los ortólogos individuales de estas especies no implica necesariamente una diferencia fundamental en la función. Por esta razón, es de crucial importancia considerar todo el conjunto de genes MADSbox de la subfamilia estudiada (Rijpkema et al., 2007).

Un caso en el cual el estudio de todos los miembros de una subfamilia aporta información sobre la función génica es el análisis de los genes de función B. Dentro del linaje $A P 3$, conocido como paleoAP3, ocurrió una duplicación en la base de las eudicotiledóneas superiores, dando lugar a dos linajes parálogos llamados euAP3 y TM6 (revisado en Kramer y Zimmer, 2006). En el linaje euAP3 la secuencia génica se ha remodelado enormemente alterando motivos proteicos conservados, mientras que el linaje TM6 ha conservado la mayoría de las características del paleoAP3 ancestral. Desafortunadamente, no existen ortólogos TM6 en Arabidopsis thaliana ni en Antirrhinum majus. Por ello, los estudios de los genes de clase B duplicados se han realizado principalmente en solanáceas, que poseen genes en ambos linajes. El gen PhDEF de Petunia hybrida (linaje euAP3) contribuye a la identidad de pétalos y estambres (van der Krol et al., 1993). El análisis de toda la subfamilia de función B en esta planta reveló que el gen PhTM6, un gen del linaje TM6, actúa redundantemente con PhDEF en la formación de las anteras (de Martino et al., 2006; Rijpkema et al., 2006). Ambos genes en conjunto reúnen todas las características típicamente asociadas con un gen de función euAP3, como se ha descrito para DEF y AP3 en Arabidopsis thaliana (Rijpkema et al., 2007).

Una última vía por la cual un gen puede evolucionar tras la duplicación génica es la neofuncionalización, en la cual una de las dos copias mantiene la función ancestral mientras que la segunda adquiere una nueva función, resultando en el mantenimiento selectivo de ambas copias (Ohno, 1970). Esta generación de funciones génicas completamente nuevas se observa en ocasiones como, por ejemplo, en el caso del gen MADS-box MPF2 de Physalis pubescens, que tiene una función novedosa que hace que los sépalos sigan creciendo tras la polinización para encapsular los frutos maduros (He y Saedler, 2005). La subfuncionalización es más probable que la neofuncionalización, pero ambos modelos no son mutuamente excluyentes, pues se ha demostrado que la 
subfuncionalización puede ser una fase transitoria hacia la neofuncionalización (He y Zhang, 2005; Rastogi y Liberles, 2005).

Desde que se describió el modelo $A B C$, ha sido el eje de estudios y especulaciones evolutivas (Bowman et al., 1991b; Doyle, 1994; Bowman, 1997). La naturaleza homeótica de este programa genético se ha visto como un mecanismo evolutivo para el origen de las angiospermas y para ciertos aspectos de su diversificación (Bowman, 1997; Albert et al., 1998). Además, los estudios de los genes MADS-box abarcan un grupo cada vez más amplio de especies de diferentes taxones, lo que permite tener una visión evolutiva de cómo estos genes pueden cambiar su función tras la duplicación y de cómo ha surgido la flor actual (Rijpkema et al., 2007). Así pues, los estudios "evo-devo" florales ofrecen oportunidades interesantes, no sólo en la investigación molecular, sino también en la comprensión de aspectos fundamentales de la evolución y las innovaciones morfológicas de las plantas. 
Objetivos 

Las leguminosas son el segundo grupo de cultivos en importancia agronómica tras las gramíneas. Sin embargo, a pesar de la importancia que tiene la floración en los sistemas de producción de estas plantas, es un proceso poco estudiado. Aunque en los últimos años se ha alcanzado un notable conocimiento en lo que respecta al desarrollo de flores e inflorescencias en las leguminosas, existen lagunas en la comprensión de los mecanismos moleculares que dirigen los procesos de iniciación y desarrollo floral de estas especies.

Medicago truncatula es un modelo valioso para el estudio de muchos aspectos únicos de la biología de las leguminosas, como la simbiosis, patogénesis o metabolismo secundario. Se han observado diferencias importantes entre Medicago truncatula o Pisum sativum respecto a los sistemas modelo Arabidopsis thaliana y Antirrhinum majus en relación a muchos aspectos del desarrollo floral (arquitectura de la inflorescencia, ontogenia floral, presencia de primordios comunes, iniciación temprana del carpelo, etc.). Dichas diferencias deben sustentarse en actividades génicas reguladoras que hay que desvelar. El conocimiento de los mecanismos moleculares que subyacen dichas diferencias permitirá elaborar modelos que ayuden a entender las bases genéticas que han contribuido a la enorme diversidad morfológica floral que se observa en la naturaleza.

Por ello, resulta relevante el estudio de los factores de transcripción MADS-box en Medicago truncatula, ya que estos genes están implicados en el control de procesos como el tiempo de floración, la determinación de la identidad del meristemo floral o el desarrollo de órganos florales, frutos y semillas. En este ámbito, es de especial interés la frecuencia de duplicaciones y subfuncionalización observada en genes MADS-box de función B y C, implicados en el desarrollo reproductivo. La subfuncionalización ocurre de manera independiente en diferentes especies, por lo que es interesante saber si ha sucedido en leguminosas y de que manera. Todas las duplicaciones en la familia MADSbox habrán sido esenciales para formar la red reguladora involucrada en el desarrollo floral de las leguminosas, ayudando a comprender aspectos fundamentales de la evolución y las innovaciones morfológicas de estas plantas. 
Dentro de este marco, como objetivos concretos de la presente Tesis Doctoral se plantea:

PRIMERO: Aislar y caracterizar nuevos miembros de la familia de genes MADS-box de Medicago truncatula involucrados en la formación del meristemo floral y el desarrollo de flores y frutos. Se estudiarán con detalle las secuencias y los patrones de expresión de los mismos y se formularán hipótesis tentativas sobre sus posibles funciones.

SEGUNDO: Comprobar la aplicabilidad de la tecnología VIGS en el silenciamiento transitorio específico de genes MADS-box en Medicago truncatula.

TERCERO: Realizar un estudio sobre la función de los genes MADS-box de Medicago truncatula homólogos al gen de clase C AGAMOUS utilizando diferentes abordajes. Con ello se pretende profundizar en las particularidades de la función $C$ en leguminosas y comprobar si estos genes presentan funciones distintas o adicionales a las descritas para sus homólogos. 
Materiales y Métodos 



\section{MATERIAL BIOLÓGICO}

\subsection{MATERIAL VEGETAL}

En la Tabla 1 se muestran las distintas líneas de Medicago truncatula, Pisum sativum y Arabidopsis thaliana utilizadas en este trabajo.

Tabla 1. Genotipos, ecotipos y procedencia de las plantas utilizadas en este trabajo

\begin{tabular}{|c|c|c|c|c|}
\hline Planta & Genotipo & Variedad/Ecotipo & Procedencia & Uso \\
\hline Medicago truncatula & Silvestre & Jemalong A17 & Dr. D. Cook ${ }^{\mathrm{a}}$ & Estudios de expresión \\
\hline Medicago truncatula & Silvestre & $2 \mathrm{HA}$ & Dr. P. Ratet ${ }^{b}$ & Transformación genética \\
\hline Medicago truncatula & Silvestre & R108 & $\begin{array}{l}\text { Samuel Roberts } \\
\text { Noble Foundation }\end{array}$ & $\begin{array}{l}\text { Etiquetado por } \\
\text { retrotransposón }\end{array}$ \\
\hline Medicago truncatula & Silvestre & SA1335 & Dra. E. Johansen ${ }^{c}$ & $\begin{array}{l}\text { Silenciamiento génico } \\
\text { inducido por virus }\end{array}$ \\
\hline Pisum sativum & Silvestre & cv. Bonneville & Dra. E. Johansen & $\begin{array}{l}\text { Silenciamiento génico } \\
\text { inducido por virus }\end{array}$ \\
\hline Arabidopsis thaliana & Silvestre & Columbia (Col) & IBMCP & Expresión constitutiva \\
\hline
\end{tabular}

${ }^{a}$ University of California; Davis USA

${ }^{b}$ Institut des Sciences du Végétal; Gif-sur-Yvette Francia

${ }^{c}$ Faculty of Agricultural Sciences, Aarhus University; Frederiksberk Dinamarca

Las muestras de los tejidos vegetales utilizadas para la extracción de ácidos nucleicos se recogieron directamente de la planta, se congelaron inmediatamente en nitrógeno líquido y se almacenaron a $-80^{\circ} \mathrm{C}$ hasta su posterior utilización.

\subsubsection{Condiciones de cultivo de las plantas}

\subsubsection{Cultivo de Medicago truncatula}

Las semillas de $M$. truncatula se escarificaron mecánicamente frotando con papel de lija hasta ver claros signos de abrasión en la cubierta de las mismas. Posteriormente, se esterilizaron por inmersión durante 40 minutos en una solución de dicloroisocianurato sódico (Bayrochlor ${ }^{\circledR}$ mini [BAYROL France, S.A.], 1 comprimido en 0,5 L de agua) y una gota de detergente común con agitación de 60-70 rpm y se lavaron 5 veces con agua Mili-Q estéril, en la campana de flujo laminar. 
Las semillas se colocaron en placas Petri con un soporte de papel filtro estéril humedecido, se sellaron con "Parafilm" y se almacenaron en oscuridad durante 2 días a temperatura ambiente. Después se realizó una incubación a $4{ }^{\circ} \mathrm{C}$ durante 7 días más con la finalidad de sincronizar la germinación de las plántulas (estratificación), ó 2 semanas para adelantar la floración (vernalización).

Las plántulas de $M$. truncatula procedentes de la germinación se trasplantaron a pastillas Jiffy de turba prensada (Jiffy-7 $41 \mathrm{~mm}$, Jiffy Products International) colocados en alveolos de plástico o se cultivaron individualmente en macetas de plástico de $13 \mathrm{~cm}$ de diámetro, en una mezcla de turba y arena 3:1 (v/v).

Las plantas se cultivaron en cabinas de invernadero o en cámara de cultivo (fitotrón). En el invernadero la temperatura se mantuvo en un rango de 20 a $22,5{ }^{\circ} \mathrm{C}$, con un fotoperiodo inductivo de $16 \mathrm{~h}$ de luz y $8 \mathrm{~h}$ de oscuridad (día largo, DL). La luz natural se suplementó con luz artificial asegurando una intensidad mínima de 5000 lx, con una media de 8000 lx, mediante lámparas de dos tipos alternadas en las filas de mesas, concretamente lámparas de halogenuro metálico POWERSTAR ${ }^{\circledR} \mathrm{HQI}^{\circledR}{ }^{-B T} 400 \mathrm{~W} / \mathrm{D}$ Daylight E40 (Osram) y de sodio a alta presión MASTER SON-T PIA Plus Hg Free 400W/220 E40 1SL (Philips).

En el fitotrón la temperatura oscilaba entre $22{ }^{\circ} \mathrm{C}$ de día y $16{ }^{\circ} \mathrm{C}$ de noche, con un fotoperiodo de día largo. En ambos casos el riego utilizado consistió en solución Hoagland no1 suplementada con oligoelementos (Hewitt, 1966) alternada semana a semana con agua desionizada, usando el sistema de riego mecánico mediante inmersión con una frecuencia que permitiera mantener húmeda la turba.

\subsubsection{Cultivo de Pisum sativum}

Las semillas de $P$. sativum se lavaron por inmersión durante 10 minutos con agitación en una solución de lejía comercial al $10 \%(v / v)$ y una gota de detergente común. Se aclararon 5 veces con agua destilada estéril.

Tras lavar las semillas, se colocaron en bandejas limpias con un soporte de papel filtro tipo Whatman $3 \mathrm{MM}$ humedecido con agua destilada estéril y se cubrieron con papel aluminio. Se incubaron en oscuridad durante 1 semana a $20{ }^{\circ} \mathrm{C}$, comprobando periódicamente la presencia de humedad. A mitad de semana se realizó un cambio del papel a fin de minimizar contaminaciones. 
Las semillas germinadas de Pisum sativum se sembraron individualmente en vermiculita en macetas de $16 \mathrm{~cm}$ de diámetro. Antes de colocarlas en el sustrato, las radículas se mojaron en solución fungicida de Benomilo 50 Vallés a $1 \mathrm{~g} / \mathrm{L}$ (IQV). Las plantas se cultivaron en cabina de invernadero en condiciones controladas, con una temperatura de $22,5{ }^{\circ} \mathrm{C}$ durante el día y $20{ }^{\circ} \mathrm{C}$ durante la noche. La luz natural se suplementó del mismo modo que para Medicago truncatula, manteniendo un fotoperiodo de día largo ( $16 \mathrm{~h}$ de luz y $8 \mathrm{~h}$ de oscuridad). El riego se efectuó por goteo automatizado con solución Hoagland nำ, suplementada con oligoelementos (Hewitt, 1966) durante 2 minutos cuatro veces al día.

\subsubsection{Cultivo de Arabidopsis thaliana}

\subsection{CULTIVO EN PLACAS PETRI}

El cultivo in vitro de Arabidopsis en placas Petri, se realizó en cámaras de crecimiento in vitro con temperatura constante de $24{ }^{\circ} \mathrm{C}$, bajo condiciones de fotoperiodo de día largo (16 h de luz y $8 \mathrm{~h}$ de oscuridad) con una intensidad de luz de $90 \mu \mathrm{E} \mathrm{m} \mathrm{m}^{-2}$ suministrada por tubos fluorescentes de luz fría tipo Gro-Lux F36W/GRO (Sylvania).

Las semillas se esterilizaron, en la campana de flujo laminar, por inmersión durante 3 minutos en una solución de etanol al $70 \%(\mathrm{v} / \mathrm{v})$ y 0,005\% Tritón X-100 (v/v) con agitación. Posteriormente se lavaron durante 1 minuto en agitación con etanol al 96\% (v/v). Se colocaron junto con el etanol por inversión sobre papel filtro estéril y se dejaron secar.

Para la selección de transformantes primarios las semillas esterilizadas se sembraron en placas Petri de $140 \mathrm{~mm}$ de diámetro (30 mg de semillas, el equivalente de unas 1500, en cada placa) que contenían medio de selección suplementado con kanamicina y timentina [2,2 g/L sales MS (Duchefa), $20 \mathrm{~g} / \mathrm{L}$ sacarosa, 0,1 g/L MES, pH 5,9, 0,6\% agar (Pronadisa), $50 \mathrm{mg} / \mathrm{L}$ kanamicina, $300 \mathrm{mg} / \mathrm{L}$ timentina]. Las placas con las semillas se almacenaron durante tres días a $4{ }^{\circ} \mathrm{C}$ en oscuridad, tras lo cual se trasladaron a una cámara de cultivo in vitro. Después de 7-10 días desde la siembra, los transformantes, que eran identificables por su color verde y raíz alongada, se trasplantaron con ayuda de unas pinzas, a alveolos de plástico de $6,5 \times 6,5 \times 5 \mathrm{~cm}$ y se cultivaron como se describe en el siguiente apartado. Para el análisis de segregación de las líneas transgénicas se sembraron 200 semillas por línea. Las semillas, tras su esterilización, se sembraron 
individualmente, con la ayuda de una pipeta Pasteur estéril, en placas Petri de $140 \mathrm{~mm}$ de diámetro (66-67 semillas/placa) que contenían medio de selección suplementado con kanamicina. Las plántulas sensibles y resistentes se contabilizaron al cabo de 15 días.

\subsection{CULTIVO EN MACETAS}

Las plantas de Arabidopsis se cultivaron en cabinas de invernadero bajo condiciones controladas de fotoperiodo y temperatura. La temperatura se mantuvo en $22{ }^{\circ} \mathrm{C}$ por el día y $19{ }^{\circ} \mathrm{C}$ por la noche y la iluminación se suplementó con luz artificial del mismo modo que el descrito para Medicago truncatula. Habitualmente, las plantas se cultivaron bajo condiciones de fotoperiodo inductivo: $16 \mathrm{~h}$ de luz y $8 \mathrm{~h}$ de oscuridad (día largo, DL).

Las semillas se sembraron en macetas de plástico de 11 ó $13 \mathrm{~cm}$ de diámetro o en bandejas de alveolos en una mezcla de turba:perlita:vermiculita (1:1:1). Las bandejas con macetas o alveolos se regaron por inmersión con agua destilada. Una vez por semana se regaba con solución Hoagland $\mathrm{n} \cong 1$, suplementada con oligoelementos (Hewitt, 1966). Tras la siembra, las bandejas se cubrieron con plástico para mantener la humedad y evitar contaminaciones de semillas procedentes de plantas próximas. Se mantuvieron en oscuridad, a $4{ }^{\circ} \mathrm{C}$, durante tres días, a fin de sincronizar la germinación, antes de pasarlas a la cabina del invernadero. Cuando apareció el primer par de hojas se perforó el plástico, y el número y tamaño de las perforaciones se fue aumentando progresivamente hasta que en 3 días se eliminó por completo el plástico.

\subsection{MICROORGANISMOS}

\subsubsection{Cepas bacterianas}

En este trabajo se han utilizado las cepas bacterianas que se detallan en la Tabla 2.

\subsubsection{Condiciones de cultivo de microorganismos}

Los cultivos líquidos de bacterias $E$. coli y $A$. tumefaciens se incubaron toda la noche a $37^{\circ} \mathrm{C}$ y $28^{\circ} \mathrm{C}$, respectivamente, con agitación de $200 \mathrm{rpm}$. Los cultivos de E. coli y $A$. tumefaciens en placas con medio sólido se incubaron toda la noche en estufa a $37^{\circ} \mathrm{C}$ y de dos a tres días a $28^{\circ} \mathrm{C}$, respectivamente. 
Tabla 2. Cepas bacterianas utilizadas en este trabajo

\begin{tabular}{lll}
\hline Cepa & Referencia / Origen & Uso \\
\hline ElectroMAX $^{\text {TM }}$ DH10B $^{\text {TM }}$ (E. coli) & Life technologies & Transformación de bacterias \\
XL1-Blue MRF' (E. coli) & Stratagene & Rastreo de genoteca \\
XLOLR (E. coli) & Stratagene & Rastreo de genoteca \\
C58/pMP90 (A. tumefaciens) & Koncz y Schell (1986) & Transformación de plantas $^{\mathrm{a}}$ \\
C58/pMP90 [pSoup] (A. tumefaciens) & Koncz y Schell (1986) & Transformación de plantas $^{\mathrm{b}}$ \\
\hline
\end{tabular}

${ }^{a}$ Para transformar con construcciones de expresión constitutiva y VIGS

${ }^{\mathrm{b}}$ Para transformar con construcciones de RNA interferente

\subsubsection{Medios de cultivo de microorganismos}

El medio de cultivo que se usó generalmente para el crecimiento de los cultivos bacterianos, tanto de $E$. coli como de A. tumefaciens es el medio LB. Se utilizaron los medios NZY y NZY top agar para el cultivo de fagos durante el rastreo de la genoteca y el medio TYP para el cultivo de $A$. tumefaciens utilizado en el silenciamiento génico inducido por virus (VIGS).

- Medio LB (Luria-Bertani): $10 \mathrm{~g} / \mathrm{L}$ triptona, $5 \mathrm{~g} / \mathrm{L}$ extracto de levadura, $10 \mathrm{~g} / \mathrm{L}$ $\mathrm{NaCl}$. Para medio sólido: $15 \mathrm{~g} / \mathrm{L}$ agar

- Medio NZY: 5 g/L NaCl, 2 g/L MgSO $4 \cdot 7 \mathrm{H}_{2} \mathrm{O}, 5 \mathrm{~g} / \mathrm{L}$ extracto de levadura, $10 \mathrm{~g} / \mathrm{L}$ $\mathrm{NZ}$ amino (hidrolizado de caseína). $\mathrm{pH}=7,5$. Para medio sólido: $15 \mathrm{~g} / \mathrm{L}$ agar

- Medio NZY top agar: Medio NZY líquido suplementado con 0,7 g/L de agarosa

- Medio TYP: $16 \mathrm{~g} / \mathrm{L}$ bactotriptona, $16 \mathrm{~g} / \mathrm{L}$ extracto de levadura, $5 \mathrm{~g} / \mathrm{L} \mathrm{NaCl}, 2,5$ g/L K ${ }_{2} \mathrm{HPO}_{4}$. Para medio sólido: $15 \mathrm{~g} / \mathrm{L}$ agar

\section{MÉTODOS DE BIOLOGÍA MOLECULAR}

\subsection{AISLAMIENTO Y PURIFICACIÓN DE ÁCIDOS NUCLEICOS}

\subsubsection{Aislamiento de DNA plasmídico de E. coli}

Las preparaciones de DNA plasmídico a pequeña escala se realizaron a partir de cultivos de $3 \mathrm{~mL}$ crecidos durante una noche en medio LB líquido suplementado con el antibiótico correspondiente, según el procedimiento de extracción y purificación de DNA plasmídico del sistema Rapid Plasmid Miniprep System de Marligen Biosciences, Inc. 
Las preparaciones a media escala se realizaron utilizando el procedimiento de extracción y purificación de DNA plasmídico del sistema QIAGEN ${ }^{\circledR}$ Plasmid Midi Kit (columnas QIAGEN-tip 100) a partir de cultivos de $100 \mathrm{~mL}$ crecidos en las mismas condiciones que para las preparaciones a pequeña escala.

En ambos casos se siguieron las recomendaciones suministradas por los fabricantes.

\subsubsection{Aislamiento de DNA plasmídico de A. tumefaciens}

Para las preparaciones a pequeña escala de DNA plasmídico se utilizó el método de lisis alcalina descrito por Sambrook et al. (1989) con ligeras modificaciones. Se partía de un cultivo de $3 \mathrm{~mL}$ crecido durante una noche en medio LB líquido suplementado con el antibiótico correspondiente. Tras añadir la solución III las muestras se centrifugaron y se recuperó el sobrenadante. Se le añadió $900 \mu \mathrm{L}$ de etanol absoluto y se incubó 30 minutos a $-80{ }^{\circ} \mathrm{C}$. Pasado este tiempo se centrifugó 5 minutos a $12.000 \mathrm{rpm}$ y el precipitado se lavó con etanol al 70\% (v/v), se secó y se resuspendió en $25 \mu \mathrm{L}$ de TE $1 \mathrm{X}$ (1 mM EDTA, 10mM Tris- $\mathrm{HCl}$ pH 8,0).

La pureza y rendimiento de la preparación de DNA obtenida no era lo suficientemente alta para realizar análisis de restricción del plásmido. Por ello, una alícuota de $1 \mu \mathrm{L}$ de esta preparación de DNA se utilizó para transformar $E$. coli. De uno de los clones transformantes de $E$. coli obtenidos se hizo una nueva preparación de DNA plasmídico que fue utilizada para los análisis de restricción pertinentes.

\subsubsection{Aislamiento y cuantificación de DNA genómico}

Se han utilizado tres protocolos distintos de aislamiento de DNA genómico durante el desarrollo de este trabajo.

EI DNA genómico utilizado para genotipar mediante PCR las plantas presuntamente transgénicas de Medicago truncatula fue aislado a partir de hoja utilizando el sistema Plant DNAzol ${ }^{\circledR}$ Reagent (Life technologies) siguiendo las instrucciones del fabricante.

Para genotipar las plantas de Arabidopsis thaliana así como las plantas de Medicago truncatula con inserción de transposon Tnt1, el DNA genómico fue aislado según el siguiente procedimiento: Se molió aproximadamente $300 \mathrm{mg}$ de hoja en $500 \mu \mathrm{L}$ de tampón de extracción (0.2 M Tris- $\mathrm{HCl}$ pH 9,0, 0,4 M LiCl, 25 mM EDTA, 1\% v/v SDS). Tras 5 minutos de centrifugación a velocidad máxima (13.200 rpm), el sobrenadante fue 
transferido a un volumen igual de isopropanol y se centrifugó 10 minutos a velocidad máxima. El sobrenadante se eliminó y el precipitado se lavó con $500 \mu \mathrm{L}$ de etanol al $70 \%$ (v/v), se secó y se resuspendió en $200 \mu \mathrm{L}$ de agua. Se utilizaron $2 \mu \mathrm{L}$ para las reacciones de PCR.

El aislamiento del DNA genómico utilizado para el análisis Southern blot se realizó siguiendo el protocolo de extracción de DNA genómico de plantas descrito por Dellaporta et al. (1983), modificado por la adición de un lavado con fenol-cloroformo 1:1 y una precipitación de los ácidos nucleicos en isopropanol después de la precipitación proteica con acetato de sodio $3 \mathrm{M} \mathrm{pH} \mathrm{5,2.} \mathrm{El} \mathrm{precipitado} \mathrm{final} \mathrm{se} \mathrm{resuspendió} \mathrm{en} 100 \mu \mathrm{L}$ de TE $1 X$.

La cuantificación del DNA se realizó por comparación con patrones de concentración conocida en geles de agarosa al 0,8\% (p/v) en TBE 1X (890 mM Tris-borato, 890 mM ácido bórico, $20 \mathrm{mM}$ EDTA, pH 8,3) con bromuro de etidio $(0,5 \mu \mathrm{g} / \mathrm{mL})$.

\subsubsection{Aislamiento de RNA total}

A $0,3 \mathrm{~g}$ de material congelado y pulverizado se añadió $500 \mu \mathrm{L}$ de tampón de extracción (4\% ácido p-aminosalicílico, 1\% ácido 1,5-naftalenodisulfónico) y $1 \mathrm{~mL}$ de fenol-cloroformo (1:1). Se incubó 10 minutos en hielo y se centrifugó a $4{ }^{\circ} \mathrm{C}$. El sobrenadante se precipitó añadiendo $1 / 10$ volumen de acetato sódico $3 \mathrm{M}$ y 2 volúmenes de etanol absoluto y se incubó 30 minutos en hielo. Se centrifugó nuevamente y el precipitado se resuspendió en $400 \mu \mathrm{L}$ de agua y se precipitó con $250 \mu \mathrm{L}$ de LiCl $8 \mathrm{M}$ durante una noche. Al día siguiente se centrifugó y se lavó el precipitado con etanol al $70 \%(v / v)$ y se dejó secar. El precipitado se resuspendió en $50 \mu \mathrm{L}$ de agua libre de RNasas. El RNA total aislado por este método se utilizó para el análisis Northern blot.

Para la extracción de RNA total de tejidos de Medicago truncatula y Pisum sativum que posteriormente se utilizó para los experimentos de PCR cuantitativa a tiempo real (qRT-PCR), se utilizó el sistema RNeasy ${ }^{\circledR}$ Plant Mini Kit de QIAGEN, siguiendo las instrucciones del fabricante.

El RNA obtenido se cuantificó mediante espectrofotometría (Sambrook et al., 1989) utilizando el espectrofotómetro UV/VIS SP8001 DINKO o el NanoDrop ${ }^{\circledR}$ ND-1000 Spectrophotometer. 


\subsection{AMPLIFICACIÓN DE DNA POR REACCIÓN EN CADENA DE LA POLIMERASA (PCR)}

En las reacciones en cadena de la polimerasa (PCR) se utilizó como molde DNA de diferente naturaleza incluyendo DNA genómico, plásmidos recombinantes purificados o cDNA obtenido a partir de la retrotranscripción de RNA. Esta técnica se empleó para amplificar fragmentos de DNA que se utilizarían para ser ligados a vectores plasmídicos, sintetizar sondas y genotipar plantas transgénicas.

Para todos los casos, las reacciones se llevaron a cabo indistintamente en los termocicladores Perkin Elmer GeneAmp PCR System 2400 o CS Cleaver Scientific Ltd GTC Thermal Cycler 54 en un volumen total de $50 \mu \mathrm{L}$. La mezcla de reacción de PCR contenía 0,3-0,5 $\mu \mathrm{M}$ de los cebadores específicos del fragmento a amplificar, $200 \mu \mathrm{M}$ de una mezcla equimolar de cada desoxirribonucleótido, $1,5 \mathrm{mM}$ de $\mathrm{MgCl}_{2}$, $1 \mathrm{X}$ tampón de $\mathrm{PCR}$ (suministrado por el fabricante), 1,5 U de DNA polimerasa y DNA molde en concentración variable.

La DNA polimerasa utilizada fue NETZYME ${ }^{\mathrm{TM}}$ DNA polymerase (N.E.E.D.), aunque en los casos donde se requería la obtención de fragmentos con alta fidelidad de copia se utilizó TaKaRa Ex Taq ${ }^{\text {TM }}$ (TaKaRa). Cabe mencionar que en la mezcla de reacción de esta última no se requiere adición de $\mathrm{MgCl}_{2}$. Para la amplificación de los fragmentos usados en las construcciones de expresión constitutiva se utilizó una mezcla 4:1 de NETZYME ${ }^{\mathrm{TM}}$ DNA polymerase con PfuTurbo DNA Polymerase (Stratagene).

Los programas de amplificación estándar consistieron en una desnaturalización inicial de 2 minutos a $94{ }^{\circ} \mathrm{C}$ seguida de 30-35 ciclos de amplificación y finalmente una extensión de 10 minutos a $72{ }^{\circ} \mathrm{C}$. Cada ciclo de amplificación estaba constituido por 3 etapas: $30 \mathrm{~s}$ a $94{ }^{\circ} \mathrm{C}$ (desnaturalización), $30 \mathrm{~s}$ a la temperatura óptima de hibridación de los cebadores (alineamiento) y por último 1 minuto/kb a $72{ }^{\circ} \mathrm{C}$ (extensión).

En cada reacción la temperatura de alineamiento se consideró en función de la temperatura de fusión estimada ( $\mathrm{Tm}$ ) de los cebadores empleados.

Los oligonucleótidos empleados como cebadores fueron sintetizados por la empresa Invitrogen ${ }^{T M}$ (http://www.invitrogen.com) con grado de purificación máximo. En la Tabla 10 se recogen los cebadores empleados en este trabajo. 


\subsection{TÉCNICAS DE CLONACIÓN}

\subsubsection{Vectores plasmídicos utilizados}

Las clonaciones se hicieron en diferentes plásmidos en función de la procedencia de los fragmentos de DNA y de los fines requeridos. Los plásmidos utilizados a lo largo de este trabajo se detallan en la Tabla 3 junto con sus características, origen y uso.

Tabla 3. Plásmidos utilizados en este trabajo

\begin{tabular}{|c|c|c|c|}
\hline Plásmido & Características & Referencia / Origen & Uso \\
\hline pGEM $^{\circledR}$ T-easy & $\begin{array}{l}\text { Amp }{ }^{r}, \text { lacZ, promotores T7 } \\
\text { y SP6 }\end{array}$ & Promega & Clonaje de fragmentos \\
\hline pAD-GAL4-2.1 & $\begin{array}{l}\text { Amp }{ }^{r} \text {, leu2, promotor } \\
A D H 1\end{array}$ & Stratagene & $\begin{array}{l}\text { Escisión in vivo de insertos } \\
\text { clonados en genoteca }\end{array}$ \\
\hline pHANNIBAL & $\begin{array}{l}\text { Amp }{ }^{r} \text {, intrón PDK, } \\
\text { promotor CaMV 35S }\end{array}$ & Wesley et al. (2001) & Construcción RNAi \\
\hline pGreenII-nosbar & $\mathrm{Kan}^{\mathrm{r}}$, lacZ, Basta ${ }^{\mathrm{r}}$ & $\begin{array}{l}\text { Benlloch, R. (Tesis } \\
\text { Doctoral, 2005) }\end{array}$ & Construcción RNAi \\
\hline pSoup & Tet $^{r}$ & Hellens et al. (2000) & Vector binario \\
\hline pBIN-JIT & $\mathrm{Kan}^{\mathrm{r}}$, promotor $2 \times 35 \mathrm{~S}$ & Ferrándiz et al. (2000) & $\begin{array}{l}\text { Construcción expresión } \\
\text { constitutiva }\end{array}$ \\
\hline pCAPE1 & $\begin{array}{l}\text { Kan }^{r} \text {, promotor CaMV 35S, } \\
\text { PEBV RNA1 }\end{array}$ & Constantin et al. (2004) & Construcción VIGS \\
\hline pCAPE2 & $\begin{array}{l}\text { Kan }^{r} \text {, promotor CaMV 35S, } \\
\text { PEBV RNA2 }\end{array}$ & Constantin et al. (2004) & Construcción VIGS \\
\hline
\end{tabular}

\subsubsection{Digestiones del DNA con enzimas de restricción}

Para cada enzima de restricción se utilizó el tampón y las condiciones recomendadas por las distintas casas comerciales. En el caso de digestiones dobles, se utilizaron tampones compatibles para la actividad de ambos enzimas. Las digestiones se llevaron a

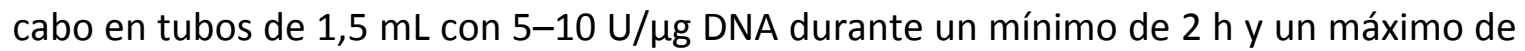
24 h a la temperatura óptima para cada enzima. La incubación se realizó en un termobloque Thermomixer comfort (Eppendorf ${ }^{\circledast}$ ). 


\subsubsection{Purificación de fragmentos de DNA de geles de agarosa}

Tras separar las muestras de DNA mediante electroforesis en geles de agarosa/TBE, las bandas de interés se visualizaron con luz ultravioleta y se cortaron del gel con una cuchilla. El DNA contenido en las mismas se purificó mediante el sistema QIAquick $^{\circledR}$ Gel Extraction Kit (QIAGEN $\left.{ }^{\circledR}\right)$, siguiendo las instrucciones del fabricante. La extracción y purificación de los fragmentos de DNA por este método se basa en la solubilización de la agarosa y la adsorción selectiva de los ácidos nucleicos en una membrana de gel de sílice, en presencia de una elevada concentración de sal. La elución se llevó a cabo en una solución baja en sales como tampón Tris- $\mathrm{HCl}$ pH 8,0 o agua.

\subsubsection{Reacciones de ligación de DNA}

Las reacciones de ligación se realizaron manteniendo una relación estequiométrica inserto:vector de 3:1 o de 5:1. Para calcular esta relación molar entre un fragmento y un vector concreto se aplicó la ecuación:

cantidad de inserto $(\mathrm{ng})=\frac{(\text { cantidad de vector }[\mathrm{ng}])(\text { tamaño del inserto }[\mathrm{kb}])}{\text { tamaño del vector }[\mathrm{kb}]} \times$ relación molar inserto $:$ vector

La reacción contenía las cantidades de inserto y vector (cortados y purificados) necesarias para obtener las proporciones molares mencionadas, $1 \mathrm{X}$ de tampón de ligación (Invitrogen ${ }^{\circledR}$ ) y 1 U de T4 DNA ligasa (Invitrogen ${ }^{\circledR}$ ) en un volumen total de $10 \mu \mathrm{L}$. Las reacciones se realizaron a $16{ }^{\circ} \mathrm{C}$ durante $16 \mathrm{~h}$ en un baño de agua (Thermomix ${ }^{\circledR} \mathrm{BU}$ acoplado a Frigomix ${ }^{\circledR}$ U, B. Braun). En las ligaciones con el vector pGEM $^{\circledR}$ T-easy (Promega) se utilizó el kit proporcionado por la casa comercial y se siguieron sus recomendaciones.

\subsection{TRANSFORMACIÓN DE CEPAS BACTERIANAS}

La cepa de Escherichia coli que se empleó en las transformaciones fue ElectroMAX ${ }^{\mathrm{TM}}$

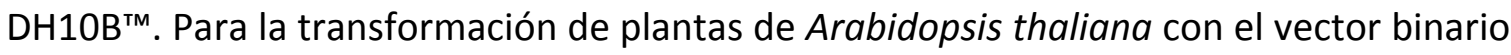
pBIN-JIT así como las plantas de Medicago truncatula y Pisum sativum con los vectores binarios pCAPE1 y pCAPE2 se utilizó la cepa de Agrobacterium tumefaciens C58/pMP90 (GV3101); para la transformación de Medicago truncatula con construcciones en el 
plásmido binario pGreenll se utilizó la cepa C58/pMP90 que ya poseía el plásmido auxiliar pSoup.

\subsubsection{Preparación de células competentes y transformación por} electroporación

La preparación de células competentes para su transformación mediante electroporación se llevó a cabo según el protocolo descrito en el catálogo Pulse controller, Accessory for bacterial and fungal electro-transformation (Bio-Rad) en el caso de E. coli y según Shen y Forde (1989) en el caso de A. tumefaciens.

Tras descongelar en hielo una alícuota de $40 \mu \mathrm{L}$ de células electrocompetentes, se añadió $1 \mu \mathrm{L}$ del vector transformante. La mezcla se introdujo en una cubeta de 0,1 cm de separación entre electrodos (Bio-Rad), previamente enfriada en hielo, y se sometió a un pulso eléctrico con un aparato Gene Pulser ${ }^{\mathrm{TM}}$ (Bio-Rad). Las condiciones de electroporación fueron $200 \Omega, 25 \mu \mathrm{F}$ y $1,8 \mathrm{kV}$ para E. coli y $400 \Omega, 25 \mu \mathrm{F}$ y 1,8 kV para $A$. tumefaciens. Después del pulso eléctrico se añadió $0,75 \mathrm{~mL}$ de $L B$ y se incubó con agitación suave $1 \mathrm{~h}$ a $37^{\circ} \mathrm{C}$ para E. coli y $3 \mathrm{~h}$ a $28^{\circ} \mathrm{C}$ para A. tumefaciens.

\subsubsection{Selección de recombinantes bacterianos}

La selección de recombinantes se llevó a cabo mediante la siembra del sedimento bacteriano procedente del cultivo transformado en placas Petri de $90 \mathrm{~mm}$ de diámetro que contenían medio LB sólido suplementado con el antibiótico adecuado según el plásmido utilizado. En la Tabla 4 se muestran los antibióticos utilizados para la selección de recombinantes bacterianos y las concentraciones usadas.

Tabla 4. Antibióticos y concentraciones utilizadas

\begin{tabular}{lcc}
\hline Antibiótico & \multicolumn{2}{c}{ Concentración $(\mu \mathrm{g} / \mathrm{mL})$} \\
\hline Ampicilina & E. coli & A. tumefaciens \\
Kanamicina & 100 & - \\
Rifampicina & 50 & 50 \\
Gentamicina & - & 100 \\
\hline
\end{tabular}

En los casos en que el vector empleado permitía seleccionar las células transformadas por $\alpha$-complementación, se añadió al medio $20 \mathrm{mg} / \mathrm{mL}$ del sustrato cromogénico 5- 
bromo-4-cloro-3-indolil- $\beta$ - $D$-galactósido (X-Gal, Duchefa). Las placas se incubaron bajo las condiciones descritas en el apartado 1.2.2.

\subsection{SECUENCIACIÓN}

Las reacciones de secuenciación se llevaron a cabo en el Servicio de Secuenciación de DNA del Instituto de Biología Molecular y Celular de Plantas (Universidad Politécnica de Valencia-CSIC) donde se utilizó un secuenciador capilar ABI 3100 (Applied Biosystems, Foster City, CA).

Se utilizaron tanto cebadores propios de los vectores plasmídicos como cebadores internos de los fragmentos de DNA objeto de estudio (ver Tabla 10).

\subsubsection{Análisis de secuencias}

El análisis de las secuencias obtenidas se realizó a través de aplicaciones de páginas web en internet. En la Tabla 5 se describen las páginas web y los programas en línea comúnmente utilizados en este trabajo.

Tabla 5. Páginas web utilizadas para el análisis de secuencias

\begin{tabular}{|c|c|c|c|}
\hline Página web & Organización & Programa & Uso \\
\hline \multirow[t]{2}{*}{ www.ebi.ac.uk } & European Bioinformatics & Align & Alinear dos secuencias \\
\hline & Institute (EMBL) & ClustalW2 & Alinear varias secuencias \\
\hline \multirow[t]{5}{*}{ www.expasy.ch } & Swiss Institute of & Translate & Traducir cDNA a proteína \\
\hline & Bioinformatics & Genewise & Comparar secuencia genómica \\
\hline & & & con secuencia proteica \\
\hline & & PROSITE & Determinar dominios y \\
\hline & & & familias génicas en proteínas \\
\hline \multirow[t]{3}{*}{ www.ncbi.nlm.nih.gov } & National Center for & BLAST & Búsqueda de homologías \\
\hline & Biotechnology & & \\
\hline & Information & & \\
\hline \multirow[t]{2}{*}{ www.bioinformatics.org } & Bioinformatics & Reverse & Generar secuencias reversas \\
\hline & Organization, Inc. & complement & y/o complementarias \\
\hline //pbil.univ-lyon1.fr/softw & Perrière y Gouy, 1996 & NJplot & Generar árboles filogenéticos \\
\hline are/njplot.html & & & \\
\hline
\end{tabular}




\subsection{ESCRUTINIO DE GENOTECA DE Medicago truncatula}

Los clones de cDNA estudiados en este trabajo proceden del escrutinio de la genoteca de cDNA construida en nuestro laboratorio según las instrucciones del sistema “HybriZAP ${ }^{\circledR}-2.1$ XR Library Construction Kit and HybriZAP ${ }^{{ }_{-}}-2.1$ XR cDNA Synthesis Kit”. La genoteca se construyó a partir de mRNA de ápices florales de $M$. truncatula en el vector HybriZAP ${ }^{\circledR}-2.1$ (Benlloch, R. Tesis Doctoral, 2005).

\subsubsection{Titulación y rastreo de la genoteca}

La genoteca se tituló al inicio de cada rastreo primario siguiendo el manual de instrucciones del sistema "HybriZAP ${ }^{\circledR}-2.1$ XR Library Construction Kit and HybriZAP ${ }^{\circledR}-2.1$ XR cDNA Synthesis Kit”. Esta titulación permitió determinar la concentración de la genoteca en $\mathrm{pfu} / \mu \mathrm{L}$ ("plaque forming units" o calvas).

En cada escrutinio primario de la genoteca se emplearon 15 placas Petri de $140 \mathrm{~mm}$ que contenían 50.000 pfu por placa, 750.000 pfu en total. Las placas Petri se incubaron a $37^{\circ} \mathrm{C}$ durante $6-8 \mathrm{~h}$ hasta que las calvas de lisis eran visibles y entonces se procedía a la transferencia de las mismas a membranas circulares de nylon.

\subsubsection{Transferencia a membrana}

La transferencia de las calvas desde el medio sólido a las membranas de nylon (Hybond ${ }^{\mathrm{TM}}-\mathrm{N}+$, Amersham) se realizó siguiendo el protocolo descrito por Sambrook et al. (1989). Sobre cada placa se depositó una membrana durante 1 minuto, se numeró y orientó con la placa marcando mediante perforaciones de aguja. La membrana se separó y colocó 5 minutos sobre papel Whatman 3MM humedecido con solución desnaturalizante $(1,5 \mathrm{M} \mathrm{NaCl}, 0,5 \mathrm{M} \mathrm{NaOH})$ y después en solución neutralizante $(1,5 \mathrm{M}$ $\mathrm{NaCl}, 0,5 \mathrm{M}$ Tris-HCL pH 7,5), dejando la cara de la membrana que no había estado en contacto directo con el medio sobre el papel. Las membranas se secaron sobre papel de filtro y finalmente el DNA se fijó por tratamiento con luz ultravioleta utilizando indistintamente las cámaras de irradiación UV Stratalinker ${ }^{\circledR} 1800$ (Stratagene) o UVC 500 UV Crosslinker (Amersham). Este proceso se realizó por duplicado para cada placa.

\subsubsection{Síntesis de sondas radiactivas}

Las sondas radiactivas se sintetizaron mediante el sistema Ready-To-Go ${ }^{\text {TM }}$ DNA Labeling Beads (-dCTP) (Amersham), siguiendo las instrucciones del fabricante. Este 
sistema se basa en el uso de cebadores al azar que se unen al DNA molde permitiendo la síntesis de la cadena complementaria (Feinberg y Vogelstein, 1983). En cada reacción se utilizó 60 ng de DNA molde y $50 \mu \mathrm{Ci}$ de $\alpha{ }^{32} \mathrm{P}$-dCTP (Amersham). Una vez sintetizadas las sondas, se purificaron para eliminar los nucleótidos no incorporados mediante columnas de cromatografía de exclusión molecular "Quick Spin Columns for radiolabeled DNA purification, Sephadex G-50" (Roche) según el procedimiento indicado por el fabricante.

\subsubsection{Hibridación y lavados}

El escrutinio de la genoteca se realizó con el objeto de aislar miembros de la familia de genes MADS-box de Medicago truncatula. Se utilizó como sonda un fragmento de $231 \mathrm{pb}$ correspondiente a la secuencia codificante del dominio MADS aislado del gen MtPISTILLATA de Medicago truncatula, clonado previamente en el vector pGEM ${ }^{\circledR}$ T-easy (Benlloch, R., Tesis Doctoral, 2005).

Las hibridaciones se llevaron a cabo por duplicado en un horno de hibridación “Hybridization oven/shaker RPN 2510" (Amersham) en condiciones de alta y baja astringencia. Primero las membranas se incubaron durante 30 minutos en $50 \mathrm{~mL}$ de solución de prehibridación (0,3 M tampón fosfato $\mathrm{pH}$ 7,2, 7\% SDS [p/v], 1 mM EDTA) y posteriormente se pasaron a $50 \mathrm{~mL}$ frescos de la misma solución, que contenía la sonda desnaturalizada 4 minutos a $95^{\circ} \mathrm{C}$. Tras un periodo de hibridación de al menos $16 \mathrm{~h}$ a 52 ${ }^{\circ} \mathrm{C}$ (baja astringencia), las membranas se lavaron 30 minutos en SSC $2 \mathrm{X}, \mathrm{SDS} 0,1 \%(\mathrm{p} / \mathrm{v})$ y posteriormente 30 minutos en SSC 0,5X, SDS 0,1\% (p/v), controlando constantemente el proceso mediante un contador Geiger. Las réplicas de éstas membranas se procesaron de la misma manera, pero hibridando al menos $16 \mathrm{~h}$ a $65^{\circ} \mathrm{C}$ (alta astringencia).

\subsubsection{Detección de la señal: autorradiografía}

Las membranas lavadas se sellaron en plástico y se expusieron a una película radiográfica FUJI Medical 100NIF X-ray film (FUJIFILM) en casetes de autorradiografía. Durante la exposición se mantuvo a $-80{ }^{\circ} \mathrm{C}$ y finalmente se reveló en una procesadora automática X-OMAT 2000 Processor (Kodak).

\subsubsection{Identificación y aislamiento de clones positivos}

Para eliminar del rastreo clones del gen $\mathrm{MtPI}$, se compararon las autorradiografías de las membranas hibridadas a $52{ }^{\circ} \mathrm{C}$ y a $65^{\circ} \mathrm{C}$ y se aislaron aquellas calvas que tenían señal 
positiva únicamente en condiciones de baja astringencia, haciendo coincidir las películas radiográficas con las placas Petri correspondientes. Las calvas positivas aisladas del escrutinio primario se sometieron a un segundo y tercer rastreo hasta aislar y purificar completamente el fago positivo. Los plásmidos que contenían el clon positivo se escindieron del fago siguiendo el protocolo indicado en el manual de instrucciones “HybriZAP ${ }^{\circledR}-2.1$ XR Library Construction Kit and HybriZAP ${ }^{\circledR}-2.1$ XR cDNA Synthesis Kit”. Una vez aislado el clon se procedió a su secuenciación.

\subsection{ESTUDIOS DE EXPRESIÓN}

\subsubsection{Análisis Northern blot y Southern blot}

\subsubsection{Electroforesis de RNA y DNA para transferencia a membrana}

Para el análisis Northern, la separación del RNA se llevó a cabo mediante electroforesis en gel desnaturalizante de agarosa al $1 \%(\mathrm{p} / \mathrm{v})$ y formaldehido $5 \%(\mathrm{v} / \mathrm{v})$ en tampón MEN 1X (20 mM MOPS, 5 mM acetato sódico, 2 mM EDTA, pH 7,0), según se describe en Sambrook et al. (1989). Cada muestra se componía de 15 ug de RNA total en un volumen de $15 \mu \mathrm{L}$, al que se añadió $23,4 \mu \mathrm{L}$ de tampón de carga (4,5 $\mu \mathrm{L}$ formaldehido, $15 \mu \mathrm{L}$ formamida, 3,8 $\mu \mathrm{L}$ MEN 10X, 0,1 $\mu \mathrm{L}$ bromuro de etidio), se desnaturalizó a $65{ }^{\circ} \mathrm{C}$ durante 10 minutos y se cargó en el gel. La electroforesis se desarrolló a 90 V durante aproximadamente $1,5 \mathrm{~h}$.

Para el análisis Southern, $10 \mu \mathrm{g}$ de DNA genómico se digirieron con $2 \mu \mathrm{L}$ de diferentes enzimas de restricción en condiciones adecuadas, en un volumen total de $40 \mu \mathrm{L}$. Al inicio de la reacción se añadió la mitad del enzima y tras 2-3 h de incubación el resto, continuando con la incubación durante una noche. La reacción de restricción se detuvo añadiendo $3 \mu \mathrm{L}$ de 0,5 M EDTA pH 8,0 y se comprobó cargando $2 \mu \mathrm{L}$ en un gel de agarosa al $0,8 \%(p / v)$. Al DNA genómico digerido se añadió $9 \mu \mathrm{L}$ de tampón de carga (6X DNA Loading Dye, Fermentas), se incubó durante 5 minutos a $65{ }^{\circ} \mathrm{C}$ e inmediatamente se cargó en un gel de agarosa al 0,7\% (p/v) en TBE 1X. La electroforesis se desarrolló a un voltaje de 35-40 V durante aproximadamente de $20 \mathrm{~h}$. 


\subsubsection{Transferencia y fijación de RNA y DNA a membrana}

En el análisis Northern, antes de la transferencia a membrana, el gel se enjuagó 3 ó 4 veces en agua destilada, para eliminar el exceso de bromuro de etidio.

En el análisis Southern, antes de la transferencia a membrana, el gel se enjuagó durante 5 minutos en agua, posteriormente se lavó en $\mathrm{HCl}$ 0,125 M durante 15 minutos y nuevamente se enjuagó en agua. Después el DNA se desnaturalizó sumergiendo el gel en un tampón de desnaturalización $(1,5 \mathrm{M} \mathrm{NaCl}, 0,5 \mathrm{M} \mathrm{NaOH})$ durante 30 minutos y se enjuagó en agua. Finalmente, el gel se incubó en un tampón de neutralización (1,5 M $\mathrm{NaCl}, 1 \mathrm{M}$ Tris- $\mathrm{HCl}$ ) durante 30 minutos y se enjuagó en agua. Todos los lavados se realizaron en agitación.

Tanto el RNA como el DNA se transfirieron de gel a membrana de nylon (Hybond-N+, Amersham) por capilaridad, en tampón SSC 20X, según el procedimiento descrito por Sambrook et al. (1989). La transferencia se realizó durante una noche y finalmente los ácidos nucleicos se fijaron a la membrana con luz ultravioleta utilizando la cámara de irradiación UVC 500 UV Crosslinker (Amersham).

\subsubsection{Marcaje de sondas radiactivas}

La obtención y marcaje de sondas radiactivas se efectuó según el apartado 2.6.3. Los oligonucleótidos específicos utilizados para amplificar las sondas de cada gen se muestran en la Tabla 10. Las secuencias nucleotídicas de las sondas obtenidas mediante PCR se comprobaron mediante restricción y secuenciación.

\subsubsection{Prehibridación e hibridación}

El proceso de hibridación se realizó como se indica en el apartado 2.6.4, enjuagando las membranas con SSC $2 \mathrm{X}$ antes de prehibridarlas. Las hibridaciones se realizaron a 65 ${ }^{\circ} \mathrm{C}$ durante 14-18 h, en un horno de hibridación Roller-Blot Hybridiser HB-3D (TECHNE). Aunque los lavados típicamente se realizaron como se indica en el apartado 2.6.4, estos variaban en función de la intensidad de la señal. Las membranas se expusieron a películas radiográficas FUJI Medical 100NIF X-ray film (FUJIFILM) en casetes de autorradiografía y finalmente se revelaron en una procesadora automática X-OMAT 2000 Processor (Kodak). 


\subsubsection{PCR cuantitativa a tiempo real}

Los oligonucleótidos utilizados como cebadores específicos en las reacciones de PCR cuantitativa a tiempo real (qRT-PCR) fueron diseñados a partir de las regiones génicas de interés con el programa Primer Express $^{\circledR}$ v2.0 (Applied Biosystems) siguiendo los parámetros establecidos por defecto. En la Tabla 6 se muestran los genes analizados mediante qRT-PCR, así como los oligonucleótidos empleados en cada caso.

Tabla 6. Genes analizados mediante qRT-PCR y oligonucleótidos empleados

\begin{tabular}{|c|c|c|c|}
\hline Gen & Oligonucleótido & Secuencia & Amplicón (pb) \\
\hline \multirow[t]{2}{*}{ MtAGa } & qMtAGa1dir & AGAGCAAAGATAGCTGAAAGTGAGAG & 54 \\
\hline & qMtAGa1rev & ATTAATATTGCTATGGTGGCTATGG & \\
\hline \multirow[t]{2}{*}{ MtAGb } & qMtAGb2dir & ACATTGAGTATGGAGATTACACATTGG & 52 \\
\hline & qMtAGb2rev & GAAAGTAGAATAAGGGTGATACATGCC & \\
\hline \multirow[t]{2}{*}{ TC77416 } & SecDIRqRT & TGGCTACTAGGGTTGCTGGC & 51 \\
\hline & SecREVqRT & CCTCACCCAGTCCAGTGGAA & \\
\hline \multirow[t]{2}{*}{ PsAGa } & qPsAGa1dir & GTGTATTACCTGGAGGCACAAACTAT & 52 \\
\hline & qPsAGa1rev & TGCTGAGTCTGAGATTGCATGG & \\
\hline \multirow[t]{2}{*}{ PsAGb } & PsAGb2dir & GAGTTTCTGGTATTTGAATCTTGACA & 51 \\
\hline & PsAGb2rev & CTTTACGCATACGCTATCATAAGATTG & \\
\hline \multirow[t]{2}{*}{ Actina } & Actina11.DIR & AGGTGCTGTACCAACCATCCA & 51 \\
\hline & Actina11.REV & CGTGAATTCCTGCTGCTTCC & \\
\hline
\end{tabular}

La extracción de RNA de las muestras utilizadas para qRT-PCR se realizó como se indica en el apartado 2.1.4. Tras la extracción, para eliminar el DNA genómico, se realizó un tratamiento de desoxirribonucleasa exógena (DNA-free ${ }^{\mathrm{TM}}$ DNase Treatment \& Removal, Ambion) siguiendo las instrucciones del fabricante.

Para la síntesis de cDNA a partir del RNA total extraído y purificado se utilizó el sistema PrimeScript ${ }^{\mathrm{TM}}$ 1st strand cDNA Synthesis Kit (TaKaRa), partiendo de $4 \mu \mathrm{g}$ de RNA y siguiendo las indicaciones del proveedor. Este kit sintetiza la primera hebra de cDNA a partir de RNA usando PrimeScript ${ }^{\mathrm{TM}}$, una retrotranscriptasa basada en el MMLV (Moloney Murine Leukemia Virus), y como cebador el Oligo dT. El cDNA obtenido se trató con ribonucleasa incubando cada muestra 20 minutos a $37{ }^{\circ} \mathrm{C}$ con $1 \mu \mathrm{L}$ de RNasa $\mathrm{H}$ (Invitrogen). 
La qRT-PCR se llevó a cabo en un termociclador 7500 Fast Real-Time PCR System acoplado con el programa informático 7500 Fast System Software v1.3.1 (ambos de Applied Biosystems). Se utilizó el programa de amplificación recomendado por el fabricante para oligonucleótidos diseñados mediante Primer Express ${ }^{\circledR}$ y consistió en una atemperación de 2 minutos a $50^{\circ} \mathrm{C}$, una desnaturalización de 10 minutos a $95^{\circ} \mathrm{C}$ y 40 ciclos de amplificación, que consistían en una desnaturalización de 15 segundos a $95{ }^{\circ} \mathrm{C}$ y una elongación de 1 minuto a $60^{\circ} \mathrm{C}$.

Las mezclas de reacción se prepararon en placas "MicroAmp ${ }^{\circledR}$ Optical 96-Well Reaction Plate with Barcode" (Applied Biosystems) en un volumen final de $20 \mu \mathrm{L}$, con 1200 ng de cDNA, $10 \mu \mathrm{L}$ de Power SYBR ${ }^{\circledR}$ Green PCR Master Mix (Applied Biosystems), y los dos oligonucleótidos a una concentración final de 0,3 $\mu \mathrm{M}$.

El cálculo de la eficiencia de los cebadores se realizó mediante qRT-PCR usando como molde diluciones $(1 / 5,1 / 25$ y $1 / 125)$ de DNA que contenía el amplicón a estudiar. Se consideraron válidas aquellas parejas de cebadores cuya eficiencia estuvo entre 90$100 \%$.

Las cuantificaciones se realizaron a partir de las reacciones de qRT-PCR en las cuales cada muestra se determinó por triplicado. El ciclo umbral (Ct) fue calculado por el software del equipo y es el ciclo en el que comienza a detectarse el amplicón. Los resultados obtenidos se estandarizaron a los niveles de los genes constitutivos normalizadores, los cuales fueron: TC77416 (homólogo a Secret Agent de Arabidopsis thaliana [Hartweck et al., 2002]) en el caso de la qRT-PCR de Medicago truncatula y Actina (Foo et al., 2005) en el caso de la qRT-PCR de Pisum sativum. Los niveles relativos de transcrito se calcularon usando el método del $2^{-\Delta \Delta C t}$ (Livak y Schmittgen, 2001), que se resume en la expresión algebraica:

$$
\begin{gathered}
\text { Inducción }=2^{[\Delta C t \text { (muestra) }-\Delta c t(\text { control })]} \\
\Delta C t(\text { muestra })=C t(R)_{m}-C t(R)_{c} \\
\Delta C t \text { (control) }=C t(P)_{m}-C t(P)_{c}
\end{gathered}
$$

Donde $\mathrm{Ct}(\mathrm{R})_{\mathrm{m}}$ y $\mathrm{Ct}(\mathrm{R})_{c}$ son el valor de $\mathrm{Ct}$ para los genes normalizadores en el tratamiento analizado y en el que se considera como control, respectivamente. Del mismo modo, $\mathrm{Ct}(\mathrm{P})_{\mathrm{m}}$ y $\mathrm{Ct}(\mathrm{P})_{\mathrm{c}}$ son el valor de $\mathrm{Ct}$ del gen estudiado en el tratamiento analizado y en el que se considera como control, respectivamente. 
Todos los análisis de expresión por qRT-PCR se realizaron sobre al menos dos réplicas biológicas, obteniéndose resultados similares. Los resultados que se muestran corresponden a una sola réplica significativa.

\subsubsection{Hibridaciones in situ de mRNA}

Las hibridaciones in situ de mRNA se realizaron sobre secciones longitudinales de ápices vegetativos, inflorescentes o frutos de Medicago truncatula siguiendo el protocolo descrito por Ferrándiz et al. (2000).

\subsubsection{Generación de ribosondas marcadas con digoxigenina}

Las ribosondas monocatenarias se sintetizaron a partir de fragmentos de cDNA específicos para cada gen clonados en el vector pGEM ${ }^{\circledR}$ T-easy. Esta construcción se linearizó con los enzimas correspondientes y se transcribió para generar las ribosondas "antisentido". También se generó una sonda "sentido" que se utilizó como control negativo frente a hibridaciones inespecíficas. En la Tabla 7 se detallan los fragmentos de cDNA utilizados como moldes para cada sonda.

Tabla 7. Sondas utilizadas en las hibridaciones in situ

\begin{tabular}{lll}
\hline Clon (es) & Nombre $^{\text {a }}$ & Fragmento $^{\text {a }}$ \\
\hline $\mathbf{1 2 . 1 1 . 1}$ & MtAGa & $572-813$ \\
$\mathbf{1 5 . 5 . 1}$ & MtAGb & $558-773$ \\
$\mathbf{1 2 . 9 . 1}$ & MtTM6 & $362-689$ \\
$\mathbf{8 . 1 . 1}$ & MtNMH7 & $289-734$ \\
$\mathbf{6 . 6 . 1}$ & MtAGL6 & $324-682$ \\
$\mathbf{8 . 2 . 1}$ & MtAGL6-like & $267-686$ \\
$\mathbf{1 2 . 1 . 1}$ & MtSOC1-like & $277-650$ \\
$\mathbf{1 5 . 4 . 1}$ & MtSEP & $219-588$ \\
$\mathbf{1 4 . 4 . 1}$ & MtSHP & $452-818$ \\
$\mathbf{1 . 3 . 1}$ & MtSOC1a & $528-721$ \\
$\mathbf{1 4 . 3 . 2}$ & MtSOC1b & $429-616$ \\
\hline
\end{tabular}

\footnotetext{
${ }^{\mathrm{a}}$ Nombre asignado por homología a genes conocidos de otras plantas modelo

${ }^{\text {b }}$ Numeración referida a los nucleótidos del cDNA considerando la adenina del codón de inicio como 1.
}

Para la transcripción in vitro se usaron como molde $2 \mu \mathrm{g}$ de plásmido linearizado para una reacción de $20 \mu \mathrm{L}$ que contenía $2 \mu \mathrm{L}$ de DIG RNA Labeling Mix (10 mM ATP, 10 mM CTP, 10 mM GTP, 6,5 mM UTP, 3,5 mM DIG-11-UTP. Roche), $2 \mu \mathrm{L}$ de inhibidor de RNasas (Protector RNase Inhibitor, Roche), $2 \mu \mathrm{L}$ de la polimerasa de RNA correspondiente (T7 o SP6, Roche) y $2 \mu \mathrm{L}$ del tampón $10 \mathrm{X}$ correspondiente (Roche). La reacción tuvo lugar a 37 ${ }^{\circ} \mathrm{C}$ durante $1,5 \mathrm{~h}$. 
Tras la incubación se trataron las sondas 15 minutos a $37{ }^{\circ} \mathrm{C}$ con $1 \mu \mathrm{L}$ de DNase I RNase-free (Roche), se precipitaron con tRNA de levadura (10 $\mu \mathrm{g} / \mu \mathrm{L}$, Roche), 0,7 M acetato amónico y $220 \mu \mathrm{L}$ de etanol $96 \%(\mathrm{v} / \mathrm{v})$ y se almacenaron a $-20{ }^{\circ} \mathrm{C}$. La eliminación de DNA se comprobó mediante electroforesis en gel de agarosa al 1,2\% ( $p / v)$.

\subsubsection{Cuantificación de las sondas}

Se centrifugaron las sondas a $13.000 \mathrm{rpm}$ durante 15 minutos, se lavaron en etanol $80 \%(v / v)$ y una vez secas se resuspendieron en $10 \mu \mathrm{L}$ de agua desionizada estéril. Con 1 $\mu \mathrm{L}$ de esta disolución se prepararon diluciones $1 / 250,1 / 1000$ y $1 / 2500$ para cuantificar la sonda. Se aplicó $1 \mu \mathrm{L}$ de cada dilución a una membrana de nylon (dot blot) que se secó y se fijó con luz ultravioleta.

La membrana se reveló junto con una tira de control de concentraciones de RNA "DIG Control Teststrips" (Roche) incubando ambas 2 minutos en TBS 1X (stock 10X: 1 M Tris$\mathrm{HCl}, 4 \mathrm{M} \mathrm{NaCl}, \mathrm{pH} 7,5)$ y a continuación 10 minutos en TBS $1 \mathrm{X}$ con 0,5\% Blocking Reagent (Roche). Se lavó 5 minutos en TBS $1 X$ con 1\% BSA (p/v) y 0,3\% Tritón X-100 (v/v) y luego 20 minutos en la misma solución adicionada con $2 \mu \mathrm{L}$ de anticuerpo Anti-Digoxigenin-AP, Fab fragments (Roche). Tras lavar en tampón de detección 1X (stock 10X: $1 \mathrm{M}$ Tris-HCl, 1 $\mathrm{M} \mathrm{NaCl}, 0,5 \mathrm{M} \mathrm{MgCl}_{2}, \mathrm{pH}$ 9,5) se reveló en $5 \mathrm{~mL}$ del mismo tampón $1 \mathrm{X}$ con sustrato [7,5 $\mu \mathrm{L}$ de NBT (100 mg/mL) y $150 \mu \mathrm{L}$ de BCIP $(50 \mathrm{mg} / \mathrm{mL})$, Roche] hasta visualizar el último punto de la tira control. La concentración de sonda a utilizar en cada caso fue la que más se aproximó al penúltimo punto de esta tira control.

\subsubsection{Preparación de las muestras}

Las muestras se recogieron directamente en FAE [50\% etanol (v/v), 5\% ácido acético glacial $(\mathrm{v} / \mathrm{v})$ y $3,7 \%$ formaldehido $(\mathrm{v} / \mathrm{v})]$. Se infiltraron al vacío usando una bomba de paletas rotativas RV5 (EDWARDS) durante 30 minutos en total, repartidos en dos tandas de 15 minutos realizadas en 3 pulsos de 5 minutos cada uno. La solución fijadora se cambió por solución fresca entre cada tanda y al finalizar la infiltración, dejando reposar durante $3 \mathrm{~h}$ a temperatura ambiente. A continuación las muestras se deshidrataron en series de etanol en concentraciones crecientes (70\% y $95 \%$ ) de 30 minutos cada una, tiñendo finalmente el tejido en Eosina- $Y$ al $0,2 \%$ en etanol al $96 \%$ a $4{ }^{\circ} \mathrm{C}$ durante la noche. 
Posteriormente, las muestras se incubaron por duplicado en etanol al $100 \%$ y luego en concentraciones crecientes (25\%, 50\%, $75 \%$ y dos al $100 \%$ ) de disolvente histológico Histo-Clear ${ }^{\circledR}$ (National Diagnostics), durante 1,5 h cada incubación. Finalmente se añadió un volumen de parafina Paraplast ${ }^{\circledR}$ Plus (McCormick Scientific) fundida a $58{ }^{\circ} \mathrm{C}$ y se incubó una noche a esa temperatura.

Al día siguiente se sustituyó la mezcla por parafina 100\%, realizando cambios de parafina cada 3 horas hasta la total eliminación del Histo-Clear ${ }^{\circledR}$. Las muestras se acomodaron en moldes de aluminio (Selecta) con parafina líquida, se cubrieron con un soporte plástico y se dejaron solidificar a $4{ }^{\circ} \mathrm{C}$.

Se obtuvieron cortes histológicos de $8 \mu \mathrm{m}$ de espesor de las muestras vegetales incluidas en parafina utilizando un microtomo MICROM HM 330 con cuchillas AccuEdge $^{\circledR}$ (Sakura), los cuales se colocaron en portaobjetos.

\subsubsection{Prehibridación e hibridación}

El tejido se desparafinó en los portaobjetos con Histo-Clear ${ }^{\circledR}$ y se rehidrató en series de etanol a concentraciones decrecientes de 2 minutos cada una. Se hidrolizaron las proteínas durante 20 minutos con $\mathrm{HCl} \mathrm{0,2} \mathrm{M} \mathrm{y} \mathrm{posteriormente} \mathrm{se} \mathrm{incubó} 15$ minutos a $37{ }^{\circ} \mathrm{C}$ con "Proteinase $\mathrm{K}$, recombinant PCR Grade" ( $1 \mu \mathrm{g} / \mu \mathrm{L}$, Roche). Los portaobjetos se lavaron con PBS 1X (stock 20X: 2,75 M NaCl, $50 \mathrm{mM} \mathrm{KCl,} 200 \mathrm{mM} \mathrm{Na} 2 \mathrm{HPO}_{4}, 35 \mathrm{mM}$ $\left.\mathrm{KH}_{2} \mathrm{PO}_{4}, \mathrm{pH} 7,4\right)$ y se bloqueó la acción de la proteinasa incubando 2 minutos en $1 \mathrm{X}$ PBS con glicina al $0,2 \%(p / v)$. Tras lavar con PBS $1 X$ se refijó el tejido durante 10 minutos con una solución de PBS 1X y formaldehído al 4\% (v/v), seguido de dos lavados con PBS 1X. Se deshidrató el tejido en series crecientes de etanol de 2 minutos hasta llegar al etanol absoluto y se dejó secar.

Para la hibridación, se precalentaron los portaobjetos con el tejido en una placa calefactora (Multiplaces, JP Selecta) a $55{ }^{\circ} \mathrm{C}$. Las sondas se diluyeron en tampón de hibridación [SSC 6X (stock 20X: $3 \mathrm{M} \mathrm{NaCl}, 0,3 \mathrm{M}$ citrato sódico, pH 7,0), 1,5\% SDS (p/v), $50 \%$ formamida $(\mathrm{v} / \mathrm{v})$, tRNA de levadura $(100 \mu \mathrm{g} / \mathrm{mL})]$ hasta la concentración establecida en la cuantificación y se desnaturalizaron a $80^{\circ} \mathrm{C}$ durante 2 minutos. Se aplicaron $300 \mu \mathrm{L}$ de la solución de hibridación a cada portaobjetos y se colocaron enfrentados uno a uno a modo de emparedado. Los portaobjetos apareados se incubaron en una cámara húmeda durante toda la noche a $53^{\circ} \mathrm{C}$. 


\subsubsection{Inmunodetección colorimétrica de la señal}

Tras separar los portaobjetos por inmersión en SSC $2 X$ con $50 \%$ formamida ( $/ \mathrm{v}$ ), se realizaron dos lavados de $1,5 \mathrm{~h}$ cada uno en esta misma solución, a $53{ }^{\circ} \mathrm{C}$. Los portaobjetos se incubaron en TBS $1 \mathrm{X}$ durante 5 minutos, luego $1 \mathrm{~h}$ en TBS $1 \mathrm{X}$ con 0,5\% Blocking Reagent (Roche) y 30 minutos en TBS $1 X$ con $1 \%$ BSA (p/v) y 0,3\% Tritón X-100 (v/v). A continuación, se incubaron 1,5 h en esta última solución con el anticuerpo AntiDigoxigenin-AP, Fab fragments (Roche) en dilución 1:3.000. Se lavaron tres veces con la misma solución sin anticuerpo y se añadió tampón de detección, compuesto por una mezcla 1:1 de tampón A $1 \mathrm{X}$ y tampón B $1 \mathrm{X}$ (Tampón A 10X: $1 \mathrm{M}$ Tris- $\mathrm{HCl}, 1 \mathrm{M} \mathrm{NaCl}, \mathrm{pH}$ 9,5. Tampón B 10X: 0,5 M MgCL $2,4 \mathrm{M} \mathrm{NaCl}$ ) sin sustratos durante 5 minutos. Finalmente se reemplazó por tampón de detección fresco suplementado con los sustratos NBT y $\mathrm{BCIP}, 1,5 \mu \mathrm{L}$ de cada uno por cada $\mathrm{mL}$ de tampón (NBT/BCIP Stock Solution, Roche). Se incubó en oscuridad durante el tiempo requerido para observar señal. La reacción se detuvo reemplazando la solución de detección por agua.

Las muestras se visualizaron como se describe en el apartado 4.2.2.

\section{TRANSFORMACIÓN GENÉTICA DE PLANTAS}

\subsection{DISEÑO DE CONSTRUCCIONES}

\subsubsection{Construcciones generadas para el silenciamiento de los genes} AGAMOUS de Medicago truncatula mediante RNA interferente

Las construcciones para el silenciamiento de los genes MtAGa y MtAGb se generaron utilizando el plásmido pHANNIBAL. Este plásmido presenta dos sitios de clonación separados por un intrón, lo que permite clonar el mismo fragmento del gen en sentido y antisentido, consecutivamente. El fragmento utilizado para el gen MtAGa fue de $241 \mathrm{pb}$ y se amplificó con los cebadores AGaRNAid y AGaRNAir (Tabla 10), que añaden los sitios de corte Xhol-Xbal en el cebador directo y HindIII-EcoRI en el cebador reverso. Por otro lado, el fragmento usado para el gen MtAGb fue de 215 pb y se amplificó con los cebadores AGbRNAid y AGbRNAir (Tabla 10), que añaden Xhol-Xbal en el cebador directo y BamHI-EcoRI en el cebador reverso. Los fragmentos amplificados se purificaron y clonaron en el pGEM $^{\circledR}$ T-easy, de donde posteriormente se escindieron 
mediante restricción, generando cuatro fragmentos distintos: Xhol-MtAGa-EcoRl, XholMtAGb-EcoRI, Xbal-MtAGa-HindIII y Xbal-MtAGb-BamHI.

La clonación de los fragmentos en pHANNIBAL se realizó en dos pasos. Primero se clonaron los fragmentos Xhol-EcoRl, dando lugar a [pHANNIBAL-fragmento "sentido"], comprobando a continuación esta clonación por restricción con los mismos enzimas. Se prosiguió con la clonación de los fragmentos Xbal-MtAGa-HindIII y Xbal-MtAGb-BamHI digiriendo la construcción transitoria [pHANNIBAL-fragmento "sentido"] con los enzimas que flanqueaban el fragmento a insertar. La clonación de los fragmentos "sentido" y "antisentido" se comprobó por restricciones simples y dobles y por secuenciación.

El vector pHANNIBAL no puede utilizarse para transformar plantas, por lo que la construcción se subclonó en el vector pGreenll-nosbar. El casete, que contenía el promotor CaMV 35S y las dos copias del fragmento génico separadas por el intrón PDK, se escindió de la construcción transitoria pHANNIBAL mediante digestión con Notl y se clonó en el sitio Notl del vector pGreenll-nosbar (Benlloch, R. Tesis Doctoral, 2005). En la Figura 9 se esquematiza la generación de las construcciones de silenciamiento de los genes MtAGa y MtAGb mediante RNA interferente (RNAi).

Las construcciones pGreenll-nosbar RNAi MtAGa y pGreenll-nosbar RNAi MtAGb se introdujeron en la cepa de $A$. tumefaciens C58/pMP90 que ya contenía el vector pSoup (vector binario que permite la replicación del pGreen y la transferencia del T-DNA). Dicha cepa se utilizó para generar plantas transgénicas de $M$. truncatula.

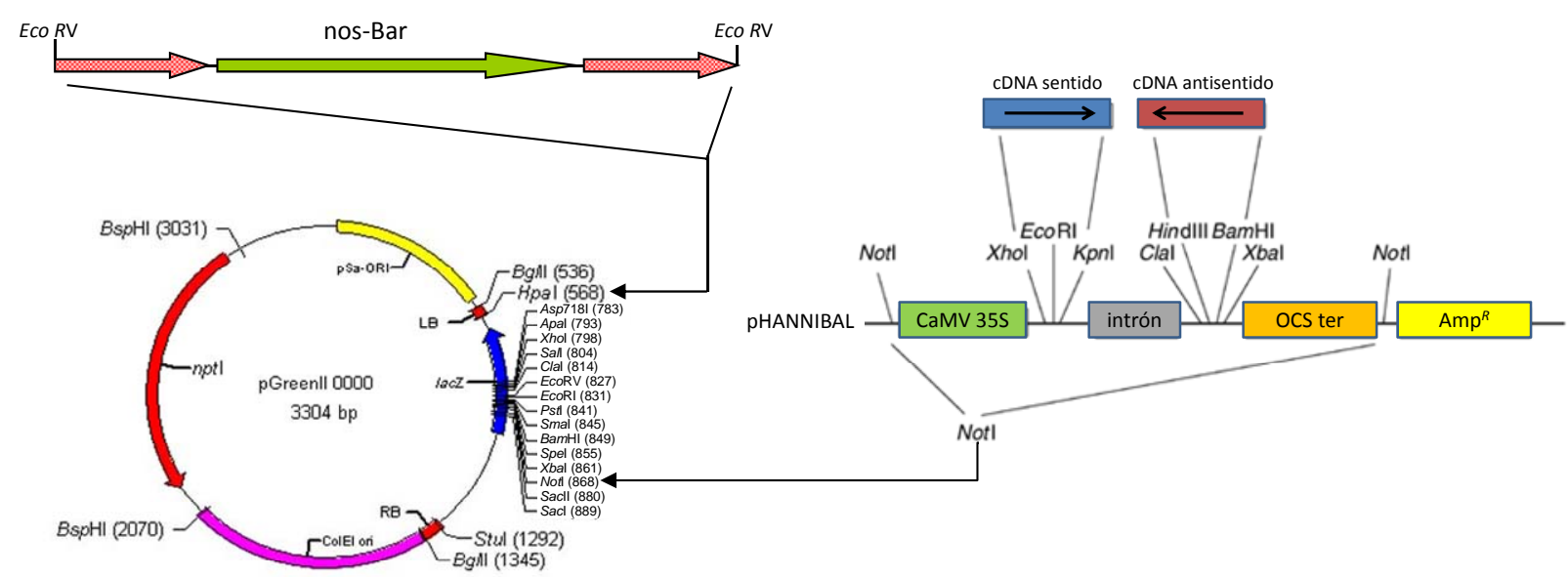

Figura 9. Generación de las construcciones de silenciamiento génico mediante RNAi 


\subsubsection{Construcciones generadas para el silenciamiento de los genes}

AGAMOUS de Pisum sativum y Medicago truncatula mediante silenciamiento

\section{génico inducido por virus (VIGS)}

En los experimentos de silenciamiento génico inducido por virus (VIGS) tanto de Pisum sativum como de Medicago truncatula, se utilizaron los vectores PCAPE1 y pCAPE2-PDS, cedidos por la Dra. Elisabeth Johansen (Aarhus University, Dinamarca).

Estos vectores contienen, respectivamente, el RNA1 y el RNA2 del Pea early-browning virus (PEBV), bajo el control del promotor CaMV $35 \mathrm{~S}$ y el terminador NOS, clonados en el vector binario pCAMBIA-1300 (CambiaLabs), en el cual reemplazan al casete de resistencia a higromicina (Figura 10). La descripción completa de la construcción de estos vectores se detalló en Constantin et al., (2004).

a) pCAPE1

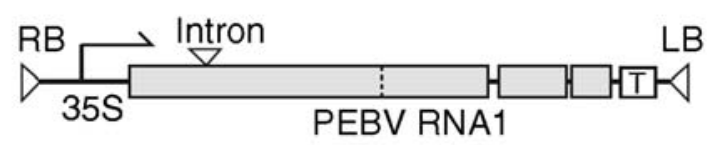

b) pCAPE2-PDS

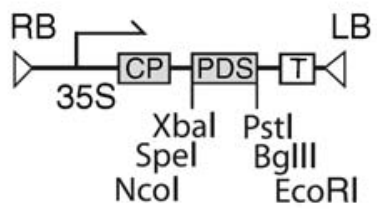

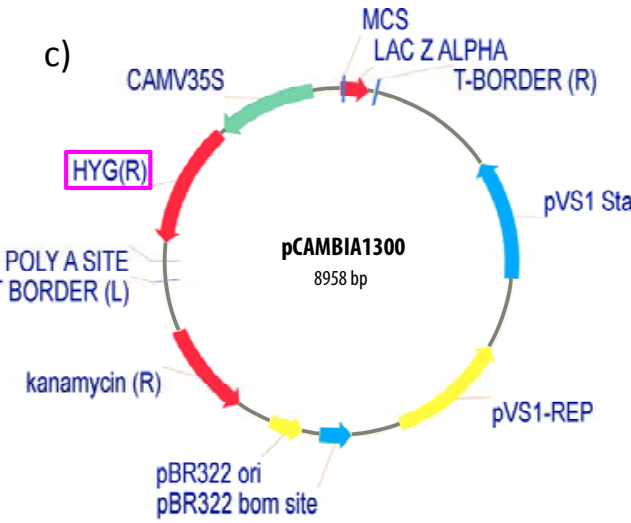

Figura 10. Descripción de los vectores pCAPE1 y pCAPE2. Los casetes RNA1 y RNA2 de expresión del PEBV insertados entre los bordes izquierdo y derecho de un vector derivado del pCAMBIA-1300 se integran entre el promotor $35 \mathrm{~S}$ y el terminador NOS (T). a) pCAPE1 contiene el CDNA completo del RNA1 y un intrón insertado para estabilizar el plásmido en la bacteria. b) pCAPE2-PDS contiene el cDNA del RNA2 con una inserción de un fragmento de $470 \mathrm{pb}$ del PSPDS supliendo a los genes requeridos para la transmisión de nemátodos; CP es la región codificante de la proteína de la cápside (Imágenes tomadas de Constantin et al., 2004). c) Mapa del plásmido pCAMBIA-1300. En el recuadro rosa se señala el casete de resistencia a la higromicina eliminado para la generación de las construcciones PCAPE.

Las construcciones VIGS de los genes que se deseaba silenciar se generaron utilizando el vector pCAPE2-PDS. En este vector la región codificante PSPDS está flanqueada por los sitios de restricción $\mathrm{Ncol}$, Spel y $\mathrm{Xbal}$ al inicio y Pstl, Bg/ll y EcoRI al final, lo que permite suplir el fragmento PsPDS con fragmentos de cDNA de los genes que se desea silenciar.

Por cada gen se diseñaron dos construcciones, con la finalidad de estudiar las diferencias en el efecto del silenciamiento generado al utilizar diferentes fragmentos del mismo gen. Se utilizaron fragmentos superiores a 300 pb que solapan en menos del $50 \%$ de la secuencia, intentando que uno de ellos fuera de más de 400 pb. En la Figura 11 se 
puede ver el esquema general de los genes MADS-box, en el cual se delimitan los fragmentos utilizados en las construcciones VIGS. El fragmento de mayor tamaño (Fragmento 1) siempre fue aquel que permitía una mayor especificidad del silenciamiento del gen, al incluir parte de la región C-terminal y la región no codificante del mismo, zonas que son específicas para cada uno de los genes MADS-box.

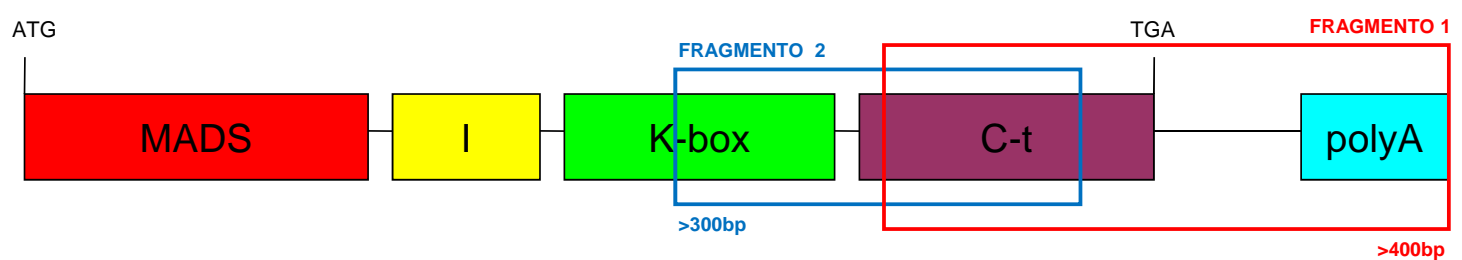

Figura 11. Esquema de la ubicación de los fragmentos VIGS en los genes MADS-box

Los fragmentos de cDNA utilizados para las construcciones oscilaban entre 300 y 500 pb. Estos fragmentos se amplificaron utilizando cebadores específicos que añaden al inicio y al final del fragmento sitios de restricción que posteriormente permitirán clonar dichos fragmentos en el vector pCAPE2-PDS.

Los fragmentos amplificados se purificaron y clonaron en pGEM $^{\circledR}$ T-easy, de donde posteriormente se escindieron mediante restricción doble con los enzimas correspondientes. Estos fragmentos se subclonaron directamente en el vector pCAPE2PDS linearizado mediante restricción con los mismos enzimas. Esta clonación supuso la sustitución del fragmento PSPDS del vector por el fragmento de cDNA del gen de interés.

Se diseñó también una construcción que permitía el silenciamiento simultáneo de ambos genes AGAMOUS de Pisum sativum. Para generar dicha construcción, se utilizaron dos fragmentos, uno de $322 \mathrm{pb}$ del gen PsAGa y uno de $320 \mathrm{pb}$ del gen PsAGb, que se amplificaron utilizando cebadores específicos que añaden al inicio y al final del fragmento sitios de restricción que posteriormente permitirán clonar dichos fragmentos en el vector pCAPE2-PDS en tándem. Así pues, se amplificaron los fragmentos NcolPsAGa-Xbal y Xbal-PsAGb-Pstl, que se clonaron de manera independiente en pGEM $^{\circledR}$ Teasy para confirmar mediante secuenciación la integración de los sitios de restricción. Los fragmentos se escindieron y seguidamente el fragmento Ncol-PsAGa-Xbal se clonó en PCAPE2-PDS linearizado con Ncol y Xbal. Finalmente, tras comprobar la inserción mediante restricción, el fragmento Xbal-PsAGb-Pstl se subclonó a la construcción 
transitoria [pCAPE2-fragmento PsAGa], linearizada con los enzimas Xbal y PstI. También se diseñó una construcción equivalente para silenciar a la vez ambos genes AGAMOUS de Medicago truncatula.

En la Tabla 8 se resumen los diferentes fragmentos utilizados, así como los enzimas usados para la clonación de los mismos. En todos los casos se comprobó la clonación de los fragmentos en pCAPE2 por restricciones dobles y por secuenciación, y se procedió a la transformación de las cepas de Agrobacterium tumefaciens C58/pMP90 (GV3101) con las construcciones generadas, para su utilización posterior en la agroinfiltración de Pisum sativum y Medicago truncatula.

Tabla 8. Fragmentos utilizados para las construcciones VIGS

\begin{tabular}{|c|c|c|c|c|}
\hline Construcción & Fragmento (pb) & Ubicación $^{\mathrm{a}}$ & S.R.A. ${ }^{b}$ inicio & S.R.A. final \\
\hline pCAPE2-MtAGa & 478 & $572-1050$ & Ncol & EcoRI \\
\hline pCAPE2-MtAGabis & 396 & $312-708$ & $\mathrm{Ncol}$ & ECORI \\
\hline pCAPE2-MtAGb & 486 & $564-1050$ & $X b a l$ & Pstl \\
\hline pCAPE2-MtAGbbis1 & 399 & $312-711$ & Ncol & ECORI \\
\hline pCAPE2-MtAGbbis2 & 357 & $312-669$ & $\mathrm{Ncol}$ & ECORI \\
\hline \multirow[t]{2}{*}{ pCAPE2-MtAGdoble } & $310(M t A G a)$ & $572-882$ & $\mathrm{Ncol}$ & $X b a l$ \\
\hline & $338(M t A G b)$ & $564-902$ & $X b a l$ & Pstl \\
\hline pCAPE2-PsAGa & 413 & $572-985$ & Ncol & EcoRl \\
\hline pCAPE2-PsAGabis & 373 & $324-697$ & $X b a l$ & Pstl \\
\hline pCAPE2-PsAGb & 451 & $561-1012$ & $X b a l$ & Pstl \\
\hline pCAPE2-PsAGbbis1 & 383 & $321-704$ & $X b a l$ & Pstl \\
\hline pCAPE2-PsAGbbis2 & 341 & $321-662$ & $X b a l$ & Pstl \\
\hline \multirow[t]{2}{*}{ pCAPE2-PsAGdoble } & $322(P s A G a)$ & $572-894$ & Ncol & $x b a l$ \\
\hline & $320($ PsAGb) & $561-881$ & $X b a l$ & Pstl \\
\hline
\end{tabular}

\footnotetext{
${ }^{a}$ Numeración referida al cDNA considerando la adenina del codón de inicio como número 1.
}

b "Sitio de restricción añadido"

\subsubsection{Construcciones generadas para la expresión constitutiva de los genes}

\section{AGAMOUS de Medicago truncatula en Arabidopsis thaliana}

Para ensayar los efectos de la expresión constitutiva de MtAGa y MtAGb en plantas transgénicas, el cDNA de cada uno de estos genes se clonó en el vector binario de expresión en plantas pBIN-JIT (Figura 12). El plásmido pBIN-JIT contiene una repetición en tándem del promotor $35 \mathrm{~S}$ del CaMV y la secuencia de poliadenilación del CaMV, 
procedentes del plásmido pJIT60 (Guerineau y Mullineaux, 1993) introducidas en el plásmido binario pBIN19. Para generar las construcciones, los cDNAs completos de MtAGa (782 pb) y MtAGb en sus formas L ("Long", 734 pb) y S ("Short", 692 pb) se amplificaron con los cebadores AGaSBXdir, AGaSBXrev, AGbSBXdir y AGbSBXrev (Tabla 10), que añaden el sitio de corte Sall en el cebador directo y BamHI en el cebador reverso.

Los fragmentos amplificados se purificaron y clonaron en el pGEM ${ }^{\circledR}$ T-easy, de donde posteriormente se escindieron mediante restricción doble Sall-BamHI. Estos fragmentos se subclonaron directamente en el vector pBIN-JIT linearizado también mediante digestión con Sall-BamHI, asegurando así la orientación del inserto en el vector.

Se comprobó la clonación de los fragmentos en pBIN-JIT por restricciones simples, dobles y por secuenciación, y se procedió a la transformación de las cepas de Agrobacterium tumefaciens C58/pMP90 con las construcciones generadas, para su utilización posterior en la transformación de Arabidopsis thaliana.

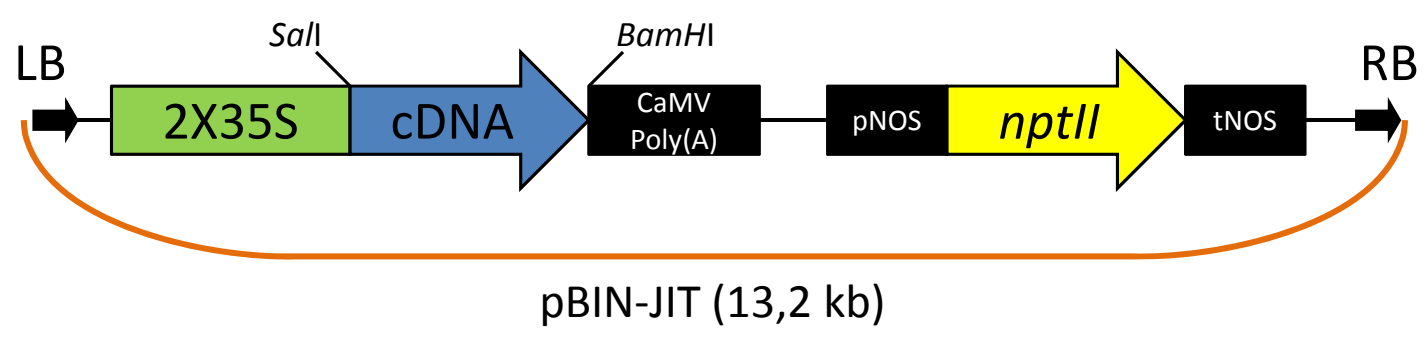

Figura 12. Construcciones utilizadas para la expresión constitutiva de los genes AGAMOUS de M. truncatula. El plásmido pBIN-JIT contiene el promotor CaMV $35 \mathrm{~S}$ con el enhancer duplicado (2X35S), la secuencia de poliadenilación del CaMV y el gen npt/l que confiere resistencia a la kanamicina flanqueado por el promotor y el terminador NOS (del gen nopalin sintetasa).

\subsection{TRANSFORMACIÓN GENÉTICA DE PLANTAS}

\subsubsection{Transformación estable de Medicago truncatula}

El método de transformación genética utilizado para generar plantas en las que se silencian los genes AGAMOUS mediante RNA interferente está descrito en detalle en Trinh et al. (2001). Consiste en la infiltración de explantes de hoja de M. truncatula (2HA) con una suspensión de $A$. tumefaciens que contiene la construcción genética de 
interés (ver apartado 3.1.1) y la posterior obtención de plantas transgénicas mediante embriogénesis somática.

Para cada experimento se utilizaron 50-100 explantes, que consistían en foliolos individuales de plantas de un mes. Los foliolos se lavaron en agua con una gota de detergente común, se enjuagaron y se esterilizaron por 14 minutos en agitación con lejía al $25 \%(v / v)$. Tras lavar varias veces con agua estéril, los foliolos se cortaron en cuadros con ayuda de un bisturí en condiciones de esterilidad. Un día antes se preparó un cultivo con $100 \mathrm{~mL}$ de LB líquido y los antibióticos correspondientes, que se inoculó con $50 \mu \mathrm{L}$ de un precultivo saturado de una colonia aislada de $A$. tumefaciens. El cultivo se creció toda la noche a $28{ }^{\circ} \mathrm{C}$ en agitación. Posteriormente se centrifugó y el precipitado se resuspendió en medio líquido SH3a (Tabla 9) hasta $\mathrm{DO}_{600}$ final de 0,2, calculando $50 \mathrm{~mL}$ de esta suspensión por cada 50 explantes a infiltrar.

Los foliolos cortados se infiltraron al vacío con esta suspensión durante 15 minutos y después se dejaron recuperar del estrés mediante una incubación de $1 \mathrm{~h}$ con agitación suave. Se secaron ligeramente y se colocaron en medio sólido SH3a, sobre el cual se incubaron 3 días a $24{ }^{\circ} \mathrm{C}$ en oscuridad. Pasado este tiempo los explantes se limpiaron del exceso de A. tumefaciens pasando cada explante varias veces por medio SH3a sólido con ayuda de pinzas y luego se transfirieron a medio SH3a sólido suplementado con 800 $\mathrm{mg} / \mathrm{L}$ Augmentine (amoxicillin sodium / clavulanate potassium, Duchefa) y 0,55 mg/L Basta (PPT: dl-phosphinothricin, Duchefa). Las placas se incubaron 2 semanas a $24^{\circ} \mathrm{C}$ en cámara de cultivo in vitro con $16 \mathrm{~h}$ de luz. Posteriormente los explantes se pasaron a medio CIM (Tabla 9), que favorece la formación de callo, suplementado con $400 \mathrm{mg} / \mathrm{L}$ de Augmentine y 0,55 mg/L de Basta incubando por 2 semanas y después al medio de proembriogénesis y selección EIM (Tabla 9) con 200 mg/L de Augmentine y 0,55 mg/L de Basta durante 4 semanas. La embriogénesis y desarrollo de plántulas se realizó en el siguiente medio EMB (Tabla 9) suplementado con $200 \mathrm{mg} / \mathrm{L}$ de Augmentine y 0,55 mg/L de Basta durante 4-5 semanas y finalmente las plántulas desarrolladas se enraizaron en medio PLANT (Tabla 9) con 200 mg/L de Augmentine durante 4-6 semanas.

Cuando las plántulas desarrollaron suficiente raíz, se transfirieron a macetas con una mezcla de turba y arena $3: 1(\mathrm{v} / \mathrm{v})$ y se taparon con plástico para mantener las condiciones de humedad. Las condiciones del invernadero fueron las descritas en el 
apartado 1.1.1.1 y, tras la aclimatación, se retiró el plástico y se realizó el seguimiento del crecimiento normal de las plantas.

Tabla 9. Medios de cultivo utilizados en la transformación genética de $M$. truncatula

\begin{tabular}{|c|c|}
\hline Medio & Composición (por litro) \\
\hline SH3a líquido & $\begin{array}{l}100 \mathrm{~mL} \text { macro N6major, } 1 \mathrm{~mL} \text { micro SHminor, } 1 \mathrm{~mL} \text { vitaminas SHvit, } 100 \mathrm{mg} \text { myo-inositol, } 20 \\
\mathrm{~mL} \text { EDFS, } 5 \mathrm{~mL} \text { 2,4-D (1 mg/mL), 0,5 mL BAP (1 mg/mL), } 30 \mathrm{~g} \text { sacarosa, } \mathrm{pH} \text { 5,8 }\end{array}$ \\
\hline SH3a sólido & SH3a sólido suplementado con $3 \mathrm{~g}$ phytagel \\
\hline CIM & 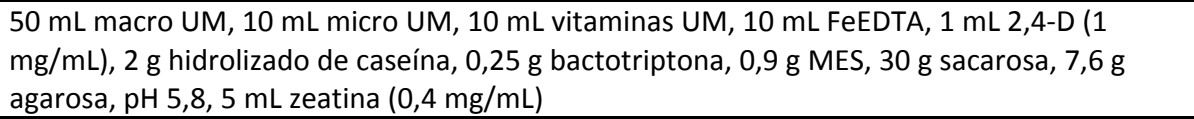 \\
\hline EIM & $\begin{array}{l}50 \mathrm{~mL} \text { macro UM, } 10 \mathrm{~mL} \text { micro UM, } 10 \mathrm{~mL} \text { vitaminas UM, } 10 \mathrm{~mL} \text { FeEDTA, } 2 \mathrm{~g} \text { hidrolizado de } \\
\text { caseína, 0,9 g MES, } 30 \mathrm{~g} \text { sacarosa, 7,6 g agarosa, } \mathrm{pH} \text { 5,8, 2,5 mL zeatina }(0,4 \mathrm{mg} / \mathrm{mL})\end{array}$ \\
\hline EMB & $\begin{array}{l}50 \mathrm{~mL} \text { macro UM, } 10 \mathrm{~mL} \text { micro P4, } 10 \mathrm{~mL} \text { vitaminas UM, } 10 \mathrm{~mL} \text { FeEDTA, 0,5 mL BAP (1 } \\
\mathrm{mg} / \mathrm{mL}), 0,1 \mathrm{~mL} \text { NAA (1 mg/mL), 0,2 mL GA }(1 \mathrm{mg} / \mathrm{mL}), 0,25 \mathrm{~g} \text { hidrolizado de caseína, } 10 \mathrm{~g} \\
\text { sacarosa, 7,6 g agarosa, } \mathrm{pH} \mathrm{5,8}\end{array}$ \\
\hline PLANT & $\begin{array}{l}25 \mathrm{~mL} \text { macro UM, } 10 \mathrm{~mL} \text { micro SH, } 10 \mathrm{~mL} \text { vitaminas SH, } 1 \mathrm{~g} \text { myo-inositol, } 10 \mathrm{~mL} \text { FeEDTA, 0,01 } \\
\mathrm{mL} \text { NAA (1 mg/mL), } 10 \mathrm{~g} \text { sacarosa, } 2 \mathrm{~g} \text { agarosa, } 2 \text { g agar Kalys, pH 5,9 }\end{array}$ \\
\hline
\end{tabular}

Composición de macroelementos, microelementos y vitaminas usados para preparar los medios:

\begin{tabular}{|c|c|c|}
\hline & Nombre & Composición \\
\hline \multirow{2}{*}{ Macroelementos } & N6 major & 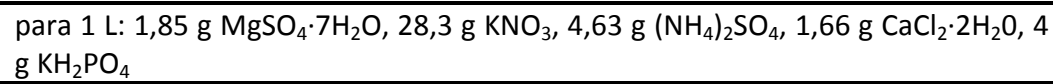 \\
\hline & UM & $\begin{array}{l}\text { para } 0,5 \mathrm{~L}: 19 \mathrm{~g} \mathrm{KNO}_{3}, 16,5 \mathrm{~g} \mathrm{NH}_{4} \mathrm{NO}_{3}, 3,7 \mathrm{~g} \mathrm{MgSO}_{4} \cdot 7 \mathrm{H}_{2} \mathrm{O}, 1,7 \mathrm{~g} \mathrm{KH}_{2} \mathrm{PO}_{4}, 4,4 \mathrm{~g} \\
\mathrm{CaCl}_{2} \cdot 2 \mathrm{H}_{2} \mathrm{O}\end{array}$ \\
\hline \multirow{4}{*}{ Microelementos } & SHminor & $\begin{array}{l}\text { para } 100 \mathrm{~mL}: 1 \mathrm{~g} \mathrm{MnSO}_{4} \cdot 4 \mathrm{H}_{2} \mathrm{O}, 500 \mathrm{mg} \mathrm{H} \mathrm{BO}_{3}, 100 \mathrm{mg} \mathrm{ZnSO} \cdot 7 \mathrm{H}_{2} \mathrm{O}, 100 \mathrm{mg} \mathrm{KI}, 10 \\
\mathrm{mg} \mathrm{NaMoO}_{4} \cdot 2 \mathrm{H}_{2} \mathrm{O}, 20 \mathrm{mg} \mathrm{CuSO} \cdot 5 \mathrm{H}_{2} \mathrm{O}, 10 \mathrm{mg} \mathrm{CoCl} \cdot 6 \mathrm{H}_{2} \mathrm{O}\end{array}$ \\
\hline & UM & $\begin{array}{l}\text { para } 500 \mathrm{~mL}: 680 \mathrm{mg} \mathrm{MnSO} \cdot 4 \mathrm{H}_{2} \mathrm{O}, 430 \mathrm{mg} \mathrm{ZnSO} \cdot 7 \mathrm{H}_{2} \mathrm{O}, 41,5 \mathrm{mg} \mathrm{KI}, 310 \mathrm{mg} \\
\mathrm{H}_{3} \mathrm{BO}_{3}, 12,5 \mathrm{mg} \mathrm{NaMoO} \cdot 2 \mathrm{H}_{2} \mathrm{O}, 1,25 \mathrm{mg} \mathrm{CuSO}{ }_{4} \cdot 5 \mathrm{H}_{2} \mathrm{O}, 1,25 \mathrm{mg} \mathrm{CoCl} \cdot 6 \mathrm{H}_{2} \mathrm{O}\end{array}$ \\
\hline & P4 & $\begin{array}{l}\text { para } 500 \mathrm{~mL}: 500 \mathrm{mg} \mathrm{MnSO} \cdot \cdot 4 \mathrm{H}_{2} \mathrm{O}, 100 \mathrm{mg} \mathrm{ZnSO}{ }_{4} \cdot 7 \mathrm{H}_{2} \mathrm{O}, 37,5 \mathrm{mg} \mathrm{Kl}, 150 \mathrm{mg} \\
\mathrm{H}_{3} \mathrm{BO}_{3}, 12,5 \mathrm{mg} \mathrm{NaMoO} \cdot 2 \mathrm{H}_{2} \mathrm{O}, 1,25 \mathrm{mg} \mathrm{CuSO} \cdot 5 \mathrm{H}_{2} \mathrm{O}, 1,25 \mathrm{mg} \mathrm{CoCl} \cdot 6 \mathrm{H}_{2} 0\end{array}$ \\
\hline & $\mathrm{SH}$ & $\begin{array}{l}\text { para } 500 \mathrm{~mL}: 500 \mathrm{mg} \mathrm{MnSO} \cdot 4 \mathrm{H}_{2} \mathrm{O}, 50 \mathrm{mg} \mathrm{ZnSO} \cdot 7 \mathrm{H}_{2} \mathrm{O}, 50 \mathrm{mg} \mathrm{KI}, 250 \mathrm{mg} \mathrm{H}_{3} \mathrm{BO}_{3} \text {, } \\
5 \mathrm{mg} \mathrm{NaMoO}_{4} \cdot 2 \mathrm{H}_{2} \mathrm{O}, 10 \mathrm{mg} \mathrm{CuSO}_{4} \cdot 5 \mathrm{H}_{2} \mathrm{O}, 5 \mathrm{mg} \mathrm{CoCl} \cdot 6 \mathrm{H}_{2} \mathrm{O}\end{array}$ \\
\hline \multirow{3}{*}{ Vitaminas } & SHvit & para $100 \mathrm{~mL}: 500 \mathrm{mg}$ ácido nicotínico, $500 \mathrm{mg}$ piridoxina $\mathrm{HCl}, 500 \mathrm{mg}$ tiamina $\mathrm{HCl}$ \\
\hline & UM & $\begin{array}{l}\text { para } 500 \mathrm{~mL}: 250 \mathrm{mg} \text { ácido nicotínico, } 500 \mathrm{mg} \text { piridoxina, } 500 \mathrm{mg} \text { tiamina, } 100 \\
\text { mg glicina, } 5 \mathrm{~g} \text { myo-inositol }\end{array}$ \\
\hline & $\mathrm{SH}$ & para $500 \mathrm{~mL}: 250 \mathrm{mg}$ ácido nicotínico, $25 \mathrm{mg}$ piridoxina, $250 \mathrm{mg}$ tiamina \\
\hline
\end{tabular}

\subsubsection{Transformación transitoria de Pisum sativum y Medicago truncatula}

La técnica de agroinfiltración usada en este trabajo para conseguir una transformación transitoria de las plantas de Pisum sativum y Medicago truncatula mediante silenciamiento génico inducido por virus se describe en detalle en Constantin et al. (2004).

Se inició con dos cultivos independientes de Agrobacterium tumefaciens: el que contenía el vector pCAPE1 y el que contenía la construcción generada en el vector pCAPE2 (ver apartado 3.1.2), crecidos sobre medio TYP sólido suplementado con 100 $\mu \mathrm{g} / \mathrm{mL}$ rifampicina y $50 \mu \mathrm{g} / \mathrm{mL}$ kanamicina. A partir de una colonia aislada se prepararon precultivos en $3 \mathrm{~mL}$ medio TYP líquido suplementado con los antibióticos, que se dejaron 
crecer toda la noche en agitación a $28{ }^{\circ} \mathrm{C}$. Se prepararon los cultivos bacterianos calculando alrededor de $130 \mathrm{~mL}$ de cada cultivo por 10 plantas para agroinfiltrar. El cultivo consistió en medio TYP líquido suplementado con los antibióticos correspondientes e inoculado con $50 \mu \mathrm{L}$ del precultivo por cada $100 \mathrm{~mL}$ de cultivo. Los cultivos se incubaron a $28{ }^{\circ} \mathrm{C}$ con agitación de $180 \mathrm{rpm}$ durante cerca de $17 \mathrm{~h}$, hasta $\mathrm{DO}_{550}$ de $1,2-1,5$ y se centrifugaron a $6.000 \mathrm{rpm}$ en un rotor Sorvall SS34 (Thermo Scientific ${ }^{\circledR}$ ) durante 15 minutos a temperatura ambiente. Se resuspendió el precipitado en medio de infiltración IVIM (10mM NaCl, 1,75 mM CaCl, $100 \mu \mathrm{M}$ acetosiringona), calculando el volumen necesario mediante la fórmula:

$$
m L I V I M=(0,1)(m L \text { cultivo inicial })\left(D O_{550}\right)
$$

A continuación se incubó el cultivo resuspendido a temperatura ambiente durante 2 h sin agitación. Los cultivos, que contenían el vector PCAPE1 y la construcción pCAPE2 se mezclaron 1:1 y esta mezcla se utilizó para infiltrar los dos pares de hojas superiores más jóvenes de las plantas, por el envés, utilizando una jeringa de $1 \mathrm{~mL} \sin$ aguja.

Para agroinfiltrar se usaron plantas de guisante cv. Bonneville cultivadas durante 2 semanas y plantas de $M$. truncatula cultivadas cerca de 1 mes en el invernadero antes de ser infiltradas (ver apartado 1.1.1).

A los 5 ó 6 días post inoculación (dpi) se recortaron los últimos 2-3 nodos de la planta, lo que impulsó la aparición de tallos secundarios. En el momento de realizar esta "decapitación" también se eliminaba cualquier tallo secundario existente. En el caso de M. truncatula, se decapitó el tallo principal alrededor del quinto o sexto nodo contando desde la base de la planta. Aproximadamente 14-20 dpi se desarrollaron las ramas secundarias. En guisante se eliminaron conservando únicamente una, la más grande que surge en la parte más baja de la rama principal que ha sido decapitada. Todas las demás ramas secundarias se fueron eliminando durante 1 a 2 semanas hasta que no aparecieron nuevas. Para M. truncatula se eliminaron los tallos secundarios dejando 3 ó 4 de ellos, eliminando después todos los que surgían en el tallo principal.

\subsubsection{Transformación estable de Arabidopsis thaliana y análisis de plantas}

\section{transgénicas}

Para la obtención plantas transgénicas de Arabidopsis thaliana se utilizaron plantas silvestres del ecotipo Columbia (Col). La transformación se realizó siguiendo el método 
descrito por Bechtold et al. (1993), modificado mediante la utilización del detergente Silwet ${ }^{\circledR}$ L-77 (HELENA ${ }^{\circledR}$; Clough y Bent, 1998). Aproximadamente unas 60 semillas de Arabidopsis se cultivaron en macetas de $11 \mathrm{~cm}$ de diámetro, tal y como se describe en el apartado 1.1.1.3.2. Tras 2 semanas desde la siembra, se hizo un aclareo del exceso de plántulas favoreciendo el crecimiento homogéneo de la población; tras 2 semanas más, aproximadamente, cuando las plantas habían producido el tallo y la última hoja caulinar se había separado unos $2-3 \mathrm{~cm}$ del ápice de la inflorescencia principal, éste se decapitó para inducir la proliferación de las inflorescencias laterales. Una vez decapitadas, las plantas se cultivaron unos 4 días más antes de la infiltración.

Tres días antes de la infiltración se preparó un precultivo de $10 \mathrm{~mL}$ de medio LB suplementado con $100 \mu \mathrm{g} / \mathrm{mL}$ rifampicina y $50 \mu \mathrm{g} / \mathrm{mL}$ kanamicina, se inoculó con la cepa de A. tumefaciens portadora de la construcción de interés (apartado 3.1.3) y se incubó una noche en oscuridad, a $28{ }^{\circ} \mathrm{C}$, con agitación de $200 \mathrm{rpm}$. Al día siguiente se preparó un cultivo de $600 \mathrm{~mL}$ de medio LB suplementado con los antibióticos correspondientes, se inoculó con el volumen total del precultivo y se incubó $48 \mathrm{~h}$ a $28^{\circ} \mathrm{C}$ con agitación.

El día de la infiltración el cultivo se centrifugó a 6.000 rpm durante 15 minutos, el sedimento se resuspendió en $200 \mathrm{~mL}$ de medio de infiltración $(2,2 \mathrm{~g} / \mathrm{L}$ "Murashige \& Skoog medium including vitamins" (Duchefa), sacarosa 5\% (p/v), 0,05 mg/L BAP, 100 $\mathrm{mg} / \mathrm{L} \mathrm{MES}, \mathrm{pH} 5,9)$ y se le adicionó $100 \mu \mathrm{L}$ del detergente Silwet ${ }^{\circledR}$ L-77. Antes de la infiltración, las plantas se limpiaron de silicuas fertilizadas y flores abiertas. Para la infiltración a vacío, las macetas se invirtieron y se introdujeron en un recipiente con los $200 \mathrm{~mL}$ de la suspensión de A. tumefaciens, de manera que las plantas completas quedaban sumergidas en el líquido. El montaje se colocó dentro de una campana de vacío conectada a una bomba de vacío RV3 (EDWARDS) y se sometió a vacío durante 1 minuto. Después las plantas se secaron ligeramente con papel absorbente, se cubrieron con bolsas de plástico y se pasaron a las cabinas del invernadero. Para aclimatar las plantas, durante los 2-3 días siguientes a la infiltración se hicieron perforaciones en las bolsas y finalmente se eliminaron por completo, dejando crecer las plantas hasta obtener semillas maduras. Las silicuas maduras de las plantas transformadas se recogieron, se separaron de las semillas y éstas se guardaron en bolsas de celofán, secándolas en una estufa a $37^{\circ} \mathrm{C}$ durante al menos una semana. 
La selección de los transformantes primarios $\left(T_{1}\right)$ se hizo conforme a lo descrito en el apartado 1.1.1.3.1 y se realizó un análisis fenotípico de esta generación hasta el momento de recoger las semillas $\mathrm{T}_{2}$.

\section{TÉCNICAS DE FOTOGRAFÍA Y MICROSCOPÍA}

\subsection{FOTOGRAFÍA DIGITAL}

Para adquirir las imágenes deseadas de plantas transgénicas de $M$. truncatula, $P$. sativum y A. thaliana a gran escala, se utilizó una cámara digital COOLPIX P80 (Nikon) de 10,1 megapíxeles y con un objetivo NIKKOR zoom de 18 aumentos. Esta cámara permitió tomar fotografías de las plantas completas, así como flores completas o montajes de despieces de flores de guisante cuyo tamaño superaba el campo de visión de un microscopio estereoscópico.

\subsection{MICROSCOPÍA}

\subsubsection{Microscopía estereoscópica}

Las imágenes de flores enteras o despiezadas de plantas transgénicas de Medicago truncatula se adquirieron utilizando el microscopio estereoscópico SMZ800 acoplado con una cámara ColorView 12 (ambos de Nikon), provisto de una unidad de iluminación externa de luz blanca fría (Intralux ${ }^{\circledR}$ 4000-1 ESD, Volpi) y ligado al software de procesamiento de imágenes AnalySIS software (versión 3.2, Nikon). Las imágenes de flores o racimos florales de plantas transgénicas de Arabidopsis thaliana y los tejidos despiezados de flores transgénicas de Pisum sativum se adquirieron utilizando indistintamente el microscopio anterior o un microscopio estereoscópico MZ16F acoplado con una cámara DFC300 FX (ambos de Leica Microsystems). El software de procesamiento de imágenes ligado a este microscopio es Leica Application Suite (versión 2.6.0 R1). Este microscopio permite adquirir imágenes de hasta 115 aumentos, sin la necesidad de separar los tejidos de interés de la planta. 


\subsubsection{Microscopía óptica}

Los cortes histológicos hibridados mediante hibridación in situ y montados sobre portaobjetos se fotografiaron utilizando el microscopio óptico Eclipse E800 acoplado con una cámara DXM1200F (ambos de Nikon) y ligado al software de procesamiento de imágenes ACT-1 (versión 2.70, Nikon). Se utilizó iluminación de campo claro y la técnica de Nomarski (contraste diferencial por interferencia), que permite detectar cierto volumen en las muestras.

\subsection{CRIOMICROSCOPÍA ELECTRÓNICA DE BARRIDO}

El uso del criomicroscopio evitó la necesidad de fijar las muestras para su estudio. Se utilizó para fotografiar a nivel celular los tejidos de las flores de las plantas transgénicas de Arabidopsis thaliana. Las muestras se procesaron en el servicio de microscopía de la Universidad Politécnica de Valencia, donde se utilizó un microscopio electrónico de barrido JSM-5410 (JEOL) acoplado al instrumental de criomicroscopía "CryoTrans 1500 Cryo-Preparation System" (Oxford Instruments).

Tabla 10. Oligonucleótidos utilizados en amplificaciones por PCR y reacciones de secuenciación

\begin{tabular}{|c|c|c|c|c|}
\hline Oligonucleótido & Secuencia $5^{\prime} \rightarrow 3^{\prime}$ & Tamaño $^{a}$ & $\mathrm{Tm}^{\mathrm{b}}$ & Uso \\
\hline MADS 3' & ACGGGGAGAAAGAAAAAGGA & 20 & 58 & \multirow{2}{*}{$\begin{array}{l}\text { Amplificar sonda } \\
\text { para el rastreo de } \\
\text { genes MADS-box }\end{array}$} \\
\hline MADS 5' & CGTGGTAGAAGGGCTGATGT & 20 & 62 & \\
\hline pADGAL (dir) & GATCGAATTAGGATCCTCTG & 20 & 58 & $\begin{array}{l}\text { Secuenciar clones } \\
\text { del rastreo }\end{array}$ \\
\hline MtAGadir & GGAACCATAGCCACCATAGC & 20 & 62 & \multirow{4}{*}{$\begin{array}{l}\text { Amplificar sondas } \\
\text { para Northern y } \\
\text { Southern blot e } \\
\text { hibridación in situ }\end{array}$} \\
\hline MtAGarev & СТTTCATACTTCTCTCAAGCAC & 22 & 62 & \\
\hline MtAGbdir & GATATCAGAAAGTGAGCAGAG & 21 & 60 & \\
\hline MtAGbrev1 & GTCTTTGCTCTTCTCAACCG & 20 & 60 & \\
\hline MtTM6 362 (dir) & GCTTCCAGCAACTGCGTAG & 19 & 60 & \multirow{15}{*}{$\begin{array}{l}\text { Amplificar sondas } \\
\text { para Northern blot } \\
\text { e hibridación in situ }\end{array}$} \\
\hline MtTM6 698 (rev) & CAACCCAGGCGCAAATCGT & 19 & 60 & \\
\hline 8.1.1 DIR & GTCAATAGGAATCTTCGCAAGG & 22 & 64 & \\
\hline 8.1.1 REV & GTGGAAAGTGATTGTGGAGTATTG & 24 & 68 & \\
\hline 6.6.1 DIR & GAGGCAGTTGCTTGGGGAAG & 20 & 64 & \\
\hline 6.6.1 REV & CATACTGGTACTGTTGGTATCC & 22 & 64 & \\
\hline 8.2.1 DIR & GATGCTAAGAGTCAAGCAATGA & 22 & 62 & \\
\hline 8.2.1 REV & CATCCAATGTTCTTGTTGCGAC & 22 & 64 & \\
\hline MtSOC1-like 3' & GGAATGTGATATCGACAC & 18 & 52 & \\
\hline MtSOC1-like 5' & GTTGCTGGTTTCAGCTCTC & 19 & 58 & \\
\hline MtSEPdir & CAGCTATGGTGCAGTAGAAG & 20 & 60 & \\
\hline MtSEPrev & GATTACCATATGCCATACTTG & 21 & 58 & \\
\hline MtSHPdir & GCAGAGTTAGATCTAGAAAGC & 21 & 60 & \\
\hline MtSHPrev & CTTCATGCAACTATTCAAGTAG & 22 & 60 & \\
\hline 1.3.1 DIR & GCCGCAGCCAACAACAAAGG & 20 & 64 & \\
\hline
\end{tabular}




\begin{tabular}{|c|c|c|c|c|}
\hline 1.3.1 REV & GTTGCTTAGTTGCAAAATGTTTC & 23 & 62 & \multirow{3}{*}{$\begin{array}{l}\text { Amplificar sondas } \\
\text { para Northern blot } \\
\text { e hibridación in situ }\end{array}$} \\
\hline 14.3.2 DIR2 & GACTAAGGTTTTCAGGGAGC & 20 & 60 & \\
\hline 14.3.2 REV & GAGGCCATGAACAATCAGTTCC & 22 & 66 & \\
\hline MtAGaGENdir1 & GAGCTGTTATTTGCTGAAATTGA & 23 & 62 & \multirow{10}{*}{$\begin{array}{l}\text { Obtener secuencia } \\
\text { genómica } M t A G a\end{array}$} \\
\hline MtAGaGENrev1 & CTGATTCTGAGACTGCATAGG & 21 & 62 & \\
\hline MtAGaGENdir4 & CACTGGATCTGCTACTGAGG & 20 & 62 & \\
\hline MtAGaGENrev2 & TCAATTTCAGCAAATAACAGCTC & 23 & 62 & \\
\hline MtAGaGENdir5 & CTATTATATTTTGGCCAATTTACC & 24 & 62 & \\
\hline MtAGaGENrev3 & AAGAGTTAGTGGTGAGACACAT & 22 & 62 & \\
\hline MtAGaGENdir6 & TCTACAATGTTCTGATAAATCATG & 24 & 62 & \\
\hline MtAGaGENrev4 & TGAAATCATGGTTATAAATGTTAGT & 25 & 62 & \\
\hline MtAGaGENdir8 & CTCTATGAGTATGCTAATAACAG & 23 & 62 & \\
\hline MtAGaGENrev6 & GTACCTTGCAATAGTCTCTTTG & 22 & 62 & \\
\hline MtAGbsplicingdir & GAACTTGAGTACATGCAGAAG & 21 & 60 & \multirow{2}{*}{$\begin{array}{l}\text { Amplificar ambas } \\
\text { formas de } M t A G b\end{array}$} \\
\hline MtAGbsplicingrev & CATTATGGTTGCTCCTCTGC & 20 & 60 & \\
\hline AGaRNAid & CTCGAGTCTAGAGGAACCATAGCCACCATAGC & 32 & 62 & \multirow{4}{*}{$\begin{array}{l}\text { Amplificar } \\
\text { fragmentos para } \\
\text { construcciones } \\
\text { RNAi }\end{array}$} \\
\hline AGaRNAir & GAATTCAAGCTTCTTTCATACTTCTCTCAAGCAC & 34 & 62 & \\
\hline AGbRNAid & CTCGAGTCTAGAGATATCAGAAAGTGAGCAGAG & 33 & 60 & \\
\hline AGbRNAir & GAATTCGGATCCGTCTTTGCTCTTCTCAACCG & 32 & 60 & \\
\hline 35Sdir & CGGGAAACCTCCTCGGATTC & 20 & 64 & \multirow{3}{*}{$\begin{array}{l}\text { Confirmar } \\
\text { transgénesis } \\
\text { plantas RNAi }\end{array}$} \\
\hline BASTAdir & GAGCCCAGAACGACGCCCG & 19 & 66 & \\
\hline BASTArev & TATCCGAGCGCCTCGTGC & 18 & 60 & \\
\hline AGaSBXdir & TGTCGACATGGATTTTCCAAATGAATCCAT & 23 & 60 & \multirow{4}{*}{$\begin{array}{l}\text { Amplificar } \\
\text { fragmentos para } \\
\text { construcciones } \\
\text { expresión } \\
\text { constitutiva (SBX) }\end{array}$} \\
\hline AGaSBXrev & TGGATCCTCAAACTAATTGAAGGGACATG & 22 & 60 & \\
\hline AGbSBXdir & \begin{tabular}{|l|} 
TGTCGACATGAGTTTTCCAAACGAATCC \\
\end{tabular} & 21 & 58 & \\
\hline AGbSBXrev & TGGATCCTTACACAAATTGAAGAGACATC & 22 & 58 & \\
\hline 2X35S (directo) & TATCCTTCGCAAGACCСTTCСTCC & 21 & 64 & $\begin{array}{l}\text { Secuenciar } \\
\text { construcciones SBX }\end{array}$ \\
\hline KAN DIR & GACGAGGCAGCGCGGCTAT & 19 & 64 & \multirow{5}{*}{$\begin{array}{l}\text { Confirmar } \\
\text { transgénesis } \\
\text { plantas expresión } \\
\text { constitutiva }\end{array}$} \\
\hline KAN REV & AAGAAGGCGATAGAAGGCGA & 20 & 60 & \\
\hline MtAGaGENrev1 & \begin{tabular}{|l} 
CTGATTCTGAGACTGCATAGG \\
\end{tabular} & 21 & 62 & \\
\hline MtAGaGENdir2 & GCAAAAGAAGAAATGGTTTGTTG & 23 & 62 & \\
\hline MtAGaGENdir3 & CTTCTCTAGCCGTGGACGG & 19 & 62 & \\
\hline MtAGaVIGSdir & GCCATGGAACCATAGCCACCATAG & 19 & 58 & \multirow{10}{*}{$\begin{array}{l}\text { Amplificar } \\
\text { fragmentos para } \\
\text { construcciones } \\
\text { VIGS de } M \text {. } \\
\text { truncatula }\end{array}$} \\
\hline MtAGaVIGSrev & CGAATTCAATGTGTCTTTTCCATAATC & 23 & 60 & \\
\hline MtAGabisVIGSdir & GCCATGGTTACCAGCAAGAGGCAGAC & 19 & 58 & \\
\hline MtAGabisVIGSrev & CGAATTCTGGATTGTAATCCAGAAACT & 21 & 58 & \\
\hline MtAGbVIGSdir & GTCTAGAAAGTGAGCAGAGGAGCA & 20 & 60 & \\
\hline MtAGbVIGSrev & CCTGCAGATTGCAATTAATTAGTAAAATTG & 25 & 60 & \\
\hline MtAGbbisVIGSdir & GCCATGGTATTACCAGCAAGAAGCTG & 20 & 58 & \\
\hline MtAGbbisVIGSrev & CCTGCAGCCTGGCATACTGATCATTG & 20 & 60 & \\
\hline MtAGaVIGS2rev & CTCTAGACTTAGCACTCATCTGCTATC & 20 & 58 & \\
\hline MtAGbVIGS2rev & CCTGCAGATACAAAGCCACTACATAG & 21 & 58 & \\
\hline PsAGaVIGSdir & GCCATGGAACCACCACCATAATATTAA & 22 & 60 & \multirow{9}{*}{$\begin{array}{l}\text { Amplificar } \\
\text { fragmentos para } \\
\text { construcciones } \\
\text { VIGS de } P \text {. sativum }\end{array}$} \\
\hline PsAGaVIGSrev & CGAATTCCTGTTCTCCATAACCTTAG & 21 & 60 & \\
\hline PsAGabisVIGSdir & GTCTAGAAGCAGATAAATTGCGTGT & 21 & 58 & \\
\hline PsAGabisVIGSrev & CCTGCAGGATTGTAATCCGGAAACTTG & 21 & 60 & \\
\hline PsAGbVIGSdir & GTCTAGAAAATGATCAGAGGAACAAC & 22 & 60 & \\
\hline PsAGbVIGSrev & CCTGCAGTACAATTTGACAAACATGTC & 22 & 58 & \\
\hline PsAGbbisVIGSdir & GTCTAGAAGCCGCGAAACTGCGA & 19 & 60 & \\
\hline PsAGbbisVIGSrev & CCTGCAGCCTGGCATACTGATTATTAG & 21 & 60 & \\
\hline PsAGaVIGS2rev & CTCTAGATTCTTACAAACCCTTCTCA & 21 & 58 & \\
\hline
\end{tabular}




\begin{tabular}{|c|c|c|c|c|}
\hline PsAGbVIGS2rev & CCTGCAGCCACTACATAGTATTGAAAG & 22 & 60 & $\begin{array}{l}\text { Amplificar } \\
\text { fragmentos para } \\
\text { construcciones } \\
\text { VIGS de } P \text {. sativum }\end{array}$ \\
\hline pCAPE2dir & CTTGTGTCTGCTGATAAGATC & 21 & 60 & \multirow{2}{*}{$\begin{array}{l}\text { Secuenciar } \\
\text { construcciones } \\
\text { VIGS }\end{array}$} \\
\hline pCAPE2rev & GAACGACCACAAGTACAGTC & 20 & 60 & \\
\hline AGb-F & TCCAAACGAATCCATGCCAGATTC & 24 & 70 & \multirow{3}{*}{$\begin{array}{l}\text { Genotipar } \\
\text { mutantes } \\
\text { insercionales Tnt1 }\end{array}$} \\
\hline Tnt1-F & ACAGTGCTACCTCCTCTGGATG & 22 & 68 & \\
\hline AGb-Rgenomic & GTTTATCCAAGCTGAGATTTGAGG & 24 & 68 & \\
\hline T7 & \multicolumn{3}{|l|}{ Servicio de secuenciación } & \multirow{2}{*}{$\begin{array}{l}\text { Secuenciar insertos } \\
\text { en pGEM }{ }^{\circledR} \text { T-easy }\end{array}$} \\
\hline SP6 & \multicolumn{3}{|l|}{ Servicio de secuenciación } & \\
\hline M13 directo & \multicolumn{3}{|l|}{ Servicio de secuenciación } & \multirow{2}{*}{$\begin{array}{l}\text { Secuenciar insertos } \\
\text { en pGreenll }\end{array}$} \\
\hline M13 reverso & \multicolumn{3}{|l|}{ Servicio de secuenciación } & \\
\hline
\end{tabular}

${ }^{a}$ Tamaño del oligonucleótido en pares de bases $(\mathrm{pb})$

${ }^{\mathrm{b}}$ Temperatura de fusión estimada del oligonucleótido $\left({ }^{\circ} \mathrm{C}\right)$ 


\section{CAPÍTULO I}

Aislamiento $Y$ CARACTERIZACIÓN DE MIEMBROS DE LA FAMILIA MADSbox EN Medicago truncatula 



\section{CAPÍTULO I}

Resultados 



\section{AISLAMIENTO Y CARACTERIZACIÓN DE MIEMBROS DE LA FAMILIA MADS-box EN Medicago truncatula}

\subsection{AISLAMIENTO DE ONCE CLONES DIFERENTES CON HOMOLOGÍA A GENES MADS- box}

A partir del escrutinio de la genoteca de cDNA de ápices florales (generada por Benlloch, R., Tesis Doctoral, 2005) se aislaron 42 clones. Para ello se utilizó como sonda la secuencia codificante del dominio MADS del gen MtPl, caracterizado por Benlloch et al. (2009). Estos clones consistían en fragmentos de entre 850 y 1200 pb clonados en el vector pAD-GAL4-2.1 (Stratagene).

Tabla 11. Características de los clones estudiados

\begin{tabular}{|c|c|c|c|c|c|c|c|c|c|}
\hline Clon & Nombre $^{a}$ & $\begin{array}{l}\text { Tamaño del } \\
\text { inserto (pb) }\end{array}$ & $5^{b}$ & $3^{\prime b}$ & ORF $^{c}$ & $\begin{array}{c}\text { Codón } \\
\text { finalización }\end{array}$ & Proteína $^{d}$ & P.M. ${ }^{e}$ & P.I. ${ }^{f}$ \\
\hline 15.4.1 & MtSEP & 1167 & 196 & 218 & 750 & TGA & 250 & 28,75 & 9,26 \\
\hline 6.6 .1 & MtAGL6 & 883 & 21 & 106 & 753 & TAA & 251 & 29,17 & 8,45 \\
\hline 8.2 .1 & MtAGL6-like & 948 & 0 & 228 & 717 & TGA & 239 & 27,58 & 8,33 \\
\hline 1.3.1 & MtSOC1a & 982 & 89 & 251 & 639 & TGA & 213 & 24,46 & 10,09 \\
\hline 14.3 .2 & MtSOC1b & 1152 & 240 & 237 & 672 & TAG & 224 & 25,70 & 9,55 \\
\hline 12.1.1 & MtSOC1-like & 851 & 63 & 170 & 615 & TGA & 205 & 23,79 & 9,28 \\
\hline 14.4.1 & MtSHP & 1027 & 38 & 254 & 732 & TGA & 244 & 28,12 & 9,67 \\
\hline 12.11.1 & $M t A G a$ & 1208 & 131 & 294 & 780 & TGA & 260 & 29,67 & 9,71 \\
\hline 15.5 .1 & $M t A G b$ & 1099 & 46 & 318 & 732 & TAA & 244 & 28,10 & 9,75 \\
\hline 12.9 .1 & MtTM6 & 1082 & 89 & 294 & 696 & TGA & 232 & 27,07 & 9,68 \\
\hline 8.1 .1 & MtNMH7 & 1030 & 83 & 257 & 687 & TAG & 229 & 26,61 & 9,68 \\
\hline
\end{tabular}

${ }^{a}$ Nombre asignado al gen por homología de secuencia a genes conocidos de otras plantas modelo

'Tamaño en pares de bases de las regiones 3' y 5' no traducidas incluidas en el clon

"Tamaño en pares de bases del "Open Reading Frame" o marco de lectura abierto más largo

${ }^{\mathrm{d}}$ Tamaño predicho de la proteína codificada por el gen, en aminoácidos

e Peso molecular predicho de la proteína codificada, en kDa

${ }^{\mathrm{f}}$ Punto isoeléctrico teórico de la proteína codificada

Todos los insertos se secuenciaron íntegramente y se descartaron 9 clones que contenían el gen MtPl, encontrándose once insertos diferentes entre los 33 clones restantes. A excepción de un clon que carecía del extremo 5', todos los insertos contenían un codón ATG de inicio de transcripción, un codón de terminación en el 
extremo $3^{\prime}$ y regiones $5^{\prime}$ y $3^{\prime}$ no traducidas, por lo que se consideraron como clones de longitud completa. En la Tabla 11 se describen las principales características de los once clones estudiados.

Las secuencias obtenidas se compararon con las bases de datos del NCBI (National Center for Biotechnology Information, http://www.ncbi.nlm.nih.gov), DFCl Gene Index Project (Dana Farber Cancer Institute, http://compbio.dfci.harvard.edu/tgi/plant.html) y TIGR Plant Transcript Assemblies database (http://plantta.jcvi.org), utilizando el programa BLAST (Basic Local Alignment Search Tool, http://blast.ncbi.nlm.nih.gov/Blast.cgi). Se encontraron homologías significativas con genes de clase MADS-box de diferentes especies. Las secuencias aminoacídicas deducidas de todos los clones aislados comparten los rasgos característicos de las proteínas MADS-box de plantas, incluyendo el altamente conservado dominio MADS y el dominio K (Shore y Sharrocks, 1995).

La Figura 13 representa un árbol no enraizado que muestra las relaciones de similitud entre los clones estudiados y genes MADS-box representativos de Arabidopsis thaliana y Pisum sativum. Las secuencias de los clones estudiados se distribuyen en cinco de los 14 grupos de genes MADS-box descritos por Becker y Theissen (2003). No se encontraron clones homólogos a genes pertenecientes a los grupos STMADS11 (SVP), AGL17 (ANR1), GGM13 (TT16), AGL12, SQUA (AP1), TM8, AGL15 y FLC (Becker y Theissen, 2003; Hecht et al., 2005). MtPI, cuya región MADS se utilizó como sonda, también se aisló en el escrutinio. Este gen pertenece al grupo $G L O(P I)$, pero no se ha incluido en el árbol al haber sido caracterizado previamente (Benlloch et al., 2009).

Figura 13. Representación de las relaciones de similitud de secuencia existentes entre los genes MADSbox de Medicago truncatula aislados en el rastreo y genes representativos de Arabidopsis thaliana y Pisum sativum. El alineamiento de los dominios $\mathrm{M}-$ - I- y K- se generó usando ClustalW2 con los parámetros de alineamiento múltiple "gap distances" 8 y "gap extension" 1.0. El árbol se construyó con el programa NJplot (Perrière y Gouy, Pôle Bioinformatique Lyonnais, 1996), utilizando el algoritmo Neighbor Joining. La clasificación de los subgrupos se hizo según Becker y Theissen (2003). At: Arabidopsis thaliana; Ps: Pisum sativum; Mt: Medicago truncatula. Los genes de Medicago truncatula se encierran en un rectángulo. 


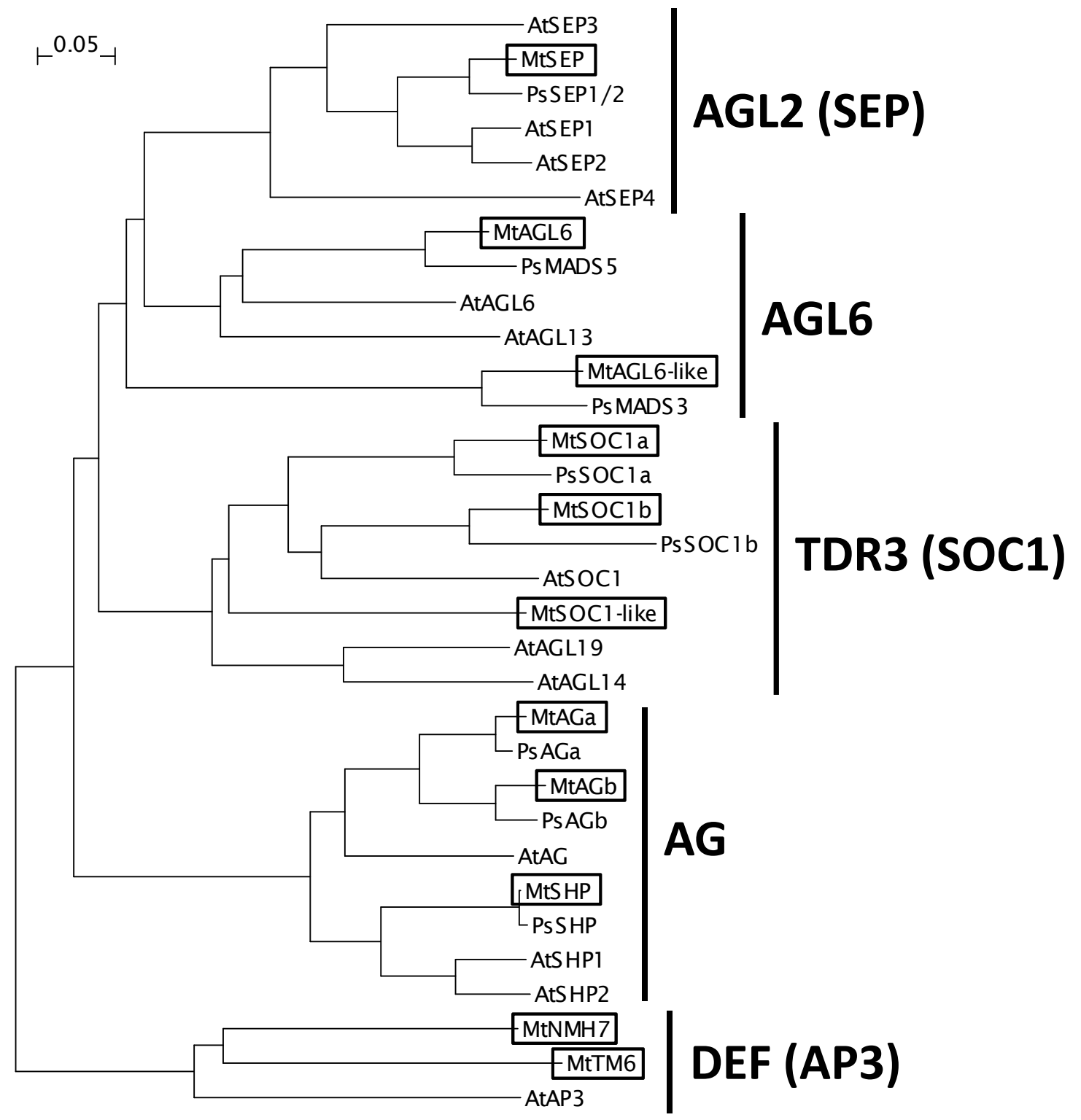

\subsection{MtSEP: UN GEN CON HOMOLOGÍA A GENES MADS-box DEL GRUPO AGL2 (SEP)}

\subsubsection{Aislamiento y análisis de secuencia de MtSEP}

El clon 15.4.1 se denominó MtSEP, en base a su alta homología con genes del grupo AGL2 (SEP). Los genes SEPALLATA constituyen una clase adicional de genes homeóticos florales en el modelo ABC, Ilamada clase E (Theissen, 2001). Este clon, de 1167 pb, presenta una región 5' no traducida de 196 pb, una pauta de lectura abierta de 750 pb, un codón de parada de traducción TGA y una región 3' no traducida de 218 pb. La proteína deducida MtSEP, de 250 aminoácidos, tiene un peso molecular calculado de 28,75 kDa y un PI teórico de 9,26. Esta secuencia se comparó con las secuencias 
incluidas en la base de datos del NCBI mediante BLAST y resultó que corresponde a la secuencia de un mRNA “desconocido” con número de acceso GenBank BT051279.1 (clon genómico MTYF1_F2_F3_F41G-A-4 de Medicago truncatula), que codifica una proteína MADS-box “desconocida" con número de acceso ACJ83943.1.

La secuencia completa de nucleótidos y la deducida de aminoácidos del clon se representa en la Figura 14.

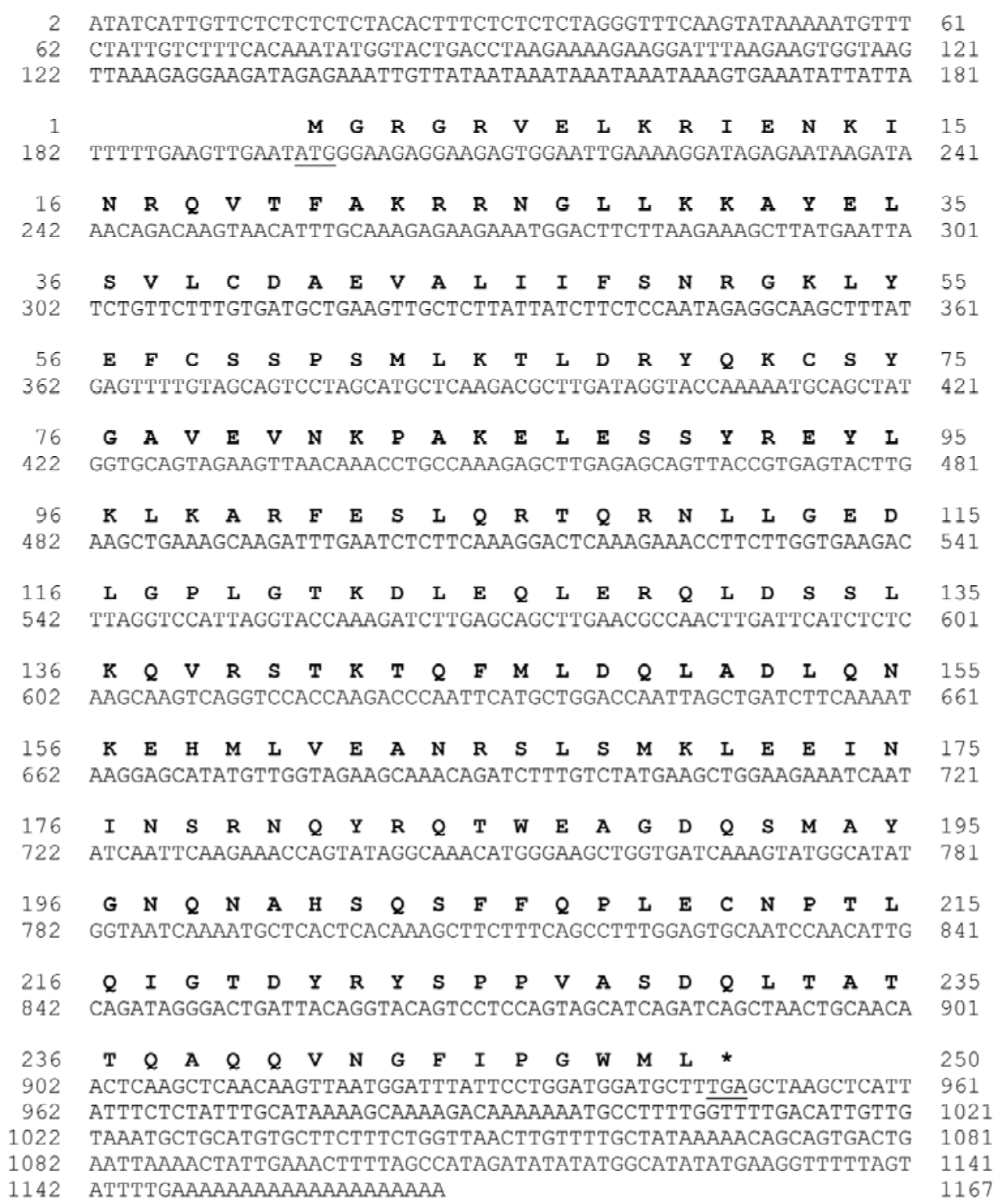

Figura 14. Secuencia del clon MtSEP. Se subrayan los codones de inicio y finalización de la transcripción; en negrita se indica la secuencia de aminoácidos de la proteína deducida.

La Figura 15 muestra un árbol filogenético en el que se utilizaron secuencias proteicas codificadas por genes MADS-box de clase E que han sido descritos en diversas especies, así como MtSEP. MtSEP se localiza en la misma rama filogenética que las proteínas 
AtSEP1 y AtSEP2 (Ma et al., 1991) de la planta modelo Arabidopsis thaliana, mientras que AtSEP3 (Fan et al., 1991) y AtSEP4 (Ma et al., 1991) se distribuyen en ramas independientes.

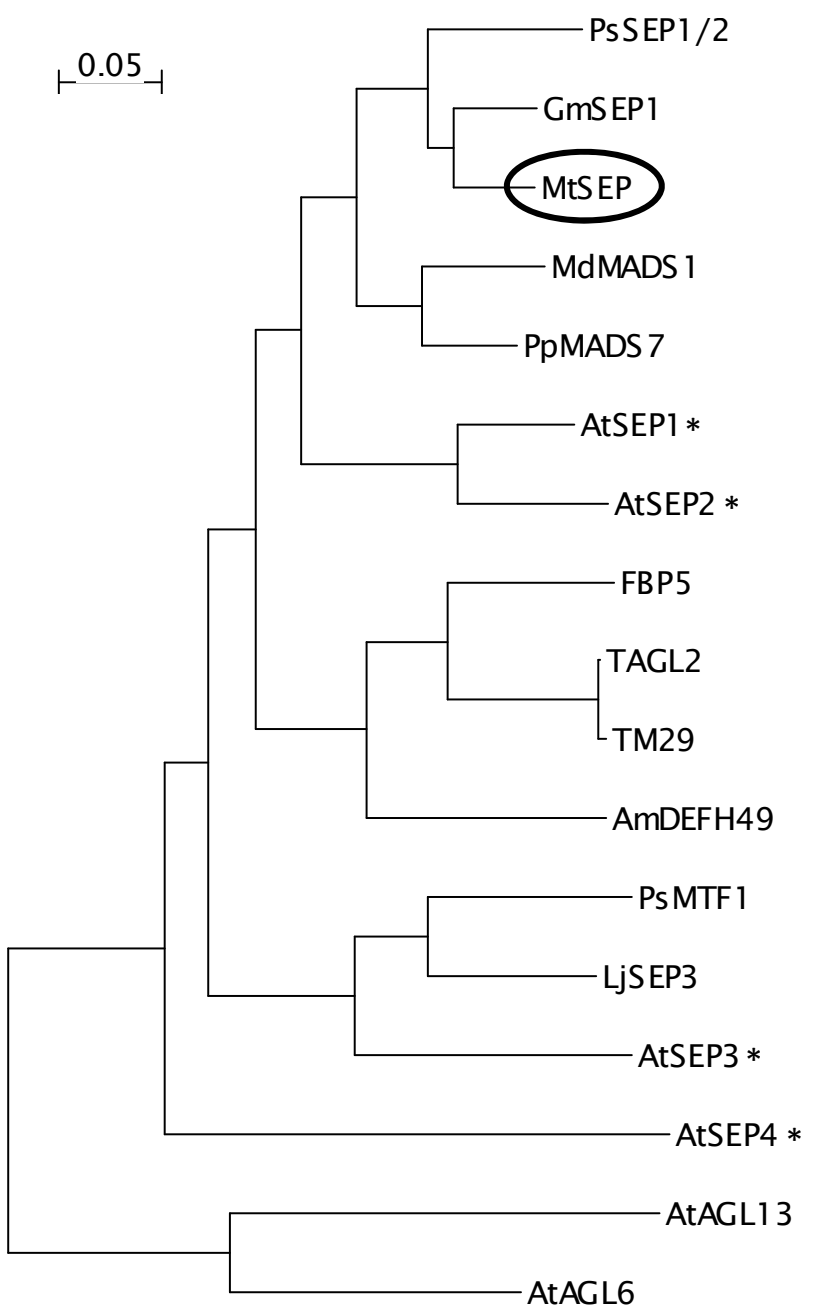

\author{
Pisum sativum \\ Glycine max \\ Medicago truncatula \\ Malus $x$ domestica \\ Prunus persica \\ Arabidopsis thaliana \\ Arabidopsis thaliana \\ Petunia $x$ hybrida \\ Solanum lycopersicum \\ Solanum lycopersicum \\ Antirrhinum majus \\ Pisum sativum \\ Lotus japonicus \\ Arabidopsis thaliana \\ Arabidopsis thaliana \\ Arabidopsis thaliana \\ Arabidopsis thaliana
}

GRUPO EXTERNO

Figura 15. Árbol filogenético de las secuencias proteicas predichas para genes del grupo AGL2. Se utilizó la secuencia proteica íntegra de los siguientes proteínas: Arabidopsis thaliana: AtSEP1, AtSEP2, AtSEP4 (Ma et al., 1991; Acc NP_001119230.1, NP_186880.1, NP_178466.1), AtSEP3 (Fan et al., 1997; Acc NP_850953.1); Pisum sativum: PsSEP1/2 (Hecht et al., 2005; Acc AAX69068.1), PsMTF1 (Buchner y Boutin, 1998; Acc CAA11258); Solanum lycopersicum: TM29 (Ampomah-Dwamena et al., 2002; Acc CAC83066), TAGL2 (Busi et al., 2003; Acc AAM33104); Glycine max: GmSEP1 (Huang et al., 2009; Acc AAZ86071.1); Malus x domestica: MdMADS1 (Sung y An, 1997; Acc AAC25922); Prunus persica: PpMADS7 (Xu et al., 2008; Acc ABO27622); Lotus japonicus: LjSEP3 (Dong et al., 2005; Acc AAX13298); Petunia x hybrida: FBP5 (Immink et al., 2002; Acc AAK21248); Antirrhinum majus: AmDEFH49 (Davies et al., unpublished; Acc CAA64741.1); Medicago truncatula: MtSEP (este trabajo). La proteína MtSEP se encierra en un óvalo y las proteínas del grupo AGL2 de Arabidopsis thaliana se señalan con un asterisco. El árbol se enraizó con AtAGL6 y AtAGL13 de Arabidopsis thaliana (Acc NP_182089.1, NP_191671.1).

El análisis filogenético indica que MtSEP está estrechamente relacionado con la subfamilia SEP1/2, situándose entre ortólogos SEP1/2 de leguminosas como GmSEP1 
(Huang et al., 2009; Acc DQ159905.1) de Glycine max o PSSEP1/2 (Hecht et al., 2005; Acc AY884290.1) de Pisum sativum. Existe además proximidad filogenética entre MTSEP y genes descritos como ortólogos de SEP1/2 en otras especies, como las leñosas Malus $x$ domestica (MdMADS1; Sung y An, 1997) o Prunus persica (PpMADS7; Xu et al., 2008).

La proteína MtSEP presenta altos porcentajes de homología de secuencia con proteínas MADS-box consideradas ortólogas de SEP1/2 en leguminosas como Glycine max (GmSEP1; Huang et al., 2009) o Pisum sativum (PsSEP1/2; Hecht et al., 2005). Comparada con proteínas del grupo AGL2 de otras plantas modelo, MtSEP tiene alta homología con AtSEP1 y AtSEP2 (Ma et al., 1991) de Arabidopsis thaliana y AmDEFH49 (Davies et al., unpublished) de Antirrhinum majus. En la Tabla 12 se muestran dichos porcentajes de homología. En la Figura 16 se representa un alineamiento múltiple entre MtSEP y las proteínas arriba mencionadas. En el alineamiento se puede ver la presencia de los motivos SEP I y SEP II, conservados en la región C-terminal de la mayoría de las proteínas de la familia SEP. Estructuralmente, estos motivos contienen principalmente aminoácidos hidrófobos y polares y no se parecen a ningún motivo de función conocida (Zahn et al., 2005a).

Tabla 12. Porcentajes de homología (\%) de aminoácidos entre diferentes regiones de MtSEP y las proteínas representativas con las que presenta homología

\begin{tabular}{|c|c|c|c|c|c|}
\cline { 2 - 6 } \multicolumn{1}{c|}{} & $\begin{array}{c}\text { Secuencia } \\
\text { completa }\end{array}$ & Caja MADS & Región I & Caja K & $\begin{array}{c}\text { Región C- } \\
\text { terminal }\end{array}$ \\
\hline GmSEP1 & $\mathbf{9 1}$ & 96 & 84 & 97 & 83 \\
\hline PsSEP1/2 & $\mathbf{8 6}$ & 96 & 88 & 93 & 69 \\
\hline AtSEP2 & $\mathbf{7 4}$ & 95 & 61 & 75 & 54 \\
\hline AtSEP1 & $\mathbf{7 6}$ & 100 & 65 & 75 & 57 \\
\hline AmDEFH49 & $\mathbf{6 8}$ & 100 & 61 & 64 & 52 \\
\hline
\end{tabular}

Gm: Glycine max; Ps: Pisum sativum; At: Arabidopsis thaliana; Am: Antirrhinum majus

\subsubsection{Patrón de expresión de MtSEP}

El patrón de expresión de MtSEP en plantas silvestres de Medicago truncatula se analizó mediante hibridación Northern blot en varios tejidos de la planta (Figura 17). Para evitar la hibridación cruzada con otros genes MADS-box, se utilizó la región Cterminal del cDNA de MtSEP como sonda. La expresión de MtSEP no se detecta en hoja ni en tallo y es leve en tejido de raíz. La expresión del gen es muy intensa en flores y en frutos. 


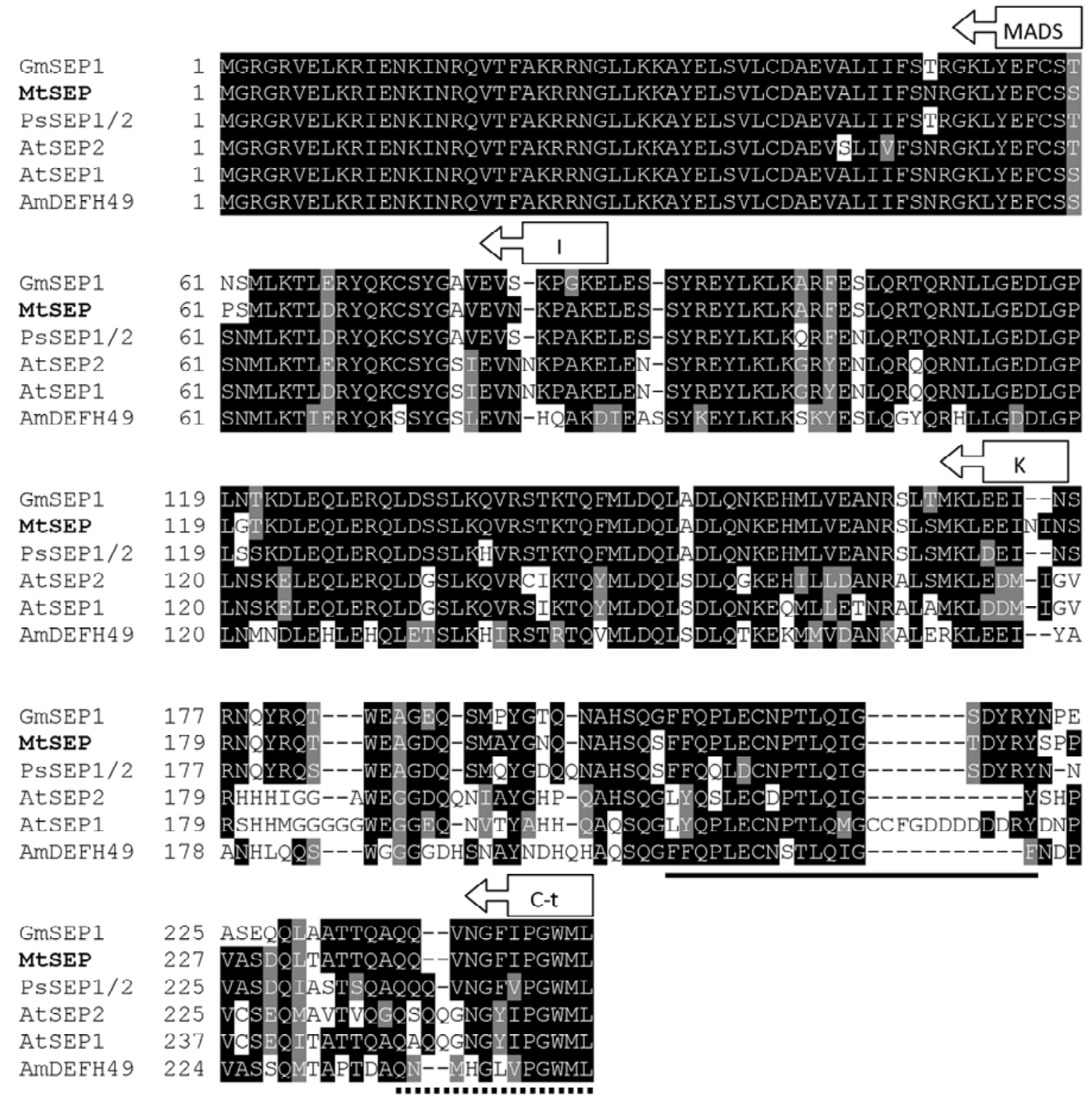

Figura 16. Alineamiento de las secuencias proteicas de MtSEP y de genes MADS-box de clase E con los que presenta homología. Las regiones sombreadas corresponden a aminoácidos conservados. Los dominios MADS y K así como las regiones I y C-terminal se señalan con flechas. El motivo SEP I se subraya con una línea continua y el motivo SEP II con una línea punteada.

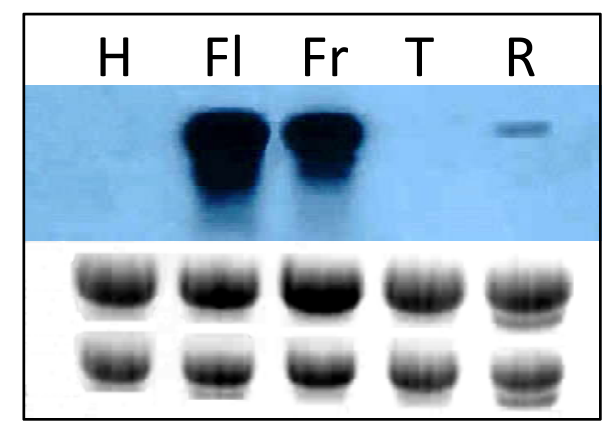

Figura 17. Análisis del patrón de expresión de MtSEP mediante Northern blot. Se utilizó RNA de diferentes tejidos de la planta: hoja $(\mathrm{H})$, flor (FI), fruto (Fr), tallo (T) y raíz (R). 
El análisis del patrón de expresión tisular de MtSEP durante el desarrollo floral se llevó a cabo mediante hibridación in situ en ápices inflorescentes de plantas silvestres de Medicago truncatula (Figura 18). Se utilizó como molde para la síntesis de la sonda el fragmento C-terminal del cDNA de MtSEP utilizado para la hibridación Northern blot.
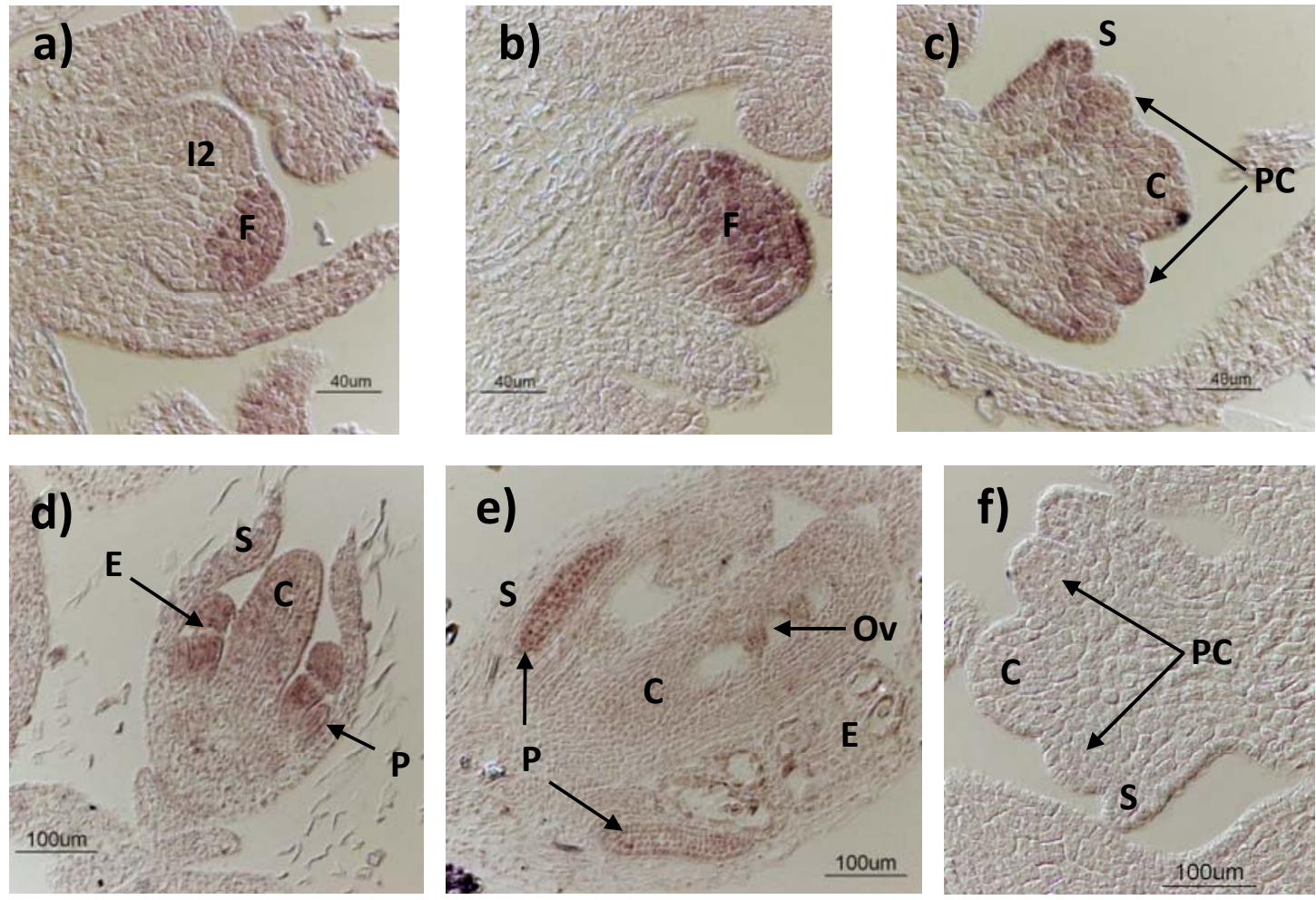

Figura 18. Análisis del patrón de expresión de MTSEP mediante hibridación in situ en ápices inflorescentes de $\boldsymbol{M}$. truncatula. a) Expresión generalizada en el meristemo floral en estadio de desarrollo 2 temprano. b) Expresión generalizada en el meristemo floral en estadio de desarrollo 2 tardío. c) Expresión generalizada pero debilitada en el meristemo floral en estadio 4. d) Flor en estadio 6. La expresión se centra en pétalos y estambres, debilitándose en carpelo y sépalos. e) Expresión detectada en pétalos y óvulos en la flor en estadio 7. f) Hibridación in situ con la sonda "sentido". 12, Meristemo inflorescente secundario; F, Meristemo floral; PC, Primordio común; S, Sépalo; C, Carpelo; E, Estambre; P, Pétalo; Ov, Óvulo.

El transcrito de MtSEP está ausente en el meristemo inflorescente secundario, pero se detecta en todo el meristemo floral desde el estadio 2 temprano (ontogenia floral según Benlloch et al., 2003) (Figura 18, a). En el estadio 2 tardío la expresión se mantiene en todo el meristemo floral y es el estadio en el que MtSEP presenta su expresión máxima (Figura 18, b). En el estadio 4, cuando se han diferenciado los primordios comunes, MtSEP aún se expresa de manera general en el meristemo floral, pero disminuye su intensidad (Figura 18, c). En el estadio 6, diferenciados ya los 
primordios comunes en primordios de pétalo y estambre, la expresión puede detectarse en estos órganos, así como débilmente en el carpelo. La expresión en sépalos prácticamente ha desaparecido (Figura 18, d). En estadios tardíos del desarrollo floral (estadio 7, Figura 18, e) la expresión de MtSEP es detectable en células de pétalo y ligeramente en los óvulos. No se detectó ninguna señal de hibridación en secciones de tejido hibridadas con la sonda "sentido" utilizada como control negativo (Figura 18, f).

\subsection{MtAGL6 Y MtAGL6-like: GENES CON HOMOLOGÍA A GENES MADS-box DEL GRUPO AGL6}

\subsubsection{Aislamiento y análisis de secuencia de MtAGL6 y MtAGL6-like}

En el escrutinio de la genoteca se aislaron dos clones de cDNA cuyas secuencias corresponden a genes del grupo AGL6. Dichos clones, el 6.6.1 y el 8.2.1 se denominaron MtAGL6 y MtAGL6-like, respectivamente, en base a su homología con genes de diferentes plantas pertenecientes a dicho grupo.

El clon 6.6.1, de $883 \mathrm{pb}$, tiene una región $5^{\prime}$ no traducida de $21 \mathrm{pb}$, una pauta de lectura abierta de 753 pb que codifica una proteína de 251 aminoácidos, un codón de parada de traducción TAA y una región 3’ no traducida de 106 pb. La proteína deducida MtAGL6 tiene un peso molecular calculado de 29,17 kDa y un PI teórico de 8,45. La secuencia de nucleótidos de MtAGL6 y su traducción en aminoácidos se representan en la Figura 19.

El clon 8.2.1, de 948 pb, tiene una región 3' no traducida de 228 pb y no incluye región 5' no traducida. Presenta una pauta de lectura abierta de 717 pb y un codón de parada de traducción TGA. La proteína deducida MtAGL6-like, de 239 aminoácidos, tiene un peso molecular calculado de 27,58 kDa y un PI teórico de 8,33. La secuencia de nucleótidos y la traducida de aminoácidos se muestran en la Figura 20.

Se realizó una comparación de las secuencias de ambos clones con las secuencias incluidas en las bases de datos mediante BLAST. EI cDNA de MtAGL6 está parcialmente contenido en la secuencia del clon genómico mth2-132a8 de Medicago truncatula ("WORKING DRAFT SEQUENCE, 33 unordered pieces"; GenBank AC233100.10). Las primeras $488 \mathrm{pb}$ del clon MtAGL6 no están contenidas en el clon genómico. El resto se 
distribuye en 3 exones $(43,152$ y 94 pb) interrumpidos por 2 intrones. Estos exones del gen MtAGL6 se sitúan entre las bases 102.956 y 103.847 del clon genómico.

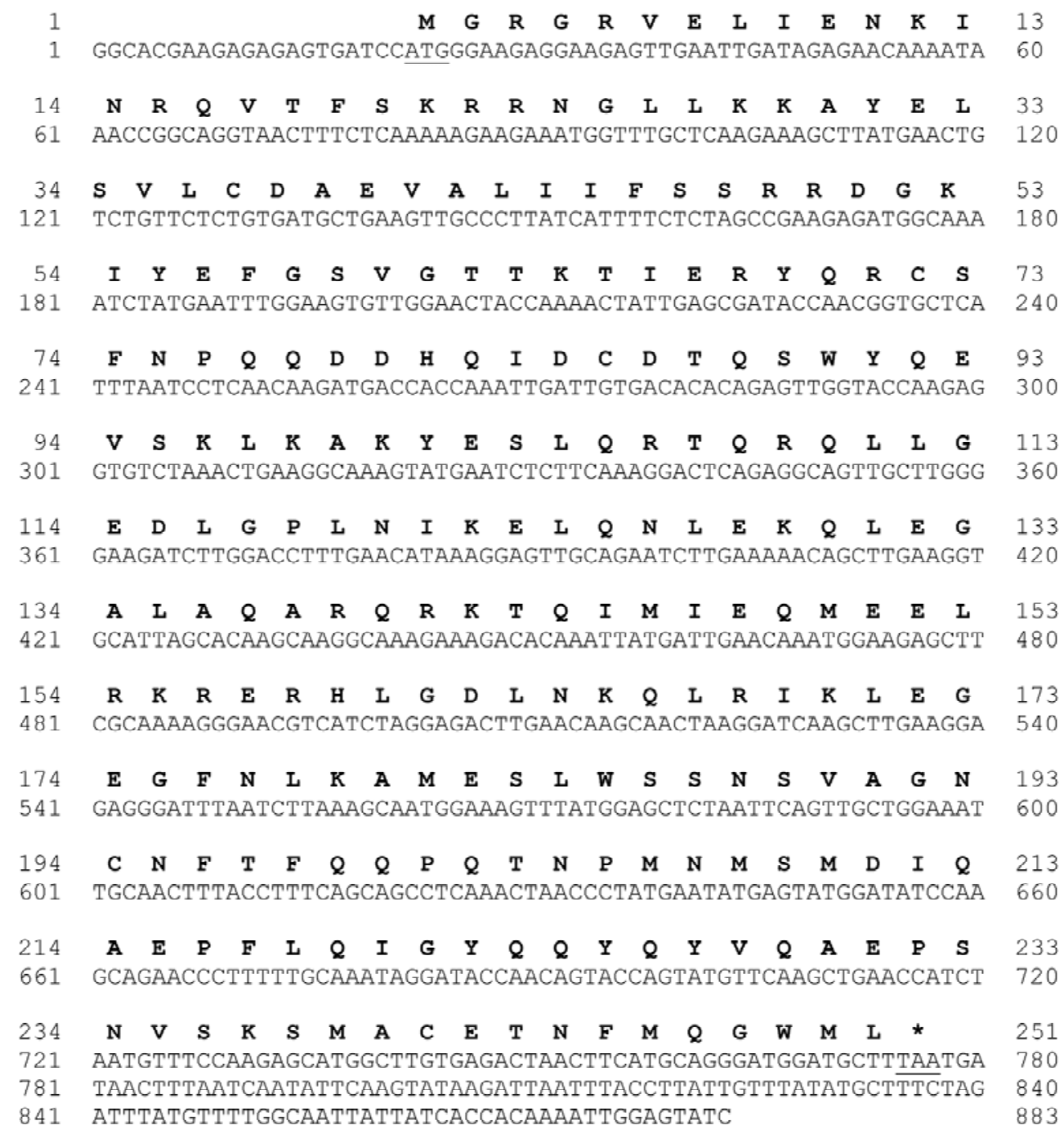

Figura 19. Secuencia del clon MtAGL6. Se subrayan los codones de inicio y finalización de la transcripción; en negrita se indica la secuencia de aminoácidos de la proteína deducida.

El clon MtAGL6-like equivale en secuencia a un cDNA denominado Medtr1g129880.1 de la base de datos "Medicago truncatula SEQUENCING RESOURCES" (www.medicago.org). Este cDNA ha sido deducido del clon genómico mth2-49g13 de Medicago truncatula ("complete sequence"; GenBank AC148527.20). MtAGL6-like se divide en 8 exones $(182,85,62,100,42,42,101$ y 106 pb) y 7 intrones. La secuencia genómica de MtAGL6-like está contenida entre las bases 62.645 y 66.185 del clon genómico mencionado. 


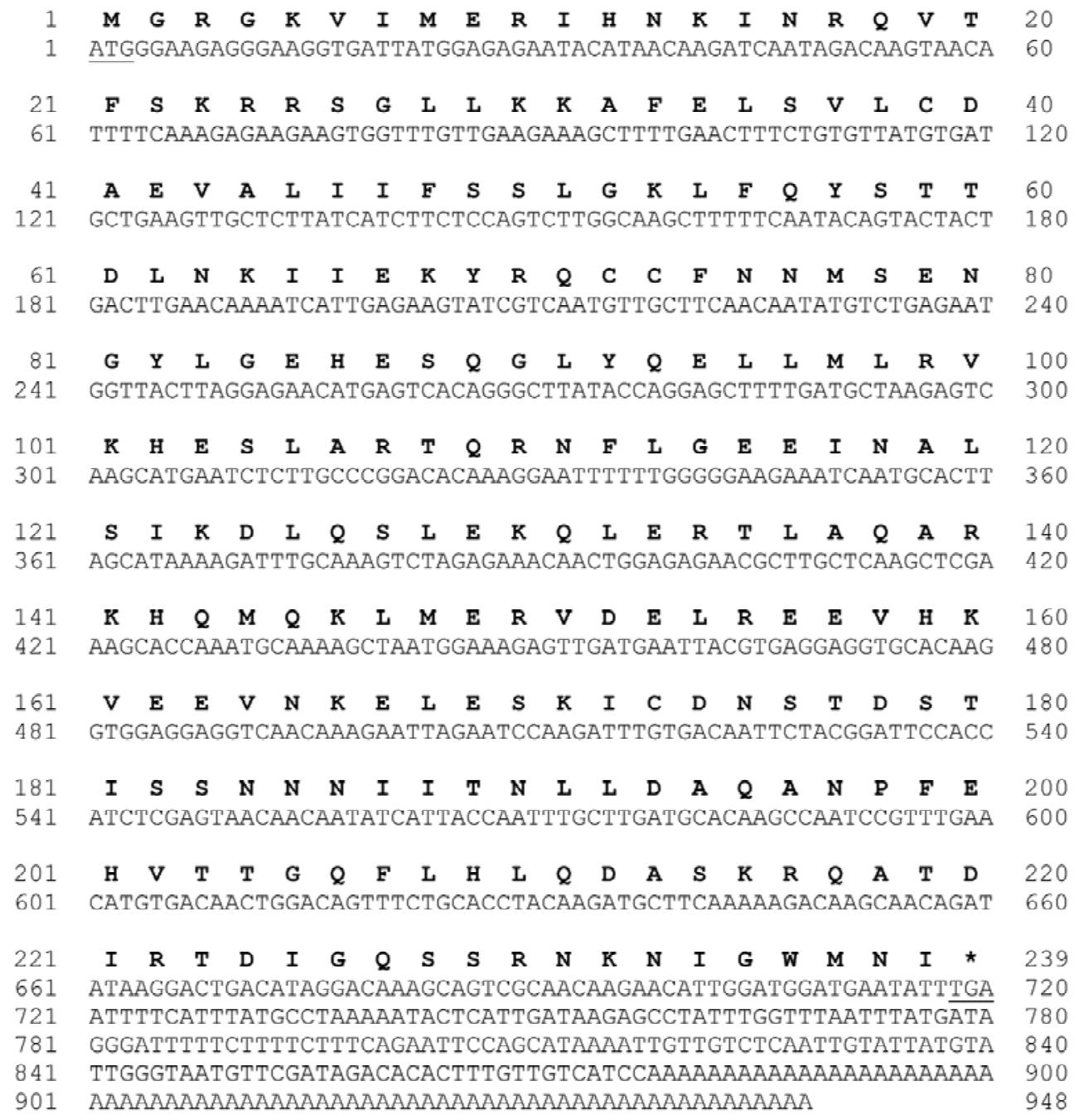

Figura 20. Secuencia del clon MtAGL6-like. Se subrayan los codones de inicio y finalización de la transcripción; en negrita se indica la secuencia de aminoácidos de la proteína deducida.

Las secuencias proteicas de MtAGL6 y MtAGL6-like se han colocado en el árbol filogenético de la Figura 21. Este árbol se ha generado utilizando secuencias proteicas codificadas por genes pertenecientes al grupo AGL6 descritos en diferentes especies, incluyendo leguminosas como Pisum sativum y Glycine max. Puede verse que MtAGL6 se agrupa con PSMADS5 (Hecht et al., 2005) y que dicha rama es filogenéticamente más cercana a los genes del grupo AGL6 de Malus $x$ domestica (Yao, 1999), Vitis vinifera (Boss et al., 2002), Arabidopsis thaliana (Ma et al., 1991; Rounsley et al., 1995) e incluso de monocotiledóneas como Oryza sativa (Li et al., 2010) o Zea mays (Mena et al., 1995). Por otro lado, MtAGL6-like forma una rama totalmente independiente con PSMADS3 (Hecht et al., 2005) de Pisum sativum y los genes aislados, pero aún no caracterizados, de soja (Glycine max, Cheung et al., unpublished). 


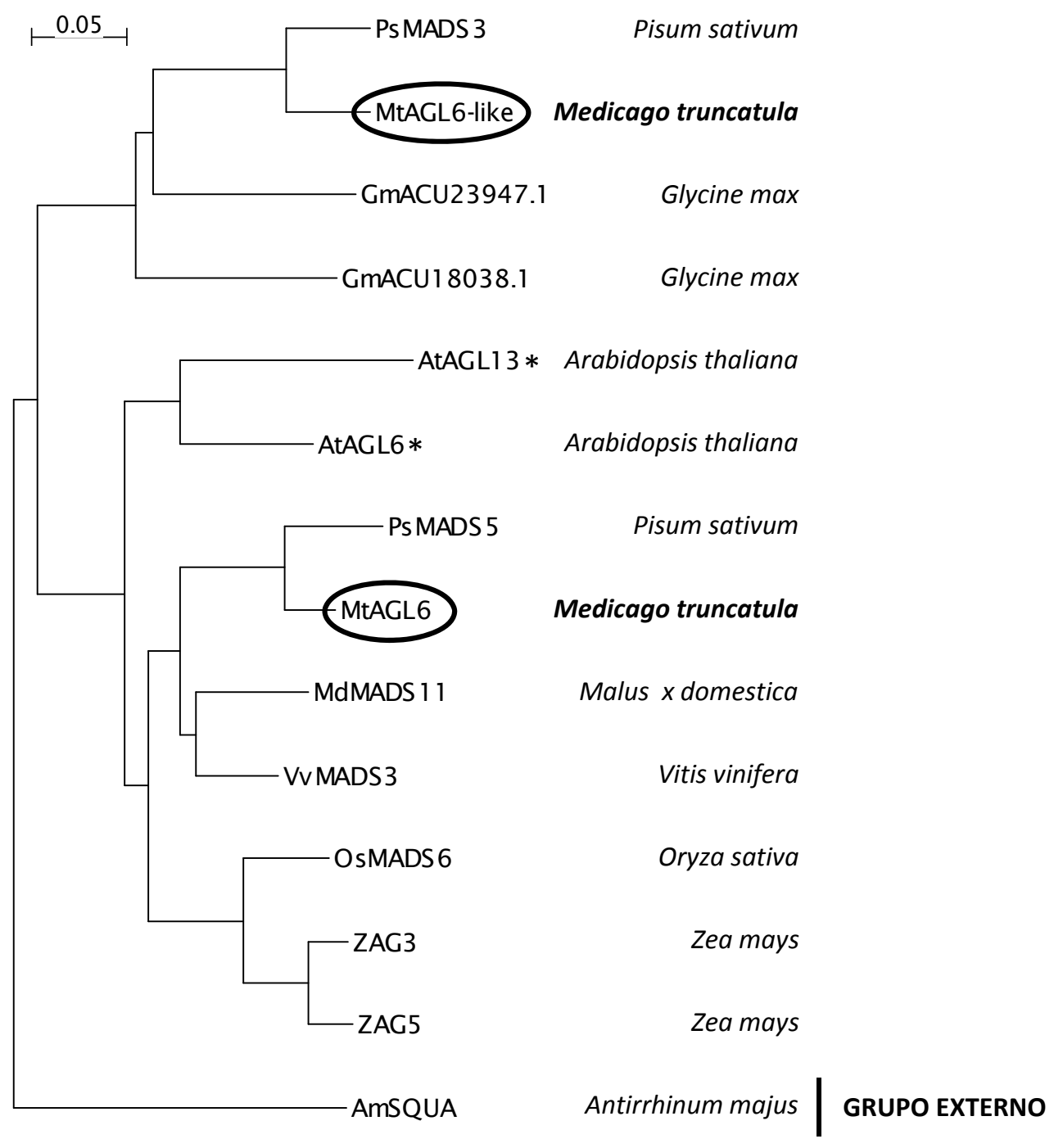

Figura 21. Árbol filogenético de las secuencias proteicas predichas para genes del grupo AGL6. Se utilizó la secuencia proteica íntegra de las siguientes proteínas: Arabidopsis thaliana: AtAGL6 (Ma et al., 1991; Acc NP_182089.1), AtAGL13 (Rounsley et al., 1995; Acc NP_191671.1); Pisum sativum: PsMADS3, PsMADS5 (Hecht et al., 2005; Acc AAX69066.1, AAX69067.1); Glycine max: GmACU18038.1, GmACU23947.1 (Cheung et al., unpublished; Acc ACU18038.1, ACU23947.1); Zea mays: ZAG3, ZAG5 (Mena et al., 1995; Acc NP_001105332.1, NP_001105692.1); Malus x domestica: MdMADS11 (Yao, 1999; Acc CAA04325.1); Vitis vinifera: VvMADS3 (Boss et al., 2002; Acc AAM21343.1); Oryza sativa: OsMADS6 (Li et al., 2010; Acc AAB64250.1); Medicago truncatula: MtAGL6, MtAGL6-like (este trabajo). Las proteínas MtAGL6 y MtAGL6-like se encierran en óvalos y las proteínas del grupo AGL6 de Arabidopsis thaliana se señalan con un asterisco. El árbol se enraizó con AmSQUA de Antirrhinum majus (Acc CAA45228.1).

Las proteínas MtAGL6 y MtAGL6-like presentan entre ellas un 41\% de homología al comparar las secuencias completas de polipéptidos. Presentan un $67 \%$ de homología en la región correspondiente a la caja MADS, $28 \%$ en la región I, $45 \%$ en la región de la caja $\mathrm{K}$ y $13 \%$ en la región C-terminal. En la Tabla 13 se muestran los porcentajes de homología de MtAGL6 y MtAGL6-like con proteínas de la leguminosa Pisum sativum y de la planta modelo Arabidopsis thaliana codificadas por genes del grupo AGL6. Según 
Dayhoff et al. (1978), dos proteínas de especies cercanas son ortólogas si conservan entre sí una homología de 75 - 90\%. Según los porcentajes de homología de secuencia (>80\%), se podría decir que MtAGL6 y PsMADS5 son probablemente proteínas ortólogas, así como MtAGL6-like y PsMADS3. Existe considerable homología (>50\%) entre MtAGL6 y las proteínas AtAGL6 y AtAGL13 de Arabidopsis thaliana, mientras que MtAGL6-like solo presenta una homología de $38-39 \%$ con las mismas.

Tabla 13. Porcentajes de homología (\%) de aminoácidos entre diferentes regiones de a) MtAGL6 y proteínas del grupo AGL6 de Pisum sativum y Arabidopsis thaliana, b) MtAGL6-like y proteínas del grupo AGL6 de Pisum sativum y Arabidopsis thaliana

\begin{tabular}{|c|c|c|c|c|c|}
\cline { 2 - 6 } \multicolumn{1}{c|}{ a) MtAGL6 } & Secuencia completa & Caja MADS & Región I & Caja K & Región C-terminal \\
\hline PsMADS5 & $\mathbf{8 5}$ & 94 & 84 & 90 & 75 \\
\hline PsMADS3 & $\mathbf{4 0}$ & 75 & 28 & 45 & 10 \\
\hline AtAGL6 & $\mathbf{6 3}$ & 93 & 29 & 69 & 43 \\
\hline AtAGL13 & $\mathbf{5 1}$ & 78 & 43 & 60 & 30 \\
\hline
\end{tabular}

\begin{tabular}{|c|c|c|c|c|c|}
\cline { 2 - 6 } \multicolumn{1}{c|}{ b) MtAGL6-like } & Secuencia completa & Caja MADS & Región I & Caja K & Región C-terminal \\
\hline PsMADS5 & $\mathbf{3 5}$ & 78 & 24 & 41 & 8 \\
\hline PsMADS3 & $\mathbf{8 3}$ & 93 & 92 & 81 & 63 \\
\hline AtAGL6 & $\mathbf{3 9}$ & 77 & 25 & 37 & 11 \\
\hline AtAGL13 & $\mathbf{3 8}$ & 73 & 17 & 41 & 8 \\
\hline
\end{tabular}

Ps: Pisum sativum; At: Arabidopsis thaliana

En la Figura 22 se representa un alineamiento múltiple entre MtAGL6, MtAGL6-like y las proteínas de Arabidopsis thaliana y Pisum sativum de la Tabla 13.

Se observa que las secuencias proteicas de MtAGL6, PsMADS5, AtAGL6 y AtAGL13 alinean muy bien entre ellas. Todas estas proteínas se agrupan dentro de la misma rama filogenética. Por otro lado, MtAGL6-like y PsMADS3 se alinean bien entre ellas, pero difieren de las primeras. Como se comentó previamente, MtAGL6-like y PsMADS3 pertenecen a una rama filogenética independiente dentro de los genes $A G L 6$.

Se ha descrito que las proteínas AGL6 suelen presentar dos secuencias bien conservadas en la región C-terminal, conocidas como motivos AGL6-I y AGL6-II. EI motivo AGL6-I se localiza en la parte media de la región C-terminal, con una secuencia consenso "DCEPTLQIGY"; el motivo AGL6-II se encuentra al final de la misma región y tiene una secuencia consenso "ENNFMLGWVL" (Ohmori et al., 2009). En el alineamiento 
puede verse que MtAGL6, PsMADS5, AtAGL6 y AtAGL13 conservan ambos motivos. Sin embargo, MtAGL6-like y PsMADS3 conservan pocos residuos aminoacídicos de dichos motivos.

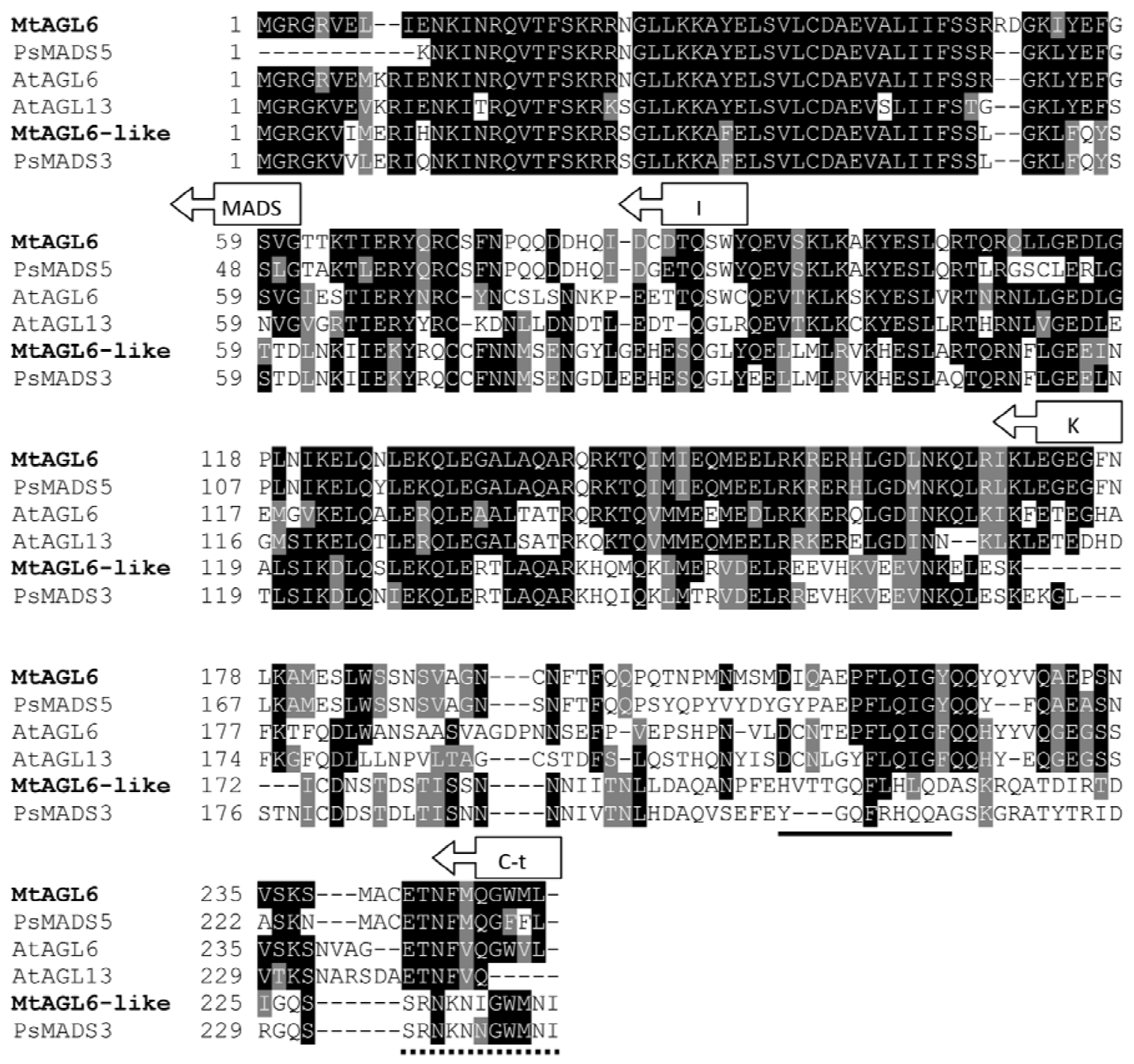

Figura 22. Alineamiento de las secuencias proteicas de MtAGL6, MtAGL6-like y de genes MADS-box homólogos de Arabidopsis thaliana y Pisum sativum. Las regiones sombreadas corresponden a aminoácidos conservados. Los dominios MADS y $\mathrm{K}$ así como las regiones I y C-terminal se señalan con flechas. El motivo AGL6-I se subraya con una línea continua y el motivo AGL6-II con una línea punteada.

\subsubsection{Patrón de expresión de MtAGL6 y MtAGL6-like}

Se analizó el patrón de expresión de ambos genes mediante hibridación Northern blot en diferentes tejidos de la planta (Figuras 23 y 26). Se usó la región C-terminal del cDNA de cada gen como sonda, a fin de evitar hibridación cruzada. El análisis del patrón de expresión tisular se realizó mediante hibridación in situ en ápices inflorescentes de Medicago truncatula (Figuras 24 y 27). 


\subsubsection{Patrón de expresión de MtAGL6}

Mediante hibridación Northern blot, la expresión de MtAGL6 se detecta intensa en flores y leve en fruto. No se detecta en los demás tejidos analizados (Figura 23).

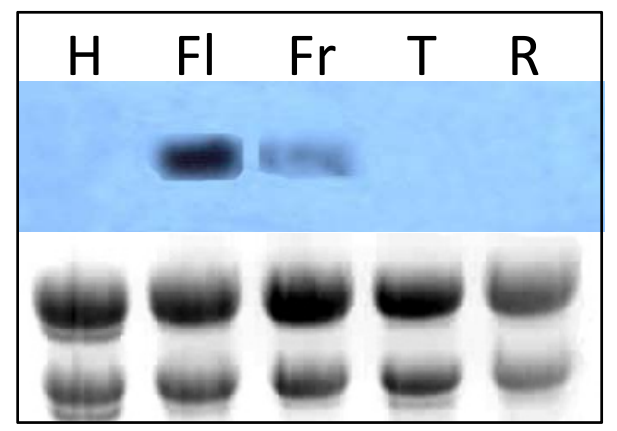

Figura 23. Análisis del patrón de expresión de MtAGL6 mediante Northern blot. Se utilizó RNA de diferentes tejidos de la planta: hoja $(\mathrm{H})$, flor (FI), fruto (Fr), tallo (T) y raíz (R).

La hibridación in situ muestra que la expresión de MtAGL6 se detecta desde el estadio 2 de desarrollo floral en dos regiones bien definidas del meristemo floral, que darán lugar a los primordios comunes (Figura 24, a). En el estadio 4, al comenzar a diferenciarse los primordios comunes, la expresión se detecta en la base de estos en forma de cuña (Figura 24, b). Cuando en el estadio 5 se diferencian los primordios de pétalos y estambres, la expresión se detecta en la base de estos órganos, manteniendo la forma característica de cuña (Figura 24, c). Posteriormente, en el estadio 6 la expresión disminuye notablemente, aunque aún puede detectarse en la zona de la base de los pétalos (Figura 24, d). Finalmente, en el estadio 7, tras la diferenciación de las anteras, la expresión se detecta principalmente en la parte interna de los óvulos (Figura 24 , e). No se detectó ninguna señal de hibridación en ninguna sección de tejido hibridada con la sonda "sentido", utilizada como control negativo (Figura 24, f).

Para hacer el seguimiento de la expresión de MtAGL6 detectada en óvulos, se realizaron hibridaciones in situ en frutos de Medicago truncatula, cuyo estadio de desarrollo era aproximadamente "Pod age: 6 DPP (días post-polinización)", según la caracterización del desarrollo de vainas y semillas de Medicago truncatula propuesto por Wang y Grusak (2005). En este momento del desarrollo del fruto, con un tamaño aproximado de $5 \mathrm{~mm}$, los embriones de las semillas están cercanos al estado globular y la estructura enrollada del fruto es definitiva. En la Figura 25 (a-c) se muestra un corte transversal a $90^{\circ}$ del eje de enrollado del fruto, en el que puede verse la expresión del 
gen concentrada en una región grande de la nucela, adyacente a la zona de unión de la semilla o funículo, así como en la epidermis de la semilla. No se detectó ninguna señal de hibridación en tejido hibridado con la sonda "sentido" (Figura 25, d).
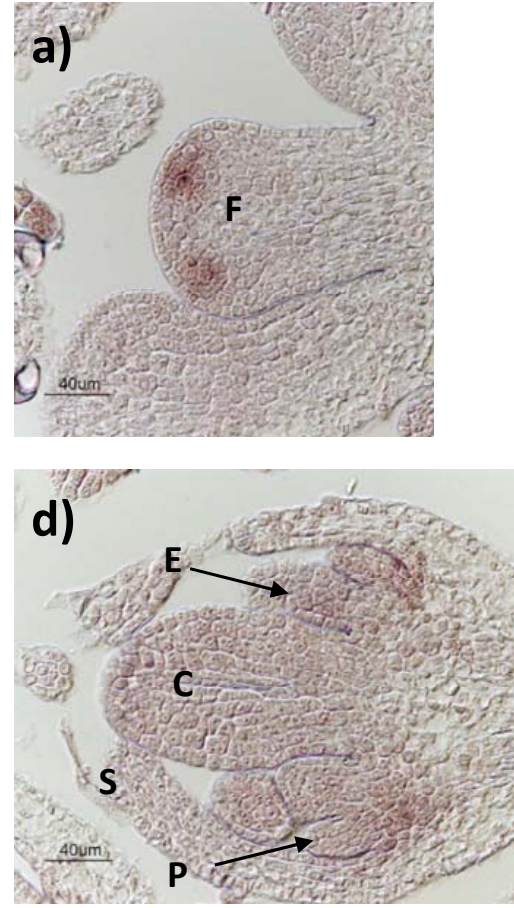
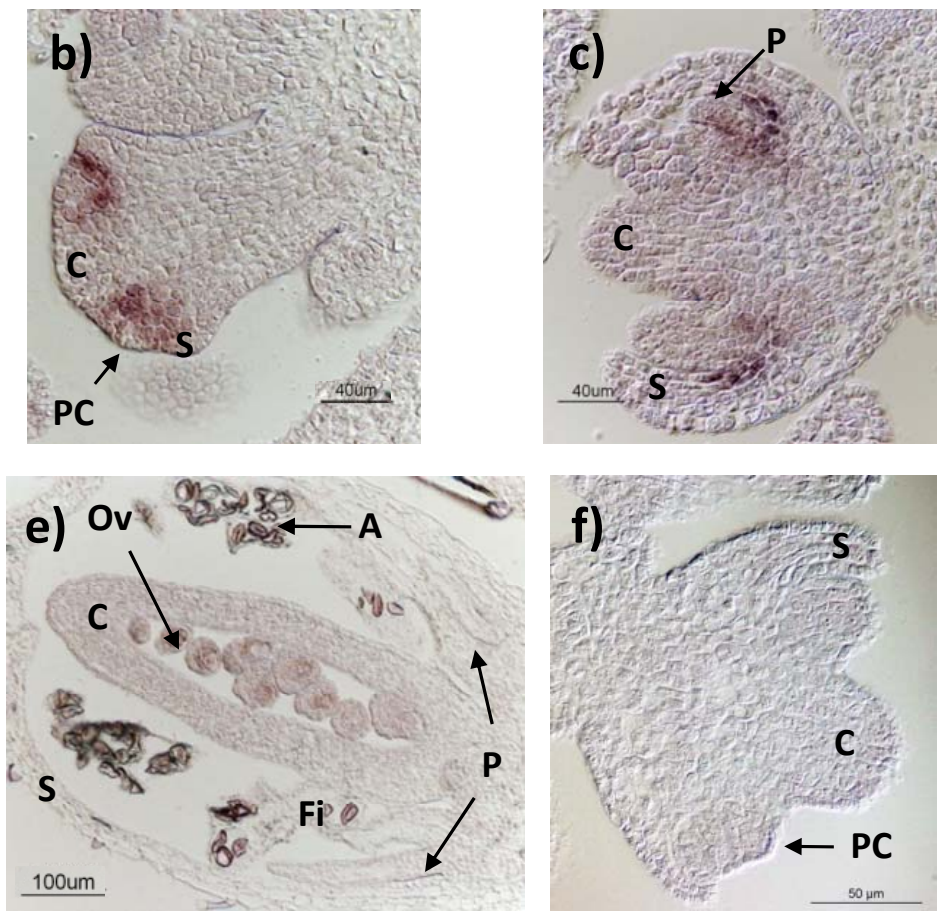

Figura 24. Análisis del patrón de expresión de MtAGL6 mediante hibridación in situ en ápices inflorescentes de $\boldsymbol{M}$. truncatula. a) Expresión en dos regiones definidas del meristemo floral en estadio de desarrollo 2. b) Expresión en forma de cuña en la base de los primordios comunes en el estadio 4. c) Expresión en la base de los primordios de pétalo y estambre durante el estadio 5. d) La expresión se debilita en la base de los pétalos y estambres en el estadio 6 del desarrollo floral. e) Expresión detectada en óvulos en la flor en estadio 7. f) Hibridación in situ con la sonda "sentido". F, Meristemo floral; PC, Primordio común; S, Sépalo; C, Carpelo; E, Estambre; P, Pétalo; Fi, Filamento; A, Antera; Ov, Óvulo.
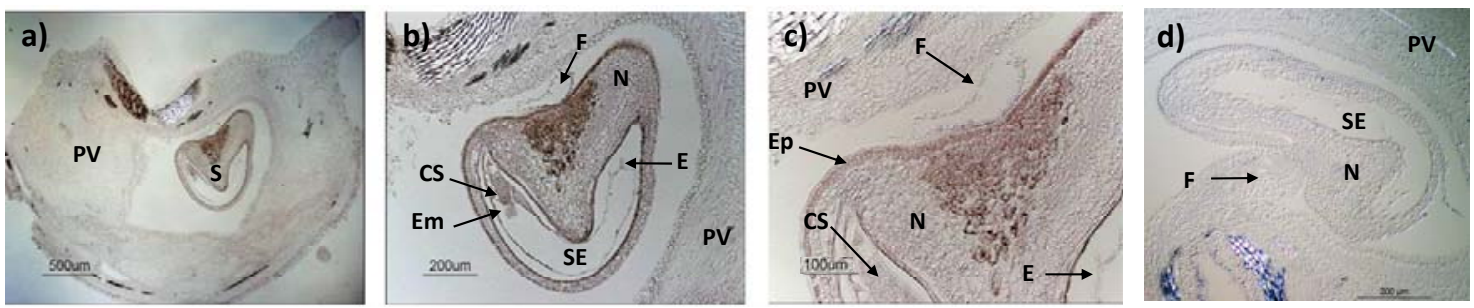

Figura 25. Análisis del patrón de expresión de MtAGL6 en frutos. Patrón de expresión mediante hibridación in situ en corte transversal del fruto y la semilla de Medicago truncatula a). Se distingue la semilla y el tejido de la vaina. b) Semilla. La expresión de MtAGL6 está contenida en una región definida del tejido nucelar. c) Expresión en la región nucelar próxima al funículo y en la epidermis. d) Hibridación in situ con la sonda "sentido". PV, Pared de la vaina; S, Semilla; N, Nucela; F, Funículo; SE, Saco embrionario; E, Endospermo; CS, Células basales del suspensor; Em, Embrión, Ep, Epidermis. 


\subsubsection{Patrón de expresión de MtAGL6-like}

La expresión de MtAGL6-like, analizada mediante Northern blot, se detecta en todos los tejidos estudiados, siendo muy intensa en flores e intensa en hojas. Es leve en tallos, frutos y raíces (Figura 26).

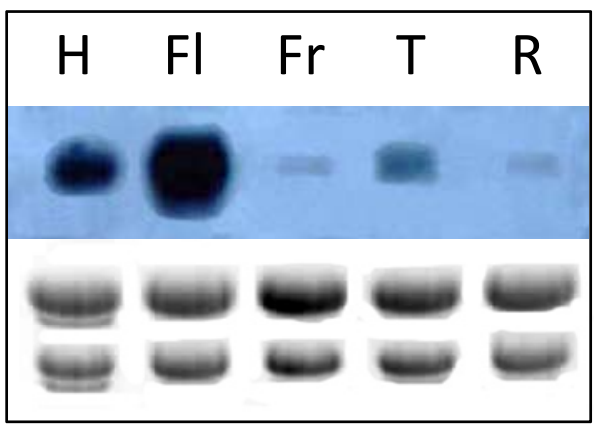

Figura 26. Análisis del patrón de expresión de MtAGL6-like mediante Northern blot. Se utilizó RNA de diferentes tejidos de la planta: hoja $(H)$, flor (FI), fruto $(F r)$, tallo $(T)$ y raíz $(R)$.

La hibridación in situ muestra que el transcrito de MtAGL6-like se detecta en todo el meristemo floral desde el estadio 2 , tendiendo a centrarse en la zona interior del mismo (Figura 27, a). En el estadio 4 la expresión se define en los primordios comunes y en las capas celulares subyacentes a dichos primordios hacia la parte central del meristemo (Figura 27, b). En el estadio 5, cuando se han diferenciado los primordios de estambres y pétalos, la expresión de MtAGL6-like se extiende por dichos primordios y es leve, haciéndose más intensa hacia el interior de su región basal (Figura 27, c). En el estadio 6, la expresión se centra principalmente en la base de los primordios de estambre (Figura 27, d). En estadios tardíos del desarrollo floral la expresión de MtAGL6-like se mantiene en la región subyacente a la base de los estambres y en franjas hacia el centro de la flor (estadio 7, Figura 27, e). No se detectó ninguna señal de hibridación en ninguna sección de tejido hibridada con la sonda "sentido", utilizada como control negativo (Figura 27, f).

A pesar de que se observó mediante hibridación Northern blot una expresión mucho menor de este gen en fruto, se realizaron estudios de expresión mediante hibridación in situ de MtAGL6-like en frutos de Medicago truncatula. Se utilizaron frutos en el estadio descrito anteriormente (Pod age: 6 DPP). En este caso, se realizaron cortes longitudinales del fruto, paralelos al eje de enrollado del mismo. En la Figura 28 (a-c) se muestra un corte en el que puede verse una expresión muy intensa de MtAGL6-like en el 
endotelio de la semilla. No se detectó ninguna señal de hibridación en tejidos hibridados con la sonda "sentido" (Figura 28, d).
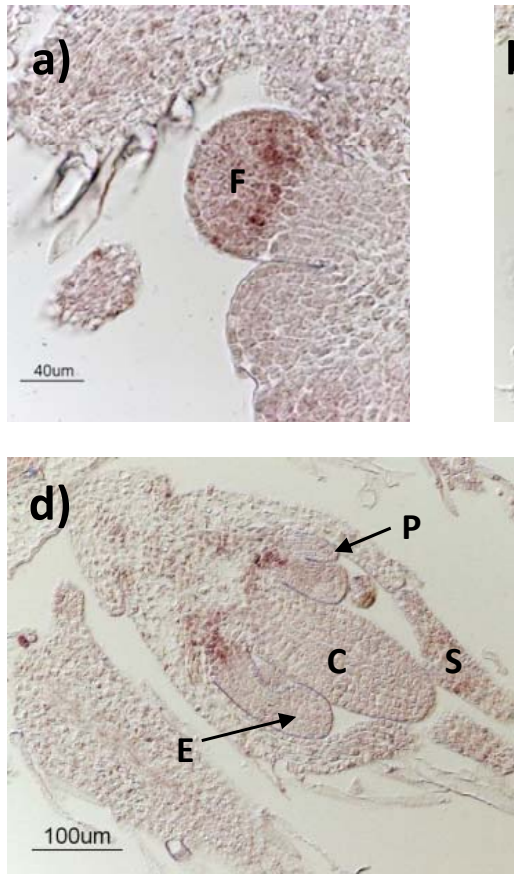
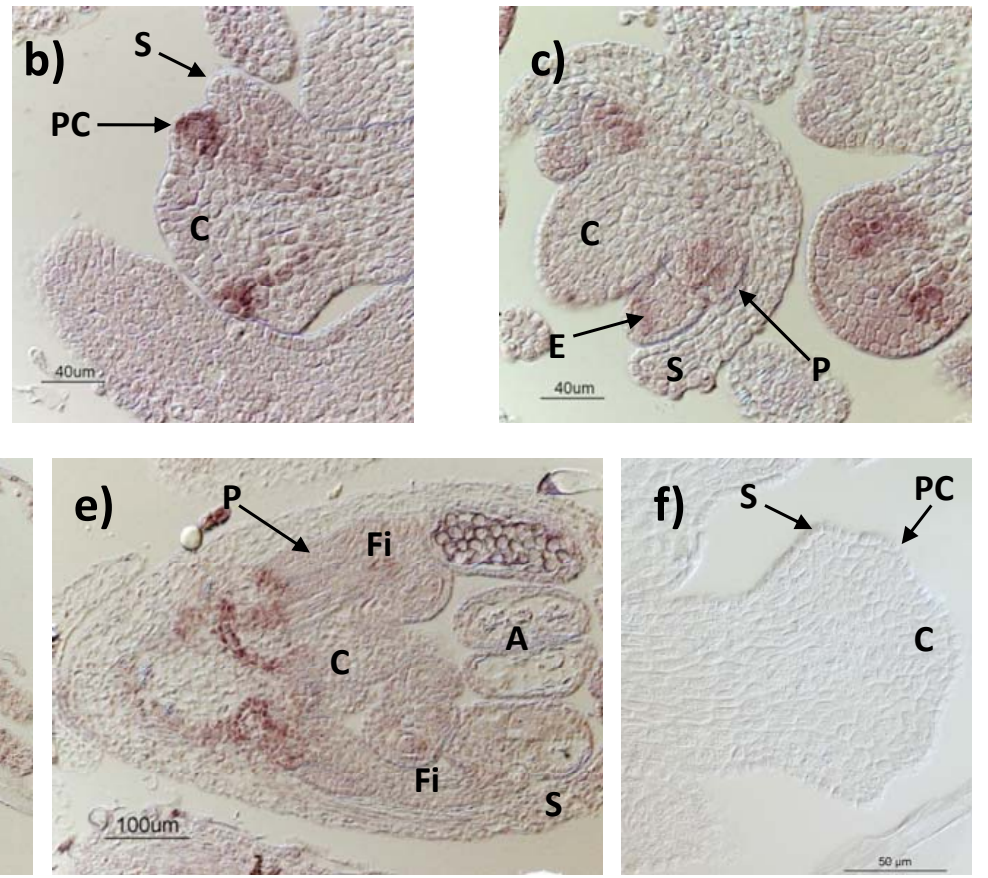

Figura 27. Análisis del patrón de expresión de MtAGL6-like mediante hibridación in situ en ápices inflorescentes de $\boldsymbol{M}$. truncatula. a) Expresión generalizada en el meristemo floral en estadio de desarrollo 2. b) Expresión en los primordios comunes y franjas celulares hacia el interior del meristemo en el estadio 4. c) Expresión concentrada en la base de los primordios de pétalo y estambre y expresión leve en la extensión de los mismos durante el estadio 5. d) La expresión se define al interior de la base de estambres en el estadio 6 del desarrollo floral. e) Expresión mantenida en la base de los estambres y franjas hacia el interior de la flor en estadio 7. f) Hibridación in situ con la sonda "sentido". F, Meristemo floral; PC, Primordio común; S, Sépalo; C, Carpelo; E, Estambre; P, Pétalo; Fi, Filamento; A, Antera.
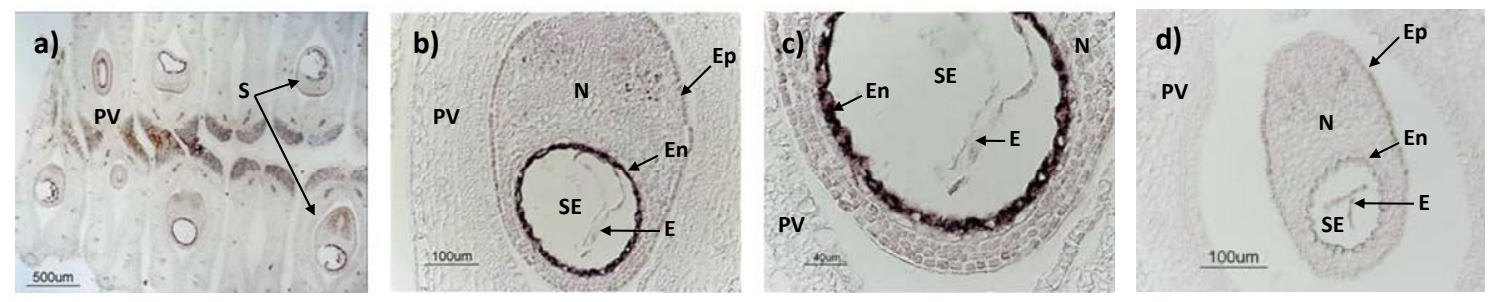

Figura 28. Análisis del patrón de expresión de MtAGL6-like en frutos. Patrón de expresión mediante hibridación in situ en corte longitudinal del fruto y la semilla de Medicago truncatula a). Se distinguen las semillas y el tejido de la vaina. b) Semilla. La expresión de MtAGL6-like está limitada al endotelio. c) Expresión de MtAGL6 en el endotelio. d) Hibridación in situ con la sonda "sentido". PV, Pared de la vaina; S, Semilla; N, Nucela; SE, Saco embrionario; E, Endospermo; Ep, Epidermis; En, Endotelio. 


\subsection{MtSOC1a, MtSOC1b Y MtSOC1-like: GENES CON HOMOLOGÍA A GENES MADS- bOX DEL GRUPO TDR3 (SOC1)}

\subsubsection{Aislamiento y análisis de secuencia de MtSOC1a, MtSOC1b y MtSOC1-}

like

Se aislaron tres clones diferentes con secuencias relacionadas con genes del poco caracterizado grupo TDR3, también llamado SOC1. Mediante la comparación de las secuencias de los clones y las secuencias contenidas en las bases de datos se pudo ver que dos de ellos, 1.3 .1 y 14.3.2, están más cercanamente relacionados por homología de secuencia al gen AtSOC1 (Lee et al., 2000) de Arabidopsis thaliana que a cualquier otro miembro del grupo SOC1 de esta planta. Estos clones se denominaron MtSOC1a (clon 1.3.1) y MtSOC1b (clon 14.3.2). El tercer clon, el 12.1.1, está menos relacionado con AtSOC1 y no corresponde claramente a ningún gen de Arabidopsis thaliana del grupo SOC1, así que se le llamó MtSOC1-like.

El clon MtSOC1a (clon 1.3.1) tiene una longitud de 982 pb (Figura 29) y contiene una región 5' no codificante de 89 pb, una pauta de lectura abierta de 639 pb y una región 3' no traducida de $251 \mathrm{pb}$. La proteína predicha MtSOC1a tiene 213 aminoácidos, una masa molecular de 24,46 kDa y un punto isoeléctrico teórico de 10,09.

El clon MtSOC1b (clon 14.3.2) tiene 1152 pb (Figura 30), con una región 5’ no codificante de 240 pb y una región 3' no codificante de 237 pb. Presenta una pauta de lectura abierta de 672 pb que codifica un polipéptido de 224 aminoácidos (25,70 kDa) con un punto isoeléctrico teórico de 9,55.

En la Figura 31 se muestra la secuencia del clon MtSOC1-like (clon 12.1.1) con la secuencia aminoacídica de la proteína predicha. La longitud completa del clon es de 851 pb y contiene una pauta de lectura abierta de 615 pb que codifica una proteína de 205 pb con un peso molecular predicho de 23,79 kDa y un punto isoeléctrico teórico 9,28. La región 5' no traducida tiene una longitud de 63 pb y la región 3' no traducida, de 170 pb.

El dominio MADS de estos tres genes del grupo SOC1 difiere de otros genes homeóticos florales pues contiene cuatro residuos de aminoácidos relativamente raros dentro de la caja MADS, incluyendo la valina (V) en la posición 2, tirosina (T) en la 6, fenilalanina ( $F$ ) en la 33 y prolina (P) en la 50 (esta última ausente en el gen MtSOC1like). Esta combinación es característica de una pequeña familia de genes MADS-box 
(Theissen et al., 1996) representada por los genes TDR3 (Pnueli et al., 1991) de Solanum lycopersicum y AtSOC1 (Lee et al., 2000) de Arabidopsis thaliana. El hecho de que MtSOC1a, MtSOC1b y MtSOC1-like presenten estos aminoácidos característicos indica que estos genes efectivamente pertenecen al grupo SOC1.

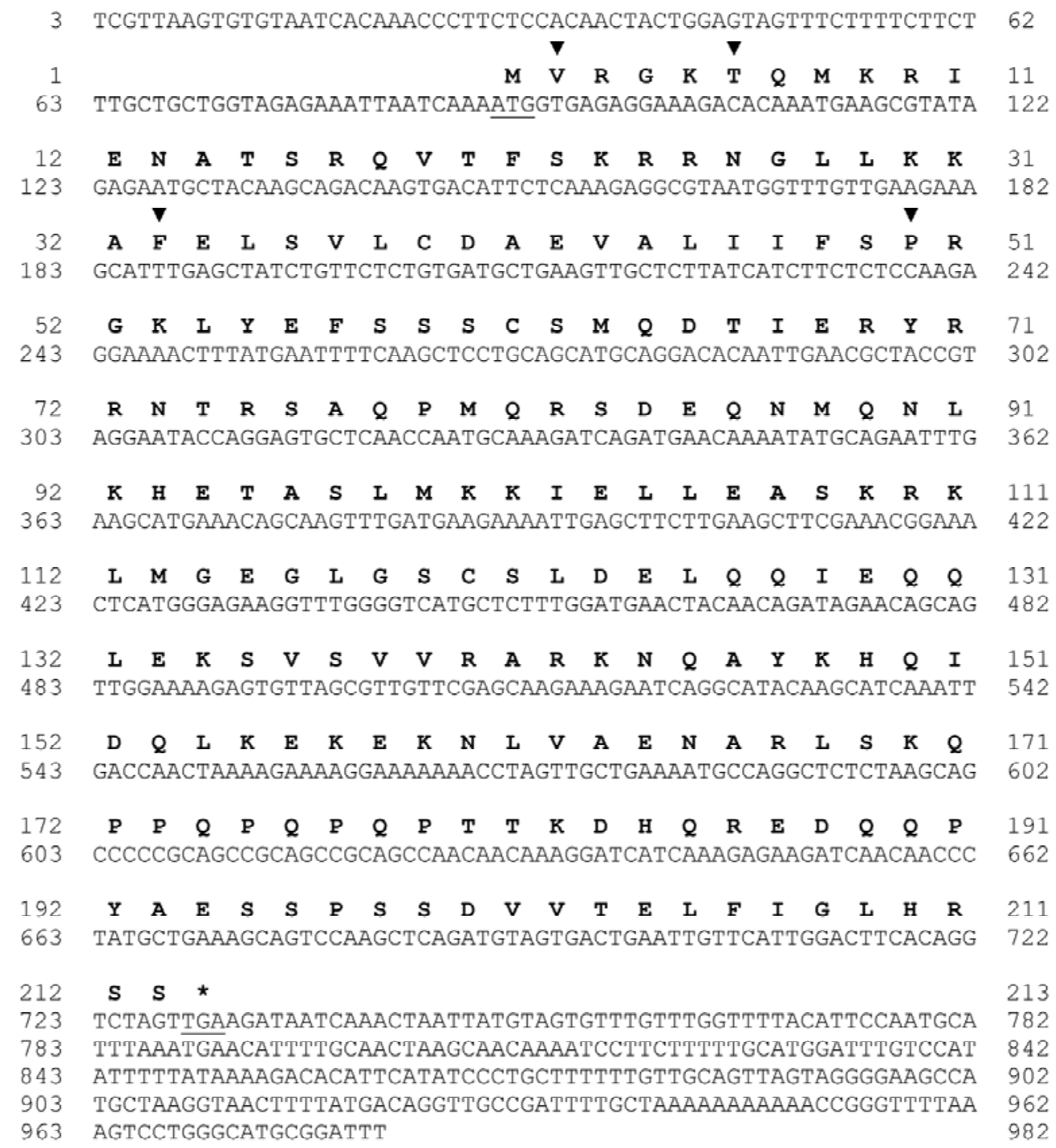

Figura 29. Secuencia del clon MtSOC1a. Se subrayan los codones de inicio y finalización de la transcripción; en negrita se indica la secuencia de aminoácidos de la proteína deducida. Con puntas de flecha negras se indican los aminoácidos característicos para el grupo SOC: V, valina (posición 2); T, tirosina (posición 6); F, fenilalanina (posición 33) y P, prolina (posición 50).

Se realizó una comparación de estas secuencias con las secuencias contenidas en las bases de datos mediante BLAST. El cDNA de MtSOC1a corresponde en secuencia a un gen contenido en el cromosoma 7 de Medicago truncatula, que se deduce del clon genómico mte1-40a8 (“complete sequence"; GenBank AC184047.1). El gen MtSOC1a 
está formado por 7 exones $(182,85,62,100,42,42$ y 129 pb) y 6 intrones. La secuencia genómica de MtSOC1a está contenida entre las bases 6.171 y 24.793 del clon mencionado.

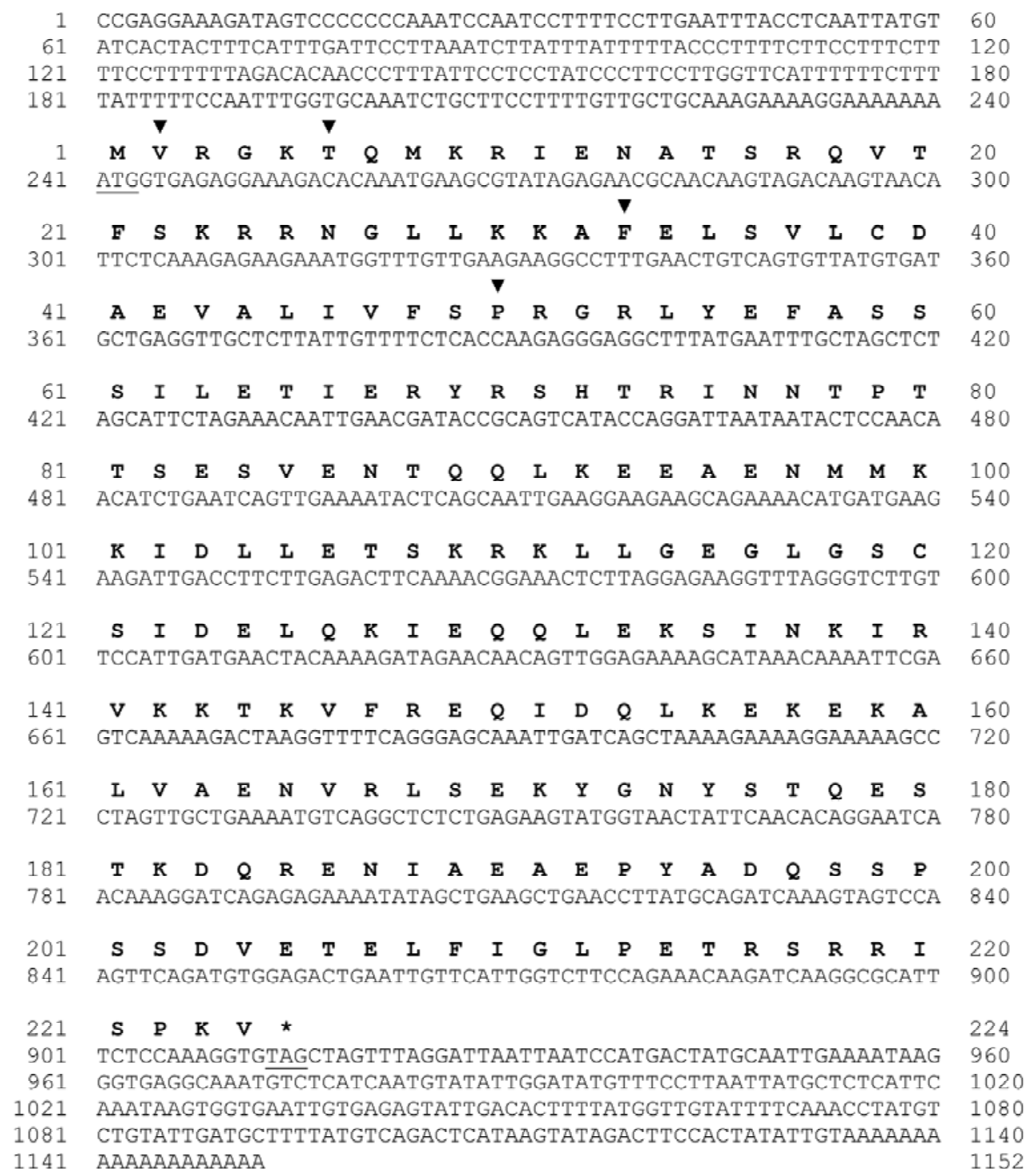

Figura 30. Secuencia del clon MtSOC1b. Se subrayan los codones de inicio y finalización de la transcripción; en negrita se indica la secuencia de aminoácidos de la proteína deducida. Con puntas de flecha negras se indican los aminoácidos característicos para el grupo SOC: V, valina (posición 2); T, tirosina (posición 6); F, fenilalanina (posición 33) y P, prolina (posición 50).

MtSOC1b corresponde en secuencia a un mRNA "desconocido" con número de acceso GenBank ACJ86138.1 (deducido del clon genómico MTYFP_FQ_FR_FS1G-E-5 de Medicago truncatula), que codifica una proteína MADS-box "desconocida" con número de acceso BT053478.1. 


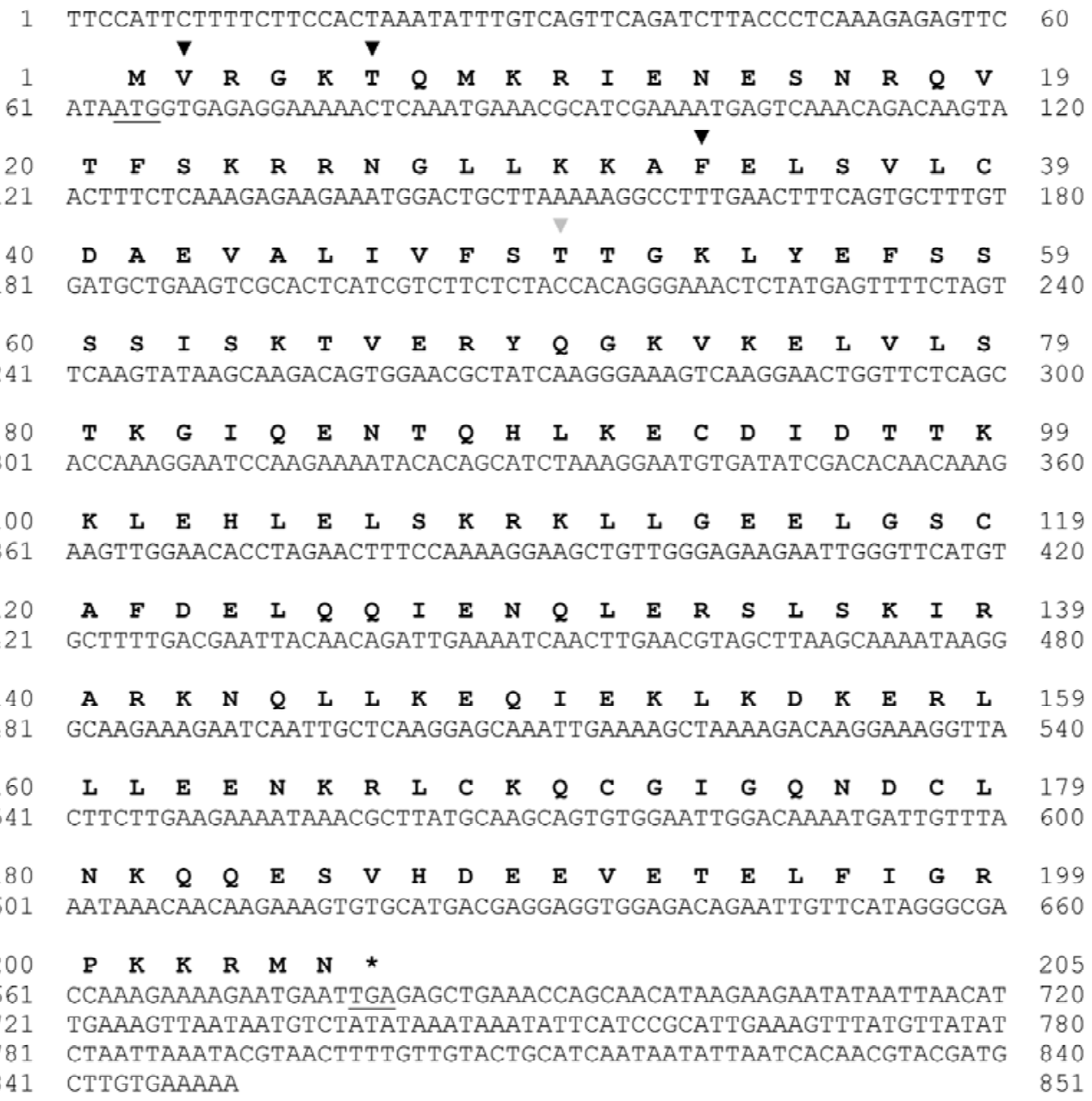

Figura 31. Secuencia del clon MtSOC1-like. Se subrayan los codones de inicio y finalización de la transcripción; en negrita se indica la secuencia de aminoácidos de la proteína deducida. Con puntas de flecha negras se indican los aminoácidos característicos para el grupo SOC: V, valina (posición 2); T, tirosina (posición 6); F, fenilalanina (posición 33). Con punta de flecha gris se indica la posición 50 , donde en lugar de prolina $(\mathrm{P})$ esta proteína posee una $\mathrm{T}$ (tirosina).

La comparación de MtSOC1-like con las secuencias de la base de datos "TIGR Plant Transcript Assemblies" (http://plantta.jcvi.org/), reflejó que el cDNA del clon equivale a un EST ("Expressed sequence tag" o marcador de secuencia expresada) con número de referencia TA24069_3880. Este EST tiene en NCBI un número de acceso GenBank BQ255341 (“MTNAH10TKM KVKC Medicago truncatula cDNA clone pKVKC-8a10”).

En la Figura 32 se muestra el árbol filogenético que se obtuvo utilizando secuencias proteicas predichas para MtSOC1a, MtSOC1b y MtSOC1-like y proteínas MADS-box del grupo SOC1 de diferentes especies. Se utilizó una colección de proteínas SOC1 de plantas modelo como Arabidopsis thaliana (Lee et al., 2000) o Solanum lycopersicum (Pnueli et al., 1991) y leguminosas como Glycine max (Xu et al., unpublished) o Pisum sativum (Hecht et al., 2005). Además se incluyeron proteínas SOC1 descritas en otras 
especies, como Malus $x$ domestica (Kotoda et al., 2010), Eucalyptus globulus (Decroocq et al., 1999), Populus tremuloides (Cseke et al., 2003) y Vitis vinifera (Fang et al., unpublished).

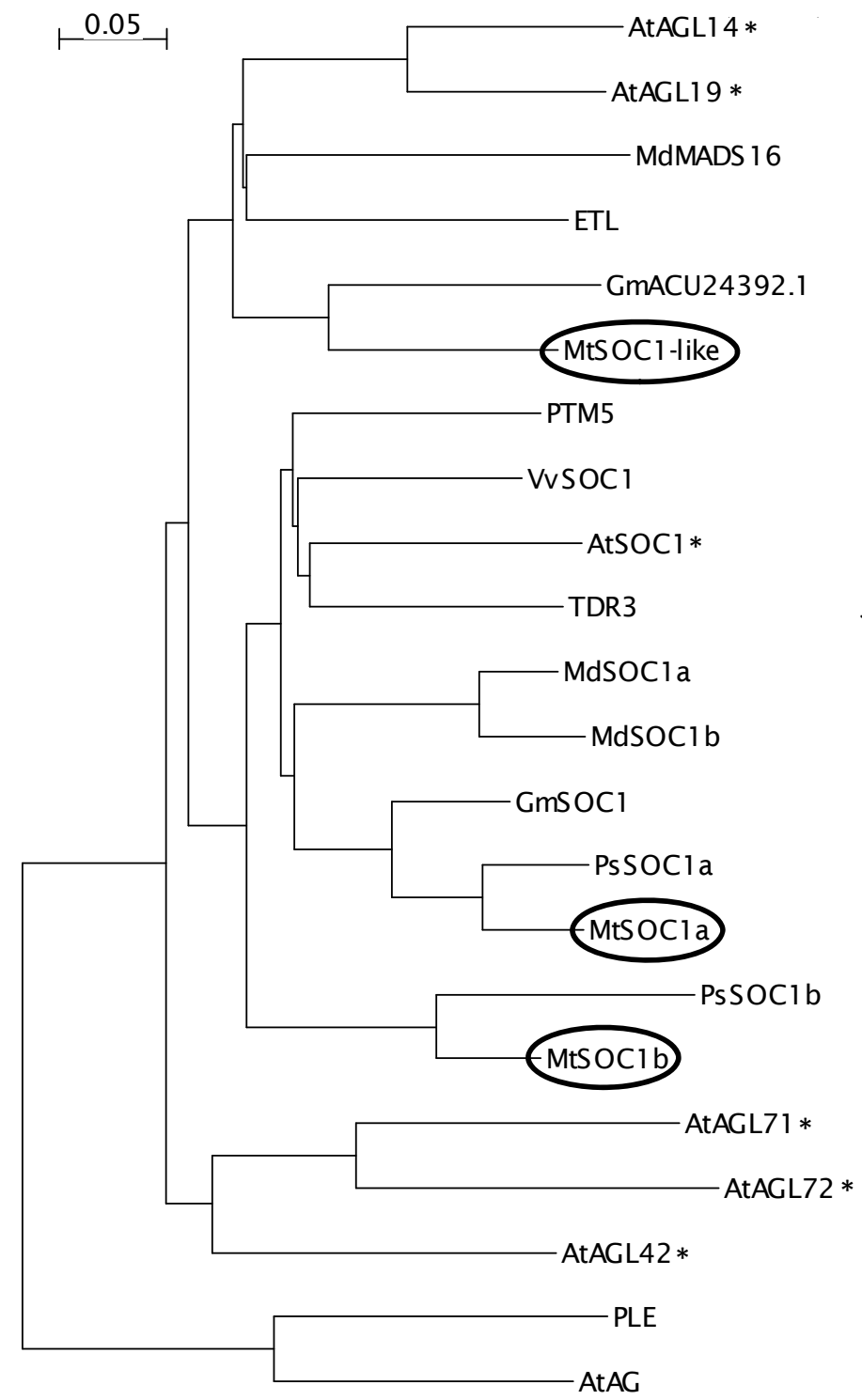

Arabidopsis thaliana

Arabidopsis thaliana

Malus $x$ domestica

Eucalyptus globulus

Glycine max

Medicago truncatula

Populus tremuloides

Vitis vinifera

Arabidopsis thaliana

Solanum lycopersicum

Malus $x$ domestica

Malus $x$ domestica

Glycine max

Pisum sativum

Medicago truncatula

Pisum sativum

Medicago truncatula

Arabidopsis thaliana

Arabidopsis thaliana

Arabidopsis thaliana

Antirrhinum majus

Arabidopsis thaliana

GRUPO EXTERNO

Figura 32. Árbol filogenético de las secuencias proteicas predichas para genes del grupo SOC1. Se utilizó la secuencia proteica íntegra de las siguientes proteínas: Arabidopsis thaliana: AtSOC1 (Lee et al., 2000; Acc NP_182090.1), AtAGL14 (Rounsley et al., 1995; Acc NP_192925.1), AtAGL19 (Alvarez-Buylla et al., 2000b; Acc NP_194026.1), AtAGL42, AtAGL71, AtAGL72 (Pařenicová et al., 2003; Acc NP_568952.1, NP_199999.1, NP_200000.3); Pisum sativum: PsSOC1a, PsSOC1b (Hecht et al., 2005; Acc AAX47171.2, AAX33629.1); Glycine max: GmSOC1 (Xu et al., unpublished; Acc ABC75835.1), GmACU24392.1 (Cheung et al., unpublished; Acc ACU24392.1); Malus $x$ domestica: MdMADS16 (Shigeta et al., unpublished; Acc BAG48169.1), MdSOC1a, MdSOC1b (Kotoda et al., 2010; Acc BAI49494.1, BAI49495.1); Vitis vinifera: VvSOC1 (Fang et al., unpublished; Acc ACZ26527.1); Populus tremuloides: PTM5 (Cseke et al., 2003; Acc AAP46287.1); Eucalyptus globulus: ETL (Decroocq et al., 1999; Acc AAD16052.1); Solanum lycopersicum: TDR3 (Pnueli et al., 1991; Acc CAA43168.1); Medicago truncatula: MtSOC1a, MtSOC1b, MtSOC1-like (este trabajo). Las proteínas MtSOC1a, MtSOC1b y MtSOC1-like se encierran en óvalos y las proteínas del grupo SOC1 de Arabidopsis thaliana se señalan con un asterisco. El árbol se enraizó con PLE de Antirrhinum majus (Acc AAB25101.1) y AtAG de Arabidopsis thaliana (Acc NP_567569.3). 
MtSOC1a, MtSOC1b y MtSOC1-like se distribuyen en dos grandes ramas o subgrupos dentro del árbol filogenético. En una de las ramas, la que incluye el gen AtSOC1 (Lee et al., 2000) de Arabidopsis thaliana, que da nombre al grupo, se localizan los genes MtSOC1a y MtSOC1b. MtSOC1a se agrupa con sus ortólogos en leguminosas PsSOC1a (Hecht et al., 2005) de Pisum sativum y GmSOC1 (Xu et al., unpublished) de Glycine max. El análisis filogenético indica que MtSOC1a es el que está más estrechamente relacionado con los genes representativos del grupo SOC1: AtSOC1 (Lee et al., 2000) de Arabidopsis thaliana y TDR3 (Antes TM3; Pnueli et al., 1991) de Solanum lycopersicum y sus ortólogos en otras plantas como Vitis vinifera (VvSOC1; Fang et al., unpublished), Populus tremuloides (PTM5; Cseke et al., 2003) o Malus $x$ domestica (MdSOC1a y MdSOC1b; Kotoda et al., 2010). Un poco más alejado, pero dentro del mismo subgrupo, se encuentran MtSOC1b y PsSOC1b (Hecht et al., 2005) de Pisum sativum.

Por otro lado, MtSOC1-like forma una rama con AtAGL14 (Rounsley et al., 1995) y AtAGL19 (Alvarez-Buylla et al., 2000b), dos genes descritos como específicos de raíz en Arabidopsis thaliana, un gen bien caracterizado de Eucalyptus globulus llamado ETL (Decroocq et al., 1999) y el gen GmACU24392.1 (Cheung et al., unpublished), aislado pero aún no caracterizado, de la leguminosa Glycine max.

Las proteínas MtSOC1a y MtSOC1b presentan entre sí una homología del $62 \%$ al comparar las secuencias aminoacídicas completas. Tienen un 93\% de homología en la región correspondiente a la caja MADS, 34\% en la región I, $61 \%$ en la región de la caja $\mathrm{K}$ y $42 \%$ en la región C-terminal. En la Tabla 14 se muestran los porcentajes de homología de MtSOC1a y MtSOC1b con proteínas de la misma rama o subgrupo filogenético, como TDR3 (Pnueli et al., 1991) de Solanum lycopersicum, AtSOC1 (Lee et al., 2000) de Arabidopsis thaliana y las proteínas SOC1 aisladas en leguminosas.

Por homología de secuencia se podría decir que MtSOC1a, PsSOC1a y GmSOC1 son proteínas ortólogas, así como MtSOC1b y PsSOC1b. Ambas proteínas de Medicago truncatula tienen una homología de $64-66 \%$, con las proteínas referentes de Solanum lycopersicum y Arabidopsis thaliana. 
Tabla 14. Porcentajes de homología (\%) de aminoácidos entre diferentes regiones de a) MtSOC1a y las proteínas representativas con las que presenta homología, b) MtSOC1b y las proteínas representativas con las que presenta homología

\begin{tabular}{|c|c|c|c|c|c|}
\cline { 2 - 6 } \multicolumn{1}{c|}{ a) MtSOC1a } & Secuencia completa & Caja MADS & Región I & Caja K & Región C-terminal \\
\hline PsSOC1a & $\mathbf{8 8}$ & 100 & 96 & 83 & 71 \\
\hline PsSOC1b & $\mathbf{5 3}$ & 76 & 30 & 54 & 37 \\
\hline GmSOC1 & $\mathbf{8 1}$ & 95 & 80 & 76 & 62 \\
\hline AtSOC1 & $\mathbf{6 6}$ & 93 & 44 & 63 & 45 \\
\hline TDR3 & $\mathbf{6 6}$ & 93 & 15 & 61 & - \\
\hline
\end{tabular}

\begin{tabular}{|c|c|c|c|c|c|}
\cline { 2 - 6 } \multicolumn{1}{c|}{ b) MtSOC1b } & Secuencia completa & Caja MADS & Región I & Caja K & Región C-terminal \\
\hline PsSOC1a & $\mathbf{6 4}$ & 93 & 36 & 59 & 51 \\
\hline PsSOC1b & $\mathbf{7 9}$ & 87 & 80 & 82 & 65 \\
\hline GmSOC1 & $\mathbf{7 0}$ & 95 & 40 & 64 & 59 \\
\hline AtSOC1 & $\mathbf{6 6}$ & 91 & 24 & 68 & 37 \\
\hline TDR3 & $\mathbf{6 4}$ & 93 & 19 & 56 & - \\
\hline
\end{tabular}

Ps: Pisum sativum; Gm: Glycine max; At: Arabidopsis thaliana; TDR3: Antes TM3, de Solanum lycopersicum

El resultado del alineamiento múltiple de MtSOC1a y MtSOC1b con las proteínas SOC1 arriba mencionadas se muestra en la Figura 33, que revela además la presencia de 11 residuos de aminoácidos en la región C-terminal, llamados "motivo SOC1", que se conservan en secuencias de proteínas SOC1 previamente publicadas. El motivo SOC1, altamente conservado, está presente en proteínas del grupo SOC1 de gimnospermas y angiospermas (Nakamura et al., 2005).

Figura 33. Alineamiento de las secuencias proteicas de MtSOC1a, MtSOC1b y de genes MADS-box del grupo SOC1 de la misma rama filogenética con los que presenta homología. Las regiones sombreadas corresponden a aminoácidos conservados. Los dominios MADS y $\mathrm{K}$ así como las regiones I y C-terminal se señalan con flechas. El motivo SOC1 se subraya con una línea continua. 


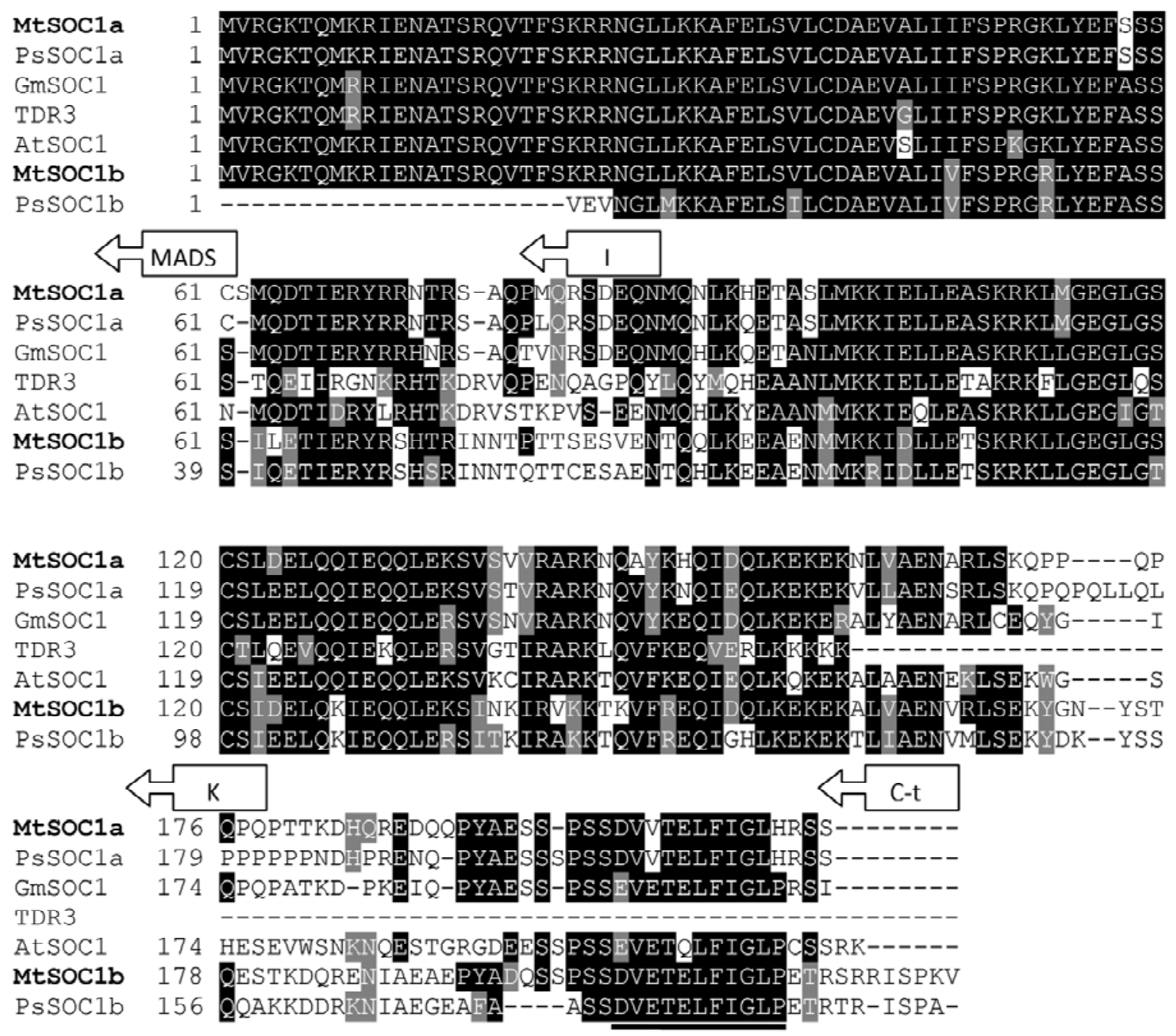

Figura 33. Alineamiento de las secuencias proteicas de MtSOC1a, MtSOC1b y de genes MADS-box del grupo SOC1 de la misma rama filogenética con los que presenta homología.

La proteína MtSOC1-like, contenida en una rama filogenética distinta de MtSOC1a y MtSOC1b, tiene un $59-60 \%$ de homología con dichas proteínas. En la Tabla 15 pueden verse los porcentajes de homología de MtSOC1-like con proteínas de su mismo subgrupo filogenético. Por homología de secuencia, la proteína de soja con número de acceso GenBank ACU24392.1 probablemente sea ortóloga de MtSOC1-like.

Tabla 15. Porcentajes de homología (\%) de aminoácidos entre diferentes regiones de MtSOC1-like y las proteínas con las que presenta mayor homología

\begin{tabular}{|c|c|c|c|c|c|}
\cline { 2 - 6 } \multicolumn{1}{c|}{} & Secuencia completa & Caja MADS & Región I & Caja K & Región C-terminal \\
\hline GmACU24392.1 & $\mathbf{7 1}$ & 91 & 64 & 63 & 50 \\
\hline ETL & $\mathbf{6 0}$ & 90 & 34 & 53 & 35 \\
\hline AtAGL14 & $\mathbf{5 8}$ & 88 & 36 & 50 & 32 \\
\hline AtAGL19 & $\mathbf{5 9}$ & 85 & 33 & 52 & 35 \\
\hline
\end{tabular}

Gm: Glycine max; ETL: TM3-like de Eucalyptus globulus; At: Arabidopsis thaliana 
El alineamiento múltiple entre las proteínas del subgrupo se muestra en la Figura 34. Todas las proteínas muestran residuos de aminoácidos que componen el motivo SOC1.

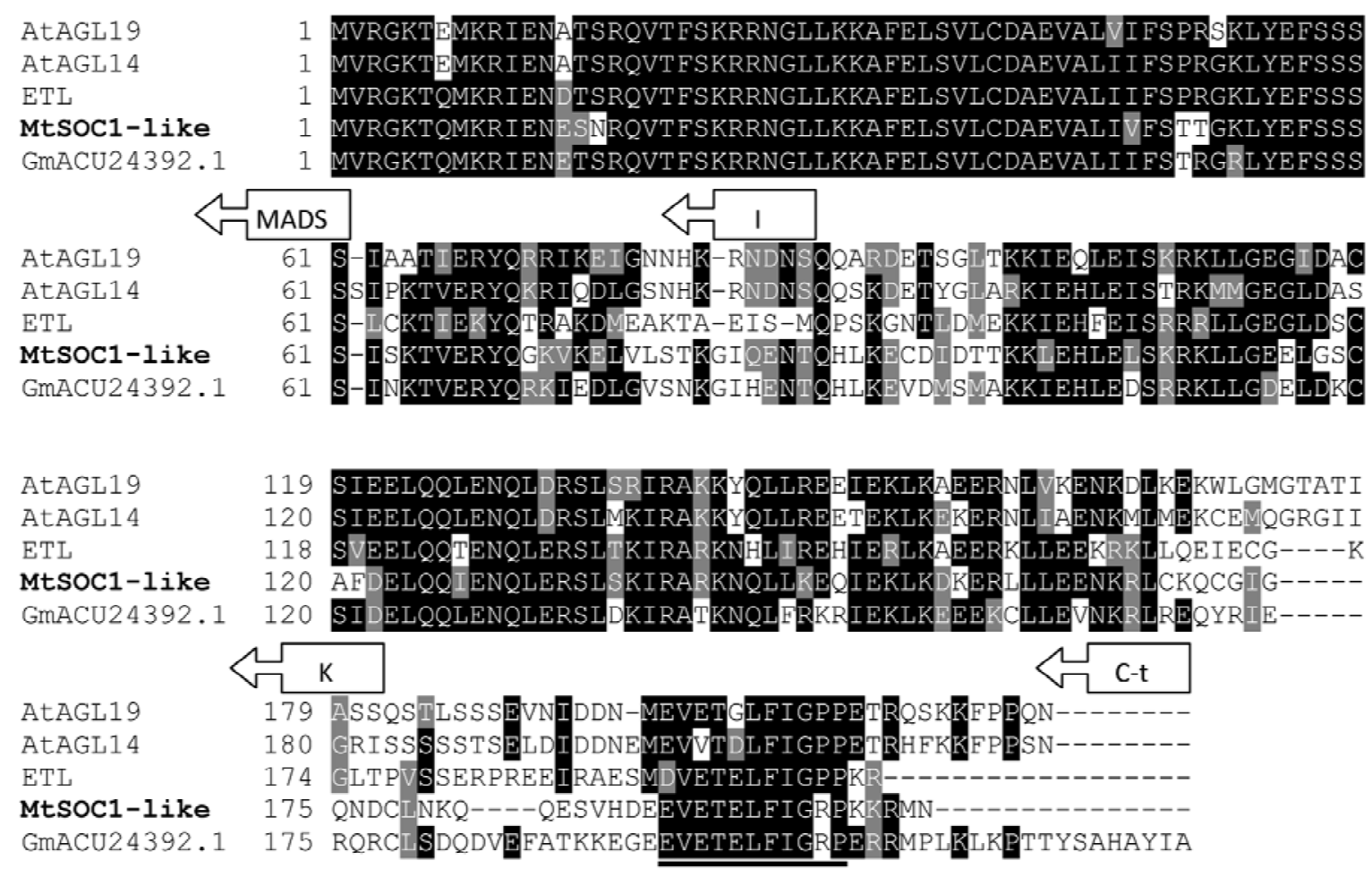

Figura 34. Alineamiento de la secuencia proteica de MtSOC1-like y de genes MADS-box del grupo SOC1 de la misma rama filogenética con los que presenta homología. Las regiones sombreadas corresponden a aminoácidos conservados. Los dominios MADS y $\mathrm{K}$ así como las regiones I y C-terminal se señalan con flechas. El motivo SOC1 se subraya con una línea continua.

\subsubsection{Patrón de expresión de MtSOC1a, MtSOC1b y MtSOC1-like}

\subsubsection{Patrón de expresión de MtSOC1a y MtSOC1b}

Se han analizado los patrones de expresión de MtSOC1a y MtSOC1b en varios tejidos de Medicago truncatula mediante Northern blot (Figuras 35, a y 36, a). Estos genes se expresan preferentemente en tejidos vegetativos. Ambos genes presentan una expresión fuerte en hoja, así como ausencia de expresión en fruto. MtSOC1a se expresa además fuertemente en tallo y con bajo nivel de transcrito en raíz. No se observa expresión en flores (Figura 35, a). MtSOC1b se expresa en raíz y la expresión en tallo y flor es muy débil (Figura 36, a).

El gen SOC1 (antes AGL20) de Arabidopsis thaliana está involucrado en el control del tiempo de floración. Este gen se activa en los meristemos apicales del brote durante la transición floral (Borner et al., 2000). A fin de ver las diferencias en la expresión de MtSOC1a y MtSOC1b en ápices vegetativos o inflorescentes tempranos, en la hibridación 
in situ se incluyeron ambos tipos de ápices (Figuras 35 , b-f y $36, b-f)$. Los patrones de expresión de MtSOC1a y MtSOC1b analizados mediante esta técnica son similares para ambos genes.

Ambos transcritos se detectan en el meristemo vegetativo, principalmente en el extremo distal del mismo, así como a lo largo de los haces vasculares del mismo. También se detectan en los primordios de hoja (Figuras 35, b y 36, b). Tras la transición floral, durante el estadio 2 de desarrollo floral, ambos genes se expresan en los meristemos florales tempranos que han emergido del meristemo inflorescente secundario. A partir del estadio 3 del desarrollo floral, la expresión de MtSOC1a desaparece del meristemo floral (Figura 35, c). No se detecta tampoco durante el estadio 4, cuando se han formado los primordios comunes (Figura 35, d). En el caso de MtSOC1b, en estadio 3 aún se detecta expresión leve del gen en la región central del meristemo floral, pero no se detecta en estadios posteriores del desarrollo floral, como en el estadio 4 (Figura 36, c y d). Los transcritos de ambos genes son indetectables en yemas florales adultas en estadio 6 de desarrollo floral (Figuras 35, e y 36, e).

En ninguna sección de estos tejidos hibridada con las sondas "sentido" se detectó señal de hibridación (Figuras 35, f y 36, f).

Figura 35. Análisis del patrón de expresión de MtSOC1a. a) Hibridación Northern blot de MtSOC1a en diferentes tejidos de la planta: hoja $(\mathrm{H})$, flor $(\mathrm{Fl})$, fruto $(\mathrm{Fr})$, tallo $(\mathrm{T})$ y raíz $(\mathrm{R})$. b-f) Análisis del patrón de expresión mediante hibridación in situ en ápices vegetativos e inflorescentes de $M$. truncatula. b) Expresión en el ápice del meristemo vegetativo y los haces vasculares. c) Expresión en meristemo floral emergente del meristemo inflorescente secundario en el estadio 2 del desarrollo floral. No hay expresión en meristemos florales más desarrollados. d) Ausencia de expresión en el estadio 4. e) Ausencia de expresión en flores en estadio 6 de desarrollo. f) Hibridación in situ con la sonda "sentido". V, Meristemo vegetativo; H, Hoja; HV, Haces vasculares; I2, Meristemo inflorescente secundario; F, Meristemo floral; PC, Primordio común; S, Sépalo; C, Carpelo; P, Pétalo; E, Estambre.

Figura 36. Análisis del patrón de expresión de MtSOC1b. a) Hibridación Northern blot de MtSOC1b en diferentes tejidos de la planta: hoja $(\mathrm{H})$, flor $(\mathrm{Fl})$, fruto $(\mathrm{Fr})$, tallo $(\mathrm{T})$ y raíz $(\mathrm{R})$. b-f) Análisis del patrón de expresión mediante hibridación in situ en ápices vegetativos e inflorescentes de $M$. truncatula. b) Expresión en el ápice del meristemo vegetativo y los haces vasculares. c) Expresión en meristemo floral durante el estadio 2 del desarrollo floral. Leve expresión en la región central del meristemo floral en estadio 3. d) Ausencia de expresión en el estadio 4. e) Ausencia de expresión en flores en estadio 6 de desarrollo. f) Hibridación in situ con la sonda "sentido". V, Meristemo vegetativo; HV, Haces vasculares; $\mathrm{H}$, Hoja; F, Meristemo floral; S, Sépalo; PC, Primordio común; C, Carpelo; E, Estambre; P, Pétalo. 
a)

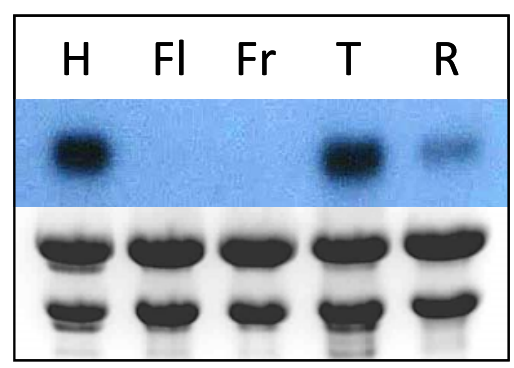

b)

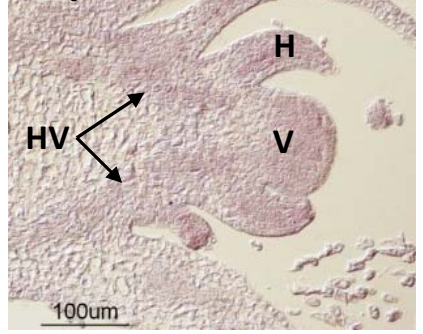

c) $s \rightarrow \stackrel{\leftrightarrow}{C}^{\mathrm{PC}}$

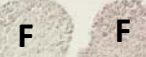

12

$-100 \mu \mathrm{m}$

f)

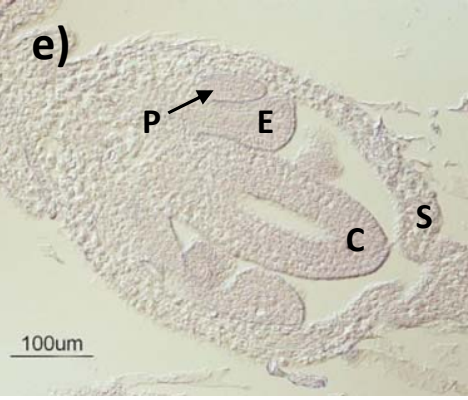

c $\mathrm{s}$

100um

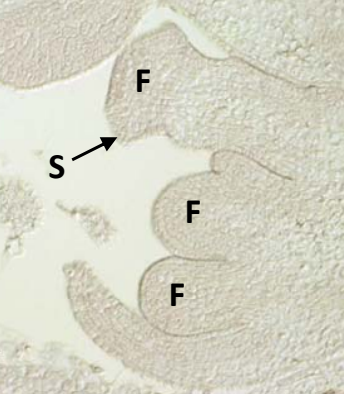

Figura 35. Análisis del patrón de expresión de MtSOC1a.

a)

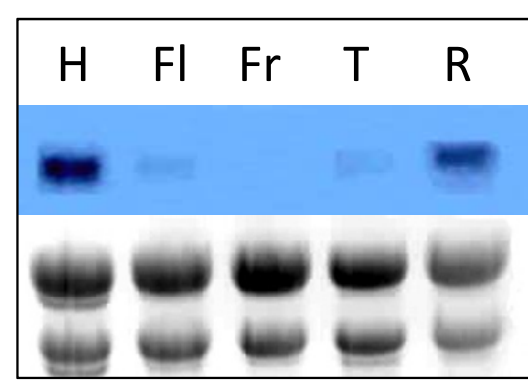

b)

b)

$100 u m$
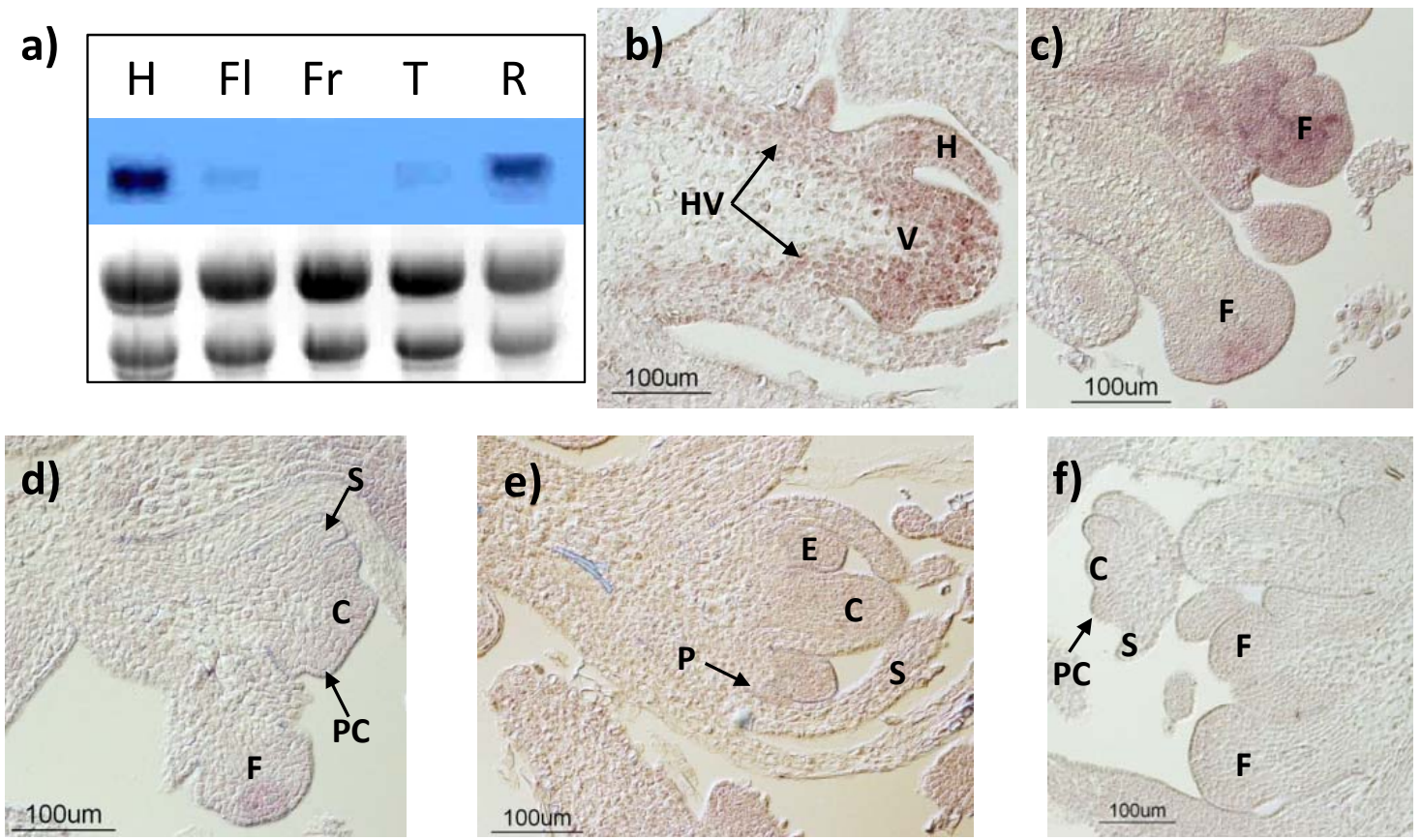
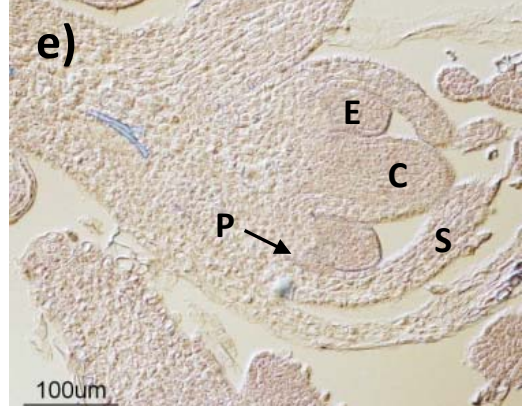

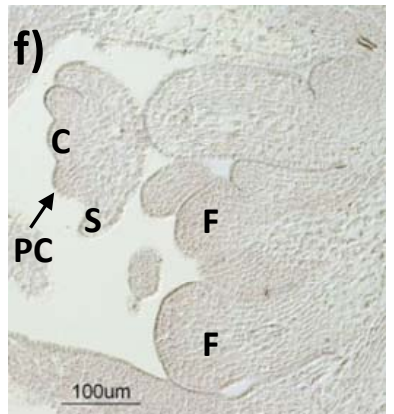

Figura 36. Análisis del patrón de expresión de MtSOC1b.

\subsubsection{Patrón de expresión de MtSOC1-like}

Se ha analizado la expresión de MtSOC1-like en varios tejidos de Medicago truncatula mediante Northern blot. La hibridación se realizó con una sonda derivada de la región Cterminal del cDNA, a fin de evitar hibridaciones cruzadas. MtSOC1-like se expresa en los 
órganos vegetativos de la planta, fuertemente en raíz y con menor nivel de expresión en hojas y tallos. No se detecta expresión en flores en antesis ni en frutos (Figura 37, a).

Debido a que el aislamiento de los genes se hizo a partir de una genoteca de ápices florales de Medicago truncatula, se realizó un seguimiento de la expresión de este gen mediante hibridación in situ en ápices inflorescentes (Figura 37, b-f).

a)

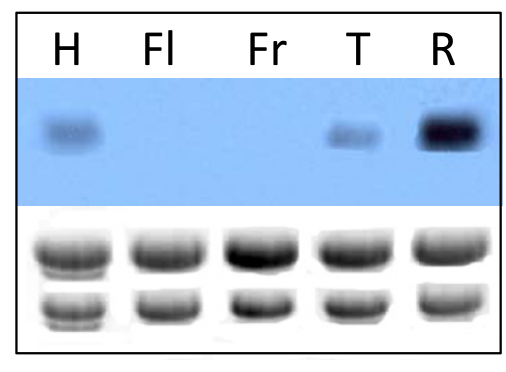

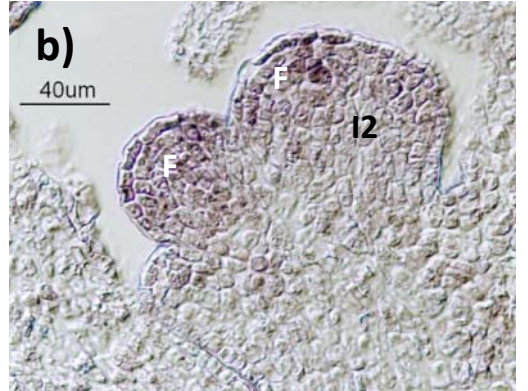
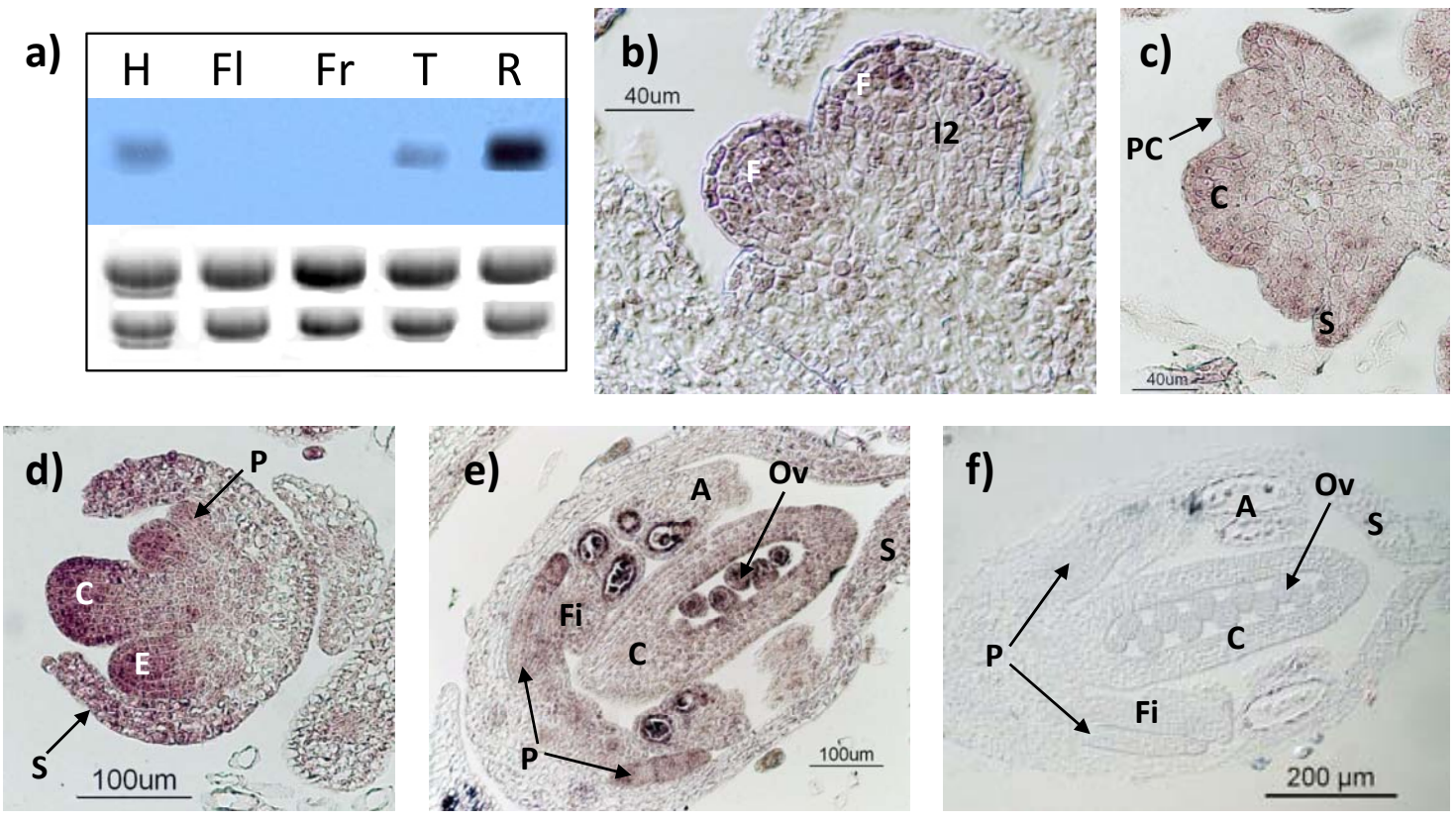

Figura 37. Análisis del patrón de expresión de MtSOC1-like. a) Hibridación Northern blot de MtSOC1-like en diferentes tejidos de la planta: hoja $(H)$, flor $(F I)$, fruto $(F r)$, tallo $(T)$ y raíz (R). b-f) Análisis del patrón de expresión mediante hibridación in situ en ápices inflorescentes de $M$. truncatula. b) Expresión en los meristemos florales en el estadio 2 de desarrollo. c) Expresión débil y generalizada sobre el meristemo floral durante el estadio 4 temprano. d) La expresión en el estadio 5 del desarrollo floral se detecta en todos los primordios de órganos, principalmente los reproductores. e) Expresión debilitada en flor adulta en estadio 7. Se detecta en pétalos, óvulos, estambres y carpelo. f) Hibridación in situ con la sonda "sentido". 12, Meristemo inflorescente secundario; F, Meristemo floral; S, Sépalo; PC, Primordio común; C, Carpelo; E, Estambre; P, Pétalo; Ov, Óvulo; Fi, Filamento; A, Antera.

Durante el estadio 2 del desarrollo floral, MtSOC1-like se expresa en los meristemos florales que emergen del meristemo inflorescente secundario, pero su expresión es más leve en este último (Figura 37, b). En el estadio 4, cuando se han diferenciado los primordios comunes, la expresión es débil y se observa de manera generalizada sobre el meristemo floral (Figura 37, c). El gen se expresa fuertemente durante el estadio 5 del desarrollo floral, principalmente en el carpelo y los primordios de estambres y pétalos, aunque puede detectarse en todos los órganos florales (Figura 37, d). Después la expresión del gen disminuye. En el estadio 7, cuando la flor se ha desarrollado 
completamente, puede detectarse la expresión en óvulos, pétalos, y más débilmente en filamentos de estambres y región distal del carpelo. Se observa expresión en el tapetum de las anteras (Figura 37, e). No se detectó ninguna señal de hibridación en los controles negativos (Figura 37, f).

Probablemente, la expresión de MtSOC1-like se pierde durante el posterior crecimiento de la flor, lo que dificulta su detección mediante hibridación Northern blot, en el cual se utilizó RNA de flores maduras en antesis.

\subsection{MtAGa, MtAGb Y MtSHP: GENES CON HOMOLOGÍA A GENES MADS-box DEL GRUPO AG}

\subsubsection{Aislamiento de MtAGa, MtAGb y MtSHP}

Se aislaron tres clones diferentes cuyas secuencias muestran alta similitud con genes MADS-box pertenecientes al grupo AGAMOUS $(A G)$. Dos de los clones aislados, 12.11 .1 y 15.5.1 presentan secuencias con homología a los genes MADS-box de clase C AGAMOUS (AG; Bowman et al., 1989) de Arabidopsis thaliana y FARINELLI (FAR, Davies et al., 1999) de Antirrhinum majus, por lo que han sido nombrados MtAGa y MtAGb. El tercer clon aislado, 14.4.1, ha sido denominado MtSHP por su homología con SHATTERPROOF1 (Ma et al., 1991; Flanagan et al., 1996) y SHATTERPROOF2 (Ma et al., 1991; Savidge et al., 1995) de Arabidopsis thaliana.

Para determinar la relación evolutiva entre ellos, se generó un árbol filogenético utilizando las secuencias proteicas íntegras predichas de MtAGa, MtAGb y MtSHP, así como 16 secuencias más de proteínas del grupo AG descritas en diferentes especies de plantas modelo y leguminosas (Figura 38).Estudios previos muestran una duplicación ocurrida en el grupo $A G$ ancestral, que produjo los linajes " $C$ " y " $D$ " (sensu Kramer et al., 2004). Además, estos estudios indican que hubo una duplicación posterior dentro del linaje " $C$ ", que resultó en los linajes euAG y PLE (Becker y Theissen, 2003; Kramer et al., 2004; Zahn et al., 2006).

Los genes del linaje " $C$ " son responsables de la especificación de los órganos reproductores florales (estambres y carpelos) y la determinación del meristemo floral (función C sensu lato; Coen y Meyerowitz, 1991; Schwarz-Sommer et al., 1992). 


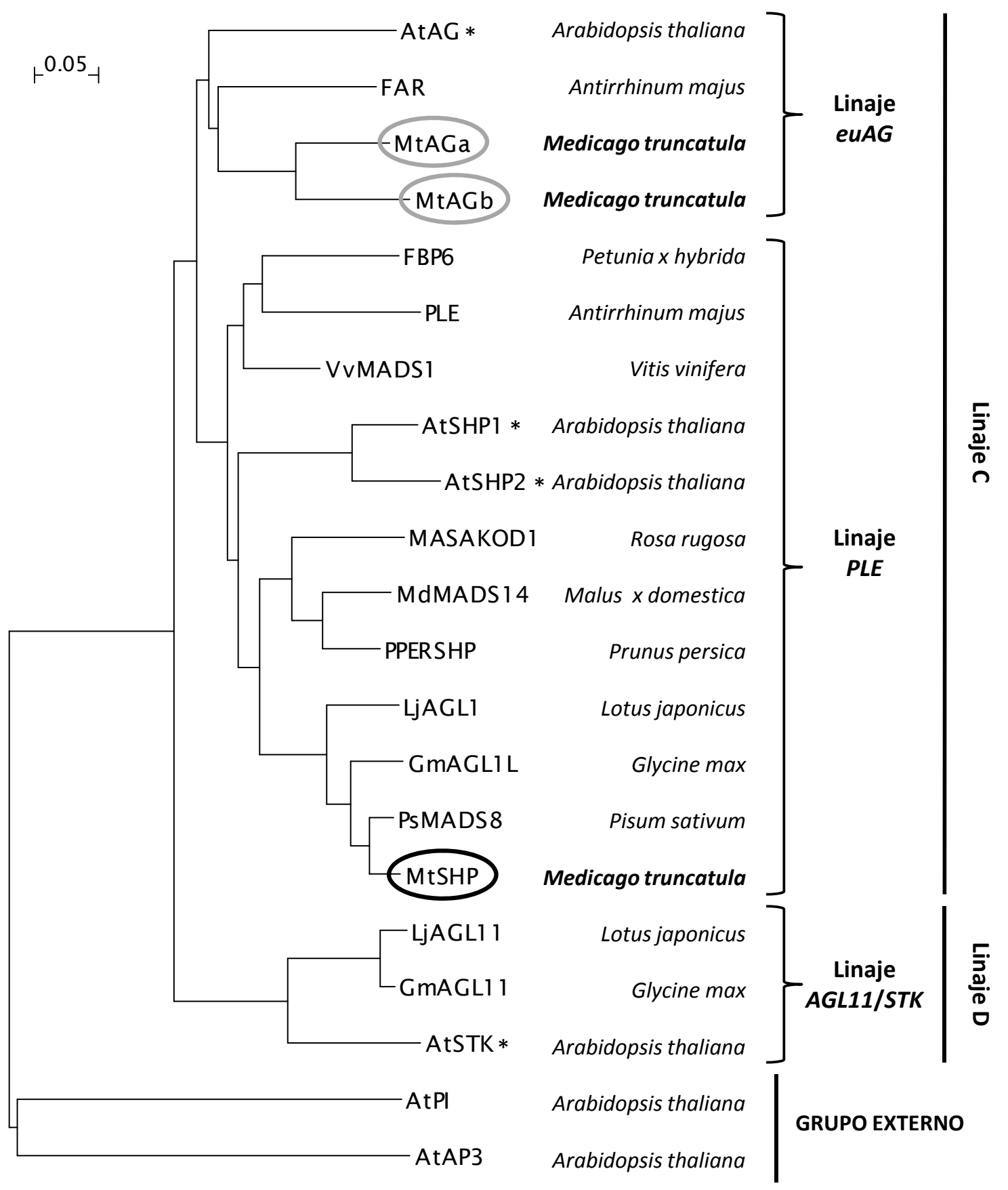

Figura 38. Árbol filogenético de las secuencias proteicas predichas para genes del grupo AG. Se utilizó la secuencia proteica íntegra de las siguientes proteínas: Arabidopsis thaliana: AtAG (Bowman et al., 1989; Acc NP_567569.3), AtSHP1, AtSHP2 (Ma et al., 1991; Acc NP_191437.1, NP_565986.1), AtSTK (Rounsley et al., 1995; Acc NP_192734.1), Petunia x hybrida: FBP6 (Angenent et al., 1993; Acc CAA48635.1), FBP7, FBP11 (Angenent et al., 1995; Acc CAA57311.1, CAA57445.1); Antirrhinum majus: FAR (Davies et al., 1999; Acc CAB42988.1), PLE (Bradley et al., 1993; Acc AAB25101.1); Pisum sativum: PsMADS8 (Hecht et al., 2005; Acc AAX69070.1); Lotus japonicus: LjAGL1 (Dong et al., 2005; Acc AAX13305.1); Glycine max: GmAGL1L (Hu et al., unpublished; Acc ACA24479.1); Malus $x$ domestica: MdMADS14 (Van der Linden et al., 2002; Acc CAC80857.1); Vitis vinifera: VvMADS1 (Boss et al., 2001; Acc AAK58564.1); Prunus persica: PPERSHP (Tani et al., 2007; Acc ABG75908.1); Rosa rugosa: MASAKOD1 (Kitahara et al., 2000; Acc BAA90743.1); Medicago truncatula: MtAGa, MtAGb, MtSHP (este trabajo). La proteína MtSHP se encierra en un óvalo negro, MtAGa y MtAGb en óvalos grises y las proteínas del grupo AG de Arabidopsis thaliana se señalan con un asterisco. El árbol se enraizó con AtPI y AtAP3 de Arabidopsis thaliana (Acc NP_197524.1, NP_191002.1). 
Estos genes se encuentran representados en la mayoría de las plantas modelo por un único gen del linaje euAG, como sucede en Arabidopsis thaliana y Antirrhinum majus. MtAGa y MtAGb se localizan dentro del linaje euAG y parecen haber resultado de una duplicación reciente en Medicago truncatula. La presencia de estos dos genes parálogos, homólogos a $A G / F A R$, dentro del linaje euAG se ha observado también en leguminosas como Pisum sativum (Berbel, A. y colaboradores, comunicación personal) y Lotus japonicus (Dong et al., 2005), de ahí el interés de realizar un estudio extensivo a estos dos genes, los cuales se describen y discuten detalladamente en el capítulo II de esta Tesis Doctoral.

El tercer clon aislado, MtSHP, se agrupa con genes pertenecientes al linaje PLE (PLENA). Este linaje está representado por SHATTERPROOF1 (SHP1; Ma et al., 1991; Flanagan et al., 1996) y SHATTERPROOF2 (SHP2; Ma et al., 1991; Savidge et al., 1995) de Arabidopsis thaliana y PLENA (PLE; Bradley et al., 1993) de Antirrhinum majus. Además, incluye genes homólogos a SHP1/2 y PLE de otras especies modelo como Petunia $x$ hybrida (FBP6; Angenent et al., 1993), Vitis vinifera (VvMADS1; Boss et al., 2001), Rosa rugosa (MASAKOD1; Kitahara et al., 2000), Malus $x$ domestica (MdMADS14; Van der Linden et al., 2002) o Prunus persica (PPERSHP; Tani et al., 2007). Puede observarse que MtSHP es filogenéticamente cercano a ortólogos de SHP1/2 en leguminosas, como PsMADS8 (Hecht et al., 2005) de Pisum sativum, GmAGL1L (Hu et al., unpublished) de Glycine max y LjAGL1 (Dong et al., 2005) de Lotus japonicus.

\subsubsection{Análisis de secuencia de MtSHP}

El clon 14.4.1, llamado MtSHP, tiene una longitud de 1027 pb y contiene una región 5' no traducida de $38 \mathrm{pb}$, una pauta de lectura abierta de $732 \mathrm{pb}$, que codifica una proteína de 244 aminoácidos, un codón de parada de traducción TGA y una región 3’ no traducida de $254 \mathrm{pb}$. La proteína deducida MtSHP tiene un peso molecular de 28,12 kDa y un PI teórico de 9,67. La secuencia de nucleótidos de MtSHP y su traducción en aminoácidos se muestra en la Figura 39.

La comparación de esta secuencia con las incluidas en la base de datos "TIGR Plant Transcript Assemblies" (http://plantta.jcvi.org/) resultó en un dato que corresponde a un marcador de secuencia expresada con número de referencia TA24477_3880, denominado "Medicago truncatula MADS-box protein M8", del que difiere en una sola 
base. Este marcador de secuencia expresada o EST está representado en la base de datos UniGene (http://www.ncbi.nlm.nih.gov/unigene) bajo el código Mtr.14585, descrito como "Transcribed locus, moderately similar to NP_191437.1 SHP1 (SHATTERPROOF1); DNA binding / transcription factor (Arabidopsis thaliana)". Según la nomenclatura de la base de datos UniGene, el término "moderately similar" se refiere a porcentajes de homología entre 70 y $90 \%$.

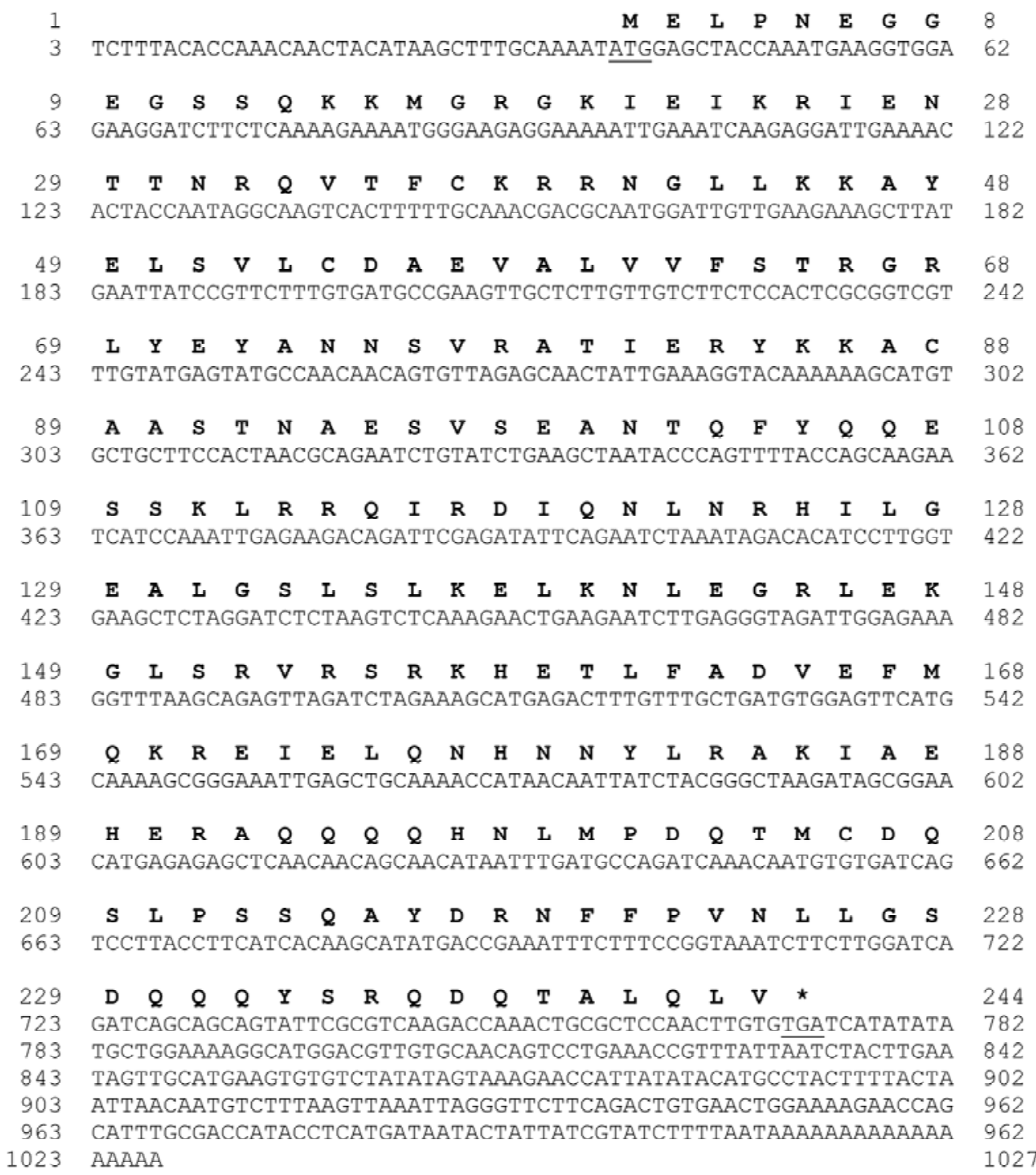

Figura 39. Secuencia del clon MtSHP. Se subrayan los codones de inicio y finalización de la transcripción; en negrita se indica la secuencia de aminoácidos de la proteína deducida.

Para estudiar las homologías entre MtSHP y otros miembros seleccionados del linaje $P L E$, se realizó una comparación de las secuencias de las proteínas predichas para estos genes. En la Tabla 16 se muestran los porcentajes de homología entre MtSHP y las 
proteínas representativas del linaje PLE, como AtSHP1, AtSHP2 (Ma et al., 1991) de Arabidopsis thaliana y PLE (Bradley et al., 1993) de Antirrhinum majus. También se incluyen las proteínas ortólogas de MtSHP en las leguminosas Pisum sativum (PsMADS8; Hecht et al., 2005), Glycine max (GmAGL1L; Hu et al., unpublished) y Lotus japonicus (LjAGL1; Dong et al., 2005).

Tabla 16. Porcentajes de homología (\%) de aminoácidos entre diferentes regiones de MtSHP y las proteínas representativas del linaje PLE

\begin{tabular}{|c|c|c|c|c|c|}
\cline { 2 - 6 } \multicolumn{1}{c|}{} & Secuencia completa & Caja MADS & Región I & Caja K & Región C-terminal \\
\hline PsMADS8 & $\mathbf{9 5}$ & 98 & 100 & 100 & 83 \\
\hline GmAGL1L & $\mathbf{9 0}$ & 100 & 88 & 100 & 68 \\
\hline LjAGL1 & $\mathbf{8 6}$ & 93 & 84 & 96 & 61 \\
\hline AtSHP1 & $\mathbf{7 1}$ & 96 & 68 & 75 & 46 \\
\hline AtSHP2 & $\mathbf{6 5}$ & 96 & 60 & 76 & 42 \\
\hline PLE & $\mathbf{6 7}$ & 95 & 76 & 62 & 59 \\
\hline
\end{tabular}

Ps: Pisum sativum; Lj: Lotus japnicus; Gm: Glycine max; At: Arabidopsis thaliana; PLE: PLENA de Antirrhinum majus

La homología más alta de MtSHP es con proteínas de leguminosas: la proteína PsMADS8 (Hecht et al., 2005) de Pisum sativum, seguida por una proteína aún no caracterizada de Glycine max (GmAGL1L, Hu et al., unpublished) y posteriormente la ortóloga de SHP1/2 de Lotus japonicus (LjAGL1, Dong et al., 2005). Puede observarse que MtSHP conserva una homología de 65 - 71\% con sus ortólogos en Arabidopsis thaliana o Antirrhinum majus. Los porcentajes de homología de MtSHP con las otras dos proteínas del grupo AG aisladas en Medicago truncatula (MtAGa y MtAGb) son de 63\% y $60 \%$ al considerar la secuencia completa y únicamente de $26 \%$ y $37 \%$, respectivamente, considerando la región C-terminal.

En la Figura 40 se representa el alineamiento entre MtSHP y las proteínas incluidas en la Tabla 16. Puede verse que todas ellas conservan en el extremo C-terminal residuos de dos motivos cortos altamente conservados en las proteínas del grupo AG, que han sido descritos por Kramer et al. (2004) y se denominan "AG motif I" y "AG motif II". Otra característica común a los genes MADS-box del linaje " $C$ " y que se observa en la Figura 40 es la presencia de una secuencia en la región $\mathrm{N}$-terminal que precede al dominio MADS (Jager et al., 2003). La ausencia de esta secuencia en LjAGL1 puede deberse a que el gen la haya perdido durante el proceso evolutivo [como en el caso del ortólogo de 
SHP1/2 de vid, VVMADS1 (Boss et al., 2001)] o que se haya omitido al incluir la secuencia en la base de datos, considerando el inicio del gen en el dominio MADS.

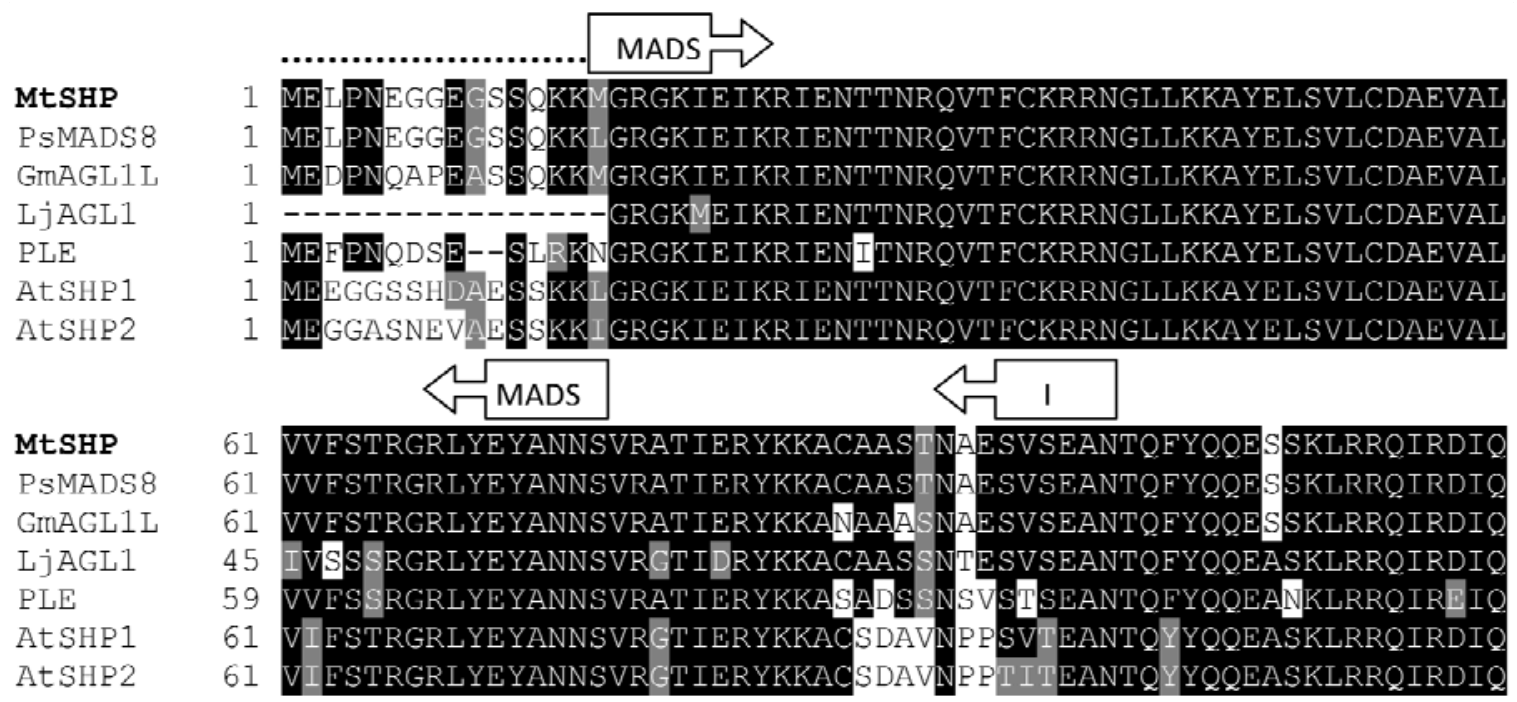

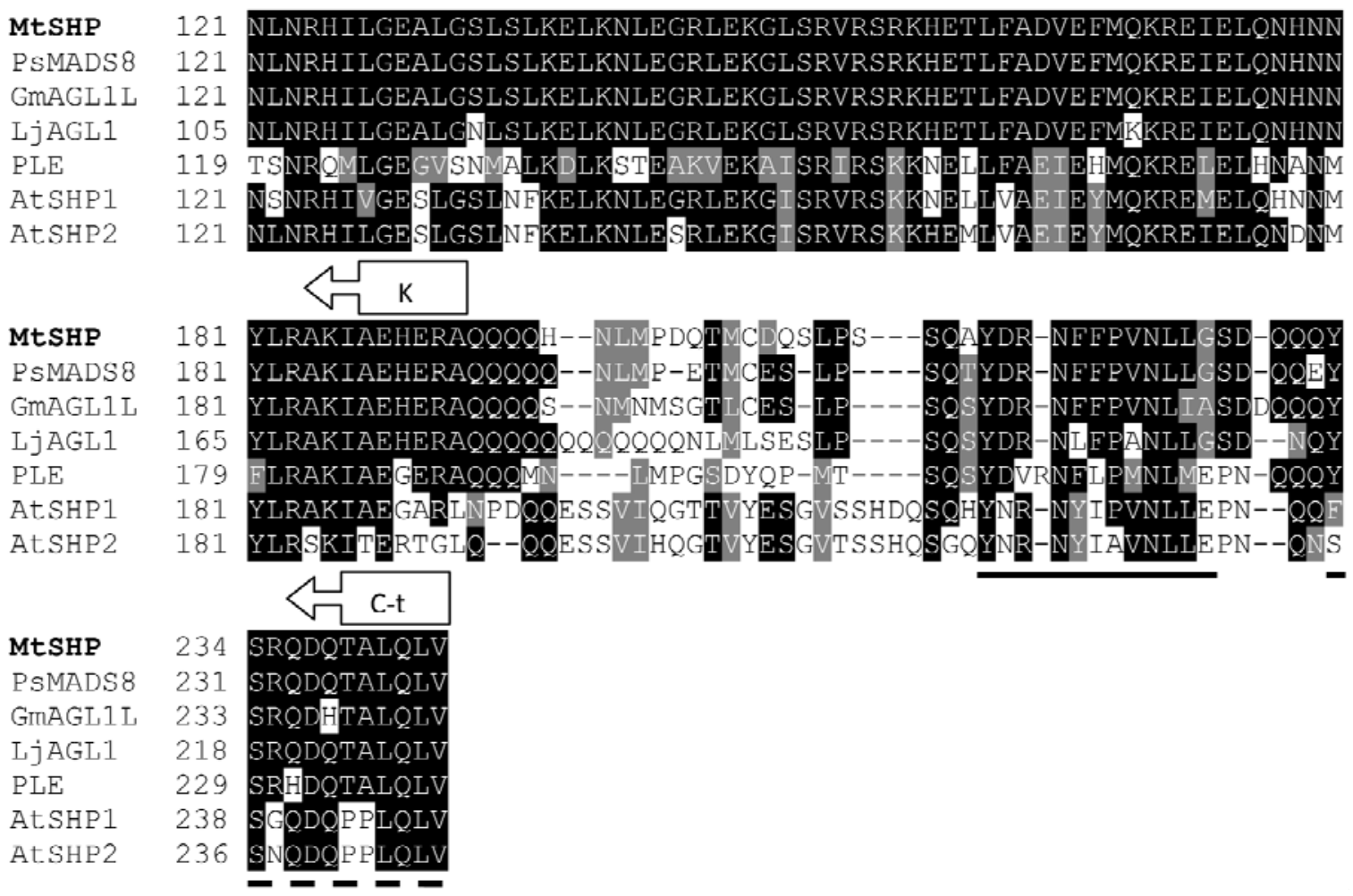

Figura 40. Alineamiento de la secuencia proteica de MtSHP y de genes MADS-box del linaje PLE, grupo $\boldsymbol{A G}$, con los que presenta homología. Las regiones sombreadas corresponden a aminoácidos conservados. Los dominios MADS y $\mathrm{K}$ así como las regiones I y C-terminal se señalan con flechas. El motivo "AG motif I" se subraya con una línea continua y el motivo "AG motif II" con una línea discontinua. Una línea de puntos indica la secuencia N-terminal previa al dominio MADS característica de los genes de tipo " $\mathrm{C}$ ".

\subsubsection{Patrón de expresión de MtSHP}

El patrón de expresión de MtSHP en plantas silvestres de Medicago truncatula se analizó mediante hibridación Northern blot en varios tejidos de la planta (Figura 41). 
Para evitar la hibridación cruzada con otros genes MADS-box, se utilizó la región Cterminal del cDNA de MtSHP como sonda. La expresión de MtSHP no se detecta en hoja, tallo ni raíz. La expresión es específica de flores y frutos.

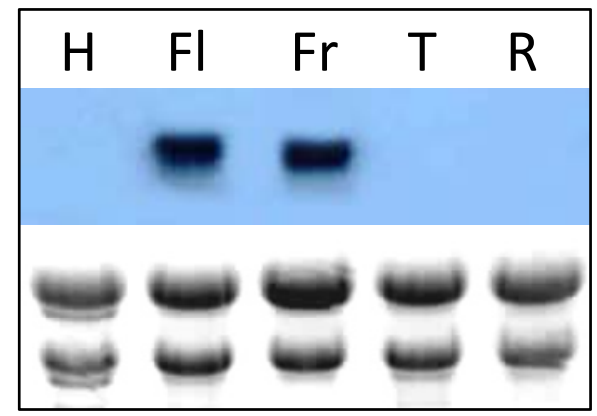

Figura 41. Análisis del patrón de expresión de MtSHP mediante Northern blot. Se utilizó RNA de diferentes tejidos de la planta: hoja $(H)$, flor (FI), fruto (Fr), tallo $(T)$ y raíz $(R)$.

El análisis del patrón de expresión tisular de MtSHP durante el desarrollo floral se llevó a cabo mediante hibridación in situ en ápices inflorescentes de plantas silvestres de Medicago truncatula (Figura 42). Durante los primeros 5 estadios del de desarrollo floral no se observa expresión de MtSHP (Figura 42, a y b). La expresión del gen se empieza a observar desde el estadio 6 del desarrollo floral, cuando los primordios comunes ya se han diferenciado en primordios de pétalo y estambre, limitándose a las paredes internas del carpelo (Figura 42, c). La expresión de MtSHP se mantiene hasta el final del desarrollo de la flor. Se observa durante el estadio 7 inicialmente en la base de los óvulos y en el carpelo en la región de la placenta cercana a la sutura ventral del carpelo (Figura 42, d). Posteriormente, en el estadio 7 tardío, la expresión es intensa en los óvulos de la flor totalmente desarrollada (Figura 42, e). No se detectó señal de hibridación en ninguna sección de tejido hibridada con la sonda "sentido" (Figura 42, f).

Para ver si el transcrito MtSHP se mantiene en las semillas que se desarrollan a partir de los óvulos que expresan el gen, se realizaron hibridaciones in situ en frutos de Medicago truncatula en estadio de desarrollo "Pod age: 6 DPP (días post-polinización)" (Wang y Grusak, 2005). En la Figura 43 se muestra un corte longitudinal paralelo al eje de enrollado del fruto, en el que puede verse expresión intensa de MtSHP en toda la extensión de la semilla (Figura 43, a). Al ampliar la imagen puede observarse que la expresión es más intensa en la región de la nucela cercana al funículo (Figura 43, b). No se detectó señal de hibridación en secciones de semilla hibridadas con la sonda "sentido" usada como control negativo (Figura 43, c). 

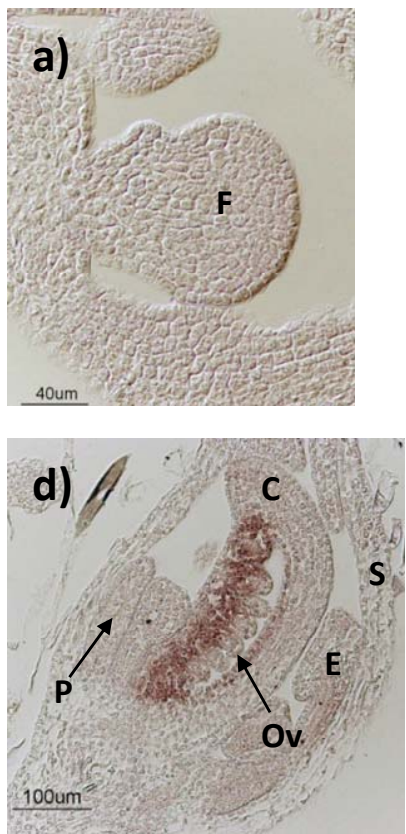
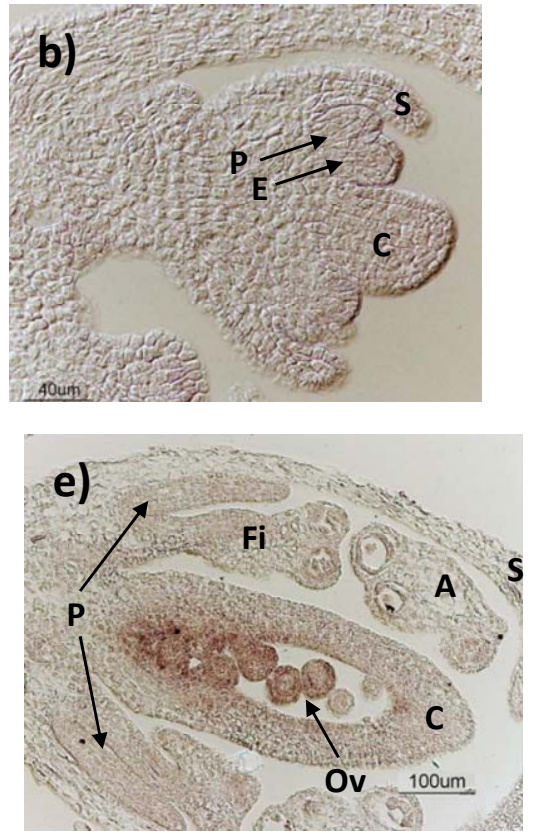
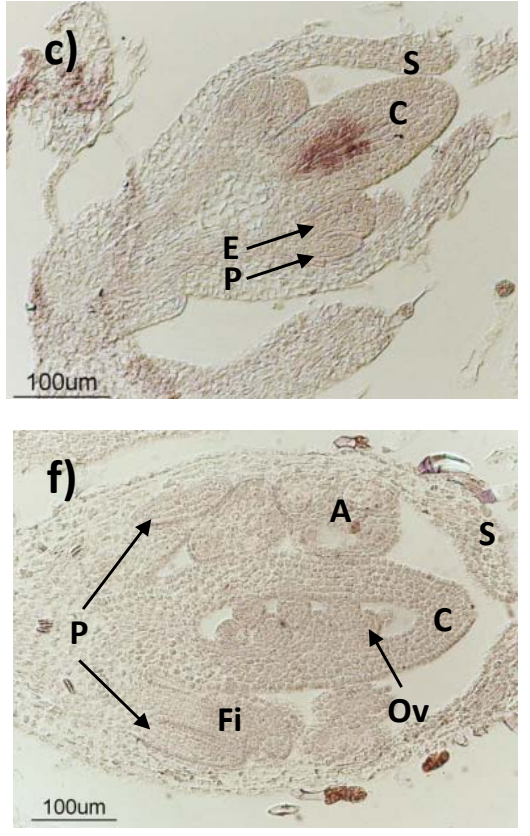

Figura 42. Análisis del patrón de expresión de MtSHP mediante hibridación in situ en ápices inflorescentes de $\boldsymbol{M}$. truncatula. a) Expresión ausente en el meristemo floral en estadio de desarrollo 2. b) Ausencia de expresión en el estadio 5. c) Expresión en las paredes internas del carpelo en el estadio 6. d) Expresión en óvulos y región placentaria adyacente a la sutura carpelar en el estadio 7 temprano del desarrollo floral. e) Expresión limitada a óvulos en el estadio 7 tardío. f) Hibridación in situ con la sonda "sentido". F, Meristemo floral; Sépalo; C, Carpelo; E, Estambre; P, Pétalo; Fi, Filamento: A, Antera; Ov, Óvulo.
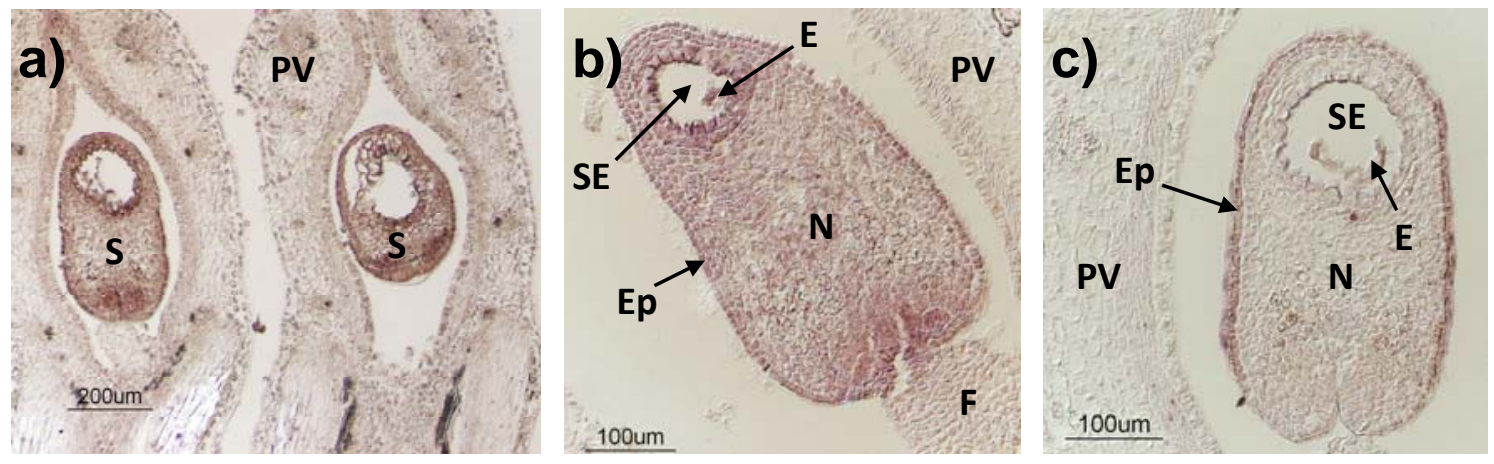

Figura 43. Análisis del patrón de expresión de MtSHP en frutos. Patrón de expresión mediante hibridación in situ en corte longitudinal del fruto y la semilla de Medicago truncatula a). Se distinguen las semillas y el tejido de la vaina. b) Semilla. MtSHP se expresa en todo el tejido nucelar. c) Hibridación in situ con la sonda "sentido". PV, Pared de la vaina; S, Semilla; N, Nucela; SE, Saco embrionario; E, Endospermo; Ep, Epidermis; F, Funículo.

MtSHP es un gen específico de carpelo y óvulos, cuyo patrón de expresión es consistente con los patrones observados para los genes SHATTERPROOF (Ma et al., 1991; Flanagan et al., 1996) de Arabidopsis thaliana y sus ortólogos en otras plantas. 


\subsection{MtTM6 Y MtNMH7: GENES CON HOMOLOGÍA A GENES MADS-box DEL GRUPO $\operatorname{DEF}(A P 3)$}

\subsubsection{Aislamiento y análisis de secuencia de MtTM6 y MtNMH7}

Los genes MADS-box de clase B se agrupan en dos linajes o grupos distintos, llamados APETALA3/DEFICIENS (AP3/DEF) y PISTILLATA/GLOBOSA (PI/GLO) (Theissen et al., 1996). Se cree que los genes de los linajes $A P 3 / D E F$ y $P I / G L O$ son parálogos que se originaron a partir de un evento de duplicación que tuvo lugar antes del origen de las angiospermas (Kramer et al., 1998; Theissen et al., 2000). Además, los genes del linaje AP3/DEF en las eudicotiledóneas superiores se han dividido en dos sub-linajes: el linaje "euAP3" y el linaje "TM6" (Kramer et al., 1998; Kramer e Irish, 2000).

Los genes MtPI y MtNGL9, ortólogos de PISTILLATA en Medicago truncatula, pertenecen al linaje $P I / G L O$ y fueron aislados y caracterizados previamente en el laboratorio por Benlloch et al. (2009).

En el presente escrutinio de la genoteca se aislaron dos clones cuyas secuencias presentan homología con genes MADS-box de clase $B$ del linaje $A P 3 / D E F$, perteneciendo además a sub-linajes diferentes dentro de este grupo. Dichos clones, el 6.2 .1 y el 8.1.1, se denominaron MtTM6 y MtNMH7.

El clon 6.2.1, Ilamado MtTM6, tiene una longitud de $1082 \mathrm{pb}$, una región 5' no traducida de $89 \mathrm{pb}$, una pauta de lectura abierta de $696 \mathrm{pb}$, que codifica una proteína de 232 aminoácidos, un codón de parada de traducción TGA y una región 3’ no traducida de 294 pb. La proteína deducida MtTM6 tiene un peso molecular calculado de 27,07 kDa y un PI teórico de 9,68. La secuencia de nucleótidos de MtTM6 y su traducción en aminoácidos se presentan en la Figura 44.

En la Figura 45 se muestra la secuencia del clon 8.1.1 con la secuencia aminoacídica predicha para la proteína MtNMH7. La longitud completa del clon es de 1030 pb y contiene una pauta de lectura abierta de 687 pb que codifica una proteína de 229 pb con un peso molecular predicho de 26,61 y un punto isoeléctrico teórico de 9,68. La región 5' no traducida tiene una longitud de 83 pb y la 3' no traducida 257 pb.

En ambas secuencias se puede observar la presencia de cuatro residuos de aminoácidos dentro del dominio MADS, característicos para el linaje AP3/DEF: fenilalanina ( $F$ ) en la posición 29 , treonina ( $T$ ) en la 36 , lisina (K) en la 42 y metionina (M) 
en la 47. Además hay una leucina (L) en la posición 35, que es un residuo aminoacídico que distingue a las proteínas del linaje AP3/DEF de las del linaje PI/GLO (Theissen et al., 1996). En el caso de MtTM6, la treonina de la posición 36 se suple por una serina (S) al modificarse una base, pero ambos aminoácidos son alifáticos de carácter hidrófilo, así que probablemente la función de la proteína no se modifica. También puede observarse la presencia de una secuencia consenso (H/Q)YExM, altamente conservada en las proteínas del linaje AP3/DEF (Kramer et al., 1998)

\begin{tabular}{|c|c|c|}
\hline & CCGAAAGAGAGAAAAAAAGTGAAGTGAAG? & 2 \\
\hline 1 & $\begin{array}{llllllllll}M & G & \text { R } & G & \text { K } & \text { I } & \text { E } & \text { I } & \text { K } & \text { L }\end{array}$ & 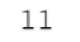 \\
\hline 63 & GTATTGTAGTAGTGAAGATCATTGAAAATGGGTCGTGGGAAGATTGAGATAAAGTTGATT & 22 \\
\hline & $\begin{array}{llllllllllllllllllllll}E & N & P & T & N & R & Q & V & T & Y & S & K & R & R & N & G & I & F & K & K\end{array}$ & 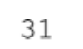 \\
\hline & GAGAATCCTACTAACAGGCAAGTGACATACTCAAAGAGAAGGAATGGTATATTCAAGAAA & 182 \\
\hline & $\begin{array}{llll}\nabla & \nabla & \nabla\end{array}$ & \\
\hline & $\begin{array}{llllllllllllllllllll}\text { A } & \text { H } & \text { E } & \text { L } & \text { S } & \text { V } & \text { L } & \text { C } & \text { D } & \text { A } & \text { K } & \text { V } & \text { S } & \text { L } & \text { I } & \text { M } & \text { F } & \text { S } & \text { K } & \text { N }\end{array}$ & 1 \\
\hline & GCACATGAACTTAGTGTTCTTTGTGATGCTAAGGTTTCACTCATCATGTTCTCCAAAAAT & \\
\hline & $\begin{array}{llllllllllllllllllll}\mathrm{N} & \mathrm{K} & \mathrm{M} & \mathrm{H} & \mathrm{E} & \mathrm{Y} & \mathrm{I} & \mathrm{T} & \mathrm{P} & \mathrm{G} & \mathrm{L} & \mathrm{S} & \mathrm{T} & \mathrm{K} & \mathrm{K} & \mathrm{I} & \mathrm{I} & \mathrm{D} & \mathrm{Q} & \mathrm{Y}\end{array}$ & \\
\hline & AACAAGATGCATGAATACATCACCCCTGGTCTCTCTACAAAGAAGATTATTGATCÃGTAT & 302 \\
\hline & 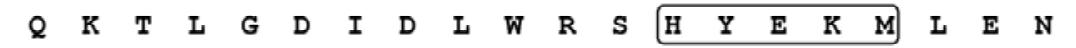 & \\
\hline & CAGAAGACTTTAGGGGATATAGATCTGTGGCGTTCTCACTATGAGAAAATGCTTGAAAAC & \\
\hline 92 & $\begin{array}{llllllllllllllllllll}L & K & K & L & K & D & I & N & H & K & L & R & R & Q & I & R & H & R & I & G\end{array}$ & \\
\hline 63 & TTGAAGAAACTGAAAGATATTAACCATAAGCTTAGAAGACAGATCAGGCATAGAATAGGT & 422 \\
\hline & $\begin{array}{llllllll}Q & \text { L } & R & S & \text { L } & E & E & D\end{array}$ & \\
\hline & GAGGGTGGTATGGAATTGGATGACCTTAGCTTCCAGCAACTGCGTAGTCTTGAAGAGGAT & 482 \\
\hline & $S \quad S \quad I \quad A$ & \\
\hline & ATGAATTCTTCCATTGCAAAAATACGTGAAAGGAAGTTTCATGTGATCAAAACTCGGACT & \\
\hline & $\begin{array}{lllllllllll}\text { L } & \text { E } & \text { Q } & \text { M } & \text { N } & \text { G } & \text { N } & \text { L } & \text { L } & \text { L } & \text { E }\end{array}$ & \\
\hline & GATACCTGTAGGAAAAAGGTTAGAAGCTTGGAGCÄGATGAATGGAAATCTCTTGCTTGAA & 502 \\
\hline & $\begin{array}{lllllllll}\text { L } & \text { K } & \text { E } & \text { K } & \text { C } & \text { V } & \text { I } & \text { H } & \text { P }\end{array}$ & \\
\hline & CTTAAGGAAAAATGTGTGATCCATCCACAATTTCTTTTCCACGACGAAGGAGACGAGGAA & 62 \\
\hline & $\begin{array}{llllllllllllllllllll}\mathbf{S} & \mathbf{A} & \mathbf{V} & \mathbf{A} & \mathbf{L} & \mathbf{A} & \mathbf{N} & \mathbf{G} & \mathbf{A} & \mathbf{S} & \mathbf{T} & \mathrm{L} & \mathbf{Y} & \mathbf{A} & \mathbf{F} & \mathbf{C} & \mathbf{Q} & \mathrm{H} & \mathrm{H} & \mathbf{S}\end{array}$ & \\
\hline & TCAGCAGTTGCATTGGCCAATGGTGCTTCCACTCTGTATGCATTCTGTCAGCACCATTCT & 72 \\
\hline & $\begin{array}{lllllllllllllllllllll}\text { H } & \text { L } & \text { N } & \text { L } & \text { P } & \text { H } & \text { H } & \text { H } & \text { G } & \text { E } & \text { E } & \text { G } & \text { Y } & \text { K } & \text { N } & \text { D } & \text { D } & \text { L } & \text { R } & \text { L }\end{array}$ & \\
\hline & CATCTGAATCTTCCTCATCACCATGGAGAAGAAGGTTACAAAAATGACGATTTGCGCCTT & 782 \\
\hline & G & \\
\hline & GGTTGP & \\
\hline & CTTGTTAAC & \\
\hline & GTTCCF & \\
\hline & AAGAAGTGTGGTCTGAAAAACAAAATATGACTGTA & \\
\hline & & \\
\hline
\end{tabular}

Figura 44. Secuencia del clon MtTM6. Se subrayan los codones de inicio y finalización de la transcripción; en negrita se indica la secuencia de aminoácidos de la proteína deducida. Con puntas de flecha negras se indican los aminoácidos característicos para el grupo AP3/DEF. Con punta de flecha gris se indica el aminoácido lisina (L) que distingue a las proteínas AP3/DEF de las PI/GLO. En un recuadro se indica la posición de la secuencia consenso (H/Q)YExM característica del grupo AP3/DEF. 
3 AAgGCCCCATAAATCAAACATAGTAAACTTGAAGAAAAAAAAACAACCAGGTGAAGAAAT 62

$\begin{array}{lllllllllllllll}1 & \text { M } & \text { A } & \text { R } & \text { G } & \text { K } & \text { I } & \text { Q } & \text { I } & \text { K } & \text { R } & \text { I } & \text { E } & \text { N } & 13\end{array}$

63 AtAtAgCtAgGtAgGtTATCTATGGCTCGAGGAAAGATCCAGATCAAGAGAATTGAGAAC 122

$\begin{array}{llllllllllllllllllllllll}14 & \mathbf{T} & \mathbf{T} & \mathbf{N} & \mathbf{R} & \mathbf{Q} & \mathbf{V} & \mathbf{T} & \mathbf{Y} & \mathbf{S} & \mathbf{K} & \mathbf{R} & \mathbf{R} & \mathbf{N} & \mathbf{G} & \mathbf{L} & \mathbf{F} & \mathbf{K} & \mathbf{K} & \mathbf{A} & \mathbf{N} & 33\end{array}$

123 ACAACTAACCGACAAGTAACTTACTCAAAACGAAGGAATGGTCTTTTCAAGAAGGCTAAT 182

$\begin{array}{lllllllllllllllllllllllll}34 & \text { E } & \text { L } & \text { T } & \text { V } & \text { L } & \text { C } & \text { D } & \text { A } & \text { K } & \text { V } & \text { S } & \text { I } & \text { I } & \text { M } & \text { F } & \text { S } & \text { S } & \text { T } & \text { G } & \text { K } & 53\end{array}$

183 GAgCTCACTGTTCTTTGTGATGCTAAGGTtTCTATTATTATGTTTTCCAGCACTGGCAAG 242

$\begin{array}{lllllllllllllllllllllll}54 & \text { L } & \text { H } & \text { E } & \text { Y } & \text { I } & \text { S } & \text { P } & \text { S } & \text { A } & \text { S } & \text { T } & \text { K } & \mathbf{Q} & \mathbf{F} & \mathbf{F} & \mathbf{D} & \boldsymbol{Q} & \mathbf{Y} & \boldsymbol{Q} & \mathbf{M} & 73\end{array}$

243 CTTCATGAATACATTAGCCCCTCCGCCTCAACAAAGCAGTTTTTCGATCAGTATCAGATG 302

$\begin{array}{llllllllllllllllllllllll}74 & \text { T } & \text { V } & \text { G } & \text { I } & \text { D } & \text { L } & \text { W } & \text { N } & \text { S } & \text { H } & \text { Y } & \text { E } & \text { N } & \text { M } & \text { Q } & \text { E } & \text { N } & \text { L } & \text { K } & \text { K } & 93\end{array}$

303 ACTGTAGGAATTGATCTGTGGAACTCTCATTATGAGAATATGCAAGAGAACTTGAAGAAA 362

$\begin{array}{lllllllllllllllllllllll}94 & \text { L } & \text { K } & \text { D } & \text { V } & \text { N } & \text { R } & \text { N } & \text { L } & \text { R } & \text { K } & \text { E } & \text { I } & \text { R } & \text { Q } & \text { R } & \text { M } & \text { G } & \text { E } & \text { C } & \text { L } & 113\end{array}$

363 CTGAAAGATGTCAATAGGAATCTTCGCAAGGAGATTAGGCAGAGGATGGGGGAATGTCTG 422

$\begin{array}{llllllllllllllllllllll}114 & \text { N } & \text { D } & \text { L } & \text { S } & \text { M } & \text { E } & \text { E } & \text { L } & \text { R } & \text { L } & \text { L } & \text { E } & \text { D } & \text { E } & \text { M } & \text { D } & \text { K } & \text { A } & \text { A } & \text { K } & 133\end{array}$

423 AATGATCTGAGCATGGAAGAGCTGAGGCTACTTGAAGATGAAATGGACAAGGCTGCCAAG 482

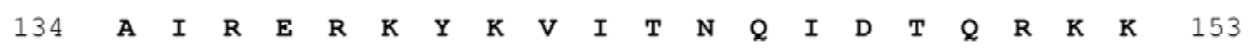

483 GCTAtTCGTGAgCGTAAgtATAAgGtGAtAACAAATCAGATtGACACCCAAAGGAAGAAG 542

$\begin{array}{llllllllllllllllllllll}154 & \mathbf{F} & \mathbf{N} & \mathbf{N} & \mathbf{E} & \mathbf{R} & \mathbf{E} & \mathbf{V} & \mathbf{H} & \mathbf{N} & \mathbf{R} & \mathbf{L} & \mathbf{L} & \mathbf{R} & \mathbf{D} & \mathbf{L} & \mathbf{D} & \mathbf{A} & \mathbf{R} & \mathbf{A} & \mathbf{E} & 173\end{array}$

543 TTtAATAATGAGAGAGAGGTGCACAACAGACTCCTGCGTGACTTGGATGCAAGAGCAGAA 602

$\begin{array}{llllllllllllllllllllll}174 & \text { D } & \text { P } & \text { R } & \text { F } & \text { E } & \text { M } & \text { M } & \text { D } & \text { N } & \text { G } & \text { G } & \text { E } & \text { Y } & \text { E } & \text { S } & \text { V } & \text { I } & \text { G } & \text { F } & \text { S } & 193\end{array}$

603 GATCCACGTTTTGAAATGATGGACAATGGAGGGGAGTATGAGTCTGTGATTGGATTCTCA 662

$\begin{array}{llllllllllllllllllllllll}194 & \text { N } & \text { L } & \text { G } & \text { P } & \text { R } & \text { M } & \text { F } & \text { A } & \text { L } & \text { S } & \text { L } & \mathbf{Q} & \mathbf{P} & \mathbf{T} & \mathbf{H} & \mathbf{P} & \mathbf{N} & \mathbf{P} & \mathbf{H} & \mathbf{N} & 213\end{array}$

663 AATTTAGGTCCACGCATGTTTGCTTTGAGCTTACAGCCTACTCATCCTAATCCTCATAAT 722

$\begin{array}{lllllllllllllllllll}214 & \text { G } & \text { G } & \text { A } & \text { S } & \text { A } & \text { A } & \text { S } & \text { D } & \text { L } & \text { T } & \text { T } & \text { Y } & \text { P } & \text { L } & \text { L } & \text { F } & \text { * } & \end{array}$

723 GGAGGAGCATCAGCTGCCTCGGATCTCACCACTTACCCTTTACTTTTTTAGTTACTTTTC 782

783 TCTCAGAACAACAAATACTCCCACAATCACTTTCCAACAATAATATGATACTATGACTCA 842

843 CGTACTGTTTAAGATATATATGGCTATGCACTCAATCTCATTCTGTTTTCAGTTAATTGT 902

903 ATGTATCTTTATATAAACATGATCATCTTAAATATCTTCGATCAAAATGCATGTAATGTA 962

963 ATGTATGATTTAAATCATAACTGATCATTAAATGTTAACCGTACTCCAAAAAAAAAAAAA 1022

1023 AAAAAAAA

Figura 45. Secuencia del clon MtNMH7. Se subrayan los codones de inicio y finalización de la transcripción; en negrita se indica la secuencia de aminoácidos de la proteína deducida. Con puntas de flecha negras se indican los aminoácidos característicos para el grupo AP3/DEF. Con punta de flecha gris se indica el aminoácido lisina (L) que distingue a las proteínas AP3/DEF de las PI/GLO. En un recuadro se indica la posición de la secuencia consenso (H/Q)YExM característica del grupo AP3/DEF.

Se realizó una comparación de las secuencias de MtTM6 y MtNMH7 con las secuencias incluidas en las bases de datos mediante BLAST. El gen MtTM6 se deduce del clon genómico de Medicago truncatula mth2-17d19 ("complete sequence" GenBank AC136451.9). El gen está formado por 7 exones (188, 70, 62, 109, 42, 45, 183) y 6 intrones. La secuencia genómica de MtTM6 está contenida entre las bases 59.035 y 60.803 del clon mencionado.

No se ha encontrado ninguna secuencia homóloga a MtNMH7 en las bases de datos de Medicago truncatula disponibles hasta el momento. 
Para colocar las secuencias obtenidas en un contexto filogenético, se construyó un árbol con las secuencias aminoacídicas predichas para MtTM6 y MtNMH7 y proteínas MADS-box de diversas especies codificadas por genes de clase B. Este árbol se muestra en la Figura 46.

Puede observarse que efectivamente las proteínas MADS-box de clase B se distribuyen en dos linajes o grupos, el AP3/DEF y el PI/GLO (Theissen et al., 1996). Dentro de la rama que conforman las proteínas del grupo PI/GLO se encuentran MtPI y MtNGL9 de Medicago truncatula, así como las proteínas representativas de este grupo en las plantas modelo Arabidopsis thaliana (AtPI; Goto y Meyerowitz, 1994) y Antirrhinum majus (AmGLO; Tröbner et al., 1992).

Dentro del grupo AP3/DEF puede verse la división en dos ramas o sub-linajes: el linaje euAP3 y el linaje TM6. La proteína MtTM6 es filogenéticamente cercana a proteínas ortólogas del linaje TM6 en leguminosas, como LjAP3-like (Dong et al., 2005) de Lotus japonicus y GmACU18610.1 (Cheung et al., unpublished) de Glycine max. En esta rama también se incluyen proteínas de otras plantas modelo como TDR6 (antes TM6; Pnueli et al., 1991) de Solanum lycopersicum, PhTM6 (Vandenbussche et al., 2004) de Petunia $x$ hybrida o GDEF1 (Yu et al., 1999) de Gerbera hybrida. Cabe mencionar que no se han descrito genes del linaje TM6 en las plantas modelo Arabidopsis thaliana o Antirrhinum majus. Por otro lado, MtNMH7 se localiza en la rama que incluye proteínas del linaje euAP3. En las plantas modelo, este linaje está representado por AtAP3 (Bowman et al., 1989) en Arabidopsis thaliana y AmDEFA (Sommer et al., 1990) en Antirrhinum majus. Además, incluye proteínas homólogas a AP3/DEF del linaje euAP3 de Petunia $x$ hybrida (PhDEF; Vandenbussche et al., 2003b), Nicotiana tabacum (NtDEF; Davies et al., 1996) o Gerbera hybrida (GDEF2; Yu et al., 1999). MtNMH7 se agrupa con proteínas ortólogas del linaje euAP3 en leguminosas, como LjAP3 (Dong et al., 2005) de Lotus japonicus y GmNMH7 (Wu et al., 2006) de Glycine max. Su relación filogenética más estrecha es con MsNMH7 (Heard y Dunn, 1995) de la especie cercana Medicago sativa. 


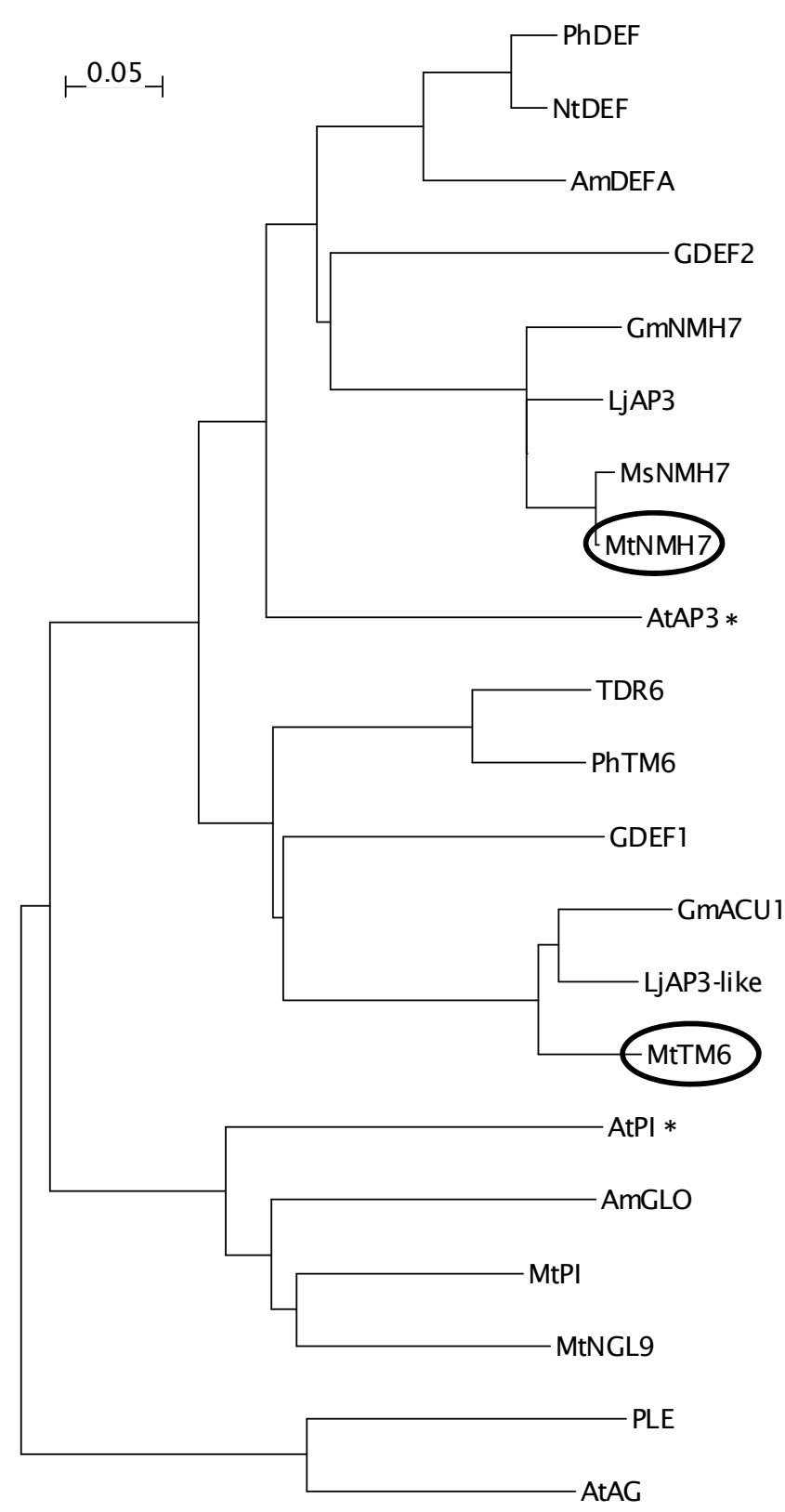

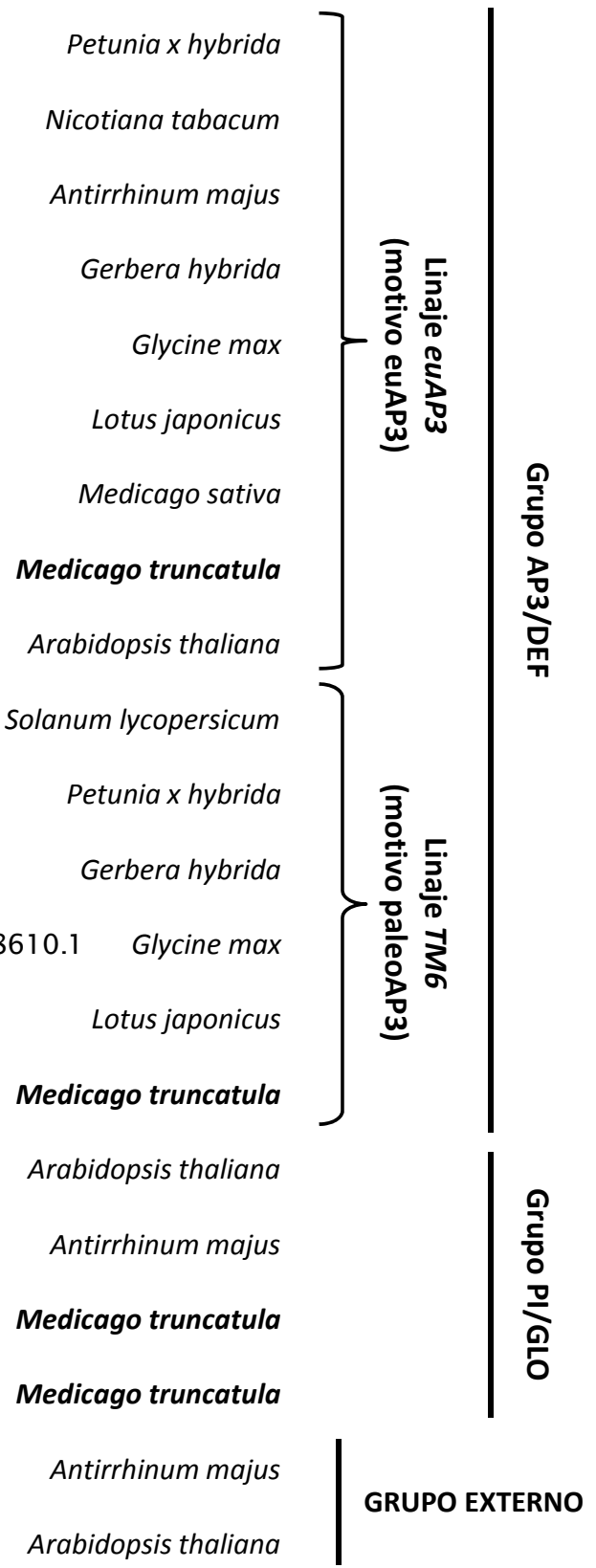

Figura 46. Árbol filogenético de las secuencias proteicas predichas para genes de clase B. Se utilizó la secuencia proteica íntegra de las siguientes proteínas: Arabidopsis thaliana: AtAP3 (Bowman et al., 1989; Acc NP_191002.1), AtPI (Goto y Meyerowitz, 1994; Acc NP_197524.1); Antirrhinum majus: AmDEFA (Sommer et al., 1990; Acc CAA36268.1), AmGLO (Tröbner et al., 1992; Acc CAA48725.1); Petunia x hybrida: PhDEF (Vandenbussche et al., 2003b; Acc AAQ72510.2), PhTM6 (Vandenbussche et al., 2004; Acc AAS46017.1); Gerbera hybrida: GDEF1, GDEF2 (Yu et al., 1999; Acc CAA08802.1, CAA08803.1); Glycine max: GmNMH7 (Wu et al., 2006; Acc AAQ81636.1), GmACU18610.1 (Cheung et al., unpublished; Acc ACU18610.1); Lotus japonicus: LjAP3, LjAP3-like (Dong et al., 2005; Acc AAX13301.1, AAX13302.1); Solanum lycopersicum: TDR6 (Pnueli et al., 1991; Acc CAA43171.1); Nicotiana tabacum: NtDEF (Davies et al., 1996; Acc CAA65288.1); Medicago sativa: MsNMH7 (Heard y Dunn, 1995; Acc AAC15419.1); Medicago truncatula: MtPI, MtNGL9 (Benlloch et al., 2009 Acc ACJ36228.1, ACJ36229.1), MtTM6, MtNMH7 (este trabajo). Las proteínas MtTM6 y MtNMH7 se encierran en óvalos y las proteínas del grupo AP3 de Arabidopsis thaliana se señalan con un asterisco. El árbol se enraizó con PLE de Antirrhinum majus (Acc AAB25101.1) y AtAG de Arabidopsis thaliana (Acc NP_567569.3). 
La proteínas MtTM6 y MtNMH7 presentan una homología del $48 \%$ al comparar las secuencias aminoacídicas completas. Tienen un $77 \%$ de homología en la región correspondiente a la caja MADS, $68 \%$ en la región I, $47 \%$ en la región de la caja $\mathrm{K}$ y únicamente $12 \%$ en la región C-terminal.

En la Tabla 17 se muestran los porcentajes de homología para todas las proteínas del linaje TM6 incluidas en el árbol filogenético. MtTM6 muestra alta homología con las proteínas del este linaje, entre ellas la representativa del grupo, TDR6 (Pnueli et al., 1991) de Solanum lycopersicum. Por homología de secuencia, las proteínas más próximas a MtTM6 son de leguminosas: GmACU18610.1 (Cheung et al., unpublished) de Glycine max y LjAP3-like (Dong et al., 2005) de Lotus japonicus.

Tabla 17. Porcentajes de homología (\%) de aminoácidos entre diferentes regiones de MtTM6 y proteínas representativas del linaje TM6

\begin{tabular}{|c|c|c|c|c|c|}
\cline { 2 - 6 } \multicolumn{1}{c|}{} & $\begin{array}{c}\text { Secuencia } \\
\text { completa }\end{array}$ & Caja MADS & Región I & Caja K & $\begin{array}{c}\text { Región C- } \\
\text { terminal }\end{array}$ \\
\hline GmACU18610.1 & $\mathbf{8 7}$ & 98 & 91 & 89 & 70 \\
\hline LjAP3-like & $\mathbf{8 6}$ & 98 & 91 & 90 & 64 \\
\hline TDR6 & $\mathbf{5 9}$ & $\mathbf{7 5}$ & 59 & 58 & 31 \\
\hline GDEF1 & $\mathbf{5 8}$ & 85 & 63 & 55 & 37 \\
\hline PhTM6 & $\mathbf{5 7}$ & $\mathbf{7 5}$ & 59 & 56 & 31 \\
\hline
\end{tabular}

Gm: Glycine max; Lj: Lotus japonicus; TDR6: Antes TM6, de Solanum lycopersicum; G: Gerbera hybrida; Ph: Petunia x hybrida

En la Figura 47 se representa un alineamiento múltiple entre MtTM6 y las proteínas arriba mencionadas. En el alineamiento se puede ver en la región C-terminal la presencia de la secuencia consenso característica del linaje TM6, YGxHDLRLA, llamada motivo paleoAP3 (Kramer et al., 1998). También puede verse la localización del motivo "PIderived". Este motivo se localiza en las proteínas AP3/DEF en la misma posición que el bien conservado motivo "PI" (MPFxFRVQPxQPNLQE) en las proteínas del linaje PI/GLO. Sin embargo, la secuencia del motivo "PI-derived", cuyo consenso es FxFRLQPSQPNLH, difiere mucho entre las diferentes proteínas del linaje AP3/DEF (Kramer et al., 1998). En el alineamiento puede observarse que el motivo "PI-derived" ha variado en las proteínas del linaje TM6 de leguminosas, siguiendo el mismo patrón de divergencia en todas ellas. 


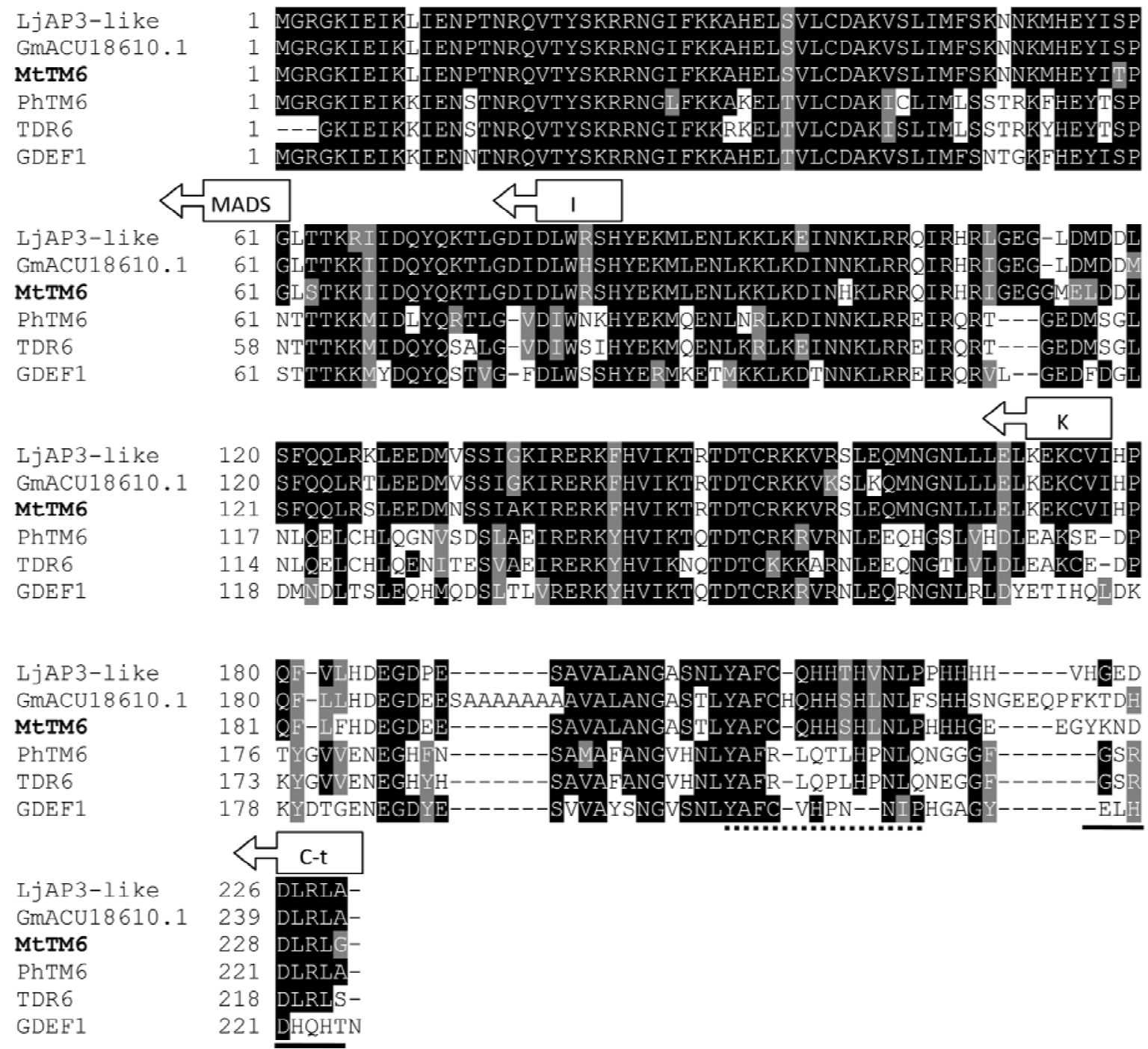

Figura 47. Alineamiento de la secuencia proteica de MtTM6 y de genes MADS-box del linaje TM6, grupo AP3, con los que presenta homología. Las regiones sombreadas corresponden a aminoácidos conservados. Los dominios MADS y K así como las regiones I y C-terminal se señalan con flechas. El motivo "paleoAP3" se subraya con una línea continua y los residuos del motivo "PI-derived" con una línea discontinua.

Hay alta homología de secuencia entre MtNMH7 y proteínas de leguminosas pertenecientes al linaje euAP3, como MsNMH7 (Heard y Dunn, 1995) de Medicago sativa, LjAP3 (Dong et al., 2005) de Lotus japonicus o GmNMH7 (Wu et al., 2006) de Glycine max. Este linaje está representado en otras plantas modelo por AtAP3 (Bowman et al., 1989) en Arabidopsis thaliana y DEF (Sommer et al., 1990) en Antirrhinum majus. En la Tabla 18 se muestran los porcentajes de homología entre MtNMH7 y las proteínas mencionadas. Puede verse una homología del 98\% con la proteína MsNMH7 (Heard y Dunn, 1995) de la especie cercana Medicago sativa. 
Tabla 18. Porcentajes de homología (\%) de aminoácidos entre diferentes regiones de MtNMH7 y las proteínas con las que presenta mayor homología

\begin{tabular}{|c|c|c|c|c|c|}
\cline { 2 - 6 } \multicolumn{1}{c|}{} & $\begin{array}{c}\text { Secuencia } \\
\text { completa }\end{array}$ & Caja MADS & Región I & Caja K & $\begin{array}{c}\text { Región C- } \\
\text { terminal }\end{array}$ \\
\hline MsNMH7 & $\mathbf{9 8}$ & 98 & 100 & 97 & 100 \\
\hline LjAP3 & $\mathbf{9 1}$ & 100 & 86 & 91 & 83 \\
\hline GmNMH7 & $\mathbf{9 0}$ & 100 & 86 & 91 & 49 \\
\hline AmDEF & $\mathbf{6 7}$ & 90 & 68 & 62 & 40 \\
\hline AtAP3 & $\mathbf{5 6}$ & 90 & 31 & 50 & 49 \\
\hline
\end{tabular}

Ms: Medicago sativa; Lj: Lotus japonicus; Gm: Glycine max; Am: Antirrhinum majus; At: Arabidopsis thaliana

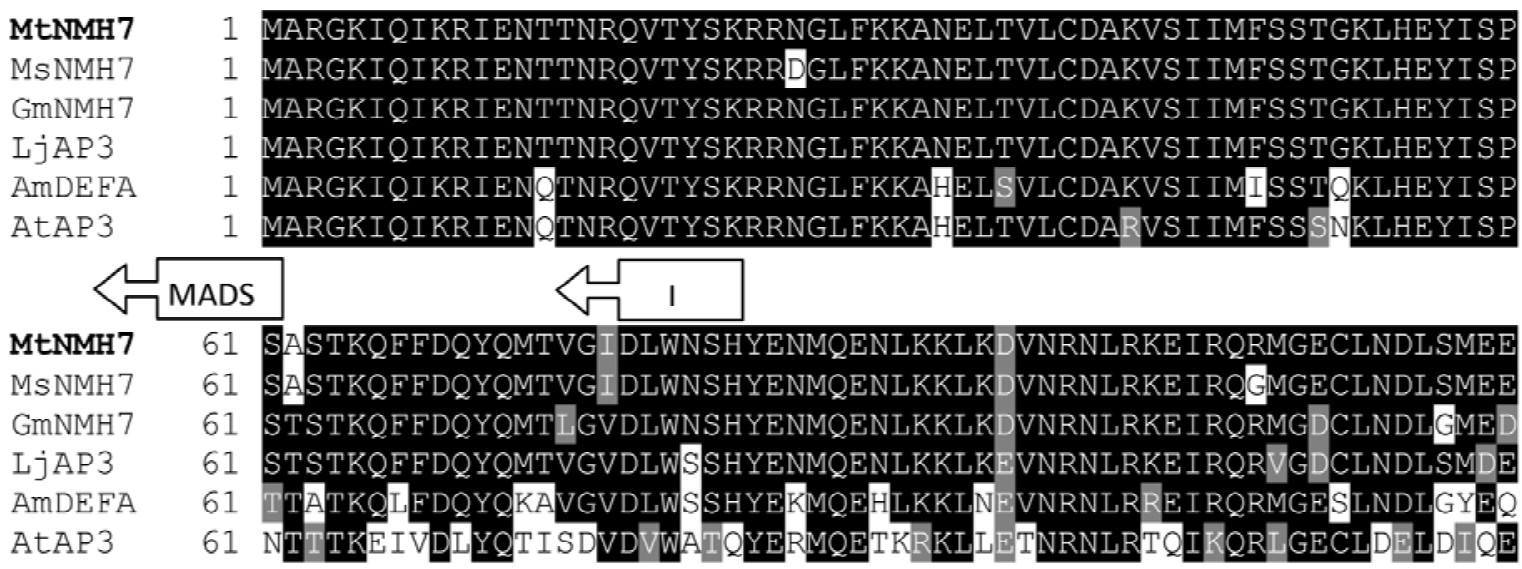

AtAP3 61 NTTTKEIVDLYQTISDVDVWATQYERMQETKRKLLETNRNLRTQI KQRLGECLDELDIQE

MENMH7 121 LRLLEDEMDKAAKAIRERKYKVITNQIDTQRKKFNNEREVHNRLLRDLDARAEDPRFEMM MSNMH7 121 LRLLEDEMDKAAKAIRERKYKVITNQIDTQRKKSNNEREVHNRLLRDLDARAEDPRFEMM GMNMH 7121 LKLLEEEMDKAAKVVRERKYKVITNQIDTQRKKFNNEKEVHNRLLRDLDARAEDPRFAI LjAP3 121 LRLLEQEMDNAAKAVRERKYKVITNQIDTQRKKFNNEREVHNRLLRDLDARAENP PYELM AmDEFA 121 IVNLIEDMDNSLKLIRERKYKVISNQI DTSKKKVRNVEEIHRNLVLEFDARREDPHFG AtAP3 121 LRRLEDEMENT FKLVRERKFKSLGNQIETTKKKNKSQQDIQKNLIHELELRAEDP

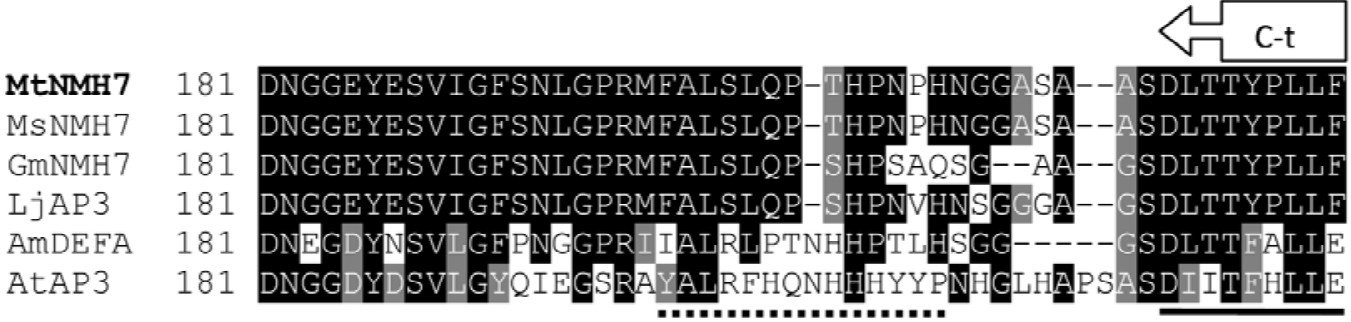

Figura 48. Alineamiento de la secuencia proteica de $M t N M H 7$ y de genes MADS-box del linaje euAP3, grupo $A P 3$, con los que presenta homología. Las regiones sombreadas corresponden a aminoácidos conservados. Los dominios MADS y K así como las regiones I y C-terminal se señalan con flechas. El motivo "euAP3" se subraya con una línea continua y los residuos del motivo "PI-derived" con una línea discontinua.

En la Figura 48 se representa un alineamiento múltiple entre MtNMH7 y las proteínas antes mencionadas. En el alineamiento se puede ver, en la región C-terminal, la 
presencia de una secuencia característica del linaje euAP3, llamada motivo euAP3, cuya secuencia consenso es D(L/I)TTFALLE (Kramer et al., 1998). También puede verse la localización de la secuencia "PI-derived" (Kramer et al., 1998) que ha divergido del mismo modo en todas las proteínas euAP3 que se muestran de leguminosas.

\subsubsection{Patrón de expresión de MtTM6 y MtNMH7}

Se analizó el patrón de expresión de ambos genes mediante Northern blot en diferentes tejidos de la planta (Figuras 49 y 51). La inclusión de nódulos en este estudio se debe a estudios previos que indican la presencia de genes del grupo AP3 en tejido nodular de otras leguminosas como Glycine max (Wu et al., 2006) o Medicago sativa (Heard y Dunn, 1995). Se usó la región C-terminal del cDNA de cada gen como sonda, a fin de evitar hibridación cruzada. El análisis de la expresión tisular de los genes se realizó mediante hibridación in situ en ápices florales de Medicago truncatula (Figuras 50 y 52), para intentar definir una posible diferencia en la función de los genes determinada por una expresión espacial y/o temporal distinta.

\subsubsection{Patrón de expresión de MtTM6}

Mediante hibridación Northern blot, la expresión de MtTM6 se detecta intensa en flores. No se detecta en otros tejidos (Figura 49).

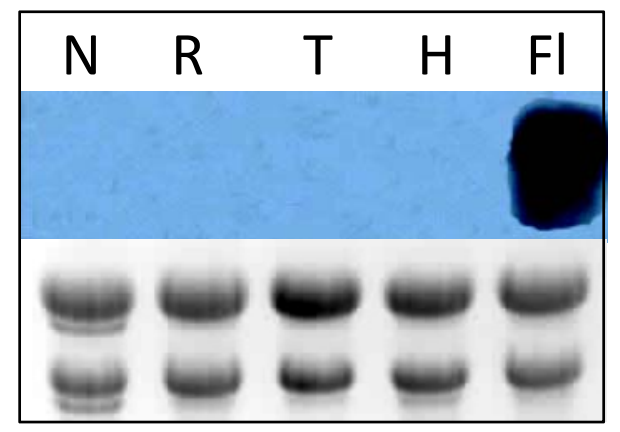

Figura 49. Análisis del patrón de expresión de MtTM6 mediante Northern blot. El análisis se realizó en diferentes tejidos de la planta: nódulos $(\mathrm{N})$, raíz $(\mathrm{R})$, tallo $(\mathrm{T})$, hoja $(\mathrm{H})$ y flor $(\mathrm{Fl})$.

La hibridación in situ muestra que la expresión de MtTM6 se detecta desde el estadio 2 de desarrollo floral en la región del meristemo floral que dará lugar a los verticilos internos (Figura 50, a). En el estadio 4, al comenzar a diferenciarse los primordios comunes, la expresión se detecta en forma de cuña alrededor de los mismos, así como en el carpelo (Figura 50, b). En el estadio 5 la expresión disminuye en carpelo y empieza 
a restringirse a la capa externa de los primordios de pétalos y estambres, aunque aún se detecta sobre ellos (Figura 50, c). Posteriormente, en el estadio 6 la expresión desaparece del carpelo y se limita a la capa celular exterior de los pétalos y los estambres (Figura 50, d).
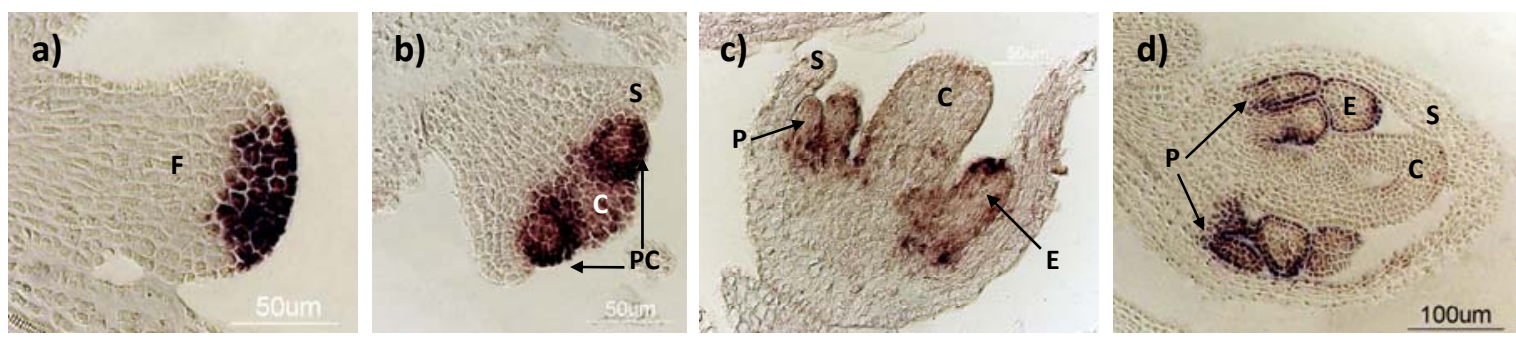

Figura 50. Análisis del patrón de expresión de MtTM6 mediante hibridación in situ en ápices inflorescentes de $\boldsymbol{M}$. truncatula. a) Expresión en el centro del meristemo floral en estadio de desarrollo 2. b) Expresión en el carpelo y en forma de cuña alrededor de los primordios comunes en el estadio 4. c) Expresión leve en carpelo y centrada a los primordios de pétalo y estambre tendiendo a la superficie externa de los mismos durante el estadio 5. d) La expresión desaparece de carpelo y se centra en la capa celular externa de los pétalos y estambres en el estadio 6 del desarrollo floral. F, Meristemo floral; PC, Primordio común; S, Sépalo; C, Carpelo; E, Estambre; P, Pétalo.

\subsubsection{Patrón de expresión de MtNMH7}

En la Figura 51 puede verse como mediante hibridación Northern blot la expresión de MtNMH7 se detecta, al igual que en MtTM6, intensa en flores y ausente en otros tejidos.

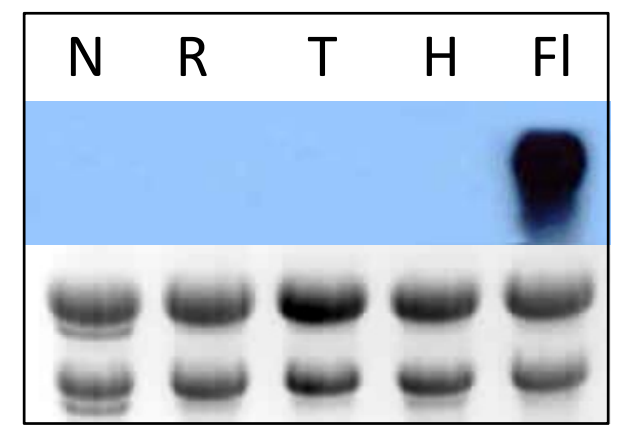

Figura 51. Análisis del patrón de expresión de $M \mathbf{H} N \mathbf{M H}$ mediante Northern blot. El análisis se realizó en diferentes tejidos de la planta: nódulos $(\mathrm{N})$, raíz $(\mathrm{R})$, tallo $(\mathrm{T})$, hoja $(\mathrm{H})$ y flor $(\mathrm{FI})$.

La hibridación in situ muestra que el transcrito de $M t N M H 7$ se detecta en la capa externa de todo el meristemo floral en el estadio 2 (Figura 52, a). En el estadio 4 la expresión se centra en los primordios comunes (Figura 52, b). En el estadio 5, cuando se han diferenciado los primordios de estambres y pétalos, hay expresión fuerte de MtNMH7 sobre dichos primordios, aunque es débil en la capa celular externa que los rodea (Figura 52, c). En el estadio 6, la expresión se centra en los pétalos y estambres, 
estando claramente ausente de la capa celular más externa que rodea a estos órganos.

(Figura 52, d).
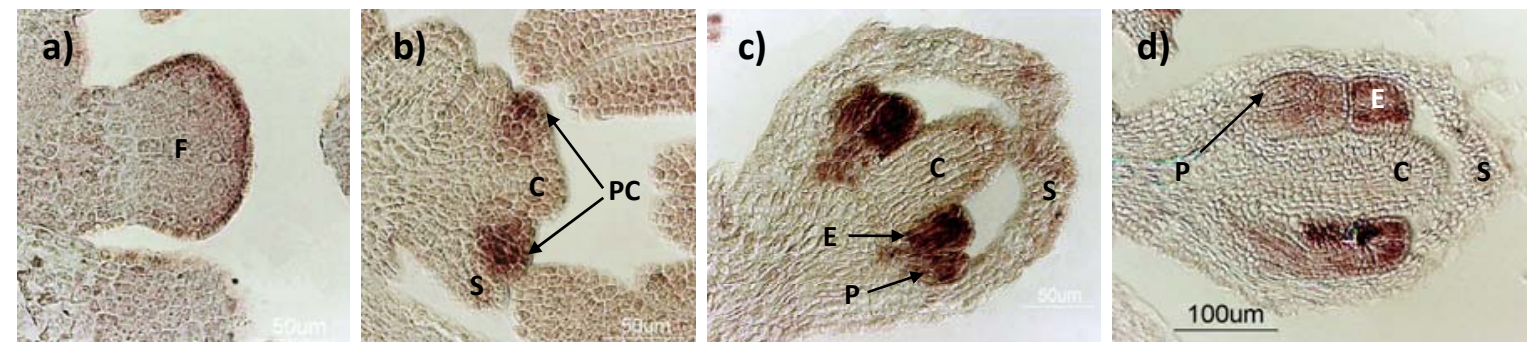

Figura 52. Análisis del patrón de expresión de MtNMH7 mediante hibridación in situ en ápices inflorescentes de $\boldsymbol{M}$. truncatula. a) Expresión leve en la capa externa del meristemo floral en estadio de desarrollo 2. b) Expresión en los primordios comunes en el estadio 4. c) Expresión fuerte en los primordios de pétalo y estambre, ausente en la superficie externa de los mismos durante el estadio 5. d) La expresión se centra en el interior de los pétalos y estambres en el estadio 6 del desarrollo floral y no se detecta en la capa celular exterior de dichos órganos. F, Meristemo floral; PC, Primordio común; S, Sépalo; C, Carpelo; E, Estambre; P, Pétalo.

Tanto MtTM6 como MtNMH7 se expresan en los verticilos segundo y tercero de la flor, coincidiendo con la expresión descrita para los genes de clase B. Los patrones de expresión de ambos genes difieren en que, a pesar de expresarse en los mismos órganos, se expresan en tejidos diferentes de dichos órganos, de manera excluyente.

Las diferencias en los patrones de expresión así como en la estructura proteica de MtTM6 y MtNMH7, sugieren que estos genes podrían tener funciones distintas en el desarrollo de pétalos y estambres. La correlación entre la divergencia a nivel de expresión entre genes duplicados del grupo AP3 (pertenecientes a los linajes TM6 y eUAP3) y el hecho de que tengan funciones diferentes ha sido descrito previamente en algunas plantas como Petunia x hybrida (Rijpkema et al., 2006) o Solanum lycopersicum (de Martino et al., 2006). 


\section{CAPÍTULO I}

Discusión 

Los genes MADS-box comprenden una gran familia de factores de transcripción cuyos miembros controlan diferentes procesos durante la vida de la planta, como el tiempo de floración, la determinación de la identidad del meristemo floral y la identidad y desarrollo de órganos florales, raíces, hojas, frutos y semillas (revisado por Rijpkema et al., 2007). Estos genes están incluidos en alguna de las clases que conforman el modelo ABCDE (Theissen, 2001; Li et al., 2003; Huang et al., 2009).

Las plantas modelo Arabidopsis thaliana, Antirrhinum majus u Oryza sativa han proporcionado mucha información acerca de los genes y las vías genéticas que controlan el proceso de floración, pero en lo que respecta a las correspondientes vías en leguminosas, el conocimiento generado es escaso. Pisum sativum (guisante) se ha usado durante décadas como sistema modelo de la genética fisiológica de la floración; sin embargo, la escasa información existente acerca de los genes implicados en la floración de esta planta, debida a las diferencias en la ontogenia floral y a la restricción en los análisis funcionales (al ser una especie difícil de transformar), ha impedido la comparación directa con otros sistemas modelo. Para resolver este problema, se han intentado identificar secuencias relacionadas con genes de floración en la leguminosa Medicago truncatula. Mediante la búsqueda en bases de datos genómicas y de EST's ("Expressed sequence tags" o marcadores de secuencia expresada), Hecht et al. (2005) identificaron 22 secuencias de genes MADS-box de clase MIKC de Medicago truncatula, concluyendo que la mayoría de los genes de floración de Arabidopsis thaliana están representados en las bases de datos de leguminosas (Hecht et al., 2005). Sin embargo, no se ha descrito el aislamiento y caracterización de estos genes en tejido floral.

En la presente Tesis Doctoral se realizó una búsqueda de genes MADS-box de Medicago truncatula en una genoteca de cDNA de ápices florales. Se aislaron y caracterizaron 11 secuencias distintas correspondientes a genes MADS-box, distribuidas filogenéticamente en cinco de los 14 grupos de genes MADS-box descritos por Becker y Theissen (2003). Cinco de las secuencias aisladas (MtAGL6, MtAGL6-like, MtSOC1a, MtAGa y MtNMH7) no se habían descrito en el trabajo previo de Hecht et al. (2005), lo que eleva a 27 el número de genes MADS-box identificados en Medicago truncatula.

Hecht et al. (2005) describen que muchos genes presentes como copia única en Arabidopsis thaliana aparentemente también están como copia única en las cuatro leguminosas analizadas (Medicago truncatula, Pisum sativum, Glycine max y Lotus 
japonicus). Sin embargo, otros genes presentan diferencias en su historial de duplicaciones. Por ejemplo, varios pares de genes parálogos de Arabidopsis thaliana están representados por un gen único en Medicago truncatula y Pisum sativum. Esto sucede con genes MADS-box como SEP1/2, SHP1/2 O AP1/CAL. También puede observarse lo contrario, que Medicago truncatula y Pisum sativum contienen varias copias de genes que son copia única en Arabidopsis thaliana, por ejemplo, SOC1a y SOC1b (Hecht et al., 2005). Los resultados obtenidos en la presente Tesis Doctoral confirman estas observaciones. Además, se observan casos de duplicaciones génicas en genes MADS-box de clase B (MtTM6 y MtNMH7) y clase C (MtAGa y MtAGb), que no habían sido descritas previamente.

En Arabidopsis thaliana, se ha propuesto que la evolución de la familia de genes MADS-box se ajusta al denominado modelo "Birth-and-Death", un proceso dinámico que sugiere la creación de genes nuevos mediante duplicación. Estos genes duplicados pueden conservarse en el genoma por mucho tiempo (sometiéndose a procesos de subo neofuncionalización) o pueden ser inactivados o eliminados del genoma (Nei et al., 1997; Nam et al., 2003; Irish y Litt, 2005). Es posible que los genes MADS-box duplicados en Medicago truncatula sigan este modelo y que hoy por hoy estén en proceso de sub- o neofuncionalización o en desaparición. Probablemente durante la evolución de las estructuras florales varios genes MADS-box se han duplicado y algunos miembros han divergido para funcionar en diferentes estructuras florales, controlando ramas distintas en la regulación de la morfogénesis floral. Alternativamente, pueden funcionar en diferentes momentos, dirigiendo las distintas fases del desarrollo floral. Aunque estos genes presentan grandes similitudes a nivel de secuencia, sus patrones de expresión sugieren que tienen funciones y dianas diferentes.

Todos los genes MADS-box aislados en el presente trabajo se expresan en la flor, en diferentes tejidos florales y/o diferentes estadios de desarrollo floral. Cinco de estos genes (MtSEP, MtAGL6-like, MtSOC1a, MtSOC1b y MtSOC1-like) se expresan además en tejidos vegetativos, probablemente cumpliendo un rango de funciones más amplio que únicamente la regulación de los eventos del desarrollo floral.

Los resultados obtenidos en este trabajo conforman la base para determinar las funciones de estos genes. Se ha visto que existe una correlación entre el patrón de expresión floral específico de cada gen y el grupo filogenético al que pertenece y se 
espera en el futuro poder llevar a cabo estudios funcionales para definir el papel de estos genes en el desarrollo de las inflorescencias, flores y frutos de Medicago truncatula. Los datos presentados ayudarán a comprender las bases genéticas del desarrollo de las estructuras florales particulares de las leguminosas y a examinar la relación entre la evolución molecular y la diversificación morfológica en este importante grupo de plantas.

\section{MtSEP ES EL ORTÓLOGO DE LOS GENES SEP1/2 EN Medicago truncatula}

Los genes del grupo AGL2 (SEPALLATA) constituyen una clase adicional de genes homeóticos florales, la llamada clase E (Theissen, 2001). Los genes SEPALLATA (SEP) se han descrito como necesarios, aunque de manera redundante, para la especificación de la identidad de los cuatro verticilos de órganos florales y del meristemo floral (Ma et al., 1991; Huang et al., 1995; Theissen et al., 2000; Pelaz et al., 2000; Ditta et al., 2004; Uimari et al., 2004; Malcomber y Kellogg, 2005).

Estudios previos han mostrado que las duplicaciones dentro del grupo SEP han ocurrido a lo largo de la evolución de las angiospermas, y el número de genes SEP-like es diferente entre las especies. Así pues, en Arabidopsis thaliana se han identificado cuatro genes SEP-like: SEP1, SEP2, SEP3 y SEP4 (antes llamados AGL2, AGL4, AGL9 y AGL3, respectivamente; Ma et al., 1991; Mandel y Yanofsky, 1998), pero hay al menos cinco en Oryza sativa (Nam et al., 2004), ocho en Zea mays (Münster et al., 2002) y ocho en Petunia x hybrida (Zahn et al., 2005a). Los genes SEP1 y SEP2 de Arabidopsis thaliana son muy similares entre sí y reflejan una duplicación reciente.

En leguminosas se han aislado varias secuencias relacionadas con genes SEP-like (Hecht et al., 2005). Se han descrito los genes ortólogos de SEP3: LjSEP3 de Lotus japonicus (Dong et al., 2005) y PsMTF1 de Pisum sativum (Buchner y Boutin, 1998). Además, se ha visto que varios pares de genes parálogos de Arabidopsis thaliana (como sucede con SEP1/2 o con SHP1/2) están representados en diversas leguminosas por un solo gen (Hecht et al., 2005). Se han descrito como ortólogos de SEP1/2: PSSEP1/2 de Pisum sativum (antes PEAM6, Ferrándiz, 1996; Navarro, 2001; Berbel, 2005) y GmSEP1 de Glycine max (Huang et al., 2009). 
En el presente trabajo se aisló MtSEP, un gen SEP-like de Medicago truncatula. MtSEP equivale al EST denominado MtSEP1/2 mencionado por Hecht et al. (2005). Los alineamientos de secuencia con otras proteínas MADS-box demostraron que la proteína MtSEP tiene una estructura de tipo MIKC y presenta los motivos SEP I y SEP II característicos de las proteínas SEP-like (Zahn et al., 2005a). Además, el árbol filogenético mostró que, dentro de los genes SEP-like, MtSEP se localiza en la rama SEP1/2. En particular, MtSEP está más cerca de GmSEP1 (Huang et al., 2009), PSSEP1/2 (Ferrándiz, 1996), MdMADS1 (Sung y An, 1997) y PpMADS7 (Xu et al., 2008), todos descritos como genes ortólogos de SEP1/2. Estos resultados sugieren que MtSEP es el ortólogo de los genes SEP1/2 en Medicago truncatula.

Se ha descrito que el gen SEP1 de Arabidopsis thaliana es específico de flores y no se expresa en meristemos inflorescentes (Flanagan y Ma, 1994). Aunque el desarrollo de la inflorescencia en leguminosas es sustancialmente diferente al de Arabidopsis thaliana (Ferrándiz et al., 1999; Benlloch et al., 2003), la expresión de MtSEP también es específica de meristemo floral y no se detecta en el meristemo inflorescente. Lo mismo sucede con el gen PSSEP1/2 de Pisum sativum (Navarro, 2001). Este tipo de expresión en los meristemos florales tempranos es coherente con la hipótesis del papel de este gen en la especificación de la identidad floral del meristemo.

En los estadios tempranos del desarrollo floral de Medicago truncatula, la expresión de MtSEP es uniforme en los primordios de todos los órganos florales en desarrollo. Durante el desarrollo floral, se detecta expresión de MtSEP en óvulos. Si consideramos el óvulo como un órgano floral adicional, como se ha sugerido basándose en su origen evolutivo (Robinson-Beers et al., 1992), se puede pensar que MtSEP funciona en el desarrollo temprano de todos los órganos florales: sépalos, pétalos, estambres, carpelos y óvulos. Entonces, MtSEP puede tener un papel importante en el establecimiento de la identidad de cada órgano floral.

El mismo patrón de expresión temprana se describió para PSSEP1/2 de Pisum sativum, aunque en flores desarrolladas también se detecta expresión en filamentos de estambres y carpelo (Navarro, 2001). La expresión de MtSEP en flores desarrolladas se detecta principalmente en pétalos, lo que se ha descrito también para el ortólogo de SEP1 en Glycine max, GmSEP1 (Huang et al., 2009). Estos resultados sugieren que MtSEP 
además de determinar la identidad del pétalo de Medicago truncatula, puede estar involucrado en el posterior desarrollo y elaboración de su morfología.

MtSEP también mostró expresión débil en raíces, indicando que puede participar en procesos biológicos en este tejido. La expresión de genes $S E P 1 / 2$ en tejidos vegetativos se ha descrito previamente para genes como GMSEP1 de Glycine max (expresión en tallo y ápices vegetativos; Huang et al., 2009) o GhGRCD2 de Gerbera hybrida (Malcomber y Kellogg, 2005).

El análisis de secuencia, el patrón de expresión y sus relaciones filogenéticas, indican que MtSEP es un gen de clase E, ortólogo a los genes SEP1/2 de Arabidopsis thaliana. MtSEP podría llevar a cabo una doble función en Medicago truncatula, estableciendo tanto la identidad floral del meristemo como la identidad de todos los órganos florales.

\section{MtAGL6 ES EL ORTÓLOGO DEL GEN AGL6 EN Medicago truncatula}

Los genes del grupo AGL6 (AGAMOUS-like6), que codifican proteínas MADS-box de tipo MIKC, se han identificado en muchas especies de plantas en las últimas dos décadas. Estos genes se consideran, en base a análisis filogenéticos, un grupo hermano de los genes del grupo SEP (Ma et al., 1991; Zahn et al., 2005a). Sin embargo, se sabe poco de las funciones de los genes del grupo $A G L 6$, debido a la ausencia de fenotipo en mutantes de pérdida de función (Ma et al., 1991; Rounsley et al., 1995; Viaene et al., 2010). El análisis del único mutante nulo con fenotipo para un gen de tipo $A G L 6$, el del gen ZAG3 de la monocotiledónea Zea mays, apunta a un papel de estos genes en el desarrollo de meristemos y órganos florales (Mena et al., 1995; Thompson et al., 2009).

El genoma de Arabidopsis thaliana contiene dos genes tipo AGL6: AGL6 y AGL13 (Mouradov et al., 1998; Rounsley et al., 1995). Son muy similares entre sí y pueden ser producto de una duplicación génica relativamente reciente (Li et al., 2010). AGL6 fue uno de los primeros genes MADS-box identificados en la planta modelo Arabidopsis thaliana (Ma et al., 1991), pero su función aún no se ha determinado. Sin embargo, estudios de expresión en otras especies sugieren papeles en la transición floral y el desarrollo de órganos florales (Hsu et al., 2003; Carlsbecker et al., 2004; Fan et al., 2007; Reinheimer y Kellogg, 2009; Rijpkema et al., 2009). 
En leguminosas, en el año 2005 se identificaron los genes PsMADS5 y PsMADS3, de Pisum sativum (Hecht et al., 2005). Estos genes se describieron previamente en nuestro laboratorio (Ferrándiz, C., Tesis Doctoral, 1996) y se incluyeron en el grupo AGL6.

En el presente trabajo se aislaron también dos genes pertenecientes al grupo AGL6 en la leguminosa modelo Medicago truncatula, denominados MtAGL6 y MtAGL6-like. La homología de secuencia entre ellos sugiere que son el resultado de la duplicación de un gen ancestral común; no obstante, hay divergencias de expresión entre ellos. Los cambios en los dominios de expresión son frecuentes entre genes duplicados (ejemplos en Conant and Wolfe, 2008) y reflejan patrones complejos de mutación y selección tras el evento de duplicación (Reinheimer y Kellogg, 2009).

Los niveles de homología de secuencia entre MtAGL6 y otros genes del grupo AGL6 demuestran que MtAGL6 es el ortólogo de PsMADS5 de Pisum sativum, un gen MADSbox de expresión específicamente floral (Ferrándiz, C., Tesis Doctoral, 1996). Además, MtAGL6 es el ortólogo del gen AGL6 de Arabidopsis thaliana (Ma et al., 1991) en Medicago truncatula. MtAGL6 tiene la mayor similitud de secuencia con VvMADS3 de Vitis vinifera (Boss et al., 2002) y MdMADS11 de Malus $x$ domestica (Yao et al., 1999), todos descritos como genes del grupo AGL6.

En la región C-terminal de MtAGL6 se han encontrado los motivos AGL6-I y AGL6-II, característicos de las proteínas del grupo AGL6 (Ohmori et al., 2009). El estudio del ortólogo de AGL6 de Oryza sativa (MFO1, antes OsMADS6) ha demostrado que el motivo AGL6-II media una activación transcripcional especialmente fuerte y que la región que va desde el motivo AGL6-I hasta el AGL6-II es un dominio potencial de activación transcripcional (Ohmori et al., 2009). La presencia de ambos motivos en MtAGL6 sugiere que esta proteína es un factor de transcripción perteneciente al grupo AGL6.

MtAGL6, al igual que su ortólogo PsMADS5 (Ferrándiz, 1996), tiene expresión específica en flor, un patrón de expresión común para los genes tipo AGL6 (Ma et al., 1991; Mouradov et al., 1998; Boss et al., 2002; Mena et al., 1995; Petersen et al., 2004; Hsu et al., 2003; Moon et al., 1999; Carlsbecker et al., 2004; Fan et al., 2007). Este patrón de expresión específico, sugiere que juega un papel primario en el desarrollo de los órganos florales. MtAGL6 está ausente de los tejidos vegetativos como hojas, tallos o raíces. 
Dentro de la flor, MtAGL6 se expresa de manera temprana en el meristemo floral. Este tipo de expresión de los genes de tipo $A G L 6$ se ha asociado con una función en la identidad del meristemo floral (Carlsbecker et al., 2004; Thompson et al., 2009; Ohmori et al., 2009; Melzer et al., 2010), así como con funciones de intermediarios en las interacciones de genes meristemáticos con genes de identidad de órgano floral (Fan et al., 1997, 2007; Moon et al., 1999; Favaro et al., 2002; Cooper et al., 2003; Hsu et al., 2003; de Folter et al., 2005; Ohmori et al., 2009).

MtAGL6 además de expresarse en los primordios comunes y en los pétalos y estambres originados a partir de dichos primordios, se expresa en óvulos y semillas en desarrollo. Diversos estudios han detectado expresión de genes del grupo AGL6 en carpelos y óvulos de angiospermas (Ma et al., 1991; Mena et al., 1995; Rounsley et al., 1995; Moon et al., 1999; Tsuchimoto et al., 2000; Boss et al., 2002; Pelucchi et al., 2002; Hsu et al., 2003; Losa et al., 2004; Petersen et al., 2004; Chanderbali et al., 2006; Fan et al., 2007). La expresión de los genes de tipo AGL6 en órganos reproductores parece ser un estatus común y un rasgo ancestral (Li et al., 2010). Posiblemente, este gen tiene una función esencial y conservada en la especificación del desarrollo de los órganos reproductores de Medicago truncatula.

En las semillas, MtAGL6 se expresa en nucela y epidermis. Investigaciones recientes han sugerido que la expresión en el integumento interno del óvulo es un patrón de expresión ancestral que se comparte con los genes tipo AGL6 de gimnospermas (Mouradov et al., 1998, Shindo et al., 1999, Winter et al., 1999, Reinheimer y Kellogg, 2009). Así pues, la expresión de MtAGL6 en óvulos se asemeja a la expresión de los genes tipo AGL6 de gimnospermas.

El análisis de secuencia y las relaciones filogenéticas indican que MtAGL6 es el ortólogo de AGL6 de Arabidopsis thaliana. El patrón de expresión preferentemente floral que comparte MtAGL6 con genes tipo AGL6 de gimnospermas (Becker et al., 2003; Mouradov et al., 1998; Tandre et al., 1998), monocotiledóneas (Hsu et al., 2003; Fan et al., 2007) y eudicotiledóneas superiores (Ma et al., 1991; Rounsley et al., 1995; Tsuchimoto et al., 2000) sugiere que MtAGL6 podría tener una función en flores que probablemente sea de origen ancestral. 


\section{MtAGL6-like FORMA PARTE DE UN NUEVO GRUPO GÉNICO EXCLUSIVO DE LEGUMINOSAS}

El gen MtAGL6-like es el ortólogo de PsMADS3 de Pisum sativum (Ferrándiz, C., Tesis Doctoral, 1996). Además, presenta alta similitud de secuencia con dos genes aún no caracterizados de Glycine max (GmACU23947.1 y GmACU18038.1, Cheung et al., unpublished). MtAGL6-like se agrupa filogenéticamente junto con estos genes en una rama separada de MtAGL6. Cabe mencionar que MtAGL6-like y PSMADS3 carecen de los motivos AGL6-I y AGL6-II (Ohmori et al., 2009) en la región C-terminal. La evolución de esta región se ha ligado a los cambios en las interacciones génicas y, en consecuencia, a diferentes funciones génicas (Vandenbussche et al., 2003a). Por ello, no puede considerarse a MtAGL6-like como ortólogo de AGL6 o AGL13 de Arabidopsis thaliana. Los resultados de los análisis filogenéticos y de secuencia indican que los genes ortólogos MtAGL6-like, PsMADS3, GmACU23947.1 y GmACU18038.1 forman un nuevo grupo de genes que parece ser exclusivo de las leguminosas. Posiblemente, estos genes realizan alguna función específica para esta familia de plantas.

La expresión de MtAGL6-like en flores y frutos se asemeja a la expresión de MtAGL6. Difieren en que, dentro de la semilla, MtAGL6-like solo se expresa en el endotelio de la misma. La expresión en las células del endotelio que rodean el saco embrionario en el óvulo maduro se ha descrito para los genes AGL6 y AGL13 de Arabidopsis thaliana (Schauer et al., 2009). Así pues, el patrón de expresión de MtAGL6-like en semillas se parece más al descrito para los genes del grupo AGL6 de la angiosperma eudicotiledónea Arabidopsis thaliana que al patrón de expresión ancestral que MtAGL6 comparte con los genes tipo AGL6 de gimnospermas.

El gen MtAGL6-like se expresa en tejidos florales y además en todos los tejidos vegetativos analizados, al igual que su ortólogo en Pisum sativum, PsMADS3, exceptuando la expresión en raíz, que no se detecta para PSMADS3 (Ferrándiz, C., Tesis Doctoral, 1996). Hay estudios que describen expresión de algunos genes del grupo AGL6 en tejidos vegetativos en gimnospermas y en ciertas angiospermas eudicotiledóneas (Ma et al., 1991; Rounsley et al., 1995; Ferrándiz, 1996; Tandre et al., 1995; Mouradov et al., 1998; Koo et al., 2010; Reinheimer y Kellogg, 2009). Esta expresión en tejido vegetativo de genes del grupo AGL6 es novedosa en las eudicotiledóneas superiores y 
aún no se ha estudiado con detalle. Posiblemente, la expresión en tejidos vegetativos ha sido adquirida por MtAGL6-like tras la duplicación del gen ancestral que dio lugar a MtAGL6 y MtAGL6-like. Además, este patrón de expresión sugiere que MtAGL6-like probablemente está implicado en muchos aspectos del desarrollo de la planta, además de su papel en el desarrollo de la flor.

Durante la evolución de ambos genes, MtAGL6-like ha adquirido la expresión a nivel vegetativo, mientras que MtAGL6 conserva la expresión exclusiva en flores que es típica de los genes de tipo AGL6 de angiospermas. Ambos genes comparten una expresión en flores que es de origen ancestral y posiblemente están involucrados en la formación tanto de los órganos reproductores como de los óvulos. Sin embargo, el patrón de expresión espacial en estos tejidos varía entre ambos genes, lo que sugiere que sus funciones en los mismos probablemente sean distintas. Es razonable pensar que la diferencia en los patrones de expresión de los distintos genes tipo AGL6 está relacionada con el desarrollo de distintas estructuras reproductivas en diferentes especies de plantas.

\section{MtSOC1a Y MtSOC1b SON ORTÓLOGOS DEL GEN INTEGRADOR FLORAL SOC1}

Dentro de la extensa familia de genes con dominio MADS-box, algunos están involucrados en el control del tiempo de floración y en la transición del crecimiento vegetativo al reproductivo. Los genes de la familia TDR3/SOC1, representada por los genes TDR3 de Solanum lycopersicum (antes TM3; Pnueli et al., 1991) y SOC1 de Arabidopsis thaliana (Borner et al., 2000), están implicados en dichos procesos. SOC1 está involucrado en la promoción de la floración (Samach et al., 2000) y la conversión de meristemos vegetativos en meristemos inflorescentes (Komeda, 2004). Este gen integra las señales de las vías que controlan el tiempo de floración, por lo que se define como "integrador floral" (Mouradov et al., 2002; Simpson y Dean, 2002).

Como se ha visto, la familia génica MADS-box parece haber sufrido duplicaciones y divergencias funcionales dentro de varios linajes de angiospermas (Theissen et al., 2000; Irish et al., 2003). Existen evidencias que sugieren que el gen ancestral TDR3/SOC1 también ha sufrido dicha divergencia durante su evolución (Lee y Lee, 2010). En 
Arabidopsis thaliana se han identificado al menos cinco factores de transcripción del grupo TDR3/SOC1: SOC1 (SUPPRESSOR OF OVEREXPRESSION OF CONSTANS 1, antes AGL20; Borner et al., 2000), AGL14 (Rounsley et al., 1995), AGL19 (Álvarez-Buylla et al., 2000b), AGL71 (Pařenicová et al., 2003) y AGL72 (Pařenicová et al., 2003).

En leguminosas se ha aislado una secuencia ortóloga a SOC1 en Glycine max (GmSOC1; Hecht et al., 2005; Xu et al., unpublished). Además, se han aislado dos secuencias relacionadas a SOC1 en Pisum sativum (PsSOC1a y PsSOC1b), ambas con elevada homología a SOC1, más que a cualquier otro miembro del clado SOC1 de Arabidopsis thaliana (Hecht et al., 2005). En el presente trabajo se aislaron tres genes pertenecientes al grupo TDR3/SOC1 en la leguminosa modelo Medicago truncatula, denominados MtSOC1a, MtSOC1b y MtSOC1-like. MtSOC1a y MtSOC1b presentan alta homología de secuencia con SOC1 de Arabidopsis thaliana y son ortólogos de los genes PsSOC1a y PsSOC1b, respectivamente.

Las secuencias de las proteínas del grupo TDR3/SOC1 se caracterizan por presentar cuatro variantes aminoacídicas raras dentro de la caja MADS (Theissen et al., 1996; Decroocq et al., 1999). Además, las proteínas de este grupo tanto de gimnospermas como de angiospermas conservan once residuos aminoacídicos en la región C-terminal, llamados "motivo SOC1" (Vandenbussche et al., 2003a; Nakamura et al., 2005). Los tres genes del grupo TDR3/SOC1 aislados en Medicago truncatula presentan ambas características. La conservación de las variantes características de la caja MADS confirma la pertenencia de estos genes al grupo TDR3/SOC1. La conservación del motivo SOC1 posiblemente refleja una similitud en las interacciones bioquímicas entre las distintas proteínas TDR3/SOC1 y otras proteínas en la formación de complejos de alto nivel (Nakamura et al., 2005).

Los genes del grupo TDR3/SOC1 descritos tanto en angiospermas como en gimnospermas, se expresan en órganos vegetativos, así como en el meristemo vegetativo, y están involucrados en la transición floral (Pnueli et al., 1991; Mandel et al., 1994; Tandre et al., 1995; Menzel et al., 1996; Walden et al., 1998; Winter et al., 1999; Becker y Theissen, 2003). En Arabidopsis thaliana, el gen SOC1 se expresa predominantemente en los tejidos meristemáticos, pero también es ampliamente expresado en raíces, hojas, brotes, inflorescencias y tallos (Onouchi et al., 2000; Samach et al., 2000). Según los patrones de expresión, es muy probable que el gen TDR3/SOC1 
ancestral tuviera funciones en el desarrollo vegetativo además de estar implicado en la transición floral (Becker y Theissen, 2003).

La expresión de los genes parálogos MtSOC1a y MtSOC1b de Medicago truncatula también se detecta principalmente en tejidos vegetativos, en los haces vasculares en desarrollo y en los primordios de hojas. La expresión de los genes del grupo TDR3/SOC1 en los haces vasculares se ha relacionado con una posible función en la regulación del transporte de sustancias específicas de la floración (Menzel et al., 1996), mientras que su función en hojas no está clara, pero puede que contribuya a la promoción de la floración en respuesta de señales ambientales como la vernalización (Searle et al., 2006).

MtSOC1a y MtSOC1b se expresan en el meristemo apical tanto vegetativo como floral. La misma expresión se ha descrito para el homólogo de SOC1 de Sinapis alba (SaMADSA; Menzel et al., 2006), al que se ha asignado un papel en la integración de señales de las vías florales de fotoperiodo, dependiente de giberelinas y de vernalización (Moon et al., 2003). Es probable que los ortólogos de SOC1 en Medicago truncatula también jueguen un papel como integradores florales en el meristemo apical durante la transición floral y, tras la inducción de la floración, en el mantenimiento de las funciones meristemáticas durante el desarrollo reproductivo. La caracterización de MtSOC1a y MtSOC1b como genes de actividad temprana durante la transición floral en Medicago truncatula puede ser el primer paso hacia la identificación de componentes involucrados en la transducción de señales tempranas en el meristemo y en la comprensión del cambio de desarrollo vegetativo a reproductivo en los meristemos apicales de las leguminosas.

\section{MtSOC1-like ES UN GEN DEL GRUPO TDR3/SOC1 QUE SE EXPRESA EN TEJIDO FLORAL ADULTO}

El gen MtSOC1-like presenta las características de secuencia que lo incluyen dentro del grupo TDR3/SOC1: los residuos aminoacídicos característicos en la región de la caja MADS (Theissen et al., 1996; Decroocq et al., 1999) y el "motivo SOC1" (Vandenbussche et al., 2003a; Nakamura et al., 2005). Además, al igual que la mayoría de los genes del grupo TDR3/SOC1 estudiados (Pnueli et al., 1991; Mandel et al., 1994; Tandre et al., 
1995; Menzel et al., 1996; Walden et al., 1998; Winter et al., 1999; Becker y Theissen, 2003), MtSOC1-like se expresa preferentemente en tejidos vegetativos.

Sin embargo, el gen MtSOC1-like pertenece a una rama filogenética distinta a la de los genes MtSOC1a y MtSOC1b. MtSOC1-like se agrupa filogenéticamente con los genes parálogos AGL14 (Rounsley et al., 1995) y AGL19 (Álvarez-Buylla et al., 2000b) de Arabidopsis thaliana, cuya expresión inicialmente se describió como específica de raíz (Rounsley et al., 1995; Álvarez-Buylla et al., 2000b), y el gen ETL de Eucalyptus globulus (Decroocq et al., 1999). Las funciones de estos genes aún no se han definido, sin embargo, según sus características, es posible que sean parcialmente redundantes con las de SOC1 (Nakamura et al., 2005).

El gen TDR3/SOC1 mejor caracterizado de esta rama filogenética es ETL de Eucalyptus globulus, el cual además de expresarse fuertemente en raíces, se detecta en los meristemos apicales inflorescentes y florales. El patrón de expresión de MtSOC1-like es igual al de ETL (Decroocq et al., 1999). En tejidos vegetativos, MtSOC1-like tiene su mayor expresión en raíz. En tejido floral, tras expresarse en los meristemos florales tempranos, se detectan los niveles más altos de expresión de MtSOC1-like en los estadios tardíos de desarrollo floral en los primordios de pétalos y posteriormente en estambres y óvulos. Este patrón de expresión indica que, tanto MtSOC1-like como ETL, además de controlar el tiempo de floración, pueden requerirse para mantener la identidad y función de los órganos florales.

Tanto sus patrones de expresión como sus secuencias conservadas sugieren que los tres genes del grupo TDR3/SOC1 de Medicago truncatula pueden jugar papeles como integradores florales e interactuar con otros genes para integrar las señales necesarias en las vías de tiempo de floración, así como mantener la identidad de los meristemos en estadios tempranos de desarrollo. Probablemente, MtSOC1-like tiene una función adicional en la determinación de la identidad de los órganos florales.

\section{MtSHP: GEN ORTÓLOGO DE LOS GENES SHP1/SHP2 CON EXPRESIÓN EN ÓVULOS}

Los genes MADS-box de función C son responsables de la especificación de la identidad de los órganos reproductivos florales y la determinación del meristemo floral 
(Coen y Meyerowitz, 1991). El gen AGAMOUS (AG) de Arabidopsis thaliana es el gen arquetípico de función C (Yanofsky et al., 1990). AG es miembro del linaje monofilético de genes MADS-box que incluye a SHP1, SHP2 y STK (antes AGL1, AGL5 y AGL11), indicando que estos cuatro genes podrían compartir funciones parcialmente redundantes (Pinyopich et al., 2003). Los genes parálogos SHP1 y SHP2 juegan un papel único en la diferenciación de los márgenes del replum y se requieren para la dehiscencia del fruto en Arabidopsis thaliana (Liljegren et al., 2000). Además, tienen un papel redundante en la determinación de la identidad de carpelo y óvulos (Western y Haughn, 1999; Pinyopich et al., 2003) y se requieren para la formación del estilo y el estigma (Colombo et al., 2010).

Varias especies angiospermas modelo estudiadas hasta el momento se caracterizan por la presencia de dos o más genes pertenecientes al grupo AG: cuatro genes en Arabidopsis thaliana ( $A G$, SHP1, SHP2 y STK), dos genes en Antirrhinum majus (PLE y FAR), cuatro genes en Oryza sativa (OsMADS3 [Kang et al., 1998], OsMADS13 [LópezDee et al., 1999], OsMADS21 [Lee et al., 2003] y OsMADS58 [Yamaguchi et al., 2003]), cuatro genes en Lotus japonicus (LjAGa, LjAGb, LjAGL1 y LjAGL11 [Dong et al., 2005]), etc. En el presente trabajo, se aislaron tres genes pertenecientes a este grupo en la leguminosa modelo Medicago truncatula: MtAGa, MtAGb y MtSHP. Previamente se describió el aislamiento de un cuarto gen, MtSTK, el ortólogo de STK de Medicago truncatula (Hecht et al., 2005).

Los genes duplicados MtAGa y MtAGb se agrupan filogenéticamente con los genes $A G$ de Arabidopsis thaliana y FAR de Antirrhinum majus dentro del linaje euAG. Estos genes parecen haber resultado de una duplicación reciente y se describen con detalle en el CAPÍTULO II. Por otro lado, Medicago truncatula tiene solo un gen perteneciente al linaje PLE, MtSHP. La mayoría de las especies eudicotiledóneas superiores, exceptuando a los miembros de la familia Brassicaceae como Arabidopsis thaliana, poseen solo un gen del linaje PLE (Becker y Theissen, 2003; Kramer et al., 2004; Moore et al., 2005; Zahn et al., 2006). En Arabidopsis thaliana, los genes SHP1 y SHP2 se produjeron por un evento de duplicación génica reciente dentro de este linaje (Moore et al., 2005) y MtSHP es el ortólogo de éstos genes duplicados de Arabidopsis thaliana.

Los porcentajes elevados de homología de secuencia entre MtSHP y sus ortólogos del linaje PLE en Pisum sativum (PSMADS8; Hecht et al., 2005), Lotus japonicus (LjAGL1; 
Dong et al., 2005) y Glycine max (GmACU18208.1; Cheung et al., unpublished), sugieren que este gen está muy conservado en especies leguminosas.

El alineamiento de MtSHP con las proteínas homólogas más cercanas de otras especies revela que posee todas las características comúnmente encontradas en las proteínas MADS-box de clase C. En el extremo N-terminal, precediendo al dominio MADS, MtSHP presenta un fragmento de 15 aminoácidos. La presencia de una secuencia $\mathrm{N}$-terminal que precede al dominio MADS es una característica común a los miembros de la clase C (Jager et al., 2003) que no se encuentra en otros genes MADS-box de tipo MIKC (Purugganan et al., 1995). Sin embargo, se ha demostrado que, al menos en Arabidopsis thaliana, este fragmento no es esencial para los aspectos más importantes de la función génica (Mizukami et al., 1996). Por otro lado, en el extremo C-terminal de MtSHP hay dos regiones cortas altamente conservadas, llamadas "AG motif I" y "AG motif II". La conservación de estos motivos en genes del grupo AG los define como sinapomorfias del mismo. Estos motivos no parecen tener relación con ningún motivo funcional conocido (Kramer et al., 2004).

Se ha sugerido que la función ancestral de los genes de clase $C$ era especificar los órganos reproductivos tanto masculinos como femeninos (Haughn y Somerville, 1988; Winter et al., 1999). Actualmente, los genes de clase $C$ tienen patrones de expresión en los órganos del tercer y cuarto verticilo, lo que probablemente representa la expresión del gen $A G$ ancestral. La mayoría de los genes del grupo $A G$ incluidos en el linaje PLE, suele expresarse en estos órganos (Bradley et al., 1993; Angenent et al., 1993, 1995; Kitahara et al., 2000; Tani et al., 2007; Vrebalov et al., 2009; Tadiello et al., 2009). No obstante, varios miembros del linaje PLE han adquirido patrones de expresión específicos del cuarto verticilo, como SHP1 (Ma et al., 1991) y SHP2 (Savidge et al., 1995) de Arabidopsis thaliana, MdMADS14 (Van der Linden et al., 2002) de Malus domestica y CAG2 (Perl-Treves et al., 1998) de Cucumis sativus. Estos genes se expresan en el carpelo en desarrollo, los óvulos y frecuentemente en semillas y frutos.

La expresión de MtSHP se detecta en la región interna del carpelo, en óvulos y semillas, lo cual ubica a MtSHP en la clase de genes del linaje PLE que se expresan primordialmente en el cuarto verticilo. Además, la ausencia de expresión de MtSHP en los estadios tempranos del desarrollo floral es consistente con la expresión génica de SHP1/SHP2, la cual no se detecta antes de la iniciación del carpelo (Savidge et al., 1995). 
Hasta el momento, PSMADS8 de Pisum sativum era el único gen ortólogo de SHP1/2 en leguminosas cuya expresión se había descrito (Hecht et al., 2005; Navarro, C., Tesis Doctoral, 2001). La expresión de PSMADS8 se detectó en los órganos correspondientes al tercer y cuarto verticilo (Navarro, C. Tesis Doctoral, 2001). El patrón de expresión de MtSHP no se corresponde con el de PsMADS8, ya que MtSHP no se expresa en el tercer verticilo. Sin embargo, los patrones de expresión de los genes del linaje PLE están muy diversificados (Zahn et al., 2006), así que es probable que los genes ortólogos MtSHP y PsMADS8 no sean equivalentes a nivel de expresión pero si a nivel funcional, considerando además las diferencias en la estructura del fruto de ambas especies.

El análisis detallado del patrón de expresión de MtSHP en flores silvestres de Medicago truncatula permite prever sus posibles funciones en el desarrollo floral. El patrón de expresión de MtSHP se limita a una región específica dentro del carpelo, al igual que ocurre con SHP1/SHP2 (Flanagan et al., 1996). Esta región corresponde probablemente a la placenta, cuyo papel es proveer nutrientes a los óvulos en desarrollo, así que MtSHP puede estar involucrado en dicha función. MtSHP también se expresa durante el desarrollo de los óvulos, sugiriendo una función en la regulación de dicho desarrollo. El hecho de que MtSHP se exprese específicamente en estos órganos lo convierte en una herramienta útil para la identificación de tejido de carpelo u óvulos en desarrollo y podría usarse como un marcador temprano de identificación de células destinadas a formar estos tejidos.

\section{MtTM6 Y MtNMH7: GENES DE CLASE B ORIGINADOS POR DUPLICACIÓN GÉNICA, PERTENECIENTES AL LINAJE AP3/DEF}

En Arabidopsis thaliana y Antirrhinum majus, la función B está representada por un par de genes MADS-box: DEFICIENS (DEF) y GLOBOSA (GLO) en Antirrhinum majus y APETALA3 (AP3) y PISTILLATA (PI) en Arabidopsis thaliana. Estos genes se expresan durante el desarrollo de la flor en los órganos del segundo y tercer verticilo y la mutación de cualquiera de ellos causa conversiones homeóticas de pétalos a sépalos y de estambres a carpelos (Bowman et al., 1989; Sommer et al., 1990; Tröbner et al., 1992; Goto y Meyerowitz, 1994; Jack et al., 1994). 
El análisis filogenético de los homólogos de $A P 3 / P I$ ha revelado un complejo patrón de duplicación génica y divergencia de los genes de clase B a lo largo de su historia evolutiva. Los linajes $P I / G L O$ y $A P 3 / D E F$ se generaron tras la duplicación de un gen ancestral $A P 3 / P I$ durante la divergencia de gimnospermas y angiospermas (Aoki et al., 2004; Fukui et al., 2001; Kim et al., 2005; Kramer et al., 1998, 2003; Kramer e Irish 1999, 2000; Mouradov et al., 1999; Purugganan et al., 1995; Stellari et al., 2004). Dentro del grupo $A P 3 / D E F$, antes de la diversificación de las eudicotiledóneas superiores, ocurrió otra duplicación que dio lugar a los linajes parálogos: euAP3 y TM6 (Kramer et al., 1998; Kramer e Irish, 1999).

En Medicago truncatula previamente se aislaron dos genes pertenecientes al linaje PI/GLO, denominados MtPI y MtNGL9. Estos genes fueron caracterizados estructural y funcionalmente, concluyendo que la función de los ortólogos de PI en Medicago truncatula podría haber divergido. MtPI podría haber mantenido un papel predominante durante el desarrollo floral, mientras que MtNGL9 podría estar involucrado en el desarrollo de los nódulos de raíz, al igual que su ortólogo en Medicago sativa, MsNGL9 (Benlloch et al., 2009).

En el presente trabajo se aislaron dos genes, MtTM6 y MtNMH7, pertenecientes al linaje $A P 3 / D E F$. Se confirma que ambos genes pertenecen al grupo $A P 3 / D E F$ por la presencia en la caja MADS de cinco residuos aminoacídicos característicos (Theissen et al., 1996) además de la secuencia (H/Q)YExM, altamente conservada en los genes pertenecientes a este grupo (Kramer et al., 1998). MtTM6 y MtNMH7 se incluyen en los linajes parálogos TM6 y euAP3, respectivamente, indicando que la duplicación génica que dio lugar a estos genes precede a la divergencia de las eudicotiledóneas superiores. Mientras los genes del linaje TM6 conservaron el motivo paleoAP3 y la región C-terminal del antecesor paleoAP3, los genes del linaje euAP3 derivaron en un nuevo motivo, llamado euAP3 (revisado en Kramer et al., 2006). MtTM6 muestra características sinapomórficas comunes con miembros del linaje TM6, como la presencia del motivo paleoAP3. Además, la proteína MtTM6 presenta alta homología con proteínas representativas del linaje TM6 y se agrupa filogenéticamente con las mismas. Por otro lado, MtNMH7 presenta el motivo euAP3 y la proteína MtNMH7 se localiza en el grupo monofilético que incluye proteínas de tipo euAP3. 
Los miembros del linaje TM6 son los genes de clase B menos estudiados, ya que no tienen ortólogos en las especies modelo Arabidopsis thaliana y Antirrhinum majus (Lamb e Irish, 2003). Hasta hoy, no se han descrito patrones de expresión para homólogos de TM6 en leguminosas. Los estudios funcionales más detallados de los genes TM6 se han realizado principalmente en solanáceas como Petunia x hybrida (Rijpkema et al., 2006) o Solanum lycopersicum (de Martino et al., 2006). En éstas especies, que presentan genes tanto del linaje TM6 como del euAP3, se ha visto que los genes TM6 están involucrados en el desarrollo de estambres pero no de pétalos, mientras que los euAP3 juegan un papel tanto en el desarrollo de pétalos como de estambres (de Martino et al., 2006; Rijpkema et al., 2006). Los genes TM6 (o TDR6) de Solanum lycopersicum (de Martino et al., 2006) y GDEF1, el gen TM6 de Gerbera hybrida (Broholm et al., 2010), muestran una expresión débil restringida a los márgenes laterales de los pétalos, aunque no siguen este patrón en los estambres. Se ha sugerido que los genes paleoAP3 (como los TM6) no son capaces de especificar completamente la identidad de los pétalos, pero pueden tener papeles secundarios en la diferenciación de los tipos celulares de éstos órganos (Kramer e Irish, 1999, 2000). MtTM6, el ortólogo de TM6 en Medicago truncatula, se expresa de manera restringida en la capa celular externa tanto de pétalos como de estambres, indicando que este gen posiblemente esta involucrado en la diferenciación de los tipos celulares de la epidermis de los órganos tanto de segundo como de tercer verticilo.

MtTM6 se expresa también en la zona del meristemo floral que da lugar al carpelo, durante los primeros estadios de desarrollo floral, aunque esta expresión es transitoria y desaparece tras el estadio 5 de la ontogenia floral. La expresión en cuarto verticilo se ha descrito para los genes TM6-like de Gerbera hybrida (Broholm et al., 2010), Petunia x hybrida (Rijpkema et al., 2006), Solanum lycopersicum (de Martino et al., 2006) o Vitis vinifera (Poupin et al., 2007), pero aún se desconoce si esta expresión es funcionalmente relevante.

Los genes de clase B representativos del linaje euAP3 son AP3 de Arabidopsis thaliana y DEF de Antirrhinum majus. La expresión de estos genes está restringida a los órganos del segundo y tercer verticilo. Este patrón de expresión se ha observado también para otros genes ortólogos euAP3 en eudicotiledóneas superiores como Malus domestica (Yao et al., 2001) o Petunia x hybrida (Vandenbussche et al., 2004). En leguminosas se ha 
descrito la expresión de LjAP3 (euAP3) en Lotus japonicus, siendo también específica de pétalos y estambres (Hecht et al., 2005.). El ortólogo euAP3 de Medicago truncatula, MtNMH7, se expresa específicamente en pétalos y estambres, en toda la extensión de estos órganos exceptuando la capa celular externa de los mismos. La expresión en estos órganos sugiere la implicación de MtNMH7 en la especificación de los órganos de segundo y tercer verticilo y es típica para los genes de clase B.

Se ha propuesto que los genes de clase B podrían haber adquirido nuevas funciones además del control de la identidad de los órganos florales, ya que se expresan en otros tejidos (Zahn et al., 2005b; Páez-Valencia et al., 2008). En el caso de las leguminosas algunos de estos genes pueden estar involucrados en el desarrollo de nódulos de raíz fijadores de nitrógeno: el gen $M s N M H 7$ inicialmente se describió como específico de nódulos de Medicago sativa (Heard y Dunn, 1995), aunque posteriormente se comprobó su expresión en tejido floral (Zucchero et al., 2001) y GmNMH7 de Glycine max presenta una expresión tanto en flores en desarrollo como en nódulos (Wu et al., 2006). En Medicago truncatula, MtNGL9, gen homólogo a PI/GLO, también presenta expresión en nódulos, aunque no se ha demostrado su función en estos órganos (Benlloch et al., 2009). La expresión en diferentes tejidos reflejaría un proceso de neofuncionalización durante la evolución de genes duplicados, que resulta de modificaciones en las regiones reguladoras de una o ambas copias (Sidow, A., 1996). Los miembros del linaje AP3/DEF estudiados en el presente trabajo, MtTM6 (TM6) y MtNMH7 (euAP3) presentan patrones de expresión específicos de flor y no se detecta expresión en ningún órgano vegetativo de la planta. Es posible que tras la duplicación que dio lugar a estos genes, sus regiones reguladoras se hayan modificado, conllevando la pérdida de expresión en nódulos.

Tanto MtTM6 como MtNMH7 se expresan únicamente en tejido floral, en los órganos del segundo y tercer verticilo. Se observa que ambos se complementan espacialmente dentro de los pétalos y los estambres: mientras el transcrito de MtNMH7 se acumula en los tejidos internos de estos órganos, MtTM6 lo hace en la periferia de los mismos. Estos resultados sugieren que los parálogos MtNMH7 y MtTM6, podrían haber sufrido un proceso de subfuncionalización reguladora, ya que se observa expresión diferencial de los genes MtTM6 y MtNMH7 en cuanto a su localización tisular. Ambos genes han 
experimentado una especialización de sus diferentes subfunciones, pudiendo ser necesaria la actividad combinada de ambos para satisfacer la función del locus ancestral.

Actualmente se está realizando un estudio funcional exhaustivo de MtTM6 y MtNMH7, que complementará los resultados de expresión génica y generará información importante acerca de la función de los genes MADS-box de clase B en el desarrollo de pétalos y estambres en Medicago truncatula. 


\section{CAPÍTULO II}

Caracterización MOLECULAR Y

FUNCIONAL DE

LOS GENES MtAGa

Y MtAGb DE

Medicago

truncatula 



\section{CAPÍTULO II}

Resultados 



\section{CARACTERIZACIÓN MOLECULAR Y FUNCIONAL DE LOS GENES MtAGa Y MtAGb DE Medicago truncatula}

Como se comentó en el capítulo anterior, en el escrutinio de una genoteca de cDNA de ápices florales se aislaron tres clones de cDNA cuyas secuencias corresponden a genes del grupo AGAMOUS (AG) del linaje C (ver apartado 1.5.1, Resultados Capítulo I). Uno de ellos, el clon 14.4.1 (MtSHP), pertenece al linaje PLE y es el ortólogo en Medicago truncatula de los genes SHATTERPROOF1 (Ma et al., 1991; Flanagan et al., 1996) y SHATTERPROOF2 (Ma et al., 1991; Savidge et al., 1995) de Arabidopsis thaliana (ver apartados 1.5 .2 y 1.5.3, Resultados Capítulo I).

Los otros dos clones aislados, el 12.11.1 (MtAGa) y el 15.5.1 (MtAGb), pertenecen al linaje euAG y presentan homología de secuencia con AGAMOUS (AtAG; Bowman et al., 1989) de Arabidopsis thaliana y FARINELLI (FAR, Davies et al., 1999) de Antirrhinum majus. Como se mencionó anteriormente, los genes del linaje euAG se encuentran representados en la mayoría de las plantas modelo por un único gen. Sin embargo, tanto en Medicago truncatula como en otras leguminosas (Pisum sativum, Berbel et al., comunicación personal; Lotus japonicus, Dong et al., 2005) se ha observado la presencia de dos genes parálogos que parecen ser el resultado de una duplicación reciente de dicho gen $e u A G$.

El estudio extensivo de estos genes del linaje euAG duplicados en Medicago truncatula permitirá ver si presentan diversificación funcional y de qué tipo. Además, ayudará a comprender el proceso de desarrollo reproductivo en ésta y otras leguminosas.

\subsection{CARACTERIZACIÓN MOLECULAR DE LOS GENES MtAGa Y MtAGb DE Medicago truncatula}

\subsubsection{Análisis de las secuencias proteicas de MtAGa y MtAGb}

El clon 12.11.1 (MtAGa), de 1208 pb, tiene una región 5' no traducida de 131 pb, una pauta de lectura abierta de 780 pb que codifica una proteína de 260 aminoácidos, un codón de parada de traducción TGA y una región 3’ no traducida de 294 pb. La proteína 
deducida MtAGa tiene un peso molecular calculado de 29,67 kDa y un PI teórico de 9,71. La secuencia de nucleótidos de MtAGa y su traducción en aminoácidos se representa en la Figura 53.

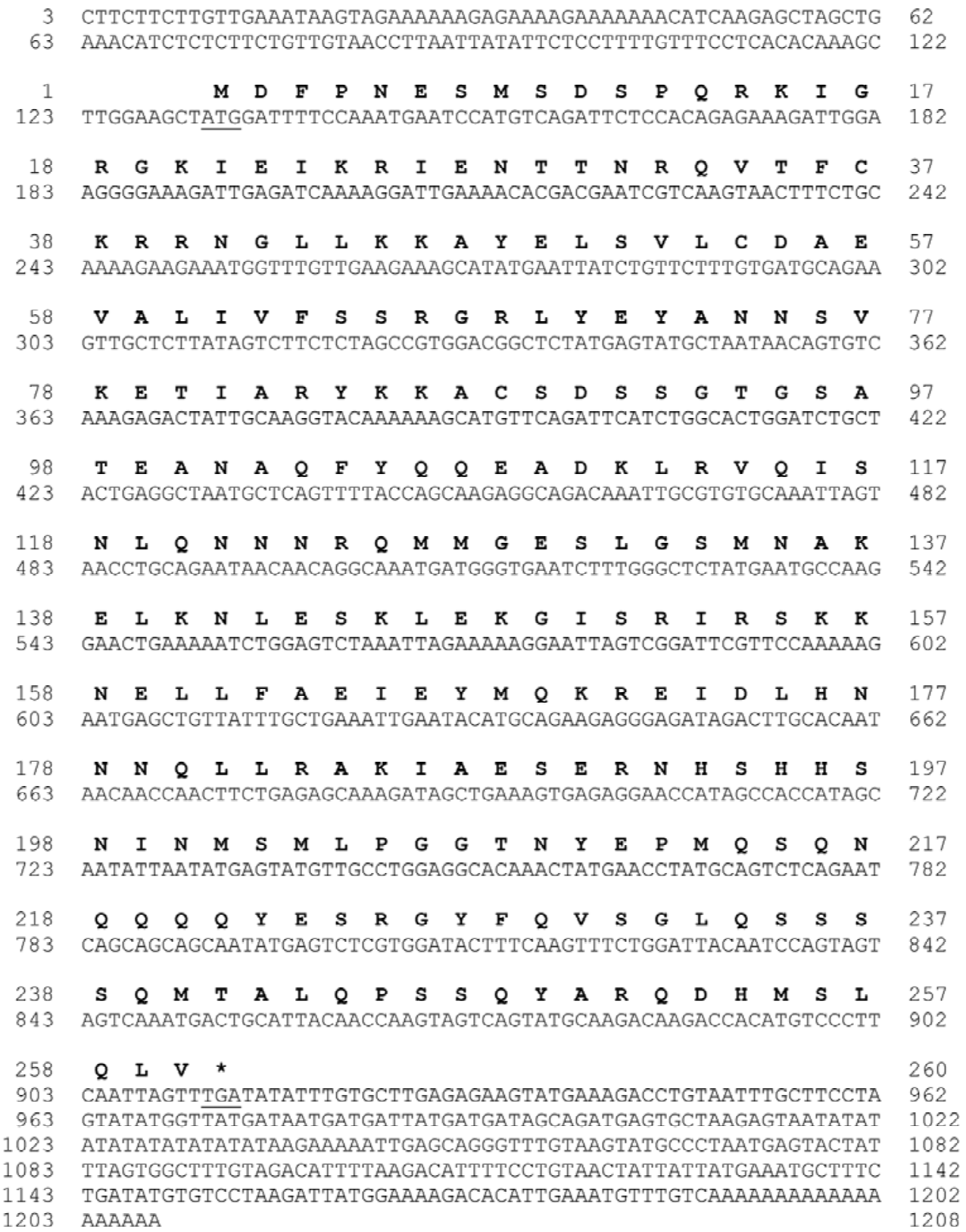

Figura 53. Secuencia del clon MtAGa. Se subrayan los codones de inicio y finalización de la transcripción; en negrita se indica la secuencia de aminoácidos de la proteína deducida.

El clon $15.5 .1(M t A G b)$, de 1099 pb, presenta una región 5' no traducida de 46 pb, una pauta de lectura abierta de 732 pb, un codón de parada de traducción TAA y una región 3' no traducida de 318 pb. La proteína deducida MtAGb, de 244 aminoácidos, tiene un peso molecular calculado de 28,1 kDa y un PI teórico de 9,75. En el escrutinio de la genoteca también se aisló el clon 14.7.2, cuya secuencia es idéntica a la del clon 
MtAGb, solo que carece de un fragmento interno de 42 pb (14 aminoácidos en pauta de lectura de la proteína MtAGb) que está presente en el clon MtAGb. La existencia de un segundo transcrito más corto sugiere que durante el procesamiento el RNA mensajero puede sufrir splicing alternativo, dando lugar a dos transcritos diferentes. En la Figura 54 se muestran la secuencia de nucleótidos y la traducida de aminoácidos de MtAGb, así como el fragmento ausente en el clon 14.7.2.

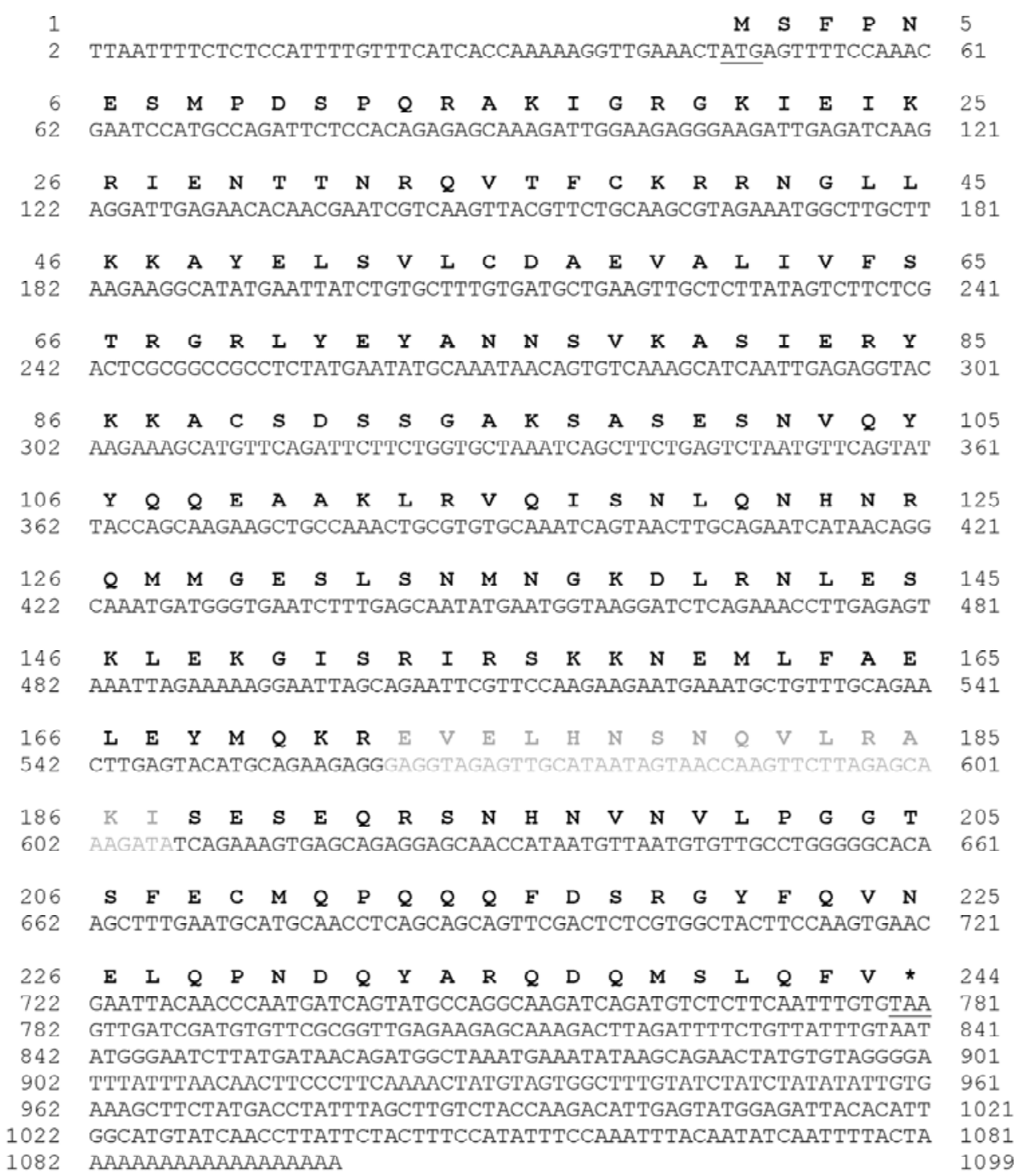

Figura 54. Secuencia del clon MtAGb. Se subrayan los codones de inicio y finalización de la transcripción; en negrita se indica la secuencia de aminoácidos de la proteína deducida. En gris se indica el fragmento de $42 \mathrm{pb}$ ausente en el clon 14.7.2.

Las secuencias proteicas de MtAGa y MtAGb se han colocado en el árbol filogenético de la Figura 55. Este árbol se ha generado utilizando secuencias proteicas codificadas por genes pertenecientes al grupo $A G$ descritos en diferentes especies, incluyendo leguminosas como Pisum sativum, Lotus japonicus y Glycine max. También se ha incluido 
el clon MtSHP (descrito previamente; ver apartados 1.5 .2 y 1.5.3, Resultados Capítulo I) y otros representantes del linaje PLE.

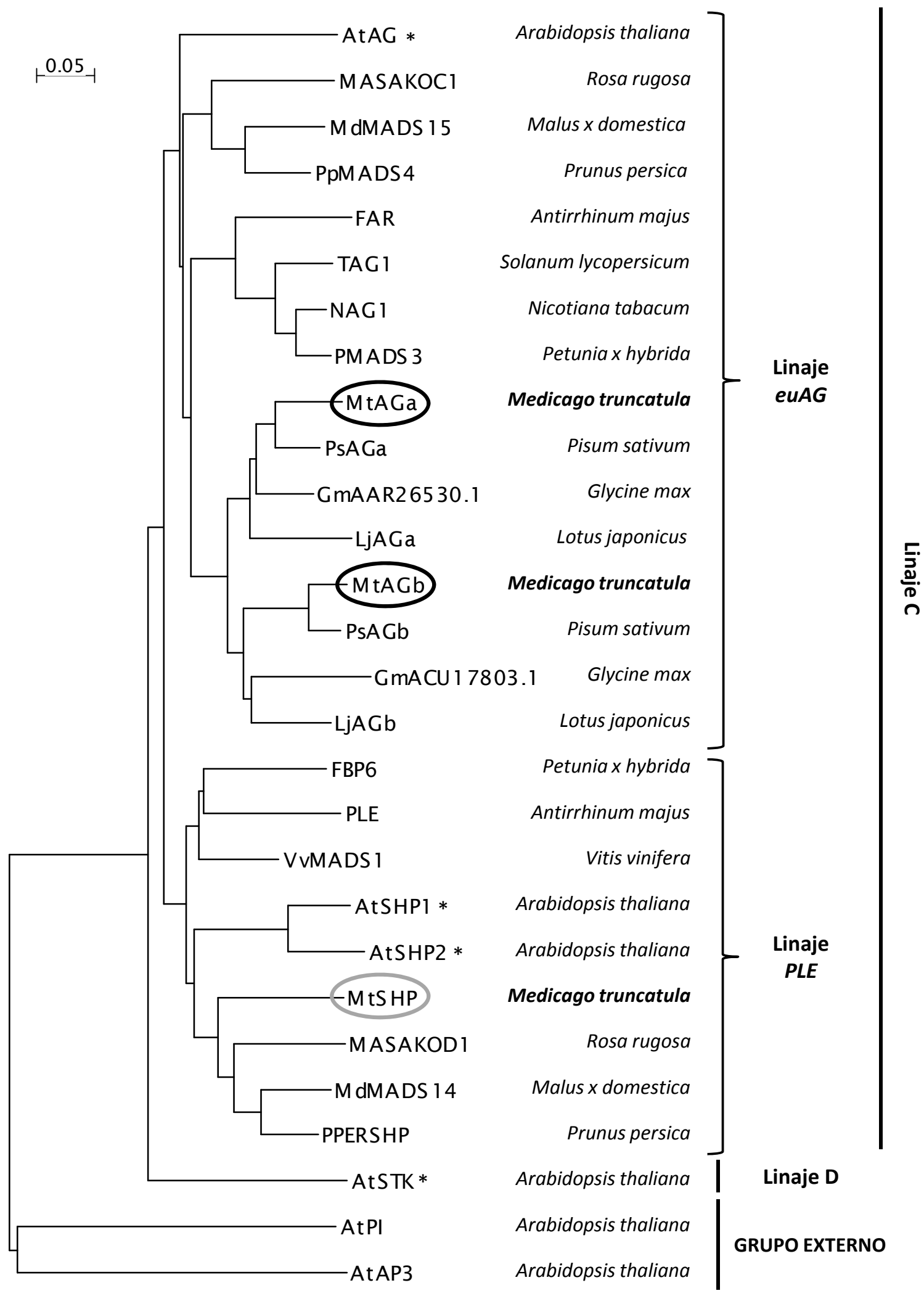

Figura 55. Árbol filogenético de las secuencias proteicas predichas para genes del grupo AG. 
MtAGa y MtAGb se agrupan con genes pertenecientes al linaje euAG (Figura 55). Este linaje está representado por AtAG de Arabidopsis thaliana y FAR de Antirrhinum majus. Además, incluye genes homólogos a AtAG/FAR de otras especies modelo como Rosa rugosa (MASAKOC1), Malus $x$ domestica (MdMADS15), Prunus persica (PpMADS4), Solanum lycopersicum (TAG1), Nicotiana tabacum (NAG1) o Petunia $x$ hybrida (PMADS3). Dentro del linaje euAG, MtAGa y MtAGb están incluidos en un subgrupo que únicamente contiene genes de leguminosas. En este subgrupo, MtAGa forma una rama con sus ortólogos: PsAGa de Pisum sativum, LjAGa de Lotus japonicus y GmAAR26530.1 de Glycine max; MtAGb se agrupa con sus respectivos ortólogos: PsAGb de Pisum sativum, LjAGb de Lotus japonicus y GmACU17803.1 de Glycine max. Este subgrupo está más alejado filogenéticamente de los genes FAR, AtAG y sus respectivos ortólogos en otras plantas modelo.

Las proteínas MtAGa y MtAGb presentan entre sí un 81\% de homología al comparar las secuencias completas de polipéptidos. Presentan un 98\% de homología en la región correspondiente a la caja MADS, $76 \%$ en la región I, $80 \%$ en la región de la caja $\mathrm{K}$ y $68 \%$ en la región C-terminal. En la Tabla 19 se muestran los porcentajes de homología de MtAGa y MtAGb con proteínas codificadas por genes del grupo $A G$ de las leguminosas Pisum sativum, Lotus japonicus y Glycine max, así como FAR de Antirrhinum majus y AtAG de Arabidopsis thaliana.

Figura 55. Árbol filogenético de las secuencias proteicas predichas para genes del grupo AG. Se utilizó la secuencia proteica íntegra de las siguientes proteínas: Arabidopsis thaliana: AtAG (Bowman et al., 1989; Acc NP_567569.3), AtSHP1, AtSHP2 (Ma et al., 1991; Acc NP_191437.1, NP_565986.1), AtSTK (Rounsley et al., 1995; Acc NP_192734.1), Petunia x hybrida: FBP6 (Angenent et al., 1993; Acc CAA48635.1), PMADS3 (Tsuchimoto et al., 1993; Acc CAA51417.1); Antirrhinum majus: FAR (Davies et al., 1999; Acc CAB42988.1), PLE (Bradley et al., 1993; Acc AAB25101.1); Pisum sativum: PsAGa (Berbel et al., unpublished), PsAGb (Navarro, C., Tesis Doctoral, 2001; Acc AAX69069.1); Lotus japonicus: LjAGa, LjAGb (Dong et al., 2005; Acc AAX13303.1, Acc AAX13304.1); Glycine max: GmAAR26530.1 (Huang et al., unpublished; Acc AAR26530.1), GmACU17803.1 (Cheung et al., unpublished; Acc ACU17803.1); Malus $x$ domestica: MdMADS14, MdMADS15 (Van der Linden et al., 2002; Acc CAC80857.1, Acc CAC80858.1); Vitis vinifera: VvMADS1 (Boss et al., 2001; Acc AAK58564.1); Prunus persica: PPERSHP (Tani et al., 2007; Acc ABG75908.1), PpMADS4 (Wu et al., 2004; Acc AAU29513.1); Rosa rugosa: MASAKOD1, MASAKOC1 (Kitahara et al., 2000; Acc BAA90743.1, Acc BAA90744.1); Solanum lycopersicum: TAG1 (Pnueli et al., 1994; Acc AAA34197.1); Nicotiana tabacum: NAG1 (Kempin et al., 1993; Acc AAA17033.1); Medicago truncatula: MtAGa, MtAGb, MtSHP (este trabajo). Las proteínas MtAGa y MtAGb se encierran en óvalos negros, MtSHP en un óvalo gris y las proteínas del grupo AG de Arabidopsis thaliana se señalan con un asterisco. El árbol se enraizó con AtPI y AtAP3 de Arabidopsis thaliana (Acc NP_197524.1, NP_191002.1). 
Tabla 19. Porcentajes de homología (\%) de aminoácidos entre diferentes regiones de a) MtAGa y proteínas del linaje euAG de leguminosas, Antirrhinum majus y Arabidopsis thaliana, b) MtAGb y proteínas del linaje euAG de leguminosas, Antirrhinum majus y Arabidopsis thaliana

\begin{tabular}{|c|c|c|c|c|c|}
\cline { 2 - 6 } \multicolumn{1}{c|}{ a) MtAGa } & Secuencia completa & Caja MADS & Región I & Caja K & Región C-terminal \\
\hline PsAGa & $\mathbf{9 4}$ & 98 & 88 & 100 & 85 \\
\hline GmAAR26530.1 & $\mathbf{8 8}$ & 98 & 84 & 93 & 72 \\
\hline LjAGa & $\mathbf{8 5}$ & 98 & 88 & 97 & 64 \\
\hline FAR & $\mathbf{7 1}$ & 95 & 72 & 80 & 40 \\
\hline AtAG & $\mathbf{6 7}$ & 96 & 64 & 72 & 44 \\
\hline
\end{tabular}

\begin{tabular}{|c|c|c|c|c|c|}
\cline { 2 - 6 } \multicolumn{1}{c|}{ b) MtAGb } & Secuencia completa & Caja MADS & Región I & Caja K & Región C-terminal \\
\hline PsAGb & $\mathbf{9 3}$ & 100 & 92 & 91 & 88 \\
\hline LjAGb & $\mathbf{8 2}$ & 96 & 80 & 83 & 70 \\
\hline GmACU17803.1 & $\mathbf{7 6}$ & 93 & 84 & 82 & 63 \\
\hline FAR & $\mathbf{6 8}$ & 93 & 68 & 70 & 50 \\
\hline AtAG & $\mathbf{6 7}$ & 95 & 60 & 65 & 50 \\
\hline
\end{tabular}

Ps: Pisum sativum; Lj: Lotus japonicus; Gm: Glycine max; FAR: FARINELLI de Antirrhinum majus; At: Arabidopsis thaliana

Dos proteínas de especies cercanas son consideradas ortólogas cuando presentan una homología de 75 - 90\% (Dayhoff et al., 1978). Según los porcentajes de homología de secuencia observados, se podría decir que MtAGa, PsAGa, LjAGa y GmAAR26530.1 son probablemente proteínas ortólogas, así como MtAGb, PsAGb, LjAGb y GmACU17803.1. Ambas proteínas de Medicago truncatula tienen una homología de 67 - 71\% con las proteínas referentes del linaje euAG FAR de Antirrhinum majus y AtAG de Arabidopsis thaliana.

En la Figura 56 se representa un alineamiento múltiple entre MtAGa, MtAGb y las proteínas incluidas en la Tabla 19. Puede verse que todas ellas conservan en el extremo C-terminal residuos de dos motivos cortos altamente conservados en las proteínas del grupo AG, que han sido descritos por Kramer et al. (2004) y se denominan "AG motif I" y "AG motif II". Otra característica común a los genes MADS-box del linaje "C" y que se observa en la Figura 56 es la presencia de una secuencia en la región $\mathrm{N}$-terminal que precede al dominio MADS (Jager et al., 2003). Estas características de secuencia, propias de las proteínas del grupo AG, se observaron también en la proteína de Medicago truncatula del linaje PLE, MtSHP (ver apartado 1.5.2, Resultados Capítulo I) 


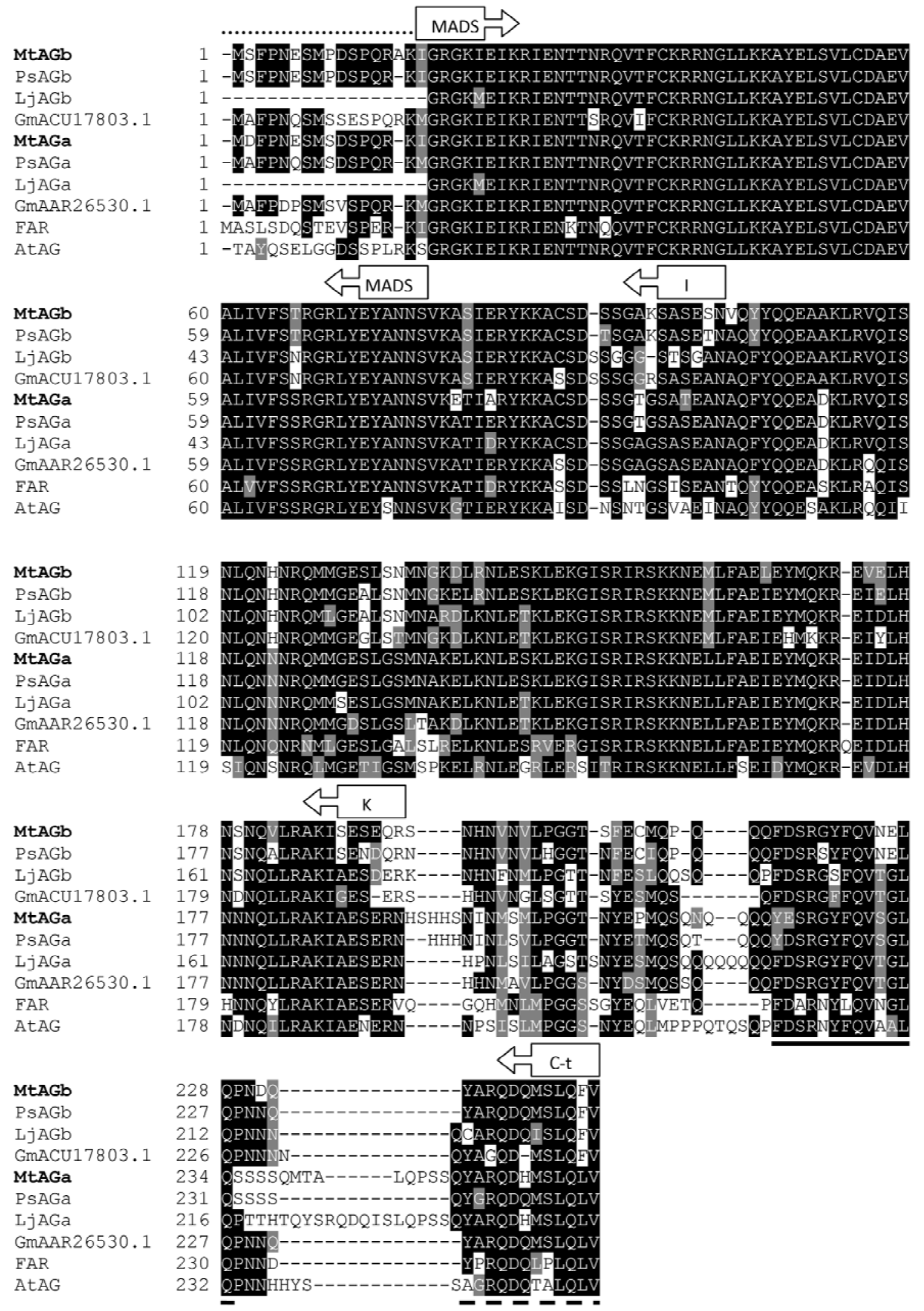

Figura 56. Alineamiento de las secuencias proteicas de MtAGa, MtAGb y de genes MADS-box del linaje euAG, grupo $A G$, con las que presenta homología. Las regiones sombreadas corresponden a aminoácidos conservados. Los dominios MADS y K así como las regiones I y C-terminal se señalan con flechas. El motivo "AG motif I" se subraya con una línea continua y el motivo "AG motif II" con una línea discontinua. Una línea de puntos indica la secuencia N-terminal previa al dominio MADS característica de los genes de tipo " $C$ ". 


\subsubsection{Análisis de las secuencias genómicas de MtAGa y MtAGb}

Se realizó una comparación de las secuencias de los clones MtAGa y MtAGb con las secuencias incluidas en diferentes bases de datos mediante BLAST. MtAGa está parcialmente contenido en la secuencia del EST s13dNF65G09GS068_462456mth2132a8 (GenBank CX539597.1). Esta secuencia incluye el fragmento $11-610$ pb del clon MtAGa.

A día de hoy, la secuencia genómica de MtAGa no se encuentra en las bases de datos. Por ello, se ha intentado obtener esta secuencia mediante la amplificación de DNA genómico con los oligonucleótidos específicos que se describen en la Tabla 10 (Materiales y Métodos). Algunos autores han observado que los genes del grupo AG tienen una estructura intrón/exón particular (Tandre et al., 1998; Rutledge et al., 1998; Jager et al., 2003). Incluso, las mismas posiciones de los intrones se han descrito en genes MADS-box no pertenecientes a este grupo (Sundström et al., 1999), lo que sugiere que la estructura intrón/exón ha sido un rasgo muy conservado durante la evolución de los genes MIKC. (Jager et al., 2003). Con estas premisas, se ha usado la estructura genómica de genes del grupo $A G$ de leguminosas como punto de inicio para buscar intrones en MtAGa.

La secuencia genómica amplificada de MtAGa (Anexo 1) incluye los exones II (parcial), III - VII y los intrones correspondientes. Los intrones presentan los extremos esenciales esperados "GT-AG" (Mount, S.M., 1982), a excepción del intrón III, que presenta extremos "GC-AG" que son menos comunes (Kitamura-Abe et al., 2004). Se intentó amplificar el fragmento de DNA genómico correspondiente a la región de los exones I y II, pero no hubo éxito en esta amplificación, posiblemente debido a la presencia de un intrón de gran tamaño, que se ha descrito en varios genes de clase C. En los genes homólogos a AtAG, este intrón tiene entre 3-5 kb de longitud (Brunner et al., 2000). En leguminosas, los genes ortólogos de MtAGa, LjAGa (secuencia genómica chr6.CM0118.440.nd; http://www.kazusa.or.jp/lotus/) y GmAAR26530.1 (secuencia genómica Glyma13g29510.1; http://www.phytozome.net), presentan entre los exones I y II un intrón de 4666 pb y 3972 pb, respectivamente. Considerando estos datos, a fin de poder representar gráficamente la estructura genómica de $M t A G a$, se ha supuesto la presencia de un intrón de $\sim 4000$ pb en el mismo sitio que en los dos genes ortólogos mencionados. Este patrón de intrones/exones de MtAGa está ilustrado en la Figura 57. 
a)

\begin{tabular}{llll}
\hline Exón & Longitud $(\mathbf{p b})$ & Intrón & Longitud $(\mathbf{p b})$ \\
\hline I & 227 & I & 4000 \\
II & 82 & II & 119 \\
III & 62 & III & 1408 \\
IV & 100 & IV & 149 \\
V & 42 & V & 120 \\
VI & 42 & VI & 99 \\
VII & 228 & & \\
\hline
\end{tabular}

b)
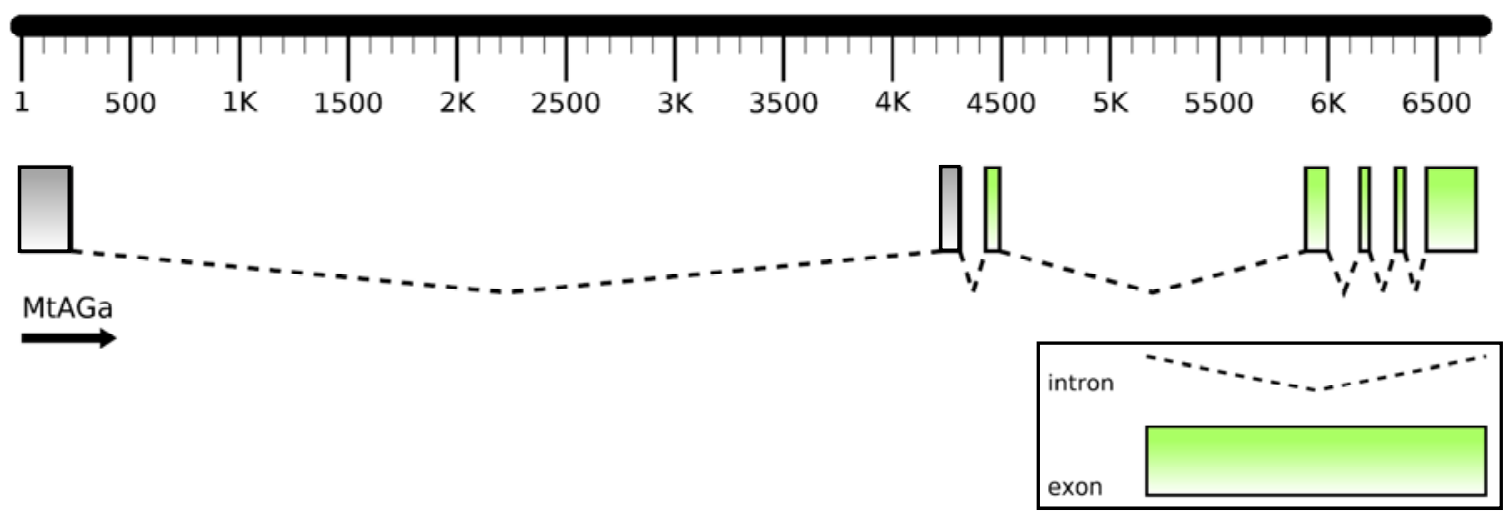

Figura 57. Estructura genómica del gen MtAGa. a) Longitud, en pares de bases, de los exones e intrones de MtAGa. En gris se indican los tamaños supuestos de los exones e intrón no secuenciados. b) Diagrama de la estructura genómica de MtAGa. Los rectángulos representan exones y las líneas punteadas intrones. Los rectángulos grises y la línea punteada entre ellos conforman el fragmento no secuenciado. En ambos casos la numeración comienza en el primer nucleótido del codón de inicio de transcripción del cDNA y termina en el último nucleótido del codón de terminación del mismo.

El clon MtAGb se encuentra en dos secuencias de clones genómicos de Medicago truncatula: mth2-30e7 (GenBank AC137837.4), en el cual la secuencia genómica de MtAGb está ubicada en antisentido entre las bases 37.642 y 33.105, y mth2-76i7 (GenBank AC153460.24), en el cual se localiza en sentido entre las bases 81.433 y 85.970. Ambas secuencias son idénticas. MtAGb se divide en 7 exones (239, 82, 62, 100 , 42,42 y $178 \mathrm{pb}$ ) y 6 intrones. Todos los intrones presentan los extremos esenciales esperados "GT-AG" (Mount, S.M., 1982). La secuencia genómica que incluye la región codificante de MtAGb se encuentra en el Anexo 2.

Como se mencionó previamente, en el escrutinio de la genoteca de cDNA de ápices florales además de aislar el clon MtAGb (15.5.1), también se aisló el clon 14.7.2, que carece de una región de 42 pb (14 aminoácidos), presente en MtAGb. Probablemente, ambos clones corresponden al mismo gen, MtAGb, que puede transcribirse de dos 
maneras mediante un proceso de splicing alternativo. Estas dos formas han sido denominadas MtAGbL ("Long", forma larga) y MtAGbS ("Short", forma corta). En la Figura 58 se presenta un esquema de la estructura genómica de MtAGb, en el que se distinguen los dos posibles transcritos identificados.

a)

\begin{tabular}{lclc}
\hline Exón & Longitud $(\mathbf{p b})$ & Intrón & Longitud (pb) \\
\hline I & 239 & I & 3007 \\
II & 82 & II & 157 \\
III & 62 & III & 105 \\
IV & 100 & IV & 119 \\
V & 42 & V & 320 \\
VI & 42 & VI & 95 \\
VII & 178 & & \\
\hline
\end{tabular}

b)

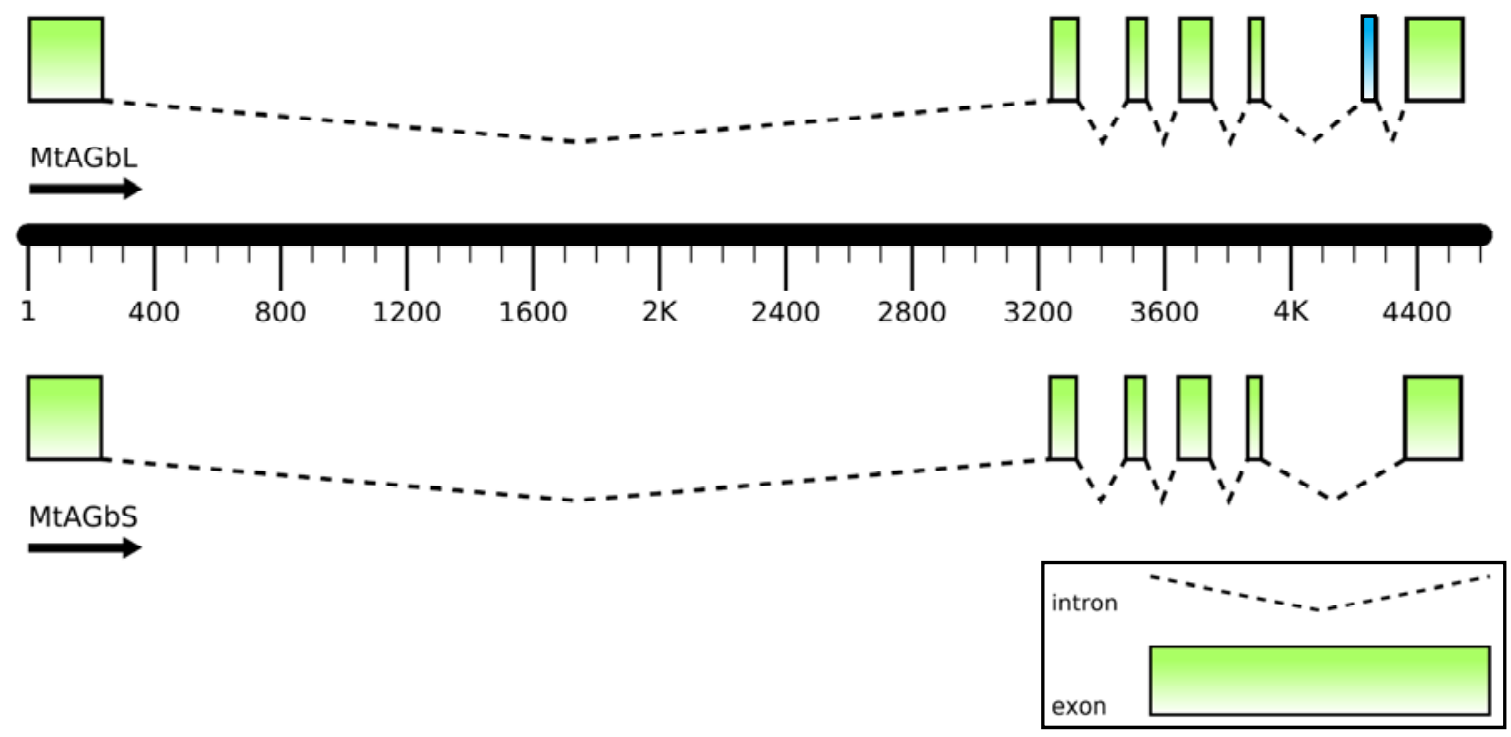

Figura 58. Estructura genómica del gen MtAGb. a) Longitud, en pares de bases, de los exones e intrones de MtAGb. En gris se indica el exón que MtAGbS pierde por splicing alternativo. b) Diagrama de la estructura genómica de MtAGbL y MtAGbS. Los rectángulos representan exones y las líneas punteadas intrones. El rectángulo azul indica el exón que MtAGbS pierde por splicing alternativo. En ambos casos la numeración comienza en el primer nucleótido del exón que contiene el codón de inicio de transcripción del cDNA y termina en el último nucleótido del exón que contiene el codón de terminación del mismo.

Para confirmar que MtAGbL y MtAGbS son dos formas del gen MtAGb que efectivamente se transcriben a partir de DNA genómico de Medicago truncatula, se realizó una PCR utilizando como molde CDNA obtenido a partir de RNA total de ápices florales de Medicago truncatula. Se utilizaron los oligonucleótidos específicos "MtAGb 
splicing dir" y "MtAGb splicing rev" (ver Tabla 10, Materiales y Métodos), que amplifican desde el extremo 3' del exón 5 hasta el extremo 5' del exón 7. En esta amplificación, se obtuvieron fragmentos que indican que existen en efecto dos transcritos del gen MtAGb (Figura 59).

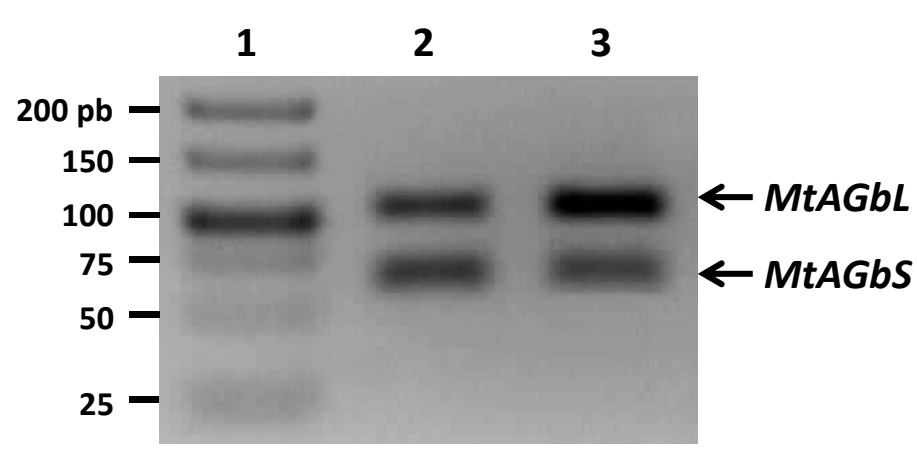

MtAGb posee un intrón de 3007 pb (intrón I) situado tras el exón que contiene la caja MADS. Varios genes de clase $\mathrm{C}$ de diferentes plantas modelo como: Arabidopsis thaliana, Antirrhinum majus, Populus trichocarpa, Petunia x hybrida o Solanum lycopersicum, también presentan un intrón de gran tamaño en la misma posición (Yanofsky et al., 1990; Bradley et al., 1993; Tsuchimoto et al., 1993; Brunner et al., 2000; Hong et al., 2003). Hay evidencias que sugieren que este intrón es esencial para la correcta expresión de los genes del grupo $A G$, ya que contiene secuencias reguladoras de la transcripción que contribuyen al control de la expresión espacial y temporal (Sieburth y Meyerowitz, 1997; Busch et al., 1999; Deyholos y Sieburth, 2000).

En la secuencia del intrón I de MtAGb se han encontrado cajas de unión de elementos reguladores. Se detectan tres secuencias consenso de sitio de unión de LFY (CCANTG[T/G]; Parcy et al., 1998; Busch et al., 1999) en las posiciones 1674, 2701 y 2952 del intrón (ver Anexo 2). Además, se utilizó el programa MORPHEUS (http://biodev.cea.fr/morpheus/) que identifica los sitios de unión de LFY en el intrón mediante la matriz de dicho factor de transcripción (Moyroud et al., 2011). El programa identificó varios posibles sitios de unión, de los cuales los cuatro mejor puntuados (posiciones 1350, 1668, 2415 y 2946) se indican en el esquema de la secuencia genómica de MtAGb (ver Anexo 2). Cabe mencionar, que el sitio de unión de LFY mejor puntuado por el programa (TATATGCCATTGTCAAACA, posición 2946) coincide con una de las secuencias consenso identificadas inicialmente (posición 2952). 
Las proteínas con dominio MADS se unen a secuencias de 10 pb conocidas como cajas CArG (CC[A/T] $]_{6}$ GG; Dolan y Fields, 1991; Treisman, R., 1992; Shore y Sharrocks, 1995), cuya presencia se ha descrito en los intrones grandes de los ortólogos de $A G$ estudiados (Hong et al., 2003). El intrón I de MtAGb contiene dos cajas CArG en las posiciones 563 y 993. Además, se observa en la posición 1087 la presencia de un motivo llamado caja aAGAAT (secuencia consenso AGAATCTNTGNTNACGTCA), que se encuentra en los ortólogos de $A G$, a excepción de PLE, y que aún se desconoce su función (Hong et al., 2003). Todas estas características se muestran en el Anexo 2.

Davies et al., (1999) describen la presencia de una secuencia de 70 pb altamente conservada en los intrones consecutivos a la caja MADS en FAR (AJ239057), PLE (Bradley, Carpenter y Coen, unpublished), AtAG (ATF13C5) y PTAG (AF052570). También se ha encontrado en el intrón equivalente en PsAGb de Pisum sativum (Navarro, C., Tesis Doctoral, 2001). Este fragmento incluye una repetición directa de la secuencia CCAATCA (Davies et al., 1999), que es un sitio de unión para las proteínas que se unen a CCAAT(Mantovani, R., 1998). En MtAGb, este fragmento se ha identificado en la posición 1745 - 1813 del intrón I, incluyendo también la repetición directa mencionada.

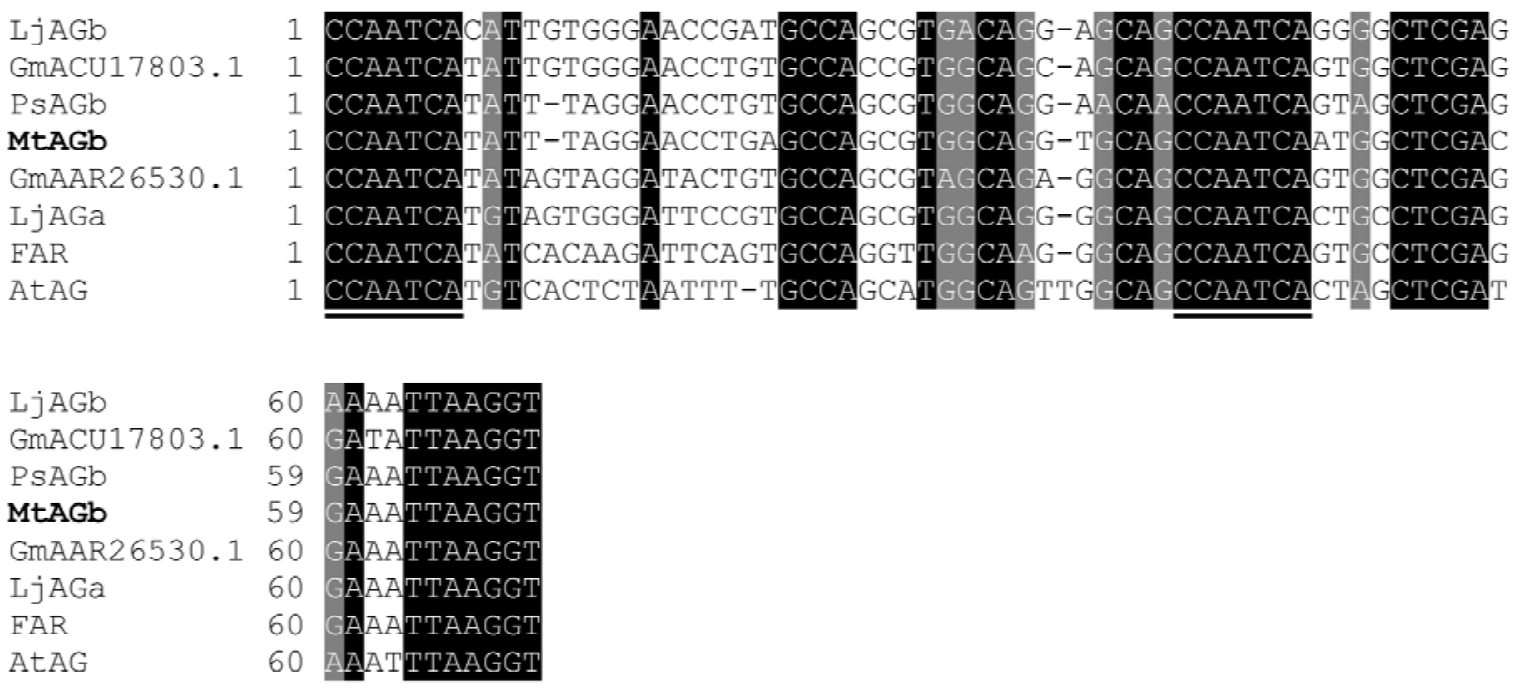

Figura 60. Alineamiento del fragmento de 70 pb altamente conservado en el intrón I de MtAGb con otros genes del linaje euAG. MtAGb de Medicago truncatula (Acc AC153460.24 y AC137837.4), LjAGa y LjAGb de Lotus japonicus (chr6.CM0118.440.nd, chr4.CM0046.1710.r2.m), PsAGb de Pisum sativum (Navarro, C., Tesis Doctoral, 2001), GmACU17803.1 y GmAAR26530.1 de Glycine max (Glyma08g12730.1 y Glyma13g29510.1), FAR de Antirrhinum majus (Davies et al., 1999; Acc AJ239057.1) y AtAG de Arabidopsis thaliana (Bevan et al., unpublished; Acc AL021711.2). La secuencia "CCAATCA" repetida se subraya con una línea continua. 
En la Figura 60 se muestra un alineamiento de este fragmento de $70 \mathrm{pb}$ de MtAGb con los fragmentos equivalentes de FAR de Antirrhinum majus (Davies et al., 1999), AtAG de Arabidopsis thaliana (Bevan et al., unpublished), LjAGa y LjAGb de Lotus japonicus (http://www.kazusa.or.jp/lotus/), GmAAR26530.1 y GmACU17803.1 de Glycine max (http://www.phytozome.net) y PsAGb de Pisum sativum (Navarro, C., Tesis Doctoral, 2001).

\subsubsection{Análisis Southern blot}

Para determinar el número de copias de MtAGa y MtAGb en el genoma de Medicago truncatula, se realizó un análisis Southern blot utilizando DNA genómico del genotipo silvestre digerido con los enzimas de restricción Notl, BamHI y Hindlll. Como sondas se utilizaron fragmentos de $241 \mathrm{pb}$ y $215 \mathrm{pb}$ de los clones MtAGa y MtAGb, respectivamente. Estos fragmentos incluyen los últimos nucleótidos de la caja $\mathrm{K}$, el resto de región codificante, el codón de terminación y un fragmento de la región 3' no codificante. Los oligonucleótidos que amplifican estos fragmentos están especificados en la Tabla 10 (Materiales y Métodos). En la Figura 61 se muestra el resultado de este análisis.

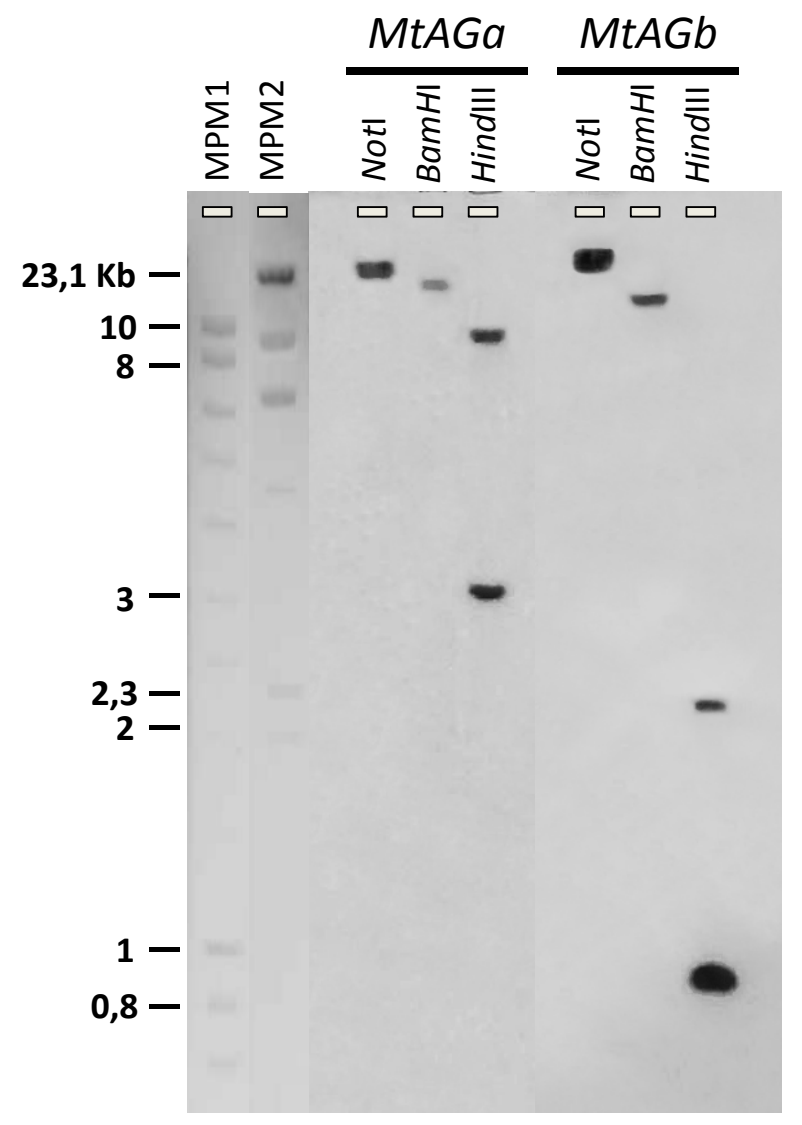

Figura 61. Análisis Southern blot de los genes MtAGa y MtAGb. El DNA genómico de Medicago truncatula de genotipo silvestre se digirió con los enzimas Notl, BamHl y Hindlll y se hibridó con las sondas MtAGa y MtAGb. MPM1 y MPM2 corresponden a dos marcadores de peso molecular distintos. 
El patrón de una sola banda obtenido para la digestión con Notl y BamHI corresponde a lo esperado si los genes son de copia única. La presencia de dos bandas en el carril correspondiente a la digestión con HindIII se debe, en el caso de MtAGb, a la presencia de este sitio de restricción en la secuencia de la sonda. En MtAGa no se encuentra el sitio de restricción en la secuencia de la sonda, pero probablemente está incluido en un intrón localizado justo tras el codón de terminación del gen, ya que la secuencia genómica de la región 3' no codificante de este gen aún se desconoce.

\subsubsection{Patrón de expresión de MtAGa y MtAGb}

Se analizó el patrón de expresión de ambos genes mediante hibridación Northern blot en diferentes tejidos de la planta (Figuras 62 y 65). Como sonda se usó la región Cterminal del cDNA de cada gen, que es la región más divergente entre ambos genes, a fin de evitar hibridación cruzada. El análisis del patrón de expresión tisular se realizó mediante hibridación in situ en ápices inflorescentes y frutos jóvenes de Medicago truncatula (Figuras 63, 64, 66 y 67).

\subsubsection{Patrón de expresión de MtAGa}

Mediante hibridación Northern blot, la expresión de MtAGa se detecta intensa en flores y leve en fruto. No se detecta en los demás tejidos analizados (Figura 62).

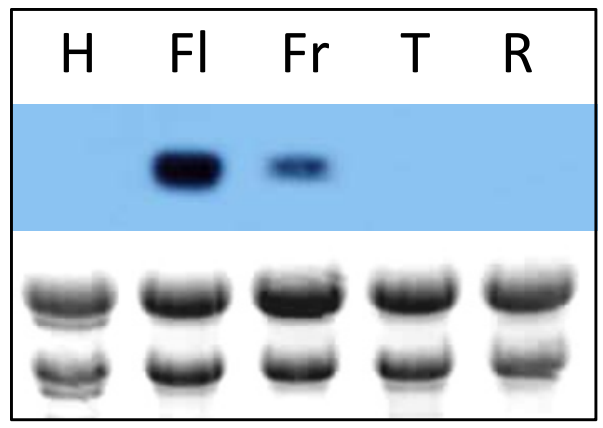

Figura 62. Análisis del patrón de expresión de MtAGa mediante Northern blot. Se utilizó RNA de diferentes tejidos de la planta: hoja (H), flor (FI), fruto (Fr), tallo (T) y raíz (R).

Los resultados de la hibridación in situ muestran que el transcrito de MtAGa se detecta en todo el meristemo floral desde el estadio 2 de desarrollo floral (Figura 63, a). En el estadio 4, cuando se han diferenciado los primordios comunes, MtAGa aún se expresa de manera general en el meristemo floral, aunque disminuye su intensidad en las capas internas del meristemo así como en los primordios de sépalo (Figura 63, b). 

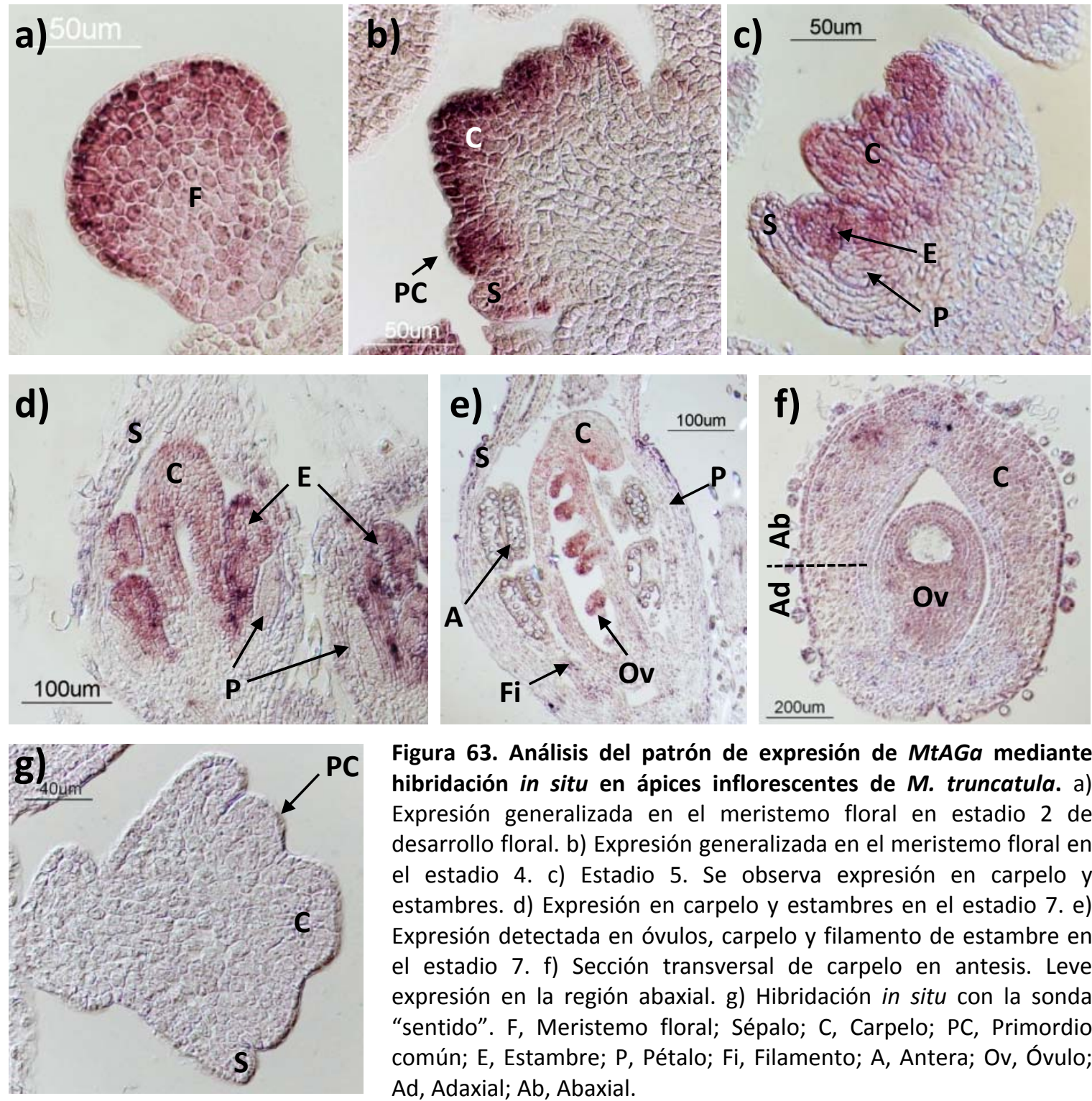

Figura 63. Análisis del patrón de expresión de MtAGa mediante hibridación in situ en ápices inflorescentes de $M$. truncatula. a) Expresión generalizada en el meristemo floral en estadio 2 de desarrollo floral. b) Expresión generalizada en el meristemo floral en el estadio 4. c) Estadio 5. Se observa expresión en carpelo y estambres. d) Expresión en carpelo y estambres en el estadio 7. e) Expresión detectada en óvulos, carpelo y filamento de estambre en el estadio 7. f) Sección transversal de carpelo en antesis. Leve expresión en la región abaxial. g) Hibridación in situ con la sonda "sentido". F, Meristemo floral; Sépalo; C, Carpelo; PC, Primordio común; E, Estambre; P, Pétalo; Fi, Filamento; A, Antera; Ov, Óvulo; Ad, Adaxial; Ab, Abaxial.

Cuando en el estadio 5 se diferencian los primordios de pétalos y estambres, la expresión se observa en el carpelo y en los primordios de estambre, no detectándose en sépalos ni en primordios de pétalo (Figura 63, c). Durante el estadio 6 la expresión de MtAGa se mantiene en los órganos del tercer y cuarto verticilo (Figura 63, d). Finalmente, en el estadio 7, tras la diferenciación de las anteras, la expresión se detecta principalmente en los óvulos, aunque puede observarse expresión leve en la región distal del carpelo y en los filamentos de estambres (Figura 63, e). En algunas secciones de flores en estadios $6-7$ pudo observarse que la expresión tendía a ser más intensa en la mitad longitudinal correspondiente a la región abaxial del carpelo. Debido a la dificultad para manipular las flores en dichos estadios, se hibridaron in situ cortes transversales de carpelos de flores en antesis para corroborar este resultado. En general, 
la expresión de MtAGa en estos tejidos es leve, aunque puede detectarse mayor concentración de transcrito en la región abaxial del carpelo y en los óvulos (Figura 63,f). No se detectó señal de hibridación en ninguna sección de tejido hibridada con la sonda "sentido", utilizada como control negativo (Figura 63, g).

También se realizaron hibridaciones in situ en frutos de Medicago truncatula en el estadio de desarrollo "Pod age: 6 DPP (días post-polinización)" (Wang y Grusak, 2005). En la Figura 64 (a-c) se muestra un corte longitudinal paralelo al eje de enrollado del fruto, en el que puede verse la expresión del gen concentrada en la epidermis de la semilla. No se detectó ninguna señal de hibridación en tejido hibridado con la sonda "sentido" (Figura 64, d).
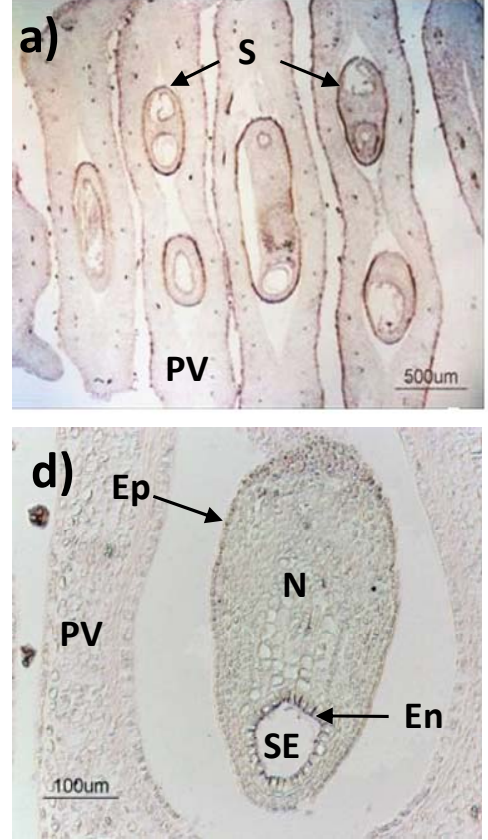
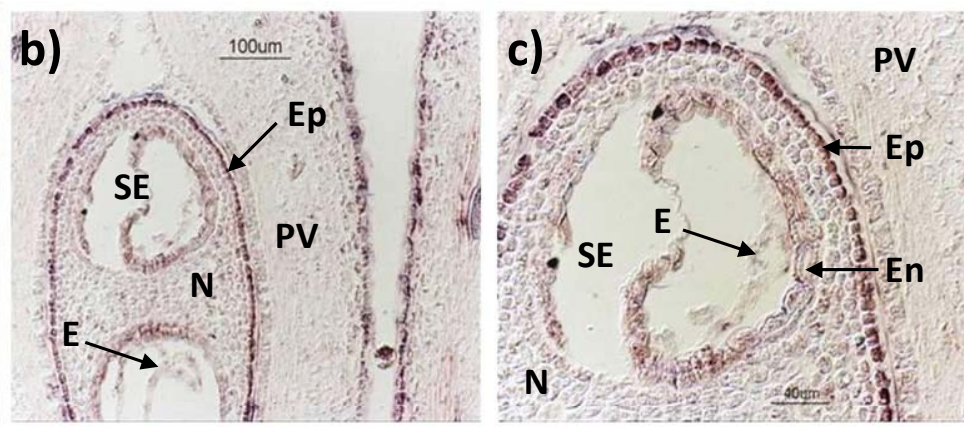

Figura 64. Análisis del patrón de expresión de MtAGa en frutos. Patrón de expresión mediante hibridación in situ en corte longitudinal del fruto y la semilla de Medicago truncatula. a) Se distinguen las semillas y el tejido de la vaina. b) Semilla. MtAGa se expresa en la epidermis de la semilla. c) Detalle de la expresión en la epidermis de la semilla. d) Hibridación in situ con la sonda "sentido". PV, Pared de la vaina; S, Semilla; N, Nucela; SE, Saco embrionario; En, Endotelio; E, Endospermo; Ep, Epidermis.

\subsubsection{Patrón de expresión de MtAGb}

La expresión de MtAGb, analizada mediante Northern blot, se detecta en flores y frutos. No se detecta en los demás tejidos analizados (Figura 65).

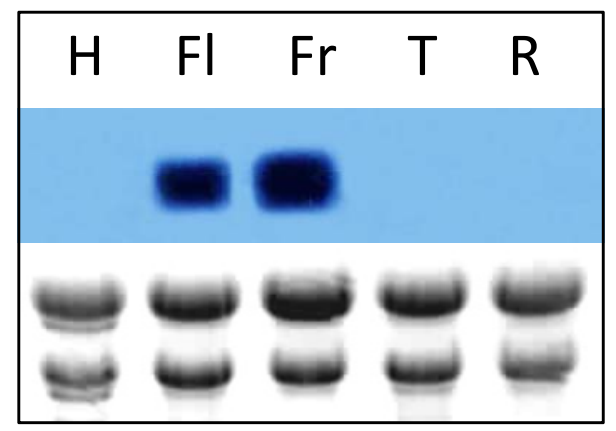

Figura 65. Análisis del patrón de expresión de MtAGb mediante Northern blot. Se utilizó RNA de diferentes tejidos de la planta: hoja $(\mathrm{H})$, flor $(\mathrm{Fl})$, fruto $(\mathrm{Fr})$, tallo (T) y raíz $(R)$. 
La hibridación in situ muestra que el transcrito de MtAGb se detecta desde el estadio 2 de desarrollo floral en la región del meristemo floral que dará lugar a los verticilos internos (Figura 66, a).
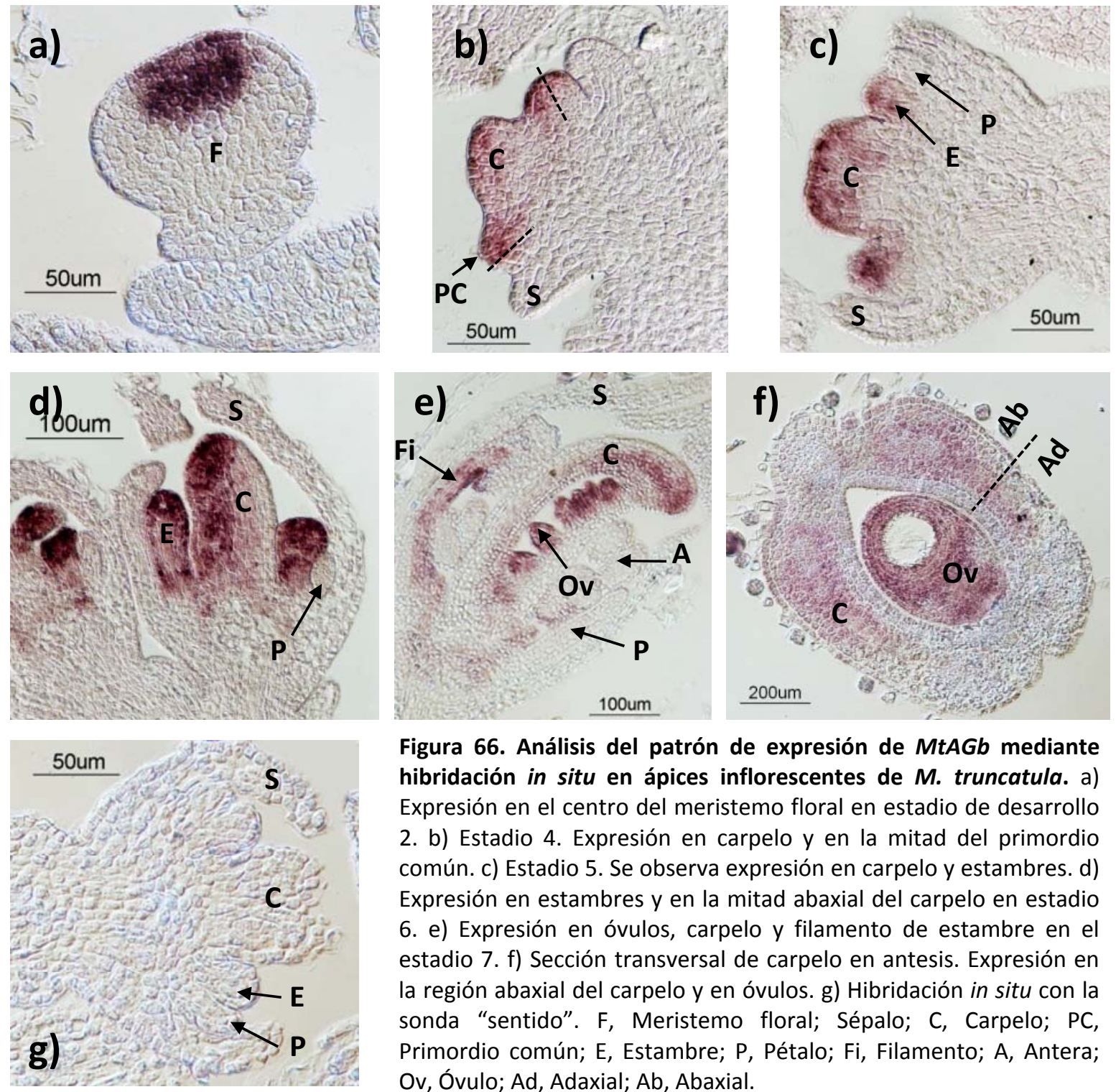

Figura 66. Análisis del patrón de expresión de MtAGb mediante hibridación in situ en ápices inflorescentes de $M$. truncatula. a) Expresión en el centro del meristemo floral en estadio de desarrollo 2. b) Estadio 4. Expresión en carpelo y en la mitad del primordio común. c) Estadio 5. Se observa expresión en carpelo y estambres. d) Expresión en estambres y en la mitad abaxial del carpelo en estadio 6. e) Expresión en óvulos, carpelo y filamento de estambre en el estadio 7. f) Sección transversal de carpelo en antesis. Expresión en la región abaxial del carpelo y en óvulos. g) Hibridación in situ con la sonda "sentido". F, Meristemo floral; Sépalo; C, Carpelo; PC, Primordio común; E, Estambre; P, Pétalo; Fi, Filamento; A, Antera; Ov, Óvulo; Ad, Adaxial; Ab, Abaxial.

En el estadio 4 la expresión se sitúa en el carpelo y en la región de los primordios comunes que dará lugar a los estambres (Figura 66, b). En el estadio 5, cuando se han diferenciado los primordios de estambres y pétalos, la expresión de MtAGb sigue presente en el carpelo y se observa también en los primordios de estambres (Figura 66, c). En el estadio 6, la expresión se mantiene en el carpelo y los estambres. Puede observarse que la expresión en el carpelo es más intensa en la mitad abaxial del mismo (Figura 66, d). En estadios tardíos del desarrollo floral la expresión de MtAGb se detecta en óvulos, en la región distal del carpelo y en los filamentos de estambres (estadio 7, 
Figura 66, e). En cortes transversales de carpelos de flores en antesis, la expresión de MtAGb se detecta en los óvulos y en la región abaxial del carpelo (Figura 66, f). No se detectó ninguna señal en secciones de tejido hibridadas con la sonda "sentido", utilizada como control negativo (Figura 66, g).

También se realizaron hibridaciones in situ en frutos de Medicago truncatula. Se utilizaron frutos en el estadio descrito anteriormente (Pod age: 6 DPP). Se realizaron cortes longitudinales del fruto, paralelos al eje de enrollado del mismo. En la Figura 67 (a-c) se muestra un corte en el que puede verse una expresión intensa de MtAGb en el endotelio de la semilla. No se detectó ninguna señal en tejidos hibridados con la sonda "sentido" (Figura 67, d).
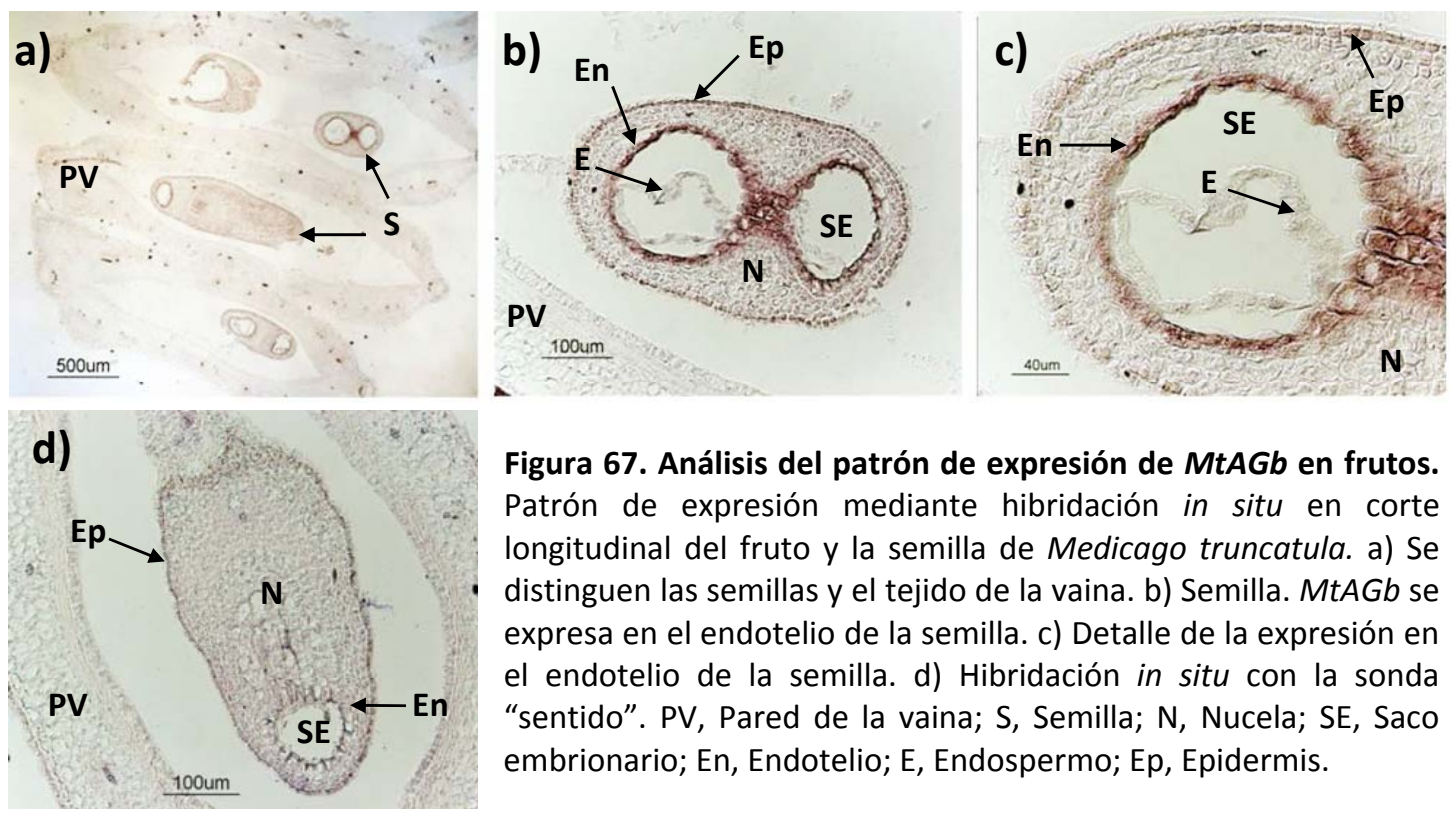

Figura 67. Análisis del patrón de expresión de MtAGb en frutos. Patrón de expresión mediante hibridación in situ en corte longitudinal del fruto y la semilla de Medicago truncatula. a) Se distinguen las semillas y el tejido de la vaina. b) Semilla. MtAGb se expresa en el endotelio de la semilla. c) Detalle de la expresión en el endotelio de la semilla. d) Hibridación in situ con la sonda "sentido". PV, Pared de la vaina; S, Semilla; N, Nucela; SE, Saco embrionario; En, Endotelio; E, Endospermo; Ep, Epidermis.

\subsection{CARACTERIZACIÓN FUNCIONAL DE LOS GENES MtAGa Y MtAGb DE Medicago truncatula}

\subsubsection{Silenciamiento génico mediante RNA interferente}

Para analizar las funciones de $M t A G a$ y $M t A G b$, se abordó la generación de plantas transgénicas de Medicago truncatula con reducción en la expresión de estos genes. Para ello, se utilizó la técnica de silenciamiento génico postranscripcional mediado por RNA interferente. La eficacia de esta herramienta de genética reversa en Medicago truncatula fue comprobada previamente en nuestro laboratorio (Benlloch et al., 2009). 
Las construcciones de RNA interferente para MtAGa (35S::RNAi-MtAGa) y MtAGb (35S::RNAi-MtAGb; ver apartado 3.1.1, Materiales y Métodos) se generaron utilizando fragmentos del extremo $3^{\prime}$ del cDNA de ambos genes. El fragmento utilizado en la construcción 35S::RNAi-MtAGa fue la secuencia comprendida entre los nucleótidos 572 y 812 del cDNA del gen. Dicha secuencia incluye desde los 5 últimos nucleótidos del dominio K hasta 29 nucleótidos de la región 3' no codificante. El fragmento utilizado en la construcción 35S::RNAi-MtAGb fue la secuencia comprendida entre los nucleótidos 558 y 772 del cDNA del gen; incluye desde los 22 últimos nucleótidos del dominio $\mathrm{K}$ hasta 37 nucleótidos de la región 3' no codificante (en ambos casos la numeración comienza en el primer nucleótido del codón de inicio de transcripción). Estos fragmentos constituyen la zona más específica de estos dos genes, lo que supone que el silenciamiento afectará concretamente a cada gen.

Para la generación de las construcciones se utilizó el vector pHANNIBAL (Wesley et al., 2001). Este vector contiene el promotor constitutivo CaMV 35S y un intrón PDK. A ambos lados de dicho intrón se clonaron los fragmentos génicos, en orientación directa por un lado e inversa por el otro. El transcrito generado bajo el control del promotor CaMV $35 \mathrm{~S}$ producirá un RNA de doble cadena, que desencadenará la degradación específica del RNA mensajero (mRNA) del gen. El casete, desde el promotor CaMV 35S hasta el terminador OCS, se transfiere al vector binario pGreenll-nosbar, adecuado para transformar plantas (Benlloch, R. Tesis Doctoral, 2005). Este vector contiene el gen bar que confiere resistencia en plantas al herbicida Basta. Ambas construcciones de RNA interferente se muestran en la Figura 68.

El método de transformación genética utilizado para generar plantas transgénicas de Medicago truncatula en las que se silencian los genes AGAMOUS mediante RNA interferente está descrito en el apartado 3.2.1 (Materiales y Métodos). Consiste en la infiltración de explantes de hoja de Medicago truncatula con una suspensión de $A$. tumefaciens que contiene la construcción genética de interés y la posterior obtención de plantas transgénicas mediante embriogénesis somática. Se realizaron ocho experimentos independientes de transformación genética: cuatro utilizando la construcción 35S::RNAi-MtAGa (322 explantes en total) y cuatro con la construcción 35S::RNAi-MtAGb (257 explantes en total). 

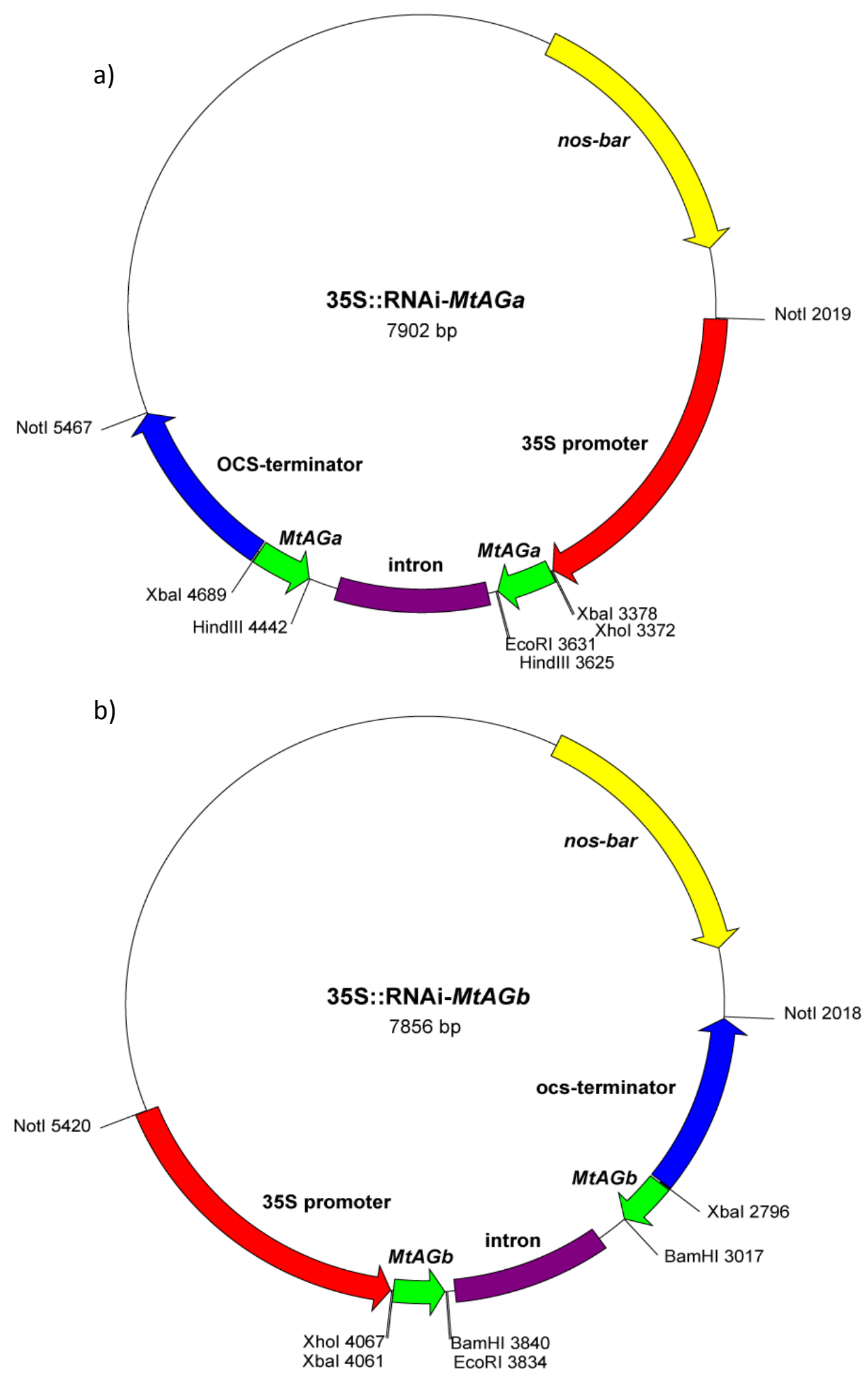

Figura 68. Esquema de las construcciones de RNA interferente. a) Construcción de RNA interferente para el gen MtAGa. b) Construcción de RNA interferente para el gen MtAGb. El casete que incluía ambos fragmentos génicos (en sentido y antisentido) separados por un intrón y bajo el control del promotor CaMV 35S, se escindió del vector pHANNIBAL (Wesley et al., 2001) y se clonó en el sitio Notl del vector pGreenll-nosbar (Benlloch, R., Tesis Doctoral, 2005), que contiene el gen bar, que confiere resistencia al herbicida Basta. 
Debido a las dificultades que se presentaron durante el proceso de transformación y regeneración (no regeneración, muerte y/o contaminación de explantes), no se logró recuperar ninguna planta transgénica de Medicago truncatula afectada en la expresión de MtAGa. Se obtuvieron un total de tres plantas transgénicas afectadas en la expresión de MtAGb, procedentes de dos explantes independientes. Estas plantas se denominaron 1.1, 1.3 y 5.7 , siendo las dos primeras procedentes del mismo explante. La transgénesis de estas plantas fue confirmada mediante PCR. Se utilizaron oligonucleótidos específicos (ver Tabla 10, Materiales y Métodos) que amplifican, por un lado, un fragmento de 561 pb que incluye las últimas $322 \mathrm{pb}$ del promotor CaMV 35S y todo el fragmento génico contiguo al promotor y, por otro lado, un fragmento de $423 \mathrm{pb}$ del gen bar (Figura 69).
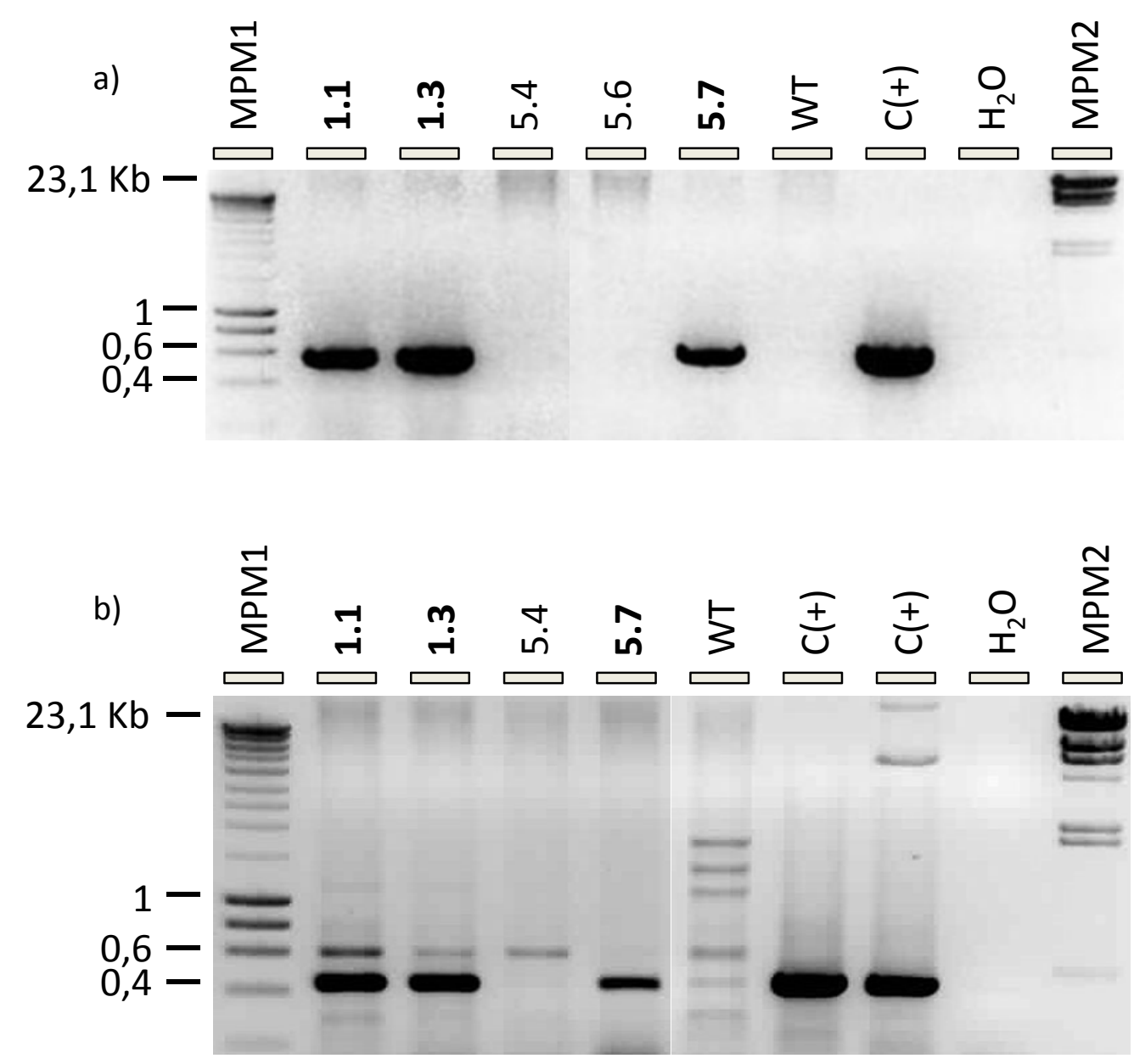

Figura 69. Confirmación de la transgénesis de las plantas 35S::RNAi-MtAGb. a) Confirmación de la presencia del fragmento de MtAGb unido al promotor CaMV 35S. b) Confirmación de la presencia del fragmento del gen bar. Las plantas transgénicas $1.1,1.3$ y 5.7 se indican en negrita. 5.4 y 5.6 son plantas no transgénicas procedentes del proceso de transformación. MPM1 y MPM2 corresponden a dos marcadores de peso molecular distintos. WT, planta silvestre; $\mathrm{C}(+)$, plásmido control positivo; $\mathrm{H}_{2} \mathrm{O}$, agua destilada. 


\subsubsection{Fenotipo de las plantas transgénicas 35S::RNAi-MtAGb}

El desarrollo vegetativo de las plantas transgénicas fue normal comparado con las plantas de fenotipo silvestre. La posición y complejidad de hojas y ramas laterales permanecieron inalteradas. El desarrollo de las flores estaba afectado severamente en las flores de la planta transgénica 5.7 (Figura 70), mientras que las dos plantas transgénicas restantes, 1.1 y 1.3, no presentaban alteraciones evidentes en el desarrollo floral.

La flor silvestre de Medicago truncatula, está formada por cuatro verticilos concéntricos de órganos: cinco sépalos, cinco pétalos (un estandarte, dos pétalos laterales o alas y dos pétalos cortos fusionados formando la quilla), diez estambres (nueve cuyos filamentos se fusionan en forma de tubo estaminal que rodea al carpelo y uno libre) y un carpelo subsésil. Tras ser fertilizado, este carpelo crece girando helicoidalmente y forma una vaina con espinas.

Las flores de la planta transgénica 35S::RNAi-MtAGb 5.7 presentaban un aspecto característico que las distinguía fácilmente de las flores de fenotipo silvestre: el tamaño general de la flor era superior al de una flor silvestre y la disposición de los órganos estaba alterada (Figura 70, b y c). El primer verticilo de estas flores presentaba sépalos de morfología normal. Los órganos del segundo verticilo estaban conformados por pétalos de morfología normal, aunque frecuentemente la disposición de estos pétalos en el verticilo resultaba irregular (Figura 70, b y c). También pudo observarse en algunas flores la falta de fusión de los dos pétalos que conforman la quilla.

Las flores de la planta transgénica 5.7 presentaban distintos tipos de malformaciones, principalmente en los órganos de tercer y cuarto verticilo. En el tercer verticilo se observó disminución del número de estambres (hasta un mínimo de 3) y faltaba el estambre libre (Figura 70, e). En algunos casos ni siquiera se formó el tubo estaminal (Figura 70, f). Algunas de las anteras no maduraban adecuadamente y no liberaban polen; no obstante, las flores eran fértiles. Se observaron, además, transformaciones homeóticas parciales de anteras en estructuras petaloides que aparecían fusionadas al tubo estaminal (punta de flecha en Figura 70, f). Estas transformaciones se manifestaban mediante la coloración amarilla y la forma petaloide característica.

El cuarto verticilo de las flores de la planta transgénica 5.7 estaba conformado por carpelos dobles. Ambos carpelos podían desarrollarse adecuadamente y enrollarse 
sobre sí mismos (Figura 70, h), generando un fruto doble. Estos carpelos dobles partían de una base común que al dividirse generaba una ruptura que dejaba ver los óvulos (punta de flecha en Figura 70, i). En algunos casos, uno de los carpelos no prosperaba y se quedaba pequeño y abierto, dejando ver los óvulos (Figura 70 , j); en este caso se generaba un fruto de fenotipo silvestre, con un apéndice constituido por el carpelo malformado.
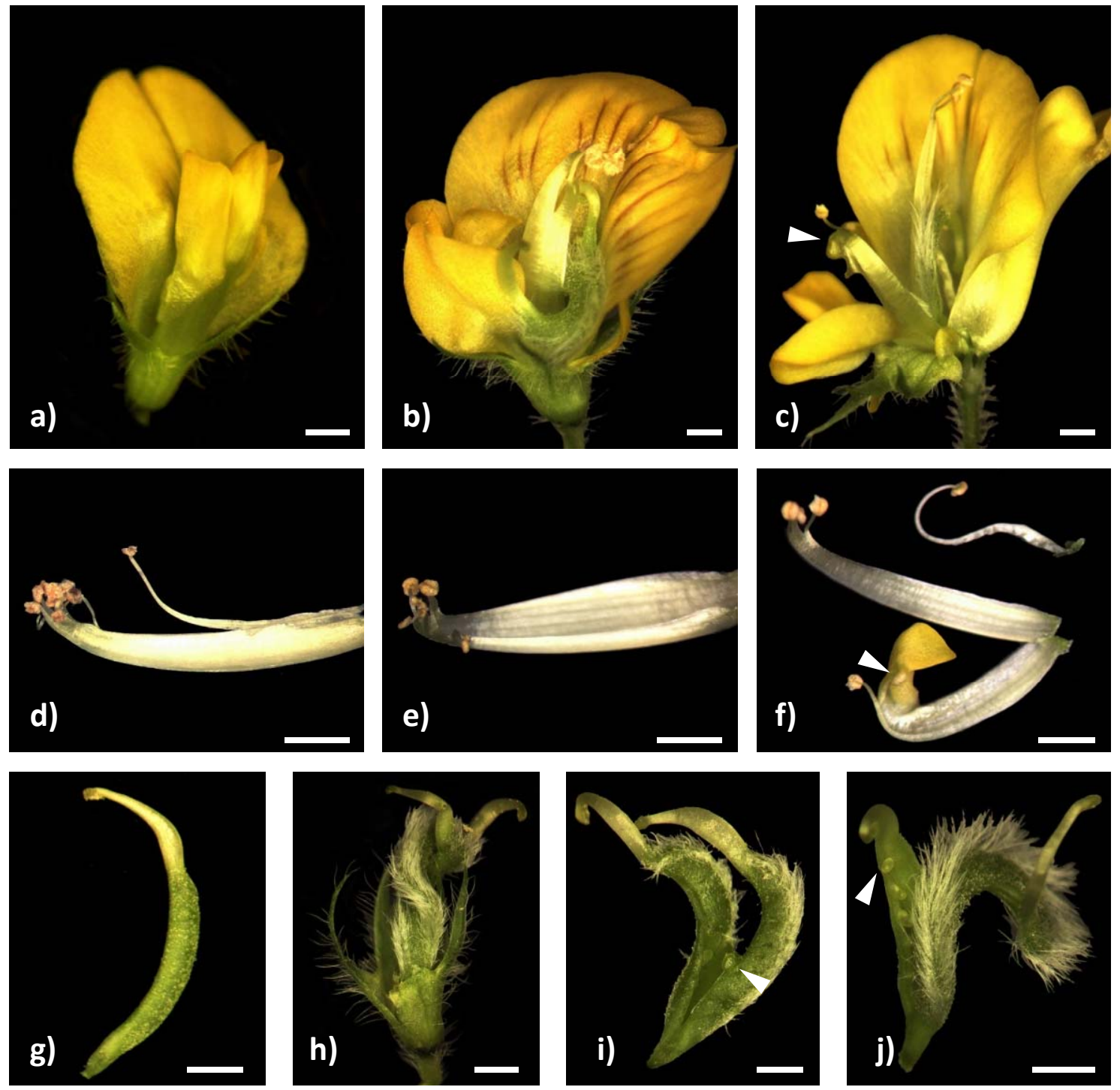

Figura 70. Fenotipo de las flores de la planta 35S::RNAi-MtAGb 5.7. a) Flor silvestre. b) Flor de la planta transgénica 5.7; se aprecia disposición irregular de los pétalos y carpelo doble. c) Flor de la planta transgénica 5.7 que presenta irregularidades en los estambres; la punta de flecha señala una estructura petaloide originada por transformación homeótica de un estambre. d) Tubo estaminal de flor silvestre. e) Tubo estaminal de flor de la planta 5.7 que presenta número reducido de anteras (7) y carece del estambre libre. f) Tubo estaminal de flor de la planta 5.7. El tubo no está fusionado y se divide en tres: un estambre libre, tres estambres fusionados y un estambre fusionado a una estructura petaloide originada por la transformación homeótica incompleta de una antera (punta de flecha). g) Carpelo de flor silvestre. h) y i) Carpelo doble de flores de la planta 5.7. La punta de flecha señala óvulos expuestos en la zona abierta del carpelo doble. j) Carpelo doble de flor de la planta 5.7. La punta de flecha señala óvulos expuestos en el carpelo malformado. Las barras indican $1 \mathrm{~mm}$. 
Mediante la siembra de la progenie de la planta 35S::RNAi-MtAGb 5.7 se pudo comprobar que el transgén se heredaba en la siguiente generación, produciendo el mismo efecto fenotípico en alrededor del $37 \%$ de la descendencia.

\subsubsection{Niveles de expresión de MtAGa y MtAGb en las plantas transgénicas 35S::RNAi-}

$\underline{M t A G b}$

Con objeto de determinar si la presencia o ausencia de fenotipo en las plantas transgénicas 35S::RNAi-MtAGb se debe a variaciones en los niveles del mRNA endógeno de los genes MtAGa y/o MtAGb, se analizó la expresión de ambos genes en ápices florales de estas plantas. La PCR cuantitativa a tiempo real (qRT-PCR) es un método altamente sensible y específico para detectar y cuantificar los niveles de expresión de un gen en diferentes situaciones (Sellars et al., 2007). Utilizando esta técnica (ver apartado 2.7.2, Materiales y Métodos), se analizaron los niveles de transcrito de MtAGa y MtAGb en las tres plantas transgénicas, normalizados respecto al nivel del gen endógeno constitutivo TC77416 (Secret Agent; Hartweck et al., 2002).

Para la detección de MtAGa se utilizaron los oligonucleótidos qMtAGa1dir y qMtAGa1rev (amplicón de $54 \mathrm{pb}$ ) que amplifican un fragmento que incluye desde las últimas 30 pb de la caja $\mathrm{K}$ hasta las primeras 24 pb de la región C-terminal. La detección de MtAGb se realizó utilizando los oligonucleótidos qMtAGb2dir y qMtAGb2rev, los cuales amplifican un fragmento de 52 pb del extremo $3^{\prime}$ no codificante que no está incluido en la construcción 35S::RNAi-MtAGb. El gen endógeno constitutivo TC77416 se amplifica con los oligonucleótidos SecDIRqRT y SecREVqRT (amplicón 51 pb).

En la Figura 71, los niveles de MtAGa y MtAGb en las plantas transgénicas se expresan en relación al nivel del transcrito correspondiente en la planta control (planta no transgénica obtenida por regeneración in vitro). Se comprobó que efectivamente había alteraciones en los niveles de transcrito de MtAGa y MtAGb en las plantas transgénicas 35S::RNAi-MtAGb. El nivel de transcrito de MtAGa (Figura 71, a) estaba reducido sobre un $30 \%$ en la planta 1.1 y $15 \%$ en la planta 1.3 . Sin embargo, en la planta 5.7 el nivel de transcrito de MtAGa presenta una mayor reducción, cerca del $60 \%$ comparado con la planta control. Se observó expresión disminuida de MtAGb (Figura 71, b) en las tres plantas transgénicas. Esta reducción fue de aproximadamente $40 \%$ en la 
planta 1.1 y $85 \%$ en la planta 1.3. En la planta 5.7 la expresión de este gen desciende alrededor de un $60 \%$.

a)

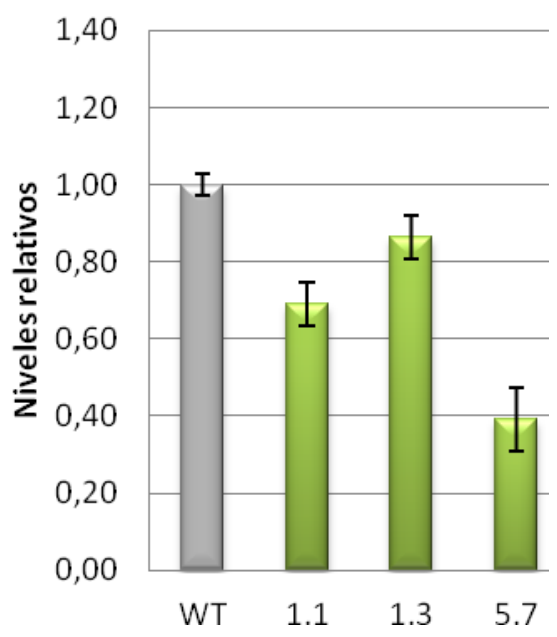

b) Niveles de MtAGb

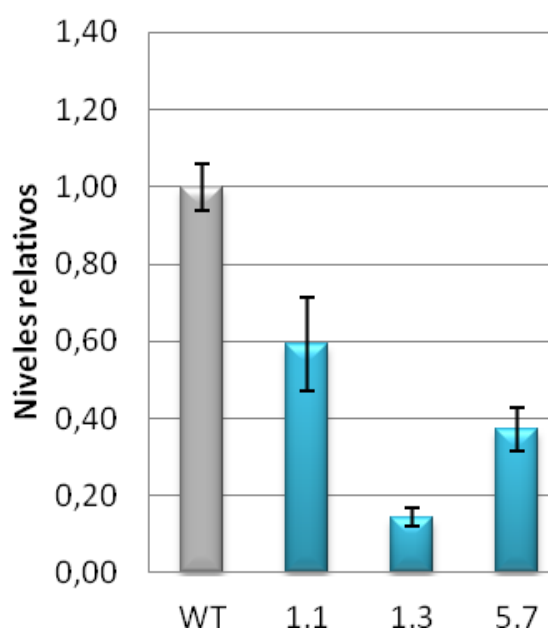

Figura 71. Niveles endógenos de MtAGa y MtAGb en las plantas 35S::RNAi-MtAGb cuantificados mediante qRT-PCR. Se muestran los niveles de expresión génica en las plantas 35S::RNAi-MtAGb relativos a los niveles de expresión génica en la planta control (WT). Las barras de error indican el error estándar de las tres réplicas técnicas.

Los resultados obtenidos en el análisis por qRT-PCR muestran que todas las plantas transgénicas 35S::RNAi-MtAGb presentan reducción en la expresión tanto de MtAGb como de MtAGa. Sin embargo, en la planta 5.7, la única transgénica que presenta fenotipo, la reducción en la expresión de MtAGa es superior a las otras dos plantas transgénicas.

\subsubsection{Mutante mtagb: etiquetado por inserción del retrotransposón Tnt1}

Para obtener más información sobre las funciones de MtAGa y MtAGb, se rastreó una colección de mutantes de Medicago truncatula (genotipo R108) producida por inserción del retrotransposón Tnt1 de Nicotiana tabacum (Tadege et al., 2005, 2008; Cheng et al., 2011) en búsqueda de mutantes que presentaran una inserción en estos genes. Esta población de mutantes ha sido generada en "The Samuel Roberts Noble Foundation" (Ardmore, Oklahoma, USA; http://bioinfo4.noble.org/mutant/) y consta de más de 19,000 líneas que contienen aproximadamente 470,000 inserciones del Tnt1 al azar en el genoma. Mediante PCR se rastrearon 10,000 líneas independientes, divididas en 20 "super-grupos" de 500 líneas cada uno. Se utilizó una combinación de oligonucleótidos específicos complementarios a las secuencias de los bordes del Tht1 y del gen de interés, 
permitiendo la confirmación de la inserción en el gen (Cheng et al., 2011). De este modo, se identificó una línea que presentaba inserciones del Tnt1 en el gen MtAGb: NF4908. No se identificó ninguna línea que presentara inserciones en el gen MtAGa.

Se sembró la población de plantas R1 correspondientes a esta línea con el objetivo de comprobar si la inserción detectada provocaba algún fenotipo morfológico apreciable a nivel macroscópico. La población consistía en 21 plantas. Aproximadamente el 70\% de las plantas presentaban un fenotipo mutante que afectaba el desarrollo floral.

\subsubsection{Caracterización molecular de la inserción y genotipado}

Para confirmar que la línea NF4908 es portadora de una inserción de Tnt1 en el gen MtAGb, se realizaron extracciones de DNA genómico de las plantas R1, sobre el cual se realizó una PCR utilizando los oligonucleótidos AGb-F y Tnt1-F, específicos del gen MtAGb y del T-DNA, respectivamente (ver Tabla 10, Materiales y Métodos). El resultado de la amplificación se muestra en la Figura 72, a.

a)

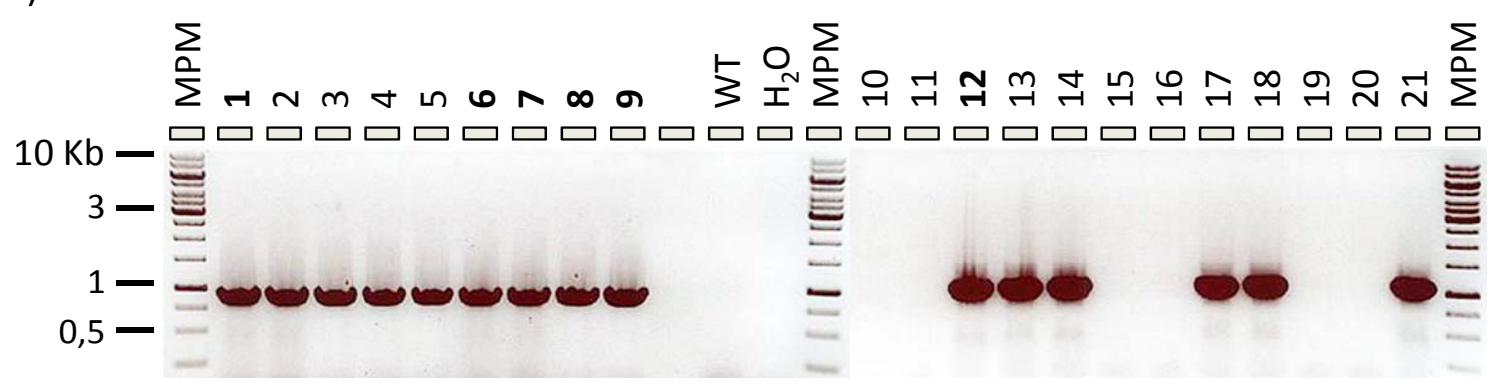

b)

\section{MtAGb}

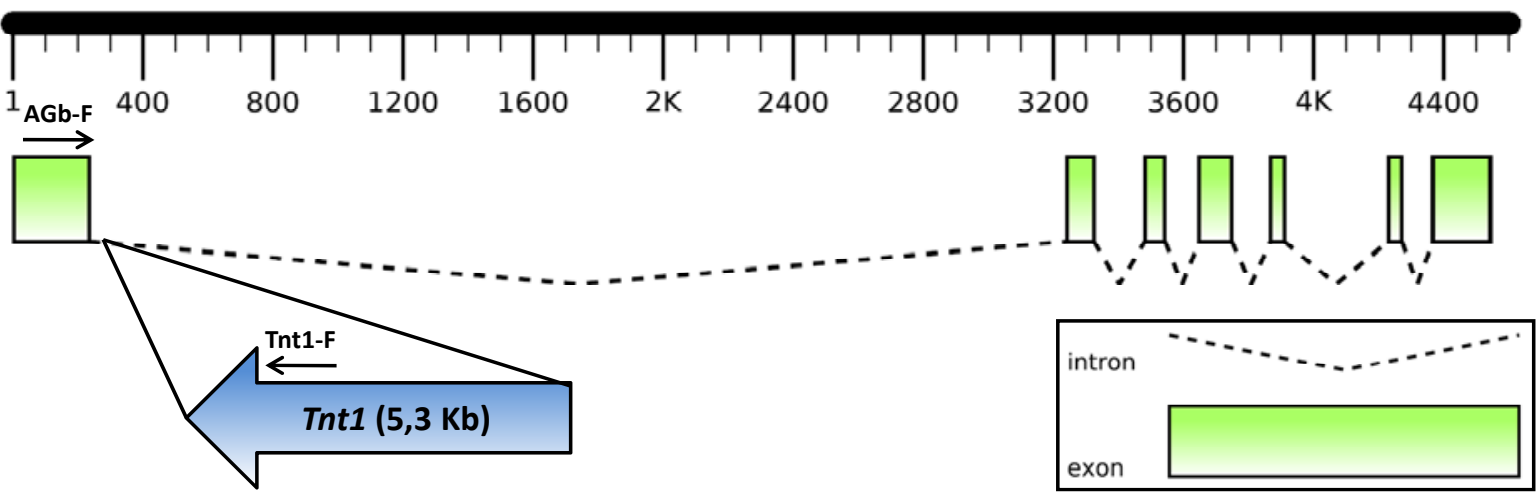

Figura 72. Inserción del Tnt1 en el locus MtAGb. a) Resultado de la amplificación de fragmentos utilizando la combinación de oligonucleótidos AGb-F/Tnt1-F. MPM corresponde al marcador de peso molecular. WT, planta silvestre; $\mathrm{H}_{2} \mathrm{O}$, agua destilada. b) Esquema de la estructura genómica del gen MtAGbL. Se indica el punto de inserción del elemento Tnt1 y la posición de los oligonucleótidos utilizados para confirmar la inserción. 
El fragmento obtenido se secuenció y se comparó con la secuencia genómica de MtAGb. Pudo verse que la inserción del Tnt1 se localiza en el primer intrón y está insertado en antisentido, a 277 pb contando desde el codón de inicio de transcripción del gen MtAGb. En la Figura 72, b se muestra la organización de los 7 exones y 6 intrones de $M t A G b$, la posición de la inserción del elemento Tnt1 y la ubicación de los oligonucleótidos utilizados. Se observa que 15 de las 21 plantas de la línea NF4908 presentan la inserción del retrotransposón.

Las plantas R1 se genotiparon para determinar si eran homocigotas o heterocigotas para la inserción del retrotransposón Tnt1. El genotipado se realizó mediante PCR utilizando oligonucleótidos específicos (AGb-F y AGb-Rgenomic; ver Tabla 10, Materiales y Métodos) que amplifican un fragmento del gen MtAGb que va desde $5 \mathrm{pb}$ tras el codón de inicio de transcripción de MtAGb hasta 1066 pb del primer intrón (contando desde el codón de inicio de transcripción del gen). Por otro lado, se aprovechó el resultado de la amplificación previa con los oligonucleótidos AGb-F/TnT1-F (Figura 72, a).

En caso de homocigosis, solo se obtuvo un fragmento utilizando la combinación de oligonucleótidos AGb-F/Tnt1-F. No se amplificó ningún fragmento utilizando la combinación AGb-F/AGb-Rgenomic, ya que la inserción del Tnt1 en ambos loci aumentaba el tamaño de dicho fragmento hasta imposibilitar su amplificación en las condiciones de PCR utilizadas. En caso de heterocigosis, se obtuvo un fragmento utilizando la combinación de oligonucleótidos AGb-F/Tnt1-F y otro utilizando la combinación AGb-F/AGb-Rgenomic, ya que la amplificación del fragmento génico sin inserción (en uno de los loci) era viable. En las plantas de genotipo silvestre no se obtuvo ningún fragmento utilizando la combinación de oligonucleótidos AGb-F/Tnt1-F, pero sí se obtuvo el fragmento amplificado por la combinación AGb-F/AGb-Rgenomic.

Un esquema de los resultados esperados en la amplificación según las combinaciones de oligonucleótidos utilizadas, así como el resultado en sí, se muestran en la Figura 73. Puede observarse que seis de las plantas de la línea NF4908 (plantas 1, 6, 7, 8, 9 y 12) son homocigotas para la inserción, nueve son heterocigotas (plantas 2, 3, 4, 5, 13, 14, 17,18 y 21 ) y seis plantas son de genotipo silvestre (plantas $10,11,15,16,19$ y 20 ). Estos resultados concuerdan con la segregación teórica esperada para las plantas 
procedentes de semillas obtenidas mediante autofecundación de una planta heterocigota ( $\mathrm{Aa} \times \mathrm{Aa}=\mathrm{AA}$ Aa $\mathrm{Aa}$ aa; 1:2:1).

a)

HOMOCIGOTA

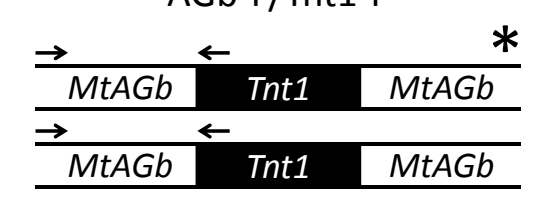

HETEROCIGOTA

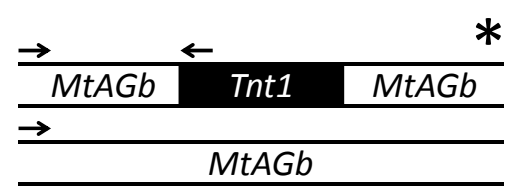

SILVESTRE

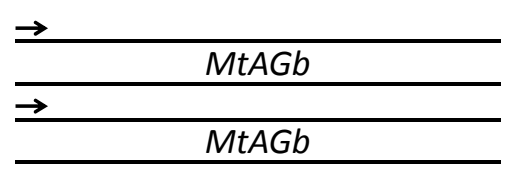

PCR con oligonucleótidos AGb-F/AGb-Rgenomic

\begin{tabular}{lll}
$\rightarrow$ & $\leftarrow$ \\
\cline { 1 - 2 } MtAGb & Tnt1 & MtAGb \\
Alelo 1 & Alelo 2
\end{tabular}
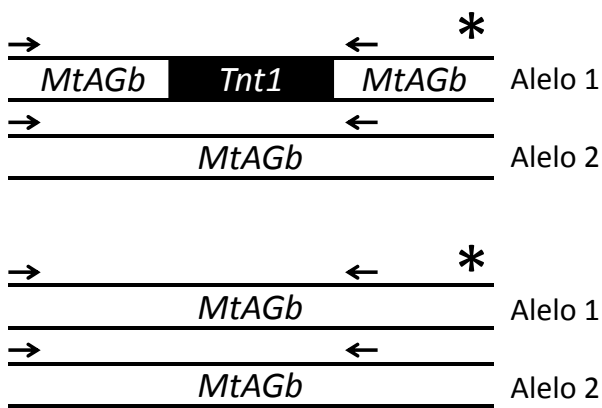

b)

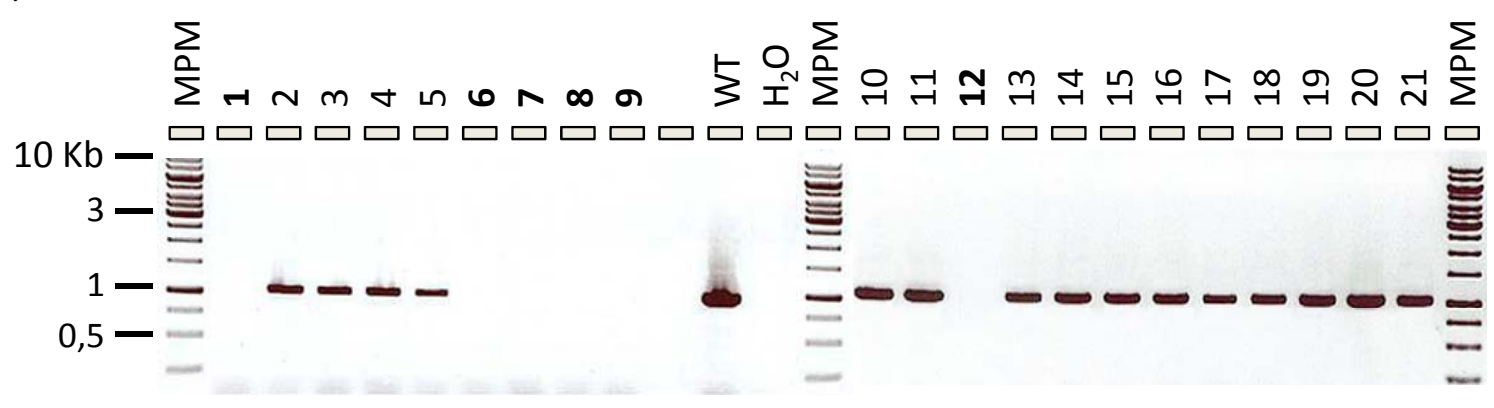

Figura 73. Genotipado de las plantas con inserción del Tnt1 en el locus MtAGb. a) Esquema de los resultados esperados en las amplificaciones utilizando las diferentes combinaciones de oligonucleótidos. El asterisco indica aquellos casos en los que se espera la amplificación de un fragmento. b) Resultado de la amplificación de fragmentos utilizando la combinación de oligonucleótidos AGb-F/AGb-Rgenomic. Las plantas homocigotas se indican en negrita. MPM corresponde al marcador de peso molecular. WT, planta silvestre; $\mathrm{H}_{2} \mathrm{O}$, agua destilada.

\subsubsection{Caracterización fenotípica del mutante mtagb}

El desarrollo vegetativo de las plantas mutantes fue normal comparado con las plantas de fenotipo silvestre. La posición y complejidad de hojas y ramas laterales permanecieron inalteradas. El desarrollo floral estaba afectado en el mutante mtagb en las plantas homocigotas, aunque cabe mencionar que no todas las flores generadas por el mutante tenían fenotipo alterado. 
Las flores del mutante mtagb presentaban un aspecto característico que las distinguía fácilmente de las flores de fenotipo silvestre (Figura 74, b y c). El primer verticilo de estas flores presentaba sépalos de morfología normal. Los órganos del segundo verticilo estaban conformados por pétalos cuya disposición en el verticilo frecuentemente resultaba irregular. Pudo observarse en algunas flores que las posiciones de los pétalos no siempre estaban ocupadas por el tipo de pétalo esperado, obteniéndose en algunos casos más estandartes o alas supliendo a otros pétalos (Figura 74, b y c).
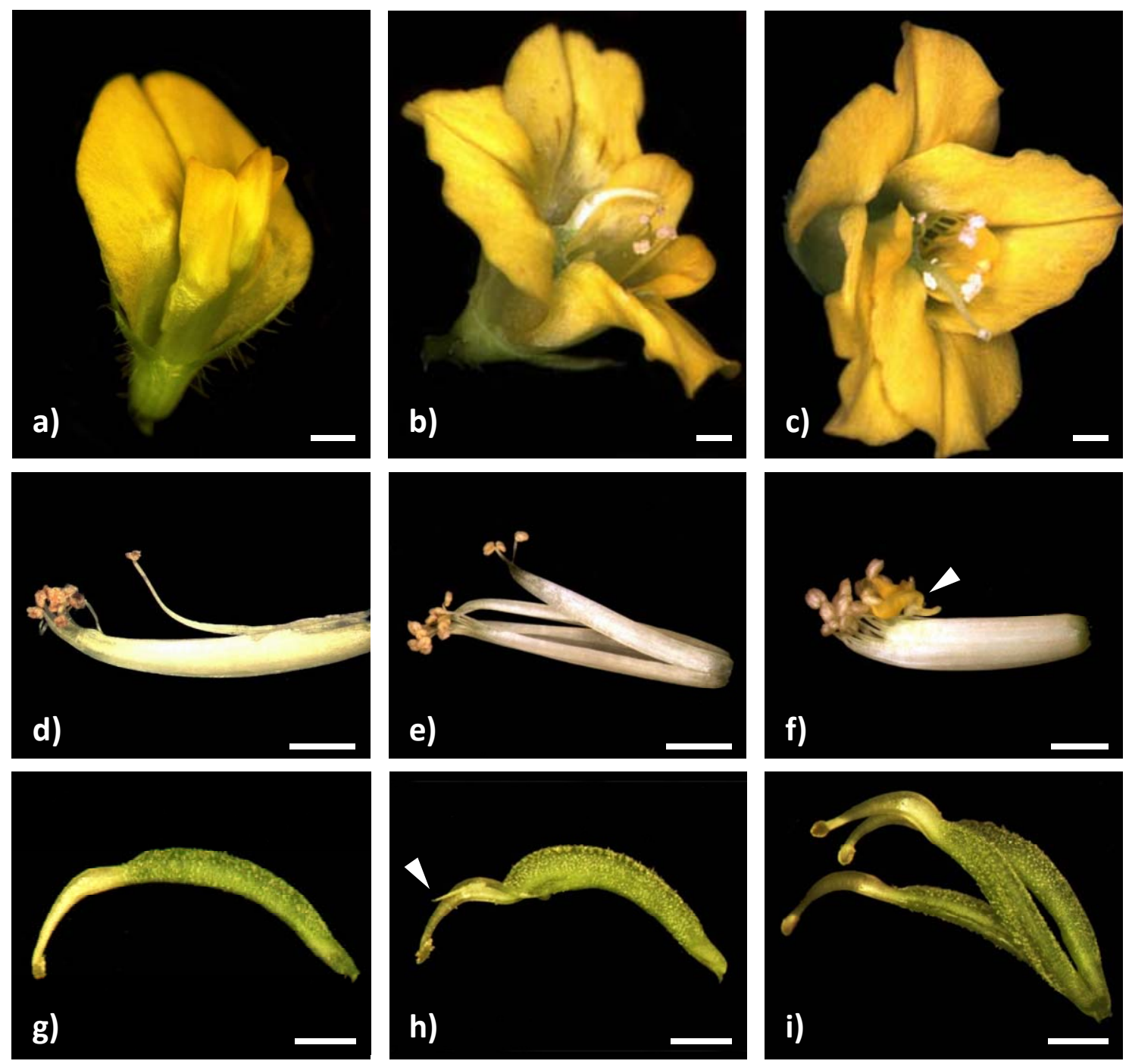

Figura 74. Fenotipo de las flores del mutante $\boldsymbol{m}$ tagb. a) Flor silvestre. b) Flor mutante $m$ tagb; se aprecia dos estandartes supliendo las alas y disminución del número de estambres. c) Flor mutante mtagb donde tres estandartes suplen un ala y la quilla. También hay alteración en el tubo estaminal. d) Tubo estaminal de flor silvestre. e) Tubo estaminal de flor mtagb que no está fusionado, dividiéndose en secciones. Se presenta aumento de anteras y éstas no maduran, limitando la liberación del polen. f) Tubo estaminal de flor mtagb. Se observa aumento en el número de anteras y éstas no maduran. Se observan estructuras petaloides originadas por la transformación homeótica incompleta de dos anteras (punta de flecha). g) Carpelo de flor silvestre. h) Carpelo de flor mtagb. La punta de flecha señala una estructura carpeloide pequeña adherida al carpelo principal. i) Carpelo triple de flor mtagb. Las barras indican $1 \mathrm{~mm}$. 
Las flores mtagb presentaban malformaciones principalmente en los órganos de tercer y cuarto verticilo. En el tercer verticilo se observó partición o fusión incompleta del tubo estaminal (Figura 74, e). El número de estambres estaba alterado y en ocasiones se presentaban dos estambres libres en lugar de uno. Algunas de las anteras no maduraban adecuadamente y no liberaban polen (Figura 74, e y f). Además, se observaron transformaciones homeóticas parciales de anteras en estructuras petaloides que aparecían fusionadas al tubo estaminal (punta de flecha en Figura 74, f). Estas transformaciones se manifestaban mediante la coloración amarilla y la forma petaloide característica. El cuarto verticilo de las flores mtagb estaba conformado por carpelos modificados. Se presentaba un carpelo con estructuras pequeñas tipo carpelo o estigma adheridas al mismo (Figura 74, h) o carpelos múltiples (Figura 74, j). En el caso de los carpelos múltiples, se observó hasta un máximo de tres, pudiendo desarrollarse todos adecuadamente y enrollarse sobre sí mismos generando un fruto múltiple.

\subsubsection{Silenciamiento génico inducido por virus (VIGS)}

Para complementar los resultados de silenciamiento génico previamente descritos, se utilizó la tecnología denominada VIGS (silenciamiento génico inducido por virus) para silenciar transitoriamente los genes AGAMOUS de dos leguminosas: Medicago truncatula y Pisum sativum. Los experimentos se realizaron en colaboración con el laboratorio de la Dra. Elisabeth Johansen (Faculty of Agricultural Sciences, University of Århus, Dinamarca), en el que han desarrollado un vector específico para VIGS en Pisum sativum, basado en el Pea early browning virus (PEBV). Este vector ha sido utilizado exitosamente en el silenciamiento de genes específicos de hoja, raíz y meristemo floral de Pisum sativum (Constantin et al., 2004, 2008). Además, su eficacia ha sido validada en distintas variedades de Medicago truncatula (Grønlund et al., 2008). Las construcciones fueron realizadas en nuestro laboratorio y los ensayos se realizaron en el laboratorio de Dinamarca, aprovechando una beca obtenida para la realización de estancias breves en centros de I+D en el extranjero.

Distintos análisis filogenéticos de leguminosas (Wojciechowski, M., 2003) sugieren que los géneros Pisum, Lathyrus, Lens, Trifolium y Medicago están estrechamente relacionados. La ontogenia y morfología floral están conservadas entre Pisum sativum y Medicago truncatula (Tucker, S., 1989, 2003; Ferrándiz et al., 1999), además de existir 
un elevado grado de sintenia entre estas plantas (Kaló et al., 2004; Aubert et al., 2006). Las principales diferencias son el tamaño de la flor, que hace más manejable experimentalmente a Pisum sativum (Figura 75) y la forma del fruto, enrollado y con espinas en Medicago truncatula.

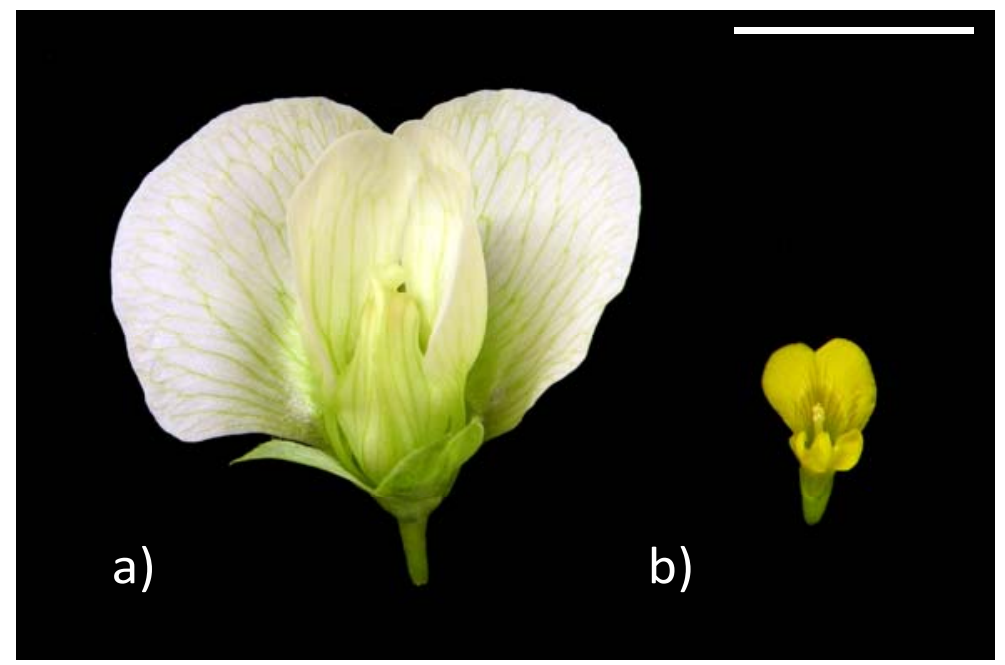

Figura 75. Comparación del tamaño de las flores de Pisum sativum y Medicago truncatula. a) Flor de Pisum sativum. b) Flor de Medicago truncatula. La barra indica $1 \mathrm{~cm}$.

En el presente trabajo se ha observado que existe una homología muy elevada entre los genes AGAMOUS de Pisum sativum y Medicago truncatula (ver Tabla 19), así que se ha optado por realizar los experimentos de silenciamiento en ambas plantas. Los resultados obtenidos pueden aportar información importante acerca de la función de estos genes duplicados en leguminosas.

\subsubsection{VIGS en Pisum sativum}

Se utilizó el vector PEBV para silenciar transitoriamente los genes PSAGa (Berbel et al., unpublished) y PsAGb (Navarro, C., Tesis Doctoral, 2001) de Pisum sativum cv. Bonneville. Este vector consiste en dos plásmidos: pCAPE1 (que incluye el RNA1 del cDNA viral) y pCAPE2 (que incluye el RNA2 del cDNA viral y en el que se inserta el fragmento génico de interés; Constantin et al., 2004). Se generaron seis construcciones de VIGS para Pisum sativum: dos para silenciar PSAGa (pCAPE2-PsAGa y pCAPE2PsAGabis), tres para silenciar PsAGb (pCAPE2-PsAGb, pCAPE2-PsAGbbis1 y pCAPE2PsAGbbis2) y una para silenciar simultáneamente ambos genes (pCAPE2-PsAGdoble; ver apartado 3.1.2, Materiales y Métodos). El esquema general de estas construcciones se muestra en la Figura 76. Las construcciones pCAPE2-PSAGa y pCAPE2-PSAGb son más específicas en el silenciamiento de los genes por separado, ya que los fragmentos que contienen corresponden a la región C-terminal y la región no codificante del gen y 
presentan entre ellos una homología de 65\%. Las construcciones pCAPE2-PsAGabis, pCAPE2-PsAGbbis1 y pCAPE2-PsAGbbis2 incluyen fragmentos génicos más pequeños y localizados entre la caja $\mathrm{K}$ y la región C-terminal, zonas de alta homología (77\%) entre PsAGa y PSAGb, lo que conlleva la posibilidad de silenciamiento de ambos genes.

a) PCAPE1

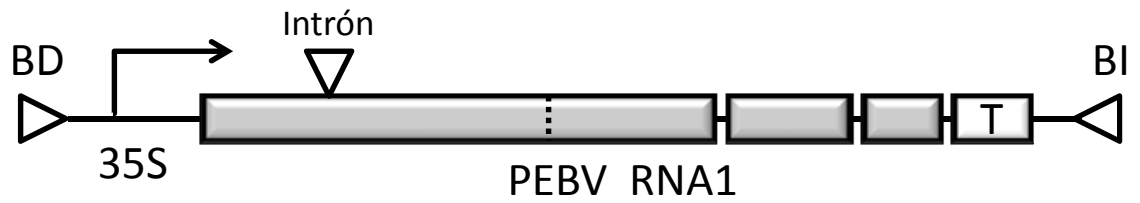

b) PCAPE2-GUS

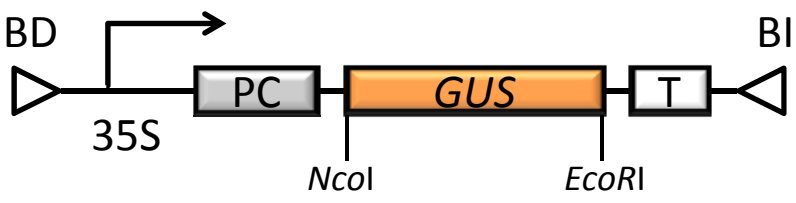

c) PCAPE2-PSAGa

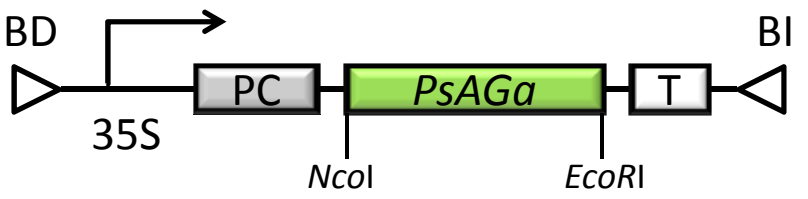

d) PCAPE2-PsAGabis

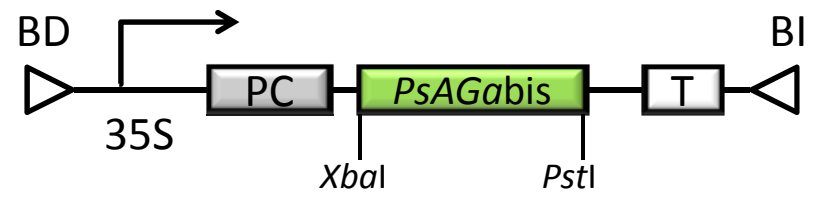

e) PCAPE2-PSAGb

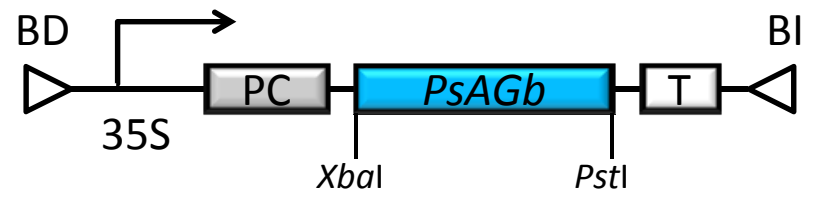

f) pCAPE2-PSAGbbis1

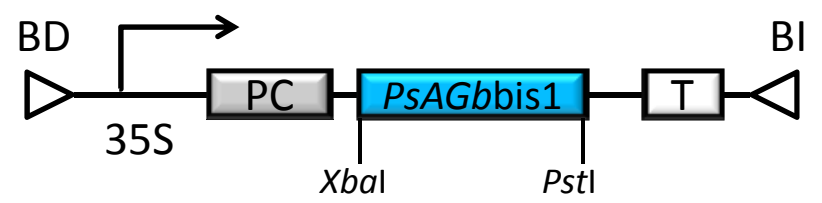

g) pCAPE2-PsAGbbis2

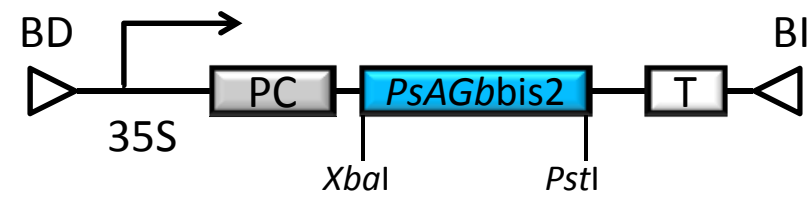

h) pCAPE2-PSAGdoble

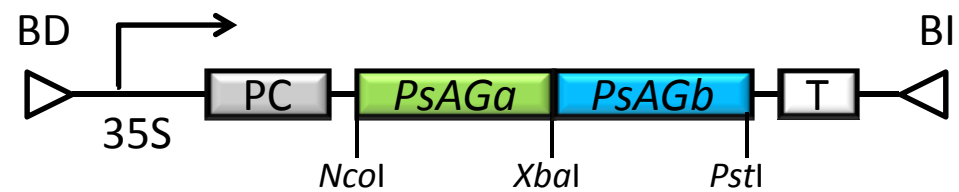

Figura 76. Esquema de las construcciones VIGS para Pisum sativum. a) pCAPE1, que contiene el cDNA completo del RNA1. b) pCAPE2-GUS. Construcción utilizada como control interno de infección viral. c) y d) pCAPE2-PsAGa y pCAPE2-PsAGabis, utilizadas para silenciar el gen PsAGa. e), f) y g) pCAPE2-PsAGb, pCAPE2-PsAGbbis1 y pCAPE2-PsAGbbis2, utilizadas para silenciar el gen PsAGb. h) pCAPE2-PsAGdoble, usada para silenciar $P S A G a$ y PSAGb simultáneamente. BD, borde derecho; BI, borde izquierdo; T, terminador NOS; PC, región codificante de la proteína de la cápside. (Imágenes adaptadas de Constantin et al., 2004). 
La diferencia entre las construcciones PCAPE2-PsAGbbis1 y pCAPE2-PsAGbbis2 es que la primera incluye las $42 \mathrm{pb}$ que se pierden por el splicing alternativo de PsAGb. En la construcción pCAPE2-PSAGdoble se utilizan, colocados en tándem, los fragmentos de las construcciones pCAPE2-PSAGa y pCAPE2-PSAGb, solo que más cortos por el extremo 5'.

Para hacer un seguimiento del efecto del virus PEBV sobre las plantas, se utilizó la construcción control pCAPE2-GUS (Constantin et al., unpublished), que contiene un inserto de 400 pb de la región no codificante del gen exógeno GUS, cuyo silenciamiento no está dirigido a ningún gen endógeno de la planta.

Las plantas VIGS de Pisum sativum cv. Bonneville se generaron mediante un proceso de agroinfiltración que se describe en el apartado 3.2.2 (Materiales y Métodos). Consiste en la inoculación del envés de las hojas, en plantas de dos semanas de edad, con una suspensión mixta de $A$. tumefaciens que contiene los vectores pCAPE1 y pCAPE2 (con el fragmento génico de interés) a partes iguales. Se realizaron dos experimentos independientes de transformación genética transitoria con un total de 229 plantas. Se incluyeron grupos de plantas transformadas con las seis construcciones AGAMOUS (40 plantas para pCAPE2-PSAGa, pCAPE2-PSAGb y pCAPE2-PSAGdoble y 10 plantas para cada una de las demás construcciones), plantas transformadas con la construcción pCAPE2GUS (control interno de infección viral; 40 plantas) y plantas sin transformar (control externo, 39 plantas).

Comparando los fenotipos de las plantas pCAPE2-PsAGabis, pCAPE2-PsAGbbis1 y pCAPE2-PsAGbbis2 con las plantas pCAPE2-PsAGa y pCAPE2-PsAGb, se ha observado que efectivamente el silenciamiento generado con las tres primeras construcciones afecta a ambos genes. Por ello, el análisis del fenotipo resultante del silenciamiento transitorio de PSAGa y PSAGb se realizó principalmente en las plantas pCAPE2-PSAGa y PCAPE2-PSAGb y se presentan los resultados de las mismas.

Las plantas se analizaron visualmente y se registró el número de nudos, nudo en el que se presenta la primera flor, así como número de flores y frutos y alteraciones en los mismos.

Todas las plantas florecieron entre los nudos 10 y 11 . El número total de nudos que presentaron todas las plantas estaba entre 14 y 15, excepto en las plantas PCAPE2PsAGdoble, en las cuales el número medio de nudos fue de 18. Es posible que este fenotipo no fuera únicamente resultante del silenciamiento simultáneo de PSAGa y 
PsAGb. Estas plantas prácticamente no formaban frutos. El fenotipo ramificado de estas plantas (Figura 77) pudo deberse a la falta de estas estructuras reproductoras florales, ya que los nutrientes favorecerían la generación de más meristemos inflorescentes al no desviarse hacia la formación de frutos (Hensel et al., 1994; Beltrán et al., 2007).

Las plantas pCAPE2-PSAGa y pCAPE2-PSAGb no presentaron alteraciones morfológicas en las estructuras vegetativas. La posición y complejidad de hojas y ramas laterales permanecieron inalteradas.

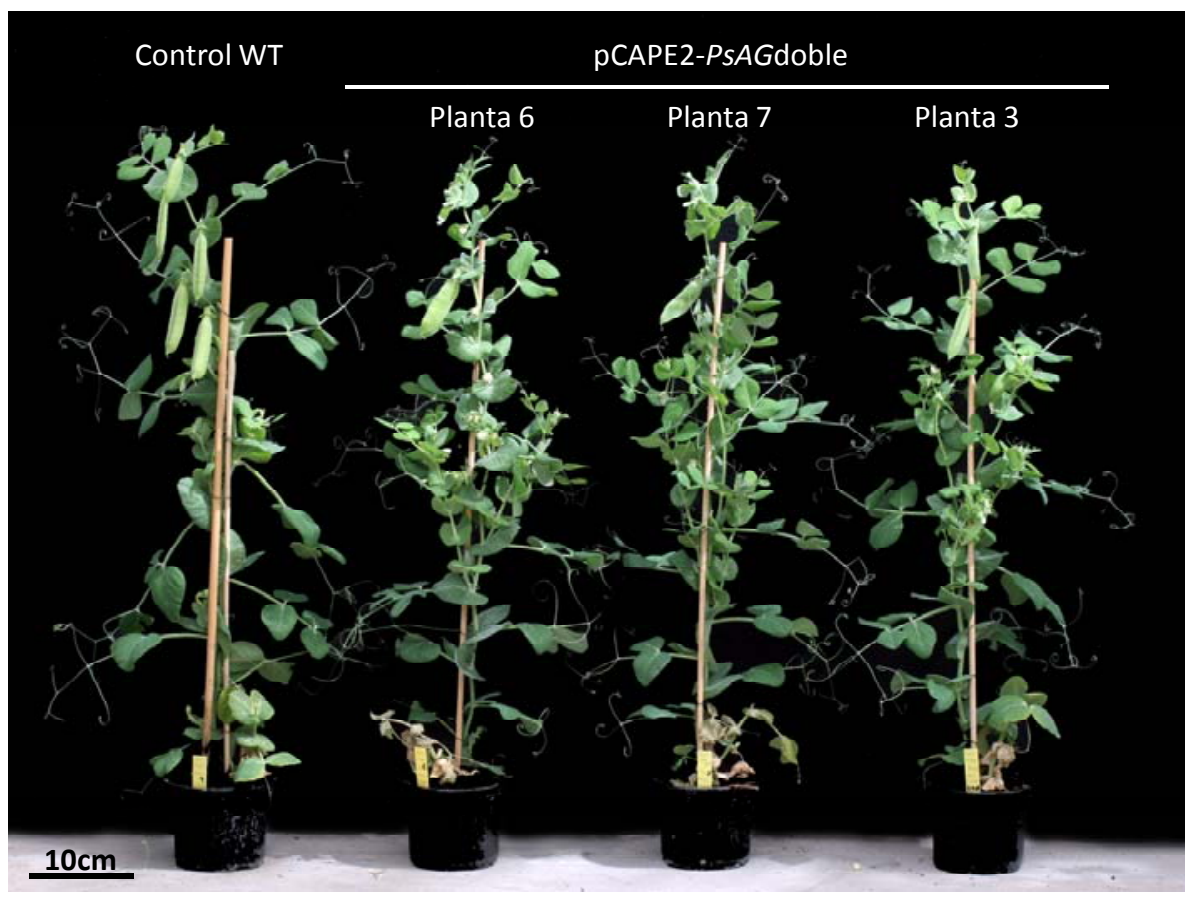

Figura 77. Plantas pCAPE2-PsAGdoble de Pisum sativum. Se muestran tres plantas pCAPE2-PsAGdoble comparadas con una planta silvestre (WT). Estas plantas tienen una estructura más ramificada que las plantas de fenotipo silvestre.

Las flores de las plantas VIGS se examinaron visualmente y se abrieron manualmente, buscando defectos obvios en las flores abiertas. El 67,8\% de las plantas pCAPE2-PSAGa produjo flores anormales, mientras que solo el 35,7\% de las plantas pCAPE2-PSAGb presentó flores con defectos. Esto puede deberse tanto a la posibilidad de que PSAGb tenga un papel funcional más débil como a la dificultad para reconocer defectos más tenues en las flores. El 85,7\% de las plantas PCAPE2-PSAGdoble generó flores anormales. La Tabla 20 resume la frecuencia y tipo de fenotipos florales observados para las tres construcciones. 
Tabla 20. Fenotipos observados en las flores de plantas VIGS de Pisum sativum

\begin{tabular}{lccccc}
\hline Fenotipo observado & WT & $\begin{array}{c}\text { pCAPE2- } \\
\text { GUS }\end{array}$ & $\begin{array}{c}\text { pCAPE2- } \\
\text { PsAGa }\end{array}$ & $\begin{array}{r}\text { PCAPE2- } \\
\text { PsAGb }\end{array}$ & $\begin{array}{r}\text { PCAPE2- } \\
\text { PsAGdoble }\end{array}$ \\
\hline $\begin{array}{l}\text { Plantas inoculadas } \\
\text { Flores totales analizadas }\end{array}$ & 39 & 40 & 40 & 40 & 40 \\
\hline Flores con fenotipo en verticilos 3 y 4 & 0 & 0 & $3(3,37 \%)$ & 0 & $73(37,24 \%)$ \\
$\begin{array}{l}\text { Flores con conversiones homeóticas } \\
\text { en los estambres }\end{array}$ & 0 & 0 & $7(7,86 \%)$ & $1(1,25 \%)$ & $77(39,28 \%)$ \\
$\begin{array}{l}\text { Flores con conversiones homeóticas } \\
\text { en el carpelo }\end{array}$ & 0 & 0 & $16(17,97 \%)$ & $3(3,75 \%)$ & $101(51,53 \%)$ \\
$\begin{array}{l}\text { Flores con defectos en la } \\
\text { determinación del meristemo }\end{array}$ & 0 & 0 & 0 & 0 & $61(31,12 \%)$ \\
\hline
\end{tabular}

Las flores pCAPE2-PSAGa alteradas se identificaron por su morfología asimétrica (Figura 78, b). Estas flores presentaron estambres parcialmente transformados: en las flores con alteraciones más severas, uno o dos de los estambres del tubo estaminal estaban convertidos totalmente en estructuras petaloides (Figura 78, e). Frecuentemente se presentaron anteras inmaduras que permanecían cerradas y no liberaban polen. Las alteraciones en el cuarto verticilo se apreciaron mejor al desarrollarse el fruto. Consistían principalmente en carpelos con múltiples puntas (2 ó 3) (Figura 78, h) o, en ocasiones, carpelos ligeramente abiertos en la región distal. En algunos casos los carpelos abortaron tras la antesis.

Los defectos en las flores PCAPE2-PSAGb fueron más difíciles de identificar. Las flores en antesis estaban abiertas y tenían una apariencia normal, excepto en algún caso puntual en el cual pudo apreciarse deformación en la morfología de los pétalos (Figura 78, c). Únicamente mediante un examen muy detallado se observaron defectos en los dos verticilos internos de la flor. En algunos estambres de flores que estaban desarrollando fruto se observó un alargamiento en el extremo distal de las anteras, generando un aspecto de antera puntiaguda (punta de flecha en Figura 78, f). Las alteraciones en el cuarto verticilo consistían principalmente en carpelos con múltiples puntas (2 ó 3) (Figura 78, i). 

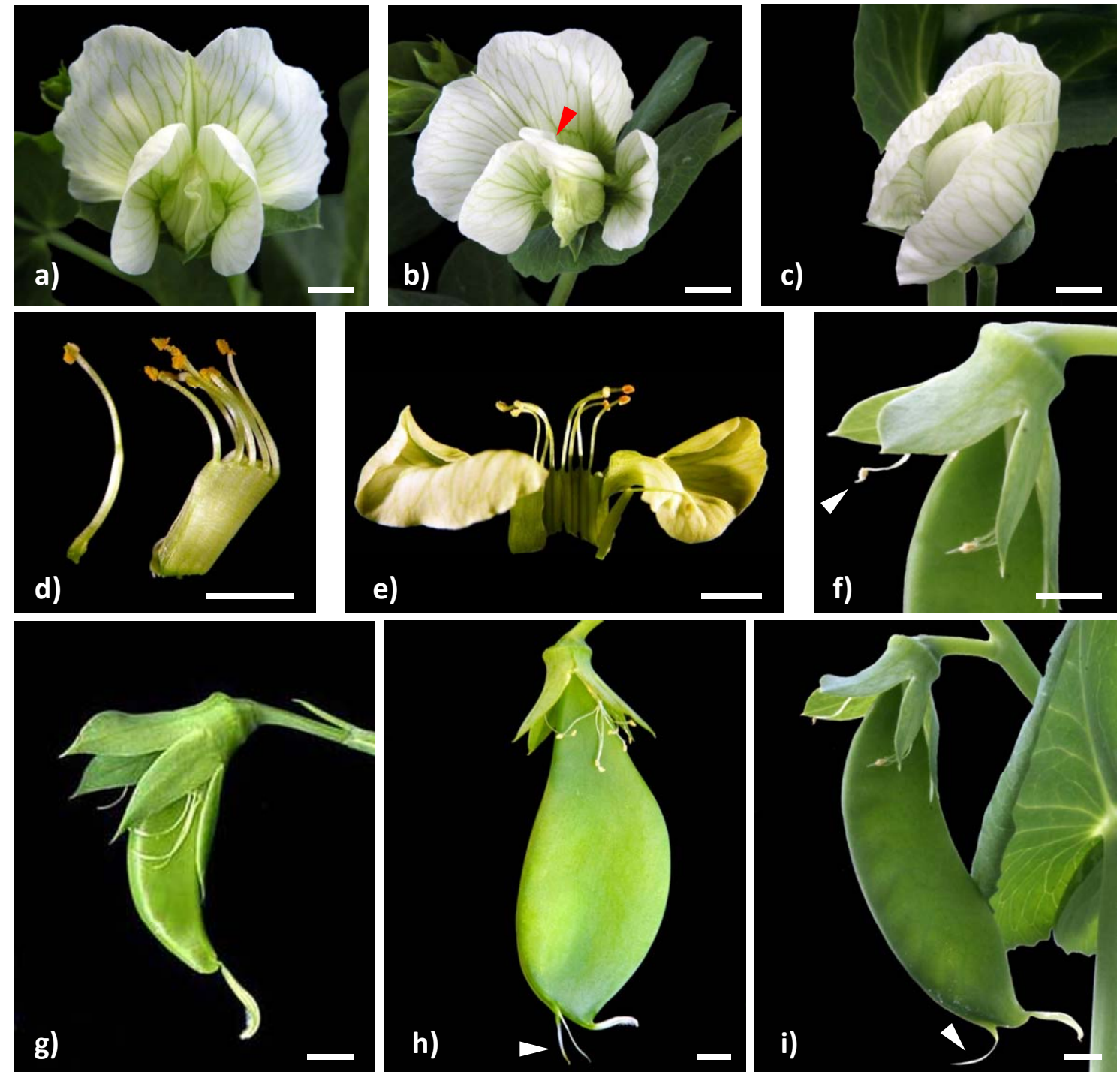

Figura 78. Fenotipo de las flores pCAPE2-PsAGa y pCAPE2-PsAGb. a) Flor silvestre. b) Flor pCAPE2-PSAGa; se aprecia la morfología asimétrica. La punta de flecha señala estambres petaloides atrapados por la quilla. c) Flor pCAPE2-PSAGb; se aprecia leve deformación en los pétalos. d) Tubo estaminal de flor silvestre. e) Tubo estaminal de flor pCAPE2-PSAGa que presenta estambres petaloides. f) Detalle de sépalos y fruto pCAPE2-PSAGb. Se observa una antera de aspecto puntiagudo (punta de flecha). g) Fruto de flor silvestre. h) Fruto pCAPE2-PsAGa que presenta múltiples puntas (punta de flecha). i) Fruto pCAPE2PsAGb que presenta múltiples puntas (punta de flecha). Las barras indican $5 \mathrm{~mm}$.

El silenciamiento simultáneo de los transcritos PSAGa y PSAGb en las plantas pCAPE2PsAGdoble generó flores con un fenotipo drástico que involucraba la pérdida de la identidad de estambres (están total o considerablemente transformados en pétalos) y carpelos (transformados en estructuras sepaloides) y una alta incidencia de pérdida de determinación del meristemo floral (Figura 79). Las flores pCAPE2-PSAGdoble eran generalmente de dos tipos: flores grandes con gran cantidad de órganos petaloides blancos y abiertos (Figura 79, b), que además podían presentar capullos florales en su interior (punta de flecha en Figura 79, c); o flores compactas que nunca llegaban a 
abrirse compuestas por muchas capas de pétalos y órganos petaloides verdosos y finos (Figura 79, d). En las flores con fenotipo más leve, en las cuales podía distinguirse aún una especie de tubo estaminal, los estambres estaban transformados en estructuras petaloides o presentaban anteras con las puntas alargadas (Figura 79, e). Los carpelos, en caso de estar presentes, consistían en un órgano que presentaba varias puntas tipo sépalo o estigma (Figura 79, f). En ocasiones estos carpelos presentaban en su interior tejido petaloide ectópico.

La determinación del meristemo floral estaba fuertemente afectada en las flores de las plantas pCAPE2-PsAGdoble. Frecuentemente, las flores de fenotipo grande y que presentaban gran cantidad de órganos petaloides blancos y abiertos desarrollaban en el interior del último verticilo (carpelo sepaloide de múltiples puntas) una flor ectópica (Figura 79, g y h). Este fenotipo "una flor dentro de otra" es típico en la pérdida de función C (Bowman et al., 1989). Asimismo, la pérdida de determinación del meristemo se puso de manifiesto en la reversión floral que sufrían varias de las flores de plantas pCAPE2-PsAGdoble: tras la dehiscencia de la flor, el órgano carpelo-sepaloide presente en el último verticilo generaba una rama nueva, la cual formaba hojas y zarcillos y finalmente resultaba en la producción de flores (generalmente de fenotipo silvestre) y frutos (Figura 79, i). Un despiece de una flor típica pCAPE2-PsAGdoble se presenta en la Figura 79, j. Pueden apreciarse los sépalos inalterados y cinco pétalos de morfología similar a la silvestre. Posteriormente, se observa una sucesión de muchos órganos tipo pétalo y estambres petaloides, sin que la flor se determine en un ningún órgano carpeloide.

Figura 79. Fenotipo de las flores pCAPE2-PsAGdoble. a) Flor silvestre. b) Flor pCAPE2-PsAGdoble con gran número de órganos petaloides. c) Flor pCAPE2-PSAGdoble. La punta de flecha señala un capullo floral ectópico en el interior de la flor. d) Flor pCAPE2-PSAGdoble compacta con órganos petaloides verdosos y finos. e) Tubo estaminal de flor pCAPE2-PSAGdoble que presenta estambres petaloides. f) Órgano con puntas sepaloides presente en el verticilo del carpelo. g) Flor pCAPE2-PsAGdoble con fenotipo "una flor dentro de otra (punta de flecha). h) Detalle del interior de la flor pCAPE2-PsAGdoble con fenotipo "una flor dentro de otra tras el despiece. i) Reversión floral en flor pCAPE2-PsAGdoble. La punta de flecha señala los sépalos de la flor original. j) Despiece de flor pCAPE2-PSAGdoble. Las barras indican $5 \mathrm{~mm}$. 

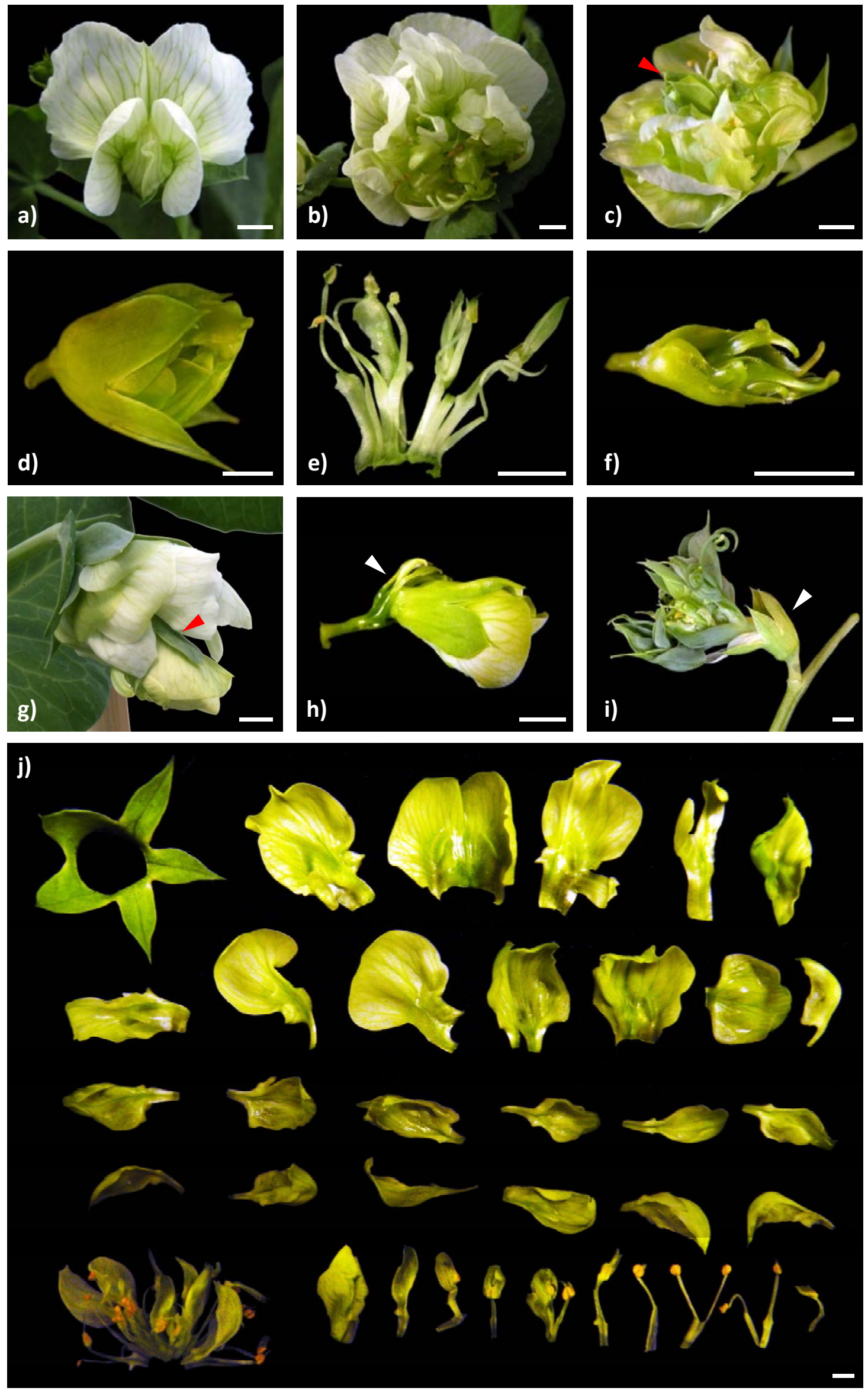

Figura 79. Fenotipo de las flores pCAPE2-PsAGdoble. 


\subsubsection{VIGS en Medicago truncatula}

El vector PEBV de Pisum sativum también se utilizó para silenciar transitoriamente los genes MtAGa y MtAGb (este trabajo) en Medicago truncatula cv. SA1335. Se generaron seis construcciones de VIGS para Medicago truncatula: dos para silenciar MtAGa (pCAPE2-MtAGa y pCAPE2-MtAGabis), tres para silenciar MtAGb (pCAPE2-MtAGb, pCAPE2-MtAGbbis1 y pCAPE2-MtAGbbis2) y una para silenciar simultáneamente ambos genes (pCAPE2-MtAGdoble; ver apartado 3.1.2, Materiales y Métodos). Los fragmentos génicos utilizados en estas construcciones son homólogos a los fragmentos utilizados para las construcciones de Pisum sativum. Igualmente, se espera mayor especificidad de las construcciones pCAPE2-MtAGa y pCAPE2-MtAGb que de las construcciones pCAPE2MtAGabis, pCAPE2-MtAGbbis1 y pCAPE2-MtAGbbis2 en el silenciamiento de los genes por separado.

Para hacer un seguimiento del efecto del virus PEBV sobre las plantas, se utilizó la construcción control pCAPE2-GUS (Constantin et al., unpublished) y para definir el momento a partir del cual pueden observarse los efectos del silenciamiento génico, se utilizó la construcción pCAPE2-MtPDS, que incluye un fragmento de 476 pb del gen MtPDS, cuyo silenciamiento genera un fenotipo de blanqueo de hojas (Kumagai et al., 1995; Constantin et al., 2004). El esquema general de estas construcciones se muestra en la Figura 80.

Las plantas VIGS de Medicago truncatula se generaron mediante agroinfiltración (ver apartado 3.2.2, Materiales y Métodos). Se realizaron dos experimentos independientes de transformación genética transitoria con un total de 153 plantas. Se incluyeron grupos de plantas transformadas con las seis construcciones AGAMOUS (20 plantas para pCAPE2-MtAGa y pCAPE2-MtAGb, 18 para pCAPE2-MtAGabis, 17 para pCAPE2MtAGbbis1 y pCAPE2-MtAGbbis2 y 21 para pCAPE2-MtAGdoble), 13 plantas transformadas con la construcción PCAPE2-GUS, 19 plantas transformadas con la construcción pCAPE2-MtPDS y 8 plantas sin transformar (control externo).

Tras la agroinoculación, las plantas se dejaron crecer hasta observar el fenotipo de blanqueo en las hojas de las plantas pCAPE2-MtPDS (19-20 días post-infiltración), señal de que el silenciamiento se estaba produciendo. Hasta este momento, todas las flores y frutos generados en las plantas se retiraron manualmente. 
a) PCAPE1

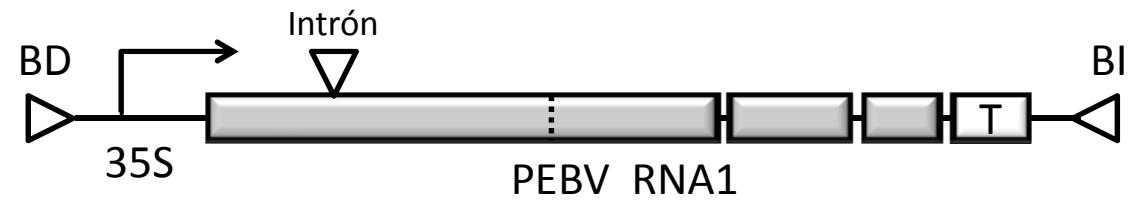

b) pCAPE2-GUS

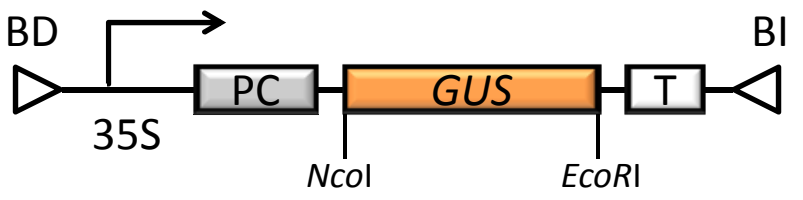

c) PCAPE2-MtPDS

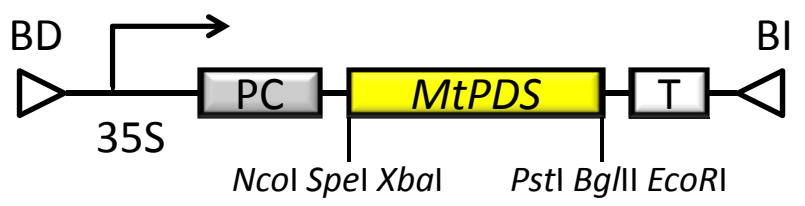

d) PCAPE2-MtAGa

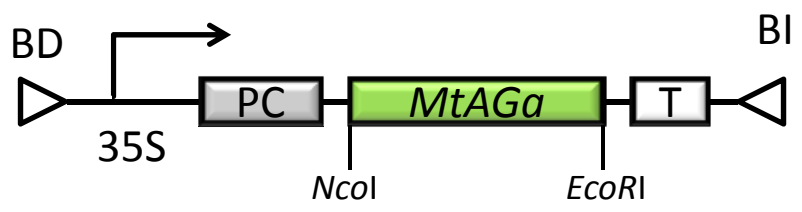

e) pCAPE2-MtAGabis

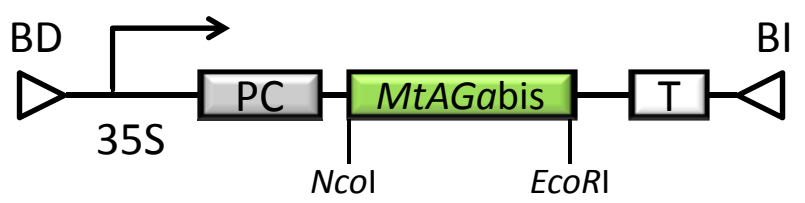

f) PCAPE2-MtAGb

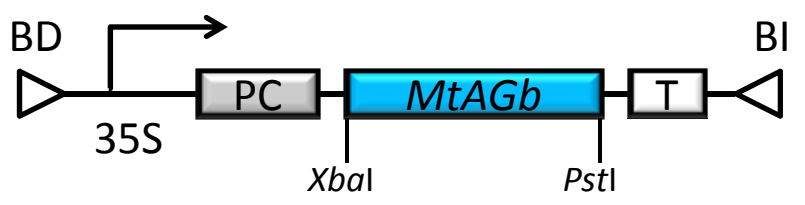

g) pCAPE2-MtAGbbis1

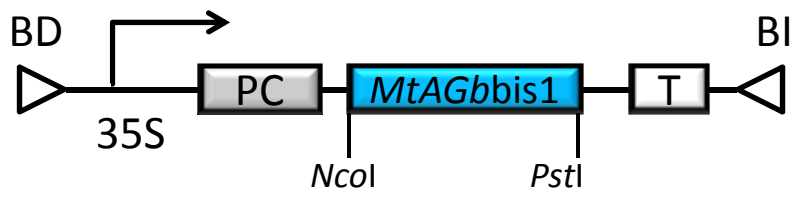

h) pCAPE2-MtAGbbis2

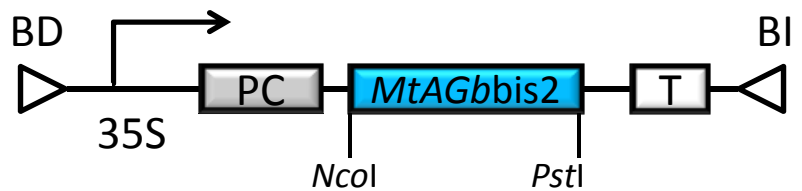

i) PCAPE2-MtAGdoble

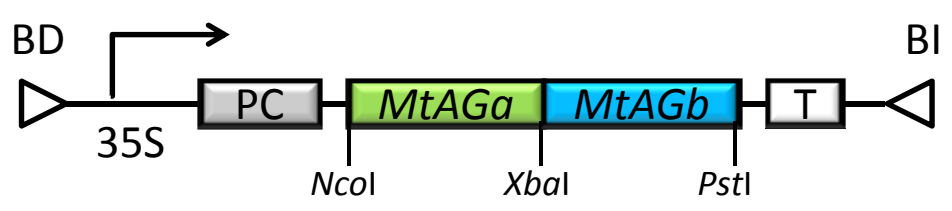

Figura 80. Esquema de las construcciones VIGS para Medicago truncatula. a) pCAPE1, que contiene el cDNA completo del RNA1. b) pCAPE2-GUS. Construcción utilizada como control positivo de infección viral, sin fenotipo. c) pCAPE2-MtPDS. Construcción utilizada como control positivo de infección viral, con fenotipo. d) y e) pCAPE2-MtAGa y pCAPE2-MtAGabis, utilizadas para silenciar el gen MtAGa. f), g) y h) pCAPE2-MtAGb, pCAPE2-MtAGbbis1 y pCAPE2-MtAGbbis2, utilizadas para silenciar el gen $M t A G b$. i) pCAPE2-MtAGdoble, usada para silenciar MtAGa y MtAGb simultáneamente. BD, borde derecho; BI, borde izquierdo; T, terminador NOS; PC, región codificante de la proteína de la cápside. (Imágenes adaptadas de Constantin et al., 2004). 
A partir de la aparición del fenotipo de blanqueo, las plantas se analizaron visualmente y se colectaron todas las flores con el fin de ser analizadas.

Las plantas pCAPE2-GUS y pCAPE2-MtPDS no presentaban ningún tipo de alteración morfológica apreciable ni en las estructuras vegetativas ni en las reproductivas. Las plantas transformadas con las construcciones AGAMOUS tampoco presentaban alteraciones en las estructuras vegetativas. La posición y complejidad de hojas y ramas laterales permanecieron inalteradas.

Con la finalidad de no pasar por alto ninguna modificación en las flores de las plantas VIGS, todas las flores de todas las plantas fueron despiezadas y analizadas por microscopía estereoscópica. Únicamente 5 de las 21 plantas pCAPE2-MtAGdoble (23,8\%) generaron flores modificadas. Ninguna de las plantas de las demás construcciones produjo flores anormales. La Tabla 21 resume la frecuencia y tipo de fenotipos florales observados.

Tabla 21. Fenotipos observados en las flores de plantas VIGS de Medicago truncatula

\begin{tabular}{|c|c|c|c|c|c|c|}
\hline Fenotipo observado & WT & $\begin{array}{c}\text { pCAPE2- } \\
\text { GUS }\end{array}$ & $\begin{array}{c}\text { pCAPE2- } \\
\text { MtPDS }\end{array}$ & $\begin{array}{l}\text { PCAPE2- } \\
M t A G a^{a}\end{array}$ & $\begin{array}{l}\text { pCAPE2- } \\
M_{t A G b^{b}}\end{array}$ & $\begin{array}{c}\text { pCAPE2- } \\
\text { MtAGdoble }\end{array}$ \\
\hline Plantas inoculadas & 8 & 13 & 19 & 38 & 54 & 21 \\
\hline Flores totales analizadas & 40 & 65 & 95 & 168 & 299 & 149 \\
\hline $\begin{array}{l}\text { Flores con fenotipo en } \\
\text { verticilos } 3 \text { y } 4\end{array}$ & 0 & 0 & 0 & 0 & 0 & $1(0,67 \%)$ \\
\hline $\begin{array}{l}\text { Flores con conversiones } \\
\text { homeóticas en los estambres }\end{array}$ & 0 & 0 & 0 & 0 & 0 & $11(7,38 \%)$ \\
\hline $\begin{array}{l}\text { Flores con conversiones } \\
\text { homeóticas en el carpelo }\end{array}$ & 0 & 0 & 0 & 0 & 0 & $2(1,34 \%)$ \\
\hline $\begin{array}{l}\text { Flores con defectos en la } \\
\text { determinación del meristemo }\end{array}$ & 0 & 0 & 0 & 0 & 0 & $1(0,67 \%)$ \\
\hline
\end{tabular}

${ }^{a}$ Se suman los datos de las plantas pCAPE2-MtAGa y pCAPE2-MtAGabis1

${ }^{\mathrm{b}}$ Se suman los datos de las plantas pCAPE2-MtAGb, pCAPE2-MtAGbbis1 y pCAPE2-MtAGbbis2

El silenciamiento simultáneo de los transcritos $M t A G a$ y $M t A G b$ en las plantas pCAPE2-MtAGdoble generó algunas flores con un fenotipo que involucraba la pérdida de la identidad de estambres (transformados en estructuras petaloides) y carpelos (están deformes o recuerdan estructuras sepaloides). Se pudo observar un caso de pérdida de determinación del meristemo floral (Figura 81). Las flores pCAPE2-MtAGdoble que 
presentaron alteraciones fueron deformes o asimétricas (Figura 81, d) y además podían presentar estructuras petaloides o sepaloides en su interior (punta de flecha en Figura $81, d)$.
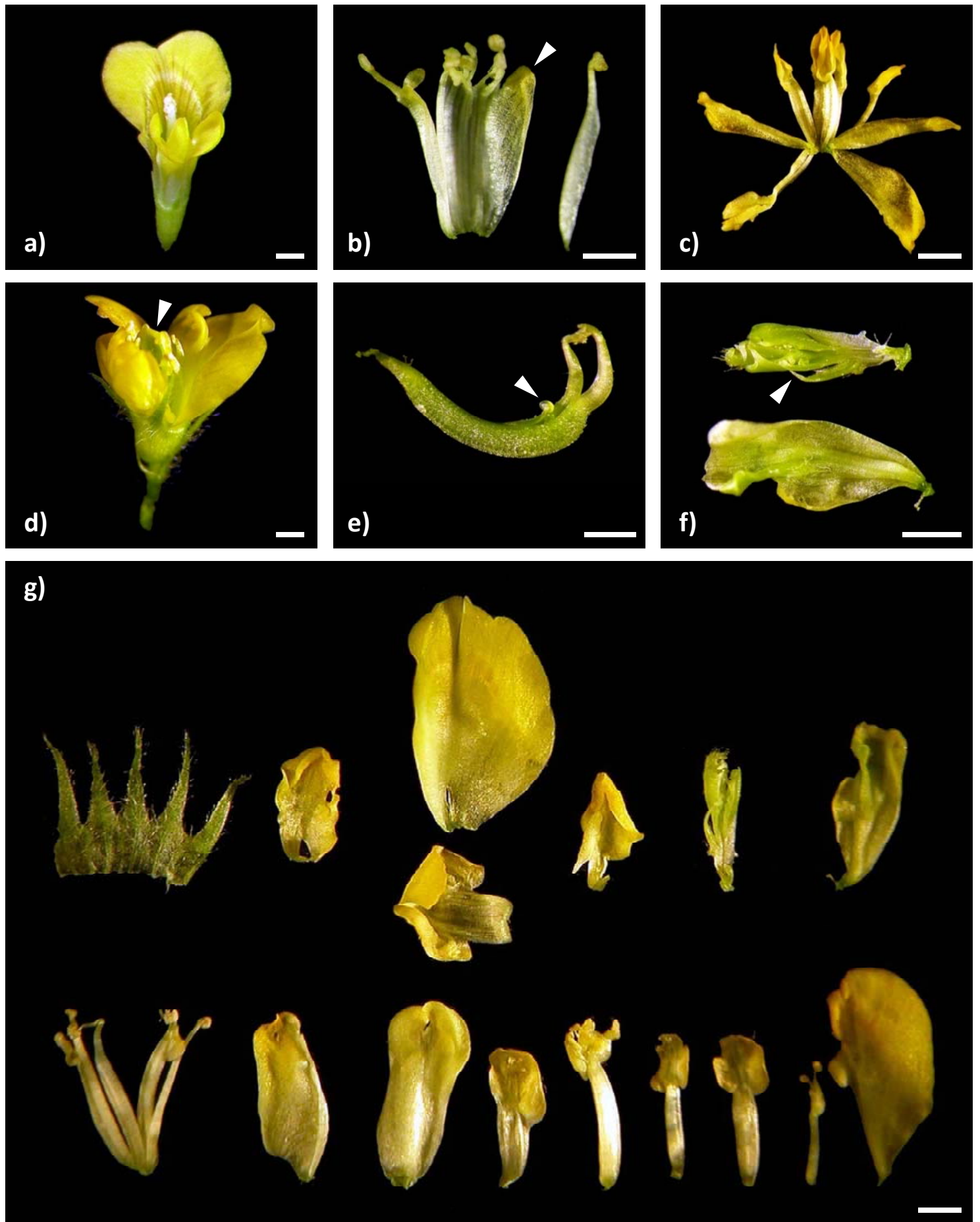

Figura 81. Alteraciones morfológicas observadas en flores pCAPE2-MtAGdoble. a) Flor silvestre. b) Tubo estaminal de flor pCAPE2-MtAGdoble que presenta anteras aplastadas, inmaduras o petaloides (punta de flecha). c) Estambres petaloides de flor pCAPE2-MtAGdoble. d) Flor pCAPE2-MtAGdoble con órganos petaloides. La punta de flecha señala un órgano sepaloide en el interior. e) Carpelo doble de flor pCAPE2MtAGdoble con un óvulo a la vista (punta de flecha). f) Órgano compuesto por capas y con puntas sepaloides (punta de flecha) presente en el verticilo del carpelo. g) Despiece de flor pCAPE2-MtAGdoble. Las barras indican $1 \mathrm{~mm}$. 
En las flores en las cuales podía distinguirse aún el tubo estaminal, las anteras se observaban inmaduras y aplanadas (Figura 81, b) o estaban transformadas en estructuras petaloides (punta de flecha en Figura 81, b). En algunos casos se perdía la fusión del tubo estaminal y los estambres sueltos presentaban diferentes niveles de transformación en órganos petaloides (Figura 81, c). En las flores pCAPE2-MtAGdoble alteradas se observaron pocas conversiones homeóticas en el cuarto verticilo. Generalmente, los carpelos eran de aspecto silvestre pero levemente empequeñecidos. Se observó la presencia de un carpelo doble (Figura 81, e) que presentaba una ruptura que dejaba ver los óvulos (punta de flecha en Figura 81, e) o un carpelo transformado en un órgano compuesto por capas y que presentaba varias puntas tipo sépalo (Figura 81, f). Este último no estaba determinado ni presentaba óvulos en su interior. El despiece de la flor pCAPE2-MtAGdoble que presenta indeterminación meristemática se presenta en la Figura 81, g. Pueden apreciarse los sépalos inalterados y cinco pétalos de morfología similar a la silvestre. Posteriormente, se observa una sucesión de órganos tipo pétalo y estambres petaloides, y un órgano sepaloide indeterminado compuesto por capas.

El fenotipo de las flores pCAPE2-MtAGdoble recuerda al fenotipo de las flores pCAPE2-PsAGdoble. Sin embargo en Medicago truncatula, a diferencia de Pisum sativum, no se observaron fenotipos en las flores de las plantas afectadas en la expresión de uno de los genes. Además, la frecuencia en la aparición de fenotipos alterados en Medicago truncatula (2\% flores alteradas) es mucho menor que en Pisum sativum (45\% flores alteradas), debido a la menor eficiencia de infección del virus PEBV en Medicago truncatula, al no ser su huésped natural.

\subsubsection{Expresión constitutiva en plantas de Arabidopsis thaliana}

Los análisis de secuencia y patrones de expresión de MtAGa y MtAGb sugieren una posible función de ambos como genes de identidad de órgano floral de clase C. Para comprobar esta hipótesis se utilizó la expresión constitutiva en el sistema transgénico heterólogo Arabidopsis thaliana como herramienta alternativa para el estudio de la función de dichos genes. Las regiones codificantes de MtAGa y MtAGb (en ambas formas: $M t A G b S$ y $M t A G b L)$ se clonaron en el vector binario de expresión en plantas pBIN-JIT bajo el control del doble promotor 2X35S CaMV (ver apartado 3.1.3, Materiales y Métodos). 
Como resultado de la transformación de Arabidopsis thaliana con las construcciones 2X35S::MtAGa, 2X35S::MtAGbS y 2X35S::MtAGbL se obtuvieron más de 300 plantas $\mathrm{T}_{1}$ independientes capaces de crecer en medio de selección con kanamicina. En la Tabla 22 se muestra el número de líneas resistentes a kanamicina obtenido, indicando aquellas que presentaron fenotipo alterado (alrededor de $1 / 3$ de las plantas 2X35S::MtAGa y 2X35S::MtAGbS y cerca de $2 / 3$ de las plantas 2X35S::MtAGbL).

Tabla 22. Número de líneas resistentes a kanamicina y número de líneas con fenotipo alterado por transformación con las construcciones de expresión constitutiva

\begin{tabular}{ccc}
\hline Construcción & Líneas resistentes & Líneas fenotipo alterado \\
\hline 2X35S::MtAGa & 119 & $45(37.8 \%)$ \\
2X35S::MtAGbS & 118 & $43(36,4 \%)$ \\
2X35S::MtAGbL & 118 & $71(60,2 \%)$ \\
\hline
\end{tabular}

\subsubsection{Expresión constitutiva de MtAGa en plantas de Arabidopsis thaliana}

Con el fin de determinar el número de inserciones de T-DNA de MtAGa se realizó el análisis de segregación de varias líneas transgénicas que mostraban alteraciones fenotípicas en la $T_{1}$, mediante la siembra de la progenie $T_{2}$ en medio de selección con kanamicina. Se sembraron semillas procedentes de plantas control (sin transformar) y transgénicas 2X35S::MtAGa. Los resultados obtenidos se muestran en la Tabla 23.

Tabla 23. Segregación de la resistencia a kanamicina en plantas transgénicas $\mathrm{T}_{2}$ 2X35S::MtAGa

\begin{tabular}{|c|c|c|c|c|c|c|c|}
\hline \multirow[b]{2}{*}{ Línea } & \multirow{2}{*}{$\begin{array}{l}\text { Plantas } \mathrm{T}_{2} \\
\text { analizadas }\end{array}$} & \multicolumn{2}{|c|}{ Fenotipo $\mathrm{Kan}^{\mathrm{R}}$} & \multirow[b]{2}{*}{ Segregación } & \multirow{2}{*}{ Valor $\chi^{2}$} & \multirow{2}{*}{$\begin{array}{c}\text { Nivel de } \\
\text { significación } \\
\text { (P) }\end{array}$} & \multirow{2}{*}{$\begin{array}{l}\text { No. } \\
\text { Copias }\end{array}$} \\
\hline & & $+(R)$ & $-(S)$ & & & & \\
\hline 1 & 163 & 116 & 47 & $3: 1$ & 1,2781 & 0,2590 & 1 \\
\hline 2 & 185 & 143 & 42 & $3: 1$ & 0,5207 & 0,4740 & 1 \\
\hline 7 & 187 & 138 & 49 & $3: 1$ & 0,1444 & 0,7039 & 1 \\
\hline 8 & 163 & 148 & 15 & $15: 1$ & 2,4250 & 0,1264 & 2 \\
\hline 19 & 180 & 128 & 52 & $3: 1$ & 1,4519 & 0,2297 & 1 \\
\hline 28 & 89 & 72 & 17 & $3: 1$ & 1,6517 & 0,1990 & 1 \\
\hline 60 & 187 & 136 & 51 & $3: 1$ & 0,5152 & 0,4762 & 1 \\
\hline 81 & 186 & 178 & 8 & $15: 1$ & 1,206 & 0,2734 & 2 \\
\hline 84 & 177 & 137 & 40 & $3: 1$ & 0,5443 & 0,4647 & 1 \\
\hline
\end{tabular}

Kan: kanamicina; R: resistentes; S: sensibles 
La tolerancia a kanamicina en las líneas $T_{2}$ analizadas se ajusta a una segregación 3:1, que corresponde a la esperada para una única inserción del transgén, con excepción de las líneas 2X35S::MtAGa-8 y 2X35S::MtAGa-81 cuyos datos de segregación (15:1) sugieren que se han producido dos inserciones.

Las líneas con expresión constitutiva de MtAGa que presentaban alteraciones fenotípicas mostraban fenotipos similares, con distintos grados de intensidad. Todas las líneas con fenotipo modificado presentaban adelanto del tiempo de floración respecto a la línea control. En la Figura 82 se ejemplifica cómo tres líneas representativas han florecido, mientras que la planta control continúa su desarrollo vegetativo.

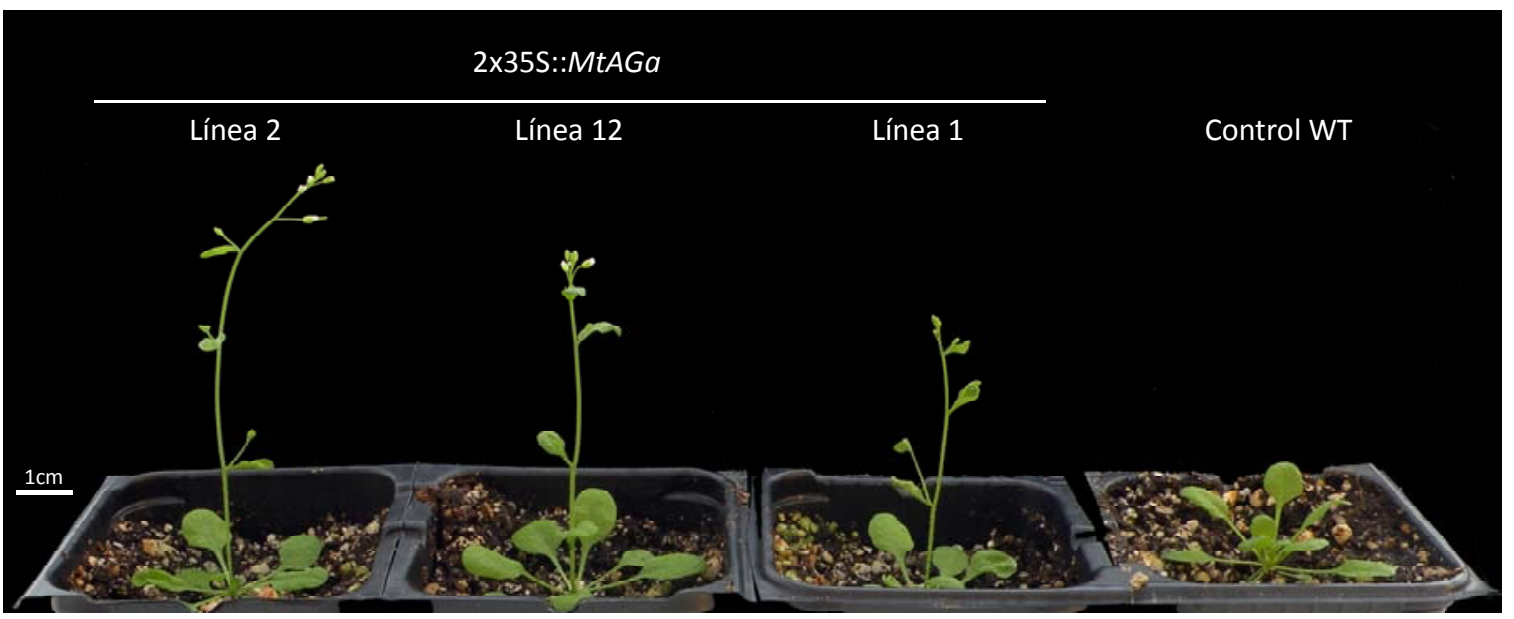

Figura 82. Plantas de líneas que expresan constitutivamente MtAGa. Se aprecia adelanto del tiempo de floración de estas líneas respecto a una planta silvestre (WT).

Las plantas transgénicas y las plantas control realizan la transición floral con el mismo número de hojas de roseta $(8-9)$, solo que las transgénicas crecen más rápido, pasando a la fase reproductiva en un tiempo más corto. En la Figura 83 se muestran los días que tardan en florecer, de media, estas plantas.

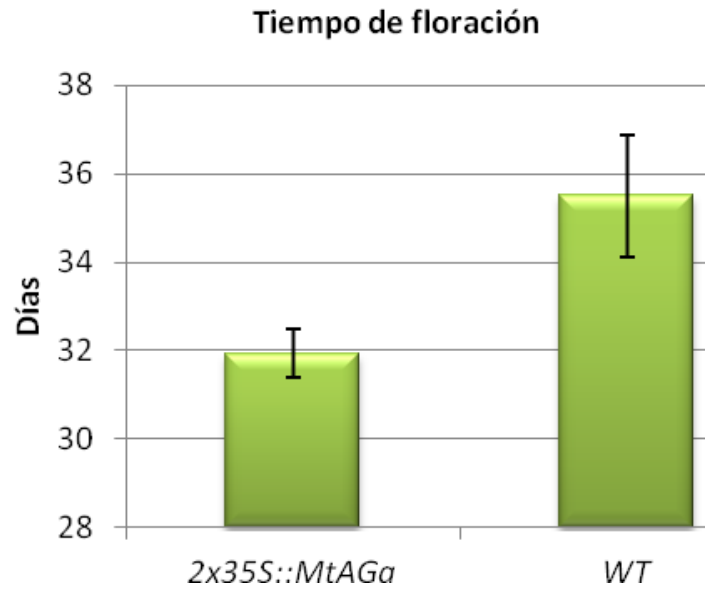

Figura 83. Tiempo de floración de las plantas 2x35S::MtAGa. Se muestran los días que tardan en florecer las plantas 2x35S::MtAGa comparadas con las plantas control (WT). Las barras indican el error estándar. 
La flor de Arabidopsis thaliana tiene una estructura simple, típica de las Brassicaceae. Posee un cáliz con cuatro sépalos y una corola de cuatro pétalos, cuya posición es alterna a la de los sépalos. En androceo está compuesto por seis estambres y el gineceo por dos carpelos fusionados.

El fenotipo de las flores de las líneas 2x35S::MtAGa está alterado: los órganos del primer verticilo suelen estar curvados hacia el interior de la flor (Figura 84, b), en ocasiones atrapando a los pétalos (indicado con punta de flecha en Figura 84, b). También presentan ocasionalmente desnivel en su altura. Los pétalos presentan transformaciones homeóticas leves hacia estambres, que se ponen de manifiesto por cambios en su morfología: aparecen más estrechos que los de la planta control (Figura 84, c). Además, la disposición de los pétalos pierde simetría. En ocasiones el número de órganos florales producido se ve alterado, encontrando flores con más o menos pétalos. El desarrollo alterado de los órganos del primer y segundo verticilo puede observarse desde estadios tempranos del desarrollo floral. A diferencia de las plantas control, en las líneas 2x35s::MtAGa muchas yemas florales tempranas del ápice inflorescente se encuentran abiertas (indicado con punta de flecha en Figura 84, d). Este aspecto "abierto y vacío" es resultado de la curvatura anormal de los sépalos y del tamaño reducido de los pétalos en las plantas transgénicas.

Además del adelanto en el tiempo de floración y las transformaciones homeóticas en el primer y segundo verticilo, se observan alteraciones en la arquitectura de la planta, como la determinación del meristemo apical en estructuras terminales modificadas, en contraste con el crecimiento indeterminado de dicho meristemo en las plantas control. Dichas estructuras consisten, en general, en transformaciones carpeloides retorcidas y fusionadas que contienen órganos florales en su interior (Figura 84, e y f). En ocasiones, en la base de dichas estructuras se forma una hoja caulinar curvada (indicado con punta de flecha en Figura 84, e).

En las plantas 2x35S::MtAGa es usual encontrar flores y frutos "dobles", es decir, dos flores fusionadas que se originan a partir del mismo pedicelo (indicado con punta de flecha en Figura 84, g). Estas flores desarrollan frutos dobles. Los frutos de fenotipo normal de las plantas transgénicas suelen presentar no-abscisión de los órganos florales, que senescen pero permanecen adheridos al fruto (Figura 84, h). Frecuentemente, los órganos vegetativos también se ven modificados, apareciendo curvadas tanto las hojas 
caulinares como las que forman parte de la roseta (indicado con punta de flecha en Figura 84, i).
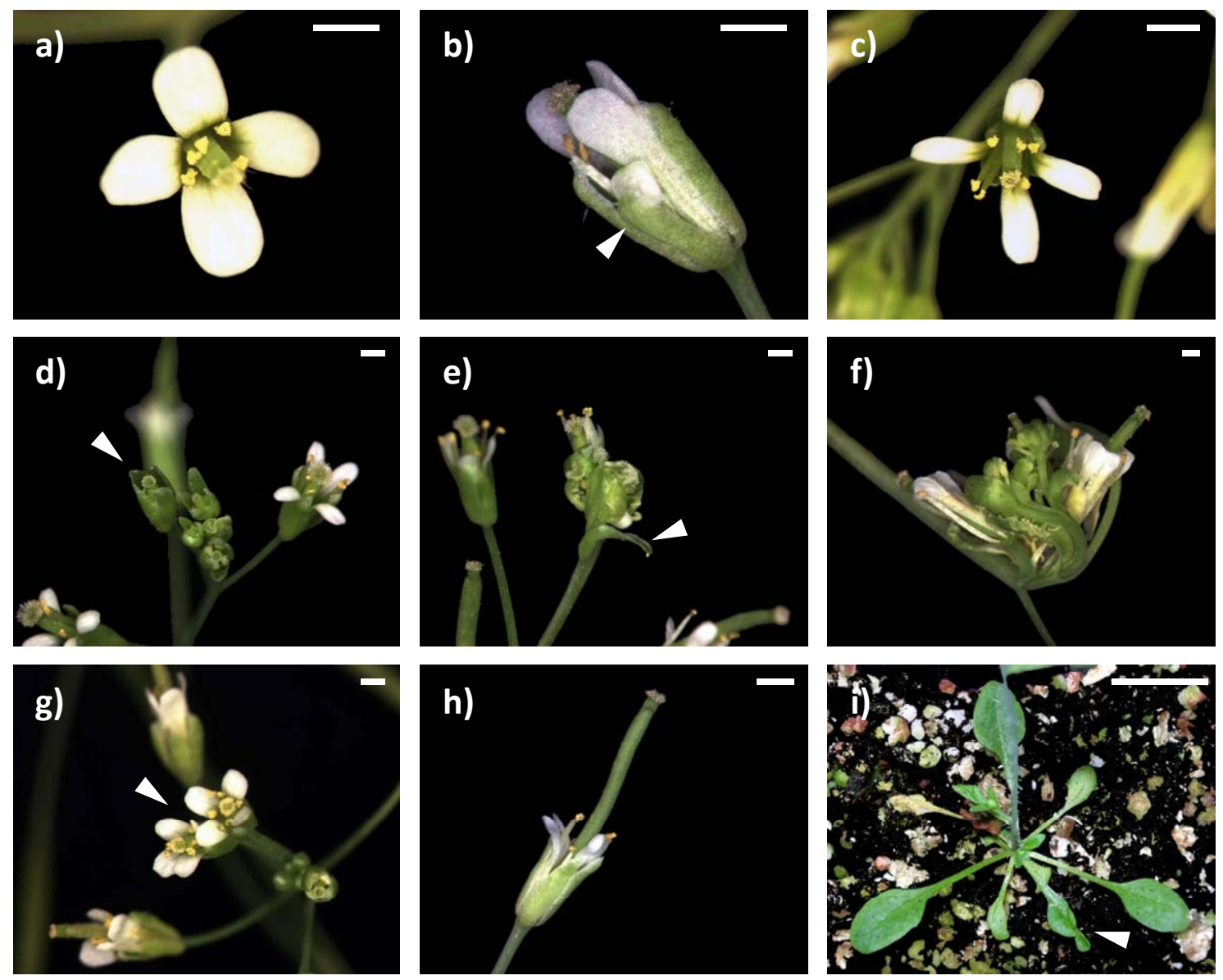

Figura 84. Fenotipo de las líneas transgénicas con expresión constitutiva de MtAGa en Arabidopsis thaliana. a) Flor silvestre. b) Flor $2 \times 355:: M t A G a$, la punta de flecha señala un sépalo curvado que atrapa al pétalo. c) Flor 2x35S::MtAGa cuyos pétalos están estrechados. d) Ápice inflorescente 2x35S::MtAGa; muchas yemas florales se presentan abiertas. e) y f) Estructuras terminales modificadas producidas por plantas 2x35S::MtAGa; la punta de flecha señala una hoja caulinar curvada. g) Flores dobles presentes en las plantas transgénicas, indicadas por una punta de flecha. h) Fruto 2×35S::MtAGa; no-abscisión de los órganos florales al desarrollarse el fruto. i) Roseta de una planta 2x35s::MtAGa; la punta de flecha señala una de las hojas curvadas. Las barras indican $1 \mathrm{~mm}$, excepto en i, donde indica $1 \mathrm{~cm}$.

El fenotipo de las flores de las plantas 2x35S::MtAGa se analizó mediante criomicroscopía electrónica de barrido. En la Figura 85 se pueden apreciar con detalle las transformaciones homeóticas anteriormente mencionadas. Se observa el aspecto "abierto y vacío" de las yemas florales tempranas de las plantas 2x35S::MtAGa (Figura 85, b), así como un tamaño más compacto de las flores transgénicas (Figura 85, d) en comparación con las flores silvestres (Figura 85, c). Puede observarse en las flores 
2×35S::MtAGa una curvatura de los sépalos hacia el interior (Figura 85, d) ligeramente más acentuada que en las flores silvestres.
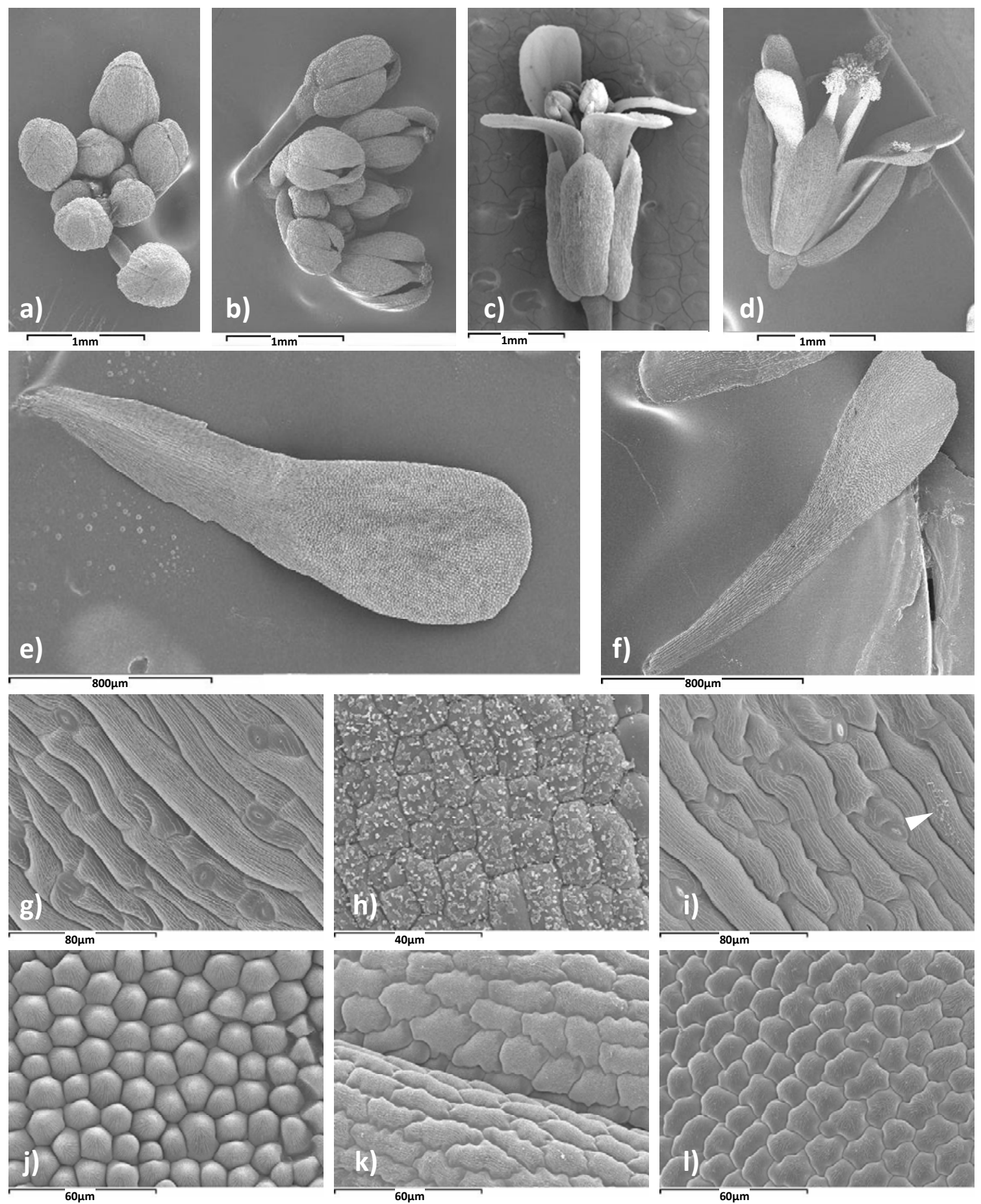

Figura 85. Fenotipo de las flores 2x35S::MtAGa observado mediante criomicroscopía electrónica de barrido. a) Ápice inflorescente de planta silvestre. b) Ápice inflorescente de planta 2x35S::MtAGa. c) Flor de fenotipo silvestre. d) Flor 2×35S::MtAGa con curvatura de sépalos y pétalos estrechados. e) Pétalo de flor de fenotipo silvestre. f) Pétalo estrechado y más pequeño de flor 2x35S::MtAGa. g) Detalle de tejido de sépalo silvestre. h) Detalle de tejido de carpelo silvestre. i) Detalle de tejido de sépalo 2x35S::MtAGa; la punta de flecha señala la presencia de ceras características de tejido de carpelo. j) Detalle de tejido de pétalo silvestre. k) Detalle de tejido de antera silvestre. I) Detalle de tejido de pétalo 2x35S::MtAGa que recuerda la estructura tisular característica de antera. Las barras indican $1 \mathrm{~mm}$ en a, b, c y d; $800 \mu \mathrm{M}$ en e y f; $80 \mu \mathrm{M}$ en g y i; $40 \mu \mathrm{M}$ en h y $60 \mu \mathrm{M}$ en j, k y l. 
También puede verse que los pétalos de las flores transgénicas presentan estrechamiento, principalmente en la región media y basal de los mismos (Figura 85, f), además de presentar un tamaño reducido en cerca de un $20 \%$ respecto a un pétalo silvestre (Figura 85 , e). A nivel celular, se observa que el tejido del sépalo 2×35S::MtAGa (Figura 85, i) presenta una estructura muy similar a la del sépalo silvestre (Figura 85, g), aunque presenta algunas ceras en su superficie (punta de flecha en la Figura 85, i), que están ausentes en sépalos silvestres, pero son comunes en carpelos silvestres (Figura 85, h). Las células del tejido de pétalo 2x35S::MtAGa (Figura 85, I) difieren de las células típicas de pétalo silvestre (Figura 85, j), recordando más bien a las células ornamentadas típicas de las anteras silvestres (Figura 85, k).

\subsubsection{Expresión constitutiva de MtAGbS y MtAGbL en plantas de Arabidopsis thaliana}

Se realizó el análisis de segregación de algunas líneas 2X35S::MtAGbL que presentaban alteraciones fenotípicas en la $T_{1}$, en función de la proporción de plantas $T_{2}$ resistentes a kanamicina. Los resultados se muestran en la Tabla 24 . La tolerancia a kanamicina en las líneas $T_{2}$ analizadas se ajusta a una segregación 3:1, que corresponde a una única inserción del transgén. En las líneas transgénicas 2X35S::MtAGbL-2 y 2X35S::MtAGbL-17 hay dos inserciones. No se analizaron plantas 2X35S::MtAGbS ya que, comparadas con las plantas control, no presentaban alteraciones fenotípicas evidentes.

Tabla 24. Segregación de la resistencia a kanamicina en plantas transgénicas $\mathrm{T}_{2}$ 2X35S::MtAGbL

\begin{tabular}{|c|c|c|c|c|c|c|c|}
\hline \multirow[b]{2}{*}{ Línea } & \multirow{2}{*}{$\begin{array}{l}\text { Plantas } \mathbf{T}_{2} \\
\text { analizadas }\end{array}$} & \multicolumn{2}{|c|}{ Fenotipo Kan $^{R}$} & \multirow[b]{2}{*}{ Segregación } & \multirow[b]{2}{*}{ Valor $x^{2}$} & \multirow{2}{*}{$\begin{array}{c}\text { Nivel de } \\
\text { significación } \\
\text { (P) }\end{array}$} & \multirow{2}{*}{$\begin{array}{c}\text { No. } \\
\text { Copias }\end{array}$} \\
\hline & & $+(\mathrm{R})$ & $-(S)$ & & & & \\
\hline 2 & 97 & 92 & 5 & $15: 1$ & 0,1990 & 0,6598 & 2 \\
\hline 3 & 89 & 70 & 19 & 3:1 & 0,6330 & 0,4296 & 1 \\
\hline 17 & 172 & 165 & 7 & $15: 1$ & 1,3950 & 0,2387 & 2 \\
\hline 34 & 42 & 29 & 13 & $3: 1$ & 0,7937 & 0,3765 & 1 \\
\hline 39 & 195 & 152 & 43 & $3: 1$ & 0,0278 & 0,8754 & 1 \\
\hline
\end{tabular}

Kan: kanamicina; R: resistentes; S: sensibles

Las líneas con expresión constitutiva de $M t A G b L$ que presentaban alteraciones mostraban fenotipos similares y, en la mayoría de las plantas, severos. Todas las líneas con fenotipo modificado presentaban adelanto del tiempo de floración respecto a la línea control, aunque este adelanto no fue tan acusado como en las plantas 
2×35S::MtAGa. En la Figura 86 se ejemplifica cómo tres líneas representativas han florecido e incluso fructificado (líneas 8 y 39), mientras que la planta control ha elongado el tallo, pero aún no ha florecido.

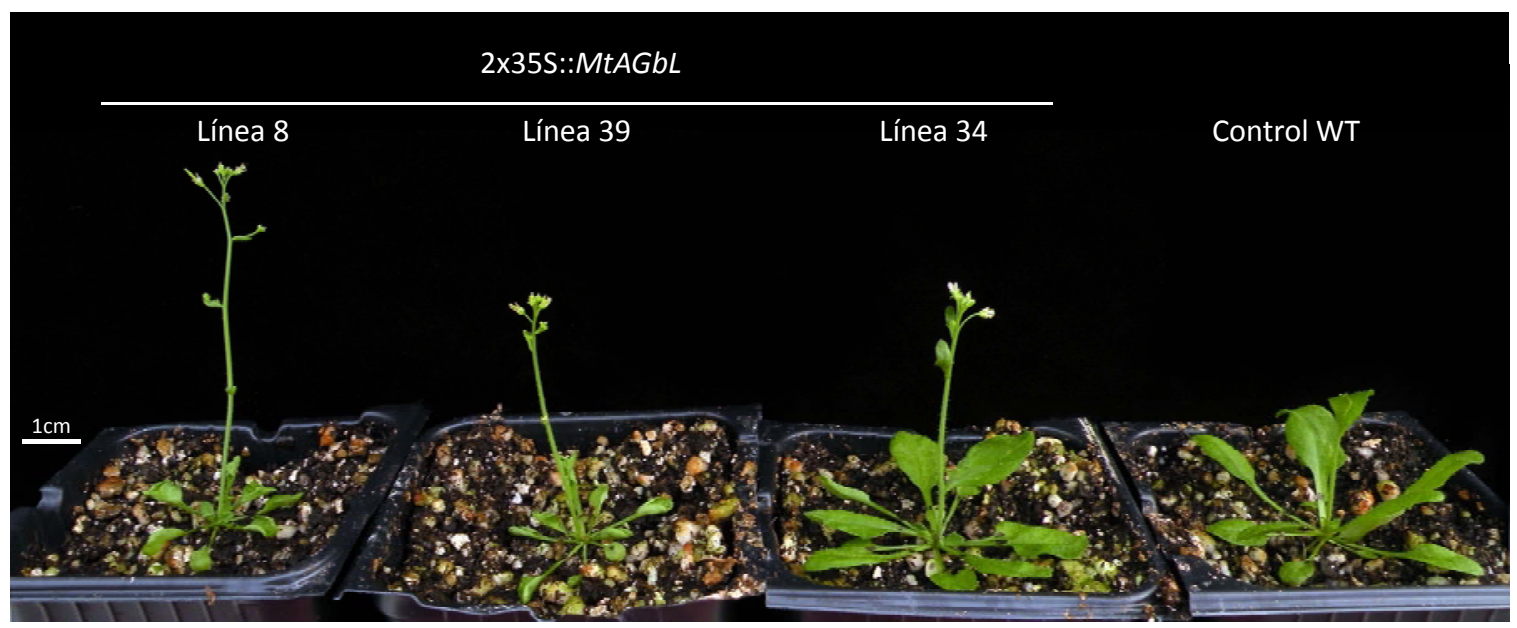

Figura 86. Plantas de líneas que expresan constitutivamente MtAGbL. Se aprecia adelanto del tiempo de floración de estas líneas respecto a una planta silvestre (WT).

Al igual que las plantas 2x35S::MtAGa, las plantas transgénicas 2x35S::MtAGbL realizan la transición floral con el mismo número de hojas de roseta que las plantas control, solo que las transgénicas pasan a la fase reproductiva en un tiempo más corto. En la Figura 87 se muestran los días que tardan en florecer, de media, las plantas que expresan constitutivamente MtAGb en su forma larga.

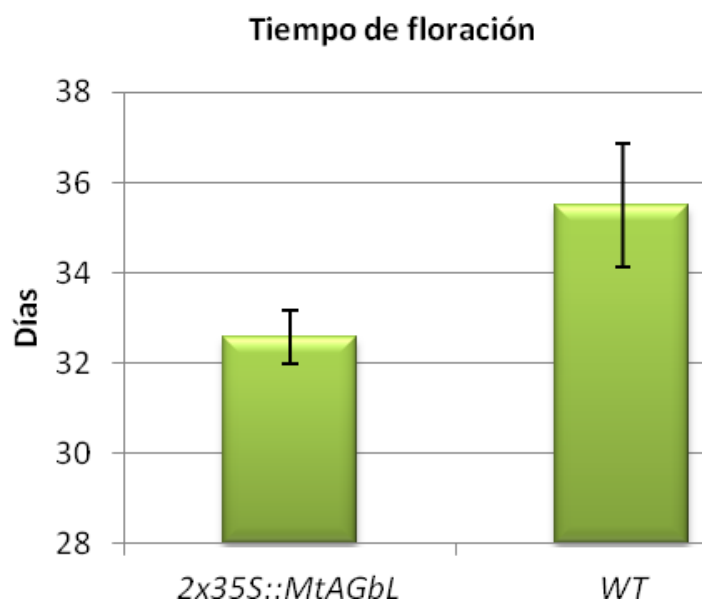

Figura 87. Tiempo de floración de las plantas 2x35S::MtAGbL. Se muestran los días que tardan en florecer estas plantas comparadas con las plantas control (WT). Las barras indican el error estándar.

Las flores de las líneas 2x35s::MtAGbL presentan las conversiones homeóticas esperadas para la expresión constitutiva de un gen de clase C. Los sépalos modificados suelen estar curvados hacia el exterior de la flor (indicado con punta de flecha en Figura 
88, d) o se presentan transformados en órganos carpeloides con óvulos y papilas estigmáticas ectópicos (indicados con punta de flecha en Figura 88, e).
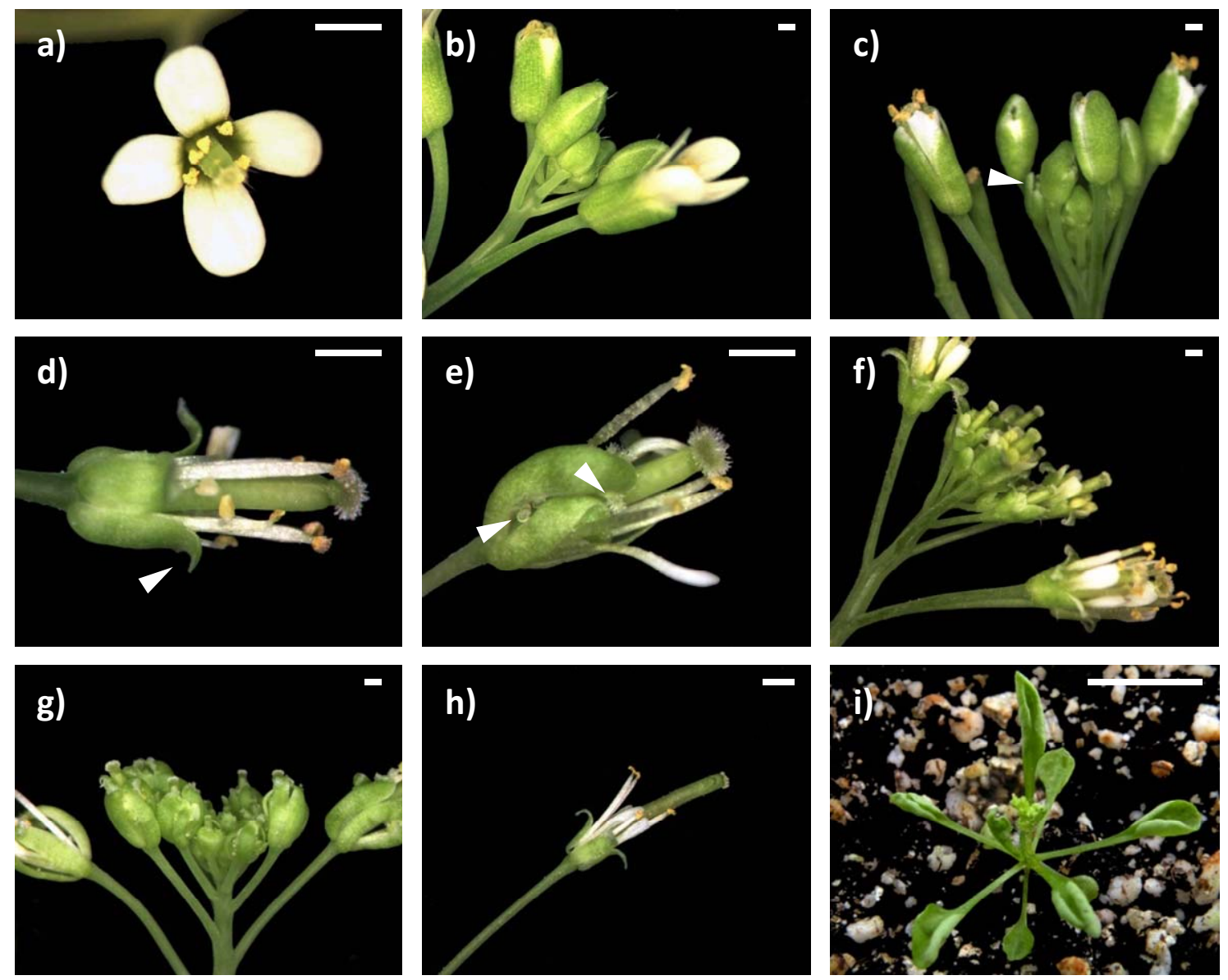

Figura 88. Fenotipo de las líneas transgénicas con expresión constitutiva de MtAGbS o MtAGbL en Arabidopsis thaliana. a) Flor silvestre. b) Ápice inflorescente silvestre; c) Ápice inflorescente 2x35S::MtAGbS; alguna yema floral se presenta abierta. d) Flor 2x35S::MtAGbL con conversiones homeóticas de pétalos a estambres. La punta de flecha señala un sépalo curvado. e) Flor 2x35S::MtAGbL con conversiones homeóticas de sépalos a carpelos. Las puntas de flecha señalan óvulos y papilas estigmáticas ectópicos. f) Ápice inflorescente 2×35S::MtAGbL; las yemas florales se presentan abiertas. g) Ápice inflorescente 2x35S::MtAGbL con conversiones homeóticas de sépalos a carpelos. Las yemas florales se presentan abiertas. h) Fruto 2x35S::MtAGbL; no-abscisión de los órganos florales al desarrollarse el fruto. i) Roseta de una planta 2x35S::MtAGbL con las hojas curvadas. Las barras indican $1 \mathrm{~mm}$, excepto en i, donde indica $1 \mathrm{~cm}$.

Los pétalos presentan transformaciones homeóticas en estambres: aparecen muy estrechados (Figura 88, e) o totalmente convertidos en estambres (Figura 88, d). El desarrollo alterado de estos órganos en las líneas 2x35S::MtAGbL puede detectarse desde estadios tempranos del desarrollo floral. La mayoría de las yemas florales se encuentran abiertas y tienen un aspecto vacío, independientemente de si las flores que se desarrollen a partir de dichas yemas presenten fenotipo con sépalos curvados hacia 
fuera o sépalos carpeloides (Figura 88, $\mathrm{f}$ y g). Este aspecto resulta de la curvatura anormal de los sépalos y de las alteraciones de los pétalos.

Además de las transformaciones homeóticas en el primer y segundo verticilo, se observan alteraciones en la arquitectura de la planta. Al igual que en las líneas 2×35S::MtAGa, los frutos 2×35S::MtAGbL presentan no-abscisión de los órganos florales, que senescen pero permanecen adheridos al fruto (Figura 88, h). Los órganos vegetativos también se ven modificados, apareciendo curvadas tanto las hojas caulinares como las de la roseta (Figura 88, i). Estos fenotipos son más severos en estas plantas que en las plantas 2×35S::MtAGa.

El fenotipo de las flores de las plantas 2x35s::MtAGbL se analizó mediante criomicroscopía electrónica de barrido. La Figura 89 presenta detalles de los aspectos fenotípicos comentados, mientras que en la Figura 90 se pueden apreciar las conversiones homeóticas de los tejidos a nivel celular.

Se observa el aspecto totalmente abierto de las yemas florales tempranas de las plantas 2x35S::MtAGbL (Figura 89, b), así como las transformaciones homeóticas de los órganos de primer y segundo verticilo en las flores transgénicas (Figura 89, d). Puede observarse en las flores 2×35S::MtAGbL la conversión de sépalos en órganos carpeloides (Figura 89, f), que diferencian estructuras semejantes a óvulos y papilas estigmáticas (indicado con puntas de flecha). Estos óvulos (Figura 89, i) y papilas estigmáticas (Figura 89, j) ectópicos presentan los fenotipos de papilas estigmáticas y óvulos silvestres (Figura 89, g y h). También puede verse que los pétalos de las flores transgénicas presentan conversiones homeóticas en estambres (Figura 89, m), presentando pseudoanteras similares a las anteras silvestres (Figura 89, I).

A nivel celular, las transformaciones homeóticas de sépalo en carpelo y de pétalo en estambre son casi completas. Los tejidos celulares de los sépalos 2x35S::MtAGbL son muy similares a los observados en carpelos silvestres, con abundante presencia de ceras (Figura 90, c). Las células de las pseudo-anteras presentes en los órganos del segundo verticilo de las flores 2x35S::MtAGbL (Figura 90, f) difieren de las células típicas de pétalo silvestre (Figura 90, d), recordando a las células ornamentadas típicas de las anteras silvestres (Figura 90, e). Además, las células de la región basal de estos órganos del segundo verticilo (Figura 90, h) se asemejan a las células del tejido de filamento estaminal de una planta silvestre (Figura 90, g). 

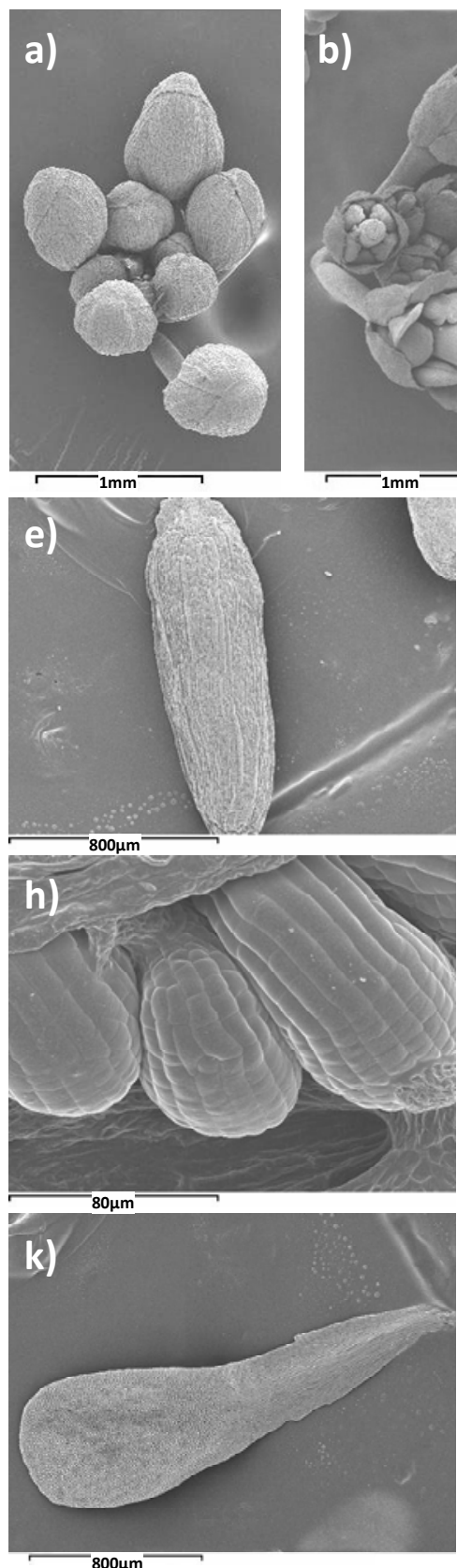
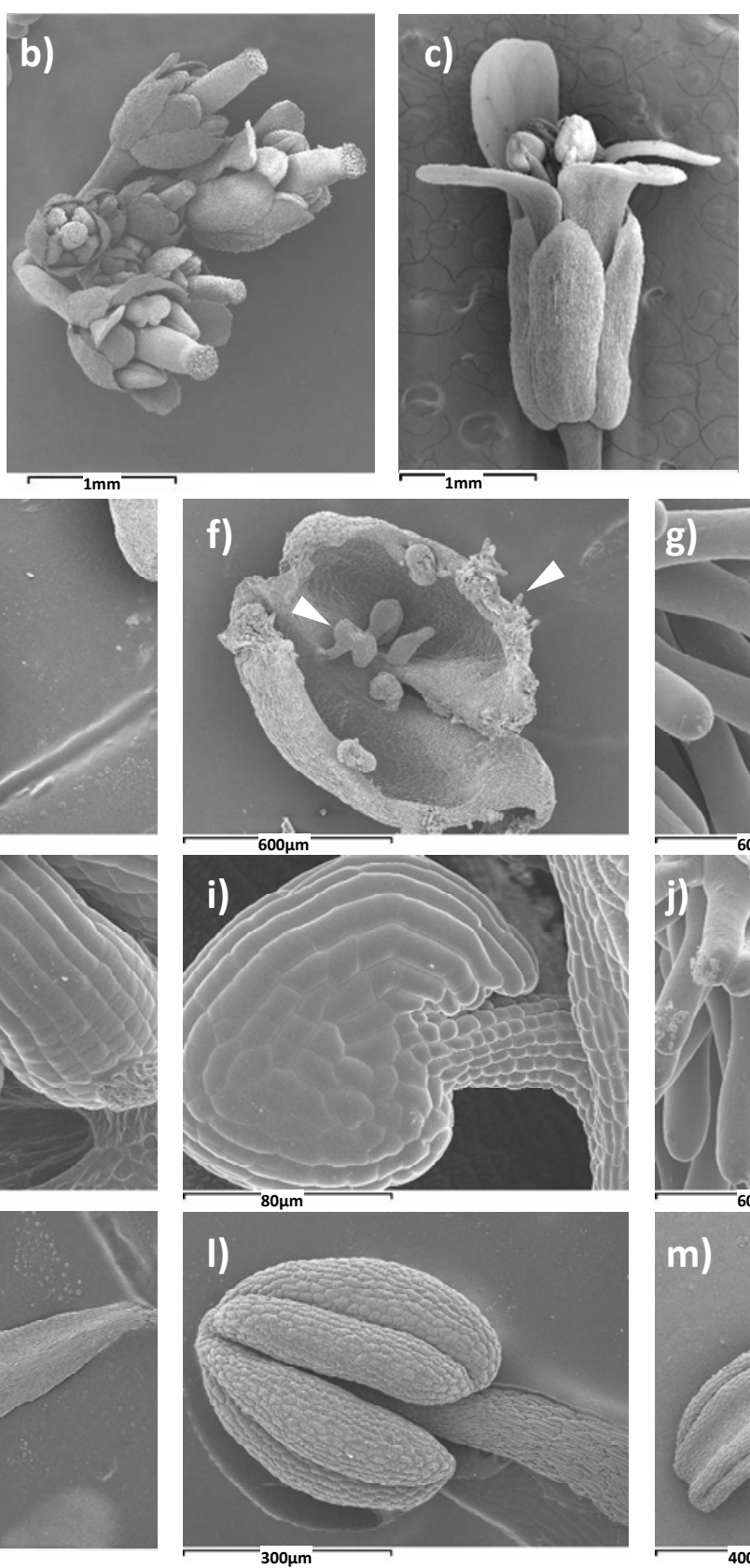
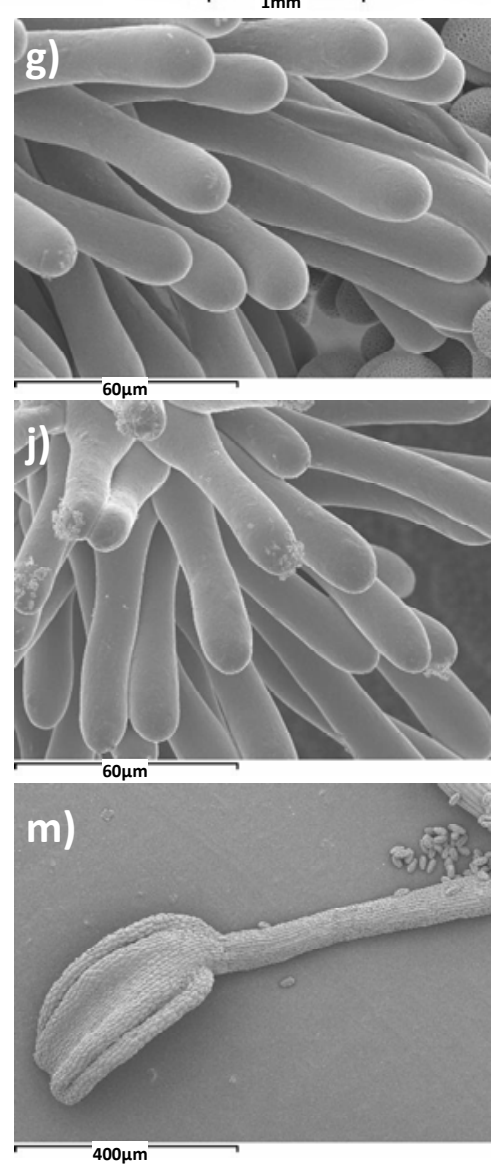

Figura 89. Fenotipo de los órganos de las flores 2x35S::MtAGbL observado mediante criomicroscopía electrónica de barrido. a) Ápice inflorescente de planta silvestre. b) Ápice inflorescente de planta 2×35S::MtAGbL. c) Flor de fenotipo silvestre. d) Flor 2×35S::MtAGbL con conversiones homeóticas en los verticilos primero y segundo; las puntas de flecha señalan la presencia de papilas estigmáticas y óvulos ectópicos. e) Sépalo de flor de fenotipo silvestre. f) Sépalo de flor 2x35S::MtAGbL; las puntas de flecha señalan la presencia de papilas estigmáticas y óvulos ectópicos. g) Papilas estigmáticas de flor de fenotipo silvestre. h) Óvulos de fenotipo silvestre. i) Óvulo ectópico de flor 2×35S::MtAGbL. j) Papilas estigmáticas de flor 2x35S::MtAGbL. k) Pétalo de flor de fenotipo silvestre. I) Antera de flor de fenotipo silvestre. $\mathrm{m}$ ) Pétalo 2x35S::MtAGbL transformado en estambre. Las barras indican $1 \mathrm{~mm}$ en a, b, c y d; $800 \mu \mathrm{M}$ en e, y k; $600 \mu \mathrm{M}$ en f; $400 \mu \mathrm{M}$ en m; $300 \mu \mathrm{M}$ en l; $80 \mu \mathrm{M}$ en h y i y $60 \mu \mathrm{M}$ en g y j. 

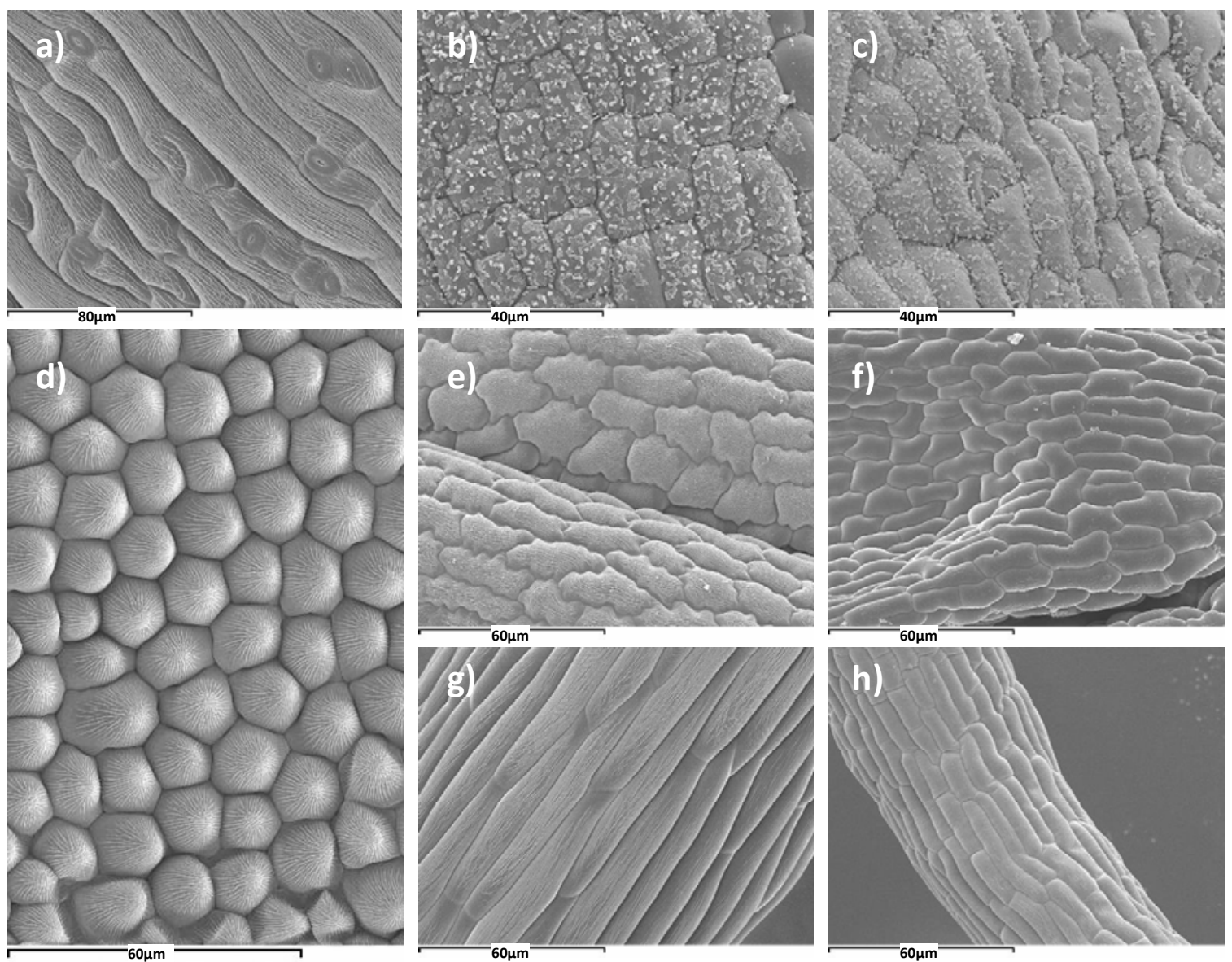

Figura 90. Morfología celular de los órganos modificados 2x35S::MtAGbL observada mediante criomicroscopía electrónica de barrido. a) Detalle de tejido de sépalo silvestre. b) Detalle de tejido de carpelo silvestre. c) Detalle de tejido de sépalo 2x35S::MtAGbL, con estructura tisular de carpelo. d) Detalle de tejido de pétalo silvestre. e) Detalle de tejido de antera silvestre. f) Detalle de tejido de la región distal del pétalo 2×35S::MtAGbL que recuerda la estructura tisular característica de antera. g) Detalle de tejido de filamento estaminal silvestre. h) Detalle de tejido de la región basal del pétalo 2x35S::MtAGbL que recuerda la estructura tisular característica de filamento de estambre. Las barras indican $80 \mu \mathrm{M}$ en $\mathrm{a} ; 60 \mu \mathrm{M}$ en $\mathrm{d}, \mathrm{e}, \mathrm{f}, \mathrm{g}$ y h y $40 \mu \mathrm{M}$ en b y $\mathrm{c}$. 


\section{CAPÍTULO II}

Discusión 

En este capítulo se describe el análisis molecular y funcional de los posibles ortólogos de AGAMOUS de Medicago truncatula. Se han identificado dos genes parálogos, MtAGa y MtAGb, cuya secuencia y patrón de expresión están estrechamente relacionados con los genes de clase $\mathrm{C}$ de Arabidopsis thaliana y Antirrhinum majus. Se han realizado experimentos de pérdida y ganancia de función para investigar si estos genes parálogos desempeñan un papel en la especificación de la identidad de los órganos florales y/o en la determinación del meristemo floral, funciones características de la mayoría de los genes de clase C ortólogos a AGAMOUS (AG, Yanofsky et al., 1990) o PLENA (PLE, Bradley et al., 1993).

Se han analizado dos tipos de plantas de Medicago truncatula con pérdida de función del gen MtAGb: plantas transgénicas generadas utilizando la técnica del RNA interferente y un mutante etiquetado por inserción del retrotransposón Tnt1. Además, se han obtenido plantas de Medicago truncatula con pérdida de función de los genes MtAGa y MtAGb, así como plantas de Pisum sativum con pérdida de función de los genes PsAGa y PsAGb (ortólogos de MtAGa y MtAGb) utilizando la tecnología VIGS. Considerando los altos niveles de sintenia entre estas dos leguminosas (Choi et al., 2004; Kaló et al., 2004), se ha considerado que es muy probable que las funciones génicas sean análogas. Para complementar los resultados obtenidos mediante pérdida de función génica, se han realizado experimentos de ganancia de función mediante la sobreexpresión de MtAGa y MtAGb en un sistema heterólogo: Arabidopsis thaliana.

\section{MtAGa Y MtAGb PRESENTAN HOMOLOGÍA ESTRUCTURAL CON GENES DE FUNCIÓN C}

Para clasificar a los genes MADS-box en sub-grupos dentro de la familia, se han utilizado varios criterios. Éstos incluyen la similitud de secuencia, la presencia de residuos aminoacídicos en posiciones características en el dominio MADS y la presencia/ausencia de una extensión N-terminal, entre otros (Davies et al., 1999). Se ha propuesto que estas características podrían sugerir funciones para genes MADS-box recién descubiertos (Theissen, 1996). MtAGa y MtAGb son dos genes MADS-box de Medicago truncatula cuyas proteínas presentan porcentajes elevados de homología de secuencia con proteínas codificadas por genes del linaje euAG del grupo AG y comparten 
las características típicas de los genes de función C, como la organización génica, la similitud de secuencia y el potencial de interacción proteína-proteína.

Se ha descrito que entre genes MADS-box cercanamente relacionados, aunque funcionalmente divergentes, es el dominio C-terminal el que presenta el mayor grado de diversificación aminoacídica (Moore et al., 2005). Este es el caso de MtAGa y MtAGb, que presentan un $81 \%$ de homología al comparar las secuencias completas, pero $68 \%$ considerando únicamente la región C-terminal. Estudios previos de genes MADS-box como AP3 y PI muestran también diferencias en el dominio C-terminal (Kramer et al., 1998; Lawton-Rauh et al., 1999; Purugganan y Suddith, 1999; Lamb e Irish, 2003), que resultan en diversificación funcional. Estos datos llevan a pensar que la diversificación funcional entre MtAGa y MtAGb es altamente posible.

Una característica común a los miembros del linaje C es la presencia de una extensión $\mathrm{N}$-terminal (de 13 a más de 52 aminoácidos) que precede al dominio MADS (Jager et al., 2003; Kramer et al., 2004) y que no está presente en otros genes MADS-box tipo MIKC (Purugganan et al., 1995). En MtAGa y MtAGb la caja MADS está precedida por 15 y 16 aminoácidos, respectivamente. Este fragmento también se ha encontrado en las proteínas ortólogas de las leguminosas Pisum sativum, Lotus japonicus y Glycine max (Navarro, C., Tesis Doctoral, 2001; Dong et al., 2005 y este trabajo). Mizukami et al. (1996) describen que la extensión N-terminal de AG no es esencial para los aspectos más importantes de la función génica. Sin embargo, ya que esta región se ha mantenido durante la evolución de las proteínas del linaje C, podría tener una función in vivo específica para ellas (Mizukami et al., 1996) como, por ejemplo, la modulación de la actividad de unión a DNA (Riechmann y Meyerowitz, 1997).

En el extremo C-terminal de MtAGa y MtAGb hay dos regiones cortas altamente conservadas, llamadas "AG motif I" y "AG motif II". También se observaron en MtSHP (ver apartado 1.5.2, Resultados Capítulo I). Estos motivos no parecen tener relación con ningún motivo funcional conocido, pero su conservación en genes del grupo $A G$ los define como sinapomorfias del mismo (Kramer et al., 2004).

MtAGbS y MtAGbL son dos transcritos del gen MtAGb derivados de un evento de splicing alternativo. Este fenómeno se ha observado en genes MADS-box, como AP3, gen de identidad floral de clase B (Sablowski et al., 1998; Yi y Jack, 1998) o EAP2 de Eucalyptus globulus (un gen de clase A homólogo de AP1; Kyozuka et al., 1997). El 
splicing alternativo que afecta a miembros de la familia $A G$ se ha descrito previamente (Kitahara y Matsumoto, 2000; Cheng et al., 2003; Lee et al., 2005; Lightfoot et al., 2008), pero la significación funcional de estos eventos aún no se ha elucidado (Hands et al., 2011). Análisis genómicos en Oryza sativa y Arabidopsis thaliana sugieren que el $20 \%$ de los genes sufren splicing alternativo, siendo la retención de intrones el efecto más común (Wang y Brendel, 2006). La pérdida o ganancia de exones puede resultar en la pérdida o adquisición de módulos funcionales discretos (Long et al., 1996) o en la neofuncionalización mediante la modificación de secuencia (Drea et al., 2006). Las dos isoformas de MtAGb difieren en que MtAGbL presenta el sexto exón, que está ausente en MtAGbS. Este exón está conformado por las $42 \mathrm{pb}$ del final de la caja $\mathrm{K}$, región implicada en la dimerización e interacción con otras proteínas (Lightfoot et al., 2008). Como se ha podido demostrar mediante experimentos de expresión constitutiva, únicamente MtAGbL es funcional como gen de clase $C$ en Medicago truncatula. Sin embargo, no debe descartarse una posible función discreta de MtAGbS. La producción de transcritos alternativos provee una manera de diversificar las funciones génicas (Hands et al., 2011). Así pues, es posible que ambos transcritos tengan funciones distintas en cuanto a sus interacciones proteína-proteína o en sus actividades transcripcionales.

El número y posición de los intrones están usualmente conservados entre los homólogos de $A G$ de diferentes especies (Yanofsky et al., 1990; Theissen et al., 1995; Rutledge et al., 1998; Kitahara y Matsumoto, 2000). En MtAGa y MtAGb así como en los genes LjAGa y LjAGb, ortólogos de MtAGa y MtAGb en Lotus japonicus (Dong et al., 2005), estas características están conservadas. Este hecho aporta evidencia adicional de que MtAGa y MtAGb son genes homólogos a AG.

En los genes homólogos a $A G$, el primer intrón es grande, de 3 a $5 \mathrm{~Kb}$ (Brunner et al., 2000) y hay evidencia que sugiere que contiene elementos reguladores que contribuyen al control de su expresión espacial y temporal (Bradley et al., 1993; Sieburth y Meyerowitz, 1997; Bomblies et al., 1999; Deyholos y Sieburth, 2000). En el intrón correspondiente de MtAGb se identificaron posibles secuencias reguladoras como cajas CArG (Shore y Sharrocks, 1995) y sitios de unión de factores de transcripción, como LFY (LEAFY; Schultz y Haughn, 1991) o WUS (WUSCHEL; Laux et al., 1996), cuya unión a AG se requiere para la actividad normal del promotor (Busch et al., 1999; Lohmann et al., 
2001). También se ha encontrado una secuencia de 70 nucleótidos que está conservada en los intrones correspondientes de varios genes de clase $\mathrm{C}$ y para la cual se ha sugerido un papel en la regulación negativa de la expresión génica (Davies, 1999a). Además, este fragmento incluye una secuencia CCAATCA, que se requiere para mantener la expresión de $A G$ (Davies et al., 1999; Mantovani, R., 1998). Quedan pendientes de realización experimentos para comprobar la funcionalidad de estos posibles elementos reguladores del intrón de MtAGb.

La presencia de todas estas características indica que MtAGa y MtAGb son genes de función C.

\section{MtAGa Y MtAGb FUNCIONAN COMO GENES DE CLASE C}

Los genes de función C se expresan principalmente en los dos verticilos internos de la flor y contribuyen al desarrollo y determinación de la identidad de estambres y carpelos, así como a la determinación del meristemo floral. Los genes MtAGa y MtAGb de Medicago truncatula se expresan con un patrón similar durante la mayor parte del desarrollo floral, coincidiendo con el descrito para genes de función C como AG o PLE (Yanofsky et al., 1990; Drews et al., 1991; Bowman et al., 1991a; Bradley et al., 1993), aunque el inicio de la expresión de MtAGa y MtAGb se produce en un estadio previo, antes de la iniciación de los primordios de sépalos. Este tipo de expresión temprana se describió para PsAGb de Pisum sativum y LjAGa/LjAGb de Lotus japonicus, relacionándola con la iniciación y determinación precoz del carpelo en las leguminosas (Navarro, C., Tesis Doctoral, 2001; Dong et al., 2005). Curiosamente, durante el desarrollo tardío del carpelo, se observó que la expresión de MtAGa y MtAGb tendía a ser más intensa en la región abaxial del carpelo y posteriormente se limitaba a la región distal del mismo. Esta expresión no se ha descrito en otras leguminosas (Navarro, C., Tesis Doctoral, 2001; Dong et al., 2005), así que es posible que esté relacionada con la morfología particular del carpelo (y posterior fruto) de Medicago truncatula. Además, la expresión diferencial de MtAGa y MtAGb en la semilla (epidermis y endotelio, respectivamente) lleva a pensar que estos genes tienen alguna función, aún desconocida, en el fruto. 
$A G$ es el único gen de clase $C$ en Arabidopsis thaliana, pero se han aislado dos genes de clase C en Antirrhinum majus (Bradley et al., 1993; Davies et al., 1999), Lotus japonicus (Dong et al., 2005), Petunia hybrida (Angenent et al., 1993; Tsuchimoto et al., 1993), Nicotiana tabacum (Kempin et al., 1993), Populus trichocarpa (Brunner et al., 2000), Eschscholzia californica (Yellina et al., 2010) y Papaver somniferum (Hands et al., 2011), entre otras. En la mayoría de estos casos, los patrones de expresión de ambos genes son casi idénticos. Sin embargo, en otras especies que contienen dos homólogos $A G$ se ha podido observar diversificación de función y/o expresión. Este es el caso de OsMADS3 y OsMADS58 de Oryza sativa, los cuales se expresan en los verticilos tres y cuatro, pero difieren en su expresión temporal (Yamaguchi et al., 2006) o los genes ZAG1 y ZMM2 de Zea mays, cuyos patrones de expresión diferenciales, el primero en carpelos y el segundo en estambres, indican que se han subfuncionalizado (Mena et al., 1996). Los dos ortólogos de $A G$ en Medicago truncatula también presentan diferencias de expresión durante el desarrollo floral. Antes de que los primordios comunes se dividan en primordios de órganos, MtAGa presenta expresión intensa en todo el meristemo, mientras que $M t A G b$ se expresa en la región central del mismo. Esto apunta a que MtAGa puede tener un papel significativo en la determinación de la identidad del meristemo floral. Más adelante, MtAGb tiene una expresión más intensa que su parálogo en los órganos de tercer y cuarto verticilo, sugiriendo que está más implicado que MtAGa en la especificación de la identidad de los órganos reproductores florales.

Según el modelo $A B C$, la pérdida de función $C$ resulta en la expansión de la función $A$ al tercer y cuarto verticilo (Bowman et al., 1991a; Coen y Meyerowitz, 1991; Weigel y Meyerowitz, 1994; Yanofsky, 1995; Ng y Yanofsky, 2001; Lohmann y Weigel, 2002; Jack, 2004). El mutante de pérdida de función C de Arabidopsis thaliana se caracteriza por presentar conversiones homeóticas de estambres en estructuras petaloides y de carpelos en estructuras sepaloides además de perder la determinación del meristemo floral (Bowman et al., 1989; Yanofsky et al., 1990). En Medicago truncatula, el knockdown (mediante RNAi) o knock-out (mediante inserción de Tnt1) del gen MtAGb resulta en las conversiones homeóticas esperadas para una pérdida de función C. Sin embargo, las alteraciones observadas son más complejas que las descritas en Arabidopsis thaliana. Por un lado, los estambres no pierden del todo su identidad (indicando que MtAGb no es capaz de establecer del todo la identidad de los órganos reproductores), así que 
probablemente no es el único gen involucrado en dicho proceso; por otro lado, el carpelo no se transforma en una estructura sepaloide sino que se presenta una multiplicación de carpelos en el cuarto verticilo, recordando los múltiples sépalos presentes en el primer verticilo. Se han descrito mutantes con carpelos múltiples en Medicago truncatula (Nair et al., 2008), Pisum sativum (Kosterin, 1999) y Glycine max (Shuff y Thomas, 1993). Sin embargo, no se han aislado los genes afectados y se ha sugerido que las mutaciones se deben al efecto de factores ambientales o incluso variación somaclonal. En Oryza sativa, un mutante del gen ortólogo de AG OsMADS3 presenta múltiples carpelos que se desarrollan en el cuarto verticilo, están fusionados en la base y su morfología es prácticamente normal. Tras el desarrollo de los múltiples carpelos el meristemo floral se consume, sugiriendo que el defecto en la determinación del meristemo floral es incompleto en este mutante (Yamaguchi et al., 2006). Del mismo modo, el fenotipo de carpelos múltiples en Medicago truncatula sugiere que MtAGb no es capaz de indeterminar totalmente el meristemo floral.

En Pisum sativum, el knock-down (mediante VIGS) de PSAGa o PsAGb resulta en conversiones homeóticas leves en los órganos de tercer y cuarto verticilo. El tipo de conversiones son las esperadas para una pérdida de función C. No obstante, la levedad de los fenotipos sugiere que PSAGa y PsAGb son esencialmente redundantes, pudiendo uno complementar la función del otro. El silenciamiento de dos genes a la vez es importante cuando existen dos rutas redundantes o parcialmente redundantes que deben ser inhibidas para poder observar un fenotipo fuerte. Este tipo de silenciamiento puede obtenerse mediante VIGS en Pisum sativum (Constantin et al., 2004). Así pues, las flores de Pisum sativum y de Medicago truncatula en las cuales se han silenciado ambos genes endógenos simultáneamente, muestran conversiones homeóticas evidentes de estambres en estructuras petaloides y de carpelos en estructuras sepaloides, además de la indeterminación del meristemo floral: fenotipo típico para la pérdida de función C. La reversión floral observada en las plantas pCAPE2-PSAGdoble es un indicador más del estado indeterminado del meristemo en estas plantas. Se sabe que tras el establecimiento del meristemo floral, el gen $A G$ sigue siendo requerido para mantener un estado indeterminado y reproductivo del meristemo (Okamuro et al., 1996; Gregis et al., 2006) y que las mutaciones en el mismo pueden llevar a una parcial o completa reversión floral (Okamuro et al., 1996; Mizukami y Ma, 1997; Parcy et al., 2002). Los 
resultados obtenidos mediante VIGS indican que ambos parálogos no solo son redundantes, sino que además son indispensables para completar la función C.

Siguiendo la predicción del modelo $A B C$, la ganancia de función $C$ conlleva la represión de la función $A$ y, con ello, la expansión de la función $C$ al primer y segundo verticilo (Coen y Meyerowitz, 1991; Weigel y Meyerowitz, 1994; Yanofsky, 1995; Ng and Yanofsky, 2001; Lohmann y Weigel, 2002; Jack, 2004). La expresión ectópica de AG en Arabidopsis thaliana ocasiona conversiones homeóticas de los órganos del primer verticilo en estructuras carpeloides y estaminoidía en los órganos del segundo verticilo, además de floración temprana, hojas curvadas y pérdida de la determinación de la inflorescencia. (Mizukami y Ma, 1992). La expresión ectópica de muchos genes homólogos a AG de eudicotiledóneas, como NAG1 de Nicotiana tabacum (Kempin et al., 1993), TAG1 de Solanum lycopersicum (Pnueli et al., 1994; Busi et al., 2003), CUM1 de Cucumis sativus (Kater et al., 1998), CaMADS1 de Corylus avellana (Rigola et al., 2001), VvMADS1 de Vitis vinifera (Boss et al., 2001), TrAG y TrSHP de Taihangia rupestris (Lü et al., 2007) y PsAGb de Pisum sativum (Navarro, C., Tesis Doctoral, 2001) resulta en alteraciones fenotípicas que reproducen las observadas en la expresión ectópica de $A G$ en Arabidopsis thaliana. El fenotipo observado en las plantas de Arabidopsis thaliana que expresan constitutivamente MtAGa o MtAGb indica que estos genes son capaces de especificar la identidad de estambres y carpelos, ya que se ha observado la presencia de sépalos carpeloides y pétalos con características estaminoides. Además, se ha presentado adelanto en el tiempo de floración. Este fenotipo coincide, en esencia, con el observado al expresar ectópicamente genes de clase $C$ de diferentes especies tanto en sistemas homólogos como heterólogos. No obstante, se han observado fenotipos diferenciales en la sobreexpresión de MtAGa y MtAGb. En las plantas 2x35S::MtAGbL se observaron conversiones homeóticas muy intensas tanto en órganos como en tejidos. Estas conversiones fueron mucho más evidentes que en las plantas 2x35S::MtAGa, indicando que MtAGb probablemente tenga una implicación mayor que MtAGa en la especificación de la identidad de los órganos reproductores. Por otra parte, en las plantas 2x35S::MtAGa se observó mayor adelanto en el tiempo de floración y la generación tanto de estructuras terminales modificadas como de frutos y flores dobles, apuntando a un posible papel clave de MtAGa en la determinación del meristemo floral. En Arabidopsis thaliana se ha comprobado que la función de $A G$ en la determinación del 
meristemo puede separarse genéticamente de su función en la identidad de órganos (Mizukami y Ma, 1995; Sieburth et al., 1995). En varias especies que presentan duplicación en los genes de clase $C$ las funciones de $A G$ también parecen haberse subfuncionalizado. En Antirrhinum majus, PLE (gen de clase C del linaje PLE) tiene una función similar a la de $A G$, mientras que $F A R$ (gen de clase $C$ del linaje euAG), es responsable del desarrollo de los órganos reproductores masculinos y es parcialmente redundante con PLE (Bradley et al., 1993; Davies et al., 1999). En Oryza sativa, OsMADS3 y OsMADS58 tienen papeles distintos: OsMADS3 se requiere principalmente para la especificación de la identidad de estambre y OsMADS58 confiere la determinación floral (Yamaguchi et al., 2006). En Cucumis sativus, la expresión constitutiva de CUM1 fenocopia a la de $A G$, mientras que la de CUM10 resulta en transformaciones parciales de pétalos en estructuras tipo estambre, indicando un papel más limitado en la identidad de órganos florales (Kater et al., 1998). Estos resultados muestran que, a diferencia de Arabidopsis thaliana, la función C en algunas angiospermas está dirigida por múltiples genes MADS que han desarrollado papeles distintos y parcialmente redundantes en el desarrollo floral (Hsu et al., 2010).

Los resultados obtenidos mediante pérdida y ganancia de función de MtAGa y MtAGb indican que son genes de clase $\mathrm{C}$ que además de tener un alto grado de redundancia, se han subfuncionalizado de tal manera que MtAGa tiene un papel prioritario en la determinación del meristemo floral, mientras que MtAGb juega un papel clave en la especificación de la identidad de los órganos reproductores florales. Estas posibles funciones génicas encajan con los patrones de expresión diferenciales descritos anteriormente.

\section{EL UMBRAL DE EXPRESIÓN DE MtAGa Y MtAGb REQUERIDO PARA DETERMINAR EL MERISTEMO O PARA ESTABLECER LA IDENTIDAD DE ÓRGANO FLORAL ES VARIABLE}

Según el análisis de los niveles de expresión de los genes MtAGa y MtAGb en las plantas RNAi, el silenciamiento no ha sido específico para MtAGb, sino que ha afectado también a su parálogo, en diferentes proporciones. En el mutante mtagb, obtenido 
mediante inserción de Tnt1, los niveles de expresión de MtAGb son nulos y que la expresión de MtAGa no se ve afectada. En resumen, los fenotipos observados en relación con los niveles de expresión génica se muestran en la siguiente Tabla (Tabla 25).

Tabla 25. Fenotipos observados en relación con los niveles de expresión génica

\begin{tabular}{lccc}
\hline Planta analizada & Nivel de MtAGa & Nivel de MtAGb & Fenotipo alterado \\
\hline 35S::RNAi-MtAGb 1.1 & $70 \%$ & $60 \%$ & Ausente \\
35S::RNAi-MtAGb 1.3 & $85 \%$ & $15 \%$ & Ausente \\
35S::RNAi-MtAGb 5.7 & $40 \%$ & $40 \%$ & Presente \\
Mutante mtagb & $100 \%$ & $0 \%$ & Presente \\
\hline
\end{tabular}

La presencia de fenotipo alterado en el mutante mtagb sugiere que el gen MtAGa no es totalmente redundante con MtAGb, ya que no es capaz de complementar plenamente la función $\mathrm{C}$ en el mismo. La redundancia funcional parcial es más estable evolutivamente que la redundancia funcional completa, como se ha podido observar para los parálogos SEP o SHP (Nowak et al., 1997; Wagner, 1999). Es de esperar que la redundancia funcional completa se vaya perdiendo a lo largo del tiempo mientras los genes duplicados llegan a un estado de equilibrio de redundancia parcial (Wagner, 1999; Moore et al., 2005).

Por otro lado, la ausencia de fenotipo en la planta 35S::RNAi-MtAGb 1.3, en la que hay un mínimo nivel de expresión de MtAGb indica que, siempre y cuando esté presente MtAGa, se requiere poca expresión de MtAGb (15\%) para completar la función C. Finalmente, la presencia de fenotipo alterado en la planta 35S::RNAi-MtAGb 5.7, donde ambos genes están disminuidos hasta un 40\%, apunta a que también hay un nivel de expresión mínimo de MtAGa requerido para completar la función $\mathrm{C}$, siempre y cuando coexista con la expresión mínima necesaria de MtAGb. Este nivel de expresión mínimo requerido de $M t A G a$ está por encima del $40 \%$.

En Arabidopsis thaliana, el papel de $A G$ en la determinación floral se ha asociado con un nivel más alto de actividad $A G$ comparado con el nivel que se requiere para la especificación de la identidad de órganos reproductores florales (Mizukami y Ma, 1995). Se ha propuesto un modelo cuantitativo que sugiere que las diferentes funciones de $A G$ dependen de la cantidad de producto génico requerido. Los fenotipos de diferentes mutantes ag han permitido ordenar las funciones, desde el mayor nivel requerido hasta 
el menor, de la siguiente manera: determinación > especificación de carpelo > especificación de estambre (Sieburth et al., 1995).

Los fenotipos obtenidos en las plantas VIGS de Pisum sativum también concuerdan con estas suposiciones. El fenotipo de las flores pCAPE2-PSAGa es ligeramente más fuerte que el fenotipo de las flores PCAPE2-PSAGb, indicando que con una disminución similar en los niveles de expresión de ambos genes, es más probable obtener fenotipos de silenciamiento en PCAPE2-PSAGa. Esta observación puede relacionarse con el hecho de que se requiere un mayor nivel de expresión mínima de PSAGa para completar la función C. También hay que considerar que los niveles génicos mínimos requeridos pueden ser variables entre Pisum sativum y Medicago truncatula. Así, la ausencia de fenotipos en las flores VIGS de Medicago truncatula en las que se intenta silenciar MtAGa o MtAGb puede deberse no solo a la menor eficiencia del virus en esta planta sino también al hecho de que la disminución de expresión génica no sea suficiente para generar un fenotipo evidente.

\section{MtaGa Y MtaGb SON GENES DUPLICADOS PARCIALMENTE REDUNDANTES QUE SE HAN SUBFUNCIONALIZADO ADQUIRIENDO PAPELES EN DIFERENTES ASPECTOS DE LA FUNCIÓN C}

Una ruta común mediante la cual evolucionan nuevos genes es la duplicación génica seguida de diversificación de función (Force et al., 1999). Se cree que este proceso acelera la velocidad de especiación (Irish, 2003). Un evento de duplicación a partir de un ancestro común produjo los linajes C y D (Kramer et al., 2004); posteriormente, en la base de las eudicotiledóneas superiores tuvo lugar una segunda duplicación, esta vez dentro del linaje $C$, dando lugar a los linajes euAG y $P L E$, que incluyen $A G$ y $S H P 1 / S H P 2$, respectivamente (Becker y Theissen, 2003; Irish, 2003; Kramer et al., 2004; Zahn et al., 2006).

El análisis de los homólogos AGAMOUS tanto de eudicotiledóneas superiores como de monocotiledóneas indica que estas funciones están ampliamente conservadas, pero que las duplicaciones génicas han introducido variación (Bradley et al., 1993; Kempin et al., 1993; Pnueli et al., 1994; Kang et al., 1998; Yu et al., 1999; Kapoor et al., 2002; 
Kyozuka y Shimamoto, 2002). Por ejemplo, en Arabidopsis thaliana, AG juega un papel crítico en la formación de estambres y carpelos y en la determinación del meristemo floral y los genes SHP1 y SHP2 están involucrados en el desarrollo de carpelos y se requieren para la diferenciación de la zona de dehiscencia (Liljegren et al., 2000; Pinyopich et al., 2003). En Antirrhinum majus, el ortólogo de SHP1/SHP2, PLE, es funcionalmente similar a $A G$ (Carpenter y Coen, 1990), mientras que el gen del linaje eUAG, FAR, tiene un papel menor en la identidad de órganos y la determinación meristemática, pero juega un papel en el desarrollo tardío de estambres (Davies et al., 1999). La duplicación de genes de clase C seguida de diversificación también se ha descrito, entre otros, en Zea mays (Mena et al., 1996), Cucumis sativus (Kater et al., 1998), Petunia hybrida (Kramer et al., 2004), Oryza sativa (Yamaguchi et al., 2006) y Eschscholzia californica (Yellina et al., 2010).

En la presente Tesis Doctoral, se ha observado que en la leguminosa Medicago truncatula también existe duplicación de los genes de clase $C$. Se han aislado tres genes MADS-box pertenecientes al linaje C: MtAGa, MtAGb y MtSHP. Los dos primeros son miembros del linaje eUAG y el último es miembro del linaje PLE. La expresión de MtSHP se detecta primordialmente en la región interna del carpelo, en óvulos y semillas. Por otro lado, el patrón de expresión de $M t A G a$ y $M t A G b$ se centra en los órganos reproductores de la flor siendo distinto pero solapante al patrón de expresión de MtSHP. Así pues, puede deducirse que tras la duplicación de los genes de clase C en Medicago truncatula, ocurrieron cambios en su expresión temporal y espacial, lo que sugiere que han sufrido varios grados de sub- y/o neofuncionalización en sus funciones en la regulación del desarrollo de las estructuras reproductoras. Muchos miembros de los linajes parálogos eUAG y PLE han mantenido secuencias proteicas que pueden proveer la asumida función ancestral, aunque hayan pasado por eventos de sub y/o neofuncionalización mediante cambios en sus patrones de expresión (Pinyopich et al., 2003; Ferrario et al., 2004; Kramer et al., 2004; Zahn et al., 2006).

La expresión constitutiva de MtAGa y MtAGb en Arabidopsis thaliana ha mostrado que estos genes son redundantes en cuanto a la función C. Sería interesante comprobar la función de MtSHP mediante la misma aproximación, ya que se sabe que la expresión constitutiva de PSMADS8, el ortólogo de MtSHP en Pisum sativum, genera fenotipos similares a los obtenidos con la sobreexpresión de MtAGa y MtAGb (Navarro, C., Tesis 
Doctoral, 2001), sugiriendo que la función C se mantiene en PSMADS8 y probablemente también en MtSHP.

Una tercera duplicación en Medicago truncatula dentro del linaje C, sublinaje euAG, ha resultado en los genes MtAGa y MtAGb. Esta duplicación parece ser específica de las especies leguminosas, ya que se presenta también en Lotus japonicus (Dong et al., 2005), Glycine max (Huang et al., unpublished; Cheung et al., unpublished) y Pisum sativum (Navarro, C., Tesis Doctoral, 2001; Berbel et al., unpublished; este trabajo), pero no se ha descrito en otras eudicotiledóneas superiores. A día de hoy, el estudio funcional de estos parálogos del linaje euAG solo se ha realizado en el presente trabajo. Los resultados muestran que los genes MtAGa y MtAGb presentan redundancia funcional parcial en lo que respecta a la función $C$, aunque se han subfuncionalizado, particionando esta función $A G$ ancestral entre ambos parálogos.

El origen de los parálogos MtAGa y MtAGb probablemente está asociado con una duplicación del genoma entero de Medicago truncatula. En las leguminosas, el momento de los eventos hipotéticos de duplicación permanece en disputa; sin embargo, se ha descrito la posibilidad de un evento antiguo de duplicación del genoma completo seguido por pérdida de genes y reorganización (Cannon et al., 2006), ocurrido hace $\sim 40$ millones de años (Lavin et al., 2005), antes de la especiación de las leguminosas. Este evento explicaría la presencia de ortólogos de ambos genes en diferentes especies leguminosas.

La redundancia funcional parcial entre genes duplicados homólogos a $A G$ refleja la actividad conservada derivada de las regiones codificantes (Pinyopich et al., 2003; Zahn et al., 2006). En Arabidopsis thaliana, la expresión ectópica de AG, SHP1 o SHP2 causa alteraciones similares en el fenotipo floral (Mandel et al., 1992a; Mizukami y Ma, 1992; Liljegren et al., 2000; Favaro et al., 2003; Pinyopich et al., 2003). La expresión ectópica de MtAGa y MtAGb en plantas transgénicas de Arabidopsis thaliana también causa estos fenotipos, sugiriendo que ambos poseen actividades ancestrales en sus regiones codificantes. En Medicago truncatula, la redundancia funcional parcial entre los genes eUAG ha sido retenida al igual que entre los genes duplicados del clado AGAMOUS en otras eudicotiledóneas (Kramer et al., 2004; Scutt et al., 2006). Esta redundancia funcional ocurre inmediatamente tras la duplicación génica y se pierde cuando los genes duplicados llegan a un estado de equilibrio de redundancia parcial (Wagner, 1999). A 
pesar de su naturaleza temporal, los genes duplicados funcionalmente redundantes existen en abundancia, ya que la redundancia protege contra las mutaciones deletéreas y contribuye a la robustez genética de un organismo (Krakauer y Nowak, 1999; Wagner, 1999; Gu, 2003; Lü et al., 2007). La redundancia funcional es frecuente en los genes ligados al desarrollo, como MtAGa y MtAGb, ya que protege contra errores en el desarrollo (Moore et al., 2005).

Sin embargo, los genes duplicados no suelen persistir evolutivamente a menos que se presente sub- o neofuncionalización mediante cambios en la expresión génica y/o secuencia codificiante, resultando en divergencia funcional (Force et al., 1999; Nowak et al., 1997; Wagner, 1999). En los genes euAG de Medicago truncatula las funciones ancestrales del linaje $\mathrm{C}$ se han dividido entre los duplicados, causando que se mantengan selectivamente sin neofuncionalización (siguiendo el modelo DDC de Force et al., 1999). MtAGa y MtAGb se han subfuncionalizado de tal manera que el primero tiene un papel primordial en la determinación del meristemo floral, mientras que el segundo está involucrado en el establecimiento de la identidad de los órganos reproductores. En este caso, la acción combinada de ambas copias génicas es necesaria para completar los requerimientos del locus ancestral. Esta complementación de subfunciones ha determinado que ambas copias se conserven en el genoma.

La diversificación funcional también puede asociarse a las diferencias en la especificidad de las reacciones proteína-proteína. Por ejemplo, MtAGa y MtAGb podrían estar interactuando específicamente con factores que se expresan preferentemente en los verticilos tres y cuatro. Los candidatos posibles de "partner" proteico podrían ser las proteínas SEP-like. En Arabidopsis thaliana, las proteínas de clase B y C requieren de las proteínas SEP-like para poder funcionar (revisado por Malcomber y Kellog, 2005), y estas proteínas forman complejos proteicos (Pelaz et al., 2000; Honma y Goto, 2001). Según el modelo del cuarteto, los productos de los genes de clase B, C y SEP ensamblan complejos cuaternarios que especifican los estambres, mientras que las proteínas de clase C y SEP controlan la identidad del carpelo (Theissen y Saedler, 2001; Zahn et al., 2005b; Wang et al., 2011). Además, se ha descrito que SEP3 puede mediar la interacción entre AG y el dímero de proteínas de clase B AP3-PI (Honma y Goto, 2001).

Los patrones de interacción de las proteínas pueden proveer información adicional sobre las diferencias funcionales (Immink et al., 2003). En Medicago truncatula la 
diversidad de complejos proteicos que pueden formarse se incrementa debido a la existencia de genes duplicados de las clases B y C. Los cambios en la composición de dichos complejos pueden producir un gran número de posibles sitios diana, modificando las interacciones proteína-proteína y aumentando el abanico de posibles funciones para los complejos formados. Identificar los "partners" proteicos de MtAGa y MtAGb podría ayudar a elucidar la naturaleza molecular de la subfuncionalización de estos genes en Medicago truncatula.

En general, la diversificación funcional de los genes MADS-box ha contribuido enormemente a la regulación genética precisa y compleja del desarrollo floral, además de dirigir la diversidad floral (Theissen et al., 2000; Kramer et al., 2004; Irish y Litt, 2005). Parece ser que la base de las eudicotiledóneas superiores fue un periodo crítico en la evolución de las angiospermas, con muchos cambios significativos tanto en la morfología floral (Endress, 1990; Kramer et al., 2004), como en los linajes génicos que controlan la identidad de los órganos florales, entre ellos, la duplicación en los linajes $A G, A P 3$ y AP1 (Litt e Irish, 2003; Kramer et al., 2005). En Medicago truncatula se ha observado duplicación en los linajes A, B y C. Es probable que los diferentes papeles de estos genes en el desarrollo de los órganos florales y en la determinación meristemática contribuyan a la trayectoria evolutiva única de las leguminosas y a la formación de órganos florales característicos.

Parece ser que los factores moleculares que controlan el desarrollo de órganos florales están bastante conservados entre Medicago truncatula, Antirrhinum majus y Arabidopsis thaliana. Es bien sabido que los genes implicados en el modelo $A B C$ establecen dominios de expresión específicos para el diseño floral. Sin embargo, el diseño floral de las leguminosas probablemente no solo responde a este modelo, sino que además puede estar regido por varios procesos como: la alteración de las funciones de los genes clave, la duplicación génica, la pérdida o ganancia de dominios proteicos funcionales y los cambios en los patrones de expresión (Dong et al., 2005; este trabajo). Así pues, aunque se espera que el modelo $A B C$ sea válido (al menos parcialmente) en las leguminosas, es necesario caracterizar los diferentes ortólogos de genes $A B C$ para comprender cómo el modelo puede explicar el diseño floral particular de estas plantas. 
Conclusiones 

De los resultados presentados en esta Tesis Doctoral se pueden extraer las siguientes conclusiones:

PRIMERA: Se han aislado y caracterizado once miembros de la familia génica MADS-box de Medicago truncatula. Según la homología de secuencia y los patrones de expresión, seis de ellos podrían estar involucrados en funciones $A B C(D E):$ MtTM6 y MtNMH7 como genes de clase B, ortólogos de AP3/DEF; MtAGa, MtAGb y MtSHP como genes de clase C, ortólogos de AG/PLE (los dos primeros) y de SHP (el último); y MtSEP como gen de clase $\mathrm{E}$, ortólogo de SEP1/2. MtSOC1a y MtSOC1b, posibles ortólogos de SOC1, participarían en la integración de señales de las vías que controlan el tiempo de floración. MtSOC1-like, según sugiere su patrón de expresión, podría ser funcionalmente redundante con MtSOC1a y MtSOC1b, aunque no se puede desacartar que ejerza alguna función adicional en la determinación de la identidad de los órganos florales. MtAGL6 y MtAGL6-like presentan homología con genes poco caracterizados en otras especies. Su patrón de expresión es compatible con un papel en la identidad del meristemo floral y el desarrollo de órganos florales. Además, se ha visto que MtAGL6-like forma parte de una rama filogenética separada en la cual sólo se agrupa con genes de leguminosas.

SEGUNDA: Varios de los genes aislados (MtSEP, MtAGL6-like, MtSOC1a, MtSOC1b y MtSOC1-like) se expresan en tejidos vegetativos además de hacerlo en flores, así que puede que tengan un rango de funciones más amplio que la regulación de los eventos del desarrollo floral.

TERCERA: Varios genes pertenecientes a la familia MADS-box presentes como copia única en Arabidopsis thaliana se encuentran duplicados en Medicago truncatula y viceversa, siendo el historial de duplicaciones de Medicago truncatula similar al observado en otras leguminosas.

CUARTA: Se han aislado y caracterizado dos nuevos genes MADS-box de Medicago truncatula, MtAGa y MtAGb, que presentan similitud de secuencia con genes de función C del linaje euAGAMOUS. Su patrón de expresión en flores de Medicago truncatula de fenotipo silvestre, así como los estudios funcionales llevados a cabo mediante técnicas 
de RNA interferente, VIGS y mutagénesis inducida por Tnt1 en Medicago truncatula y expresión génica constitutiva en Arabidopsis thaliana, demuestran que ambos genes son componentes de la función C en Medicago truncatula.

QUINTA: MtAGb se encuentra como dos especies de mRNA (MtAGbS y MtAGbL), que son consecuencia del splicing alternativo del RNA. El análisis funcional ha mostrado que únicamente $M t A G b L$ es funcional como gen de clase $C$. Por el momento se desconoce el posible significado funcional de este evento de splicing.

SEXTA: Los experimentos de pérdida y ganancia de función de MtAGa y MtAGb indican que estos genes parálogos tienen un alto grado de redundancia en lo que respecta a la función $C$, aunque se han subfuncionalizado, dividiendo esta función de tal manera que MtAGa tiene un papel prioritario en la determinación del meristemo floral, mientras que MtAGb juega un papel clave en la especificación de la identidad de los órganos reproductores florales. 


\section{Bibliografía}



Albert, V.A., Gustafsson, M.H.G. y Di Laurenzio, L. (1998). Ontogenetic systematics, molecular developmental genetics, and the angiosperm petal. En: Molecular Systematics of Plants, II. Soltis, D., Soltis, P. y Doyle, J.J., eds. (New York: Chapman and Hall). 349-374.

Alvarez-Buylla, E.R., Garcia-Ponce, B. y Garay-Arroyo, A. (2006). Unique and redundant functional domains of APETALA1 and CAULIFLOWER, two recently duplicated Arabidopsis thaliana floral MADS-box genes. J Exp Bot. 57, 3099-3107.

Alvarez-Buylla, E.R., Pelaz, S., Liljegren, S.J., Gold, S.E., Burgeff, C., Ditta, G.S., Ribas de Pouplana, L., Martínez-Castilla, L. y Yanofsky, M.F. (2000a). An ancestral MADS-box gene duplication occurred before the divergence of plants and animals. Proc Natl Acad Sci U S A. 97, 5328-5333.

Alvarez-Buylla, E.R., Liljegren, S.J., Pelaz, S., Gold, S.E., Burgeff, C., Ditta, G.S., VergaraSilva, F. y Yanofsky, M.F. (2000b). MADS-box gene evolution beyond flowers: expression in pollen, endosperm, guard cells, roots and trichomes. Plant J. 24, 457-466.

Amasino, R. (2004). Vernalization, competence and the epigenetic memory of winter. Plant Cell. 16, 2553-2559.

Ampomah-Dwamena, C., Morris, B.A., Sutherland, P., Veit, B. y Yao, J. (2002). Downregulation of TM29, a tomato SEPALLATA homolog, causes parthenocarpic fruit development and floral reversión. Plant Physiol. 130, 605-617.

Andersen, J.W., Story, L., Sieling, B., Chen, W.J., Petro, M.S. y Story, J. (1984). Hypocholesterolemic effects of oat-bran or bean intake for hypercholesterolemic men. Am J Clin Nutr. 40, 1146-1155.

Angenent, G.C. y Colombo, L. (1996). Molecular control of ovule development. Trends Plant Sci. 1, 228-232.

Angenent, G.C., Franken, J., Busscher, M., Colombo, L. y van Tunen, A.J. (1993). Petal and stamen formation in petunia is regulated by the homeotic gene fbp1. Plant J. 4, 101112.

Angenent, G.C., Franken, J., Busscher, M., Van Dijken, A., VanWent, J.L., Dons, H.J.M. y Van Tunen, A.J. (1995). A novel class of MADS box genes is involved in ovule development in petunia. Plant Cell. 7, 1569-1582.

Aoki, S., Uehara, K., Imafuku, M., Hasebe, M. e Ito, M.J. (2004). Phylogeny and divergence of basal angiosperms inferred from APETALA3- and PISTILLATA-like MADSbox genes. Plant Res. 117, 229-244.

Arora, R., Agarwal, P., Ray, S., Singh, A.K., Singh, V.P., Tyagi, A.K. y Kapoor, S. (2007). MADS-box gene family in rice: genome-wide identification, organization and expression profiling during reproductive development and stress. BMC Genomics. 8, 242. 
Aubert, G., Morin, J., Jacquin, F., Loridon, K., Quillet, M.C., Petit, A., Rameau, C., Lejeune-Hénaut, I., Huguet, T. y Burstin, J. (2006). Functional mapping in pea, as an aid to the candidate gene approach and for investigating the synteny with the model species Medicago truncatula. Theor Appl Genet. 112, 1024-1041.

Bechtold, N., Ellis, J., y Pelletier, G. (1993). In planta Agrobacterium-mediated gene transfer by infiltration of adult Arabidopsis thaliana plants. Comp. Rend. L'Acad. des Sci. Serie III. 316, 1194-1199.

Becker, A. y Theissen, G. (2003). The major clades of MADS-box genes and their role in the development and evolution of flowering plants. Mol Phylogenet Evol. 29, 464-489.

Beltrán, J.P., Roque, E., Medina, M., Madueño, F., Gómez, M.D. y Cañas, L. (2007). Androesterilidad inducida mediante ingeniería genética en plantas: fundamentos y aplicaciones biotecnológicas. An R Acad Nac Farm. 73, 1237-1264.

Benedito, V.A., Torres-Jerez, I., Murray, J.D., Andriankaja, A., Allen, S., Kakar, K., Wandrey, M., Verdier, J., Zuber, H., Ott, T., Moreau, S., Niebel, A., Frickey, T., Weiller, G., He, J., Dai, X., Zhao, P., Tang, Y y Udvardi, M. (2008). A gene expression atlas of the model legume Medicago truncatula. Plant J. 55, 504-513.

Benlloch, R. (2005). Medicago truncatula (Gaernt.) como especie modelo para el análisis genético molecular del desarrollo floral en leguminosas. Tesis Doctoral. Universidad Politécnica de Valencia.

Benlloch, R., Berbel, A., Serrano-Mislata, A. y Madueño, F. (2007). Floral initiation and inflorescence architecture: a comparative view. Ann Bot. 100, 659-676.

Benlloch, R., Navarro, C., Beltrán, J.P. y Cañas, L.A. (2003). Floral development of the model legume Medicago truncatula: ontogeny studies as a tool to better characterize homeotic mutations. Sex Plant Reprod. 15, 231-241.

Benlloch, R., Roque, E., Ferrándiz, C., Cosson, V., Caballero, T., Penmetsa, R.V., Beltrán, J.P., Cañas, L.A., Ratet, P. y Madueño, F. (2009). Analysis of B function in legumes: PISTILLATA proteins do not require the PI motif for floral organ development in Medicago truncatula. Plant J. 60, 102-111.

Berbel, A. (2002). Análisis funcional de genes reguladores del desarrollo floral de guisante (Pisum sativum L.) en sistemas heterólogos. Tesis Doctoral. Universidad de Valencia.

Berbel, A., Navarro, C., Ferrándiz, C., Cañas, L.A., Beltrán, J.P. y Madueño, F. (2005). Functional conservation of PISTILLATA activity in a pea homolog lacking the PI motif. Plant Physiol. 139, 174-185.

Berbel, A., Navarro, C., Ferrándiz, C., Cañas, L.A., Madueño, F. y Beltrán J.P. (2001). Analysis of PEAM4, the pea AP1 functional homologue, supports a model for AP1-like 
genes controlling both floral meristem and floral organ identity in different plant species. Plant J. 25, 441-451.

Bomblies, K., Dagenais, N. y Weigel, D. (1999). Redundant enhancers mediate transcriptional repression of AGAMOUS by APETALA2. Dev Biol. 216, 260-264.

Borner, R., Kampmann, G., Chandler, J., Gleissner, R., Wisman, E., Apel, K. y Melzer, S. (2000). A MADS domain gene involved in the transition to flowering in Arabidopsis. Plant J. 24, 591-599.

Boss, P.K., Bastow, R.M., Mylne, J.S. y Dean, C. (2004). Multiple pathways in the decision to flower: enabling, promoting, and resetting. Plant Cell. 16, S18-S31.

Boss, P.K., Sensi, E., Hua, C., Davies, C. y Thomas, M.R. (2002). Cloning and characterization of grapevine (Vitis vinifera L.) MADS-box genes expressed during inflorescence and berry development. Plant Sci. 162, 887-895.

Boss, P.K., Vivier, M., Matsumoto, S., Dry, I.B. y Thomas, M.R. (2001). A cDNA from grapevine (Vitis vinifera L.), which shows homology to AGAMOUS and SHATTERPROOF, is not only expressed in flowers but also throughout berry development. Plant Mol Biol. 45, 541-553.

Bowman, J.L. (1997). Evolutionary conservation of angiosperm flower development at the molecular and genetic levels. Journal of Bioscience. 22, 515-527.

Bowman, J.L., Drews, G.N. y Meyerowitz, E.M. (1991a). Expression of the Arabidopsis floral homeotic gene AGAMOUS is restricted to specific cell types late in flower development. Plant Cell. 3, 749-758.

Bowman, J.L., Smyth, D.R. y Meyerowitz, E.M. (1989) Genes directing flower development in Arabidopsis. Plant Cell. 1, 37-52.

Bowman, J.L., Smyth, D.R. y Meyerowitz, E.M. (1991b). Genetic interactions among floral homeotic genes of Arabidopsis. Development. 112, 1-20.

Bradley, D., Carpenter, R., Sommer, H., Hartley, N. y Coen, E. (1993). Complementary floral homeotic phenotypes result from opposite orientations of a transposon at the plena locus of Antirrhinum. Cell. 72, 85-95.

Broholm, S.K., Pöllänen, E., Ruokolainen, S., Tähtiharju, S., Kotilainen, M., Albert, V.A., Elomaa, P. y Teeri, T.H. (2010). Functional characterization of B class MADS-box transcription factors in Gerbera hybrida. J Exp Bot. 61, 75-85.

Brunner, A.M., Rottmann, W.H., Sheppard, L.A., Krutovskii, K., DiFazio, S.P., Leonardi, S. y Strauss, S.H. (2000). Structure and expression of duplicate AGAMOUS orthologues in poplar. Plant Mol Biol. 44, 619-634. 
Buchner, P. y Boutin, J.P. (1998). A MADS box transcription factor of the AP1/AGL9 subfamily is also expressed in the seed coat of pea (Pisum sativum) during development. Plant Mol Biol. 38, 1253-1255.

Burgeff, C., Liljegren, S.J., Tapia-Lopez, R., Yanofsky, M.F. y Alvarez-Buylla, E.R. (2002). MADS-box gene expression in lateral primordia, meristems and differentiated tissues of Arabidopsis thaliana roots. Planta. 214, 365-372.

Busch, M.A., Bomblies, K. y Weigel, D. (1999). Activation of a floral homeotic gene in Arabidopsis. Science. 285, 585-587.

Busi, M.V., Bustamante, C., D’Angelo, C., Hidalgo-Cuevas, M., Boggio, S., Valle, E. y Zabaleta, E. (2003). MADS-box genes expressed during tomato seed and fruit development. Plant Mol Biol 52, 801-815.

Cannon, S.B., Sterck, L., Rombauts, S., Sato, S., Cheung, F., Gouzy, J., Wang, X., Mudge, J., Vasdewani, J., Schiex, T., Spannagl, M., Monaghan, E., Nicholson, C., Humphray, S.J., Schoof, H., Mayer, K.F., Rogers, J., Quétier, F., Oldroyd, G.E., Debellé, F., Cook, D.R., Retzel, E.F., Roe, B.A., Town, C.D., Tabata, S., Van de Peer, Y. y Young, N.D. (2006). Legume genome evolution viewed through the Medicago truncatula and Lotus japonicus genomes. Proc Natl Acad Sci USA. 103, 14959-14964.

Carlsbecker, A., Tandre, K., Johanson, U., Englund, M. y Engström, P. (2004). The MADS-box gene DAL1 is a potential mediator of the juvenile-to-adult transition in Norway spruce (Picea abies). Plant J. 40, 546-557.

Carmel-Goren, L., Liu, Y.S., Lifschitz, E. y Zamir, D. (2003). The SELF-PRUNING gene family in tomato. Plant Mol Biol. 52, 1215-1222.

Carpenter, R. y Coen, E.S. (1990). Floral homeotic mutations produced by transposonmutagenesis in Antirrhinum majus. Genes Dev. 4, 1483-1493.

Causier, B., Castillo, R., Zhou, J., Ingram, R., Xue, Y., Schwarz-Sommer, Z. y Davies, B. (2005). Evolution in action: following function in duplicated floral homeotic genes. Curr Biol. 15, 1508-1512.

Causier, B., Schwarz-Sommer, Z. y Davies, B. (2010). Floral organ identity: 20 years of ABCs. Semin Cell Dev Biol. 21, 73-79.

Chanderbali, A.S., Kim, S., Buzgo, M., Zheng, Z., Oppenheimer, D.G., Soltis, D.E. y Soltis, P.S. (2006). Genetic footprints of stamen ancestors guide perianth evolution in Persea (Lauraceae). Int J Plant Sci. 167, 1075-1089.

Cheng, X., Wen, J., Tadege, M., Ratet, P. y Mysore, K.S. (2011). Reverse genetics in Medicago truncatula using Tnt1 insertion mutants. Methods Mol Biol. 678, 179-190. 
Cheng, Y., Kato, N., Wang, W., Li, J. y Chen, X. (2003). Two RNA binding proteins, HEN4 and HUA1, act in the processing of AGAMOUS pre-mRNA in Arabidopsis thaliana. Developmental Cell. 4, 53-66.

Cho, S., Jang, S., Chae, S., Chung, K.M., Moon, Y., An, G. y Jang, S.K. (1999). Analysis of the C-terminal region of Arabidopsis thaliana APETALA1 as a transcription activation domain. Plant Mol Biol. 40, 419-429.

Choi, H.K., Mun, J.H., Kim, D.J., Zhu, H., Baek, J.M., Mudge, J., Roe, B., Ellis, N., Doyle, J., Kiss, G.B., Young, N.D. y Cook, D.R. (2004). Estimating genome conservation between crop and model legume species. Proc Natl Acad Sci USA. 101, 15289-15294.

Clough, S.J. y Bent, A.F. (1998). Floral dip: a simplified method for Agrobacteriummediated transformation of Arabidopsis thaliana. Plant J. 16, 735-743.

Coen, E.S. y Meyerowitz, E.M. (1991). The war of the whorls: genetic interactions controlling flower development. Nature. 353, 31-37.

Colombo, L., Franken, J., Koetje, E., Van Went, J., Dons, H.J.M., Angenent, G., y Van Tunen, A.J. (1995). The petunia MADS box gene FBP11 determines ovule identity. Plant Cell. 7, 1859-1868.

Colombo, M., Brambilla, V., Marcheselli, R., Caporali, E., Kater, M.M. y Colombo, L. (2010). A new role for the SHATTERPROOF genes during Arabidopsis gynoecium development. Dev Biol. 337, 294-302.

Conant, G.C. y Wolfe, K.H. (2008). Turning a hobby into a job: How duplicated genes find new functions. Nat Rev Genet. 9, 938-950.

Constantin, G.D., Grønlund, M., Johansen, I.E., Stougaard, J. y Lund, O.S. (2008). Virusinduced gene silencing (VIGS) as a reverse genetic tool to study development of symbiotic root nodules. Mol Plant Microbe Interact. 21, 720-727.

Constantin, G.D., Krath, B.N., MacFarlane, S.A., Nicolaisen, M., Johansen, I.E. y Lund, O.S. (2004). Virus-induced gene silencing as a tool for functional genomics in a legume species. Plant Journal. 40, 622-631.

Cook, D.R. (1999). Medicago truncatula-a model in the making!. Curr Opin Plant Biol. 2, 301-304.

Cooper, B., Clarke, J.D., Budworth, P., Kreps, J., Hutchison, D., Park, S., Guimil, S., Dunn, M., Luginbuhl, P., Ellero, C., Goff, S.A. y Glazebrook, J. (2003). A network of rice genes associated with stress response and seed development. Proc Natl Acad Sci USA. 100, 4945-4950.

Crawford, E.J., Lake, A.W.H. y Boyce K.G. (1989). Breeding Annual Medicago Species for Semiarid Conditions in Southern Australia. Advances in Agronomy. 42, 399-437. 
Cseke, L.J., Zheng, J. y Podila, G.K. (2003). Characterization of PTM5 in aspen trees: a MADS-box gene expressed during woody vascular development. Gene. 318, 55-67.

Cui, L., Wall, P.K., Leebens-Mack, J.H., Lindsay, B.G., Soltis, D.E., Doyle, J.J., Soltis, P.S., Carlson, J.E., Arumuganathan, K., Barakat, A., Albert, V.A., Ma, H. y dePamphilis, C.W. (2006). Widespread genome duplications throughout the history of flowering plants. Genome Res. 16, 738-749.

Davies, B., Di Rosa, A., Eneva, T., Saedler, H. y Sommer, H. (1996). Alteration of tobacco floral organ identity by expression of combinations of Antirrhinum MADS-box genes. Plant J. 10, 663-677.

Davies, B., Motte, P., Keck, E., Saedler, H., Sommer, H. y Schwarz-Sommer, Z. (1999). PLENA and FARINELLI: redundancy and regulatory interactions between two Antirrhinum MADS-box factors controlling flower development. EMBO J. 18, 4023-4034.

Dayhoff, M.O. (1979). En: Atlas of Protein Sequence and Structure. Vol 5, Supplement 3. (Washington, DC, USA: Nat. Biomed. Res. Found.). 345-352.

De Bodt, S., Raes, J., Van de Peer, Y. y Theissen G. (2003). And then there were many: MADS goes genomic. Trends Plant Sci. 8, 475-483.

de Folter, S., Immink, R.G., Kieffer, M., Pařenicová, L., Henz, S.R., Weigel, D., Busscher, M., Kooiker, M., Colombo, L., Kater, M.M., Davies, B. y Angenent, G.C. (2005). Comprehensive interaction map of the Arabidopsis MADS box transcription factors. Plant Cell. 17, 1424-1433.

de Martino, G., Pan, I., Emmanuel, E., Levy, A. y Irish, V.F. (2006). Functional analyses of two tomato APETALA3 genes demonstrate diversification in their roles in regulating floral development. Plant Cell. 18, 1833-1845.

Decroocq, V., Zhu, X., Kauffman, M., Kyozuka, J., Peacock, W.J., Dennis, E.S. y Llewellyn, D.J. (1999). A TM3-like MADS-box gene from Eucalyptus expressed in both vegetative and reproductive tissues. Gene. 228, 155-160.

Delaet, J., Clinkemaillie, D., Jansen, S. y Smets, E. (1995). Floral ontogeny in the Plumbaginaceae. J Plant Res. 108, 289-304.

Dellaporta, S.L., Wood, J., y Hicks, J.B. (1983). A plant DNA minipreparation: version II. Plant Mol Biol Rep. 1, 19-21.

Deyholos, M.K. y Sieburth, L.E. (2000). Separable whorl-specific expression and negative regulation by enhancer elements within the AGAMOUS second intron. Plant Cell. 12, 1799-1810. 
Ditta, G., Pinyopich, A., Robles, P., Pelaz, S. y Yanofsky, M.F. (2004). The SEP4 gene of Arabidopsis thaliana functions in floral organ and meristem identity. Curr Biol. 14, 19351940.

Dolan, J.W. y Fields, S. (1991). Cell-type-specific transcription in yeast. Biochim Biophys. Acta. 1088, 155-169.

Dong, Z.C., Zhao, Z., Liu, C.W., Luo, J.H., Yang, J., Huang, W.H., Hu, X.H., Wang, T.L. y Luo, D. (2005). Floral patterning in Lotus japonicus. Plant Physiol. 137, 1272-1282.

Doyle, J.J. (1994). Evolution of a plant homeotic multigene family: Toward connecting molecular systematics and molecular developmental genetics. Systematic Biology. 43, 307-328.

Doyle, J.J. (2001). Leguminosae. En: Encylopedia of Genetics. Brenner, S., Miller, J.H., eds. (San Diego: Academic Press). 1081-1085.

Doyle, J.J. y Luckow, M.A. (2003). The rest of the iceberg. Legume diversity and evolution in a phylogenetic context. Plant Physiol. 131, 900-910.

Doyle, J.J., Doyle, J.L., Ballenger, J.A. y Palmer, J.D. (1996). The distribution and phylogenetic significance of a $50 \mathrm{~kb}$ chloroplast DNA inversión in the flowering plant family Leguminosae. Mol Phylogenet Evol. 5, 429-438.

Drea, S.C., Lao, N.T., Wolfe, K.H. y Kavanagh, T.A. (2006). Gene duplication, exon gain and neofunctionalization of OEP16-related genes in land plants. Plant J. 46, 723-735.

Drews, G.N., Bowman, J.L. y Meyerowitz, E.M. (1991). Negative regulation of the Arabidopsis homeotic gene AGAMOUS by the APETALA2 product. Cell. 65, 991-1002.

Duarte, J.M., Cui, L., Wall, P.K., Zhang, Q., Zhang, X., Leebens-Mack, J., Ma, H., Altman, N. y dePamphilis, C.W. (2006). Expression pattern shifts following duplication indicative of subfunctionalization and neofunctionalization in regulatory genes of Arabidopsis. Mol Biol Evol. 23, 469-478.

Egea-Cortines, M., Saedler, H. y Sommer, H. (1999). Ternary complex formation between the MADS-box proteins SQUAMOSA, DEFICIENS and GLOBOSA is involved in the control of floral architecture in Anthirrinum majus. EMBO J. 18, 5370-5379.

Endress, P.K. (1990). Patterns of floral construction in ontogeny and phylogeny. Biol J Linn Soc. 39, 153-175.

Evans, R.C. y Dickinson, T.A. (1996). North-American black fruited hawthorns. II. Floral development of 10-stamen and 20-stamen morphotypes in Crataegus section Douglasii (Rosaceae, maloideae). Amer J Bot. 83, 961-978. 
Fan, H.Y., Hu, Y., Tudor, M. y Ma, H. (1997). Specific interactions between the K domains of $A G$ and AGLs, members of the MADS domain family of DNA binding proteins. Plant J. 12, 999-1010.

Fan, J., Li, W., Dong, X., Guo, W. y Shu, H. (2007). Ectopic expression of a hyacinth AGL6 homolog caused earlier flowering and homeotic conversion in Arabidopsis. Sci China $C$ Life Sci. 50, 676-689.

Farag, M.A., Huhman, D.V., Dixon, R.A. y Sumner, L.W. (2008). Metabolomics reveals novel pathways and differential mechanistic and elicitor-specific responses in phenylpropanoid and isoflavonoid biosynthesis in Medicago truncatula cell cultures. Plant Physiol. 146, 387-402.

Favaro, R., Pinyopich, A., Battaglia, R, Kooiker, M., Borghi, L., Ditta, G., Yanofsky, M., Kater, M. y Colombo, L. (2003). MADS-box protein complexes control carpel and ovule development in Arabidopsis. Plant Cell. 15, 2603-2611.

Feinberg, A.P. y Vogelstein, B. (1983). A technique for radiolabelling DNA restriction endonuclease fragments to high specific activity. Anal Biochem. 132, 6-13.

Ferrándiz, C. (1996). Morfogénesis floral de mutantes homéoticos de Pisum sativum L. Aislamiento y caracterización molecular de genes de la familia MADS. Tesis Doctoral. Universidad de Valencia.

Ferrándiz, C., Liljegren, S.J., y Yanofsky, M.F. (2000). Negative regulation of the SHATTERPROOF genes by FRUITFULL during Arabidopsis fruit development. Science. 289, 436-438.

Ferrandiz, C., Navarro, C., Gomez, M.D., Canas, L.A. y Beltran, J.P. (1999). Flower development in Pisum sativum: from the war of the whorls to the battle of the common primordia. Dev Genet. 25, 280-290.

Ferrario, S., Immink, R.G. y Angenent, G.C. (2004). Conservation and diversity in flower land. Curr Opin Plant Biol. 7, 84-91.

Flanagan, C.A. y Ma, H. (1994). Spatially and temporally regulated expression of the MADS-box gene AGL2 in wild-type and mutant arabidopsis flowers. Plant Mol Biol. 26, 581-595.

Flanagan, C.A., Hu, Y. y Ma, H. (1996). Specific expression of the AGL1 MADS-box gene suggests regulatory functions in Arabidopsis gynoecium and ovule development. Plant J. 10, 343-353.

Foo, E., Bullier, E., Goussot, M., Foucher, F., Rameau, C. y Beveridge, C.A. (2005). The branching gene RAMOSUS1 mediates interactions among two novel signals and auxin in pea. Plant Cell. 17, 464-474. 
Force, A., Lynch, M., Pickett, F.B., Amores, A., Yan, Y.L. y Postlethwait, J. (1999). Preservation of duplicate genes by complementary, degenerative mutations. Genetics. 151, 1531-1545.

Fukui, M., Futamura, N., Mukai, Y., Wang, Y., Nagao, A. y Shinohara, K. (2001). Ancestral MADS box genes in Sugi, Cryptomeria japonica D. Don (Taxodiaceae), homologous to the B function genes in angiosperms. Plant Cell Physiol. 42, 566-575.

Gepts, P., Beavis, W.D., Brummer, E.C., Shoemaker, R.C., Stalker, H.T., Weeden, N.F. y Young, N.D. (2005). Legumes as a model plant family. Genomics for food and feed report of the Cross-Legume Advances Through Genomics Conference. Plant Physiol. 137, 1228-1235.

Goto, K. y Meyerowitz, E.M. (1994). Function and regulation of the Arabidopsis floral homeotic gene PISTILLATA. Genes Dev. 8, 1548-1560.

Graham, P.H y Vance, C.P. (2003). Legumes: importance and constraints to greater use. Plant Physiol. 131, 872-877.

Gregis, V., Sessa, A., Colombo, L. y Kater, M.M. (2006). AGL24, SHORT VEGETATIVE PHASE, and APETALA1 redundantly control AGAMOUS during early stages of flower development in Arabidopsis. Plant Cell. 18, 1373-1382.

Griffiths, S., Dunford, R.P., Coupland, G. y Laurie, D.A. (2003). The evolution of CONSTANS-like gene families in barley, rice and Arabidopsis. Plant Physiol. 131, 1-13.

Grønlund, M., Constantin, G., Piednoir, E., Kovacev, J., Johansen, I.E. y Lund, O.S. (2008). Virus-induced gene silencing in Medicago truncatula and Lathyrus odorata. Virus Research. 135, 345-349.

Grusak, M.A. (2002). Phytochemicals in plants: genomics-assisted plant improvement for nutritional and health benefits. Curr Opin Biotechnol. 13, 508-511.

Gu, X. (2003). Evolution of duplicate genes versus genetic robustness against null mutations. Trends Genet. 19, 354-356.

Guerineau, F. y Mullineaux, P. (1993). Plant Transformation and expression vectors. En: Plant Molecular Biology LABFAX. Croy, R.R.D., ed., (Oxford, UK: ßios Scientific and Blackwell Scientific). 121-147.

Hands, P., Vosnakis, N., Betts, D., Irish, V.F. y Drea, S. (2011). Alternate transcripts of a floral developmental regulator have both distinct and redundant functions in opium poppy. Ann Bot. 107, 1557-1566.

Hartmann, U., Hoehmann, S., Nettesheim, K., Wisman, E., Saedler, H. y Huijser, P. (2000). Molecular cloning of SVP: a negative regulator of the floral transition in Arabidopsis. Plant J. 21, 351-360. 
Hartweck, L.M., Scott, C.L. y Olszewski, N.E. (2002). Two O-linked $N$-acetylglucosamine transferase genes of Arabidopsis thaliana L. Heynh. have overlapping functions necessary for gamete and seed development. Genetics. 161, 1279-1291.

Hasebe, M. y Banks, J.A. (1997). Evolution of MADS gene family in plants. En: Evolution and Diversification of Land Plants. Iwatsuki, K. y Raven, R.H., eds. (Tokyo, Japan: Springer-Verlag). 179-197.

Haughn, G.W. y Somerville, C.R. (1988). Genetic control of morphogenesis in Arabidopsis. Dev Genet. 9, 73-89.

Hayama, R., Yokoi, S., Tamaki, S., Yano, M. y Shimamoto, K. (2003). Adaptation of photoperiodic control pathways produces short-day flowering in rice. Nature. 422, 719722.

He, C. y Saedler, H. (2005). Heterotopic expression of MPF2 is the key to the evolution of the Chinese lantern of Physalis, a morphological novelty in Solanaceae. Proc Natl Acad Sci USA. 102, 5779-5784.

He, X.L. y Zhang, J.Z. (2005). Rapid subfunctionalization accompanied by prolonged and substantial neofunctionalization in duplicate gene evolution. Genetics. 169, 1157-1164.

Heard, J. y Dunn, K. (1995). Symbiotic induction of a MADS-box gene during development of alfalfa root nodules. Proc Natl Acad Sci USA. 92, 5273-5277.

Hecht, V., Foucher, F., Ferrándiz, C., Macknight, R., Navarro, C., Morin, J., Vardy, M.E., Ellis, N., Beltrán, J.P., Rameau, C. y Weller, J.L. (2005). Conservation of Arabidopsis flowering genes in model legumes. Plant Physiol. 137, 1420-1434. Erratum in: Plant Physiol 138, 2417.

Hellens, R.P., Edwards, A., Leyland, N.R., Bean, S. y Mullineaux, P.M. (2000). pGreen: a versatile and flexible binary Ti vector for Agrobacterium mediated plant transformation. Plant Mol Biol. 42, 819-832.

Hensel, L.L., Nelson, M., Richmond, T. y Bleecker, A.B. (1994). The fate of inflorescence meristems is controlled by developing fruits in Arabidopsis. Plant Physiol. 106, 863-876.

Hewitt, E.J. (1966). En: Sand and Water Culture Methods Used in the Study of Plant Nutrition. 2nd Ed. (Farnham Royal, England: Commonw. Agr. Bur. Tech. Commun.).

Hirsch, A.M. (2004). Plant-microbe symbioses: a continuum from commensalism to parasitism. Symbiosis. 37, 345-363.

Hirsch, A.M., Krupp, R.S.N., Lin, Y., Wang, S.W., Yang, W. y Tucker, S.C. (2002). Inflorescence and flower development in wild-type and sid mutant in Melilotus alba. Can J Bot. 80, 732-740. 
Hong, R.L., Hamaguchi, L., Busch, M.A. y Weigel, D. (2003). Regulatory elements of the floral homeotic gene AGAMOUS identified by phylogenetic footprinting and shadowing. Plant Cell. 15, 1296-1309.

Honma, T. y Goto, K. (2001). Complexes of MADS-box proteins are sufficient to convert leaves into floral organs. Nature. 409: 525-529.

Hsu, H.F., Hsieh, W.P., Chen, M.K., Chang, Y.Y. y Yang, C.H. (2010). C/D class MADS box genes from two monocots, orchid (Oncidium Gower Ramsey) and lily (Lilium longiflorum), exhibit different effects on floral transition and formation in Arabidopsis thaliana. Plant Cell Physiol. 51, 1029-1045.

Hsu, H.F., Huang, C.H., Chou, L.T. y Yang, C.H. (2003). Ectopic expression of an orchid (Oncidium Gower Ramsey) AGL6-like gene promotes flowering by activating flowering time genes in Arabidopsis thaliana. Plant Cell Physiol. 44, 783-794.

Huang, F., Chi, Y., Gai, J. y Yu, D. (2009). Identification of transcription factors predominantly expressed in soybean flowers and characterization of GMSEP1 encoding a SEPALLATA1-like protein. Gene. 438, 40-48.

Huang, H., Tudor, M., Weiss, C.A., Hu, Y. y Ma, H. (1995). The Arabidopsis MADS-box gene $A G L 3$ is widely expressed and encodes a sequence-specific DNA-binding protein. Plant Mol Biol. 28, 549-567.

Immink, R.G., Ferrario, S., Busscher-Lange, J., Kooiker,M., Busscher, M., and y Angenent, G.C. (2003). Analysis of the petunia MADS-box transcription factor family. Mol Gen Genom. 268, 598-606.

Immink, R.G., Gadella, T.W.Jr., Ferrario, S., Busscher, M. y Angenent, G.C. (2002). Analysis of MADS box protein-protein interactions in living plant cells. Proc Nat Acad Sci USA. 99, 2416-2421.

Immink R.G., Tonaco I.A., de Folter, S., Shchennikova, A., van Dijk, A.D., BusscherLange, J, Borst, J.W. y Angenent, G.C. (2009). SEPALLATA3: the 'glue' for MADS box transcription factor complex formation. Genome Biol. 10, R24.

Irish, V.F. (2003). The evolution of floral homeotic gene function. Bioessays. 25, 637-646.

Irish, V.F. y Litt, A. (2005). Flower development and evolution: gene duplication, diversification and redeployment. Curr Opin Genet Dev. 15, 454-460.

Jack, T. (2004). Molecular and genetic mechanisms of floral control. Plant Cell. 16, S1S17.

Jack, T., Fox, G.L. y Meyerowitz, E.M. (1994). Arabidopsis homeotic gene APETALA3 ectopic expression: transcriptional and post transcriptional regulation determine floral organ identity. Cell. 76, 703-716. 
Jager, M., Hassanin, A., Manuel, M., Le Guyader, H. y Deutsch, J. (2003). MADS-box genes in Ginkgo biloba and the evolution of the AGAMOUS family. Mol Biol Evol. 20, 842854.

Jensen, E.S. y Hauggaard-Nielsen, H. (2003). How can increased use of biological N2 fixation in agriculture benefit the environment?. Plant and Soil. 252, 177-186.

Jofuku, K.D., den Boer, B.G., Montagu, M.V. y Okamuro, J.K. (1994). Control of Arabidopsis flower and seed development by the homeotic gene APETALA2. Plant Cell. 6, 1211-1225.

Kalo, P., Seres, A., Taylor, S.A., Jakab, J., Kevei, Z., Kereszt, A., Endre, G., Ellis,T. H.N. y Kiss, G.B. (2004). Comparative mapping between Medicago sativa and Pisum sativum. Mol Genet Genomics, 272, 235-246.

Kamenetsky, R. y Akhmetova, M. (1994). Floral development of Eremurus-Altaicus (Liliaceae). Israel J Plant Sci. 290, 344-347.

Kang, H.G., Jeon, J.S., Lee, S. y An, G. (1998). Identification of class B and class C floral organ identity genes from rice plants. Plant Mol Biol. 38, 1021-1029.

Kapoor, M., Tsuda, S., Tanaka, Y., Mayama, T., Okuyama, Y., Tsuchimoto, S. y Takatsuji, H. (2002). Role of petunia pMADS3 in determination of floral organ and meristem identity, as revealed by its loss of function. Plant J. 32, 115-127.

Kater, M.M., Colombo, L., Franken, J., Busscher, M., Masiero, S., Van Lookeren Campagne, M.M. y Angenent, G.C. (1998). Multiple AGAMOUS homologs from cucumber and petunia differ in their ability to induce reproductive organ fate. Plant Cell. 10, 171-182.

Kempin, S.A., Mandel, M.A. y Yanofsky, M.F. (1993). Conversion of perianth into reproductive organs by ectopic expression of the tobacco floral homeotic gene NAG1. Plant Physiol. 103, 1041-1046.

Kim, S., Koh J., Ma, H., Hu, Y., Endress P.K., Hauser B.A., Buzgo M., Soltis P.S. y Soltis D.E. (2005). Sequence and expression Studies of A-, B-, and E-Class MADS-Box homologues in Eupomatia (Eupomatiaceae): Support for the bracteate origin of the calyptra. Int J Plant Sci. 166, 185-198.

Kirchoff, B.K. (1997). Inflorescence and flower development in the Hedychae (Zingibereaceae)-Hedychium. Can J Bot. 75, 581-594.

Kitahara, K. y Matsumoto, S. (2000). Rose MADS-box genes 'MASAKO C1 and D1' homologous to class C floral identity genes. Plant Sci. 151, 121-134. 
Kitamura-Abe, S., Itoh, H., Washio, T., Tsutsumi, A. y Tomita, M.J. (2004). Characterization of the splice sites in GT-AG and GC-AG introns in higher eukaryotes using full-length cDNAs. Bioinform Comput Biol. 2, 309-331.

Komeda, Y. (2004). Genetic regulation of time to flower in Arabidopsis thaliana. Annu Rev Plant Biol. 55, 521-535.

Koncz, C., y Schell, J. (1986). The promoter of TL-DNA gene 5 controls the tissue-specific expression of chimaeric genes carried by a novel type of Agrobacterium binary vector. Mol Gen Genet. 204, 383-396.

Kondrashov, F.A., Rogozin, I.B., Wolf, Y.I. y Koonin, E.V. (2002). Selection in the evolution of gene duplications. Genome Biol. 3, research0008.1-research0008.9.

Koo, S.C., Bracko, O., Park, M.S., Schwab, R., Chun, H.J., Park, K.M., Seo, J.S., Grbic, V., Balasubramanian, S., Schmid, M., Godard, F., Yun, D.J., Lee, S.Y., Cho, M.J., Weigel, D. y Kim, M.C. (2010). Control of lateral organ development and flowering time by the Arabidopsis thaliana MADS-box gene AGAMOUS-LIKE6. Plant J. 62, 807-816.

Kosterin, O.E. (1999). A floral homeiotic mutation affecting B function of florogenesis control in the pea. Pisum Genetics. 31, 9-10.

Kotoda, N., Hayashi, H., Suzuki, M., Igarashi, M., Hatsuyama, Y., Kidou, S., Igasaki, T., Nishiguchi, M., Yano, K., Shimizu, T., Takahashi, S., Iwanami, H., Moriya, S. y Abe, K. (2010). Molecular characterization of FLOWERING LOCUS T-like genes of Apple (Malus $x$ domestica Borkh.). Plant Cell Physiol. 51, 561-575.

Krakauer, D.C. y Nowak, M.A. (1999). Evolutionary preservation of redundant duplicated genes. Semin Cell Dev Biol. 10, 555-559.

Kramer, E.M. (2007). Understanding the genetic basis of floral diversity. Bioscience. 57, 479-487.

Kramer, E.M. y Hall, J.C. (2005). Evolutionary dynamics of genes controlling floral development. Curr Opin Plant Biol. 8, 13-18.

Kramer, E.M. e Irish, V.F. (1999). Evolution of genetic mechanisms controlling petal development. Nature. 399, 144-148.

Kramer, E.M. e Irish, V. (2000). Evolution of the petal and stamen developmental programs: evidence from comparative studies of the lower eudicots and basal angiosperms. Int J Plant Sci. 161, S29-S40.

Kramer E.M. y Zimmer, E.A. (2006). Gene duplication and floral developmental genetics of basal eudicots. En: Advances in Botanical Research: Developmental Genetics of the Flower. Soltis, D.E., Soltis, P.S. y Leebens-Mack, J., eds. (London: Academic Press). 354385. 
Kramer, E.M., Di Stilio, V.S. y Schlüter P.M. (2003). Complex patterns of gene duplication in the APETALA3 and PISTILLATA lineages of the Ranunculaceae. Int J Plant Sci. 164, 1-11.

Kramer, E.M., Dorit, R.L. y Irish, V.F. (1998). Molecular evolution of genes controlling petal and stamen development: duplication and divergence within the APETALA3 and PISTILLATA MADS-box gene lineages. Genetics. 149, 765-783.

Kramer, E.M., Jaramillo, M.A. y Di Stilio, V.S. (2004). Patterns of gene duplication and functional evolution during the diversification of the AGAMOUS subfamily of MADS box genes in angiosperms. Genetics. 166, 1011-1023.

Kramer, E.M., Su, H.J., Wu, C.C. y Hu, J.M. (2006). A simplified explanation for the frameshift mutation that created a novel C-terminal motif in the APETALA3 gene lineage. BMC Evol Biol. 6, 30.

Kumagai, M.H., Donson, J., Della-Cioppa, G., Harvey, D., Hanley, K. y Grill, L.K. (1995). Cytoplasmic inhibition of carotenoid biosynthesiswith virus-derived RNA. Proc Natl Acad Sci USA. 92, 1679-1683.

Kyozuka, J. y Shimamoto, K. (2002). Ectopic expression of OSMADS3, a rice ortholog of AGAMOUS, caused a homeotic transformation of lodicules to stamens in transgenic rice plants. Plant Cell Physiol. 43, 130-135.

Kyozuka, J., Harcourt, R., Peacock, W.J. y Dennis, E.S. (1997). Eucalyptus has functional equivalents of the Arabidopsis AP1 gene. Plant Mol Biol. 35, 573-584.

Lamb, R.S. e Irish, V.F. (2003). Functional divergence within the APETALA3/PISTILLATA floral homeotic gene lineages. Proc Natl Acad Sci USA. 100, 6558-6563.

Laux, T., Mayer, K.F., Berger, J. y Jürgens, G. (1996). The WUSCHEL gene is required for shoot and floral meristem integrity in Arabidopsis. Development. 122, 87-96.

Lavin, M., Herendeen, P.S. y Wojciechowski, M.F. (2005). Evolutionary rates analysis of Leguminosae implicates a rapid diversification of lineages during the tertiary. Syst Biol. 54, 575-594.

Lawton-Rauh, A.L., Buckler, E.S. y Purugganan, M.D. (1999). Patterns of molecular evolution among paralogous floral homeotic genes. Mol Biol Evol. 16, 1037-1045.

Lee, H., Suh, S.S., Park, E., Cho, E., Ahn, J.H., Kim, S.G., Lee, J.S., Kwon, Y.M. y Lee, I. (2000). The AGAMOUS-LIKE 20 MADS domain protein integrates floral inductive pathways in Arabidopsis. Genes Dev. 14, 2366-2376.

Lee, J. y Lee, I. (2010). Regulation and function of SOC1, a flowering pathway integrator. J Exp Bot. 61, 2247-2254. 
Lee, J.H., Cho, Y.S., Yoon, H.S., Suh, M.C., Moon, J., Lee, I., Weigel, D., Yun, C.H. y Kim, J.K. (2005). Conservation and divergence of FCA function between Arabidopsis and rice. Plant Mol Biol. 58, 823-838.

Lee, J.M., Grant, D., Vallejos, C.E. y Shoemaker, R.C. (2001). Genome organization in dicots. II. Arabidopsis as a "bridging species" to resolve genome evolution events among legumes. Theor Appl Genet. 103, 765-773.

Lee, S., Kim, J., Son, J.S., Nam, J., Jeong, D.H., Lee, K., Jang, S., Yoo, J., Lee, J., Lee, D.Y., Kang, H.G. y An, G. (2003). Systematic reverse genetic screening of T-DNA tagged genes in rice for functional genomic analyses: MADS-box genes as a test case. Plant Cell Physiol. 44, 1403-1411.

Leebens-Mack, J., Soltis, D.E. y Soltis, P.S. (2005). Plant reproductive genomics at the Plant and Animal Genome Conference. Comp Funct Genomics. 6, 159-169.

Lenhard, M., Bohnert, A., Jurgens, G. y Laux T. (2001). Termination of stem cell maintenance in Arabidopsis floral meristems by interactions between WUSCHEL and AGAMOUS. Cell. 105, 805-814.

Leseberg, C.H., Li, A., Kang, H., Duvall, M. y Mao, L. (2006). Genome-wide analysis of the MADS-box gene family in Populus trichocarpa. Gene. 378, 84-94.

Lewis, G., Schrire, B., MacKinder B. y Lock, M. (2005). En: Legumes of the World. (Richmond, Surrey, UK: The Royal Botanical Gardens, Kew).

Li, G., Meng, Z., Kong, H., Chen, Z. y Lu, A. (2003). ABC model and floral evolution. Chin Sci Bull. 48, 2651-2657.

Li, H., Liang, W., Jia, R., Yin, C., Zong, J., Kong, H. y Zhang, D. (2010). The AGL6-like gene OsMADS6 regulates floral organ and meristem identities in rice. Cell Research. 20, 299313.

Lightfoot, D.J., Malone, K.M., Timmis, J.N. y Orford, S.J. (2008). Evidence for alternative splicing of MADS-box transcripts in developing cotton fibre cells. Mol Genet Genomics. 279, 75-85.

Liljegren, S.J., Ditta, G.S., Eshed, Y., Savidge, B., Bowman, J.L. y Yanofsky, M.F. (2000). SHATTERPROOF MADS-box genes control seed dispersal in Arabidopsis. Nature. 404, 766-770.

Limpens, E., Ramos, J., Franken, C., Raz, V., Compaan, B., Franssen, H., Bisseling, T. y Geurts, R. (2004). RNA interference in Agrobacterium rhizogenes-transformed roots of Arabidopsis and Medicago truncatula. J Exp Bot. 55, 983-992. 
Litt, A. e Irish, V.F. (2003). Duplication and diversification in the APETALA1/FRUITFULL floral homeotic gene lineage: implications for the evolution of floral development. Genetics. 165, 821-833.

Litt, A. y Kramer, E.M. (2010). The ABC model and the diversification of floral organ identity. Semin Cell Dev Biol. 21, 129-137.

Livak, K.J. y Schmittgen, T.D. (2001). Analysis of relative gene expression data using realtime quantitative PCR and the $2^{-\Delta \Delta C}$ method. Methods. 25, 402-408.

Lohmann, J.U. y Weigel, D. (2002). Building beauty: The genetic control of floral patterning. Dev Cell. 2, 135-142.

Lohmann, J.U., Hong, R.L., Hobe, M., Busch, M.A., Parcy, F., Simon, R. y Weigel, D. (2001). A molecular link between stem cell regulation and floral patterning in Arabidopsis. Cell. 105, 793-803.

Long, M., de Souza, S.J., Rosenberg, C. y Gilbert, W. (1996). Exon shuffling and the origin of the mitochondrial targeting function in plant cytochrome $\mathrm{c} 1$ precursor. Proc Natl Acad Sci USA. 93, 7727-7731.

Lopez-Dee, Z.P., Wittich, P., Enrico Pè, M., Rigola, D., Del Buono, I., Gorla, M.S., Kater, M.M. y Colombo, L. (1999). OsMADS13, a novel rice MADS-box gene expressed during ovule development. Dev Genet. 25, 237-244.

Losa, A., Caporali, E., Spada, A., Martinelli, S. y Marziani, G. (2004). AOM3 and AOM4: Two MADS box genes expressed in reproductive structures of Asparagus officinalis. Sex Plant Reprod. 16, 215-221.

Lü, S., Du, X., Lu, W., Chong, K. y Meng, Z. (2007). Two AGAMOUS-like MADS-box genes from Taihangia rupestris (Rosaceae) reveal independent trajectories in the evolution of class C and class D floral homeotic functions. Evol Dev. 9, 92-104.

Lynch, M. y Conery, J.S. (2000). The evolutionary fate and consequences of duplicate genes. Science. 290, 1151-1155.

Ma, H., Yanofsky, M.F. y Meyerowitz, E.M. (1991). AGL1-AGL6, an Arabidopsis gene family with similarity to floral homeotic and transcription factor genes. Genes Dev. 5, 484-495.

Madar, Z. y Stark, A.H. (2002). New legume sources as therapeutic agents. Br J Nutr. 88, S287-S292.

Maere, S., De Bodt, S., Raes, J., Casneuf, T., Van Montagu, M., Kuiper, M. y Van de Peer, Y. (2005). Modeling gene and genome duplications in eukaryotes. Proc Natl Acad Sci USA. 102, 5454-5459. 
Malcomber, S.T. y Kellogg, E.A. (2005). SEPALLATA gene diversification: brave new whorls. Trends Plant. 10, 427-435.

Mandel, M.A. y Yanofsky, M.F. (1998). The Arabidopsis AGL9 MADS box gene is expressed in young flower primordia. Sex Plant Reprod. 11, 22-28.

Mandel, M.A., Bowman, J.L., Kempin, S.A., Ma, H., Meyerowitz, E.M. y Yanofsky, M.F. (1992a). Manipulation of flower structure in transgenic tobacco. Cell. 71, 133-143.

Mandel, M.A., Gustafson-Brown, C., Savidge, B. y Yanofsky, M.F. (1992b). Molecular characterization of the Arabidopsis floral homeotic gene APETALA1. Nature. 360, 273277.

Mandel, T., Lutziger, I. y Kuhlemeier, C. (1994). A ubiquitously expressed MADS-box gene from Nicotiana tabacum. Plant Mol Biol. 25, 319-321.

Mantovani, R. (1998). A survey of 178 NF-Y binding CCAAT boxes. Nucleic Acids Res. 26, 1135-1143.

Melzer, R., Verelst, W. y Theissen, G. (2009). The class E floral homeotic protein SEPALLATA3 is sufficient to loop DNA in 'floral quartet'-like complexes in vitro. Nucl Acids Res. 37, 144-157.

Melzer, R., Wang, Y.Q. y Theissen, G. (2010). The naked and the dead: the ABCs of gymnosperm reproduction and the origin of the angiosperm flower. Semin Cell Dev Biol. 21, 118-128.

Mena, M., Ambrose, B.A., Meeley, R.B., Briggs, S.P., Yanofsky, M.F. y Schmidt, R.J. (1996). Diversification of C-function activity in maize flower development. Science. 274, 1537-1540.

Mena, M., Mandel, M.A., Lerner, D.R., Yanofsky, M.F. y Schmidt, R.J. (1995). A characterization of the MADS-box gene family in maize. Plant J. 8, 845-854.

Menzel, G., Apel, K. y Melzer, S. (1996). Identification of two MADS box genes that are expressed in the apical meristem of the long-day plant Sinapis alba in transition to flowering. Plant J. 9, 399-408.

Mizukami, Y. y Ma, H. (1992). Ectopic expression of the floral homeotic gene AGAMOUS in transgenic Arabidopsis plants alters floral organ identity. Cell. 71, 119-131.

Mizukami, Y. y Ma, H. (1995). Separation of $A G$ function in floral meristem determinacy from that in reproductive organ identity by expressing antisense AG RNA. Plant Mol Biol. 28, 767-784.

Mizukami, Y. y Ma, H. (1997). Determination of Arabidopsis floral meristem identity by AGAMOUS. Plant Cell. 9, 393-408. 
Mizukami, Y., Huang, H., Tudor, M., Hu, Y. y Ma, H. (1996). Functional domains of the floral regulator AGAMOUS: characterization of the DNA binding domain and analysis of dominant negative mutations. Plant Cell. 8, 831-845.

Moon, J., Suh, S.S., Lee, H., Choi, K.R., Hong, C.B., Paek, N.C., Kim, S.G. y Lee, I. (2003). The SOC1 MADS-box gene integrates vernalization and gibberellin signals for flowering in Arabidopsis. Plant J. 35, 613-623.

Moon, Y.H., Kang, H.G., Jung, J.Y., Jeon, J.S., Sung, S.K. y An, G. (1999). Determination of the motif responsible for interaction between the rice APETALA1/AGAMOUS-LIKE9 family proteins using a yeast two-hybrid system. Plant Physiol. 120, 1193-1204.

Moore, R.C., Grant, S.R. y Purugganan, M.D. (2005). Molecular population genetics of redundant floral-regulatory genes in Arabidopsis thaliana. Mol Biol Evol. 22, 91-103.

Mount, S.M. (1982). A catalogue of splice junction sequences. Nucleic Acids Res. 10, 459-472.

Mouradov, A., Cremer, F. y Coupland, G. (2002). Control of flowering time: interacting pathways as a basis for diversity. Plant Cell. 14, 111-130.

Mouradov, A., Glassick, T.V., Hamdorf, B.A., Murphy, L.C., Maria, S.S., Yang, Y. y Teasdale, R.D. (1998). Family of MADS-box genes expressed early in male and female reproductive structures of Monterey pine. Plant Phys. 117, 55-61.

Mouradov, A., Hamdorf, B., Teasdale, R.D., Kim, J.T., Winter, K.U. y Theissen, G. (1999). A DEF/GLO-like MADS-box gene from a gymnosperm: Pinus radiata contains an ortholog of angiosperm B class floral homeotic genes. Dev Genet. 25, 245-252.

Moyroud, E., Minguet, E.G., Ott, F., Yant, L., Posé, D., Monniaux, M., Blanchet, S., Bastien, O., Thévenon, E., Weigel, D., Schmid, M. y Parcy, F. (2011). Prediction of regulatory interactions from genome sequences using a biophysical model for the Arabidopsis LEAFY transcription factor. Plant Cell. 23, 1293-1306.

Münster, T., Deleu W., Wingen L.U., Ouzunova M., Cacharron, J., Faigl, W., Werth, S., Kim, J.T.T., Saedler, H. y Theissen, G. (2002). Maize MADS-box genes galore. Maydica. 47, 287-301.

Münster, T., Pahnke, J., Di Rosa, A., Kim, J.T., Martin, W., Saedler, H. y Theissen, G. (1997). Floral homeotic genes were recruited from homologous MADS-box genes preexisting in the common ancestor of ferns and seed plants. Proc. Natl. Acad. Sci. USA. 94, 2415-2420.

Nair, R., Peck, D., Dundas, I., Samac, D., Moore, A. y Randles, J. (2008). Morphological characterisation and genetic analysis of a bi-pistil mutant (bip) in Medicago truncatula Gaertn. Sex Plant Reprod. 21, 133-141. 
Nakamura, T., Song, I.J., Fukuda, T., Yokoyama, J., Maki, M., Ochiai, T., Kameya, T. y Kanno, A. (2005). Characterization of TrCMADS1 gene of Trillium camtschatcense (Trilliaceae) reveals functional evolution of the SOC1/TM3-like gene family. J Plant Res. 118, 229-234.

Nam, J., dePamphilis, C.W., Ma, H. y Nei, M. (2003). Antiquity and evolution of the MADS-box gene family controlling flower development in plants. Mol Biol Evol. 20, 14351447.

Nam, J., Kim, J., Lee, S., An, G., Ma, H. y Nei, M. (2004). Type I MADS-box genes have experienced faster birth-and-death evolution than type II MADS-box genes in angiosperms. Proc Natl Acad Sci USA. 101, 1910-1915.

Navarro, C. (2001). Genes reguladores del desarrollo floral en guisante (Pisum sativum L.). Tesis Doctoral. Universidad de Valencia.

Nayak, S.N., Zhu, H., Varghese, N., Datta, S., Choi ,H.K., Horres, R., Jüngling, R., Singh, J., Kishor, P.B., Sivaramakrishnan, S., Hoisington, D.A., Kahl, G., Winter, P., Cook, D.R. y Varshney, R.K. (2010). Integration of novel SSR and gene-based SNP marker loci in the chickpea genetic map and establishment of new anchor points with Medicago truncatula genome. Theor Appl Genet. 120, 1415-1441.

Nei, M., Gu, X. y Sitnikova, T. (1997). Evolution by the birth-and-death process in multigene families of the vertebrate immune system. Proc Natl Acad Sci USA. 94, 77997806.

Ng, M. y Yanofsky, M.F. (2001). Function and evolution of the plant MADS-box gene family. Nat Rev Genet. 2, 186-195.

Norman, C., Runswick, M., Pollock, R. y Treisman, R. (1988). Isolation and properties of cDNA clones encoding SRF, a transcription factor that binds to the $c$-fos serum response element. Cell. 55, 989-1003.

Nowak, M.A., Boerlijst, M.C., Cooke, J. y Smith, J.M. (1997). Evolution of genetic redundancy. Nature. 388. 167-171.

Ohmori, S., Kimizu, M., Sugita, M., Miyao, A., Hirochika, H., Uchida, E., Nagato, Y. y Yoshida, H. (2009). MOSAIC FLORAL ORGANS1, an AGL6-like MADS box gene, regulates floral organ identity and meristem fate in rice. Plant Cell. 21, 3008-3025.

Ohno, S. (1970). En: Evolution by Gene Duplication. (Heidelberg, Germany: Springer).

Okamuro, J.K., den Boer, B.G., Lotys-Prass, C., Szeto, W. y Jofuku, K.D. (1996). Flowers into shoots: photo and hormonal control of a meristem identity switch in Arabidopsis. Proc Natl Acad Sci USA. 93, 13831-13836. 
Oldroyd, G.E. y Geurts, R. (2001). Medicago truncatula, going where no plant has gone before. Trends in Plant Science. 6, 552-554.

Onouchi, H., Igeño, M.I., Périlleux, C., Graves, K. y Coupland, G. (2000). Mutagenesis of plants overexpressing CONSTANS demonstrates novel interactions among Arabidopsis flowering time genes. Plant Cell. 12, 885-900.

Paetau, I., Chen, C.Z. y Jane, J.L. (1994) Biodegradable plastic made from soybean products: 1. Effect of preparation and processing on mechanical properties and water absorption. Indust Eng Chem Res. 33, 1821-1827

Paez-Valencia, J., Sanchez-Gomez, C., Valencia-Mayoral, P., Contreras-Ramos, A., Hernandez-Lucas, I., Orozco-Segovia, A. y Gamboa-deBuen, A. (2008). Localization of the MADS domain transcriptional factor NMH7 during seed, seedling and nodule development of Medicago sativa. Plant Science. 175, 596-603.

Parcy, F., Bomblies, K. y Weigel, D. (2002). Interaction of LEAFY, AGAMOUS and TERMINAL FLOWER1 in maintaining floral meristem identity in Arabidopsis. Development. 129, 2519-2527.

Parcy, F., Nilsson, O., Busch, M.A., Lee, I. y Weigel, D. (1998). A genetic framework for floral patterning. Nature. 395, 561-566.

Pařenicová, L., de Folter, S., Kieffer, M., Horner, D.S., Favalli, C., Busscher, J., Cook, H.E., Ingram, R.M., Kater, M.M., Davies, B., Angenent, G.C. y Colombo, L. (2003). Molecular and phylogenetic analyses of the complete MADS-box transcription factor family in Arabidopsis: new openings to the MADS world. Plant Cell. 15, 1538-1551.

Pelaz, S., Ditta, G.S., Baumann, E., Wisman, E. y Yanofsky, M.F. (2000). B and C floral organ identity functions require SEPALLATA MADS-box genes. Nature. 405, 200-203.

Pelucchi, N., Fornara, F., Favalli, C., Masiero, S., Lago, C., Pe, M.E., Colombo, L. y Kater, M.M. (2002). Comparative analysis of rice MADS-box genes expressed during flower development. Sex Plant Reprod. 15, 113-122.

Perl-Treves, R., Kahana, A., Rosenman, N., Xiang, Y. y Silberstein, L. (1998). Expression of multiple AGAMOUS-like genes in male and female flowers of cucumber (Cucumis sativus L.). Plant Cell Physiol. 39, 701-710.

Perrière, G. y Gouy, M. (1996) WWW-Query: An on-line retrieval system for biological sequence banks. Biochimie. 78, 364-369.

Petersen, K., Didion, T., Andersen, C.H. y Nielsen, K.K. (2004). MADS-box genes from perennial ryegrass differentially expressed during transition from vegetative to reproductive growth. J Plant Physiol. 161, 439-447. 
Pinyopich, A., Ditta, G.S., Savidge, B., Liljegren, S.J., Baumann, E., Wisman, E. y Yanofsky, M.F. (2003). Assessing the redundancy of MADS-box genes during carpel and ovule development. Nature. 424, 85-88.

Pnueli, L., Abu-Abeid, M., Zamir, D., Nacken, W., Schwarz-Sommer, Z. y Lifschitz, E. (1991). The MADS box gene family in tomato: temporal expression during floral development, conserved secondary structures and homology with homeotic genes from Antirrhinum and Arabidopsis. Plant J. 1, 255-266.

Pnueli, L., Hareven, D., Rounsley, S.D., Yanofsky, M.F. y Lifschitz, E. (1994). Isolation of the tomato AGAMOUS gene TAG1 and analysis of its homeotic role in transgenic plants. Plant Cell. 6, 163-173.

Polhill, R.M., Raven, P.H. y Stirton, C.H. (1981). Evolution and systematics of the Leguminosae. En Advances in Legume Systematics Part 1. Polhill, R.M. y Raven, P.H., eds. (Richmond, Surrey, UK: The Royal Botanical Gardens, Kew). 1-26.

Poupin, M.J., Federici, F., Medina, C., Matus, J.T., Timmermann, T. y Arce-Johnson, P. (2007). Isolation of the three grape sub-lineages of B-class MADS-box TM6, PISTILLATA and APETALA3 genes which are differentially expressed during flower and fruit development. Gene. 404, 10-24.

Prince, V.E. y Pickett, F.B. (2002). Splitting pairs: the diverging fates of duplicate genes. Nat Rev Genet. 3, 827-837.

Purugganan, M.D. y Suddith, J.I. (1998). Molecular population genetics of the Arabidopsis CAULIFLOWER regulatory gene: non neutral evolution and naturally occurring variation in floral homeotic function. Proc Natl Acad Sci USA. 95, 8130-8134.

Purugganan, M.D., Rounsley, S.D., Schmidt, R.J. y Yanofsky, M.F. (1995). Molecular evolution of flower development: diversification of the plant MADS-box regulatory gene family. Genetics. 140, 345-356.

Putterill, J., Laurie, R. y Macknight, R. (2004). It's time to flower: the genetic control of flowering time. Bioessays 26, 363-373

Rastogi, S. y Liberles, D.A. (2005). Subfunctionalization of duplicated genes as a transition state to neofunctionalization. BMC Evolutionary Biology. 5, 28.

Reinheimer, R. y Kellogg, E.A. (2009). Evolution of AGL6-like MADS box genes in grasses (Poaceae): ovule expression is ancient and Palea expression is new. Plant Cell. 21, 25912605.

Repetto, O., Rogniaux, H., Firnhaber, C., Zuber, H., Küster, H., Larré, C., Thompson, R. y Gallardo, K. (2008) Exploring the nuclear proteome of Medicago truncatula at the switch towards seed filling. Plant J. 56, 398-410. 
Riechmann, J.L. y Meyerowitz, E.M. (1997). MADS domain proteins in plant development. Biol Chem. 378, 1079-1101.

Rigola, D., Pè, M.E., Mizzi, L., Ciampolini, F. y Sari-Gorla, M. (2001). CaMADS1, an AGAMOUS homologue from hazelnut, produces floral homeotic conversion when expressed in Arabidopsis. Sexual Plant Reproduction. 13, 185-191.

Rijpkema, A.S., Gerats, T. y Vandenbussche, M. (2007). Evolutionary complexity of MADS complexes. Curr Opin Plant Biol. 10, 32-38.

Rijpkema, A.S., Royaert, S., Zethof, J., van der Weerden, G., Gerats, T. y Vandenbussche, M. (2006). Analysis of the Petunia TM6 MADS box gene reveals functional divergence within the DEF/AP3 lineage. Plant Cell. 18, 1819-1832.

Rijpkema, A.S., Vandenbussche, M., Koes, R., Heijmans, K. y Gerats, T. (2010). Variations on a theme: changes in the floral ABCs in angiosperms. Semin Cell Dev Biol. 21, 100-107.

Rijpkema, A.S., Zethof, J., Gerats, T. y Vandenbussche, M. (2009). The petunia AGL6 gene has a SEPALLATA-like function in floral patterning. Plant J. 60, 1-9.

Robinson-Beers, K., Pruitt, R.E. y Gasser, C.S. (1992). Ovule development in wild-type Arabidopsis and two female-sterile mutants. Plant Cell. 4, 1237-1249.

Robles, P. y Pelaz, S. (2005). Flower and fruit development in Arabidopsis thaliana. Int J Dev Biol. 49, 633-643.

Ronse Decraene, L.P., Clinkemaillie, D. y Smets, E. (1993). Stamen-petal complexes in Magnoliatae. Bull Jard Bot Nat Belg. 62, 97-112.

Rounsley, S.D., Ditta, G.S. y Yanofsky, M.F. (1995). Diverse roles for MADS box genes in Arabidopsis development. Plant Cell. 7, 1259-1269.

Russelle, M. (2001). Alfalfa. Am Sci. 89, 252-259.

Rutledge, R., Regan, S., Nicolas, O., Fobert, P., Côté, C., Bosnich, W., Kauffeldt, C., Sunohara, G., Séguin, A. y Stewart, D. (1998). Characterization of an AGAMOUS homologue from the conifer black spruce (Picea mariana) that produces floral homeotic conversions when expressed in Arabidopsis. Plant J. 15, 625-634.

Sablowski, R.W.M. y Meyerowitz, E.M. (1998). Temperature-sensitive splicing in the floral homeotic mutant apetala3 -1. Plant Cell. 10, 1453-1463.

Samach, A., Onouchi, H., Gold, S.E., Ditta, G.S., Schwarz-Sommer, Z., Yanofsky, M.F. y Coupland, G. (2000). Distinct roles of CONSTANS target genes in reproductive development of Arabidopsis. Science. 288, 1613-1616. 
Sambrook, J., Fritsch E.F. y Maniatis, T. (1989). En: Molecular cloning: a laboratory manual. 2nd Ed. (New York, USA: Cold Spring Harbor Laboratory Press).

Sattler, R. (1967). Petal inception and the problem of pattern detection. J Theor Biol. 17, 31-39.

Savidge, B., Rounsley, S.D. y Yanofsky, M.F. (1995). Temporal relationship between the transcription of two Arabidopsis MADS box genes and the floral organ identity genes. Plant Cell. 7, 721-733.

Schauer, S.E., Schlüter, P.M., Baskar, R., Gheyselinck, J., Bolanos, A., Curtis, M.D. y Grossniklaus, U. (2009). Intronic regulatory elements determine the divergent expression patterns of AGAMOUS-LIKE6 subfamily members in Arabidopsis. Plant J. 59, 987-1000.

Schmutz, J., Cannon, S.B., Schlueter, J., Ma, J., Mitros, T., Nelson, W., Hyten, D.L., Song, Q., Thelen, J.J., Cheng, J., Xu, D., Hellsten, U., May, G,D., Yu, Y., Sakurai, T., Umezawa, T., Bhattacharyya, M.K., Sandhu, D., Valliyodan, B., Lindquist, E., Peto, M,. Grant, D., Shu, S., Goodstein, D., Barry, K., Futrell-Griggs, M., Abernathy, B., Du, J., Tian, Z., Zhu, L., Gill, N., Joshi, T., Libault, M., Sethuraman, A., Zhang, X.C., Shinozaki, K., Nguyen, H.T., Wing, R.A., Cregan, P., Specht, J., Grimwood, J., Rokhsar, D., Stacey, G., Shoemaker, R.C. y Jackson, S.A. (2010). Genome sequence of the palaeopolyploid soybean. Nature. $\mathbf{4 6 3}, \mathbf{1 7 8 - 1 8 3 .}$

Schultz, E.A. y Haughn, G.W. (1991). LEAFY, a homeotic gene that regulates inflorescence development in Arabidopsis. Plant Cell. 3, 771-781.

Schwarz-Sommer, Z., Huijser, P., Nacken, W., Saedler, H. y Sommer, H. (1990). Genetic control of flower development by homeotic genes in Antirrhinum majus. Science. 250, 931-936.

Schwarz-Sommer, Z., Hue, I., Huijser, P., Flor, P.J., Hansen, R., Tetens, F., Lönnig, W.E., Saedler, H. y Sommer, H. (1992). Characterization of the Antirrhinum floral homeotic MADS-box gene deficiens: evidence for DNA binding and autoregulation of its persistent expression throughout flower development. EMBO J. 11, 251-263.

Scutt, C.P., Vinauger-Douard, M., Fourquin, C., Finet, C. y Dumas, C. (2006). An evolutionary perspective on the regulation of carpel development. J Exp Bot. 57, 21432152.

Searle, I., He, Y., Turck, F., Vincent, C., Fornara, F., Krober, S., Amasino, R.A. y Coupland, G. (2006). The transcription factor FLC confers a flowering response to vernalization by repressing meristem competence and systemic signaling in Arabidopsis. Genes Dev. 20, 898-912. 
Seastedt, T.R. y Knapp, A.K. (1993) Consequences of nonequilibrium resource availability across multiple time scales: the transient maxima hypothesis. Am Nat. 141, 621-633.

Sellars, M.J., Vuocolo, T., Leeton, L.A., Coman, G.J., Degnan, B.M. y Preston, N.P. (2007). Real-time RT-PCR quantification of Kuruma shrimp transcripts: a comparison of relative and absolute quantification procedures. J Biotechnol. 129, 391-399.

Shen, W.J. y Forde, S. (1989). Efficient transformation of Agrobacterium spp. by high voltage electroporation. Nucl Acids Res. 17, 8385.

Shindo, S., Ito, M., Ueda, K., Kato, M. y Hasebe, M. (1999). Characterization of MADS genes in the gymnosperm Gnetum parvifolium and its implication on the evolution of reproductive organs in seed plants. Evol Dev. 1, 180-190.

Shore P. y Sharrocks A.D. (1995). The MADS-Box family of transcription factors. Eur J Biochem. 229, 1-13.

Shuff, T. y Thomas, J. (1993). Normal floral ontogeny and cool temperature-induced aberrant floral development in Glycine max (Fabaceae). Amer J Bot. 80, 429-448.

Sidow, A. (1996). Gen(om)e duplications in the evolution of early vertebrates. Curr Opin Genet Dev. 6, 715-722.

Sieburth, L.E. y Meyerowitz, E.M. (1997). Molecular dissection of the AGAMOUS control region shows that cis elements for spatial regulation are located intragenically. Plant Cell. 9, 355-365.

Sieburth, L.E., Running, M.P. y Meyerowitz, E.M. (1995). Genetic separation of third and fourth whorl functions of AGAMOUS. Plant Cell. 7, 1249-1258.

Simpson, G.G. y Dean, C. (2002). Arabidopsis, the Rosetta stone of flowering time? Science. 296, 285-289.

Singh, R. J. (2005). Landmark research in grain legumes. En: Genetic Resources, Chromosome Engineering, and Crop Improvement Series: Grain legumes, Vol. 1. Singh, R.J. y Jauhar, P.P., eds. (Boca Raton, Fla.: CRC Press, Inc). 1-9.

Singh, R.J., Chung, G.H. y Nelson, R.L. (2007). Landmark research in legumes. Genome. 50, 525-537.

Smil, V. (1999). Nitrogen in crop production. Global Biogeochem Cycles. 13, 647-662.

Smyth, D.R., Bowman, J.L. y Meyerowitz, E.M. (1990). Early flower development in Arabidopsis. Plant Cell 2, 755-767. 
Soderlund, C., Descour, A., Kudrna, D., Bomhoff, M., Boyd, L., Currie, J., Angelova, A., Collura, K., Wissotski, M., Ashley, E., Morrow, D., Fernandes, J., Walbot, V. y Yu, Y. (2009). Sequencing, mapping, and analysis of 27,455 maize full-length cDNAs. PLoS Genet. 5, e1000740.

Soltis, D.E., Chanderbali, A.S., Kim, S., Buzgo, M. y Soltis, P.S. (2007). The ABC model and its applicability to basal angiosperms. Ann Bot. 100, 155-163.

Soltis, D.E., Soltis, P.S., Albert, V.A., Oppenheimer, D.G., dePamphilis, C.W., Ma, H., Frohlich, M.W. y Theissen, G. (2002). Missing links: the genetic architecture of flowers [correction of flower] and floral diversification. Trends Plant Sci. 7, 22-31.

Somers, D.A., Samac, D.A. Y Olhoft, P.M. (2003). Recent advances in legume transformation. Plant Physiol. 131, 892-899.

Sommer, H., Beltrán, J.P., Huijser, P., Pape, H., Lönnig, W.E., Saedler, H. y SchwarzSommer, Z. (1990). Deficiens, a homeotic gene involved in the control of flower morphogenesis in Antirrhinum majus: the protein shows homology to transcription factors. EMBO J. 9, 605-613.

Sprague, G.F. (1990). Combinatorial associations of regulatory proteins and the control of cell type in yeast. Adv Genet. 27, 33-62.

Starker, C.G., Parra-Colmenares, A.L., Smith, L., Mitra, R.M. Y Long, S.R. (2006). Nitrogen fixation mutants of Medicago truncatula fail to support plant and bacterial symbiotic gene expression. Plant Phys. 140, 671-680.

Stellari, G.M., Jaramillo, M.A. y Kramer, E.M. (2004). Evolution of the APETALA3 and PISTILLATA lineages of MADS-box-containing genes in the basal angiosperms. Mol Biol Evol. 21, 506-519.

Sundberg, M.D. (1982). Floral ontogeny in Cyclamen persicum "F1 Rosemunde rose" (Primulaceae). Amer J Bot. 69, 380-388.

Sundström, J., Carlsbecker, A., Svensson, M.E., Svenson, M., Johanson, U., Theissen, G. y Engström, P. (1999). MADS-box genes active in developing pollen cones of Norway spruce (Picea abies) are homologous to the B-class floral homeotic genes in angiosperms. Dev Genet. 25, 253-266.

Sung, S.K. y An, G. (1997). Molecular cloning and characterization of a MADS-Box cDNA clone of the fuji apple. Plant Cell Physiol. 38, 484-489.

Tadege, M., Ratet, P. y Mysore, K.S. (2005). Insertional mutagenesis: a Swiss Army knife for functional genomics of Medicago truncatula. Trends Plant Sci. 10, 229-235.

Tadege, M., Wen, J., He, J., Tu, H., Kwak, Y., Eschstruth, A., Cayrel, A., Endre, G., Zhao, P.X., Chabaud, M., Ratet, P. y Mysore, K.S. (2008). Large-scale insertional mutagenesis 
using the Tnt1 retrotransposón in the model legume Medicago truncatula. Plant J. 54, 335-347.

Tadiello, A., Pavanello, A., Zanin, D., Caporali, E., Colombo, L., Rotino, G.L., Trainotti, L. y Casadoro, G. (2009). A PLENA-like gene of peach is involved in carpel formation and subsequent transformation into a fleshy fruit. J Exp Bot. 60, 651-661.

Tandre, K., Albert, V.A., Sundås, A. y Engström, P. (1995). Conifer homologues to genes that control floral development in angiosperms. Plant Mol Biol. 27, 69-78.

Tandre, K., Svenson, M., Svensson, M.E. y Engström, P. (1998). Conservation of gene structure and activity in the regulation of reproductive organ development of conifers and angiosperms. Plant J. 15, 615-623.

Tani, E., Polidoros, A.N. y Tsaftaris, A.S. (2007). Characterization and expression analysis of FRUITFULL- and SHATTERPROOF-like genes from peach (Prunus persica) and their role in split-pit formation. Tree Physiol. 27, 649-659.

Theissen, G. (2001). Development of floral organ identity: stories from the MADS house. Curr Opin Plant Biol. 4, 75-85.

Theissen, G. y Saedler, H. (1995). MADS-box genes in plant ontogeny and phylogeny: Haeckel's 'biogenetic law' revisited. Curr Opin Genet Dev. 5, 628-639.

Theissen, G. y Saedler, H. (2001). Plant biology. Floral quartets. Nature. 409, 469-471.

Theissen, G., Becker, A., Di Rosa, A., Kanno, A., Kim, J.T., Münster, T., Winter, K.U. y Saedler, H. (2000). A short history of MADS-box genes in plants. Plant Mol Biol. 42, 115149.

Theissen, G., Kim, J.T. y Saedler, H. (1996). Classification and phylogeny of the MADSbox multigene family suggest defined roles of MADS-box gene subfamilies in the morphological evolution of eukaryotes. J Mol Evol. 43, 484-516.

Theissen, G., Strater, T., Fischer, A. y Saedler, H. (1995). Structural characterization, chromosomal localization and phylogenetic evaluation of two pairs of AGAMOUS-like MADS-box genes from maize. Gene. 156, 155-166.

Thomas, J. (2004). Molecular and genetic mechanisms of floral control. Plant Cell. 16, S1-S17.

Thompson, B.E., Bartling, L., Whipple, C., Hall, D.H., Sakai, H., Schmidt R y Hake, S. (2009). bearded-ear encodes a MADS box transcription factor critical for maize floral development. Plant Cell. 21, 2578-2590.

Treisman, R. (1992). The serum response element. Trends Biochem. Sci. 17,423-426. 
Trinh, H., Barker, D. y Ratet, P. (2001). Regeneration and transformation methods. En: Course Manual of EMBO. Practical course on the new plant model system Medicago truncatula. Organized by Kondorosi, A. and Dénarié J. Nov 19 - Dec 1. Gif-sur-Yvette, France.

Tröbner, W., Ramirez, L., Motte, P., Hue, I., Huijser, P., Lönnig, W.E., Saedler, H., Sommer, H. y Schwarz-Sommer, Z. (1992). GLOBOSA: a homeotic gene which interacts with DEFICIENS in the control of Antirrhinum floral organogenesis. EMBO J. 11, 46934704.

Tsuchimoto, S., Mayama, T., van der Krol, A. y Ohtsubo, E. (2000). The whorlspecificaction of a petunia class B floral homeotic gene. Genes Cells. 5, 89-99.

Tsuchimoto, S., van der Krol, A.R. y Chua, N.H. (1993). Ectopic expression of pMADS3 in transgenic petunia phenocopies the petunia blind mutant. Plant Cell. 5, 843-853.

Tucker, S.C. (1984). Unidirectional organ initiation in leguminous flowers. Amer J Bot. 71, 1139-1148.

Tucker, S.C. (1987). Floral initiation and development in legumes. En: Advances in Legume Systematics. Vol III. Stirton, C.H., ed. (Richmond, Surrey, UK: The Royal Botanical Gardens, Kew). 183-239.

Tucker, S.C. (1989). Overlapping organ initiation and common primordial in flowers of Pisum sativum (Leguminosae: Papilionoideae). Amer J Bot. 76, 714-729.

Tucker, S.C. (2003). Floral development in legumes. Plant Physiol. 131, 911-926.

Uimari, A., Kotilainen, M., Elomaa, P., Yu, D., Albert, V.A. y Teeri, T.H. (2004). Integration of reproductive meristem fates by a SEPALLATA-like MADS-box gene. Proc Natl Acad Sci USA. 101, 15817-15822.

van der Krol, A., Brunelle, A., Tsuchimoto, S. y Chua, N. (1993). Functional analysis of Petunia floral homeotic MADS box gene pMADS1. Genes Dev. 7, 1214-1228.

van der Linden, C.G., Vosman, B. y Smulders, M.J. (2002). Cloning and characterization of four apple MADS box genes isolated from vegetative tissue. J Exp Bot. 53, 1025-1036.

Vance, C.P., Graham, P.H. y Allan, D.L. (2000). Biological nitrogen fixation. Phosphorus: a critical future need. En: Nitrogen Fixation: From Molecules to Crop Productivity. Pedrosa, F.O., Hungria, M., Yates, M.G. y Newton, W.E., eds. (Dordrecht, The Netherlands: Kluwer Academic Publishers). 506-514.

Vandenbussche, M., Theissen, G., Van de Peer, Y. y Gerats, T. (2003a). Structural diversification and neo-functionalization during floral MADS box gene evolution by $\mathrm{C}$ terminal frameshift mutations. Nucleic Acids Res. 31, 4401-4409. 
Vandenbussche, M., Zethof, J., Royaert, S., Weterings, K. y Gerats, T. (2004). The duplicated B-class heterodimer model: whorl-specific effects and complex genetic interactions in Petunia hybrida flower development. Plant Cell. 16, 741-754.

Vandenbussche, M., Zethof, J., Souer, E., Koes, R., Tornielli, G.B., Pezzotti, M., Ferrario, S., Angenent, G.C. y Gerats, T. (2003b). Toward the analysis of the petunia MADS box gene family by reverse and forward transposon insertion mutagenesis approaches: $B, C$, and D floral organ identity functions require SEPALLATA-like MADS box genes in petunia. Plant Cell. 15, 2680-2693.

Viaene, T., Vekemans, D., Becker, A., Melzer, S. y Geuten, K. (2010). Expression divergence of the AGL6 MADS domain transcription factor lineage after a core eudicot duplication suggests functional diversification. BMC Plant Biol. 10, 148.

Vitousek, P.M., Aber, J.D., Howarth, R.W., Likens, G.E., Matson, P.A., Schindler, D.W., Schlesinger, W.H. y Tilman, D.G. (1997). Human alteration of the global nitrogen cycle: sources and consequences. Ecol Appl. 7, 737-750.

Vrebalov, J., Pan, I.L., Arroyo, A.J., McQuinn, R., Chung, M., Poole, M., Rose, J., Seymour, G., Grandillo, S., Giovannoni, J. e Irish, V.F. (2009). Fleshy fruit expansion and ripening are regulated by the Tomato SHATTERPROOF gene TAGL1. Plant Cell. 21, 30413062.

Wagner, A. (1999). Redundant gene functions and natural selection. J Evol Biol. 12, 1-16.

Walden, A.R., Wang, D.Y., Walter, C. y Gardner, R.C. (1998). A large family of TM3 MADS-box cDNAs in Pinus radiata includes two members with deletions of the conserved K domain. Plant Sci. 138, 167-176.

Wang, B.B. y Brendel, V. (2006). Genomewide comparative analysis of alternative splicing in plants. Proc Natl Acad Sci USA. 103, 7175-7180.

Wang, H. y Grusak, M. (2005). Structure and development of Medicago truncatula pod wall and seed coat. Annals of Botany. 95, 737-747.

Wang, S.Y., Lee, P.F., Lee, Y.I, Hsiao, Y.Y., Chen, Y.Y., Pan, Z.J., Liu, Z.J. y Tsai, W.C. (2011). Duplicated C-class MADS-box genes reveal distinct roles in gynostemium development in Cymbidium ensifolium (Orchidaceae). Plant Cell Physiol. 52, 563-577.

Waterhouse, P.M. (2001). Construct design for efficient, effective and high-throughput gene silencing in plants. Plant J. 27: 581-590.

Weigel, D. y Meyerowitz, E.M. (1994). The ABCs of floral homeotic genes. Cell. 78, 203209.

Wesley, S.V., Helliwell, C.A., Smith, N.A., Wang, M.B., Rouse, D.T., Liu, Q., Gooding, P.S., Singh, S.P., Abbott, D., Stoutjesdijk, P.A., Robinson, S.P., Gleave, A.P., Green, A.G., 
Waterhouse, P.M. (2001). Construct design for efficient, effective and high.throughput gene silencing in plants. Plant J. 27, 581-590.

Western, T.L. y Haughn, G.W. (1999). BELL1 and AGAMOUS genes promote ovule identity in Arabidopsis thaliana. Plant J. 18, 329-336.

Winter, K.U., Becker, A., Münster, T., Kim, J.T., Saedler, H. y Theissen, G. (1999). MADSbox genes reveal that gnetophytes are more closely related to conifers than to flowering plants. Proc Natl Acad Sci USA. 96, 7342-7347.

Wojciechowski, M.F. (2003). Reconstructing the phylogeny of legumes (Leguminosae): an early $21^{\text {st }}$ century perspective. En: Advances in Legume systematics, Vol 10 . Higher Level Systematics. Klitgaard, B.B. y Bruneau, A., eds. (Richmond, Surrey, UK: The Royal Botanical Gardens, Kew). 5-35.

Wu, C., Ma, Q., Yam, K.M., Cheung, M.Y., Xu, Y., Han, T., Lam, H.M. y Chong, K. (2006). In situ expression of the $G m N M H 7$ gene is photoperiod-dependent in a unique soybean (Glycine max [L.] Merr.) flowering reversion system. Planta. 223, 725-735.

Xu, Y., Zhang, L., Xie, H., Zhang, Y.Q., Oliveira, M.M. y Ma, R.C. (2008). Expression analysis and genetic mapping of three SEPALLATA-like genes from peach (Prunus persica (L.) Batsch). Tree Genet. Genomes. 4, 693-703.

Yamaguchi, T., Lee, D.Y., Miyao, A., Hirochika, H., An, G. y Hirano, H.Y. (2006). Functional diversification of the two C-class MADS box genes OSMADS3 and OSMADS58 in Oryza sativa. Plant Cell. 18, 15-28.

Yanofsky, M.F. (1995). Floral meristems to floral organs: Genes controlling early events in Arabidopsis flower development. Annu Rev Plant Physiol Plant Mol Biol. 46, 167-188.

Yanofsky, M.F., Ma, H., Bowman, J.L., Drews, G.N., Feldmann, K.A. y Meyerowitz, E.M. (1990). The protein encoded by the Arabidopsis homeotic gene agamous resembles transcription factors. Nature. 346, 35-39.

Yao, J.L., Dong, Y.H. y Morris, B.A.M. (2001). Parthenocarpic apple fruit production conferred by transposon insertion mutations in a MADS-box transcription factor. Proc Natl Acad Sci USA. 98, 1306-1311.

Yao, J.L., Dong, Y.H., Kvarnheden, A. y Morris, B.A.M. (1999). Seven MADS-box genes in apple are expressed in different parts of the fruit. J Am Soc Hortic Sci. 124, 8-13.

Yellina, A.L., Orashakova, S., Lange, S., Erdmann, R., Leebens-Mack, J. y Becker, A. (2010). Floral homeotic C function genes repress specific B function genes in the carpel whorl of the basal eudicot California poppy (Eschscholzia californica). Evodevo. 1, 1:13. 
Yi, Y. y Jack, T. (1998). An intragenic suppressor of the Arabidopsis floral organ identity mutant apetala3 -1 functions by suppressing defects in splicing. Plant Cell. 10, 14651477.

Young, N.D. y Udvardi, M. (2009). Translating Medicago truncatula genomics to crop legumes. Curr Opin Plant Biol. 12, 193-201.

Young, N.D., Cannon, S.B., Sato, S., Kim, D., Cook, D.R., Town, C.D., Roe, B.A. y Tabata, S. (2005). Sequencing the genespaces of Medicago truncatula and Lotus japonicus.Plant Physiol. 137, 1174-1181.

Yu, D., Kotilainen, M., Pöllänen, E., Mehto, M., Elomaa, P., Helariutta, Y., Albert, V.A. y Teeri, T.H. (1999). Organ identity genes and modified patterns of flower development in Gerbera hybrida (Asteraceae) the Fuji apple. Plant J. 17, 51-62.

Yu, H., Ito, T., Wellmer, F. y Meyerowitz, E.M. (2004). Repression of AGAMOUS-LIKE24 is a crucial step in promoting flower development. Nat Genet. 36, 157-161.

Zahn, L.M., Kong, H., Leebens-Mack, J.H., Kim, S., Soltis, P.S., Landherr, L.L., Soltis, D.E., dePamphilis, C.W. y Ma, H. (2005a). The evolution of the SEPALLATA subfamily of MADS-box genes: A preangiosperm origin with multiple duplications throughout angiosperm history. Genetics. 169, 2209-2223.

Zahn, L.M., Leebens-Mack, J., DePamphilis, C.W., Ma, H. y Theissen, G. (2005b). To B or Not to $\mathrm{B}$ a flower: the role of DEFICIENS and GLOBOSA orthologs in the evolution of the angiosperms. J Hered. 96, 225-240.

Zahn, L.M., Leebens-Mack, J.H., Arrington, J.M., Hu, Y., Landherr, L.L., dePamphilis, C.W., Becker, A., Theissen, G. y Ma, H. (2006). Conservation and divergence in the AGAMOUS subfamily of MADS-box genes: evidence of independent sub- and neofunctionalization events. Evol Dev. 8, 30-45.

Zhang, H. y Forde, B.G. (1998). An Arabidopsis MADS-box gene that controls nutrientinduced changes in root architecture. Science. 279, 407-409.

Zohary, D. y Hopf, M. (2000). En: Domestication of Plants in the Old World. The Origin and Spread of Cultivated Plants in West Asia, Europe and the Nile Valley. 3rd. Ed. (New York: Oxford University Press Inc.).

Zucchero, J.C., Caspi, M. y Dunn, K. (2001). ng/9: a third MADS box gene expressed in alfalfa root nodules. Mol Plant Microbe Interact. 14, 1463-1467. 
Anexos 



\title{
1 SECUENCIA GENÓMICA AMPLIFICADA QUE CONTIENE LA REGIÓN CODIFICANTE DEL GEN MtAGa DE Medicago truncatula
}

\author{
1 ATGGATTTTC CAAATGAATC CATGTCAGAT TCTCCACAGA GAAAGATTGG AAGGGaAAG \\ 61 ATtGAGATCA AAAGGATTGA AAACACGACG AATCGTCAAG TAACTTTCTG CAAAAGAAGA
}

121 AATGGTTTGT TGAAGAAAGC ATATGAATTA TCTGTTCTTT GTGATGCAGA AGTTGCTCTT 181 ATAGTCTTCT CTAGCCGTGG ACGGCTCTAT GAGTATGCTA ATAACAGTGT CAAAGAGACT 241 ATtGCAAGG ACAAAAAGC ATGTTCAGAT TCATCTGGCA CTGGATCTGC TACTGAGGCT 301 AATGCTCAG g tattgattaa ttcatttttt tttcttcata ttaattcctt caaattaatg 361 gttgatatt tatttaacta tataaaaaa ctaacattta taaccatgat ttcatatata

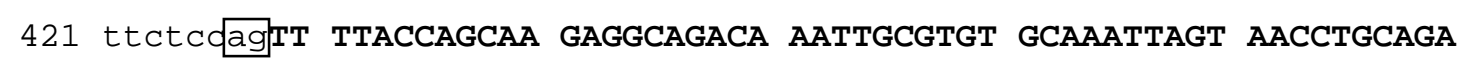
481 ATAACAACAG @(C)aagtctaa ctaaccttaa tgccttagaa ctcactgaat aagaaaaaga 541 gaagagagaa ttacattctt ctcccttaaa ttacacttat tttttattta tcttaaaatt 601 tataccattc ccttaaaaag taaaaccatc agtaaccaaa aaaaaaagt aaaactatct 661 attatattt tgtcaattta accaagcttc ttatgcatat attttctct ctatttttg 721 ttcacagcat cattaagatt taagaaacct aactatctac tatgaaataa gttttgcca 781 aactatttgt gctaatgaaa aagctattta tagctgaatt tcaacttcta aattacaaaa 841 tcaatagaaa ggtgtttcaa attatttgtc tccggcattc tacctcggca cactttatgc 901 taggtatgtt cttttgttgg taatatatc tatttgact tgtttaaaaa aaataaaatt 961 atttttcatc ggcttgaatg ttgcaaagaa gcaaattttt gaagtgatta tttaaagtt 1021 ttggctatcc ttaaaatttt tttttgtag taatacttat ttacttttta tgaagagaaa 1081 catagatttc aacacaagac aatagtgaaa ttcaattatg tttagaggaa tgagtataat 1141 ttatcctaaa tttttgaag agatttcaat tttaaaacca ctaatttaat tttacaattg 1201 gggatgaaat aaattattat taattaacgt agtttatggt cattttacaa ctcatttcga 1261 ggggattgag gtccgttcct tgagttaaaa ggtcaaactt agtcgataac tcattacaca 1321 aatcactaat ttgttgataa aacaattttt gttaacatag tttatggtca ttttacaact 1381 catttcgagg ggattgaggt ccgttccttg agttaaaagg tcaaacttag tactaagagc 1441 atccacaatg gagaccctca aattgaagat cttaagcggg ttccatttgt acacatcact 1501 ttttttatta ttttataata aaagtaccta ataggtactc ggtcactcca atggagatct 1561 tctaacaaaa agtctaaatg tgtcccacca ctaactctta ttcatttaaa tttcagcact 1621 aacatattat tttaataaaa atgtgtgtgg ggactactta aagatggggg tcttaagtta 1681 gaccccatgt cttagaagac cccaaatttt attcccacaa tgggagtacc tattaggtac 1741 taggtcttaa atggtgaaga cctcaccatt gtagatgctc taagccgata cctcattaca 1801 caaatcacta attgttgat aaaacaattt tgaaaccatc taattaattt gtaatttgca 1861 tcatctgaat atccttgctg aaaatgatta aatgcag GC AAATGATGGG TGAATCTTTG 1921 GGCTCTATGA ATGCCAAGgA ACTGAAAAAT CTGGAGTCTA AATTAGAAAA AGgAATTAGT 1981 CGGATTCGTT CCAAAAAGgt atacatatt cttatgttat caaccagtcc tttctacaat 2041 ttgtttcata agattcatga ttttatctac aatgttctga taaatcatgc atttttctga 2101 ctctctcctt tcttttgct tgctctacaa tccaaacatc aactcagAAT GAGCTGTTAT 


\begin{abstract}
2161 TTGCTGAAAT TGAATACATG CAGAAGAGg tacacatt t t t tctataca cattagtct 2221 ctttagtaac aaattcaaat tatatcatga tttgtgttgc cctaagtttc aaatgaagta 2281 tcatatacta acctatatgt acacagdag G AGATAGACTT GCACAATAAC AACCAACTTC 2341 TGAGAGCAAA Ggtcatttct tttatctct atatcttct tcatatact cctatgtgca 2401 atttgatat tttcaagtat cttatggttt tatgattttg gtgtgtatag ATAGCTGAAA 2461 GTGAGAGGAA CCATAGCCAC CATAGCAATA TTAATATGAG TATGTTGCCT GGAGGCACAA 2521 ACTATGAACC TATGCAGTCT CAGAATCAGC AGCAGCAATA TGAGTCTCGT GGATACTTTC 2581 AAGTTTCTGG ATTACAATCC AGTAGTAGTC AAATGACTGC ATTACAACCA AGTAGTCAGT 2641 ATGCAAGACA AGACCACATG TCCCTTCAAT TAGTTTGA
\end{abstract}

Anexo 1. Como nucleótido 1 se tomó el primero de la región codificante. Los exones se representan en negrita y mayúscula, en minúscula se señalan los intrones; el codón de inicio de la traducción (ATG) y el codón de parada (TGA) se muestran subrayados. Los nucleótidos indicados en cursiva (exón I, intrón I, parte del exón II y parte del exón VII) no fueron amplificados mediante PCR. Con un triángulo se señala la supuesta posición del intrón I. Se encierran en cuadros los extremos esenciales típicos de los intrones (GT$A G$ ) y en un círculo el extremo esencial menos común (GC).

\title{
2 SECUENCIA GENÓMICA AMPLIFICADA QUE CONTIENE LA REGIÓN CODIFICANTE DEL GEN MtAGb DE Medicago truncatula
}

\footnotetext{
1 ATGAGTTTTC CAAACGAATC CATGCCAGAT TCTCCACAgA GAGCAAAgAT TGGAGAgGg

61 AAgATTGAGA TCAAGAGgAT TGAGAACACA ACGAATCGTC AAGTTACGTT CTGCAAGCGT 121 AGAAATGGCT TGCTTAAGAA GGCATATGAA TTATCTGTGC TTTGTGATGC TGAAGTTGCT 181 CTTATAGTCT TCTCGACTCG CGgCCGCCTC TATGAATATG CAAATAACAG gtaactactg 241 aagaatttt ctagctttt gtgttattgt tcttttcta tttgtttgca gtttttgata 301 agtcaaagaa atgtctttgt tgcttcttt tgaggaacat tgagtttata tttatgttca 361 tgttaataga tcttttgaaa gagtacatta gttaacttaa ccaaaagaga ctaatcattt 421 ttgtgttaaa tttttctctt tgtatgtctg tttctgcaa ccaagattca cttgtgtttg 481 tttcttctat tttggccttt ttctgttcct tccataaact ttttaagttc atttctcaa 541 cctctttct ttgtgtctat gagaatttc ctagttttt ttttgggtt tggtggacac 601 atagatctgg tataacagaa atgtatagaa gcactatggt tgttatttgt tagtagtatc 661 attcaggtaa ggatttggga agatttgaag aagggttgtg agatcagcca atccctaact 721 tccttcttca ttttgttctt aaactttcca cttttcttt tttttctct ttctcttct 781 aatgttattc ctcctaataa ggcctaaagc aagtggaaaa agctagttgt caatgagtta 841 aattgaaatt attaataaaa taataaagaa aaagcaaggg ttatttaggg tttgtgaaaa 901 gcctaaaact atagttcctc acttattata cagaaaaatt tcttaatgaa gaaattatac 961 aggaaattt ctttttaat tcgacagaaa taaatctgat taagaacact atttcaatt 1021 cttaatttga aaaaagggtt tccctcaaat ctcagcttgg ataaacaata accctagaaa 1081 ttagggttt attaacatct aatttatgag atggataaca actaatcaaa gggatacaaa
} 
1141 tgaaaatgaa agaaagacag aaactttaca aaattatagt caaaagggta tattggaaat 1201 ctcattttgt tgtttaattt ccccaattta ggaaataggg cctgttgttg ttatttctgg 1261 ttagggctta aaggactcac tagctagaca ctgatttcaa ttttgtcttg gatgaaaaga 1321 atctttagtc atgtcacaag tgaattttct ctttaaagat gaatcctaaa gttaatccta 1381 tatatcctta gttaatcttt cagttatcat aaggtaaaaa tccaaatat ctgttgtttt 1441 ttttattaat ctaaatatat tgttttacat agttagaaaa gaacaataca atagagagtg 1501 atgatgtaat gaatagggtg gttatcataa tttcattgtt gccaaagatc tttcaaataa 1561 tagatcaaat ctgtgaaagt tatagactga ggaagaaaaa ggaaagggtt ttctttctaa 1621 gctaaatgaa tgatgtaaat ggaggcagag acaacgtacg acaatttgag acagccaata 1681 agattgttat caacattttt gtcttcttcc atgcaacgga aacgtactac tgttccttct 1741 gctacatcta tagcagtgtc tgcccgaacc tattggacg gctgtgatt tatcacattc 1801 agaaagaaaa gactgaaaac aaaataaaat attattttaa tattttacta ataagtttgg 1861 taaaaaaaca aggtaggtaa taaattgtat ttgagagtat tatccaatgt_gtatgagatg 1921 gttccttcat atggcagtgg aaataattta aaaaaagcac taaaaatggt tgaaccaatc 1981 atatttagga acctgagcca gcgtggcagg tgcagccaat caatggctcg acgaaattaa 2041 ggtatcactg gtcaaatatg ctgaaaatga aacaaaaata aaaagggttt tttaccattt 2101 ctttttatgc tattatttat tgtattttat tatcaacaca tccaatcaac tttgtttctg 2161 atgaatgcac atctaatcaa cattgacgtc aaggttttga ggaatgagat cttttgatgt 2221 gtgtttttca agattgtgtt ttaaggttca gtttactcaa ctagctggat gatttgactg 2281 caaattatgt cattattttg aaatagattt attactttac ttttgtttat tcttgttcaa 2341 cgagtaactg aaatacttgg atgaagattc atataaaaat tggataaaga tgatatgtag 2401 aatagagtct attttttatg ataattcaaa aggtagcggt ttctggtatc atctagaata 2461 gaagtaatgt atagtttata cacttatgtt tggttactct ctagacaagt tagtccatgt 2521 ctgcttttgt agtgagtatg gatatggatg aatgaatcac ggtgcaatga ttttgcaaaa 2581 attatactta tagaacttca ataaataatg tcactttgat tttgtcaaag ccaacttaat 2641 accaaatatt tctttggtca atcgcacggt gccatcacta gtttcaaac tcgggctatc 2701 acgaatttag tgtacatgtg attttatgct aacctttaca ttaaacttgt tttcaaatag 2761 aaatatatgg atataaatta cttcacttta aactcaattt tacgaaatca aattcttca 2821 aatatatatt tactaaacac caaacacaca ctacttacaa catgagttgg cacaacatta 2881 tgattccaac ccttctcttt ctcaaaatca aacatttgga aatgagcctt ccaatggtat 2941 gggtatatgg agaatgagtg tactgatatc atgtatgtga tgtgatattg gctatatata 3001 gtttgttcct gttgactgac taatgcccaa ttaaatttca aattaaatgg attgaattat 3061 agattttatt aatttgtggc caggaatggg acaatcattg ttttggtta gtaattgata 3121 gtattccatg atatgatgat aattaagaat tcagaaattt ccccttctt attattatat 3181 gccattgtca aacaacatct agcataattg atgaaaatga tatataccac ttttcagTGT 3241 CAAAGCATCA ATTGAGAGgT ACAAGAAAGC ATGTTCAGAT TCTTCTGGTG CTAAATCAGC 3301 TTCTGAGTCT AATGTTCAGg tattcattat ttattcacta caattacaca gcctcaaaca 3361 caagcacaag cacaagcaaa atgaatatct aacgataact acaacaaaaa gtaaattgaa 3421 tataaaataa tgtaataaat aaactaaccc ctttaaacat gattgcttaa tttcagTATT 3481 ACCAGCAAGA AGCTGCCAAA CTGCGTGTGC AAATCAGTAA CTTGCAGAAT CATAACAGgt 3541 aagttgaaca agtgtcttat actttcatat attaggacaa gcaaagagat attgagcatt 


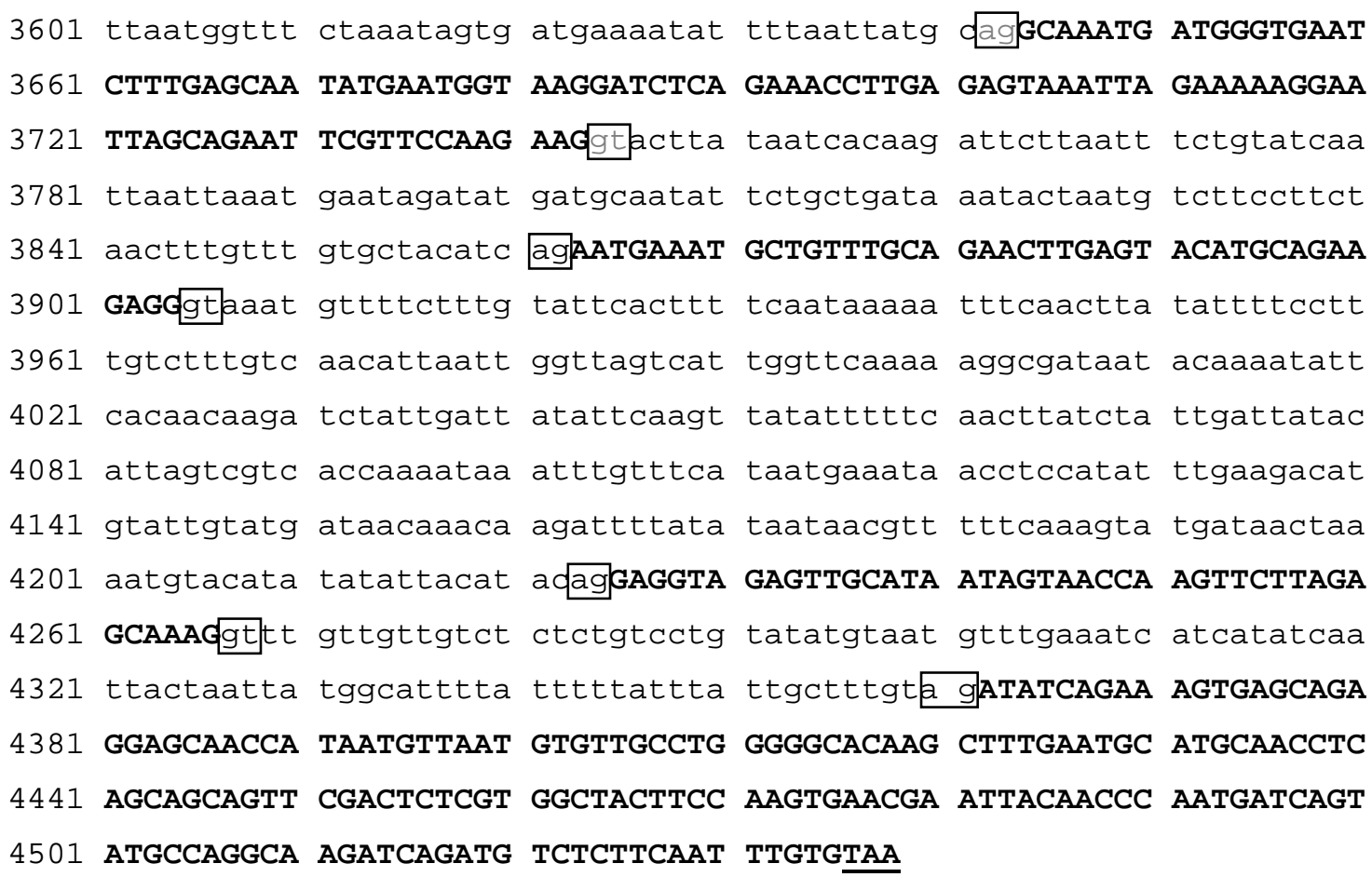

Anexo 2. Como nucleótido 1 se tomó el primero de la región codificante. Los exones se representan en negrita y mayúscula, en minúscula se señalan los intrones; el codón de inicio de la traducción (ATG) y el codón de parada (TAA) se muestran subrayados. Se encierran en cuadros los extremos esenciales típicos de los intrones (GT-AG). Dentro del intrón I se detallan: resaltadas en gris las secuencias consenso de unión a $L F Y$ (CCANTG[T/G]) y con subrayado discontinuo los posibles sitios de unión a $L F Y$ según el programa MORPHEUS. Se resaltan en rosa las posibles cajas CArG (consenso $C C[A / T]_{6} G G$ ) y en azul la secuencia consenso de la caja aAGAAT. El fragmento de 70 pb conservado en varios genes ortólogos de AGAMOUS se indica con doble subrayado y se resaltan en amarillo las repeticiones CCAATCA. Las posiciones de los elementos reguladores de este intrón se han numerado considerando como inicio el primer nucleótido del mismo. 

